\title{
Vakverenigingsvrijheid in Latijns Amerika in het licht van de normen van de Internationale Arbeidsorganisatie
}

Citation for published version (APA):

van der Wilt, H. G. (1993). Vakverenigingsvrijheid in Latijns Amerika in het licht van de normen van de Internationale Arbeidsorganisatie. [Doctoral Thesis, Maastricht University]. Thela Publishers. https://doi.org/10.26481/dis.19931216hw

Document status and date:

Published: 01/01/1993

DOI:

10.26481/dis.19931216hw

Document Version:

Publisher's PDF, also known as Version of record

Please check the document version of this publication:

- A submitted manuscript is the version of the article upon submission and before peer-review. There can be important differences between the submitted version and the official published version of record.

People interested in the research are advised to contact the author for the final version of the publication, or visit the DOI to the publisher's website.

- The final author version and the galley proof are versions of the publication after peer review.

- The final published version features the final layout of the paper including the volume, issue and page numbers.

Link to publication

\footnotetext{
General rights rights.

- You may freely distribute the URL identifying the publication in the public portal. please follow below link for the End User Agreement:

www.umlib.nl/taverne-license

Take down policy

If you believe that this document breaches copyright please contact us at:

repository@maastrichtuniversity.nl

providing details and we will investigate your claim.
}

Copyright and moral rights for the publications made accessible in the public portal are retained by the authors and/or other copyright owners and it is a condition of accessing publications that users recognise and abide by the legal requirements associated with these

- Users may download and print one copy of any publication from the public portal for the purpose of private study or research.

- You may not further distribute the material or use it for any profit-making activity or commercial gain

If the publication is distributed under the terms of Article $25 \mathrm{fa}$ of the Dutch Copyright Act, indicated by the "Taverne" license above, 


\section{VAKVERENIGINGSVRIJHEID IN LATIJNS AMERIKA IN HET LICHT VAN DE NORMEN VAN DE INTERNATIONALE ARBEIDSORGANISATIE}




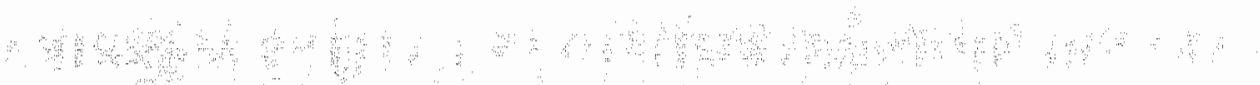

3 Pat

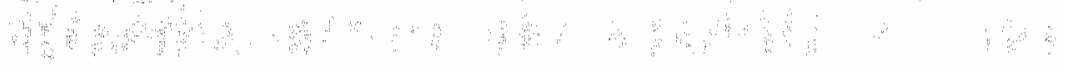




\title{
VAKVERENIGINGSVRIJHEID IN LATIJNS AMERIKA IN HET LICHT VAN DE NORMEN VAN DE INTERNATIONALE ARBEIDSORGANISATIE
}

\section{PROEFSCHRIFT}

\author{
ter verkrijging van de graad van doctor \\ aan de Rijksuniversiteit Limburg te Maastricht, \\ op gezag van de Rector-magnificus, Prof. dr. H. Philipsen, \\ volgens het besluit van het College van Dekanen, \\ in het openbaar te verdedigen op donderdag 16 december 1993 \\ om 12.00 uur
}

door

Harmen Gijsbrecht van der Wilt

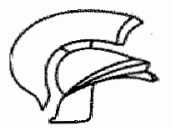




\section{Promotoren:}

Prof. mr. Th. van Boven

Prof. mr. C. Flinterman

\section{Beoordelingscommissie:}

Prof. mr. A.J.C.M. Geers, voorzitter

Prof. dr. P.R. Baehr (Universiteit Utrecht/Rijksuniversiteit Leiden)

Prof. dr. R.Th.J. Buve (Rijksuniversiteit Leiden)

Mr. G.J.J. Heerma van Voss 


\section{Woord vooraf}

Het schrijven van een proefschrift vergt een lange adem. Eenieder die aan een dergelijke riskante onderneming begint, kent het "tunnel-gevoel": voor noch achter valt enig licht te ontwaren. Daarom is het goed dat er voortdurend welwillende mensen bereid zijn de soms desperate promovendus een hart onder de riem te steken. Als het project dan eindelijk is afgerond, voel je de behoefte om deze mensen te bedanken.

Allereerst mijn beide promotores, Prof. mr. Theo van Boven en Prof. mr. Kees Flinterman. Theo, jij hebt mij door de jaren heen deelgenoot gemaakt van je rijke en soms ook droevige ervaringen op het gebied van de rechten van de mens. Daar heb ik veel van geleerd. Toch gaf je er tijdens onze talrijke lunches de voorkeur aan wat lichtere onderwerpen aan te snijden: waar je goede doch betaalbare wijnen kan krijgen, het steenuiltje op de zolder van jullie boerderij, die schitterende omhaal van Ronald de Boer op de paal... Voor deze vriendschappelijke omgang ben ik je erg dankbaar.

Kees: hoofdschuddend spoorde je mij aan tot een "geserreerder" taalgebruik, terwijl je toch ook kon gniffelen om de "tale Kanaäns" die ik pleeg te bezigen. Je gevoel voor humor en je scherpzinnige maar altijd opbouwende kritiek: veel dank.

Dank ben ik ook verschuldigd aan de leden van de beoordelingscommissie, Prof. mr. A. Geers (voorzitter), Prof. dr. P.R. Baehr, Prof. dr. R.Th.J. Buve en Mr. G.J.J. Heerma van Voss.

Van enige afstand volgde Dr. Jean Carrière van het CEDLA in Amsterdam mijn vorderingen. Jean, jij benadrukte dat Latijns Amerika geen abstract concept is, maar dat het om "loving and caring and kicking people" gaat. Bovendien getuigde je van inlevingsvermogen door erop te wijzen dat het schrijven van een dissertatie "the loneliest job in the world" is.

De medewerkers van de Bibliotheek van het CEDLA, met name Pauline Beckers, Sjaak van Laar, Anneke Roos en Peter Runhaar, stelden alles in het werk om mij van achtergrondinformatie te voorzien en toonden bovendien een warme belangstelling voor het wel en wee van "our man in Maastricht". 
Halverwege het traject verliet ik de vakgroep internationaal recht voor de vakgroep strafrecht. Mijn huidige werkbazen Prof. mr. Theo de Roos en Prof. mr. Gerard Mols, en mijn collegae van de vakgroep strafrecht ben ik erkentelijk voor hun geduld: eerst moest die zonderling zijn exotische onderwerp afmaken, nu kan hij pas recht volwaardig lid worden van de rebellenclub.

Margot de Boer en Josta Mommertz, secretaresses van de vakgroep strafrecht, hebben er zorg voor gedragen dat het manuscript in fatsoenlijke staat naar de uitgever kon. Met Margot heb ik korte tijd een ware "hot line" onderhouden.

Ingrid Westendorp, secretaresse van de vakgroep internationaal recht, heeft met haar doortastende optreden dikwijls mijn onpraktische instelling ruimschoots gecompenseerd.

Vele vrienden, collegae en studenten hebben in de loop der jaren blijk gegeven van hun belangstelling en bemoedigende woorden gesproken. Het zou ondoenlijk zijn om hen allen bij name te noemen, maar ik wil enkele uitzonderingen maken. Allereerst de vriendinnen van het eerste uur: Malva Driessen en Liesbeth Lijnzaad. Malva, ik bewaar goede herinneringen aan ons bezoek aan Genève. Jij bent natuurlijk minstens even eigenwijs als ik maar het heeft een hechte vriendschap nooit in de weg gestaan. Mijn kamergenotes, Jacqueline Parlevliet en Dorothe Garé hebben als degelijke barometers mijn wisselende stemmingen moeten verduren. José Maria Blanco Fernandez: het volksgeloof wil dat Spanjaarden temperamentvoller zijn dan Nederlanders. Wij hebben het tegendeel bewezen: op bedachtzame wijze wist jij mijn vaak heetgebakerde uitspraken te nuanceren. Bovendien kon ik mijn onvolledige kennis van het Spaans altijd door jou laten bijspijkeren. Met Rob Bakker deel ik de fascinatie voor het Perfide Albion. Daarom stel ik het extra op prijs dat hij de Engelse samenvatting kritisch heeft doorgelicht.

Het belangrijkste heb ik voor het laatst bewaard: familie en gezin. Mams, wij hebben veel over je in de rats gezeten, maar gelukkig kun je het allemaal nog beleven. Mijn vader heeft jammergenoeg het begin, noch het einde kunnen meemaken: hij zou wel trots zijn geweest denk ik. Mijn broer Gerritjan heeft vanaf het prille begin mijn worsteling met de materie gevolgd en heeft altijd intens meegeleefd.

Zelden zal een hapering in de gestage voortgang van een dissertatie zo welkom zijn als bij de geboorte van een kind. Onze drie dropjes, Martje, Femke en Bram zijn gedurende deze periode geboren. $\mathrm{Zij}$ hebben natuurlijk nog niet zoveel weet van de sores van hun ouders, maar Fem zegt altijd bezwerend: "Papa navond thuis, hè?"

Last but not least is er de rots in de branding, Joke, mijn Lief. Aan haar draag ik dit boek op. 


\section{Inhoudsopgave}

Inleiding

Hoofdstuk 1 De politieke dimensie van de vrijheid van vakvereniging Een inventarisatie van de uitspraken van de Internationale Arbeidsorganisatie over de verhouding tussen staat en vakbeweging

Inleiding

De Internationale Arbeidsorganisatie en de vrijheid van vakvereniging

2.2 Normstelling op het gebied van de vrijheid van vakvereniging

2.3 De ILO en het toezicht op de naleving van internationale arbeidsnormen

3.2 Het onderscheid tussen burger- en politieke rechten en sociale, economische en culturele rechten in het licht van de universaliteitsproblematiek

3.3 Differentiatie-methoden en de vrijheid van vakvereniging

Politieke activiteiten van de vakbeweging als oorzaak van conflicten tussen staat en vakbeweging

4.1 Het scheiden van het politieke kaf van het vakbondsrechtelijke koren: twee procedurele voorvragen

4.2 De nadere afbakening van de grens tussen politieke activiteiten die wel en die niet tot de, in art. 3 van Conventie 87 beschermde, vakbondsactiviteiten behoren 
4.3 De relatie tussen de bescherming van algemene mensenrechten en het ontplooien van politieke activiteiten

4.3.1 De bescherming tegen (willekeurige) arrestatie en detentie en de vereisten van een eerlijk proces

4.3.2 De vrijheid van meningsuiting 33

4.3.3 Het recht van vrijheid van vergadering 34

4.4 Discriminatie op politieke gronden bij de vrijheid van organisatie

4.4.1 "...zonder enig onderscheid..."

4.4.2 "'...zonder voorafgaande toestemming..." 36

4.4.3 Politieke overtuiging als onderscheidend criterium bij kandidaatsteiling voor vakbondsleiderschap 36

4.5 De "politieke" staking.

Controle en overheersing van de wakbeweging door de staat in het licht van de beginselen van vakverenigingsvrijheid.

5.1 De geloofsbrievenprocedure 39

5.2 De Commissie Mc Nair: betekenis en werkzaamheden 42

5.3 Toezichtsmaatregelen en andere vormen van overheidsinterventie in vakbondsaangelegenheden 44

5.3.1 De aanwezigheid van autoriteiten tijdens vakbondsvergaderingen 44

$\begin{array}{lll}\text { 5.3.2 Het verbinden van voorwaarden aan de erkenning van vakbonden } \quad 45 & 44\end{array}$

5.3.3 Staatsinmenging in vakbondsverkiezingen 46

5.3.4 Het dwingend voorschrijven van bepalingen in vakbondsstatuten 46

5.3.5 Financiële afhankelijkheid van de staat $\quad 47$

5.3.6 Staatsinterventie in collectieve onderhandelingen 48

5.3.6.1 Verplichtingen met betrekking tot de inhoud van de CAO 49

5.3.6.2 Verplichte goedkeuring en wijziging achteraf van CAO's 50

$\begin{array}{ll}\text { 5.3.6.3 Bemiddelings- en arbitrageprocedures } & 51\end{array}$

5.4 De problematiek van (beperking van) vakverenigingsvrijheid voor werknemers in de publieke sector $\quad 52$

5.4.1 Organisatierechten 53

5.4.2 Collectieve onderhandelingen $\quad 54$

$5.4 .3 \quad$ Stakingen 55

6 Staatsingrepen in de organisatiestructuur van de vakbeweging. De problematiek van vakbondsmonopolies versus vakbondspluralisme

6.1 Beperkingen van het recht van vakbonden om zich in (con)federaties te verenigen 
6.2.1 De wettelijke regeling van vakbondsmonopolies

6.2.2 Toelaatbaarheid van begunstiging van vakbonden uit hoofde van hun representativiteit

6.2.3 Uitsluiting van concurrentie door de vakbeweging zelf op grond van "closed shop"-bepalingen

$7 \quad$ Evaluatie van de resultaten en conclusies

Hoofdstuk 2 Een typologie van de Latijnsamerikaanse vakbeweging

Structurele aspecten van de Latijnsamerikaanse vakbeweging

De verhouding tussen staat en vakbeweging in Latijns Amerika in historisch perspectief

3.2 Nationalistisch-populistische regimes en de vakbeweging

Crisis van de nationalistisch-populistische regimes en opkomst van de militairen

3.4 De ondergang van de militaire regimes en het herstel van de democratie

Hoofdstuk 3 Chili: de ILO-reactie op de vakbondspolitiek van het regime-Pinochet

De verhouding tussen staat en vakbeweging in Chili in historisch perspectief 
3.3 Arrestatie en detentie van vakbondsleiders

3.4 De ontbinding van de CUTCh 105

3.5 De ontmanteling van overige "marxistische" vakverenigingen 106

3.6 Ontslag en diskwalificatie van vakbondsleiders

Bevriezing van de gedoogde vakbeweging

4.3 Collectieve onderhandelingen en stakingen

Een periode van dooi in de verhouding tussen regime en vakbeweging: het intermezzo "Diaz Estrada"

Pinochet en de vakbeweging na 1976: de verschuiving van "militaire" naar "economische" repressie

Het Plan Laboral: essentiële kenmerken en praktische consequenties

7.1.2 Regels met betrekking tot het functioneren van vakbonden; extern toezicht

7.1.3 Ontbinding van vakbonden; totstandkoming van (con)federaties; toepasselijkheid van het wetsdecreet

Collectieve onderhandelingen

9 De protestbeweging in dle jaren tachtig als opmaat tot het herstel van de democratie 
De invloed van de koffie-economie op de sociale en politieke ontwikkelingen in Colombia

De bloeiperiode van de a-politieke vakbeweging (1945-1965)

De geleidelijke teloorgang van de controle-politiek (1965-1977)

5.3 De weigering van rechtspersoonlijkheid als repressief instrument

De laatste 16 jaar (1977-1993): van "controle" naar "repressie"

6.1 Het algehele stakingsverbod als uitvloeisel van uitzonderingswetgeving

6.2 Ontbinding van vakorganisaties en intrekking van rechtspersoonlijkheid

Ontslag en diskwalificatie van vakbondsleiders en -leden

6.5.2 Moord op en mishandeling van vakbondsleden welke mogelijk verband houden met deelname aan nationale stakingen 
$1 \quad$ Inleiding

De verhouding tussen staat en vakbeweging in historisch perspectief

2.1 Inleiding 1940-1970: een periode van politieke stabiliteit en economische groei

2.5 1970-1992: De alliantie. tussen staat en vakbeweging onder groeiende druk

3.3.1 Coöptatie van vakbondsleiders als mogelijke inbreuk op de interne vakbondsdemocratie

3.3.2 Vakbondsmonopolies in de Mexicaanse wetgeving en rechtspraktijk

3.3.2.1 Het wettelijk voorgeschreven vakbondsmonopolie in de publieke sector

2.2 De scherpe politieke tegenstellingen tussen de Chileense vakbeweging en het militaire regime van Pinochet 
2.3 Colombia: het wettelijke verbod op (partij-)politieke activiteiten en de "politieke" stakingen van 1963 en 1977

$2.4 \quad$ Politieke conflicten tussen staat en vakbeweging in Mexico.

De nationale spoorwegstakingen van 1958-1959

2.5 Onderlinge vergelijking van de uitspraken en plaatsing in het bredere perspectief van de ILO-opvattingen

De nationale rechter en de ILO-normen inzake de vrijheid van vakvereniging

3.1 Inleiding

3.2 De verhouding tussen internationaal recht en nationaal recht. Monisme versus dualisme

3.2.2 De problematiek van de rechtstreekse werking

3.2.3 De hiërarchie tussen internationale normen en nationaal recht

De doorwerking van internationaal gewoonterecht in de nationale rechtsorde

3.3 De internationale verplichtingen van de staat en de constitutionele bepalingen inzake het internationale recht als uitgangspositie voor de nationale rechter

3.4 De hantering van internationale (arbeids)normen door de rechter in de praktijk

Vakbondsmonopolies revisited. Een kritische beschouwing over het ILO-standpunt inzake "closed shops"

4.2 De verhouding tussen "closed shops"-clausules en de positieve en negatieve coalitievrijheid

4.3 Het verplichte vakbondslidmaatschap als waarborg en als keurslijf: een afweging van belangen

4.3.2 De positieve coalitievrijheid en het bestaansrecht van minderheidsvakbonden 
4.3.3 De "closed shop"-clausule die uitdrukkelijk het lidmaatschap van andere vakbonden verbiedt

4.4 Een nader onderzoek naar de motieven die ten grondslag kunnen liggen aan wettelijke en feitelijke vakbondsmonopolies

4.5 Korte samenvatting en proeve tot herziening van het

ILO-standpunt inzake "closed shop"-clausules

Hoe de verschillen in doelstelling en methodes van "fact-finding" de taxatie van een vakbondssituatie door de ILO en NGO's kunnen beïnvloeden

$5.1 \quad$ Inleiding

5.2 Fact-Finding en effectiviteit. De Direct contact-procedure en de procedure van de Onderzoeks- en Bemiddelingscommissie in vergelijkend perspectief

5.2.1 De Direct contact-procedure

5.2.2 De Onderzoeks- en Bemiddelingscommissie: een pleidooi voor eerherstel

5.3 Enkele reflecties over de aard, werkzaamheden en doelstellingen van IGO's en NGO's in relatie tot methodes van "fact-finding"

5.3.1 IGO's en "Fact-Finding"

5.3.1.1 Procedures met betrekking tot de beoordeling van globale mensenrechtensituaties

5.3.1.2 Klachtenprocedures

Korte evaluatie

Resumen 


\section{Inleiding}

Deze studie is het verhaal van een ontmoeting tussen een internationale organisatie en een continent, of - beter gezegd - een drietal landen van dat continent. Het ligt in mijn bedoeling om te onderzoeken hoe de Internationale Arbeidsorganisatie (hierna: ILO, naar de Engelse afkorting) de vakbondssituatie in Latijns Amerika beoordeelt. Deze globale doelstelling werpt onmiddellijk twee vragen op: waarom de ILO? En: waarom Latijns Amerika? De eerste vraag is aanzienlijk eenvoudiger te beantwoorden dan de tweede. De vrijheid van vakvereniging vormt de ruggegraat van de ILO. De organisatiestructuur van de ILO wordt gekenmerkt door haar tripartiet karakter: naast regeringsvertegenwoordigers, hebben ook vertegenwoordigers van werknemers- en werkgeversorganisaties zitting in de belangrijke organen van de ILO. Deze tripartiete structuur zou een lege huls zijn, indien werkgevers- en werknemersorganisaties niet onafhankelijk van elkaar en ten opzichte van de staat konden bestaan en functioneren. Het ligt daarom in de rede dat de ILO van de lid-staten verlangt dat zij de vrijheid van vakvereniging respecteren. $\mathrm{Zij}$ heeft daartoe normen opgesteld en toezichtsmechanismen ontwikkeld.

Het tweede aspect - waarom Latijns Amerika? - vereist iets meer toelichting. Eén van de uitgangspunten van deze studie is dat de vrijheid van vakvereniging in Latijns Amerika voortdurend onder druk heeft gestaan. De gespannen verhouding tussen staat en vakbeweging in Latijns Amerika valt ten diepste te herleiden tot de omstandigheid dat de Latijnsamerikaanse vakbeweging in hoge mate "gepolitiseerd" is. Onder "politisering" versta ik niet, althans niet primair, de situatie dat vakbonden politieke doelen najagen, maar veeleer de strategische keuze van vakorganisaties om, ter verwezenlijking van vakbondsbelangen, in overleg te treden met of druk uit te oefenen op politieke partijen en autoriteiten. Nu is het op zichzelf in het geheel niet opzienbarend dat vakbonden "aan politiek doen". Vanuit historisch perspectief valt het voeren van politieke actie te verklaren uit de drang naar staatserkenning van vakorganisaties en het recht op collectieve onderhandelingen.' Los van deze historisch bepaalde, dus tijdelijke, interesse van vakorganisaties voor de staat, beantwoordt de vervlechting tussen vakbeweging en politiek evenwel ook in het algemeen aan een bepaalde logica. Vakbonden streven dikwijls verscheidene doelen na, zoals hogere lonen, volledige 
werkgelegenheid en beteugeling van de inflatie. Vooropgesteld dat deze doelstellingen deels tegenstrijdig zijn, is het maken van rationele beleidskeuzen, op grond van prioriteitenstelling, onvermijdelijk. Waar de primaire belangen van de vakbeweging, zoals werkgelegenheid en loon- en prijsontwikkeling tevens voor de overheid de peilers van de economische politiek zijn, ligt het zowel voor de vakbeweging als voor de overheid voor de hand om, op basis van gemeenschappelijke belangen, met elkaar in overleg te treden. Een aspect dat hierbij niet uit het oog mag worden verloren is dat de vakbeweging over het organisatorische potentieel beschikt om de werknemers te mobiliseren ter ondersteuning van een politieke (regerings)partij die oog heeft voor hun belangen.

Kan de logica van politieke actie dus tot op zekere hoogte worden gekenschetst als een universele wetmatigheid, in Latijns Amerika heeft de nauwe verstrengeling tussen vakbeweging en politiek een extra krachtige impuls gekregen onder invloed van economische en politieke factoren. Binnen het bestek van een inleiding moet worden volstaan met een globale schets. In Latijns Amerika zijn staat en vakbeweging tot elkaar veroordeeld geweest. Vanuit het perspectief van de vakbeweging is de toenadering tot de staat of politieke partijen een negatieve keuze geweest. In het licht van een grote arbeidsreserve die het gevolg was van de co-existentie van en onvolledige integratie tussen moderne en traditionele economische sectoren, was de onderhandelingspositie van werknemers en vakbonden ten opzichte van werkgevers doorgaans zwak. Noodgedwongen richtten de vakbonden zich met hun eisen tot politieke partijen en de staat.

Aan de andere kant was voor de staat, gelet op het doorgaans instabiele politieke klimaat, de politieke steun van de vakbeweging van kritiek belang. Aangezien de Latijnsamerikaanse economieën in hoge mate afhankelijk zijn van internationale economische ontwikkelingen, moesten eventuele concessies aan de vakbeweging - in ruil voor de politieke steun - echter zorgvuldig afgewogen worden tegen de eisen van een rationele economische politiek, waarbij rekening werd gehouden met internationale ontwikkelingen. Vooral de dreiging van een hoge inflatie, een chronische kwaal in Latijns Amerika, maakte de regering dikwijls terughoudend om al te snel aan vakbondseisen tegemoet te komen.

De relatie van wederzijdse afhankelijkheid is de aanleiding geweest tot het ontplooien van specifieke strategieën. De vakbeweging trachtte de autoriteiten te bewegen tot het inwilligen van vakbondseisen, waarbij de belofte van politieke steun werd afgewisseld door de dreiging met sociale onrust. Deze strategie heeft in de literatuur een zekere vermaardheid verkregen onder de term "political bargaining"."

De staat streefde er daarentegen naar om de vakbeweging als politieke machtsfactor te neutraliseren. De belangrijkste overweging die aan deze opzet ten grondslag lag, was waarschijnlijk dat inwilliging van vakbondseisen weliswaar op korte termijn de vakbeweging zou apaiseren, maar op de langere duur, door middel van het inflatie-mechanisme, wederom tot sociale onrust zou leiden. Bij het ontwikkelen van een vakbondspolitiek zagen de 
autoriteiten zich dan ook geplaatst voor het moeilijke vraagstuk om de broodnodige politieke steun van de vakbeweging te behouden en tegelijkertijd de handen vrij te houden voor het voeren van een economische politiek die dikwijls niet in het voordeel was van de vakbeweging. Waar deze doelstellingen niet te verenigen waren, was het in ieder geval zaak om sociale wrijving te beperken. De technieken die de autoriteiten hebben toegepast om de vakbeweging te stroomlijnen naar de eigen politieke behoeften, hebben de weg geplaveid voor schendingen van vakbondsrechten.

\section{Repressie en Controle}

Globaal genomen zijn "repressie" en "controle" de twee belangrijkste manifestaties van de Latijnsamerikaanse vakbondspolitiek.

Repressie is doorgaans de reactie op een conflict tussen staat en vakbeweging en vindt dan ook meestal plaats in het kader van een gepolariseerde verhouding tussen beide. Indien repressie het patroon van een vakbondspolitiek bepaalt, draagt zij dikwijls enkele opvallende kenmerken. Een repressief bewind pleegt op grote schaal "ernstige" inbreuken op vakbondsrechten, zoals ontbinding van vakbonden of diskwalificatie van (onafhankelijke) vakbondsleiders. Daarbij vinden meestal ook schendingen van andere rechten van de mens plaats, zoals arrestatie en detentie zonder vorm van proces, mogelijkerwijs folteringen of "verdwijningen". In de Latijnsamerikaanse context is het opmerkelijk dat de autoriteiten repressief optreden voorstellen als een gerechtvaardigde sanctie op politieke grensoverschrijdingen van de kant van de vakbeweging.

In tegenstelling tot een repressief bewind, onderhouden regeringen die controle uitoefenen (ogenschijnljk) harmonieuze betrekkingen met een vakbeweging. Tot op zekere hoogte is controle geworteld in een convergentie van belangen, waarbij de vakbeweging in ruil voor politieke steun sociaal-economische voordelen verkrijgt. Een wezenlijke component van controle als overheersingsstrategie is evenwel dat de autoriteiten de actieradius van de vakbeweging vaststellen en tevens bepalen in hoeverre sociaal/economische eisen als politiek wisselgeld wel of niet worden ingewilligd.

Om de gedachten te bepalen is het nuttig enige kenmerken van politieke controle te noemen. Allereerst komt controle dikwijls tot uitdrukking in een organisatorische vervlechting tussen een regeringspartij en één of meer vakcentrales. De gecontroleerde vakcentrale(s) genieten daarbij min of meer een monopoliepositie. Een derde kenmerk is dat controle meestal indirect of trapsgewijs wordt uitgeoefend: het vakbondskader maakt deel uit van het politieke "establishment" en draagt er zorg voor dat de vakbondseisen stroken met de economische politiek van de overheid. Directe interventie van de kant van de autoriteiten neemt dikwijls de vorm aan van het instellen van (verplichte) conciliatie- en arbitrageprocedures die arbeidsconflicten in de kiem moeten smoren. 
Het zojuist geschetste, nogal impressionistische beeld van de dichotomie tussen repressie en controle suggereert een tegenstelling tussen beide tactieken en is in zoverre dan ook een simplificatie van de werkelijkheid. Controle en repressie liggen in elkaars verlengde; zij worden naast elkaar of, liever gezegd, complementair toegepast. Waar het ondergeschikt maken van de vakbeweging aan politieke doeleinden bereikt kan worden zonder conflicten, zal de staat een voorkeur hebben voor controle. Indien segmenten van de vakbeweging zich niet (langer) de controle laten welgevallen zullen de autoriteiten mogelijk hun toevlucht moeten zoeken tot selectieve repressie. In deze voorstelling van zaken is repressie een tweede keuze, een gelegenheidsoplossing. ${ }^{3}$ Controle is geen reële optie in landen waar de gehele vakbeweging streeft naar onafhankelijkheid en zich verzet tegen een regeringspolitiek die te weinig rekening houdt met haar belangen. Een dergelijke situatie is een ideale voedingsbodem voor conflicten tussen staat en vakbeweging en effent de weg voor repressie.

Ondanks het feit dat repressie en controle alternatief en complementair worden toegepast, wil ik in deze studie aantonen dat de vakbondspolitiek in sommige Latijnsamerikaanse staten in overwegende mate "repressief" is, terwijl in andere staten politieke controle de overhand heeft.

\section{Verantwoording van de keuze der landen}

Bij de keuze van de landen heb ik mij laten leiden door de vraag in welke landen karakteristieke repressie- en controle-patronen tot ontwikkeling zijn gekomen. Een complicerende factor bij deze selectie is dat de verhouding tussen staat en vakbeweging doorgaans geen statisch gegeven is, maar in de loop der jaren aan verandering onderhevig kan zijn. Bovendien doet zich het probleem voor dat de vakbeweging zelden een monoliet is, maar veeleer een conglomeraat van diverse organisaties en stromingen die hun eigen specifieke betrekkingen onderhouden met politieke partijen of autoriteiten. Indien we er ons van bewust zijn dat bij elke weergave van de vakbondssituatie in een land tot op zekere hoogte geabstraheerd moet worden van dergelijke variabelen, kunnen we enkele algemene lijnen schetsen.

De vakbeweging in Chili heeft immer in nauwe relatie gestaan tot links-georiënteerde politieke partijen en kent een lange traditie van strijdbare autonomie ten opzichte van de autoriteiten. Met een zekere regelmaat heeft de vakbeweging voor deze militante opstelling

Alan Amgell heeft met betrekking tot de Latijnsamerikaanse vakbondssituatie "repressie" gekenmerkt als een minder efficiënt wapen achter de hand om de vakbeweging in bedwang te houden: "Apart from open attempts to regulate labour, governments do not hesitate to employ other methods. The most notorious is that of repression and instances are sadly too frequent of labour leaders removed from office, deported or even assassinated in the interests of 'national security'. However, it may be questioned whether this is as effective a method of "control" as co-optation of labour leaders by a system of patronage and comuption and of unionists by an extensive system of govemment social welfare schemes." (cursivering HvdW) Angell A. Trade Unians in Latin America in: Collier S. Blakemore H. and Skidmore Th.E. (eds.) The Cambridge Encyclopedia of Latin America and the Carribean, Cambridge 1985, p. 327. 
een tol moeten betalen, doordat de regering haar beantwoordde met harde repressie. Wat dit betreft ligt de vakbondspolitiek van de regering-Pinochet nog vers in het geheugen.

Mexico bevindt zich aan het andere uiteinde op het continuüm repressie-controle. In geen enkel ander Latijnsamerikaans land heeft politieke controle over de vakbeweging zo lang stand kunnen houden als juist in Mexico. Waar de belangrijkste vakcentrale, de CTM, tot op de dag van vandaag deel uitmaakt van de regeringspartij, heeft de controle een geïnstitutionaliseerd karakter. Hoewel er aanwijzingen zijn dat de controle aan erosie onderhevig is, behoort de nauwe vervlechting tussen staat en vakbeweging nog niet tot het verleden.

Colombia tenslotte neemt een interessante tussenpositie in. Staatscontrole over de vakbeweging manifesteerde zich na de Tweede Wereldoorlog in wetgeving die de uitoefening van vakbondsrechten begrensde. Binnen dit kader konden vakorganisaties relatief onafhankelijk van de staat opereren door met werkgevers(organisaties) over de arbeidsvoorwaarden te onderhandelen. In dit opzicht is de Colombiaanse vakbeweging dan ook a-typisch voor Latijns Amerika. Zodra de vakbeweging in de loop van de jaren zeventig politieke expressie begon te geven aan haar eisen, kwam zij in conflict met de autoriteiten die (gematigd) repressief reageerden. De ontwikkeling van de vakbondssituatie in Colombia toont het complementaire karakter van controle en repressie aan.

\section{Probleemstelling}

Na deze voorzichtige terreinverkenningen is het mogelijk om de - gelaagde - probleemstelling te formuleren. Allereerst wil ik in deze studie onderzoeken of de ILO de beschreven repressieen controlepatronen aanmerkt als schendingen van vakbondsrechten.

De probleemstelling is neutraal geformuleerd, maar maskeert een meer "gekleurde" hypothese. Het lijkt mij aannemelijk dat de ILO een repressieve vakbondspolitiek betrekkelijk eenvoudig zal kunnen herkennen en zal kunnen kwalificeren als schending van vakbondsrechten. De ILO zal daarentegen aanzienlijk meer moeite hebben om politieke controle over een vakbeweging te onderkennen, laat staan dat zij die controle zal interpreteren als een inbreuk op de vrijheid van vakvereniging.

Voor een goed begrip van het in deze hypothese gemaakte onderscheid, is het noodzakelijk om in het kort liets te zeggen over de voornaamste kenbronnen van de ILO. De ILO pleegt haar uitspraken te baseren op de bestudering varn wetgeving en op de beoordeling van klachten over schending van vakbondsrechten. In geval van repressie openbaart zich een conflict tussen staat en vakbond. De repressie zal dikwijls aanleiding zijn tot het indienen van een klacht. Aan de hand van de klacht kan de ILO beoordelen of de autoriteiten zich schuldig hebben gemaakt aan een schending van vakbondsrechten, dan wel uitsluitend de overschrijding van de eigen bevoegdhedensfeer door de vakbond gecorrigeerd hebben. De uitkomst van deze afweging hangt uiteraard samen met de concrete toedracht van het conflict en wordt bovendien beïnvloed door het standpunt van de ILO inzake de toelaatbaarheid van het ontplooien van 
politieke activiteiten door de vakbeweging. Een groot aantal klachten over stelselmatige en ernstige inperkingen van de vakverenigingsvrijheid zal de ILO eerder tot de slotsom brengen dat de autoriteiten het opleggen van administratieve en strafrechtelijke sancties wegens illegale vakbondsactiviteiten als alibi hanteren om de vakbeweging te ontmantelen.

Uit de definitie van politieke controle vloeit al voort dat klachten uit de gelederen van een efficiënt gecontroleerde vakbeweging niet verwacht mogen worden. Vooralsnog kunnen we daarbij in het midden laten of deze afwezigheid van klachten toe te schrijven is aan vrees voor repressie, apathie of instemming met de controle. Incidentele klachten vormen een aanwijzing dat de controle geen, of althans niet voldoende succes sorteert. Om het fenomeen van politieke controle op het spoor te komen, is de ILO afhankelijk van deze klachten en eventueel van wetgeving, waarbij overigens onmiddellijk moet worden aangetekend dat controle niet altijd in wetgeving verankerd hoeft te zijn.

Niet alleen wat betreft de hoeveelheid (bewijs)materiaal, maar ook in kwalitatief opzicht onderscheidt controle zich van repressie. In tegenstelling tot repressie is er bij controle niet zozeer sprake van een verbod op het uitoefenen van vakbondsrechten, maar veeleer van een inperking van vakbondsactiviteiten. Vakbonden mogen functioneren binnen bepaalde marges die door de autoriteiten gesteld zijn. Voorlopig is het nog een open vraag of de ILO dergelijke marges die in sporadische klachten worden aangevochten en die mogelijk in wetgeving zijn aangegeven, in het licht van de internationale normen op het gebied van de vrijheid van vakvereniging al dan niet toelaatbaar acht.

Men zal zich wellicht inmiddels in gemoede afvragen of ik geen spoken zie. Moet de conclusie niet simpelweg luiden dat controle geen schending van de vrijheid van vakvereniging oplevert, indien de meerderheid van de vakbeweging zich er niet over beklaagt en indien de ILO geen termen aanwezig acht om, op basis van spaarzame klachten en wetgeving, tot de slotsom te komen dat de vrijheid van vakvereniging in het geding is? Die conclusie is mogelijk maar niet dwingend. Allereerst is het prematuur on te veronderstellen dat de ILO controle niet aanmerkt als een schending van vakverenigingsvrijheid. De mogelijkheid is geopperd maar zij moet nog grondig onderzocht worden. In de tweede plaats wil ik trachten aan te tonen dat bepaalde maatregelen die door de autoriteiten in het kader van een controlepolitiek genomen worden, in strijd zijn met de vrijheid van vakvereniging, ongeacht of de toezichthoudende organen van de ILO die maatregelen ook als zodanig kwalificeren.

Bovenstaande bespiegelingen voeren tot de tweede "laag" van de probleemstelling. Uiteindelijk beoog ik met deze studie uitsluitsel te krijgen over de vraag of de ILO-normen en toezichtsmechanismen op het gebied van de vrijheid van vakvereniging toereikend zijn om "controle" te kwalificeren als een schending van de vrijheid van vakvereniging. 
De hierboven ontwouwde visie op de specifieke betrekkingen tussen staat en vakbeweging in Latijns Amerika ontleen ik aan politicologische en historische studies over Latijns Amerika. Aangezien deze visie het referentiekader vormt van mijn gehele onderzoek, is het uiteraard van belang om de verhouding tussen staat en vakbeweging in Latijns Amerika uitvoerig te beschrijven en te verklaren tegen de achtergrond van economische en politieke ontwikkelingen. Tegelijkertijd moet worden benadrukt dat ik geen empirisch onderzoek heb verricht om deze visie op haar validiteit te toetsen. Het gevaar dat een analyse van de verhouding tussen staat en vakbeweging in Latijns Amerika uitmondt in grove generalisaties die de werkelijkheid geweld aandoen, is dan ook geenszins denkbeeldig. Dit gevaar kan althans in enige mate bezworen worden door de doelstellingen te beperken. Zo acht ik het fenomeen van de gepolitiseerde vakbeweging tot op zekere hoogte kenmerkend voor geheel Latijns Amerika en in het algemene hoofdstuk over staat en vakbeweging in Latijns Amerika zal het onderzoek zich dan ook toespitsen op een verklaring van dit fenomeen. Hoe deze politisering van de vakbeweging vervolgens is uitgekristalliseerd in een repressieve of controlerende vakbondspolitiek, zal nader onderzocht worden in de hoofdstukken over Chili, Colombia en Mexico. Hoewel er sterke aanwijzingen zijn dat ook regeringen in andere Latijnsamerikaanse landen gebruik hebben gemaakt van repressie- en controlemechanismen, ligt het niet in mijn bedoeling om de vakbondssituatie in deze landen uitvoerig te behandelen.

In de drie hoofdstukken over Chili, Colombia en Mexico wordt de historisch/politicologische verhandeling telkens gevolgd door een juridische analyse van de uitspraken van de ILO. Deels zijn de analyses vanuit de optiek der verschillende vakgebieden overigens met elkaar vervlochten. Bij de juridische analyse ligt het accent op de titspraken van het ILOComite inzake de Vrijheid van Vakvereniging dat in het kader van de speciale toezichtsprocedure voor de vrijheid van vakvereniging belast is met het onderzoek en de beoordeling van klachten van werkgevers- en werknemersorganisaties. Naast deze speciale procedure kent de ILO een algemene rapportage-procedure, waarbij staten verplicht zijn om regelmatig te rapporteren in hoeverre wetgeving en rechtspraktijk overeenstemmen met geratificeerde ILO-Verdragen. Ook deze rapporten en het commentaar daarop van het Comité van Onafhankelijke Deskundigen zullen aan een nader onderzoek worden onderworpen.

Nu deze studie draait om de verhouding tussen staat en vakbeweging, staat met name ILO-Conventie no. 87 inzake de Vrijheid van Vereniging en het Recht om zich te Organiseren centraal. Deze Conventie beoogt namelijk de vrijheid van vakvereniging te beschermen tegen inbreuken van de autoriteiten. Het andere belangrijke instrument, Conventie no. 98 inzake de Vrijheid van Organisatie en Collectieve Onderhandelingen, heeft hoofdzakelijk tot oogmerk om vakbonden te vrijwaren tegen de aanvallen van werkgevers(organisaties). De bepalingen van dit verdrag zijn in het kader van deze studie van belang, voorzover inbreuken op de vrijheid van vakvereniging zijn aan te merken als het produkt van samenspanning tussen staat en werkgevers. 
Het chronologisch beginpunt van de juridische analyse zal wan land tot land verschillen. Primair wordt het gezamenlijke beginpunt bepaald door de datum van de totstandkoming van de Conventies -Verdrag no. 87 dateert uit 1948, Verdrag no. 98 uit 1949 - en van de speciale toezichtsprocedure (1950). Lid-staten van de ILO zijn namelijk onderworpen aan de "jurisdictie" van het Comite inzake de Vrijheid van Vakvereniging, ongeacht de vraag of zij de relevante Verdragen al dan niet geratificeerd hebben. Ratificatie leidt tot de staatsverplichting om regelmatig te rapporteren, zodat de uitspraken van het Comite van Onafhankelijke Deskundigen met betrekking tot Mexico reeds vanaf 1950 (jaar van ratificatie van Conventie no. 87 door Mexico) beschikbaar zijn, terwijl Colombia pas in 1976 zowel Conventie no. 87 als Conventie no. 98 geratificeerd heeft. De afwijkende behandeling van de vakbondssituatie in Chili kan verklaard worden uit mijn oogmerk om, aan de hand van een analyse van de vakbondspolitiek van het regime-Pinochet, te illustreren hoe de ILO reageert op een bij uitstek repressieve benadering van de vakbeweging. De juridische component van het hoofdstuk over Chili beslaat dan ook uitshitend de periode $1973-1990$.

Een enkel woord zou ik tenslotte nog willen wijden aan de implicaties van de keuze voor de ILO. Het overheersende accent dat in deze studie gelegd wordt op de uitspraken van de ILO, is mijns inziens legitiem in het licht van de overweging dat geen enkele andere internationale organisatie de betekenis en de draagwijdte van de vrijheid van vakvereniging zo verfijnd en geconcretiseerd heeft. In de landen-hoofdstukken zal hier en daar worden gerefereerd aan uitspraken van andere internationale organisaties, zoals de Verenigde Naties en de Organisatie van Amerikaanse Staten. Bovendien zal in het laatste hoofdstuk incidenteel aandacht geschonken worden aan uitspraken van nationale rechters. De functie van deze verwijzingen is om de uitspraken van de ILO nader te duiden. Met opzet heb ik afgezien van een systematische vergelijkende analyse, aangezien een dergelijke exercitie naar mijn mening afbreuk zou doen aan de bijzondere verdiensten van de ILO op het terrein van de vrijheid van vakvereniging.

\section{Hoofdstukindeling}

Deze studie opent in hoofdstuk 1 met een algemene inventarisatie van ILO-uitspraken die betrekking hebben op repressie- en controle-patronen in de verhouding tussen staat en vakbeweging. Meer specifiek beoog ik tweeërlei. Enerzijds wil ik nagaan welke maatstaven de ILO aanlegt bij de beoordeling van politiek getinte conflicten die de aanleiding vormen tot het uitoefenen van repressie door de autoriteiten.

Anderzijds wil ik concreet aangeven wan welke instrumenten regeringen gebruik maken om controle uit te oefenen over een vakbeweging en onderzoeken hoe de ILO deze instrumenten in het licht van haar normen waardeert.

Hoofdstuk 2 bevat de historisch/politieke analyse van de ontwikkeling in de verhouding tussen staat en vakbeweging in Latijns Amerika. In de literatuur bestaat een tamelijk grote 
mate van eensgezindheid met betrekking tot de conceptie dat de gefaseerde integratie van Latijns-Amerika in de wereldeconomie telkens tot ingrijpende politieke veranderingen heeft geleid. Het ligt in mijn bedoeling aan te tonen dat deze veranderingen de relatie tussen staat en vakbeweging diepgaand beïnvloed hebben.

In de hoofdstukken 3 tot en met 5 staat de vakbondssituatie in resp. Chili, Colombia en Mexico centraal. Deze hoofdstukken vormen het "corpus" van mijn dissertatie. Hier vindt de confrontatie plaats tussen de ILO en de drie landen. Hier zullen de ILO-normen tot leven komen en een specifieke betekenis krijgen tegen de achtergrond van concrete verhoudingen tussen staat en vakbeweging. Aan de hand van deze analyses verwacht ik uitsluitsel te krijgen over de hierboven opgeworpen vraagstelling en hypotheses.

Hoofdstuk 6 vormt de synthese van de voorgaande hoofdstukken. In dit hoofdstuk zal ik bepaalde onderwerpen die in de verscheidene landen-hoofdstukken aan de orde zijn gekomen, in vergelijkend perspectief behandelen. Daarbij zal ik trachten om eventuele knelpunten en inconsistenties in de jurisprudentie van de ILO, waarop ik bij de analyse van de uitspraken ben gestuit, te verklaren in het licht van de opvattingen van de ILO met betrekking tot de vrijheid van vakvereniging. Speciale aandacht zal daarbij geschonken worden aan de vraag hoe de tripartiete organisatiestructuur die opvattingen heeft beïnvloed. 



\section{De politieke dimensie van de vrijheid van vakvereniging}

Een inventarisatie van de uitspraken van de Internationale Arbeidsorganisatie over de verhouding tussen staat en vakbeweging

\section{$1 \quad$ Inleiding}

Zoals in de inleiding is aangegeven, beoog ik in deze studie te onderzoeken hoe de ILO oordeelt over de vakbondssituatie in Chili, Colombia en Mexico. Om mu enig inzicht te verkrijgen in de vraag hoe de uitspraken van de ILO met betrekking tot deze drie landen zich verhouden tot de algemene jurisprudentie van de ILO, zal in dit hoofdstuk geïnventariseerd worden hoe de ILO oordeelt over "repressie" en "controle".

Bij een dergelijke inventarisatie is een kanttekening op haar plaats. Men dient zich ervan bewust te zijn dat de ILO over het algemeen geen oordeel uitspreekt over een algehele vakbondspolitiek. De toezichthoudende organen van de ILO verifiëren of concrete wetgeving of rechtspraktijk in overeenstemming is met de ILO-normen op het gebied van de vrijheid van vakvereniging. Anticiperend op de analyses van de vakbondssituatie in Latijns Amerika, zullen dus instrumenten en matregelen worden geselecteerd die kenmerkend zijn voor een repressieve of controlerende vakbondspolitiek en zal worden nagegaan hoe de ILO deze concrete instrumenten beoordeelt. Aan de hand van een "collage" van de ILO-standpunten kunnen we dan een indruk krijgen hoe de ILO denkt over repressieve of controlerende vakbondspolitiek in het algemeen.

Nu de ILO in deze studie zo'n prominente plaats inneemt, zal eerst in 2 een korte kennismaking worden gearrangeerd, waarbij het accent zal liggen op de relatie tussen de ILO en de vrijheid van vakvereniging. De uitweidingen in 3 over de universaliteit van het recht van vakverenigingsvrijheid dienen een specifiek doel. Pas nadat is vastgesteld of, en zo ja, in hoeverre de ILO van mening is dat de vrijheid van vakvereniging universele gelding heeft, kunnen we ervan uitgaan dat de in dit hoofdstuk ontvouwde standpunten van overeenkomstige toepassing zijn op de drie landen.

De analyse van de ILO-uitspraken in 4 tot en met 6 vormt het "pièce de résistance" van dit hoofdstuk. Zoals gezegd, wordt de repressie-controle-dichotomie tot leidraad genomen. Waar, althans in Latijns Amerika, repressie dikwijls het staatsantwoord is op ongewenste politieke actie van de kant van de vakbeweging, zal in 4 het politieke conflict tussen staat en vakbeweging centraal staan.

Politieke activiteiten van de vakbeweging hebben de ILO immer veel hoofdbrekens bezorgd. Het dilemma, waarvoor de ILO zich geplaatst zag (en ziet) bij het innemen van een standpunt 
terzake van de toelaatbaarheid van politieke activiteiten van de vakbeweging, kan als volgt geschetst worden. Aan de ene kant kan men zich afvragen of en in hoeverre vakbonden nog aanspraak kunnen maken op bescherming van hun rechten, indien zij hun bevoegdheden te buiten gaan door zich (te veel) in te laten met politiek. Aan de andere kant zal de staat soms inbreuken op vakbondsrechten proberen te rechtvaardigen met het excuus dat de vakbond in kwestie politieke activiteiten heeft ontplooid, terwijl het voeren van politieke actie dikwijls een onvermijdelijk onderdeel is van vakbondsactiviteiten.' De ILO zal nauwkeurig de grenzen moeten bepalen, waarbinnen vakbonden politieke activiteiten mogen ontplooien, teneinde te kunnen beoordelen of, in geval van een conflictsituatie, de staat dan wel de vakbeweging de eigen bevoegdhedensfeer heeft overschreden.

In 5 en 6 verschuift de aandacht naar controle. Intensieve contacten tussen staat en vakbeweging hoeven immers niet gepaard te gaan met conflicten, indien beide partijen tot op zekere hoogte gebaat zijn bij een goede samenwerking. Gezien de ongelijke machtsverhouding tussen staat en vakbeweging en het feit dat zij, naar hun aard, verschillende doelstellingen nastreven, bergen al te innige betrekkingen tussen staat en vakbeweging het gevaar van controle en overheersing in zich. ${ }^{2}$

Het meest wezenlijke kenmerk van een dergelijke verhouding is dat de vrijheid van de vakbeweging om, ter vervulling van haar taken, middelen en doelen te kiezen, beperkt is en dat de manoeuvreerruimte van de vakbeweging bepaald wordt door de staat. In beginsel kunnen twee motieven ten grondslag liggen aan pogingen van de staat om de vakbeweging te controleren. In de eerste plaats kan de staat zijn legitimatie wensen te versterken door zich te verzekeren van de morele en politieke steun van (een gedeeite van) de arbeidersklasse. In de tweede plaats kan de staat een vaste greep op de loonontwikkeling willen houden met het oog op, bijwoorbeeld, de beteugeling van de inflatie of de versterking van de concurrentiepositie ten opzichte van het buitenland. ${ }^{3}$

Binnen een structurele controle-politiek ten aanzien van de vakbeweging kan onderscheid gemaakt worden tussen twee categorieën maatregelen. ${ }^{4}$ Enerzijds kan een staat door het

1. Zie hierover: Crouch C. Trade Unions: The Logic of Collective Action , Glasgow 1982. Met name Chapter 6 "The Inevitability of Politics".

2 In zjjn bijdrage aan de bundel "Comparative Labour Law and Industrial Relations" Ed. R. Blanplain; Deventer 1987, wijst $\mathbf{J}$. Schregle op de neiging van regeringen wan ontwikkelingslanden om aan de ene kant de oprichting van vakbonden te stimuleren, maar aan de andere kant deze te controleren, met het oog op de verwezenlijking van nationale ontwikkelingsplannen. Schregle J. Labour Law and Industrial Relations ist the Third World, a.w. p. 59 .

3 Natuurlijk kunnen beide doelstellingen samenvloeien en tegelijkertijd werwezenlijkt worden, indien de staat erin slaagt om bij de vakbondsleden de suggestie te wekken dat een bepaalde positieverbetering het hoogst haalbare is en dlat zij deze verbetering aan de inspanningen van de staat te danken hebben.

4 In zajin verhandeling over de vakbeweging in Latijns Amerika brengt Alan Angell dit muttige onderscheid aan. Angell A. "Trade Unions in Latin America" in: Collier 5 , Blakemore $\mathbf{H}$. and Skidmore Th.E. (eds.) The Cambridge Encychopedia of Latin America and the Camibean, Cambridge 1985, p. 327. 
uitoefenen van toezicht en door zich te mengen in interne vakbondsaangelegenheden, zich er direct van verzekeren dat vakbondsactiviteiten stroken met de regeringspolitiek. In $5 \mathrm{zal}$ onderzocht worden hoe de toezichtsorganen van de ILO in het licht van de beginselen van vrijheid van vakvereniging oordelen over dergelijke controle-maatregelen.

Anderzijds kan de staat een organisatiestructuur in het leven roepen die hetzij de vakbeweging als politieke en sociaal/economische machtsgroepering in hoge mate verzwakt, hetzij de staat in de gelegenheid stelt om de vakbeweging volledig in te kapselen. Deze diametraal tegenover ellkaar staande strategieèn en de reactie van de ILO dienaangaande vormen het onderwerp van 6.

In 7 tenslotte, zal ik proberen een synthese te geven van de standpunten van de ILO inzake het heikele vraagstuk van de politieke verhouding tussen staat en vakbeweging in al haar facetten.

\section{De Intermationale Arbeidsorganisatie en de vrijheid van vakvereniging}

De Internationale Arbeidsorganisatie zag het licht in 1919. Het Statuut dat de oprichting van de ILO bezegelde, maakte deel uit van het Vredesverdrag van Versailles. Door het Verdrag te ondertekenen, traden staten zowel toe tot de Volkenbond als tot de ILO. Deze automatische koppeling was de vrucht van het groeiende inzicht dat internationale vrede gegrondvest diende te zijn in sociale rechtvaardigheid. ${ }^{5}$

Na de Tweede Wereldoorlog trad de ILO in 1946 als eerste gespecialiseerde organisatie toe tot de Verenigde Naties. De automatische koppeling tussen beide organisaties werd evenwel niet voortgezet.

\subsection{Het institutionele kader}

Het beginsel van de tripartiete vertegenwoordiging doortrekt als een zuurdesem de organisatiestructuur van de ILO. Zo vaardigt elke lid-staat van de ILO jaarlijks naar de Internationale Arbeidsconferentie (ILC) een delegatie af die bestaat uit twee regeringsvertegenwoordigers, éen vertegenwoordiger van werkgevers(organisaties) en één vertegenwoordiger van "werknemers(organisaties). De werknemers- en werkgeversvertegenwoordigets

Het spreekt vanzelf dat een regering deze maatregelen niet alternatief maar juist naast elkaar zal treffen om een valbeweging te controleren.

5 Een andere belangrijke drijfveer woor de oprichting van de ILO was de overweging dat statten, met het oog op de internationale concurrentie, eerder geneigd zouden zijn om, op het terrein van de arbeidswetgeving, bepaalde minimum-verplichtingen te aanvaarden, indien andere staten tot hetzelfde gehouden zouden zijm. Vgl. Valticos N. Intemational Labour Law, Deventer 1979, p. 21-23.

Bovendien wordt de oprichting van de ILO wel gekenschetst als een poging on de groeiende invloed van het communisme een halt toe te roepen. 
worden "benoemd in overeenstemming met de meest representatieve werkgevers- en werknemersorganisaties, indien deze in het land bestaan". "Veruit de belangrijkste taak van de ILC is het opstellen en aannemen van internationale arbeidsnormen die, naar gelang de ILC van mening is dat deze normen staten al dan niet moeten binden, worden gegoten in het vat van een Conventie of van een Aanbeveling. Een Conventie of Aanbeveling wordt aangenomen, indien tweederde van de leden er vór stemt. Werkgevers- en werknemersvertegenwoordigers stemmen zonder last van of ruggespraak met hun regering?

Naast deze regelgevende bevoegdheid, omvat de taak van de ILC ook onder andere nog het toezien op de naleving van bestaande internationale arbeidsnormen, het goedkeuren van de begroting, het toelaten van nieuwe leden tot de organisatie en het amenderen van het Statuut. De wetgevende arbeid van de ILC kan moeilijk overschat worden. Sinds 1919 heeft de Conferentie meer dan 170 Conventies aangenomen die betrekking hebben op diverse onderwerpen, zoals werkgelegenheid, sociale zekerheid, bescherming van vrouwen en kinderen tegen uitputtende arbeidsomstandigheden en vrijheid van wakvereniging.

Een ander belangrijk orgaan van de ILO dat eveneens tripartiet is samengesteld, is de Raad van Beheer. De 56 leden van de Raad worden om de drie jaar door de ILC gekozen, conform de volgende verdeelsleutel: de helft van de leden wordt gekozen door en uit de regeringsvertegenwoordigers, 14 leden door en uit de afgevaardigden van werknemers en 14 door en uit de vertegenwoordigers van werkgevers. Tien van de regeringszetels zijn permanent gereserveerd voor de belangrijkste industriële landen. ${ }^{8}$

De Raad van Beheer fungeert als een soort trechter voor de ILC: hij convoceert de vergaderingen van de ILC, bepaalt welke kwesties ter Conferentie aan de orde zullen komen en stelt op grond van deze keuze de agenda van de Conferentie vast. Bovendien heeft de Raad de supervisie over de naleving van geratificeerde verdragen. Gezien het feit dat de taak van de Raad in de loop der jaren zeer omvangrijk is geworden, zijn verscheidene werkzaamheden gedelegeerd aan commissies van de Raad. Eén van de belangrijkste dezer commissies is het Comité inzake de Vrijheid van Vakvereniging dat in deze studie zo'n vooraanstaande plaats inneemt.

Het Internationale Arbeidsbureau is het secretariaat van de ILO. Het Bureau verzorgt het documentatiemateriaal voor de ILC en de Raad van Beheer, teneinde hun wetgevende en toezichthoudende werkzaamheden te vergemakkelijken. Bovendien verleent het administratieve en juridische assistentie aan staten bij de implementatie van verdragen en aanbevelingen.

6. Vgl. art. 3, lid 5 van het ILO-Statuut.

7 ILO-Statuut, art. 4, lid 1.

8 Het ligt overigens in de bedoeling om de bevoorrechte positie van de industriële landen af te schaffen. Volgens de plannen zal de nieuwe Raad van Beheer bestaan wit 108 leden, in de werhouding 54:27:27, waarbij rekening gehouden zal worden met een evenwichtige verdeling tussen vier regio's (Afrika, Amerika, Azië en Europa). 
In het kader van deze studie is het vermeldenswaardig dat het Bureau fungeert als postadres voor het indienen van klachten wegens de schending van vakbondsrechten.

Aan het hoofd van het Bureau staat een Directeur Generaal. Het Internationale Arbeidsbureau bestaat voorts uit onafhankelijke deskundigen, hetgeen niet zo verwonderlijk is in het licht van het niet-politieke karakter van de werkzaamheden van het Bureau.

\subsection{Normstelling op het gebied van de vrijheid van vakvereniging}

Gezien de grote betekenis die de ILO toekent aan de vrijheid van vakvereniging, zal het wellicht enige verwondering wekken dat de ILC pas na de Tweede Wereldoorlog de belangrijke Conventies op het gebied van de vrijheid van vakvereniging heeft aangenomen. Weliswaar refereerde het Verdrag van Versailles al aan "het recht van vereniging tot alle wettige doeleinden, zowel voor werknemers als voor ondernemers" $\left({ }^{(}\right)$, maar de nadere uitwerking van het beginsel werd merkwaardig genoeg vooral gedwarsboomd door werknemerswertegen-

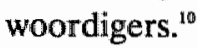

De Philadelphia-Verklaring van 10 mei 1944 die de fundamentele beginselen van de ILO opnieuw bevestigde en, sinds haar totstandkoming, integraal deel uitmaakt van de Preambule van het ILO-Statuut, gaf de aanzet tot nieuwe inspanningen om de vrijheid van vakvereniging in een verdrag te regelen. In deze Verklaring worden vrijheid van meningsuiting en vrijheid van vereniging gekenschetst als wezenlijke voorwaarden voor gestadige vooruitgang. In 1947 besprak de ILC, op aandringen van de Economische en Sociale Raad van de VN (ECOSOC), de problematiek van de vrijheid van vakvereniging. Het jaar daarop nam de ILC de Conventie inzake de vrijheid van vakvereniging en de bescherming van het recht op organisatie (no. 87) aan, terwijl in 1949 de Conventie betreffende de toepassing van het recht zich te organiseren en collectief te onderhandelen (no. 98) tot stand kwam. Aangezien beide Conventies, met name no. 87 , in deze studie nog uitgebreid aan de orde komen, wil ik hier volstaan met een korte weergave wan de inhoud."

De essentie van de vrijheid van vakvereniging komt onmiddellijk tot uitdrukking in art. 2 van Conventie no. 87 dat werknemers en werkgevers, zonder enig onderscheid en zonder voorafgaande goedkeuring van de autoriteiten, het recht toekent om vakorganisaties op te richten en er vrijelijk lid van te worden. Art. 3 somt vervolgens de bevoegdheden van deze organisaties op: het opstellen van statuten en reglementen, de vrije verkiezing van de eigen

9 Verdrag van Versailles, art. 427.

10 De weerstand van de werknemersvertegenwoordigers gold met name het voorstel om de negatieve coalitiewrijheid in een verdrag te regelen. Voorts achtten de werknemers het tijdsgewricht niet gunstig om een dergelijk belangrijk verdrag alan te nement in veel landen maakten totalitaire regimes de dienst uit. Vgl. Valticos (1979), a.w. p. 80.

11 Bovendien zijn beide Conventies als bijlagen opgenomen in dit boek. 
vertegenwoordigers en de uitoefening van activiteiten en programma"s. Het tweede lid van deze bepaling verbiedt de autoriteiten uitdrukkelijk zich in deze bevoegdheden te mengen. Art. 4 van de Conventie beoogt werknemers- en werkgeversorganisaties in bescherming te nemen tegen ontbinding of schorsing door de uitvoerende macht. De artikelen 5 tot en met 7 hebben betrekking op de mogelijkheid om federaties en vakcentrales op te richten, op het zoeken van aansluiting bij internationale organisaties en op het verkrijgen van rechtspersoonlijkheid voor vakorganisaties in het algemeen. In art. 8 wordt een Salomonsoordeel uitgesproken bij de afweging van de belangen van regeringen enerzijds en de belangen van werkgevers- en werknemersorganisaties anderzijds: tegenover de eis aan het adres van werkgevers- en werknemersorganisaties, bij de uitoefening van hun rechten de wet van het land te respecteren (lid 1); staat de verplichting van de overheid geen afbreuk te doen aan de waarborgen in dit verdrag voorzien (lid 2).

Waar art. 10 aangeeft wat onder het begrip "organisatie" in de Conventie dient te worden verstaan, bepaalt art. 11 tenslotte dat iedere verdragsstaat zich verbindt om alle noodzakelijke en geschikte maatregelen te treffen ter verzekering van het recht van werknemers en werkgevers om zich vrijelijk te organiseren.

Het slotartikel van Conventie no. 87 opent het verschiet naar Conventie no. No. 98: tijdens de beraadslagingen in de ILC die vooraf gingen aan de aanname van deze Conventie, werd overwogen dat Conventie no. 98 een gedetailleerde toepassing was van art: 11 van Conventie no. $87 .^{12}$

De strekking van beide Conventies verschilt overigens wel degelijk. Beoogt Conventie no. 87 voornamelijk werkgevers- en werknemersorganisaties te beschermen tegen een bemoeizuchtige overheid, Conventie no. 98 heeft vooral betrekking op de relatie tussen werkgever en werknemer. Zo bepaalt art. 1 van de Conventie dat werknemers toereikende bescherming dienen te genieten tegen anti-vakbondsmaatregelen in relatie tot hun werk. Een werkgever mag het lidmaatschap van een vakbond niet opvoeren als reden om een werknemer niet in dienst te nemen of hem te ontslaan. Art. 2 heeft tot oogmerk om organisaties van werknemers en werkgevers te weerhouden van inmenging in elkanders aangelegenheden. Dat op de staat overigens een verplichting rust om werkgevers en werknemers te dwingen elkaars rechten te respecteren, komt duidelijk tot uitdrukking in art. 3. De bepaling maant de autoriteiten, zo nodig, geschikte maatregelen te treffen om de vrijheid van vakorganisatie in de verhouding tussen werkgevers en werknemers te garanderen.

Zoals de naam van de Conventie al aangeeft, bevat zij tevens een regeling wan één van de meest essentiële bestaansgronden van vakorganisaties: het onderhandelen over de arbeidsvoorwaarden. Zo bepaalt art. 4 dat de overheid een gunstig klimaat moet scheppen, waarbinnen vrijwillige onderhandelingen kunnen gedijen. 


\subsection{De LOO en het toezicht op de naleving van internationale arbeidsnormen}

In de loop der jaren heeft de ILO een zeer verfijnd stelsel van toezichtsprocedures ontwikkeld dat alom faam geniet. ${ }^{13}$ Waar het verdragenrecht ervan uit gaat dat staten eerst gebonden zijn, nadat zij verdragen hebben geratificeerd, heeft de ILO in twee opzichten met dit uitgangspunt gebroken. Allereerst is elke lid-staat verplicht binnen de termijn van een jaar elke Conventie of aanbeveling voor te leggen aan de bevoegde autoriteiten (in de meeste gevallen het parlement). ${ }^{14}$ In de tweede plaats moeten staten die bepaalde verdragen niet geratificeerd hebben, op gezette tijden aan de Directeur Generaal rapporteren welke omstandigheden de bekrachtiging van die verdragen vertragen of belemmeren. Het Comite van Onafhankelijke Deskundigen inzake de Naleving van Verdragen en Aanbevelingen beoordeelt de inhoud van de rapporten. ${ }^{15}$ Beide procedures hebben uiteraard tot doel om het aantal ratificaties te vergroten.

Binnen de procedures, waaraan een staat onderworpen is, zodra hij een verdrag heeft geratificeerd, kan onderscheid worden gemaakt tussen de reguliere rapportage-procedure en de klachtenprocedures.

Krachtens art. 22 Statuut moeten staten in beginsel om de twee jaar rapporten opstellen, waarin zij aangeven welke maatregelen zij getroffen hebben om geratificeerde Conventies ten uitvoer te brengen. Het Comité van Onafhankelijke Deskundigen bestudeert de rapporten en voorziet ze van commentaar, indien het van mening is dat wetgeving of rechtspraktijk niet in overeenstemming zijn met de Conventie. Dit commentaar neemt de vorm aan van een "Observation", indien het een fundamentele discrepantie betreft, terwijl kleine oneffenheden verwerkt worden in een "Direct Request". Vervolgens worden de belangrijkste "Observations" aan een nader onderzoek onderworpen door een speciale commissie van de ILC, die op haar beurt weer een selectie maakt van commentaren die plenair worden besproken door de ILC. Al deze toezichthoudende organen kunnen aanbevelingen doen, teneinde een regering ertoe te bewegen om gesignaleerde discrepanties op te heffen.

Naast deze voortgangscontrole kent het Statuut twee klachtenprocedures. Op grond van art. 26 Statuut kan een staat een klacht indienen tegen een andere staat wegens schending van

13 Een goed owerzicht kan men vinden in: Valticos $N$. The intemational protection of economic and social rights in: Rechten wan de Mens in Mundiaal en Europees Perspectief, Ars Aequi, Nijmegen 1986, pp. $163-166$ en: International Labour Office, LLO Principles, Standards and Procedures conceming Freedom of Association, Geneva 1985.

Specifiek met betrekking tot het toezicht op de naleving wan de wrijheid van vakwereniging zijn nog van belang: Potobsky G. von, Protection of Trade wnion Rights: Twesty Years" Work by the Comnittee on Freedom of Association, I.LL.R., January 1972 , pp. $69-83 \mathrm{en:}$ Valticos. P. Les méthodes de la protection intemationale de la libenté syndicale, Rec. Cours 144, 1975-I, pp. 79-138.

14 ILO-Statuut, art. 19 , lid $5 \mathrm{~b}$ en $6 \mathrm{~b}$.

15 ILO-Statuut, art. 19, lid 5 sub e. 
een Conventie, op voorwaarde dat beide staten de Conventie in kwestie hebben geratificeerd. Ook de Raad van Beheer kan deze procedure starten, hetzij op eigen initiatief, hetzij op instigatie van een afgevaardigde bij de ILC. De Raad wan Beheer kan vervolgens een Commissie van Onderzoek, bestaande uit onafhankelijke personen, instellen die na een grondig onderzoek aanbevelingen kan doen. De betrokken staten moeten aangeven of zij deze aanbevelingen accepteren. Zo niet, dan kunnen zij de zaak voorleggen aan het Internationale Gerechtshof. ${ }^{16}$ De zogenaamde bezwaarschriftenprocedure vindt haar juridische grondslag in art. 24 en 25 van het Statuut. Werkgevers- en werknemersorganisaties kunnen bij de Raad van Beheer een bezwaarschrift indienen tegen een staat in verband met een vermeende schending van een Conventie die door de staat geratificeerd is. De Raad van Beheer legt het bezwaarschrift voor aan de staat en kan besluiten de kwestie in de publiciteit te brengen, indien de staat niet reageert of diens commentaar onbevredigend is. ${ }^{17}$

De ontwikkeling van speciale toezichtsprocedures op het terrein van de vakverenigingsvrijheid sproot voort uit de behoefte om ook staten die de sleutel-conventies niet geratificeerd hadden, te bewegen tot eerbiediging van dit fundamentele beginsel. Een gezamenlijke resolutie van de ECOSOC en de ILO in 1950 stond aan de wieg van twee hoogst belangrijke commissies.

Het zwaarste geschut is de zogenaamde Onderzoeks-en Bemiddelingscommissie inzake de Vrijheid van Vakvereniging. Deze commissie die bestaat uit negen onafhankelijke personen, kan op verzoek van de Raad van Beheer een diepgaand onderzoek instellen naar de vakbondssituatie in een land. $\mathrm{Zij}$ gaat daarbij te werk volgens een procédé dat sterke gelijkenissen vertoont met de procedure van een Commissie van Onderzoek. De Commissie hoort getuigen uit gouvernementele en uit non-gouvernementele hoek, bezoekt het land in kwestie en overlegt met de regering hoe bepaalde knelpunten verholpen kunnen worden. In het hoofdstuk over Chili zal uitvoerig worden ingegaan op de werkwijze van de Commissie.

In beginsel kan de Commissie een onderzoek instellen naar de vakbondssituatie in elke ILO-lidstaat, ongeacht of deze staat de sleutelconventies al dan niet geratificeerd heeft. Gezien het ingrijpende karakter van de procedure is evenwel de toestemming vereist van staten die de conventies niet geratificeerd hebben. Juist de weigering van een aantal landen gedurende de jaren vijftig om medewerking te verlenen aan het onderzoek, gaf het Comité inzake de Vrijheid van Vakvereniging dat oorspronkelijk uitsluitend tot taak had om te onderzoeken welke klachten voor nadere bestudering door de Onderzoeks-commissie in aanmerking kwamen, de gelegenheid om tot grote bloei te komen. Het Comité maakt deel uit van de Raad van Beheer en is dan ook tripartiet samengesteld. In tegenstelling tot de Onderzoekscommissie baseert het Comité zijn bevindingen uitsluitend op schriftelijk geformuleerde klachten en op de repliek van de aangeklaagde regering. Klachten kunnen worden ingediend door nationale werkgevers- en werknemersorganisaties die rechtstreeks belang hebben bij

16 In relatio tot de vrijheid van vakvereniging is van deze "zware" procedure driemaal gebruik gemaakt: in 1968 (Griekenland), in 1983 (Polen) en in 1991 (Nicaragua), In geen van deze gevallen werd het Internationale Gerechtshof overigens ingeschakeld.

17 Deze procedure is niet toegepast in relatie tot de vrijheid van vakvereniging. 
de aangekaarte kwestie, door internationale vakverenigingen die consultatieve status hebben bij de ILO en door andere internationale organisaties van werknemers of werkgevers, mits de klacht betrekking heeft op een situatie die een bij hen aangesloten organisatie direct raakt. Indien het Comite tot de slotsom komt dat de vrijheid van vakvereniging inderdaad geschonden is, kan het de Raad van Beheer aanbevelen om de betrokken staat hierop attent te maken.

Het groeiende besef dat een schriftelijke gedachtenwisseling soms ontoereikend is om grote problemen op te lossen, heeft de weg geplaveid voor de zogenaamde "Direct contact"procedure. De Directeur Generaal kan een onafhankelijke deskundige of een ILO-functionaris verzoeken om met een regering in contact te treden met het oog op het oplossen van langdurige of ernstige controversen. Deze procedure dateert van 1967 en komt in de volgende hoofdstukken nog uitvoerig aan de orde.

\section{De Universaliteit van de Vrijheid van Vakvereniging ${ }^{\mathrm{At}}$}

\subsection{Inleiding}

Het universaliteitsconcept in relatie tot de rechten van de mens heeft vooral een normatieve lading. Het impliceert dat de rechten van de mens universeel nageleefd behoren te worden en dat aanvaarding van deze praemisse "conditio sine qua non" is voor de daadwerkelijke universele eerbiediging van de rechten van de mens.

Deze gedachte is niet onbetwist. Pleitbezorgers van het cultuur-relativisme betogen dat de rechten van de mens een. Westers concept zijn dat niet - althans niet op gelijke wijze gedeeld wordt door niet-westerse culturen. De controverse tussen universalisten en cultuurrelativisten behoort tot het terrein van de rechtsfilosofie en de culturele antropologie. De materie is te complex en te veelzijdig om zelfs maar globaal in het kader van deze studie te behandelen. ${ }^{19}$ Zelf ben ik de mening toegedaan dat met name de zogenaamde burgeren politieke rechten ten diepste gegrondvest zijn in de menselijke waardigheid en niet (uitsluitend) het produkt zijn van de Westerse rechtstatelijke opvattingen over staat en individu. Van harte onderschrijf ik dan ook de stellingname van de Duitse UNESCO-Commissie: "Eine Relativierung der im Westen anerkannten Freiheitsrechte sei weder unter ökonomischen

18 Deze paragraal is een bewerking van mijn bijdrage aam: van Bioven Th./Flinterman C. Universaltiteir wan Mensenrechten: fundamenteel en controversieel, Leiden 1992. Vgl. van der Will H.G. De Intemationale Arbeidsonganisatie en de universaliteit wan het beginsel van wakwerenigingswijheid: Reikwijds en strekking van het universele karakter met speciale aandacht voor thet stakingsrecht, pp. 53-63.

19 Een uitvoerige verhandeling treft men aan bij Kuhnhardt $\mathbb{L}$. Die Universalitat der Menschewtechte, München 1987, met name het derde deel: Menschenrechte zwischen Universalismus und Rellativismus Begriffskontroversen und Verwirklichungsbedingungen, pp. 279-395. Zic werder Alston Ph. The United Nations and the elliptical notion of the universality of human rights in: Is universality in jeopardy? United Nations, New York 1987, pp. 53-56; Donnelly J. Cultural relativism and umiversal human rights in: Human rights quarterly, Vol. 6, 1984. 
noch unter kulturellen oder politischen Gesichtspunkten zur Förderung der Dritten Welt erforderlich, (...) die Fãhigkeit zum Erlernen demokratischer Verhaltensformen sei nicht auf westliche Staaten begrenzt."

De Internationale Arbeidsorganisatie heeft de universele geldigheid van de vrijheid van vakvereniging expliciet erkend door het gewoonterechtelijke karakter van de norm te benadrukken: de lid-staten van de ILO zijn, ongeacht of ze de toepasselijke verdragen hebben geratificeerd, gehouden om de vrijheid van vakvereniging te respecteren. ${ }^{21}$

Aanvaarding van de universaliteit van de rechten van de mens houdt nog niet automatisch in dat men van alle staten verlangt dat zij alle mensenrechten op dezelfde wijze naleven. Oog voor geografische - politieke en culturele - diversiteit ligt ten grondslag aan de opvatting dat universaliteit nog niet uniformiteit betekent. Ook de aard van de norm kan een aanleiding zijn om het universaliteitsconcept enigszins te relativeren. Bij de beoordeling van de naleving van sociaal/economische rechten moet rekening gehouden worden met het sociaal/economische ontwikkelingspeil van de staat in kwestie. Beide standpunten vormen een pleidooi aan het adres van internationale organisaties om bij het formuleren van normen, dan wel bij het toezicht op de naleving van die normen flexibele criteria te hanteren. Tot op zekere hoogte is deze wens legitiem: een (te) veeleisende, strak geredigeerde norm zal immers geen universele pretenties kunnen hebben, aangezien zij door veel staten hooguit met de mond beleden zal. worden of, hetgeen met het oog op de duidelijkheid nog wel te prefereren is, openlijk verworpen zal worden. Aan de andere kant brengt een eenzijdige nadruk op de universele acceptatie van een norm het gevaar met zich mee dat de norm verwatert tot een elastische, amorfe "grootste gemene deler" die elke prikkel tot verbetering verloren heeft.

Met deze spanning tussen het streven naar universele aanvaarding en het streven naar integrale aanvaarding heeft elke internationale organisatie te maken. ${ }^{22}$ Door nu, hetzij ex ante bij de formulering van de norm, hetzij ex post bij de controle op de naleving van de norm, rekening te houden met de internationale diversiteit, kan een internationale organisatie proberen om, zoals Valticos het noemt, "een onontbeerlijk minimum aan precisie te verzoenen met de variëteit van nationale omstandigheden"."

We zullen de bovenstaande abstracte bespiegelingen nu verder toespitsen op de vraag of de ILO bereid is om, met betrekking tot de vrijheid van vakvereniging, flexibele maatstaven

20 Deutsche UNESCO-Kommission Menschenrechte und "Rechte der Vöker". Ein Gespräch, München 1983, p. 86. Geciteerd in: Kühnhardt, a.w. pp. 302-303.

21 Vgl. Report of the Fact-Finding and Conciliation Commission on Freedom of association on the trade union situation in Chile, Geneva $1975, \$ 466$.

22 De terminologie is van Lijnzaad L. Paradoxale uniwersaliteit, of de beperkingen van het verdragenrecht in: van Boven Th./Flinterman C. a.w. p. 7.

Valticos N. Universalité des Droits de l'Homme et Diversité des Conditions Nationales in: Liber Amicorum Discipulorumque pour René Cassin, vol. 1. Paris 1969, p. 390. 
te hanteren, dan wel het standpunt inneemt dat de naleving van de vrijheid van wakvereniging in elke staat, ongeacht de specifieke politieke of sociaal/economische omstandigheden, op eenzelfde wijze beoordeeld moet worden. Dit vraagstuk wordt benaderd vanuit twee invalshoeken. In 3.2 staat de aard van de norm centraal. In 3.3 komen vier technieken aan de orde die de ILO toepast om specifieke nationale omstandigheden te laten meewegen bij de beoordeling van de naleving van internationale arbeidsnormen. Nagegaan zal worden in hoeverre de ILO deze technieken toepasselijk acht in het geval van de vrijheid van vakvereniging.

\subsection{Het onderscheid tussen burger-en politieke rechten en sociale, economische en culturele} rechten in het licht van de universaliteitsproblematiek

De Universele Verklaring van de Rechten van de Mens omvat zowel burger- en politieke rechten als sociale, economische en culturele rechten. Met dit principe van ondeelbaarheid van de rechten van de mens werd tot op zekere hoogte gebroken, toen in 1966 twee separate verdragen - het International Verdrag inzake Burgerrechten en Politieke Rechten en het Internationaal Verdrag inzake Economische, Sociale en Culturele Rechten tot stand kwamen. ${ }^{24}$ De verdeling in twee afzonderlijke verdragen was de vrucht van slepende en dikwijls verhitte debatten en wordt wel gekenschetst als een morele overwinning van de Westerse landen die duidelijk prioriteit gaven aan de "klassieke" vrijheidsrechten.. Voor sommige auteurs die niet bereid bleken om sociaal/economische "aanspraken" de status van universeel mensenrecht te verlenen, was deze tweedeling koren op de molen. De essentie van mensenrechten is, zo luidt hun argument, dat zij ondeelbaar, altijd en tegenover eenieder inroepbaar en afdwingbaar moeten zijn. Sociaal/economische rechten voldoen niet aan die voorwaarde. ${ }^{25}$

24 Tot op zekere hoogte: in de vrijwel adentieke preambule wan beide verdragen werd de nauwe samenhang tussen beide categorieèn mensenrechten benadrukt. "Recognizing that, in accordanco with the Universal Declaration of Human Rights, the ideal of free human beings enjoying civil and political freedom and frecdom from fear and want can only be achiewed if conditions are created whereby everyone may enjoy his civil and politicail. rightss, as well as his economic, social and cultural rights."

25 Vg. Graefrath B. Universal Declaration of Human Rights - 7988 in: SIM Special No. 9 The Unihersal Dectanation of Hurvan rights: its significance in 1988, Utrecht 1988, p. 48 .

Een nitwoerig verslag van de discussies die vooraf gingen aan de totstandkoming van beide verdragen, treft men aan in: Jhabvala F. On Human Rights and the Sociat-Economic Context in: Netherlands International Law Review 1984, pp. 153-160.

26 Een extreme exponent van deze opvatting is Maurice Cranston, vgl. zijn Human Rights Today, New York 1962 , pp. 37-39 en What are human rights?, London 1973, p. 1973. Ook Kühnhardt (4.w. p. 338) is deze mening toegedaan: "Menschenrechte können nur jene Rechtsansprüche seîn, die in allen Kulturen, Staaten, Wirtschaftsystemen und sozialen Entwicklungsstadien für jeden Menschen jederzeit Bedeutung besitzen und unter allen Umständen eingehalten werden können." 
Hoewel deze opvattingen tegenwoordig nauwelijks meer navolging vinden, wordt het onderscheid tussen beide categorieën in wat genuanceerdere vorm nog immer verdedigd. Zo gebruikt Bossuyt de vraag of een recht een financiële inspanning van de overheid vergt, dan wel simpelweg gerealiseerd kan worden doordat de overheid zich juist onthoudt van ingrijpen, als onderscheidend criterium woor kwalificatie van het recht als sociaal/economisch resp. burger/politiek. Burgerrechten kunnen op eenzelfde wijze in alle landen, rijk en arm, verzekerd worden, terwijl de implementatie van sociale rechten noodzakelijkerwijze varieert, afhankelijk van het welvaartsniveau van elk land en van de prioriteit die aan het gestelde doell gegeven wordt. ${ }^{27}$ Vierdag kiest een andere invalshoek. Zijns inziens dient men binnen de catalogus van sociale en economische rechten te differentiëren op basis van de vraag of de burger een nauwkeurig definieerbaar "recht" bezit dat hij in rechte kan afdwingen. Aan de hand van dit criterium komt hij tot een driedeling. Het recht op vakverenigingsvrijheid en het stakingsrecht rangschikt hij onder een eerste categorie van rechten die onmiddellijk en kosteloos beschikbaar en derhalve in beginsel direct afdwingbaar zijn. In de tweede plaats onderscheidt hij sociale rechten die weliswaar een financiële prestatie van de overheid vereisen, maar in landen met een bepaald niveau van ontwikkeling reeds beschikbaar zijn. Het feit dat nieuwe groepen individuen aanspraak maken op deze rechten, impliceert een herallocatie van de beschikbare middelen. Tenslotte bestaat er een categorie sociale rechten die slechts gerealiseerd kunnen worden door een extra financiële inspanning van de overheid. De implementatie van deze "programmarechten" is veeleer een kwestie van politiek dan van "recht".28

De opvattingen van Bossuyt en Vierdag zijn niet (langer) gemeengoed. Vooral binnen de Verenigde Naties wordt in toenemende mate benadrukt dat beide categorieën mensenrechten ondeelbaar en interdependent zijn. ${ }^{\star 2}$ Daarbij wordt opgemerkt dat het criterium of de overheid zich van inmenging moet onthouden - in geval van burger- en politieke rechten dan wel juist actief moet optreden - in geval van economische, sociale en culturele rechten nogal kunstmatig en weinig nauwkeurig is. Aan de ene kant vergt de verwezenlijking van (sommige) burger- en politieke rechten soms wel degelijk wetgevende en financiële inspannin-

Alston (a.w. p. 63) heeft principieel stelling genomen tegen dit standpunt en kwalificeert het als de ernstigste hedendaagse ondermijning wan het universaliteitsconcept in relatie tot de rechten van de mens.

27 Bossuyt M. La distinction juridique entre les droits civils et politiques et les droits economiques, sociaux et culturels in: Human Rights Journal, Vol. VIII (1975), pp. 789-792.

28 Vierdag E.W. The Legal Nature of the Rights granted by the International Covenant ont Economic, Social and Cuttural Rights, Netherlands Yearbook of International Law 1978, met name pp. 83-94 en pp. 102-103.

29 Vgll. Coomans A.P.M. De intemationale bescheming wan het recht op Ondenwijs, pp. 20-26. Een zeer recente vertolking wan dit standpunt treft men aan in de Lienna Decalaration and Programme of Action van de Wereldconferentie inzake Mensenrechten (A/Conf. 157/23, 12-07-1993) onder Par. 3: "All human rights are universal, indivisible and inter-dependent and inter-related. The international community must treat human rights globally in a fair and equal manner, on the same footing and with the same emphasis." 
gen van de kant van de overheid. ${ }^{30}$ Aan de andere kant zijn er binnen de zogenaamde sociale "programmarechten" harde kern-verplichtingen te ontwaren, waaraan alle staten, ongeacht het ontwikkelingsniveau en de financiële draagkracht, gebonden zijn. Een groep vooraanstaande deskundigen op het gebied van de rechten van de mens heeft in de "Limburg principles" een aantal waardevolle suggesties gedaan met betrekking tot de implementatie van het ESOCUL Verdrag, waarbij in het bijzonder gewezen wordt op deze "harde"t" verplichtingen.

Niettegenstaande deze nuttige en terechte nuanceringen, zou ik toch willen volhouden dat het onderscheid tussen burger- en politieke rechten enerzijds en sociale, economische en culturele rechten anderzijds enige waarde bezit waar het gaat om het identificeren van normen die in overwegende mate een verbod van statelijke inmenging behelzen en normen die een staat vooral een positieve - financiële - verplichting opleggen ${ }^{32}$ Laatstgenoemd onderscheid is van eminent belang voor de betekenis die men hecht aan de overweging dat een bepaalde norm universele gelding bezit. Mijns inziens valt niet te ontkennen dat het voor een internationale organisatie die belast is met het toezicht op de naleving van internationale verdragen op het gebied van de rechten van de mens, wel degelijk uitmaakt of een norm een staat gebiedt om iets niet te doen, dan wel opdraagt een financiële prestatie te leveren. In het eerste geval dient de internationale organisatie uniforme maatstaven te hanteren, terwijl in het tweede geval, afhankelijk van het ontwikkelingsnivean van een staat, juist een zekere

30 Coomans refereert aan het recht op een eerlijk proces en het recht van politieke participatie, aw. p. 14. Kortheidshalve kan ook gewezen worden op de belangrijke rechtsontwikkelingen op het gebied van art. 8 EVRM ("family life") na het Marckx-arrest (EHRM, 13-06-1979, Serie A, Vol. 31): de eerbiediging van "family. life" brengt voor de staat een myriade aan positicwe verplichtingen met zich mee, vgl. Wiarda G.J. Rechterlijke voonwarendheid en rechterlike tenghouding bij de toepassing van de Europese Conventie tot bescheming van de rechten wan de mens, 's-Gravenhage 1986 , p. 10.

31 "The Limburg Principles on the Implementation of the Intemational Covenant on Economic, Social and Cultural' Rights" UN-Doc. E/CN.4/1987/17, Annex. Tevens gepubliceerd in Human Rights Quarterly 9 (1987) pp. 122-135. Limburg Principle 8 maakt een nuttig onderscheid tussen rechten die onmiddellijk en rechten die na verloop van tijd opeisbaar zijn. Ongeacht het niveau van ontwikkeling is iedere staat gehouden om (a) onmiddellijk stappen te ondernemen teneinde natar beste vermogen sociale, economische en culturele rechten te verwezenlijken (Limburg Principles 16, 21 en 28), (b) discriminatie bij het toekennen van deze rechten te vermijden (Limburg Principles 13, 22 en 35-41), (c) bepatde minimum-rechten te garanderen (Limburg Principle 25).

Ook Trubeck leidt een universeel geldende, maximale inspanningsverplichting af uit de bewoordingen van art. 2, lid 2 ESOCUL-Verdrag, vgl. Trubeck D.M. Economic, Social and Cultural Rights in the Thind World in: Meron Th. (ed.) Human Rights in Intemational Law. Legal and Policy Issitus, Oxford 1985, pp. 214-215. Zie voorts over de aard van de statsverplichtingen onder art. 2, lid 1 ESOCUL-Verdrag: General Comment No. 3 (1990) wan het Comite inzake Economische, Sociale en Culturelle Rechten; UN-Doc. E/1991/23, Annex III, 8 1-14.

32 Ook het Comité inzake Economische, Sociale en Culturele Rechten onderkent dat er een significant verschill bestaat tussen de onmiddellijke verplichting om bepaalde rechten te waarborgen wan art. 2, BUPO-Verdrag en de verplichting tot gelejdelijke verwezenilijking van art. 2 ESOCUL-Verdrag. Het voegt er well aan toe dat het ESOCUL-Verdrag in "clear obligations" voor de staten-partijen voorziet. General Comment No. 3 ; 9 . 
mate van souplesse in acht moet worden genomen. De verwezenlijking van sociale rechten vraagt $t_{\xi}$ in sterkere mate dan dit over het algemeen bij burger-en politieke rechten het geval is, een financiële inspanning van een staat, zodat bij de implementatie rekening gehouden moet worden met de financiële armslag van een overheid. ${ }^{33}$ De bewering dat uit sociale, economische en culturele rechten een maximale inspanningsverplichting voortvloeit, impliceert immers al dat men van deze inspanning niet bij elke staat hetzelfde resultaat mag verwachten.

Met de nadrukkelijke kanttekening dat de schotten tussen beide categorieën mensenrechten niet waterdicht zijn( $\left.{ }^{34}\right)$, acht ik het onderscheid tussen politieke en burgerrechten enerzijds en economische, sociale en culturele rechten anderzijds toch van enig belang voor de discussie over het universele karakter van de rechten van de mens. ${ }^{35}$

Welke consequenties hebben bovenstaande bespiegelingen nu voor de beoordeling van het universele karakter van het recht van vakverenigingsvrijheid in al zijn aspecten? Dat de schotten tussen beide categorieën mensenrechten niet waterdicht zijn, springt bij het recht van vakverenigingsvrijheid onmiddellijk in het oog: waar de vrijheid van vakvereniging als species van de vrijheid van vereniging zowel in art. 22 van het BUPO-Verdrag als in art. 8 van het ESOCUL-Verdrag is opgenomen, wordt het stakingsrecht dat in de zienswijze van de ILO onverbrekelijk met de vrijheid van vakvereniging samenhangt, alleen in het ESOCULVerdrag geformuleerd. We moeten derhalve onderzoeken welke eisen de norm "vrijheid van vakvereniging" stelt aan een staat, zodra die staat heeft toegezegd de norm te zullen eerbiedigen. Een essentieel element van het recht van vakverenigingsvrijheid is dat het de burger/werknemer bij de uitoefening van zijn rechten in bescherming beoogt te nemen tegen een opdringerige overheid. Ook het stakingsrecht kan, zoals Ben Israël terecht aangeeft, eenvoudig door middel van negatief geformuleerde wetgeving gegarandeerd worden in de

33 Vergelijk Baehr: "Het respecteren van de burgerlijke en politieke rechten wordt niet afhankelijk gesteld van de mate van econonische ontwikkeling wan het betrokken land. Het is veeleer zo dat er rekening mee wordt gehouden dat, afhankelijk van de situatie in een land, de werwezenlijking van economische en sociale rechten slechts geleidelijk mogelijk is." Baehr. P.R. Universaliteit en de rechten van de mens in: Internationale Spectator, februari 1986, XL-2, p. 88.

34 Ook het Europese Hof voor de Rechten van de Mens heeft in de Airey-case (Eur. Court H.R., judgment of 9-10-1979 Series A No. 32, p. 15) onderkend diat op grond van het criterium van de financiële verplichtingen van een staat geen strak onderscheid tussen beide categorieën mensenrechten gemaakt kan worden: "Whilst the Convention sets forth what are essentially civil and political rights, many of them have implications of a social or economic nature. The Court therefore considers, like the Commission, that the mere fact that an interpretation of the Convention may extend into the sphere of social and economic rights should not be a decisive factor against such an interpretation; there is no water-tight division separating that sphere from the field covered by the Convention."

35 Ook Valticos (a.w. p: 395) onderkent het nut van de indeling, hoewel hij toegeeft dat het een onnauwkeurig en zeer algemeen rïchtsnoer is. 
zin dat de overheid zich slechts heeft te onthouden van inbreuken op het recht. ${ }^{36}$ Naar mijn idee kan hetzelfde beweerd worden van het recht op collectieve onderhandelingen. Een wezenlijk aspect van dit recht is immers dat de overheid de vrijheid van werkgevers en vakbonden om zich met elkaar te verstaan niet mag doorkruisen door middel van verplichte conciliatie- en arbitrageprocedures. ${ }^{37}$

De constatering dat de vrijheid wan vakvereniging in al haar geledingen van de overheid geen andere prestatie verlangt dan dat zij zich onthoudt van het maken van een inbreuk op dit recht, heeft belangrijke implicaties. Het houdt in dat een internationale organisatie - in het bijzonder de ILO - bij de beoordeling van de vraag of een staat de vrijheid van vakwereniging voldoende respecteert, voor alle staten, ongeacht hun politieke systeem of economische ontwikkelingsniveau, gelijke maatstaven dient te hanteren. In het verlengde hiervan betekent het dat een beroep op politieke of sociaal/economische omstandigheden om een inbreuk op de vrijheid van vakvereniging te rechtvaardigen, niet gehonoreerd kan worden.

\subsection{Differentiatie-methoden en de vrijheid van vakvereniging}

Uit de conclusie aan het einde van de vorige paragraaf kan worden afgeleid dat een internationale arganisatie bij het toezicht op de naleving van de vrijheid van vakvereniging in elke staat dezelfde maatstaven moet hanteren. Het is de vraag of de ILO dit standpunt ook huldigt. Een analyse van de vier technieken die de ILO toepast om rekening te kunnen houden met specifieke nationale omstandigheden kan licht werpen op deze kwestie. ${ }^{38}$

In de eerste plaats kan onderscheid gemaakt worden tussen het rechtsbeginsel dat in de norm vervat is en de toepassingsmodaliteiten op nationaal niveau. Deze techniek wordt met name gebruikt om tegemoet te komen aan de grote variëteit aan rechtssystemen. Een fraai voorbeeld levert het eerder genoemde artikel 4 van Verdrag no. 98, waarin expliciet verwezen wordt naar nationale omstandigheden.

Voorzover Verdrag no. 87 in art. 8 , lid 2 melding maakt van nationale wetgeving, is dit niet om de wetgever een vrije marge te gunnen bij de regeling van de normen van het verdrag, maar om hem te wijzen op een nauwkeurig omschreven normenstelsel, waarvan hij niet mag

36 Ben Israël R. Intemational Labour Stondards: The Case of Freedom to Strike, Deventer 1988, pp. 16-21. Dat ook Ben Israèl waarde hecht aan de traditionele indeling van mensenrechten, blijkt wit haar opmerking dat het stakingsrecht sterke verwantschap vertoont met de politieke en burgerrechten.

37 Het recht op collectieve onderhandelingen theeft ook een "programmatisch" aspect dat tot uitdrukiking komt in art. 4 van Verdrag no. 98: Aan nationale omstandigheden aangepaste maatregelen moeten genomen worden om collectieve onderhandelingen tussen werknemersorganisaties en werkgevers(organisaties te stimuleren. Nu de verwezenlijking van dit recht een positieve verplichting van de overheid met zich meebrengt, zal er ook meer ruimte zijn om naar nationale omstandigheden te differentiëren.

38 De vier technieken zijn uitwoerig beschrewen door Valticos in zijn bijdrage aan de Cassin-bundel. 
afwijken. ${ }^{30}$ De in het verdrag gewaarborgde vakbondsrechten worden dus niet door de ILO "ter vrije expressie" uitgeleverd aan de staat. ${ }^{40}$

Beoogt de zojuist beschreven techniek wooral problemen van juridisch/technische aard te verhelpen, de tweede methode refereert aan verschillen in sociaal/economische ontwikkeling en in levensstandaard die tussen staten bestaan. Normen die particulieren een aanspraak verlenen op een financiële prestatie van de stalat, veronderstellen dat de staat over de middelen beschikt om die prestatie te leveren en dat is niet in alle staten in gelijke mate het geval. Sommige ILO-verdragen voorzien in de mogelijkheid dat staten bepaalde normen geleidelijk implementeren: de verplichtingen die de staten uit hoofde van de ratificatie van dat verdrag op zich hebben genomen, zijn niet voor al die staten gelijk maar zijn gerelateerd aan hun welvaartsniveau: De rapportage over geratificeerde verdragen stelt het Deskundigen-Comité in de gelegenheid om te verifiëren of de inspanningen van de overheid wel gelijke tred houden met de economische ontwikkeling. In Verdrag no. 87 treft men geen clausules aan die wijzen op de mogeijkheid van geleidelijke implementatie. Hieruit kunnen we afleiden dat de ILO de erkenning van vakbondsrechten niet afhankelijk acht van het economische ontwikkelingsniveau.

Een derde methode stelt staten in de gelegenheid om slechts bepaalde gedeelten van een verdrag te aanvaarden. Dat kan in beginsel geschieden op twee manieren. In de eerste plaats kan een staat besluiten om één of meer voorbehouden bij een verdrag te maken. In de tweede plaats kan een verdrag zelf enkele facultatieve bepalingen bevatten. Over deze technieken in relatie tot de vrijheid van vakvereniging kunnen we kort zijn. De tripartiete organisatiestructuur van de ILO verdraagt zich niet met het maken van voorbehouden bij verdragen. De medewerking van werkgevers- en werknemersorganisaties bij de totstandkoming van verdragen zou immers illusoir zijn, indien staten eenzijdig hun uit die verdragen voortspruitende verplichtingen zouden kunnen wijzigen."

Voorts kent Verdrag no. 87 geen facultatieve bepalingen. Verdrag no. 87 is met andere woorden "à prendre ou à laisser" of, beter gezegd, "à prendre", gezien het gewoonterechtelijke en fundamentele karakter van het beginsel van vakverenigingsvrijheid.

39 Artikel 8, lid 2 bepaalt dat de wet, noch de toepassing ervan de garanties van Verdrag no. 87 mag aantasten.

40 Specifiek met betrekking tot het stakingsrecht verschilt de benadering wan de IIO wat dit betreft met die van de opstellers van het ESOCUL-Verdrag. Art. 8 , lid 1 sub d van dit verdrag bepaalt namelijk uitdrukkelijk dat de verdragspartijen het stakingsrecht erkennen, op voorwaarde dat het wordt uitgeoefend in overeenstemming met de wet van het land in kwestie. Deze coullantie ten aanzien van de nationale wetgever wordt echter weer terug genomen door lid 3 vam hetzelfde artikel dat staten-partijen bij] ILO-Verdrag no. 87 verbiedt om wetgevende maatregelen te treffen die de waarborgen van dat verdrag doorkruisen.

41 Zie: Pleitnotitie van de ILO in de Genocide-zaak, 1951, ICJ, Pleadings "Reservations to the Convention on the Prewention and Punishment of the Crime of Genocides ${ }^{*}$ pp. 216-282. 
De vierde techniek tenslotte, heeft betrekking op de toegestane beperkingen van een bepaald recht en is vooral uit het oogpunt van het stakingsrecht het meest interessant. Uit de "case law" van de ILO blijkt dat het uitoefenen van stakingsrechten begrensd wordt door de behartiging van de openbare staatstaak, de openbare orde en de bescherming van belangen van derden. De toelaatbare beperkingen kunnen een absoluut karakter hebben - de ILO heeft geen bezwaar tegen stakingsverboden in essentiële diensten - of van tijdelijke aard zijn het stakingsrecht kan onder bepaalde voorwaarden opgeschort worden tijdens een acute noodtoestand of tijdens een bemiddelings- of arbitrageprocedure. Voorts kunnen restricties gelden ten aanzien van de methodes die gebruikt worden - de staking moet een vreedzaam verloop hebben - en ten aanzien van de doelstellingen die met de staking worden nagestreefd - de zuiver "politieke" staking valt buiten de bescherming van de ILO.

De exacte inhoud van de toelaatbare restricties komt later in dit hoofdstuk nog uitvoerig aan de orde. In het licht van de universaliteit van de vrijheid van vakvereniging is het met name van belang om te signaleren dat de ILO de portée van de toegestane beperkingen nauwkeurig omschrijft en bij de toetsing van concrete wetsteksten en situaties aan de ILOnormen terzake, zonder onderscheids des lands, gelijke maatstaven aanlegt.

\subsection{Evaluatie en conclusies}

De voornaamste conclusie die uit het bovenstaande kan worden getrokken, is dat de ILO wat betreft de vrijheid van vakvereniging "harde" normen tot aitgangspunt neemt, waaraan alle staten moeten voldoen. De eerste drie methoden die de strekking hebben om te differentiëren naar gelang de politieke of sociaal/economische context, acht de ILO zonder meer niet toepasselijk bij de vrijheid van vakvereniging. Beperkingen van vakbondsrechten vindt de ILO, vooral in relatie tot de uitoefening van het stakingsrecht, aanvaardbaar, maar bij de beoordeling van de toelaatbaarheid van restricties hanteert de ILO in alle landen gelijke maatstaven.

Het krachtige en compromisloze standpunt van de ILO in deze kwam tot uitdrukking in de verwerping door de ILC van een amendement van de Zuidafrikaanse werkgeversvertegenwoordiger, Gemmill, dat de strekking had om bij het toezicht op de verwezenlijking van vakbondsrechten het ontwikkelingspeil van elk land te laten meewegen. Gemmill beriep zich op een criciale passage uit de Philadelphia-verklaring die als volgt luidt:

"Considérant que les principes énoncés dans la présente Déclaration sont pleinement applicables à tous les peuples du monde et que, si, dans les modalités de leur application, il doit être dument tenu compte du degré de développement social et économique de chaque peuple, leur application progressive aux peuples qui sont encore dépendants aussi bien qu'à ceux qui ont atteint le stade où ils se gouvernent eux-mêmes, intéresse l'ensemble du monde civlisé ..." 
Gemmill drong erop aan dat deze passage integraal zou worden overgenomen in de Preambule wan Verdrag no. 87, teneinde, zoals hij het uitdrukte, rekening te kunnen houden met de sociale en economische omstandigheden in elk land.

De Commissie inzake de Vrijheid van Vakvereniging, belast met de formulering van de bepalingen van Verdrag no. 87, achtte de passage onverenigbaar met de strekking en de geest van de Conventie en in de Arbeidsconferentie werd het amendement met 85 tegen 23 stemmen verworpen . $^{42}$

De uitkomst van dit debat stemt tot diepe tevredenheild. Zoals Ben Israël overtuigend heeft aangetoond is de vrijheid van vakvereniging opgebouwd uit drie dimensies: het recht om zich te organiseren, het recht op collectieve onderhandelingen en het stakingsrecht. ${ }^{43}$ Elk van deze rechten kan door een overheid gewaarborgd worden door zich te onthouden van inmenging. Een inbreuk op én van de rechten door een overheid die zich beroept op specifieke sociaal/economische of politieke omstandigheden, betekent, gezien het complementaire karakter van de rechten, een aantasting van het gehele rechtsbeginsel en doet de universele geldigheid van de vrijheid van vakvereniging geweld aan.

\section{Politieke activiteiten van de vakbeweging als oorzaak van conflicten tussen staat en vakbeweging ${ }^{\text {st }}$}

In 1952 heeft de ILC de Resolutie inzake de Onafhankelijkheid van de Vakbeweging aangenomen, waarin expliciet aandacht wordt besteed aan de politieke dimensie van vakbondsactiviteiten. ${ }^{45} \mathrm{Na}$ eerst benadrukt te hebben dat de primaire en permanente taak van de vakbeweging de economische en sociale positieverbetering van de werknemers is en dat de vakbeweging te dien einde haar vrijheid en onafhankelijkheid moet bewaren, doet de ILC in punt 5 een uitspraak over het ondernemen van politieke actie: "Wanneer vakbonden - in overeenstemming met de nationale praktijk en op grond van een besluit van hun leden -

42 Het verslag van de discussie treft men aan in: Compte Rendu de la Conférence Intemationale du Travail, XXXIe Session 1948, pp. 243-244.

43 Ben Israël, a.w; pp. $25-29$.

44 Een voorpublicatie van deze paragraaf is verschenen in:

NJCM-Bulletin, Jrg. 11-2 (maart 1986) "De gepolitiseerde vakbond: een dilemma woor de Intemationale Arbeidsorganisatie".

Bij de analyse van de uitspraken wan de toezichthoudende organen van de ILO heb ik gebruik gemaakt van: International Labour Office, Freedom of Association and Collective Bargaining General Survey by the Committee of Experts, Geneva, 1983 (hierna: Survey) en van:

International Labour Office, Freedom of Association. Digest of decisions and principles of the Freedom of Association Committee, Gieneva, 1985 (hierna: Digest; in een aantal gevallen is direct verwezen naar de relevante "Case").

45 De Resolutie werd aangenomen tijdens de 35 e zitting van de ILC in 1952 en werd gepubliceerd in: Official Bulletin Vol. XXXV, No. 2, 15-08-1952, pp. 83-84. 
beslissen relaties aan te knopen met een politieke partij of constitutionele politieke actie te ondernemen als middel tot de bevordering van hun economische en sociale doelstellingen, dan dienen deze politieke relaties of acties niet van dien aard te zijn dat zij het bestaan van de vakbeweging of diens economische en sociale functies in gevaar brengen, ongeacht de politieke veranderingen in het land".

De Resolutie laat aan duidelijkheid veel te wensen over. Allereerst kan men uit de formulering opmaken dat de ILO blijkbaar aan politieke actie een instrumentele functie toekent: zij moet in dienst staan wan de behartiging van sociale en economische vakbondsbelangen. Het najagen van een zuiver politiek doel kan met andere woorden niet gerekend worden tot de normale en legitieme vakbondsactiviteiten. Aangezien de ILC echter niet aangeeft welke politieke doelen geen verband houden met vakbondsbelangen, is het onderscheid weinig verhelderend. ${ }^{46}$

Een tweede beperkingsgrond - de politieke activiteiten van de vakbeweging mogen haar voortbestaan of sociale en economische functies niet in gevaar brengen - biedt evenmin veel houvast, aangezien niet nader wordt gepreciseerd, wanneer dit het geval is.

De toezichtsorganen van de ILO hebben evenwel deze resolutie als richtsnoer genomen en aan de hand van concrete gevallen een duidelijke opinie ontwikkeld met betrekking tot de vraag welke politieke activiteiten binnen de sfeer van de vakbeweging vallen. Bovendien hebben zij aangegeven op welke wijze conflicten tussen staat en vakbeweging op politiek terrein moeten worden opgelost, opdat het beginsel van vakverenigingsvrijheid niet in gevaar wordt gebracht.

4.1 Het scheiden van het politieke kaf van het vakbondsrechtelijke koren: twee procedurele voorvragen

Voordat het Comité inzake de Vrijheid van Vakvereniging een klacht over schending van vakbondsrechten aan een nader onderzoek onderwerpt, maakt het een eerste schifting van zaken die dermate politiek gekleurd zijn dat zij geen verdere afhandeling verdienen. Het overmatig politieke karakter van een klacht kan gelegen zijn in de intentie van de klager en theoretisch dan ook tot diens niet-ontvankelijkheid leiden. Voorts kan de klacht betrekking hebben op politieke feiten en omstandigheden die geen verband houden met de vrijheid van vakvereniging, in welk geval het Comité zich onbevoegd moet verklaren. Dikwijls zal de politieke vooringenomenheid van de klager zich manifesteren in de aard van diens beschuldigingen.

46 In een analyse van de pogingen die in de westeuropese literatuur en rechtspraak zijn ondernomen, om tot een duidelijke afbakening van het begrip "politieke staking" te komen, toont Betten overtuigend aan hoe moeilijk politieke doelen en sociale en professionele belangen te scheiden zijn. Betten $\mathrm{L}$. The Right to Strike in Community Law, Den Haag 1985, pp. 158-161 en pp. 170-173. 


\subsubsection{De ontvankelijkheid van de klacht}

Een politieke "animus" bij de klager is op zich geen grond om de klacht niet ontvankelijk te verklaren. Het Comité heeft een limitatieve opsomming gegeven van de vereisten voor ontvankelijkheid. ${ }^{7}$ De klager dient aan te tonen dat hij enige connectie heeft met de zaak of met een organisatie die in de zaak betrokken is. Een dergelijke voorziening biedt staten natuurlijk wel enige bescherming tegen aantijgingen van vakorganisaties die op geen enkele wijze betrokken zijn bij de praktijk waartegen de klacht is ingediend en slechts om politieke redenen de staat in diskrediet willen brengen. Maar de (mogelijke) politieke intentie van de klager is voor het Comité geen aanleiding om de klacht niet in behandeling te nemen. De politieke animus van de klager kan wel de geloofwaardigheid en het gewicht van diens klacht aantasten, zodat het Comitê, na een inhoudelijk onderzoek, besluit om de kwestie verder te laten rusten. ${ }^{48}$

\subsubsection{De competentie van het Comite}

Het Comité acht zich uitsluitend bevoegd om kennis te nemen van schendingen van vakbondsrechten. Soms zijn beschuldigingen zo zuiver politiek van karakter dat de vakbondsrechtelijke dimensie uit het gezichtsveld verdwijnt. In zeldzame gevallen heeft dit ertoe geleid dat het Comité zichzelf onbevoegd heeft verklaard. ${ }^{4 e t}$ Comité neemt namelijk het standpunt in dat een klacht die gekenmerkt wordt door haar politieke lading, toch nader onderzocht moet worden, indien er mogelijk tevens vakbondsrechten in het geding zijn. Het enkele oordeel van de regering dat een klacht; vanwege het zuiver politieke of ideologische karakter,verworpen dient te worden, vermag het Comité niet van een nader zelfstandig onderzoek af te houden. ${ }^{50}$ Van groot belang is nog op te merken dat het Comité uitdrukkelijk bepaald heeft dat het feit dat het zichzelf bevoegd acht om de klacht te onderzoeken, geen enkele voorspellende waarde heeft met betrekking tot het uiteindelijke oordeel. ${ }^{\text {.1 }}$ De bovengeschetste marginale toetsing dient uitsluitend ertoe om het politieke kaf van het vakbondsrechtelijke koren te scheiden. Vervolgens moet het Comité inhoudelijk de klacht bestuderen om zich een oordeel te vormen over de vraag of de politieke aspecten van de zaak dermate overheersend zijn dat het alsnog tot de conclusie moet komen dat de klacht

47

Digest, $\$ 34$. Zie hierboven, p. 9.

Jenks verwijst natar Case No. 67 (Egypte), $13 \mathrm{e}$ Rap. $\$ 100$ Jenks C.W. The Intemational Protection of Trade Union Freedom, London 1957, p. 463.

Jenks noemt ter illustratie de volgende zaken: Een klacht betreffende een proteststaking tegen een kieswet (Case No. 86 (Italië), 11e Rap. \$21) en een klacht inzake het ontslag van vakbondsfunctionarissen, vanwege het ontplooien wan politieke activiteiten. (Case No. 90 (Frankrijk), 11e Rap. $\$ 25$ ). Jenks, a.w. pp. 445-446. Case No. 12 (Argentinië), 6e Rap. $\$ \$ 190-191$.

Case No. 18 (Griekenland), 6e Rap. $\$ 340$. 
geen nadere behandeling verdient. ${ }^{52}$ Het antwoord op deze vraag hangt, zoals Jenks terecht opmerkt, ten nauwste samen met de ruimte die het Comité aan de vakbeweging toekent om zich in te laten met politieke activiteiten.

4.2 De nadere afbakening van de grens tussen politieke activiteiten die wel en die niet tot de, in art. 3 van Conventie no. 87 beschermde, vakbondsactiviteiten behoren

De inspanningen van de toezichthoudende organen van de ILO om, bij het ontplooien van politieke activiteiten door vakbonden, de belangen van staat en vakbeweging zorgvuldig tegen elkaar af te wegen, duiden erop dat de ILO onderkent dat politieke activiteiten een voedingsbodem vormen voor conflicten tussen staat en vakbeweging. Vooral het Comite inzake de Vrijheid van Vakvereniging heeft zich in de "case law" met betrekking tot art. 3 van Verdrag no. 87 een diplomatiek evenwichtskunstenaar betoond.

Om te beginnen roept het Comité regeringen een halt toe: "een algemeen verbod aan het adres van de vakbeweging om zich in te laten met politieke activiteiten zou niet alleen onverenigbaar zijn met het beginsel van vrijheid van vakvereniging, maar ook onrealistisch in praktijk zijn. ${ }^{154}$ Vervolgens stelt het Comité grenzen aan de actieradius van vakbonden op politiek terrein: "Vakorganisaties dienen zich niet teveel over te geven aan politieke activiteiten en buiten hun werkelijke functies te treden door bij uitstek politieke belangen te behartigen".5s Het Comité gaat verder: "Vakbonden kunnen slechts aanspraak maken op bescherming tegen inmenging in hun activiteiten, voorzover zij ervoor waken dat hun eisen niet een duidelijk politiek karakter aannemen". ${ }^{16}$ Onmiddellijk brengt het Comité evenwel een correctie aan op deze uitspraak: "Aan de andere kant is het moeilijk een duidelijke scheidslijn te trekken tussen politieke activiteiten en vakbondsactiviteiten in engere zin. Deze twee begrippen overlappen elkaar dikwijls". .7 $^{\text {st }}$

Men kan zich moeilijk aan de indruk onttrekken dat het Comité, in een al te scrupuleuze poging om de belangen van staat en vakbeweging te respecteren, wat om de hete brei blijft heendraaien. Een concreet antwoord op de vraag welke politieke activiteiten nu specifiek tot het domein van de vakbeweging horen, wordt immers niet gegeven:

Het Comité van Deskundigen geeft een iets duidelijker indicatie omtrent de aard van de door de vakbeweging te ontplooien activiteiten, door zich te bezinnen op de functie van

52 Case No. 18 (Griekenland) 6e Rap. $\$ 347$.

53 Jenks, a.w. p. 450 .

54 Cases Nos. 685, 781, 806, 814 (Boliwia), 162e Rap. 33.

Case No. 842 (Argentinië), 201e Rap. $\$ 40$.

55 Cases Nos. 685, 781, 806, en 814 (Bolivia), 162e Rap. \$ 33,

56 Cases Nos. 698 en 749 (Senegal), 147e Rap. $\$ 88$.

Case No. 920 (Verenigd Koninkrijk/Antugua), $197 \mathrm{e}$ Rap. $\$ 136$.

57 Case No. 528 (Marokko) 112e Rap. 112-115. 
politiek voor de vakbeweging. Allereerst stelt het Comite vast dat de vakbeweging het zich eenvoudig niet kan veroorloven om zich uitsluitend bezig te houden met activiteiten in de beroepssfeer, aangezien de algemene - economische - politiek directe consequenties heeft voor de situatie van de werknemers (men denke aan loonontwikkeling, vakantieregeling, arbeidsvoorwaarden, bestuur van de onderneming etc.). Bovendien, zo vervolgt het Comite, impliceert het proces van collectief onderhandelen steeds vaker dat vakbonden betrokken worden bij het uitstippelen van sociaal/economisch beleid. Dit betekent dat vakbonden aandacht moeten kunnen besteden aan vraagstukken van politieke aard, in de ruimste zin van het woord, en bijvoorbeeld hun mening over de sociaal/economische politiek van de regering publiekelijk kenbaar moeten kunnen maken, aangezien het de fundamentele doelstelling van de vakbeweging is om het sociaal en economisch welzijn van de werknemers te bevorderen.

Uit het grondbeginsel, neergelegd in de ILC-Resolutie, dat politieke actie een middel moet zijn voor de belangenbehartiging van de werknemers, leidt het Comite de aard van de politieke activiteiten af die, in de ogen van de ILO, binnen de sfeer van de vakbeweging vallen.

\subsection{De relatie tussen de bescherming van algemene mensenrechien en het ontplooien van politieke activiteiten}

In 1970 nam de ILC de belangrijke Resolutie inzake de Rechten van Vakbonden en hun Verhouding tot Burgerrechten aan." Onder verwijzing naar de Universele Verklaring van de Rechten van de Mens en het VN-Verdrag inzake Burger- en Politieke rechten, verkondigde de ILC dat vakbondsrechten gegrondvest moesten zijn in het respect voor burgerlijke vrijheden en dat de afwezigheid van deze vrijheden de betekenis van het concept van vakbondsrechten ontkrachtte. Een normale uitoefening van vakbondsrechten, zo vervolgde de $\mathrm{KC}$, vereiste in het bijzonder de eerbiediging van een vijftal rechten: bescherming tegen willekeurige arrestatie en detentie, vrijheid van meningsuiting, wrijheid van vergadering, het recht op een eerlijk proces en het recht van bescherming van eigendom.

Juist beweerde schendingen van vakbondsrechten die een uitvloeisel zijn van beperkingen van burgerlijke vrijheden, doen vaak de vraag rijzen of de activiteiten, waarvoor bescherming wordt gezocht, ontplooid zijn ter nastreving van vakbondsdoeleinden of dat de vakbond de eigen activiteitensfeer heeft overschreden. ${ }^{50}$

59 ILO: Record of Proceedings, ILC, 54th Session 1970, p. 733.

60 Aldus de Directeur Generaal in zijn rapport aan de rLC tijdens diens 75e Zitting International Labour Office, Human Rights - A Common Responsiblity, Geneva 1988 , p. 16. 
4.3.1 De bescherming tegen (willekeurige) arrestatie en detentie en de vereisten van een eerlijk proces

Het Comité inzake de Vrijheid van Vakvereniging neemt tot uitgangspunt dat vakbondsleden en -leiders, hoewel zij zich natururlijk niet kunnen beroepen op strafrechtelijke immuniteit, niet vanwege het ontplooien van legitieme vakbondsrechten gearresteerd of gedetineerd mogen worden. ${ }^{61}$ A contrario kan men hieruit afleiden dat het Comite het blijkbaar in beginsel gerechtvaardigd acht dat vakbondsleden strafrechtelijk vervolgd worden indien zij hun bevoegdheden overschrijden. Gelijk alle gearresteerde personen, moeten vakbondsleden evenwel zo snel mogelijk voor een onpartijdige rechter geleid worden teneinde een eerlijk proces te krijgen, ook in gevallen waarin zij beschuldigd zijn van politieke of strafrechtelijke vergrijpen die, naar het oordeel van de regering, geen verband houden met hun vakbondsactiviteiten. ${ }^{62}$ Strikt genomen is deze laatste toevoeging natuurlijk overbodig, omdat de eis van een eerlijk proces voor alle arrestanten geldt, ongeacht de aard van de tegen hen ingediende aanklacht.

De overwegingen van het Comité hebben uitsluitend betrekking op de rechtsbescherming tegen een overheid die wellicht wat al te gretig het stempel "politiek subversief" hanteert. Het Comité doet de nationale rechter geen concrete vuistregels aan de hand, op grond waarvan deze kan beoordelen of de gewraakte activiteiten inderdaad buiten de competentiesfeer van de vakbeweging vallen. Het is wel van groot belang dat het Comite zich het recht voorbehoudt om, na bestudering van de rechterlijke uitspraak, uiteindelijk zelf te bepalen of de veroordeling al dan niet verband hield met het uitoefenen van vakbondsrechten. Vanzelfsprekend zal het Comité daarbij de eigen maatstaven hanteren en mogelijk tot een oordeel komen dat afwijkt van de rechterlijke uitspraak.

\subsubsection{De vrijheid van meningsuiting}

Het recht van vrije meningsuiting is én van de rechten, waarvan eerbiediging essentieel wordt geacht voor een normale uitoefening van vakbondsrechten. Kunnen politiek-getinte vakbondspublicaties nu ook aanspraak maken op protectie tegen overheidscensuur? Allereerst herhaalt het Comité inzake de Vrijheid van Vakvereniging zijn, hierboven al geciteerde, standpunt dat vakbonden alleen aanspraak kunnen maken op bescherming tegen staatsinmenging, voorzover zij ervoor zorgen dat hun eisen niet een duidelijk politiek karakter aannemen. De afweging die het Comité vervolgens maakt tussen de belangen van staat en vakbeweging loopt grotendeels parallel aan de afweging die het bij de toelaatbaarheid van politieke

61 Case No. 1211 (Bahrain), 233e Rap. \$589.

62 Een groot aantal uitspraken, zie o.a. Case No. 125 (Brazilië), 24e Rap. $\$ 216$ en Case No. 131 (Guatemala), $24 \mathrm{e}$ Rap. 185. Zie o.a. Case No. 147 (Zuid Afrika), 28e Rap. $\$ 237$ en Case No. 492 (Mexico), 118e Rap. $\$ 107$. 
activiteiten in het algemeen heeft gemaakt. De enkele vrees van de autoriteiten dat een vakbondskrant politieke doeleinden zal dienen, rechtwaardigt nog niet een verschijningsverbod van die krant. ${ }^{4}$

Aan de andere kant dient de vakbeweging, bij het uitvaardigen van publicaties, de beginselen van de ILC-Resolutie van 1952 tot richtsnoer te nemen en zich rekenschap te geven van het feit dat haar fundamentele taak de bevordering van het sociale en economische welzijn van de werknemers is. ${ }^{.5}$ Daarbij erkent het Comite dat de scheidslijn tussen vakbondsaangelegenheden en politieke kwesties vaak moeilijk te trekken is. Deze noties overlappen elkaar dikwijls, zo vervolgt het Comite, en het is onvermijdelijk en soms normaal dat vakbondspublicaties een standpunt innemen ten aanzien van vraagstukken met politieke aspecten. Het Comité besteedt daarbij aandacht aan de toonzetting van een publicatie. In het geval van een vakbondskrant die, bij het uiten van beschuldigingen aan het adres van de regering, de grenzen van de welvoegelijkheid had overschreden, maande het Comité de auteurs van het artikel tot het vermijden van al te gespierdle taal. ${ }^{\$ 6} \mathrm{Bij}$ vakbondspublicaties die een duidelijk politiek of anti-nationaal karakter bezitten, lijkt het Comite een distributieverbod niet op voorhand uit te willen sluiten. ${ }^{\text {"? }}$

\subsubsection{Het recht van wrijheid van vergadering}

De vrijheid van vergadering is een essentieel onderdeel van het scala van vakbondsrechten en de overheid moet het recht van vergadering zo min mogelijk beperken. ${ }^{68}$ De vraag die hier beantwoord moet worden is of, en zo ja in hoeverre de overheid ook moet toestaan dat tijdens vakbondsvergaderingen politieke kwesties aan de orde komen. In een geval waarin de autoriteiten een nationaal vakbondscongres hadden verboden, omdat zij van mening waren dat deze bijeenkomst mogelijk voor politieke doeleinden gebruikt zou worden, gaf het Comite inzake de Vrijheid van Vakvereniging als zijn mening te kennen dat een vakbeweging de grootst mogelijke vrijheid gegeven diende te worden om actie te ondernemen in de beroepssfeer, voorzover deze vrijheid tenminste de openbare orde niet in gevaar bracht. ${ }^{\infty}$

Het criterium voor de toelaatbaarheid van restricties van het vergaderingsrecht is dus niet zozeer het al dan niet politieke karakter van de vergadering maar veeleer de mate waarin de bijeenkomst de openbare orde kan verstoren. Uit dien hoofde maakt het Comite dan ook een onderscheid tussen vergaderingen in besloten ruimten enerzijds, en openbare bijeen-

Case No. 224 (Griekenland), 620 Rap. 97.

Zie 0.a. Case No. 75 (Frankrijk/Madagascar), 12e Rap. $\$ 290$ en Case No. 125 (Brazilië) 24e Rap. \$219. Zie 0.a. Case No. 528 (Marokko), 112e Rap. \$\$ 112-115. Cases Nos. 685, 781, 806 en 814 (Bollivia) $162 \mathrm{e}$ Rap. $\$ 62$.

Case No. 75 (Frankrijk/Madlagascar), 12e Rap. 291.

Digest \$ 141

Case No. 61 (Tunesië), 12e Rap. $\$ 489$ en 491. 
komsten en demonstraties anderzijds. Binnen deze laatste categorie maakt het wel degelijk verschil of alleen vakbondsdoeleinden worden nagestreefd, of dat ze gehouden worden met andere oogmerken. ${ }^{\text {to }}$

In dit geval neemt het Comité de moeite om aan te geven welke bijeenkomsten beschouwd kunnen worden als een typische uitoefening van vakbondsrechten. Het organiseren van bijeenkomsten ter gelegenheid van de $1 \mathrm{Mei}$-viering behoort hier zeker toe en het uiten van eisen van sociaal/economische aard tijdens dergelijke bijeenkomsten is ook een traditionele vorm van vakbondsactie. ${ }^{n}$

\subsection{Discriminatie op politieke gronden bij de vrijheid van organisatie}

Een staat die niet instemt met de politieke koers van een vakbond, bezit de macht om diens existentie aan te tasten door de vakbond in kwestie te ontbinden, de rechtspersoonlijkheid in te trekken of de leiders van hun functie te beroven. Bovendien vertonen sommige staten de neiging om te discrimineren op grond van politieke overtuiging bij het toekennen van organisatierechten, zowel ten aanzien van individuele werknemers als ten aanzien van vakbonden in oprichting. De ILO beziet dergelijke sancties met de grootst mogelijke argwaan en pleit voor voldoende juridische waarborgen tegen misbruik van overheidsmacht.

\subsection{1 "...zonder enig onderscheid..."}

Krachtens art. 2 van Verdrag no. 87 hebben werknemers (en werkgevers), zonder enig onderscheid, het recht om zich te organiseren en zich aan te sluiten bij de organisatie van hun keuze. Het Comité inzake de Vrijheid van Vakvereniging heeft overwogen dat discriminatie op grond van politieke overtuiging een "onderscheid" in de zin van art. 2 inhoudt."

Het standpunt van het Comité van Deskundigen in deze is enigszins duister. Na eerst geconstateerd te hebben dat in sommige landen werknemers die subversieve activiteiten ontplooien of uitsluitend subversieve ideeën koesteren, hun organisatierechten verspelen als voorbeeld worden Turkije en de Filippijnen genoemd -, overweegt het Comitê dat niemand beroofd mag worden van zijn vakbondsrechten vanwege het hebben van een politieke overtuiging of vanwege het ontplooien van legitieme politieke activiteiten die geen verband houden met het vakbondslidmaatschap. Vervolgens laat het Comité de clausules "legitiem" en "geen verband met vakbondslidmaatschap" vallen en beweert dat zelfs een veroordeling

70 Digest, $\$ 154$.

71 Digest, $\$ \$ 1.55$ en 156 .

72 Case No. 638 (Lesotho), 126e Rap. 25.

Case No. 857 (Ver. Koninkrijk/Antigua), 187e Rap. $\$ 268$. 
wegens een politiek misdrijf in geen enkel geval een redelijke grond oplevert voor het intrekken van het vakbondslidmaatschap. ${ }^{\text {.3 }}$

\subsection{2 "...zonder voorafgaande toestemming...."}

Werknemers en werkgevers hebben, op grond van art. 2 van Verdrag no. 87, het recht om organisaties op te richten zonder voorafgaande toestemming van de autoriteiten. In sommige landen moeten aspirant-vakbonden aan enkele administratieve formaliteiten voldoen om geregistreerd te worden of rechtspersoonlijkheid te verkrijgen. Een dergelijke praktijk is niet in strijd met het verdrag. Problemen rijzen echter zodra de wet aan de administratieve autoriteiten de discretionaire bevoegdheid toekent om erkenning te weigeren en vooral indien de registratie-procedure door de staat als zeef wordt gehanteerd om aan politiek onwelgevallige vakbonden het bestaansrecht te ontzeggen. Deze constructie vindt geen genade in de ogen van het Comite inzake de Vrijheid van Vakvereniging: "De weigering om een vakbond te registreren omdat de autoriteiten, van te voren en naar eigen inzicht, overwegen dat registratie politiek onwenselijk zou zijn, zou overeenkomen met het onderwerpen van verplichte registratie van vakbonden aan de voorafgaande toestemming van de autoriteiten, hetgeen onverenigbaar is met de voorzieningen van verdrag no. $87^{7.74}$

Het toezicht op vakbondsactiviteiten, zo erkent ook het Comité van Deskundigen, moet a posteriori plaatsvinden en dient onderworpen te zijn aan rechterlijke controle. ${ }^{\text {s5 }}$

4.4.3 Politieke overtuiging als onderscheidend criterium bij kandidaatstelling voor vakbondsleiderschap

Eén van de vakbondsactiviteiten die in art. 3, lid 1 van Verdrag no. 87 expliciet genoemd worden en waarmee, conform art. 3 , lid 2, de staat zich niet dient te bemoeien, is het recht van organisaties om in volledige vrijheid hun vertegenwoordigers te kiezen. Het Comite van Deskundigen merkt op dat de wetgeving van sommige staten negatief geformuleerde voorwaarden van politieke aard verbindt aan verkiesbaarheid. Deze voorwaarden kunnen variëren van een verbod van kandidaatstelling aan het adres van personen die zich inlaten met subversieve activiteiten tot uitsluiting van personen die tot een bepaalde politieke partij of beweging behoren. ${ }^{76}$ De toezichtsorganen van de ILO zijn van mening dat wetgeving die personen uitsluitend op grond van hun politieke overtuiging het recht ontzegt om het ambt

General Survey, pp. $32-33, \$ \$ 99$ en 100.

Case No. 239 (Griekenland), 68e Rap. $\$ \$ 31$ en 32.

Case No. 514 (Colombia), 129e Rap. $\$ 115$.

75 General Survey, p. 37, 115 .

76 Survey, \$161. Als woorbeelden worden Australië resp. Maleisië en de Verenigde Staten genoemd. 
van vakbondsleider te bekleden, in strijd is met het recht van organisaties om in volledige vrijheid hun vertegenwoordigers te kiezen. ${ }^{n}$

Het Comite inzake de Vrijheid van Vakvereniging keurt daarentegen ontheffing uit het leidersambt als sanctie op het ontplooien van ontoelaatbare politieke activiteiten, niet bij voorbaat af. Ook hier stelt het Comité evenwel duidelijk grenzen aan de bevoegdheden van de administratieve autoriteiten, door te bepalen dat hun besluiten aan rechterlijke goedkeuring dienen te worden onderworpen. ${ }^{78}$ Bovendien dient de wetgeving nauw omschreven eriteria te bevatten, op grond waarvan de rechter kan oordelen of de ontzetting uit het ambt gerechtvaardigd is, wegens de wandaden die de vakbondsleider gepleegd heeft. ${ }^{x}$ Een vage maatstaf, zoals "de hogere belangen van de natie en het algemene welzijn", op basis waarvan de arbeidsrechter moet beslissen of een diskwalificatie billijk is, kan beter uit de wet worden geschrapt.

\subsection{De "politieke" staking}

Tot dusver blijkt uit de jurisprudentie dat de ILO "tot op zekere hoogte" politieke activiteiten van de vakbeweging accepteert en vakbonden in bescherming neemt tegen inbreuken op fundamentele vakbondsrechten wegens het ontplooien van dergelijke activiteiten. De jurisprudentie geeft evenwel nauwelijks uitsluitsel over de vraag wèlke activiteiten de ILO toelaatbaar acht. Eerst in relatie tot de "politieke" staking krijgt het ILO-standpunt in deze meer reliëf.

Op het eerste gezicht zijn de opvattingen van het Comité inzake de Vrijheid van Vakvereniging nogal behoudend. Het Comité beschouwt de staking uitsluitend als een fundamenteel vakbondsrecht, voorzover zij gebruikt wordt als een instrument om economische belangen te verdedigen. ${ }^{\text {gI }}$ Het begrip "economische belangen" moet echter ook niet te eng worden opgevat. Hieronder moet niet alleen de verbetering van arbeidsvoorwaarden of collectieve eisen die in de beroepssfeer liggen, worden verstaan. Werknemers en hun organisaties moeten ook in de gelegenheid gesteld worden om in een bredere context uiting te geven aan hun ontevredenheid over de sociaal/economische politiek, voorzover deze de

77 General Survey, 162 en Case No. 911 (Maleisië), 202e Rap. \$139.

Specifiek met betrekking tot de uitsluiting van personen met communistische sympathieën, zie Case No. 146 (Colombia), 24 e Rap. $\$ 273$.

78 Zie o.a. Case No. 185 (Griekenland), 36e Rap. \$169.

Case No. 385 (Brazilië), 116e Rap. \$187.

79 Case No. 654 (Portugall), 125 e Rap. \$78.

80 Case No. 266 (Portugal), 113e Rap. \$ 75 .

81 Case No. 156 (Algerije), 27 e Rap. 287.

Case No. 885 (Ecuador), 172e Rap. 384.

Case No. 1067 (Argentinie), 214e Rap. \& 208. 
belangen van de leden aantast en met dit oogmerk dienen zij een staking te kunnen uitroepen. ${ }^{22}$ Stakingen van een zuiver politiek karakter vallen evenwel buiten de reikwijdte van de beginselen van vakverenigingsvrijheid.

Met deze uitspraken heeft de ILO kleur bekend. Het ILO-standpunt is volgens mij ruimer dan de interpretatie die de Nederlandse Hoge Raad op het vlak van de politieke staking geeft aan art. 6 , lid 4 wan het Europees Sociaal Handvest dat het stakingsrecht garandeert. Volgens de Hoge Raad dekt het ESH uitsluitend een politieke staking, waaraan eisen ten grondslag liggen die ook bij CAO geregeld hadden kunnen worden. ${ }^{\text {ga }}$ Gelet op de formulering van de ILO-uitspraken, zal de ILO evenwel ook een staking tegen (bijvoorbeeld) een verhoging van het rentepeil accepteren. Hoewel werkgevers geen invloed kunnen uitoefenen op een dergelijke maatregel, maakt de maatregel immers wel degelijk deel uit van de sociaal/economische overheidspolitiek en raakt hij de belangen van de werknemers.

Stakingen die als oogmerk hebben om het gevaar van een staatsgreep te bezweren of om te protesteren tegen ongrondwettige handelingen van een regering, vallen, hoe lofwaardig de doelstellingen ook mogen zijn, buiten het bereik van de vakbondsrechten die de ILO beoogt te garanderen. ${ }^{\text {s }}$

Deze opvatting is volledig consistent met het algemene standpunt van de TLO inzake de toelaatbaarheid van politieke activiteiten. Waar de band tussen het voeren van politieke actie en sociaal/economische belangenbehartiging volledig is doorgesneden, waar, anders gezegd, de politiek gepromoveerd wordt van middel tot doel-in-zichzelf, ontvalt de vakbeweging de protectie van de ILO die zij bij het uitoefenen van haar rechten geniet.

Het Comité van Deskundigen acht sancties in dergelijke gevallen dan ook gerechtvaardigd, mits deze sancties evenredig zijn aan de ernst van de overtreding. Zolang de stakingen, ook al zijn ze van politieke aard, een vreedzaam karakter hebben, moet gevangenisstraf in ieder geval achterwege blijven, aangezien dit de ontwikkeling van harmonieuze industriële verhoudingen schaadt. ${ }^{* 6}$

82 Digest, \$ 368 en 388 . In dezelfde zin het Comité van Deskundigen, Survey, \$ 216.

83. Zie bijwoorbeeld Cases Nos. 737-744 (Japan), 139e Rap. \$124.

$84 \mathrm{HR}, 30-05-1986, \mathrm{NJ} 1986,688$. De relevante passage luidt aldus: "Daarmede is voor wat betreft art. 6 , lid 4 tevens de grens bepaald tussen collectieve acties met een "politiek element" die nog wèl, en collectieve acties met een "politiek element" die niet meer door het door de verdragstaten erkende recht worden gedekt: richten degelijke acties zich tegen overheidsbeleid op het stuk van arbeidsvoorwaarden die het onderwerp plegen of behoren te zijn van collectief onderhandelen, dan vallen zij (nog) onder art. 6, lid 4; keren zij zich tegen andersoortig wertheidsbeleid, dan vallen zij daarbuiten en is in die zin sprake van een zuiver politieke stakking $(. . .)^{\mathrm{u}}$.

85 Seiter rangschikt dergelijke stakingen onder de zogenaamde "politische Widerstandskämpfe". Seiter $\mathbf{H}$. Streikrecht and Ausspernugsrecht, Tübingen 1975, p. 499.

General Survey, p. $69, \$ 223$. 
Van meet af aan heeft staatscontrole over de vakbeweging de ILO de nodige zorgen gebaard. Bij gebrek aan adequate instrumenten, waaraan een dergelijke regeringspolitiekgetoetst zou kumnen worden, is de degradatie van de vakbeweging tot politiek instrument voor en vlak na de Tweede Wereldoorlog regelmatig een twistpunt geweest in het kader van de zogenaarnde geloofsbrievenprocedure. De grote verdeeldheid die dit delicate onderwerp in ILO-gelederen teweeg bracht, vormde mede de aanleiding tot de oprichting van de Commissie Mc Nair die belast werd met het inventariseren van de mate, waarin vakbonden over de gehele wereld door de staat gedomineerd werden. Om een goed inzicht te verkrijgen in de betrokkenheid van de ILO bij dit moeilijke vraagstuk, is een korte verhandeling over de geloofsbrieven-procedure en de Commissie Mc Nair onontbeerlijk.

Met de totstandkoming van de beide sleutel-conventies en de ILC-Resolutie inzake de Onafhankelijkheid van de Vakbeweging kregen de toezichthoudende organen het geschikte gereedschap in handen om controle over de vakbeweging aan de kaak te stellen. Punt 6 van de genoemde resolutie van de ILC verwijst ondubbelzinnig naar een situatie, waarin de vakbeweging ingekapseld en gecontroleerd wordt door de staat:

"Regeringen dienen, bij het zoeken naar de medewerking van vakbonden om hun sociale en economische politiek te verwezenlijken, te erkennen dat de waarde van deze medewerking in hoge mate rust op de vrijheid en onafhankelijkheid van de vakbeweging als een essentiële factor bij de bevordering van sociale vooruitgang. $\mathrm{Zij}$ moeten niet proberen om de vakbeweging te transformeren in een instrument ter nastreving van politieke doeleinden. Evenmin moeten zij proberen om zich te bemoeien met de normale activiteiten van de vakbeweging vanwege diens in vrijheid gevestigde verhouding met een politieke partij".

Met deze uitspraak was de toon gezet. Op de schouders van de toezichthoudende organen rustte vervolgens de moeilijke taak om specifieke controle-maatregelen op het spoor te komen en te toetsen aan de ILO-normen. Een extra complicatie hierbij was dat regeringen soms de neiging vertoonden om op zichzelf legitieme beperkingen van vakbondsrechten in de publieke sector uit te breiden over grote groepen werknemers die strikt genomen niets met de openbare dienst te maken hadden.

\subsection{De geloofsbrievenprocedure}

Voordat de beide sleutelconventies Nos. 87 en 98 het licht zagen, was de zogenaamde geloofsbrievenprocedure een geliefd instrument om staatscontrole over vakbewegingen aan de kaak te stellen. Art. 3, lid 5 van het ILO-Statuut bepaalt dat regeringen afgevaardigden van niet-gouvernementele organisaties dienen te benoemen in overeenstemming met organisaties uit het bedrijfsleven, indien dergelijke organisaties bestaan, die het meest representatief zijn voor hetzij de werkgevers, hetzij de werknemers in hun land. Lid 9 van 
art. 3 stelt vervolgens vast dat de geloofsbrieven van de afgevaardigden onderzocht zullen worden door de Internationale Arbeidsconferentie en dat de Conferentie, met tweederde meerderheid van de aanwezige afgevaardigden, kan besluiten om een afgevaardigde niet toe te laten, indien diens benoeming niet is geschied conform de eisen van art. 3 , lid 5 . In eerste instantie onderzoekt het tripartiet samengestelde Geloofsbrieven-Comité de tegen een afgevaardigde ingediende bezwaren. Zodra eén lid van het Comite van mening is dat het bezwaar ontvankelijk is of gefundeerd is, dan wel indien het gehele Comite eensgezind adviseert om de afgevaardigde niet toe te laten, wordt de kwestie aan de voltallige Conferentie ter beoordeling woorgelegd. ${ }^{8 \pi}$

Vlak voor en na de Tweede Wereldoorlog werden veel bezwaren ingediend tegen werknemersvertegenwoordigers uit communistische en fascistisch/corporatistische landen waar de vakbeweging, zo luidde de klacht, volledig ondergeschikt was aan de officiële staatsideologie.

Kon het Comité in 1937, naar aanleiding van een bezwaar van de Internationale Vereniging van Christelijke Vakbonden tegen de afgevaardigde van de Sovjet Unie, nog eensgezind verklaren dat het bezwaar onvoldoende gefundeerd was $\left({ }^{\circledR}\right)$, de consensus met betrekking tot de bezwaren tegen de afgevaardigden uit fascistisch/corporatistische landen was ver te zoeken. ${ }^{90}$ In essentie kwamen de tegengestelde standpunten van het werknemers-lid van het Comite enerzijds, en het werkgevers-en regeringslid anderzijds telkens op hetzelfde neer. Eerstgenoemde betoogde dat de organisatie in overeenstemming waarmee de werknemersafgevaardigde was aangesteld, niet een werknemersorganisatie in de betekenis van het ILOStatuut was, maar een politiek instrument van de staat. De beide andere leden van het Comité overwogen daarentegen dat er in het desbetreffende land geen andere werknemersorganisatie bestond die de regering had moeten raadplegen bij de benoeming van de afgevaardigde. De Conferentie koos woor het meerderheids-standpunt: in geen enkel geval werd de in opspraak gebrachte afgevaardigde de toegang ontzegd.

$\mathrm{Na}$ de Tweede Wereldoorlog deden zich twee gevallen voor, waarin het Comité wel unaniem adviseerde om de werknemersafgevaardigden te weigeren en de Conferentie dit advies opvolgde. In 1945 en 1949 vonden in Argentinië resp. Venezuela staatsgrepen plaats die onder andere de opschorting van constitutionele waarborgen en de ontbinding van vakcentrales inhielden. Het Comité verwoordde zijn standpunt het duidelijkst in het rapport over de situatie in Venezuela. Aangezien de regering de werknemersorganisatie die het meest representatief was, juist ontbonden had, kon hij onmogelijk met een dergelijke organisatie

87 De belangrijkste grond voor niet-ontvankelijkheid is dat het bezwaar gebaseerd is op feiten en beschuldigingen. die de Conferentie al eender besproken heeft en afgedaan heeft als irrelevant of inhoudsloos. Huishoudelijk Reglement van de ILC, art. 26, lid 4.

88 Ook tegen afgevaardigden wan werkgevers werden bezwaren ingediend. Deze materie valt echter buiten het bestek wan dit proefschrift.

89 Vierde Rapport, 23e Zitting, 1937, 23 Record of Proceedings, 1937, p. 543.

90 Tussen 1923 en 1938 werden bezwaren ingediend tegen de werknemersafgevaardigden wan Italië, Duitsland, Oostenrijk, Bulgarije, Griekenland, Letland en Litouwen. 
tot overeenstemming zijn gekomen over de aanstelling van een afgevaardigde. De regering had dan ook zijn toevlucht moeten nemen tot het recruteren van een afgevaardigde uit kleine, plaatselijke vakbonden.".1

De herintrede in de ILO van de Sovjet Unie, na een afwezigheid van 15 jaar, vormde voor het Internationaal Verbond van Vrije Vakverenigingen en de Internationale Vereniging van Christelijke Vakbonden aanleiding om met frisse moed het instrument van de geloofsbrievenprocedure weer te beproeven. Bezwaren werden ingediend tegen de werknemersafgevaardigden van Tsjechoslowakije en de Sovjet Unie. Hoewel de bezwaren, net als in 1937, wederom te herleiden waren tot kritiek op het ontbreken van vakverenigingswrijheid, achtte het Comité het wenselijk, gelet op het verstrijken van de tijd, de nieuwe omstandigheden en het belang van de zaak, om de aanklacht op zijn merites te beoordelen.

Het is de moeite waard om wat uitvoeriger in te gaan op de opvattingen van de meerderheid van het Comitê, in dit geval de regerings- en de werknemersvertegenwoordiger, omdat deze een aardige synthese vormen van het standpunt van het Geloofsbrievencomité na de Tweede Wereldoorlog. In de eerste plaats stelde de meerderheid dat het Geloofsbrievencomité, gezien de beperkte beschikbare tijd en informatie, niet in een positie verkeerde om beschuldigingen inzake afwezigheid van vakverenigingsvrijheid en onderworpenheid van organisaties aan de staat inhoudelijk te beoordelen. Dat was de taak van andere organen die speciaal voor dat doel in het leven waren geroepen. Verder gaven zij als hun mening te kennen dat vrijheid van vakvereniging weliswaar een belangrijke doelstelling van de ILO was, maar geen voorwaarde voor het lidmaatschap of voor het uitoefenen van bevoegdheden die het lidmaatschap met zich meebracht. Het Comite hoefde zich uitsluitend ervan te vergewissen dat de afgevaardigden zelf representatief waren voor de werknemers in hun land. Direct in aansluiting op deze overweging, presenteerden de genoemde leden hun belangrijkste argument betreffende de interpretatie en afweging van de zinsneden "in overeenstemming met de meest representatieve organisaties" en "indien deze organisaties bestaan". De indieners van de bezwaren hadden niet beweerd dat de afgevaardigden niet representatief waren. $\mathrm{Zij}$ hadden uitsluitend uit de afwezigheid van vakverenigingsvrijheid geconcludeerd dat de afgevaardigden niet representatief konden zijn (cursivering HvdW). De beide leden van het Comité namen, teneinde deze redenering te ontkrachten, juist de clausule "indien zulke organisaties bestaan" tot uitgangspunt. Dit betekende dat, indien er geen organisaties bestonden, de regering volgens het Statuut zelf de werknemersafgevaardigden mocht benoemen. Bovendien zou de regering, indien slechts één werknemersorganisatie bestond, deze kunnen raadplegen, tenzij werd aangetoond dat deze organisatie niet representatief was. Met andere woorden: de bewijslast rustte op de indieners van de bezwaren."

Hoewel deze argumentatie een zekere juridische spitsvondigheid niet ontzegd kan worden, bevredigen de resultaten ervan niet helemaal. Bij zijn afscheid in 1947 als werknemerslid van het Comité, na 27 jaar trouwe dienst, gaf Léon Jouhaux zijn opvatting bondig weer:

91 Vierde Rapport, 33e Zitting, 1950, 33 Record of Proceedings, p. 397.

92 Vierde Rapport, 37e Zitting, 1954, 37 Rec. of Proc., 1954 pp. 440-441. 
"Overeenstemming" veronderstelt "vrije will" en "vrije will" veronderstelt "vrijheid van vakvereniging". Hij pleittte dan ook voor het instellen van onderzoeken door de Conferentie, indien mocht blijken dat met vrijheid van vakvereniging de hand werd gelicht. ${ }^{93}$ Kort daarop kwam de ILO aan de wensen wan Jouhaux tegemoet door het aannemen van de beide Conventies en de uitbreiding van het implementatie-instrumentarium. Nu de ILO in deze lacune woorzien heeft, kan men ook beter instemmen met de opmerking van Jenks bij zijn evaluatie van de geloofsbrievenprocedure. "It is not, however, was never intended to be, and in the nature of the case cannot be, a satisfactory procedure for dealing with problems relating to the infringement of trade union rights as such. For this purpose, the International Labour Organisation relies primarily on other procedures $(. . .)^{\mathrm{m}} .4$.

\subsection{De Commissie Mc Nair: betekenis en werkzaamheden}

Halverwege de jaren vijftig werd onder auspiciën van de ILO een Commissie in het leven geroepen die zich expliciet zou buigen over het vraagstuk van overheersing en controle van werkgevers- en werknemersorganisaties door de staat. Een Resolutie van de Raad van Beheer vormde de juridische basis van deze, naar haar voorzitter vernoemde, Commissie Mc Nair. ${ }^{95}$

Zowel de Raad van Beheer als de Commissie refereerden aan twee beginselen die ten grondslag lagen aan de ILO: het beginsel van universaliteit en het beginsel dat werkgeversen werknemersorganisaties vrij en onafhankelijk dienen te zijn van de staat. Het beginsell van universaliteit impliceerde dat zoveel mogelijk landen lid dienden te zijn van de ILO. Het onafhankelijkheidsbeginsel werd afgeleid uit art. 3 , lid 1 en 5 , in samenhang met art. 4, lid 1 van het ILO-Statuut."

Het recht om individueel te stemmen behelsde het recht van werkgevers- en werknemersvertegenwoordigers om onafhankelijk van hun regeringen te spreken en te stemmen, zo legde de Commissie inzake Internationale Arbeidswetgeving al in 1919 in een rapport aan de Vredesconferentie uit. In 1946 bevestigde de Conferentie-delegatie inzake Constitutionele Vraagstukken dat "de vrijheid van Werkgevers- en Werknemersafgevaardigden om hun achterban te vertegenwoordigen zonder regeringsinstructies of - inmenging en vrijuit te spreken en te stemmen zonder regeringscontrole" éen van de essentiẽle beginselen was, waarop het functioneren van de ILO rustte." Tussen deze beginselen bestond (en bestaat

93 Derde Rapport, 30e Zitting, 1947, 30 Rec. of Proc., 1947, p. 346.

94 Jenks a.w. p. 141.

95 Resolutie van de Raad van Beheer, 128e Zitting, 04-03-1955.

96 Art. 3, de leden 1 en 5 regelen, kort gezegd, de tripartiete structuur van de ILO. Art. 4, lid 1 bepaalt dat elke afgevaardigde het recht heeft om individueel te stemmen over alle zaken die door de ILC in beschouwing worden genomen.

97 ILC, 29e Zitting, 1946, Rapport II (1), p. 94. 
nog steeds) een spanning die door de Raad van Beheer als volgt werd verwoord: "problemen op het gebied van de toepassing van dit beginsel - het tripartiete stelsel - rijzen vanwege het feit dat verhoudingen tussen regeringen aan de ene kant en werkgevers- en werknemersorganisaties aan de andere kant variêren van land tot land".

De spanning was onder invloed van het kille klimaat van de Koude Oorlog nog dichter aan de oppervlakte gekomen. Het veelvuldig indienen van bezwaren tegen werkgevers- en werknemersvertegenwoordigers in het kader van de geloofsbrieven-procedure, vormde namelijk de directe aanleiding tot het ondernemen van actie door de Raad van Beheer. Me Nair achtte het haar taak om een rapport woor te bereiden, dat het gehele ledenbestand van de ILO zou dekken, betreffende de mate van vrijheid van werkgevers- en werknemersorganisaties van regeringsoverheersing of -controle.

De Commissie won informatie in bij het Internationale Arbeidsbureau over de wetgeving in de lidstaten, stuurde questionnaires op naar de regeringen en stelde, aan de hand van de verzamelde informatie, een aantal landen-monografieën samen. Deze monografieên werden weer naar de regeringen gezonden, ter becommentariëring.

Begin 1956 had de Commissie haar werk voltooid. De vrucht van haar arbeid was een waardevol overzicht van de wetgeving met betrekking tot de verhouding tussen staat en vakbeweging in 56 landen. Een samenvatting van de monografieën werd gepubliceerd in het Official Bulletin, waarbij de specifieke wetsbepalingen gerangschikt werden aan de hand van de artikelen van Verdrag no. 87 en, voorzover van toepassing, Verdrag no. $98 .{ }^{\circ}$

De resultaten van het onderzoek zijn voor dit proefschrift slechts in beperkte mate bruikbaar. In de eerste plaats is het overzicht sterk gedateerd. In de tweede plaats heeft de Commissie zich vooral toegelegd op een inventarisatie van de wetgeving. Het uitoefenen van repressie of controle door de regering in de praktijk - maatregelen die ook met de nationale wetgeving op gespannen voet kunnen staan - blijft goeddeels buiten het gezichtsveld van de Commissie. ${ }^{100}$ De rapporten van het Comité inzake de Vrijheid van Vakvereniging blijven, als aanvullende bron van informatie, dan ook onontbeerlijk.

Het onderzoek van de Mc Nair Commissie is niettemin interessant, omdat het een helder licht werpt op de problemen die de ILO (en natuurlijk elke andere internationale organisatie) ontmoet bij het streven naar universeel respect voor de vrijheid van vakvereniging (resp. andere rechten van de mens) in een wereld waarin grote politieke en culturele verschillen bestaan. De bezwaren die in het kader van de geloofsbrieven-procedure vlak voor en na de Tweede Wereldoorlog tegen de werkgevers- en werknemersafgevaardigden waren ingediend, werwezen naar specifieke inkapselingspatronen in fascistisch/corporatistische en communistische staten.

Jenks, a.w. pp. 174 en 175.

99 Official Bulletin, Vol. XXXIX, 1956, No. 9, pp. 475-599. Hierna: Rapport Commissie.

100 De Commissie was zich van deze beperking wel degelijk bewust: "Het is duidelijk dat elke regering die zou wensen om controle of overheersing uit te oefenen over werknemers-of werkgeversorganisaties, een grote variatic aan middelen ter beschikking zou staan om dit te doen, zonder dat een Verdrag of (grond)wet dit zou kunnen woorkomen"', Rapport Commissie, \$60. 
De Raad van Beheer en in diens voetspoor de Commissie Mc Nair benadrukten het belang van de onathankelijkheid van werkgevers- en werknemersorganisaties ten opzichte van de staat. Tegelijkertijd leidde de Commissie de aandacht af van de concrete situaties door de brede opzet van het onderzoek. Voorts beperkte de Commissie zich voornamelijk tot het weergeven van de wetsbepalingen, zonder deze van kritisch commentaar te voorzien. Waar in de slotparagrafen werd geconcludeerd dat bepaalde wettelijke constructies op gespannen voet stonden met het beginsel van vakverenigingsvrijheid, werd de vermelding van staten achterwege gelaten. Waar daarentegen staten wel met name genoemd werden, onthield de Commissie zich van het uitspreken van een kritisch oordeel. ${ }^{101}$

In het algemeen zou men kunnen stellen dat de benadering van de Commissie een verzoenend karakter had. Binnen het kader van de geloofsbrievenprocedure waren met name de politieke tegenstellingen op de spits gedreven. Hierdoor was het universaliteitsprincipe onder grote druk komen te staan. De Commissie probeerde het universaliteitsbeginsel in ere te herstellen door te abstraheren van de concrete situatie en te benadrukken dat de onafhankelijkheid van de vakbeweging ten opzichte van de staat mogelijk was ondanks de grote diversiteit van economische en politieke omstandigheden.

\subsection{Toexichtsmaatregelen en andere vormen van overheidsinterventie in vakbondsaangelegenheden}

De verzoenende houding van de Commissie Mc Nair en haar nadruk op het universaliteitsbeginsel kunnen niet los gezien worden van het tijdsgewricht, waarin politieke polarisatie hoogtij vierde. Bovendien vatte de Commissie haar mandaat aldus op dat zij niet een oordeel behoefde te vellen.

De taak van de toezichtsorganen van de ILO is een geheel andere: zij worden geconfronteerd met een concrete vakbondssituatie en moeten deze situatie toetsen aan normen op het gebied van vakverenigingswrijheid. Hieronder volgt een overzicht van de opvattingen van de ILO met betrekking tot toezichthoudende maatregelen en andere vormen van staatsinmenging in vakbondsaangelegenheden.

\subsubsection{De aanwezigheid van autoriteiten tijdens vakbondsvergaderingen}

De aanwezigheid van autoriteiten, bijvoorbeeld politie-functionarissen, tijdens vakbondsvergaderingen kan een inmenging in interne vakbondsaangelegenheden opleveren, waarvan de autoriteiten zich krachtens art. 3, lid 2 van Verdrag no. 87 dienen te onthouden,

101 Exemplarisch is de opmerking van de Commissie dat zij zich niet bevoegd acht am te beoordelen in hoeverre de Communistische Partij de 40 miljoen werknemers van de vakbeweging in de Sovjet Unie domineert. Rapport Commissie, p. 583. 
aldus het Comitê inzake de Vrijheid van Vakvereniging. ${ }^{i p z}$ Het Comité schetst de gevaren van een dergelijke inmenging: het bijwonen van vergaderingen door een vertegenwoordiger van de autoriteiten kan het besluitvormingsproces beïnvloeden ook al is dit geenszins de bedoeling van de autoriteiten. ${ }^{103}$

Waar de aanwezigheid van autoriteiten geen incidentele aangelegenheid is, maar een algemene voorwaarde voor het plaatsvinden van vakbondsvergaderingen, laat het Comite zijn voorzichtige formulering varen. Indien voorafgaande toestemming voor het houden van een vergadering vereist is, de politie aanwezig moet zijn en de organisatoren kopieën van de notulen moeten overleggen, dan is dit duidelijk onverenigbaar met het beginsel dat regeringen zich dienen te onthouden van inmenging in de organisatie en het verloop van vakbondsvergaderingen. ${ }^{104}$ Ook de verplichtingen om de namen van sprekers mee te delen, inzage in de agenda te verschaffen en opnameapparatuur tijdens vergaderingen toe te laten, zijn in strijd met het recht van vakbonden om in vrijheid vergaderingen te houden. ${ }^{105}$

\subsubsection{Het verbinden van voorwaarden aan de erkenning van vakbonden}

Zoals in 4 is aangegeven, kunnen de autoriteiten misbruik maken van een erkennings- of registratieprocedure teneinde vakbonden die hen in politiek opzicht niet bevallen, het bestaansrecht te ontzeggen. Dergelijke repressieve maatregelen zijn kenmerkend voor een situatie van sterke polarisatie tussen de staat en (delen van) de vakbeweging. Typerend voor een controlesituatie is het verbinden van positief geformuleerde voorwaarden op het gebied van samenwerking tussen staat en vakbeweging aan erkenning en/of registratie. Zulke voorwaarden brengen de onafhankelijkheid van de vakbeweging in gevaar. Het Comité inzake de Vrijheid van Vakvereniging heeft dan ook overwogen dat de koppeling van de goedkeuring van vakbondsregels, als noodzakelijke voorwaarde voor het verkrijgen van rechtspersoonlijkheid, aan de eis dat de autoriteiten, naar eigen inzicht, zich ervan vergewist hebben dat de organisatie in kwestie in het economisch en social belang is van de gemeenschap, niet verenigbaar is met het recht van werknemers om organisaties op te richten "zonder voorafgaande toestemming". ${ }^{106}$

102 Cases Nos. 251 and 414,107 e Rap. $\$ 39$ (Zuid-Rhodesië).

103 Case No. 385 (Braziliẽ), 112e Rap. $\$ 72$ en 73.

104 Case No. 439 (Paraguay), 127e Rap. \&105.

105 Cases Nos. 1207 en 1209 (Uruguay), 2360 Rap. \$168.

106. Case No. 266 (Portugal), 65e Rap. \$ 34. 


\subsubsection{Statsinmenging in vakbondsverkiezingen}

Het Comité van Onafhankelijke Deskundigen maakt een onderscheid tussen twee manieren; waarop autoriteiten kunnen interveniëren in vakbondsverkiezingen. In de eerste plaats kan de staat voorwaarden verbinden aan de verkiesbaarheid van vakbondsleiders. In de tweede plaats kan de staat de verkiezingsprocedure in detail regelen en er toezicht op uitoefenen. ${ }^{\text {10r }}$

Een extreme variant van de eerstgenoemde methode doet zich voor, indien de autoriteiten besluiten om zelf vakbondsleiders te benoemen. Zowel het Comité van Deskundigen als het Comité inzake de Vrijheid van Vakvereniging achten een dergelijke praktijk een flagrante schending van Verdrag no. $87^{\text {nos }}$

Wat betreft de regeling van verkiezingsprocedures, heeft het Comité inzake de Vrijheid van Vakvereniging overwogen dat wetten die de frequentie van verkiezingen en de maximale termijnen voor vakbondsleiderschap bepalen, de vrijheid van vakvereniging niet aantasten. Een al te gedetailleerde regeling van de procedure staat evenwel op gespannen voet met het recht van werknemers om thun vertegenwoordigers te kiezen. ${ }^{109}$

De verplichte aanwezigheid van, bijvoorbeeld, arbeidsinspecteurs tijdens verkiezingen is te beschouwen als een specialis van de aanwezigheidsplicht van autoriteiten tijdens vakbondsvergaderingen en wordt door de toezichtsorganen van de ILO dan ook onverenigbaar geacht met het recht op vrije vakbondsverkiezingen. ${ }^{110}$

Tenslotte heeft met name het Comité van Deskundigen erop gewezen dat in sommige landen verkiezingen slechts rechtsgeldig zijn, nadat de resultaten zijn goedgekeurd door de autoriteiten. Het Comité beschouwt deze goedkeuring-achteraf als een inmenging van de kant van de autoriteiten die onverenigbaar is met Verdrag no. $87 . .^{1.1}$

\subsubsection{Het dwingend voorschrijven van bepalingen in vakbondsstatuten}

Vakbonden hebben het recht om hun eigen statuten en regels op te stellen, zo bepaalt art. 3 van Verdrag no. 87. In een aantal landen plegen de autoriteiten zich te bemoeien met de inhoud van deze statuten en regels. Soms dienen vakbondsreglementen ter goedkeuring te

107 General Survey, 155 .

108 Case No. 824 (Dahomey), 158e Rap. \$ 298.

Het Comite van Deskundigen noemt Kenya en Tanzania als woorbeelden wan landen, waar zulke praktijken gebruikelijk zijn. General Survey, \$171.

109 General Survey, $\$ 172$.

Zie verder o.a. Case No. 771 (Uruguay), 143e Rap. \&117.

110 General Survey, $\$ 170$ en 173. Het Comité van Deskundigen noemt o.a. Argentinië, Braziliê, Chili en Colombia als landen, waar de autoriteiten toezicht plegen te houden op verkiezingen. Zie verder:

Case No. 451 (Bolivia), 86e Rap. $\$ 135$ en 136

Case Nos, 668 en 730 (Jordanie), 147e Rap. $\$ 61$.

111 General Survey, $\$ 171$ en 174. Als woorbeelden worden 0.a. Argentiniè en Colombia genoemd. 
worden voorgelegd aan de autoriteiten. ${ }^{12}$ In andere gevallen eist de wetgeving dat de reglementen van vakbonden stroken met de statuten van de enige federatie of vakcentrale of dat zij worden goedgekeurd door de enige vakcentrale. ${ }^{\text {it }}$

Van een typische controle-situatie kan gesproken worden, indien de autoriteiten zelf voorschrijven wat de reglementen moeten behelzen. In dit verband wijst het DeskundigenComité op twee extreme gevallen waarin de autoriteiten de statuten van de vakcentrales zelf hebben opgesteld. ${ }^{124}$ Het beschikbaar stellen van model-reglementen door de autoriteiten aan vakbonden in oprichting als een vorm van dienstverlening, hoeft op zich geen ontoelaatbare inmenging in vakbondsaangelegenheden op te leveren, mits de vakbonden niet verplicht zijn of onder druk staan om deze reglementen te accepteren. ${ }^{15}$ De zaken liggen anders, indien het opnemen van bepaalde clausules in vakbondsreglementen verplicht is gesteld. $\mathrm{Zo}$ is het Comite inzake de Vrijheid van Vakvereniging van mening dat het verplicht opnemen van bepalingen die een zekere mate van ondergeschiktheid van de vakbonden aan de economische politiek van de regering impliceren, niet strookt met de vrijheid van vakvereniging. ${ }^{1 t \hbar}$ Wetgeving die zeer gedetailleerd de verkiezingsprocedures en de samenstelling van de uitvoerende organen regelt, de dagen vaststelt waarop vergaderingen dienen te worden gehouden en exact de termijnen voor vakbondsleiderschap bepaalt, is evenmin verenigbaar met de vakbondsrechten, die Verdrag no. 87 beoogt te beschermen. ${ }^{117}$

\subsubsection{Financiële afhankelijkheid van de staat}

Indachtig het spreekwoord "wiens brood men eet, diens woord men spreekt", lijkt financiering van staatswege op het eerste gezicht fnuikend voor de onafhankelijke positie van een vakbeweging. Niettemin nemen de toezichtsorganen van de ILO in deze een genuanceerd standpunt in en kenschetsen niet elke subsidie van de staat aan vakbonden als een inbreuk op hun onafhankelijkheid (waarmee het betrekkelijke waarheidsgehalte van spreekwoorden

112 Het Comité van Deskundigen noemt als voorbeeld Argentinië, Colombia en Jemen. Het acht dergelijke voorzieningen onverenigbaar met Verdrag no. 87 . Surwey, 151.

113 Bijvoorbeeld in Roemenie en in Bulgarije. Survey, \&152. Dergelijke bepalingen raken aan de problematiek van vakbondsmonopolies die in $\$ 6$ uitwoerig aan de orde zal komen.

114 Kenya en Tanzania. Survey, $\$ 152$.

115 Survey, $\$ 153$.

Case No. 11 (Brazillië), Ge Rap. $\$ 107$ en 108.

Case No. 298 (Zuid-Rhodesië), 66e Rap. $\$ 516$ en 518.

Cases Nos. 825 en 849 (Nicaragua), 168e Rap. 147.

116 Case No. 266 (Portugal), 65e Rap. \$\$ 35-37.

117 Zie o.a. Case No. 823 (Chili), $197 \mathrm{e}$ Rap. 383.

Case No. 927 (Brazilië), 202e Rap. 174. 
weer eens is aangetoond). Reeds de Commissie Mc Nair maakte gewag van een grote variatie aan subsidie-systemen die in verscheidene landen van krachi waren.

Het Comite inzake de Vrijheid van Vakvereniging is van mening dat in het licht van de omstandigheden wan het concrete gevall beoordeeld moet worden of financièle steun schade toebrengt aan de autonomie wan de vakbeweging." Uit de jurisprudentie van het Comité blijkt dat de financiering op zich nog niet op grote bezwaren stuit. Het zijn vooral de tegenprestaties die vakbonden moeten leveren in ruil voor financiele steun, waartegen het Comite bedenkingen heeft. Zo vindt het Comite het vanzelfsprekend dat vakbonden profiteren van materiele en morele steun bij de training van vakbondskader, maar moet deze training wel door de bonden zelf geschieden. ${ }^{12}$ Meer in het algemeen acht het Comité elke financiële steun van overheidswege die het de autoriteiten mogelijk maakt om macht wit te oefenen over de vakbeweging, een inbreuk op de onafhankelijkheid van de vakbeweging. ${ }^{\text {iz }}$

\subsubsection{Staatsinterventie in collectieve onderhandelingen}

De staat kan zich in diverse fasen van de procedure mengen in de onderhandelingen tussen werkgever(s) en vakbond over de arbeidsvoorwaarden. In de eerste plats kan de staat eisen dat bepaalde kwesties bij CAO geregeld moeten worden of tijdens de onderhandelingen juist. buiten beschouwing moeten blijven. In de tweede plaats kan de staat verlangen dat de CAO ter goedkeuring wordt overgelegd. Tenslotte kan de staat bedingen dat, indien werkgever en vakbond niet tot overeenstemming zijn gekomen, het geschil voorgelegd moet worden aan een conciliatie- en/of arbitragetribunaal.

In beginsel kan de staat langs deze wegen controle uitoefenen over de vakbeweging. De toezichtsorganen van de ILO hebben dan ook zorgvuldig aangegeven onder welke voorwaarden dergelijk overheidsingrijpen uit het oogpunt van de vrijheid van vakbonden om hun eigen activiteiten te ontplooien toelaatbaar is.

118 Met nante in Oost-Europese staten waren wakbonden belast met uitwoerende werkzaamheden op het gebied van verzekering, arbeidsprotectie en activiteiten in de sociale en culturele sfeer. Zij ontvingen hierwoor grote sommen gelds. In Zwitserland worden vakcentrales schadieloos gesteld woor de diensten die hun secretariaten loveren aan het land. Rapport Commissie, p. 545.

119 Cases Nos. 121 en 341 (beide Griekenland), resp. 19e Rap. \$180 en 75e Rap. \$101.

120 Desalmiettenin achtte het Comite een systeem, waarin de werknemers verplicht waren om contributie te betalen aan een overheidsinstantie die, op haar beurt, vakbonden financierde, een ernstige inbreuk op de onafhankelijkheid van deze vakbonden. Case No. 341 (Griekenland), 75e Rap. $\$ 106$.

121 Case No. 385 (Braziliê), 103e Rap. \$140.

122 Case No. 121 (Griekenland), 24e Rap. $\$ 74$.

Case No. 341 (Griekenland), 75e Rap. $\$ 106$.

Case No. 644 (Mali), 127 e Rap. $\$ 252$. 


\subsubsection{Verplichtingen met betrekking tot de inhoud van de CAO}

Het Comité van Deskundigen signaleert een tendens in een groot aantal landen om de inhoud van CAO's van overheidswege dwingend te regelen. In sommige landen moeten bepaalde arbeidsvoorwaarden, zoals lonen, werkuren, vakantiedagen, arbeidsveiligheid, bij CAO geregeld worden. ${ }^{123}$ In andere landen mogen bepaalde kwesties juist niet het voorwerp zijn van collectieve onderhandelingen $\left({ }^{124}\right)$ of stelt de wet duidelijk grenzen aan de vrijheid van werkgever en vakbond om in onderling overleg - met name - de hoogte van de lonen overeen te komen. ${ }^{125}$

Het Comité heeft bedenkingen tegen het uitsluiten van bepaalde kwesties betreffende de arbeidsvoorwaarden van collectieve onderhandelingen en acht dergelijke restricties in strijd met het recht van werkgevers- en werknemersorganisaties om hun eigen activiteiten te organiseren. Bovendien strookt het niet met het beginsel, neergelegd in art. 4 van Verdrag no. 98 , dat collectieve onderhandelingen gestimuleerd moeten worden. ${ }^{126}$

Ook het Comité inzake de Vrijheid van Vakvereniging verwijst naar art. 4 van Verdrag no. 98. Wetgeving die het Ministerie van Arbeid bevoegdheden verleent lonen, werkuren, vrijwillig ontslag en arbeidsvoorwaarden te regelen, vervolgens bepaalt dat met deze regelingen rekening moet worden gehouden in CAO's en zodoende dergelijke belangrijke aangelegenheden onttrekt aan de reikwijdte van collectieve onderhandellingen, is in strijd met genoemd artikel. ${ }^{127}$

Met het oog op de bescherming van vakbonden tegen pogingen van de staat om hen in te kapselen en te degraderen tot een verlengstuk van de eigen politiek, is het interessant om te vernemen dat de ILO de interventie van de autoriteiten in collectieve onderhandelingen, met het doel om zich ervan te verzekeren dat partijen hun belangen ondergeschikt maken aan de nationale economische politiek, niet accepteert. Het Comité inzake de Vrijheid van Vakvereniging acht een dergelijke inmenging in strijd met het recht van werknemers- en werkgeversorganisaties om hun activiteiten in vrijheid te ontplooien en met het beginsel dat de autoriteiten zich dienen te onthouden van elke inmenging die dit recht beperkt of de rechtmatige uitoefening ervan belet. ${ }^{128}$

Is elke staatsinmenging in collectieve onderhandelingen uit overwegingen van economische politiek ontoelaatbaar? De toezichtsorganen van de ILO bieden een opening. Als onderdeel

123 Het Comité noemt als voorbeeld Mexico, de Filippijnen en de Sovjet Unie. Survey, $\$ 306$.

124 Bijvoorbeeld Singapore en Maleisie,, waar ontslagen, promoties, recrutering van staf, kortom: allerlei aangelegenheden die samenhangen met het beleid en het management van de onderneming, niet in $\mathrm{CAO}^{s} \mathrm{~s}$ aan de orde gesteld mogen worden. Survey, \$307.

125 In dit verband wijst het Comite erop dat regeringen in toenemende mate geneigd zijn om de loonvorming te beinnloeden door middel van niet-bindende, tripartiete afspraken. In somaige gevallen komen deze afspraken neer op, min of meer verplichte, loonsbevriezingen. Survey, $\$ 309$.

126 Survey, \& 311.

127 Case No. 551 (Cuba), 116e Rap. $\$ 109$.

128 Zie o.a. Case No. 266 (Portugal), 65e Rap. \$70. 
van een stabilisatie-politiek, kan een regering besluiten dat de hoogte van de arbeidslonen niet vrijelijk overeengekomen kan worden door middel van collectieve onderhandelingen, mits een dergelijke maatregel een tijdelijk en uitzonderlijk karakter heeft en vergezeld wordt van toereikende waarborgen voor de levensstandaard van de werknemers. ${ }^{120}$

\subsubsection{Verplichte goedkeuring en wijziging achteraf van CAO's}

Nauw verwant aan het voorgaande is de eis dat CAO's eerst aan de autoriteiten moeten worden voorgelegd ter goedkeuring, alvorens zij van kracht worden ${ }^{130}$ Een dergelijke voorziening stelt de staat immers in de gelegenheid om achteraf CAO's te toetsen aan de (economische) politiek en eventueel nog te wijzigen.

In zijn kritiek op zulke vereisten, benadrukt het Comite inzake de Vrijheid van Vakvereniging wooral het vrijwillige karakter van collectieve onderhandelingen. Het vereiste van voorafgaande goedkeuring zou het gebruik van vrijwillige collectieve onderhandelingen kunnen ontmoedigen en is op zich in strijd met het gehele systeem van vrijwillige onderhandelingen. ${ }^{13 i}$ Een weigering van goedkeuring op grond van vormgebreken in de overeenkomst is, in de ogen van de toezichtsorganen van de ILO, aanvaardbaar, mits dit motief niet als dekmantel wordt gebruikt om CAO's die onverenigbaar zijn met de algemene regeringspolitiek, te verbieden. ${ }^{192}$

Wijzigingen van de inhoud van collectieve contracten die al van kracht zijn, hetzij door middel van wetgeving $\left({ }^{133}\right)$, hetzij rechtstreeks door de autoriteiten, worden door de toezichtsorganen van de ILO in de regel niet toelaatbaar geacht. Zij baseren hun standpunt op het beginsel van autonomie van de partijen die betrokken zijn bij de collectieve onderhandelingen. Dit beginsel werd algemeen erkend tijdens de voorbereidende besprekingen die leidden tot de aanvaarding van het ILO-Verdrag inzake Collectieve Onderhandelingen van 1981 (no. 154). Evenals in geval van staatsinmenging tijdens collectieve onderhandelingen, zijn de beide Comités van mening dat overheidsinterventie achteraf gerechtvaardigd kan zijn om belangrijke

129 Surwey, $\$ 31.5$.

Zie ook Cases Nos: 1183 en 1205 (Chili), 233 e Rap. \$ 482.

Case No. 1206 (Peru), $236 \mathrm{e} \mathrm{Rap.} \$ 507$.

130 Het Comite wan Deskundigen noemt Bolivia en Nicaragua als voorbeelden van landen, walar deze eis van kracht is.

Survey, $\$ 310$.

131 Zie o.a. Case No. 823 (Chili), $176 \mathrm{e}$ Rap. 23.

132 Survey, 811 .

Case No. 341 (Griekenland), 85e Rap. \$\$ 185 en 186.

Case No. 1267 (Papoea-Nieuw Guinea), $236 \mathrm{e}$ Rap. $\$ 43$.

133 Case No. 541 (Argentinië), 106e Rap. $\$ 12-16,19$. 
sociale en economische redenen en in het algemeen belang. ${ }^{134}$ Niettemin spreken de Comites hun voorkeur uit voor overreding boven dwang. Indien een CAO duidelijk in strijd is met de economische politiek die de regering voert, verdient het aanbeveling om overleg te plegen over de conflicterende belangen en deze eventueel voor te leggen aan een raadgevend orgaan. Dit orgaan kan de partijen bij de $\mathrm{CAO}$ verzoeken om de overeenkomst in heroverweging te nemen en daarbij rekening te houden met de economische doelstellingen van de regering, maar de uiteindelijke beslissing om dit advies al dan niet op te volgen, dient bij de partijen te liggen. ${ }^{135}$

\subsubsection{Bemiddelings- en arbitrageprocedures}

Indien werkgever(s) en vakbond tijdens de collectieve onderhandelingen niet tot een vergelijk kunnen komen, rijst de vraag hoe de conflicten alsnog bevredigend opgelost kunnen worden. In veel landen voorziet de arbeidswetgeving in bemiddelings- en arbitrageprocedures, ten overstaan van een doorgaans tripartiet samengesteld tribunaal.

Op zichzelf is het gebruikelijk dat de staat zich opwerpt als bemiddelaar om gerezen arbeidsconflicten langs vreedzame weg te beslechten. Geformaliseerde bemiddelings- en arbitrageprocedures hoeven dan ook niet te wijzen op de neiging van de staat om de vakbeweging te controleren of anderszins inbreuk te maken op vakverenigingsrechten, zeker niet indien de procedures een vrijwillig karakter hebben. ${ }^{136}$ Het Comité inzake de Vrijheid van Vakvereniging acht zelfs wetgeving die conciliatie en arbitrage verplicht stelt, alvorens een staking wordt uitgeroepen, niet in strijd met de vrijheid van vakvereniging (mits de staking na het mislukken van het overleg mogelijk is): ${ }^{137}$ Het Comité benadrukt daarbij wel de noodzaak dat de leden van een bemiddelings- en/of arbitragetribunaal niet alleen onpartijdig zijn maar ook door de partijen in het geding - werkgever(s) en vakbond - als zodanig worden beschouwd. ${ }^{138}$

In feite vormt de bemiddelings- en arbitrageprocedure de schakel tussen twee onvervreemdbare rechten van vakbonden: het recht op collectieve onderhandelingen en het

134 Survey, $\$ 312$.

Zie 0.a. Case No. 1052 (Pamama), 211e Rap. $\$ 155$.

135 Survey, $\$ 313$ en 314.

Zie o.a. Case No. 1007 (Nicaragua), 208e Rap. $\$ 389$.

Case No. 1109 (Chili), 217 e Rap. $\$ 480$.

136. De ILO voorziet zelf in deze mogelijkheid, getnige de Aanbeveling inzake Vrijwillige Conciliatie en Arbitrage, 1951 (No. 92).

137 Een groot aantal uitspraken. Zie o.a.:

Case No. 5 (India), 4e Rap. $\$ 27$;

Case No. 50 (Turkije), Ge Rap. 864 .

138 Case No. 179 (Japan), 54e Rap. 61.

Case No. 804 (Pakistan), 151e Rap. \& 176. 
stakingsrecht. Zodra de procedure dan ook inbreuk maakt op één van deze rechten, komen de toezichtsorganen wan de ILO in het geweer. ${ }^{19}$ In een geval waarin de wet collectieve onderhandelingen voorschreef als middel om problemen op het gebied van efficiënte bedrijfsvoering op te lossen en arbitrage door de arbeidsautoriteiten verplicht stelde, indien de partijen niet tot overeenstemming konden komen, kwam het Comite inzake de Vrijheid van Vakvereniging tot de conclusie dat een dergelijk systeem strijdig was met het beginsel van vrijwillige onderhandeling (cursivering HvdW). ${ }^{\text {140 }}$

Voorts mogen verplichte bemiddelings- en arbitrageprocedures het stakingsrecht niet illusoir maken. ${ }^{141}$ De toezichtsorganen van de ILO passen hier een a contrario redenering toe. Uit het feit dat de ILO accepteert dat in essentiële diensten het stakingsrecht vervangen wordt door verplichte arbitrageprocedures, blijkt dat een dergelijke vervanging in andere sectoren niet aanvaardbaar is. ${ }^{142}$ Zolang de beschikbare procedures van onderhandelingen, bemiddeling en arbitrage nog niet zijn uitgeput, zijn tijdelijke restricties van het stakingsrecht geoorloofd. ${ }^{\text {143 }}$

Het Comité van Deskundigen wijst er evenwel op dat sommige wettelijke regelingen van verplichte arbitrageprocedures in praktijk neerkomen op een algemeen stakingsverbod. Dit is vooral het geval indien de beslissing van het arbitragetribunaal bindend is voor partijen of indien de autoriteiten carte blanche hebben om arbeidsconflicten te onderwerpen aan

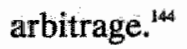

\subsection{De problematiek van (beperking van) vakverenigingsvrijheid voor werknemers in de publieke sector}

Dikwijls vallen werknemers in de publieke sector onder een ander juridisch regime dan hun collegae in particuliere sectoren. Dit onderscheid in rechtspositie is deels te verklaren (en te billijken) uit de specifieke rechtsverhouding waarin deze werknemers tot hun werkgever staan en hangt deels samen met de speciale taken waarmee zij belast zijn. Uit budgettaire overwegingen kan het onwenselijk zijn dat de salarissen van werknemers in een overheidsdienst door middel van onderhandelingen "vrijelijk" worden vastgesteld, met name indien deze dienst

139 Loonstra merkt in dit werband op dat verplichte, door de wetgever opgelegde arbitrage in strijd is met zowel thet recht op onderhandelen als het recht op collectieve actie.

Loonstra C.J. Nooit meer staken? in: Intermediair, 20-10-1989, p. 63.

140 Case No. 541 (Argentinië), 116e Rap. $\$ 71$ en 72.

141 Artikel 7 van de Aanbeweling inzake Vrijwillige Conciliatie en Arbitrage stelt uitdrukkellijk dat geen enkele bepaling van de Aanbeveling opgevat mag worden als een beperking van het stakingsrecht.

142 Case No. 1140 (Colombia), 236 e Rap. $\$ 144$.

143 Zie o.a. Case No. 614 (Peru), 123e Rap. \$ 37;

Case No. 636 (Argentinië), 122e Rap. \$41.

144 Survey, $\$ 204$. Het Comitê noemt als voorbeelden wan landen waar dergelijke rigide arbitrageregelingen van kracht zijn onder andere: Bolivia, Brazilië en Colombia. 
niet volgens het winstprincipe opereert en diens financiële armslag onderworpen is aan parlementaire goedkeuring.

Stakingen van politie of ziekenhuispersoneel kunnen de openbare orde in gevaar brengen en uit dien hoofde aan beperkingen onderhevig zijn. In beginsel kan de ILO begrip opbrengen voor restricties van vakbondsrechten in de publieke sector, restricties die in de particuliere sector eigenlijk ontoelaatbaar zijn. Zowel in de verdragen als in de op basis van de verdragen ontwikkelde jurisprudentie wordt rekening gehouden met het bijzondere karakter van de publieke sector.

Indien de staat de vakbondsrechten van werknemers in de publieke sector sterk inperkt en bovendien de neiging vertoont om de categorie van werknemers, waarvoor deze beperkingen gelden, flink uit te breiden, is het gerechtvaardigd om te veronderstellen dat de staat probeert om de controle over de vakbeweging te versterken. Een dergelijke attitude heeft namelijk dikwijls een uitstralend effect op de verhouding tussen de staat en de gehele vakbeweging. ${ }^{\text {.as }}$

\subsubsection{Organisatierechten}

Over het recht van werknemers in de publieke sector om zilch te organiseren in vakverenigingen, kunnen we kort zijn: buiten de expliciet in art. 9 van Verdrag no. 87 genoemde beroepsgroepen - leger en politie - accepteren de toezichtsorganen van de ILO geen beperkingen. Slinkse pogingen om met name de politie uit te breiden met brandweerlieden en gevangenispersoneel, worden door het Comitế van Deskundigen ontmaskerd. ${ }^{146}$ De toezichtsorganen van de ILO achten algemeen geldende organisatieverboden voor personeel in overheidsdienst of voor werknemers van staatsbedrijven zonder meer in strijd met art. 2 van Verdrag no. 87.197

Wat betreft het blote recht om zich te organiseren, maakt de ILO dus geen onderscheid tussen werknemers in de publieke en de private sector. ${ }^{148}$ Maar welke concrete rechten spruiten hieruit voort voor werknemers in de publieke sector? Het Comité van Deskundigen acht het toekennen van het recht om sociale en culturele activiteiten te organiseren aan verenigingen van werknemers in overheidsdienst duidelijk te mager. ${ }^{149}$ Het Comité inzake

145 Judge Cornelius heeft in żjn "seperate opinion" bij het Rapport van de Commissie Mc Nair op dit gevaar gewezen.

Rapport Commissie, a.w. p. 599 .

146 In Gabon, Japan en Soedan mogen brandweerlieden zich niet organiseren.

In o.a. Colombia en Mexico geldt het organisatieverbod ook voor het gevangenispersoneel. Survey, 87 .

147 Zie o.a. Case No. 5 (India), 4e Rap. 25;

Case No. 144 (Guatemala), 24e Rap. $\$ 243$.

Het Comité van Deskundigen constateert met nauwelijks verhollen afgrijzen dat in Liberia zelfs werknemers in staatsbedrijven het recht ontzegd is om zich te organiseren; Survey, $\$ 85$.

148 Zie nog eens expliciet Case No. 861 (Ecuador), \$203 en Case No. 885 (Bangladesh), $\$ 205$.

149 Survey, \& 84, waar verwezen wordt naar Paraguay. 
de Vrijheid van Vakvereniging meent dat ambtenaren over de mogelijkheid moeten beschikken om organisaties op te richten teneinde hun belangen te behartigen en, in het bijzonder, vergaderingen moeten kunnen houden zonder inmenging van de autoriteiten. ${ }^{150}$ Van het recht op collectieve onderhandelingen en het stakingsrecht wordt geen melding gemaakt.

\subsubsection{Collectieve onderhandelingen}

Art. 6 van Verdrag no. 98 verklaart het verdrag uitdrukkelijk niet van toepassing op ambtenaren. Dit impliceert dat de staat niet noodzakelijkerwijs met organisaties die deze werknemers vertegenwoordigen, langs de weg van collectieve onderhandelingen tot overeenstemming over de arbeidsvoorwaarden behoeft te komen. ${ }^{\mid 51}$ Het Comite van Deskundigen heeft deze categorie van werknemers in de publieke sector nader omschreven als personen die handelen of optreden in naam van de staat. Ter toelichting voegt het Comité hieraan toe dat onderscheid gemaakt moet worden tussen ambtenaren die werkzaam zijn op ministeries en andere vergelijkbare organen aan de ene kant en andere personen in overheidsdienst die onder contract staan van staatsbedrijven of autonome publieke instituten, aan de andere kant. Uitsluitend de eerste categorie kan uitgesloten worden van de reikwijdte van het Verdrag. ${ }^{152}$ ?

Op basis van deze nadere precisering, heeft het Comité inzake de Vrijheid van Vakvereniging een uitvoerige jurisprudentie ontwikkeld met betrekking tot beroepsgroepen die niet onder de uitzondering van genoemd art. 6 vallen. Personeel van een radio- en televisieomroep $\left({ }^{153}\right)$, onderwijzers $\left({ }^{154}\right)$, PTT-personeel $((155)$ en civiele vliegtuigbouwkundigen in dienst van het leger $\left({ }^{150}\right)$ : zij allen kunnen aanspraak maken op het recht van collectieve onderhandelingen.

Evenals in het geval van organisatierechten, achten de toezichtsorganen van de ILO inbreuken op het recht van collectieve onderhandelingen in principe toelaatbaar, mits de categorie van werknemers waarvoor deze restricties gelden, nawweurig omschreven is.

150 Cases Nos. 1126,1136 en 1137 (Chili), 218e Rap. $\$ 215$.

151 Art. 7 van Verdrag no. 159 van 1978 (Arbeidswerhoudingen in de Publieke Sector) verwijst, naast collectieve onderhandelingen, naar "andere methoden die vertegenwoordigers van ambtenaren in stalat stellen om deel te nemen an de vaststelling van arbeidswoorwaarden".

152 Survey, $\$ 255$.

153. Case No. 764 (Colombia), 143e Rap. \$ 87.

154 Zie o.a. Case No. 573 (Bolivia), 118e Rap. \& 194.

155 Case No. 725 (Japan), Rap. $139 \$ 278$.

156 Case No. 598 (Ecuador), 116e Rap. $\$ \$ 375-378$. 


\subsubsection{Stakingen}

Stakingsverboden in de publieke sector zijn, onder bepaalde omstandigheden en ten aanzien van bepaalde categorieën van werknemers geoorloofd, aldus de toezichtsorganen van de ILO. Wederom wordt de kring van werknemers wier rechten kunnen worden beperkt, iets vernimd (in vergelijking met hen die geen recht op collectieve onderhandelingen en - a fortiori - geen organisatierechten hebben): niet alleen aan ambtenaren die handelen of optreden namens de staat, maar ook aan werknemers in essentiële diensten kan het stakingsrecht ontzegd worden. Als maatstaf voor een "essentiële dienst" geldt een dienst wiens onderbreking het leven, de persoonlijke veiligheid of de gezondheid van de gehele bevolking of een deel daarvan in gevaar zou brengen. ${ }^{15}$ ?

Het zou te ver voeren om de gehele casuïstiek met betrekking tot de vraag welke economische sectoren aanspraak kunnen maken op de kwalificatie "essentiele diensten" op deze plaats te behandelen. De vindingrijkheid en fantasie wan de staat in het uitvinden van nieuwe essentiële diensten kent nauwelijks grenzen. ${ }^{158}$ Om een indruk te geven van het standpunt van de ILO kan melding gemaakt worden van een uitspraak van het Comité inzake de Vrijheid van Vakvereniging over werknemers van olie-producerende bedrijven: hoewel hun werkverzuim op de langere termijn ernstige consequenties kan hebben voor de nationale economie, bedreigt het niet het leven, de persoonlijke veiligheid of de gezondheid van de gehele bevolking of een deel daarvan. Met andere woorden: een absoluut stakingsverbod in deze sector is niet geoorloofd. ${ }^{159}$ Ziekenhuispersoneel $\left({ }^{160}\right)$ en werknemers die belast zijn met de watervoorziening $\left({ }^{161}\right)$ zijn wel werkzaam in essentiële diensten. Ter compensatie van het verlies van het belangrijke stakingsrecht moeten deze categorieën werknemers wel toegang hebben tot toereikende, onpartijdige en snelle conciliatie- en arbitrageprocedures. De uitspraken van de tribunalen moeten bindend zijn voor beide partijen en zij moeten snel en volledig ten uitvoer worden gelegd. ${ }^{162}$

Bij wijze van afsluiting van dit onderwerp, kan geconstateerd worden dat de toezichtsorganen van de ILO, met het oog op het ingrijpende karakter van beperkingen van vakbondsrechten in de publieke sector, strenge eisen stellen aan de vaststelling wan de kring van werknemers, waarvoor deze restricties van toepassing zijn. Mijns inziens vormt dit standpunt van de ILO een goede waarborg tegen pogingen van de staat om dergelijke categorieèn naar eigen

157 Survey, 214.

Zie o.a. Case No. 719 (Colombia), 138e Rap. \& 72;

Case No. 776 (Jamaica), 145e Rap. $\$ 43$.

158 Bij de behandeling van de ILO-case law met betrekking tot de wakbondssituatie in Chili, Colombia en Mexico zullen concrete voorbeelden aan de orde komen.

159 Case No. 1255 (Noorwegen), 234e Rap. 190.

160 Zie o.a. Case No. 910 (Griekenland), $199 \mathrm{e}$ Rap. $\$ 117$.

161 Case No. 1179 (Dom. Rep.), 234e Rap. $\$ 295$.

162. Survey, \& 214. 
goeddunken vast te stellen en daarmee de controle over de vakbeweging te versterken.

\section{Staatsingrepen in de organisatiestructuur van de vakbeweging. De problematiek van vakbondsmonopolies versus vakbondspluralüme}

Een staat wiens beleid erop gericht is om de vakbeweging zoveel mogelijk ondergeschikt te maken aan de eigen politieke doelstellingen, kan, indien hij besluit om in te grijpen in de organisatiestructuur van de vakbeweging verschillende tactieken volgen. Hij kan kiezen voor een strak hiërarchische; monolitische vakbondsstructuur. De staat zal het vakbondskader bewegen om de looneisen te matigen, zo min mogelijk stakingen uit te roepen en in het algemeen het vakbondsbeleid af te stemmen op de regeringspolitiek. Daarbij zal hij erop speculeren dat het kader voldoende gezag heeft over de basis om de staatsdirectieven door te voeren. ${ }^{\text {: }}$

Het succes van een dergelijke controle-politiek is in hoge mate afhankelijk van het vermogen van de staat om, hetzij alleen, hetzij in samenwerking met de gecontroleerde vakbeweging, pogingen om onafhankelijke vakbonden op te richten in de kiem te smoren. Vanuit deze optiek kan het verbod aan het adres van werknemers om andere (dan de bestaande, gecontroleerde) vakbonden op te richten, opgevat worden als de reflex van een succesvolle inkapselingspolitiek. De ILO verdiept zich evenwel niet primair in de vraag of vakbondsmonopolies de staat in de gelegenheid stellen om de vakbeweging te controleren en uit dien hoofde op gespannen voet staan met de vrijheid van vakvereniging. Voor de ILO staat voorop hoe vakbondsmonopolies zich verhouden tot de vrijheid van werknemers om zich aan te sluiten bij een vakbond naar eigen keuze. De ILO-opvattingen in deze komen in 6.2 aan de orde.

De staat kan daarentegen ook proberen om de vakbeweging als economische en politieke machtsfactor te verzwakken, door federalisatie tegen te gaan en de vakbeweging te versnipperen. Het feit dat in veel ontwikkelingslanden de ondernemingsvakbond de overheersende organisatievorm is, valt voor een deel toe te schrijven aan de obstructie door werkgevers en regeringen van pogingen om federaties en vakcentrales op te richten, uit vrees voor sterke politisering en massaprotesten. ${ }^{164}$ Deze letterlijke verdeel-en heerspolitiek vormt het onderwerp van 6.1 .

163 Pankert wijst op de politieke motieven die ten grondslag liggen aan het streven van een staat om een vakbondsmonopolie te creëren.

Pankert A. Freedom of Association, in: Comparative Labour Law and Industrial Relations, a.w. p. 179.

Cella G. and Treu T. National Trade Union Movements in:

Comparative Labour Law and Industrial Relations, a.w. p. 202. 


\section{Beperkingen van het recht van vakbonden om zich in (con)federaties te verenigen}

De artikelen 5 en 6 van Verdrag no. 87 kennen vakbonden het recht toe om zich te verenigen in (con)federaties en verlenen deze (con)federaties dezelfde rechten als eerste graadsvakbonden, ${ }^{\text {.6s }}$

Het Comité van Deskundigen maakt melding van de bonte verscheidenheid aan wettelijke bepalingen die op één of andere wijze de mogelijkheid van vakbonden om zich te verenigen in (con)federaties blokkeren. Zo geldt in een aantal landen een wettelijk minimum voor het aantal vakbonden dat vereist is om een organisatie van een hoger niveau op te richten. ${ }^{106}$ In andere landen worden obstakels opgeworpen om een horizontale organisatiestructuur te vestigen, doordat de wet eist dat de leden-organisaties tot dezelfde beroeps- of bedrijfssector behoren. ${ }^{167}$ Het wettelijke verbod aan het adres van vakbonden uit verschillende departementen om een gezamenlijke federatie op te richten, verijdelt daarentegen juist de vestiging van een verticale organisatiestructuur. ${ }^{168} \mathrm{Al}$ deze wettelijke bepalingen zijn, volgens de toezichthoudende organen van de ILO, in strijd met het recht van vakbonden ori zich te verenigen in (con)federaties. ${ }^{169}$.

Specifieke problemen kunnen zich voordoen in de publieke en de agrarische sector, waar wetgeving in sommige landen geen bezwaren makt tegen federatievorming binnen de sector zelf, maar agrarische- en ambtenarenbonden verbiedt om zich aan te sluiten bij resp. federaties van niet-agrarische bonden en federaties van vakbonden in de particuliere sector. ${ }^{170}$ Het Comité van Deskundigen acht deze wettelijke regelingen niet verenigbaar met het recht van werknemersorganisaties om zich aan te sluiten bij (con)federaties. ${ }^{177}$

165 Men kan onderscheiden tussen (con)federaties met een werticale en met een horizontale organisatiestructuur. Verticale (con)federaties bestaan uit vakbonden van werknemers die cenzelfde beroep uitoefenen of werkzaam zijn in dezelfde bedrijfssector. Horizontale (con)federaties opereren op geografische basis en omwatten vakbonden die werknemers met verschillende bercepen of die afkomstig zijn uit verschillende bedrijfssectoren, vertegenwoordigen.

166 Bijwoorbeeld in Brazilië, Colombia en El Salvador.

Survey, $\$ 240$.

167 Het Comite van Deskundigen noemt Koeweit, Maleisië en Peru als voorbeelden. Survey, 252.

168 Het Comite inzake de Vrijheid van Vakvereniging kenschetsi een dergelijke bepaling als een inbreuk op art. 5 van Verdrag no. 87.

Case No. 662 (Nicaragua), 128 e Rap. \& 40.

169 Survey, \$245.

Case No. 335 (Peru), 85 e Rap. $\$ 460$.

Case No. 823 (Chili), 197e Rap. \$389.

170 In Liberia mogen agrarische bonden zich niet aansluiten bij een nationale centrale van industriële bonden. Case No. 506, $108 \mathrm{e}$ Rap. $\$ 226$.

Maleisie: Mexico en Peru staan vermenging tussen particuliere en publieke vakbonden niet toe.

Survey, 247 .

171 Surwey, 248. 
Tenslotte moet in dit verband nog gewezen worden op het feit dat sommige landen niet zozeer de federatievorming op zich tegenwerken maar trachten om (con)federaties te degraderen tot tandenloze tijgers door hen stakingsrechten, onderhandelingsrechten of beiden te ontzeggen. ${ }^{122}$ Het is interessant om te vernemen op grond van welke argumenten het Comité van Deskundigen deze wetgeving bekritiseert, aangezien dit een helder licht werpt op het standpunt van de ILO ten aanzien van staatspogingen om de macht van de vakbeweging te beteugelen. Beperkingen van deze aard, zo verklaart het Comite, schaden de ontwikkeling van industrielle verhoudingen, vooral in het geval van kleine bonden die, vanwege hun beperkte kracht en ongetraind kader, wellicht niet in staat zijn om zelf op effectieve wijze de belangen van hun leden te behartigen. ${ }^{\text {is }}$

\subsection{Het ILO-standpunt inzake vakbondsmonopolies}

De IIO spreekt geen voorkeur uit voor vakbondsmonopolies of -pluralisme. ${ }^{124}$ Deze opstelling getuigt van wijsheid. Vakbondspluralisme kan een sterke versplintering van de vakbeweging in de hand werken. Een sterke versplintering verzwakt, zoals in de vorige paragraaf is betoogd, de positie van de vakbeweging, zowel ten aanzien van werkgevers(organisaties) als ten aanzien van de staat. Aan de andere kant zal een vakbondsmonopolie de keuzevrijheid van werknemers beperken en mogelijkerwijs de staat in de gelegenheid stellen om de greep over de vakbeweging te versterken. Hetzal van de concrete omstandigheden afhangen of een vakbondsmonopolie of juist vakbondspluralisme de beste garanties biedt voor de onafhankelijkheid van de vakbeweging. ${ }^{175}$

In aansluiting hierop maken de toezichtsorganen van de ILO een duidelijk onderscheid tussen vakbondsmonopolies die door de staat zijn opgelegd en in de wet zijn verankerd en situaties, waarin werknemers zich vrijwillig verenigen in én organisatie, zonder dat dit het directe of indirecte gevolg is van wettelijke bepalingen. ${ }^{176}$ Door de wet voorgeschreven, dwingend opgelegde vakbondsmonopolies verdragen zich niet met het, in art. 2 van Verdrag no. 87 gegarandeerde, recht van werknemers om zich aan te sluiten bij organisaties "naar eigen keuze",

Hieronder zullen de opvattingen van de ILO met betrekking tot door de wet opgelegde en feitelijke vakbondsmonopolies worden weergegeven. Beide varianten worden gescheiden

172 Het Comité van Deskundigen noemt o.a. Chili, Colombia en Uruguay als voorbeelden. Survey, $\$ 249$.

173 Survey, $\$ 249$. Zie yoorts: Case No. 1109 (Chili), $217 \mathrm{e}$ Rap. $\$ 483$.

174 In $\$ 223$ van de Digest wordt gerefereerd aan een uitspraak van de ILC die dexe strekking heeft. Onder "vakbondspluralisme" wordt verstaan het naast elkaar opereren van concurrerende vakbonden binnen én onderneming, een bedrijfstak, een regio of op centraal niveau.

175 Ook Schregle wijst op de bezwaren die verbonden zijn aan de beide organisatiestructuren. Schregle, a.w. p. 66 .

176 Digest $\$ 224$; General Survey, $\$ 136$. 
door een paragraaf over staatsbegunstiging van vakbonden die eveneens de keuzevrijheid van de werknemers kan beperken.

\subsubsection{De wettelijke regeling van vakbondsmonopolies}

Zoals hierboven werd aangegeven, maken de toezichtsorganen van de ILO bezwaren tegen vakbondsmonopolies die het resultaat zijn van wettelijke maatregelen.

Het Comité van Deskundigen schetst de rijke variëteit aan wettelijke systemen met betrekking tot de regeling van vakbondsmonopolies. In sommige landen bepaalt de wet dat slechts één vakbond binnen een onderneming of bedrijfstak mag opereren. ${ }^{{ }^{77}}$ Een dergelijke regeling is niet alleen in strijd met art. 2 van Verdrag no. 87 maar vergemakkelijkt ook inmenging door de werkgever in vakbondsaangelegenheden. ${ }^{178}$

De situatie is evenwel aanmerkelijk ernstiger indien het monopolie-systeem doorgevoerd is op alle organisatieniveaus, van onderneming, via bedrijfstak en regio, to nationale vakcentrale. Deze vakbondsmonopolies worden dikwijls gekenmerkt door een strakke hiërarchische organisatiestructuur die in stand gehouden kan worden door - bijvoorbeeld ondernemingsvakbonden te verplichten zich te conformeren aan de statuten van de enige vakcentrale, op straffe van onwettigheid. ${ }^{17}$ Bovendien bestaan er in de meeste landen met een vakbondsmonopolie nauwe banden tussen vakbeweging en regeringspartij. ${ }^{100}$

Al te doorzichtige constructies - zoals de bepaling dat een vakbond in een onderneming of bedrijfstak meer dan $50 \%$ van de werknemers moet vertegenwoordigen - worden door de toezichtsorganen van de ILO onmiddellijk ontmaskerd als een poging om door middel van wetgeving een vakbondsmonopolie te creëren ${ }^{181}$ Soms legt een staat iets meer misleidend raffinement aan de dag door vakbondsmonopolies niet dwingend voor te schrijven maar te bepalen dat de omstandigheid dat in een onderneming of bedrijfstak al een vakbond opereert, een grond kan opleveren om registratie van een andere vakbond te weigeren. Ook dergelijke regelingen kunnen de toets der kritiek niet doorstaan. ${ }^{182}$ Het Comitê inzake de Vrijheid van Vakvereniging acht de verplichte contributie die werknemers moeten betalen aan de enige nationale vakcentrale, een middel om de monopolie-positie van deze centrale te

177 Als woorbeelden van de eerste regeling noemt het Comite: Bolivia, Colombia, Mexico (in de publieke sector) en Peru. Bedrijfstak-monopolies komen voor in Kameroen en Mauretanië. General Survey, 133.

178 General Survey, $\$ 133$.

179 Vooral in Afrikaanse landen zijn wakbondsmonopolies in zwang (Gabon, Nigeria, Zambia etc.) General Survey, \& 134.

180 Bijvoorbeeld Algerije en Angola, Survey, \& 135 .

181 General Survey, $\$ 133$.

Case No. 335 (Peru), 85e Rap. $\$ 438$ en 439.

182 General Survey, \&139.

Digest, \$2 229 en 231. 
versterken en is van mening dat zo'n verplichting onverenigbaar is met art. 2 van Verdrag no. 87.

Hoezeer de ILO beducht is voor staatsinmenging in de organisatiestructuur van de vakbeweging blijkt uit het feit dat zowel het Deskundigen-Comité als het Comitê inzake de Vrijheid van Vakvereniging ernstige bedenkingen hebben tegen de wettelijke institutionalisering van een feitelijke monopolie-situatie, ook al geschiedt dit op verzoek van de vakbeweging. Werknemers, zo voegt het Deskundigen-Comite er ter verklaring aan toe, moeten te allen tijde over de vrijheid beschikken om vakbonden op te richten buiten de gevestigde vakbondsstructuur, Voorts verdienen de rechten wan werknemers die zich niet willen aansluiten bij de bestaande vakbonden ook bescherming. ${ }^{185}$

Het Comité inzake de Vrijheid van Vakvereniging rondt de bespiegelingen over de wettelijke regeling van vakbondsmonopolies af met de uitspraak dat maatregelen, genomen tegen werknemers die buiten de officiële vakbeweging proberen om vakbonden op te richten, in strijd zijn met het recht om organisaties naar eigen keuze op te richten. ${ }^{186}$

\subsubsection{Toelaatbaarheid van begunstiging van vakbonden uit hoofde van hun representativiteit}

In veel staten genieten vakbonden privileges op grond van hun representatieve karakter. Op zich levert dit geen strijd op met de letter en de geest van Verdrag no. 87. De ILO zelf heeft immers het begrip "meest representatieve werknemersorganisatie" in haar Statuut geïntroduceerd en kent aan deze vakbonden het voorrecht toe om geconsulteerd te worden door de staat bij de werving van werknemersvertegenwoordigers. ${ }^{187}$

Problemen rijzen pas indien de toekenning van een bevoorrechte positie aan representatieve vakbonden impliceert dat andere, niet representatieve vakbonden niet of nauwelijks hun rechten kunnen uitoefenen. De vrijheid van werknemers om zich aan te sluiten bij de organisatie van hun keuze wordt in zo'n geval immers beknot en een dergelijke constructie zou praktisch neerkomen op het instellen van een vakbondsmonopolie. ${ }^{188}$

Een tweede, hieraan nauw verwant probleem doet zich voor indien een staat, al dan niet onder het voorwendsel van "representativiteit", bepaalde vakbonden voortrekt boven andere.

183 Case No. 266 (Portugal), 65 e Rap. $\$ 61$ en 62.

184 General Survey, $\$ 137$.

Case No. 393 (Syriē), 83e Rap. $\$ \$ 4$ en 65 .

185 General Survey $\$ 137$. Deze laatste toevoeging is opmerkelijk, gezien de terughoudende opstelling van de ILO ten aanziten van "closed shop"-clausules. Ik kom hier aanstonds op terug.

186 Zie o.a. Case No 143 (Spanje), 60e Rap. $\$ 62$.

187 Statuut art. 3 , lid 5 .

188 General Survey, $\$ 141$.

Digest, $\$ 235$. 
De toezichtsorganen van de ILO hebben behoedzaam en op systematische wijze deze delicate materie behandeld. Om te beginnen hebben zij aangegeven op welke terreinen representatieve vakbonden privileges genieten. In beginsel hebben zij alleen een bevoorrechte positie bij collectieve onderhandelingen, consultatie door regeringen en het aanwijzen van vertegenwoordigers in internationale organisaties. Minderheids-organisaties moeten in de gelegenheid gesteld worden om te functioneren en op z'n minst het recht hebben om de belangen van hun leden te verdedigen. ${ }^{1 * 0}$

Het Comite inzake de Vrijheid van Vakvereniging heeft, vooral met betrekking tot collectieve onderhandelingen, in detail de criteria uitgewerkt, op grond waarvan vastgesteld kan worden welke vakbond aanspraak kan maken op het predikaat "meest representatief". Als algemene vuistregel geldt dat deze vaststelling dient te geschieden aan de hand van objectieve en van te voren opgestelde maatstaven. ${ }^{100}$ Het Comité noemt enkele garanties voor een eerlijke gang van zaken: het waarmerk "meest representatieve organisatie" moet verleend worden door een onafhankelijke instantie, de representatieve organisatie moet worden verkozen door de meerderheid van de werknemers in de eenheid waarvoor de CAO wordt afgesloten en minderheids-vakbonden dienen het recht te hebben om na verloop van tijd nieuwe verkiezingen te eisen. ${ }^{191}$

Uit bovenstaande voorwaarden valt in de eerste plaats op te maken dat de overheid het aan de werknemers moet overlaten om te bepalen door wie zij aan de onderhandelingstafel vertegenwoordigd willen worden. Het toekennen, door de overheid, van privileges op het gebied van collectieve onderhandelingen aan minderheids-vakbonden of aan organisaties die slechts in beperkte mate representatief zijn, maakt inbreuk op het recht op collectieve onderhandelingen van meerderheids-organisaties en is bovendien in strijd met het beginsel dat de autoriteiten zich niet dienen te mengen in interne vakbondsaangelegenheden. ${ }^{192}$

In de tweede plaats onderkent het Comité dat de voorkeur van werknemers voor een bepaalde organisatie, op grond waarvan deze organisatie bepaalde voorrechten geniet, geen statisch gegeven is. De krachtsverhoudingen die gebaseerd zijn op de aanhang onder de werknemers kunnen zich wijzigen en de bevoegde autoriteiten dienen dan ook elke aanspraak van een vakbond dat zij - inmiddels - de meerderheid binnen een onderrieming vertegenwoordigt, te verifièren, vooropgesteld dat deze aanspraak plausibel lijkt. ${ }^{193}$

189 General Survey, \$141.

Digest, 236.

190 Digest, $\$ 239$.

191 Digest, $\$ 237$.

192 Cases Nos. 589 en 594 (India), 118e Rap. $\$ 81$ en 82.

Case No. 1087 (Portugal), 117 e Rap. $\$ 222-224$.

Case No. 1174 (Portugal), 230e Rap. $\$ 214$ en 215.

193 Zie o.a. Case No. 728 (Jamaica), 138e Rap. $\$ 53$. 
Indien er twijfel bestaat over de vraag welke vakbond het meest representatief is, moeten de autoriteiten, zo zij over deze macht beschikken, vakbondsverkiezingen uitschrijven om aan de onzekerheid een einde te maken. ${ }^{194}$

Uit het feit dat de toezichtsorganen van de ILO de voorrechten van meest representatieve organisaties begrenzen tot enkele, specifiek genoemde, activiteiten en bovendien deze privileges beschouwen als een afgeleide van de wil van de werknemers, kan worden opgemaakt dat het toekennen van andere rechten door de overheid aan favoriete vakbonden door de ILO beschouwd wordt als een ontoelaatbare begunstiging. Begunstiging en achterstelling zijn natuurlijk twee zijden van dezelfde medaille en het ligt voor de hand dat het Comité inzake de Vrijheid van Vakvereniging uitsluitend te oordelen heeft gehad over klachten van vakbonden naar aanleiding van (vermeende) achterstelling.

Het uitoefenen van druk op werknemers door middel van publieke verklaringen $\left({ }^{110}\right)$, de ongelijke verdeling van subsidies onder vakbonden $\left({ }^{150}\right)$ en de weigering om leiders van bepaalde organisaties te erkennen $\left({ }^{197}\right)$ : het zijn alle informele methoden van de overheid om het vakbondslidmaatschap van werknemers te beïnvloeden. $\mathrm{Zij}$ zijn moeilijk te bewijzen maar vormen een bedreiging van het recht van werknemers om zich aan te sluiten bij de organisatie van hun keuze.

In sommige gevallen liggen begunstiging resp. achterstelling meer aan de oppervlakte. Zo heeft het Comite inzake de Vrijheid van Vakvereniging in een aantal zaken het toekennen van vakbondslokalen aan een bepaalde organisatie en de onteigening van vakbondslokalen ten behoeve van een andere vakbond gekwalificeerd als discriminerende handelingen. ${ }^{198}$ Verder heeft het Comité bepaald dat de toekenning van privileges aan geregistreerde vakbonden niet als pendant mag hebben dat niet-geregistreerde vakbonden onderworpen zijn aan speciale maatregelen van politietoezicht. ${ }^{109}$ Indirect refererend aan de specifieke terreinen waar de meest representatieve vakbonden privileges genieten, heeft het Comité a contrario uitdrukkelijk gesteld dat deze organisaties niet over het exclusieve recht dienen te beschikken om federaties op te richten of zich daarbij aan te sluiten.

Tenslotte heeft het Comité de rol van de staat bij de vaststelling van de meest representatieve organisatie voor de deelname aan arbitrage-tribunalen, beperkt tot een formele erkenning van de feitelijke situatie. Iedere andere staatsinterventie moet vermeden worden. ${ }^{201}$

194 Zie o.a. Case No. 624 (Ver.Kon./Brits. Honduras), 121e Rap. $\$ 55$.

195 Case No. 494 (Soedan), 93 e Rap. 333.

196 Case No. 361 (Marokko), 79e Rap. $\$ 98$.

197 Case No. 763 (Uruguay), 170e Rap. \$14.

198 Zie o.a. Case No. 248 (Senegall), 57e Rap. $\$ 28$.

199 Case No. 298 (Zuid-Rhodesiè), 74e Rap. $\$ 45$. Cases Nos. 251 en 414 (Zuid-Rhodesië), 107 e Rap. \& 39.

200 Case No. 842 (Argentinië), 201e Rap. $\$ 55$.

201 Case No. 341 (Griekenland), 85e Rap. $\$ 195$. 
6.2.3 Uitsluiting van concurrentie door de vakbeweging zelf op grond van "closed shop"bepalingen

Uit beide voorgaande paragrafen kan worden afgeleid dat de toezichtsorganen van de ILO huiverig staan tegenover pogingen van staatswege om, hetzij door het van bovenaf opleggen van een organisatiestructuur, hetzij door het overladen van bepaalde vakbonden met gunstbewijzen, de keuze van (aspirant)vakbondsleden voor een organisatie te beinvloeden. In deze paragrafen stond niet zozeer de vrees voor het verlies van onafhankelijkheid van de gehele vakbeweging centraal. De zorg van de ILO gold met name de rechten van werknemers, wier inspanningen om, buiten de gevestigde vakbondsstructuren om, organisaties op te richten gedwarsboomd werden.

Hierboven werd al aangegeven dat de toezichtsorganen van de ILO een onderscheid maken tussen door de staat opgelegde vakbondsmonopolies en feitelijke monopolie-situaties. Deze laatste situatie kan zich bijvoorbeeld voordoen indien een werkgever en een vakbond bij $\mathrm{CAO}$ overeenkomen dat de werkgever in geval van een vacature uitsluitend kan recruteren uit het ledenbestand van de vakbond. Een dergelijke "closed shop"-clausule impliceert tevens dat werknemers vakbondslid moeten blijven om hun baan te behouden. "Closed shop"-clausules verdragen zich natuurlijk niet met het recht van werknemers om zich niet aan te sluiten bij een vakbond: de zogenaamde negatieve coalitie-vrijheid. ${ }^{202}$

In ILO-verband zijn verhitte debatten gevoerd over de vraag of de negatieve coalitievrijheid een integrerend onderdeel vormt van de vrijheid van vakvereniging en derhalve aan de tenuitvoerlegging van "closed shop"-clausules in de weg staat. ${ }^{203}$ Uiteindelijk is deze vraag in negatieve zin beantwoord. Met verwijzing naar de relevante discussies stelt het Comité van Deskundigen dat "art. 2 van Verdrag no. 87 het aan de praktijk en de regelingen van elke staat overlaat om te beslissen of het geschikter is om de negatieve coalitievrijheid te garanderen, dan wel om "closed shop"-clausules toe te staan en, zo nodig, te regulleren". Op basis van dit algemene ILO-standpunt weigert het Comité inzake de Vrijheid van Vakvereniging dan ook klachten in behandeling te nemen die betrekking hebben op verplicht vakbondslidmaatschap als uitvloeisel van "closed shop"-clausules. ${ }^{205}$

De situatie ligt geheel anders indien de wet "closed shop"-bepalingen dwingend voorschrijft teneinde het lidmaatschap van een bepaalde vakbond verplicht te stellen. Dergelijke voorzieningen sorteren hetzelfde effect als bepalingen die een vakbondsmonopolie vestigen en zijn riet

202 Zie ower de werhouding tussen de negatieve coalitievrijheid en "closed shop"-clausules de heldere bijdrage van Thürer D. The Right not to Organize in: Die Koalitionsfreiheit des Arbeinehmers, Rechtswergleichung und Völkerrecht, Band 2, Max Planck-Institut, Heidelberg 1980, pp. 1245-1253.

203 Zie Record of Proceedings, ILC, 30e Zitting 1947, p. 571.

204 General Survey, $\$ 142$.

205 Zie o.a. Case No. 96 (Ver. Koninkrijk), 13e Rap. $\$ \$ 130$ en 131.

Case No. 492 (Mexico), \$121. 
verenigbaar met de keuzevrijheid van werknemers om zich aan te sluiten bij een organisatie, zo merkt het Deskundigen-Comitê op.

Ook het Comitê inzake de Vrijheid van Vakvereniging verwijst naar het recht van vrije keuze, waar het stelt dat een werknemer die door de wet verplicht wordt om een dubbel lidmaatschap aan te gaan, teneinde zijn baan te behouden, in zijn rechten geschonden wordt ${ }^{20}$

Tenslotte moet vermeld worden dat het Comite inzake de Vrijheid van Vakvereniging wel enig begrip toont voor de positie van de werknemer die gedupeerd wordt door een systeem dat lidmaatschap van een bepaailde vakbond als verplichte voorwaarde koppelt aan het verkrijgen van een baan. Er kan sprake zijn van discriminatie, indien er onredelijke eisen wordengesteld aan mensen die dit lidmaatschap verlangen en indien vakbondsleden willekeurig uit de desbetreffende organisatie worden gezet.

Ondanks laatstgenoemde nuancering van het ILO-standpunt inzake "closed shop"bepalingen, heeft de bewuste keuze van de organisatie om deze bepalingen binnen het kader van de vakverenigingsvrijheid toelaatbaar te achten, tot gevolg dat feitelijke vakbondsmonopolies niet gekritiseerd worden. "Closed shop"-bepalingen staan in praktijk vaak aan de existentie van verscheidene vakbonden binnen eén onderneming of bedrijfstak in de weg. De hooggeschatte keuzevrijheid van werknemers komt juist door het bestaan van "closed shop"clausules in het gedrang. Hoewel werknemers in theorie een concurrerende vakbond kunnen oprichten, zullen praktische bezwaren hen van dit voornemen afhouden. De financiële offers van een dubbel vakbondslidmaatschap zullen dikwijls niet door de werknemer kunnen worden opgebracht. Bovendien zal de angst voor royement - uit wraak voor een dissidente opstelling veel werknemers ervan weerhouden om een nieuwe vakbond op te richten.

Zonder zelf een hand te hebben gehad in de creatie van de organisatiestructuur, kan een staat wel profijt trekken van een dergelijk vakbondsmonopolie, dat immers, zoals hierboven betoogd is, de controle over de vakbeweging vergemakkelijkt.

Voorlopig wil ik volstaan met het plaatsen van deze kanttekeningen. In het vervolg van deze studie kom ik hier nog op terug.

\section{Evaluatie van de resultaten en conclusiles}

Bovenstaande paragrafen bevatten een inventarisatie van de ILO-standpunten met betrekking tot verschillende staatsmaatregelen ten aanzien van de vakbeweging, voorzover die maatregelen mogelijk op gespannen voet staan met de vrijheid van vakvereniging. De voornaamste "waterscheiding" is aangebracht tussen 4 enerzijds en 5 en 6 anderzijds. 4 verwijst naar een conflictsituatie, waarin de staat - vaak à l'improviste - repressieve maatregelen neemt tegen

206 General Survey, $\$ 145$.

207 Case No. 266 (Portugal), 65e Rap. $\$ 60$.

208 Case No. 114 (Verenigde Statem), 15e Rap. $\$ 62$.

Zie ook Pankert, a.w. p. 184. 
de vakbeweging als sanctie op de onafhankelijke politieke koers die de vakbeweging volgt. 5 en 6 hebben betrekking op een situatie, waarin de staat een structurele vakbondspolitiek voert met het oogmerk de controle over de vakbeweging te bestendigen en conflicten juist te voorkomen.

Naar dit onderscheid tussen, wat ik kortheidshalve wil aanduiden als het "repressiemodel" en het "controlemodel"; zal men in de uitspraken van de toezichthoudende organen van de ILO tevergeefs zoeken. ${ }^{20}$ De ILO is primair geïnteresseerd in de vraag of vakbonden over een vrije ruimte beschikken, waarbinnen zij hun activiteiten kunnen ontplooien en of deze ruimte al dan niet wordt ingeperkt door de staat. Zowel repressieve maatregelen als excessieve controle impliceren een overheidsinmenging in interne vakbondsaangelegenheden, die door Verdrag no. 87 wordt verboden. De ILO pleegt zich dan ook over beide vormen van vakbondspolitiek in kritische bewoordingen wit te laten.

De kracht van een dergelijke geïntegreerde benadering van het overheidsinstrumentarium, waarmee de vrijheid van vakvereniging kan worden ingeperkt, schuilt in het feit dat hiermee de nauwe samenhang tussen controle en repressie wordt onderkend. Binnen een controlemodel zal de staat repressieve maatregelen als stok achter de deur houden om de gecontroleerde vakbeweging eraan te herinneren geen politieke trouwbreuk te plegen. Het daadwerkelijk toepassen van repressie betekent in zekere zin gezichtsverlies voor de staat, omdat het een teken is dat de controle heeft gefaald en het louter dreigen met repressie niet toereikend is geweest. ${ }^{20}$ Aan de andere kant zal de staat zijn toevlucht nemen tot repressie met het oogmerk om de (politiek) onafhankelijke vakbeweging te temmen en zodoende de weg te plaveien voor controle. Kort samengevat; zou men kunnen stellen dat "controle" en "repressie" complementaire machtsmiddelen zijn in de handen van een staat die de vakbeweging wenst te overheersen. In hun zuivere, "archetypische" vorm komen het repressiemodel en het controlemodel in de praktijk niet voor. Een separate behandeling van het "repressie-model" en het "controle-model" in afzonderlijke paragrafen is mijns inziens evenwel verantwoord, aangezien in sommige landen de relatie tussen staat en vakbeweging voomamelijk gekenmerkt wordt door conflicten tussen de staat en een onafhankelijk-kritische vakbeweging, terwijl in andere landen doorgaans een (bedrieglijke) rust op het arbeidsfront heerst, omdat de vakbeweging met de staat in de pas loopt.

Met deze laatste kanttekening loop ik al enigszins vooruit op de rest van deze studie, waarin de analyse van de concrete vakbondssituatie in enkele Latijnsamerikaanse landen door de toezichtsorganen van de ILO centraal staat. Nu we enig inzicht hebben gekregen hoe de ILO globaal oordeelt over staatsmaatregelen die kenmerkend zijn voor het repressieen het controlemodel, zullen we ons vervolgens verdiepen in de vraag hoe de ILO-standpunten

209 Men kan stellen dat in de ILC-Resolutie van 1952 punt 5 en punt 6 werwijzen naar resp. het repressie- en het controlemodel, met dien werstande dat in punt 5 gekozen is voor het perspectief van de vakbeweging en geen melding wordt gemaakt van de reactie van de staat.

210 Hiermee wordt gesuggereerd dat controle als middel om de wakbeweging te overheersen, doeltreffender is dan repressie. Deze opvatting wordt gedeeld door A. Angell, a.w. p. 327. 
nader gestalte krijgen in relatie tot landen waar, naar wij veronderstellen, een repressieve of controlerende wakbondspolitiek wordt gevoerd.

Bij wijze van afsluiting, zullen de ILO-standpunten nog in het kort de revue passeren.

De voornaamste conclusie die uit $\mathbf{4}$ getrokken kan worden, is dat de ILO tot op zekere hoogte politiek als een normaal onderdeel van vakbondsactiviteiten beschouwt. Politiek bevindt zich, zo erkent de ILO, echter aan de periferie van de activiteitensfeer van de vakbeweging en zal, juist om deze reden, een bron van conflicten tussen staat en vakbeweging vormen. Bij de afweging van belangen van staat en vakbeweging, stelt de ILO voorop dat de inperking van vakbondsrechten van werknemers of bonden, vanwege het koesteren van een bepaalde politieke overtuiging niet aanvaardbaar is. Indien bonden of werknemers, bij het ontplooien van hun vakbondsactiviteiten, voornamelijk of uitsluitend politieke doeleinden nastreven, dan kunnen zij evenwel niet langer aanspraak maken op een volledige bescherming van hun vakbondsrechten. De ILO hanteert de vraag of de politieke actie in dienst staat van de belangenbehartiging van de vakbondsleden als maatstaf voor de toelaatbaarheid van politieke activiteiten. In praktijk betekent dit dat vakbonden met name de sociaal/economische politiek van de staat kritisch zullen volgen, voorzover deze direct of indirect consequenties heeft voor hun leden. Tenslotte dient de rechter te beoordelen of vakbonden, door zich in te laten met politieke activiteiten, al dan niet hun bevoegdheden overschreden hebben.

Men kan wel vrede hebben met dit standpunt van de ILO. Het gaat niet aan om de tamelijk vergaande protectie die vakbondsleden bij het uitoefenen van hun rechten op grond van internationale verdragen genieten, te verlenen aan vakbondsleden die in feite misbruik maken van deze rechten. Bovendien biedt de inschakeling van de rechter althans in beginsel een goede garantie voor een onpartijdige afweging van de belangen van staat en vakbeweging.

In 5 zijn toezichthoudende maatregelen en andere vormen van overheidsinmenging in vakbondsaangelegenheden aan de orde geweest die in principe deel uit kunnen maken van een structurele controle-politiek. In het geval van toezichthoudende maatregelen volstaat de ILO, met voorbijgaan aan de politieke motieven van de staat die ook dikwijls moeilijk te achterhalen zullen zijn, met te stellen dat staatssupervisie over vakbondsactiviteiten in strijd is met de vrijheid van vakvereniging, vooral indien die supervisie een structureel karakter heeft. Waar de staat aan de erkenning van vakbonden of de goedkeuring van statuten de voorwaarde verbindt dat zij bij het ontplooien van hun activiteiten rekening dienen te houden met de (economische) politiek, onthult de stat zijn boze opzet' om de vakbeweging te controleren. Het is verheugend dat de toezichtsorganen van de ILO, overigens geheel in overeenstemming met de Resolutie van de ILC, er niet voor terugdeinzen om een structurele controle-politiek aan de kaak te stellen. Ook aan inmenging in collectieve onderhandelingen en aan beperkingen van vakbondsrechten in de publieke sector liggen dikwijls politieke drijfveren ten grondslag. Zodra de intentie van de autoriteiten om de vakbonden te conformeren aan de eigen politiek aan de oppervlakte komt, schromen de toezichtsorganen 
niet om de maatregelen te kwalificeren als een aantasting van de onafhankelijkheid van de vakbeweging.

Tenslotte zijn in 6 de uitspraken van de ILO met betrekking tot staatsingrepen in de organisatiestructuur aan een nader onderzoek onderworpen. Elke organisatiestructuur die door de staat van bovenaf is opgelegd impliceert een schending van de vrijheid van vakvereniging, zo kan men het algemene standpunt van de ILO samenvatten. De ILO onderkent hierbij gedeeltelijk de onderliggende politieke motieven van de staat om controle uit te oefenen over de vakbeweging: een sterk verbrokkelde organisatiestructuur verzwakt de positie van de vakbeweging als politieke en sociaal/economische machtsgroepering.

In het geval van vakbondsmonopolies, neemt de ILO de positie van werknemers die, buiten de gevestigde vakbondsstructuur om, vakbonden willen oprichten en door het bestaan van een vakbondsmonopolie in hun streven gefrustreerd worden, tot uitgangspunt. Hoewel de toezichtsorganen van de ILO hier en daar toespelingen maken op de mogelijkheden van staten om hun greep over vakbewegingen die een monopoliepositie genieten, te versterken, is het (mogelijke) verlies van politieke onafhankelijkheid niet de voornaamste reden om vakbondsmonopolies aan de kaak te stellen. In het licht van de verdragsbepalingen, op basis waarvan de toezichtsorganen tot een evenwichtige taxatie van de vakbondssituatie moeten komen, is deze benadering begrijpelijk en zelfs verstandig. Art. 2 van Verdrag no. 87 bied. een duidelijk aanknopingspunt om door de staat ingestelde vakbondsmonopolies te kritiseren. Het bewijs dat de staat speciaal met het oog op het controleren van de vakbeweging, een vakbondsmonopolie in het leven heeft geroepen, zal daarentegen moeilijk te leveren zijn. Bovendien is de ILO, door de problematiek uit de geschetste invalshoek te benaderen, in staat om begunstiging van bepaalde vakbonden te kwalificeren als een aantasting van vakbondsrechten van bonden en werknemers die zich niet in de steun van de staat mogen verheugen.

Het venijn schuilt in de staart: de ILO weigert te oordelen over feitelijke vakbondsmonopolies die het gevolg zijn van het wijd verbreid van kracht zijn van "closed shop"-clausules. In 6 heb ik volstaan met enkele kritische kanttekeningen. In hoeverre dit standpunt nu gevolgen heeft voor de beoordeling van een controle-politiek die in hoge mate gefundeerd is op het bestaan van dergelijke feitelijke vakbondsmonopolies, zal nader onderzocht worden in de volgende hoofdstukken. 
s... 


\section{Een typologie van de Latijnsamerikaanse vakbeweging}

\section{$1 \quad$ Inleiding}

Wie een beeld probeert te verkrijgen van de Latijnsamerikaanse vakbeweging, stuit onvermijdelijk op de nauwe vervlechting tussen regeringen of politieke partijen aan de ene kant en de vakbeweging aan de andere kant. Deze nauwe vervlechting wordt door een groot aantal schrijvers onderkend.' In een poging om de politieke mobilisatie van de arbeidersklasse te controleren en met het oogmerk om de inwilliging van looneisen af te stemmen op de eigen economische politiek, hebben regeringen vakbonden opgericht en hebben zij regelmatig ingegrepen in de arbeidsverhoudingen. Soms hebben georganiseerde werknemers, wier onderhandelingspositie ten opzichte van de werkgever doorgaans zwak is $\left({ }^{2}\right)$, van deze staatsinterventies geprofiteerd, maar de regeringscontrole heeft tot verlies van politieke autonomie geleid en de vakbeweging bovendien afhankelijk gemaakt van economisch regeringsbeleid.

In enkele landen - Bolivia, Chili, Peru - waar een militante vakbeweging tot ontwikkeling is gekomen die nauwe betrekkingen onderhoudt met links-georiënteerde politieke partijen, heeft de vakbeweging een zekere mate van onafhankelijkheid ten opzichte van de staat weten te behouden. ${ }^{3}$ In deze landen plegen vakbonden door middel van het organiseren van algemene stakingen en massa-demonstraties rechtstreeks pressie uit te oefenen op de staat, teneinde

1 Zie o.a. Alba V. Politics and the Labor Movement in Latin America; Stanford 1968/Alexander R.J. Organized Labor in Latin America; New York 1965 en Poblette Troncoso M. and Burmett B.G. The Rise of the Latin American labor movement; New York 1960.

Ook in studies van meer recente datum worden de nauwe betrekkingen tussen staat en vakbeweging onderkend: zie met name Davis Ch. L. Working Class Mobilization and Political Control in Venezuela and Mexico, Kentucky 1989/Touraine A. La Parole et le Sang; Paris 1988 en Epstein E.C. (ed.) Labor Autonomy and the State in Latin America; Boston 1989.

Francisco Zapata (El Conflicto Sindical en América Latina; Mexico 1986) signaleert evenwel een groeiende verwijdering tussen staat en wakbeweging.

2 Vergelijk Carrierre J./Haworth N. and Roddick J. (eds.) The State, Industrial Relations and the Labour Mowement in Latï America; Hampshire 1989, p. 7 en Zapata (1986), a.w. p. 54.

3 Vgl. Touraine (1988), a.w. p. 262. 
hun belangen te verwezenlijken. ${ }^{4}$ Bovendien komt het radicale karakter van de vakbeweging in deze landen vaak tot uitdrukking in de aard van de eisen: vakbonden beperken zich niet tot de verbetering van de sociaal-economische positie van hun leden (de zogenaamde "breadand-butter-issues"), maar dringen aan op fundamentele politieke hervormingen en herverdeling van de nationale rijkdommen. ${ }^{5}$ Politiek radicalisme en vakbondsmilitantie gaan in deze landen met andere woorden regelmatig hand in hand.

De afgelopen jaren zijn er enkele studies verschenen, waarin fundamentele kritiek wordt geleverd op de zojuist geschetste "orthodoxe" visie op de Latijnsamerikaanse vakbeweging. Het concept van een sterk gepolitiseerde vakbeweging is volgens deze schrijvers achterhaald. In de eerste plaats zou de vakbeweging er niet op uit zijn om een sociale revolutie te ontketenen maar primair geïnteresseerd zijn in de verbetering van de eigen levensstandaard. In de tweede plaats zou de vakbeweging bezig zijn zich te ontworstelen aan de staatsbevoogding. Als relatief bevoorrechte sociale actoren, hebben vakbonden juist een sterke onderhandelingspositie ten opzichte van werkgevers(organisaties), zodat zij de protectie van de overheid, die altijd het gevaar van autonomieverlies met zich meebrengt, niet (langer) nodig hebben.

Ongetwijfeld vormt deze nieuwe kijk op de complexe wisselwerking tussen vakbeweging, staat, politieke partijen en werkgevers(organisaties) een nuttige correctie op de wellicht wat statische, conventionele visie en doet zij recht aan de grote verschillen die niet alleen tussen landen onderling, maar ook tussen de verscheidene economische sectoren binnen één land bestaan. Toch erkennen ook de pleitbezorgers van een herinterpretatie van de positie van de Latijnsamerikaanse vakbeweging dat de staatsinvloed in arbeidsverhoudingen, met name waar deze verankerd is in wetgeving, een persistent karakter heeft.' Hieruit kan men afleiden dat, niettegenstaande de meningsverschillen over de recente ontwikkeling van de vakbeweging in Latijns Amerika, er met betrekking tot de oorspronkelijke nauwe betrekkingen tussen staat en vakbeweging een grote mate van consensus bestaat.

Het ligt in de bedoeling om in dit hoofdstuk de voor Latijns Amerika typerende vervlechting tussen vakbeweging en politiek tot uitgangspunt te nemen en deze te verklaren tegen de achtergrond van sociaal/economische en politieke ontwikkelingen op het continent.

4. Aan deze directe confrontatie tussen staat en wakbeweging heeft James Payne de benaming "political bargaining" gekoppeld. Payne J. Labor and Politics in Penu, New Haven Conn. 1965.

5 Om begripsverwarring te vermijden, lijkt het mij raadzaam om de terminologie van Landsberger aan te houden. Deze spreekt van politieke activiteiten, indien een vakbond wia politieke partijen of door druk uil te oefenen op de staat, haar eisen tracht te verwezenlijken, ongeacht de aard van die eisen. Wanneer een vakbeweging een politieke "animus" heeft die zich bijwoorbeeld kan openbaren in het principieel ter discussie stellen van de politieke legitimatie van een regering of in fundamentele kritiek op diens buitenlands beleid, spreekt Landsberger over ideologische motieven. Landsberger H. The Labor Elite: Is it revolutionary? in: Lipset S.M./Salari A. Elites in Latin America; Londan 1967, p. 264.

6. Zie met name Cordöva E. (ed.) Las Relaciones Colectivas en América Latina; Ginebra 1981, en Roxborough 1. Unions and Politics in Mexico: The Case of the Mexican Automabile Industry; Cambridge 1984.

7 Zie met name won Potobsky G. Las Onganizaciones Sindicales in: Cordova (1981), a.w. p. 26. 
Ik ben mij er terdege van bewust dat een dergelijke globale benadering onvermijdelijk een impressionistisch beeld oplevert dat als verklarend model een betrekkelijk geringe waarde heeft. Gedeeltelijk wordt dit bezwaar ondervangen doordat in de latere hoofdstukken over de afzonderlijke landen die in dit proefschrift centraal staan, nadere details en nuances worden aangebracht. In het historisch overzicht wordt namelijk een fasering aangegeven in de verhouding tussen staat en vakbeweging - "heroïsche" fase, nationalistisch-populistische regeringen, bureaucratisch-autoritaire regimes, herstel van de democratie - die zich niet in alle Latijnsamerikaanse landen op gelijke wijze voltrokken heeft. Zo hebben in Chili populistische regimes nimmer vaste voet aan de grond kunnen krijgen. Anderzijds is noch in Colombia, noch in Mexico de democratische regeringsvorm gedurende de jaren zestig en zeventig onderbroken geweest door een bureaucratisch-autoritair intermezzo. Dergelijke "verstoringen" van het algemene beeld lenen zich bij uitstek voor een nadere analyse in de specifieke landen-hoofdstukken.

Oog voor geografische diversiteit kan echter nog niet verhelpen dat algemene thema's, zoals samenstelling van de beroepsbevolking en organisatiegraad en -structuur van de vakbeweging, in een historische verhandeling wat onderbelicht blijven. Juist dergelijke structurele aspecten kunnen het inzicht in de plaats van de Latijnsamerikaanse vakbeweging in het sociaal/economische en politieke krachtenveld en in haar sterke en zwakke punten verscherpen. Om in dit hiaat te voorzien, heb ik besloten $\mathrm{om}$, voorafgaand aan de historische analyse, een paragraaf op te nemen, waarin in het kort aandacht wordt besteed aan deze onderwerpen.

\section{Structurele aspecten van de Latijnsamerikaanse vakbeweging}

\section{I Samenstelling van de beroepsbevolking}

De samenstelling van de beroepsbevolking in Latijns Amerika heeft de afgelopen decennia drastische veranderingen ondergaan. De ontvolking van thet platteland of, anders gezegd, de urbanisatie heeft in vrijwel alle Latijnsamerikaanse landen geleid tot een aanzienlijke afname van het percentage van de bevolking dat werkzaam is in de agrarische sector. In tegenstelling tot wat halverwege de jaren ' 50 werd voorspeld, is slechts een bescheiden deel van deze stedelijke migranten geassimíleerd door de industriële sector. Sterker nog: in enkele landen is het percentage van de beroepsbevolking dat werkzaam is in de industrie, zelfs afgenomen. (zie Tabel 1)

Tabel 1. Veranderingen in de samenstelling van de beroepsbevolking in Argentinië, Brazilië, Chili, Mexico, Peru en Venezuela tussen 1950-1970 en 1970-1980 (in procenten). 
- 8,8

1970-1980

\section{Brazillië}

1950-1970

1970-1980

Chill

1950-1970

1970-1980

Mexico

1950-1970

1970-1980

Peru

1950-1970

1970-1980

Venezuela

1950-1970

1970-1980
- 2,7

- 15,6

- 15

- 8,8

- $\quad 5,3$

- 16,0

- 0,6

- 12,3

- 0,6

- 20

$+2$

$$
+\quad 0,5
$$

- 2,5

$+8,3$

$+5,2$

$+1,6$

$+5$

$+6,7$

$+\quad 4,7$

- 2,8

- 1,0

$+11,6$

$+6,4$

$+\quad 0,6$

$+9,8$

$+\quad 1,8$

- 2,3

$+\quad 1,8$

$+10,5$

$+\quad 0,2$

- 2,8

$+\quad 4,9$

$+15,3$

$-1,5$

- 0,5

Bron: ILO, Statistical Yearbook, Geneva 1981. Gegevens over Brazilië en Argentinië (19701980): ILO, Statistical Yearbook, Geneva 1984.

De dienstensector heeft, zo kan men uit bovenstaande tabel afleiden, het meest "geprofiteerd" van de urbanisatie. Voor het overige zijn de stedelijke migranten terecht gekomen in de moeilijk definieerbare informele sector (zie tabel 2). ${ }^{8}$

Vrij algemeen wordt verondersteld dat er een verband bestaat tussen de aard van de sector en de (economische) potentie van vakbonden. ${ }^{9}$ Vakbonden plegen vooral goed te gedijen in grote industriële ondernemingen, aangezien in deze ondernemingen werknemers met gemeenschappelijke belangen samenwerken in gelijke arbeidsomstandigheden en onder gelijke arbeidsvoorwaarden. Daarbij hebben grote ondernemingen minder te duchten van concurrentie, zodat zij concessies aan een vakbond in de vorm van loonsverhogingen gemakkelijker kunnen verdisconteren in prijsstijgingen.

Gegeven het feit dat in Latijns Amerika slechts een betrekkelijk gering percentage van de arbeidsbevolking emplooi vindt in de industriële sector en dat bovendien het panorama

8 Carrière rekent tot de informele sector de onbetaalde arbeidskrachten van een familiebedrijf en de kleine zelfstandigen. Carrière (1989), a.w. p. 2.

9 Vergelijk Crouch C. Trade Unions: the Logic of Collective Action, Gllasgow 1982, pp. 67-70. Landsberger (1967), a.w. p. 288 . Zapata (1986), a.W. p. 39. 
in deze sector beheerst wordt door kleine bedrijven, lijkt de veronderstelling gerechtvaardigd dat de beroepsstructuur een negatief effect heeft op de ontwikkeling van de vakbeweging."

Bovendien wordt wel aangenomen dat de groei van de informele sector de onderhandelingspositie van vakbonden in de industriële sector ondermijnt. ${ }^{11} \mathrm{De}$ aanwezigheid van een arbeidsreserve, bestaande uit kleine zelfstandigen in de dienstverlening die op zoek zijn naar een betrekking in loondienst, vormt een permanente bedreiging voor eenieder die min of meer een "vaste" baan heeft, voorzover hij of zij tenminste betrekkelijk eenvoudig te vervangen is. ${ }^{12}$ Deze omstandigheid ontmoedigt werknemers om zich aan te sluiten bij een vakbond, aangezien zij liever vermijden om bij de werkgever bekend te staan als militante en "lastige" arbeidskrachten. ${ }^{13}$

Tabel 2. Stedelijke informele sector als percentage van de totale arbeidsbevolking in enkele Latijnsamerikaanse landen, 1950 en 1980.

1950

$\begin{array}{lll}\text { Argentinië } & 15,2 \% & 21,4 \% \\ \text { Brazilië } & 10,7 \% & 16,5 \% \\ \text { Chili } & 22,1 \% & 21,7 \% \\ \text { Colombia } & 15,3 \% & 22,3 \% \\ \text { Mexico } & 12,9 \% & 22,0 \% \\ \text { Peru } & 16,9 \% & 19,8 \% \\ \text { Venezuela } & 16,4 \% & 18,5 \%\end{array}$

10 Zapata onderschrijft deze stelling in grote lijnen, maar plaatst er met betrekking tot Latijns Amerika een relativerende kanttekening bij waar hij erop wijst dat de afgelopen decennia zowel werknemers in de primaire en de tertiaire sector als werknemers in kleine bedrijven erin gesllaagd zijn om zich te organiseren. Zapata (1986), a.w. p. 39.

11 Vgl. Carriere (1989), p. 7: "One could trace elements in the practice of industrial relations in the region to the old mutualista societies' preoccupation with legalism (...) a strategy which still retains a certain logic where the existence of surplus labour weakens workers" bargaining power". (cursivering HwdW). Vergelijk oök Zapalla (1986), a.w.p. 54 .

12. De relatief hoge scholingseisen in de industriëlle sector die werknemers beschermen tegen concurrentie van ongeschoolden, worden wel beschouwd als een factor die de vorming van vakbonden begunstigt; vgl; Landsberger (1967), a.w. p. 288. Humphrey's analyse van meer recente datum toont evenwel aan dat bijwoorbeeld de Braziliaanse werknemers in de auto-assemblagefabrieken in het geheel geen speciffeke professionele kwalificaties hebben en dat het verloop in deze sector groot is. Humphrey J. Capitalist Control and Workers'Stnuggle in the Brazilian Auto Industry, Princeton 1982. Humplurey werkt zijn bevindingen vooral uit in hoofdstuk 3: Wages and Working Conditions in the Auto Industry.

13 Deze bewering doet natuurlijk alleen opgeld in een "institutioneel vacuüm", waar vakbondsleden geen bescherming genieten tegen ontslag. Ontslagbescherming kan evenwel uitsluitend geboden worden door de overheid en maakt vakbonden dus in zekere zin afhankelijk van haar handelen of nalaten. 
Bron: Beyond the Crisis (Santiago: ILO-PREALC (Employment Programme for Latin America and the Carribean), 1985).

\subsection{Organisatiegraad}

In Tabel 3 is het percentage van de beroepsbevolking dat zich in vakbonden heeft georganiseerd, per land weergegeven.

Tabel 3. Percentage van georganiseerde werknemers in relatie tot de gehele beroepsbevolking.

$\begin{array}{lrlr}\text { Argentinië } & 33,6 \% & \text { Mexico } & 26,5 \% \\ \text { Bolivia } & 11,6 \% & \text { Paraquay } & 9,2 \% \\ \text { Brazillië } & 6,6 \% & \text { Peru } & 14,2 \% \\ \text { Colombia } & 24,3 \% & \text { Uruquay } & 18,9 \% \\ \text { Chili } & 32,6 \% & \text { Venezuela } & 52,7 \%\end{array}$

Equador $\quad 5,0 \%$

Overgenomen uit: Zapata (1986), a.w. p. 44. (Let wel: de ciffers dateren uit de jaren '60/'70 en vormen dan ook niet meer dan een ruwe indicatie omtrent de numerieke sterkte van de vakbeweging.)

In de voorgaande paragraaf is verondersteld dat de arbeidsverhoudingen in sommige sectoren (met name de industriële) zich beter lenen voor de totstandkoming van vakorganisaties dan die in andere sectoren. Het is interessant om te onderzoeken of deze bewering gestaafd wordt door de cijfers over de organisatiegraad binnen de onderscheiden economische sectoren van een land. In tabel 4 zijn deze cijfers opgenomen voor Chili en Mexico.

Tabel 4. Percentage van georganiseerde werknemers in relatie tot de totale bevolking, werkzaam in de desbetreffende sector.

Chill

$14 \%$

$62 \%$

Mijnbouw

Industrie

Bouw

Electriciteit, gas en water

Handel

Vervoer

Diensten (zowel part. als publiek)
$40 \%$

$27 \%$

$36 \%$

$22 \%$

$48 \%$

$35 \%$
Mexico

$2,9 \%$

$93,8 \%$

$68,3 \%$

$26,4 \%$

$98,1 \%$

$3,8 \%$

$84,5 \%$

$8,2 \%$ 
Bronnen: Chili (1968): Memoria del consejo directivo al $5^{\circ}$ congreso de la CUT, 19-24 Nov. 1968, p. 51. Mexico (1983): Anderson R. Mexico in: Greenfield/Maram (eds.) Latin.American Labor Organizations, Westport 1987, p. 514.

Op basis van bovenstaand cijfermateriaal kunnen twee voorlopige conclusies worden getrokken. Allereerst verschilt de organisatiegraad sterk van land tot land: In sommige landen - Argentinië, Chili, Mexico - is het percentage georganiseerde werknemers vergelijkbaar met dat in Westerse landen als de Verenigde Staten (24\%), Duitsland (40\%) en Frankrijk (25\%), terwijl in andere landen de vakbeweging bij de arbeidersklasse nawwelijks voet aan de grond heeft gekregen.

In de tweede plaats blijken vakbonden in sommige sectoren, met name de industrie, de mijnbouw en de vervoerssector, inderdaad een sterkere positie in te nemen dan in andere sectoren. Opmerkelijk is wel dat slechts in een zeer gering aantal sectoren de vakbeweging de arbeidsmarkt geheel of nagenoeg geheel controleert.

\subsection{Organisatiestructuur}

De organisatiestructuur van de vakbeweging tenslotte, is het laatste onderwerp dat onze aandacht verdient. Globaal genomen kan men onderscheiden tussen landen waar vakbonden de werknemers van een gehele bedrijfstak vertegenwoordigen en landen waar de ondernemingsvakbond de centrale organisatie-eenheid is. Collectieve arbeidsovereenkomsten worden afgesloten voor alle werknemers van de desbetreffende bedrijfstak, resp. voor de werknemers die binnen de onderneming werkzaam zijn. ${ }^{14}$ Sommige schrijvers postuleren een nauwe relatie tussen de organisatiestructuur en (met name) het politieke karakter van de vakbeweging. ${ }^{15}$ Vooral voor ondernemingsvakbonden die binnen kleine en middelgrote ondernemingen opereren, zijn de mogelijkheden om concessies af te dwingen bij de werkgever beperkt. Dit gebrek aan economische slagkracht zou gecompenseerd worden door een hoog democratisch gehalte, grote strijdvaardigheid en een relatief autonome positie ten opzichte van de staat. De sociale afstanden tussen vakbondskader en basis zouden binnen de ondernemingsvakbond gering zijn. De onderlinge klassesolidariteit maakt vakbondsleiders betrekkelijk immuun voor inkapselingspogingen van de kant van werkgevers of overheid. ${ }^{16}$ Vakbondsleiders van

14 Tot de eerstgenoemde categorie behoren Argentinie,, Brazilië en Uruguay, terwijl Bolivia, Chili, Equador, Colombia en Peru tot de tweede categorie gerekend kunnen worden. Mexico neemt een tussenpositie in: hier geldt de ondernemingswakbond als de belangrijkste organisatie-eenheid, maar de arbeidsovereenkomst is dikwijls van toepassing woor alle werknemers in de bedriffstak. Vgl. von Potobsky (1981), a.w. pp. 28-31.

15 Angell A. Politics and the Labour Movenent in Chile, London 1972, pp. 229-236. Touraine (1988), a.w. pp. 285-286. Zapata (1986), a.w. pp. 33-36.

16. Angell brengt hier een nuance aan, waar hij stelt dat in hele kleine ondernemingen wak paternalistische werhoudingen heersen: "Very small establishments often have a pattern of relationships which binds employers and employees together rather than seperates them into potentially antagonistic social sectors". Angell (1972), aw.w. p. 229. Vervolgens wergelijkt hij de ondernemingswakbond in een middelgroot bedrijf met bonden die 
ondernemingsvakbonden zouden dikwijls gelieerd zijn aan linkse politieke partijen en zouden, door hun goede contacten met de achterban, de vakbondsleden gemakkelijk kunnen mobiliseren om deze partijen te ondersteunen.

Vergeleken met de ondernemingsvakbond kan de bedrijfstak-bond in beginsel meer economische voordelen verwerven doordat hij; bij het streven naar uniforme arbeidsvoorwaarden voor de werknemers van een gehele economische sector, in veel mindere mate rekening hoeft te houden met concurrentieverhoudingen. Anderzijds treedt binnen de bedrijtstak-bond regelmatig verureemding op tussen de vakbondsbasis en de bureaucratische top. Het vakbondskader van bedrijfstak-bonden blijkt vaker verbonden te zijn met partijen van de gevestigde orde dan met de oppositie, zodat de vakbondsleiders meer de belangen van de staat plegen te dienen dan die van hun achterban. ${ }^{17}$ Op grond van bovenstaande overwegingen zou staatscontrole over de vakbeweging meer voor de hand liggen in landen met een gecentraliseerde organisatiestructuur dan in landen met een gedecentraliseerde structuur.

Naar het mij voorkomt is de organisatiestructuur wel van enige invloed geweest op de mate waarin de vakbeweging haar onafhankelijkheid ten opzichte van de staat heeft kunnen bewaren, maar moet men het belang van deze factor toch niet overschatten. Zoals in de afzonderlijke landen-hoofdstukken aangetoond zal worden, verschilt de verhouding tussen staat, politieke partijen en vakbeweging in Chili en in Colombia essentieel, terwijl toch in beide landen de ondernemingsvakbond de centrale organisatie-eenheid is.

Hoewel we buitengewoon voorzichtig moeten zijn met het trekken van al te voorbarige en algemene conclusies op grond van bovenstaande gegevens, lijken de samenstelling van de beroepsbevolking, het gebrek aan controle over de arbeidsmarkt en de gefragmentiseerde organisatiestructuur omstandigheden op te leveren die de economische positie van de Latijnsamerikaanse vakbeweging verzwakken. In de navolgende historische analyse zal bezien worden hoe de economische zwakte en de politieke activiteiten van de vakbeweging zich tot elkander verhouden.

een gehele sector vertegenwoordigen: "In Chile, the small size of the unions, their financial weakness, and the legal restrictions on payment of leaders inhibits the development of an institutionalized bureaucratic leadership which elsewhere often replaces democracy by oligarchy in the labour movement". A.w. p. 230. 
Zoals hierbowen al is aangegeven, ligt het in de bedoeling om de interactie tussen staat en vakbeweging te beschrijven tegen de achtergrond van politieke en economische ontwikkelingen. Vanuit het perspectief van de staat kan diens houding ten opzichte van de vakbeweging het beste vergeleken worden met een pendelbeweging tussen uitsluiting/repressie (tijdens de "heroïsche" fase en de militaire regimes) en (pogingen tot) incorporatie (tijdens de bloeiperiode van het populisme en na de restauratie van de democratie). Vanuit de optiek van de vakbeweging wordt het streven naar meer autonomie ten opzichte van de staat steeds duidelijker zichtbaar.

\subsection{De heroïsche fase}

"Moderne" vakbonden kwamen in Latijns Amerika rond de jaren tachtig van de vorige eeuw tot ontplooiing in de export-sectoren. De onpersoonlijke arbeidsverhoudingen plaveiden de weg voor de onderkenning van de belangentegenstelling tussen arbeid en kapitaal, hetgeen een prikkel vormde tot organisatie van werknemers. Voordien organiseerden handwerkslieden en werknemers van kleine bedrijven zich in verenigingen voor wederzijdse bijstand. Deze zogenaamde "mutualistas" voorzagen, bij gebrek aan een deugdelijk sociaal verzekeringsstelsel, in financiële steun in geval van arbeidsongeschiktheid en hadden vooral een sociale en educatieve functie. De verhouding tussen werkgever en werknemer was sterk paternalistisch van aard en van klassenstrijd was dan ook geen sprake."

De integratie van de Latijnsamerikaanse landen in de wereldeconomie die de aanleiding vormde tot de "desarrollo hacia afuera" (ontwikkeling naar buiten) en de daarmee samenhangende opkomst van de vakbeweging, kwam tot stand na de centralisatie van het staatsgezag. Tot diep in de $19 \mathrm{e}$ eeuw hadden "caudillos", kleurrijke regionale leiders die sterke persoonlijke banden onderhielden met hun aanhangers, elkaar de macht betwist. In een dergelijk instabiel politiek klimaat was een centraal geleide economie ondenkbaar. Zodra Én van de caudillos de overhand had gekregen over zijn rivalen, kon hij zich toeleggen op de monopolisering van de zwaardmacht en de bestuurlijke ordening van de maatschappij.

18 Een enkele kanttekening is nog op zijn plaats. Onderstaande analyse heeft uitsluitend betrekking op de grote, geïndustrialiseerde landen van Zuid Amerika (Argentinię, Brazilie, Chili, Colombia, Peru en Venezuela) en Mexico. Bovendien verschilt de ontwikkeling vain de verhouding tussen staat en vakbewreging tussen deze landen op belangrijke punten. Zoals gezegd komen afwijkingen van het algemene, schetsmatige patroon aan de orde in de afzonderlijke landen-hoofdstukken.

19 Voor een beschrijving van de achtergronden en de wezenstrekken van de "mutualistas" wordt werwezen naar Alba, a.w. pp. 194-197 en. Poblete/Troncoso, a.w. pp. 14-15.

20 Davis wijst op het hardnekkige karakter wan het "caudillismo" in Mexico en Venezuela dat economische groei verhinderde. Davis Ch. L. (1989), a.w. pp. 44-45. 
De politieke stabilisatie lokte buitenlandse investeerders en met de opbrengsten uit de groeiende economische activiteiten kon wederom de versterking van het staatsgezag gefinancierd worden."

De ontwikkeling naar buiten impliceerde een internationale arbeidsverdeling, waarbij de Latijnsamerikaanse landen zich toelegden op de export van voedselprodukten - vlees en graan in Argentinie en Uruguay, koffie in Brazilie en Colombia - of ruwe grondstoffen salpeter in Chill - en industrieprodukten invoerden uit Europa en de Verenigde Staten Deze typische exporteconomie die vooral gebaat was bij lage produktiekosten in verband met de concurrentiepositie op de internationale markt en geen belang had bij vergroting van de interne markt, stond haaks op de belangen van werknemers.

In politiek opzicht beschikten vakbonden althans in eerste instantie evenmin over veel mogelijkheden om druk uit te oefenen ten bate van hun leden. De staat beperkte zich tot het stimuleren van de exporteconomie door middel van het verschaffen van kredieffaciliteiten, het creëren van belastingvrije zones en het verlenen van concessies aan buitenlandse ondernemingen, maar hield zich verre van de sociale kwestie. De politieke participatie van de arbeidersklasse was bovendien sterk begrensd ten gevolge van census-kiesrecht en aan het stemrecht verbonden alfabetiseringseisen.

Gegeven de onvermurwbare opstelling van de werkgevers en bij gebrek aan een institutioneel/juridisch kader, moesten werknemers en hun vakbonden wel hun toevlucht nemen tot directe actie in de vorm van sabotage en "wilde" stakingen om de aandacht te vestigen op hun miserabele arbeidsomstandigheden. Deze zogenaamde "heroïsche fase" $\left(^{2 y}\right)$ werd gekenmerkt door bloedige conflicten tussen werknemers en de staat die dikwijls niet schroomde om het leger in te zetten. ${ }^{23}$ Wellicht werd de intensiteit van de confrontaties mede bepaald door de politieke kleur van de vakbonden. Inderdaad was directe, spontane actie het keurmerk van uit Zuid Europa afkomstige anarchistische immigranten die met name in Argentinïe en in Uruguay binnen de FORA resp. de FORU een belangrijke invloed uitoefenden. Toch moet men de betekenis van de anarchisten en de anarcho-syndicalisten, zoals ook Touraine terecht opmerkt, niet overschatten, aangezien hun afkeer van organisatie en compromis zich tegen hen keerde, zodra zich politieke alternatieven voordeden. ${ }^{24}$

Vanaf het tweede decennium wan de 20 e eeuw kan men een kentering bespeuren in de houding van de politieke machthebbers ten opzichte van de arbeidersbeweging. De groeiende exporteconomie had de dienstensector gestimuleerd en dit leidde tot de opkomst van de

21 Deze wisselwerking tussen economische groei en versterking van het centrale gezag, met name door middel van de professionalisering van het leger, is helder geanalyseerd door Philip G. The Mititary in South American Politics, London 1985, pp. 109-112.

22 Deze term wordt onder andere gebezigd door Zapata (1986); a.w. p. 26 en door Barria Jorge S. El movimiento obrena en Chile, Santiago de Chille 1972, pp. 15 en 31.

23 Vgl. Spalding H.A. Onganized Labor in Latin America, New York 1977, pp. 31-34.

24 Touraine, a.w. p. 261. 
middenklasse. Het machtsmonopolie van de traditionele oligarchie van grootgrondbezitters en zakenlieden in de export-sector werd weliswaar nog niet geheel doorbroken maar wel betwist door witte boorden-employes en beoefenaren van de vrije beroepen die hun groeiende economische betekenis vertaald wensten te zien in meer politieke zeggenschap. De middenklasse trachtte haar politieke invloed te vergroten door eerst te pleiten voor herziening van het kiesstelsel, zodat ook de arbeidersklasse kon stemmen en vervolgens aan te dringen op sociale wetgeving. ${ }^{25}$ Zo kwam tegen het einde van de Eerste Wereldoorlog in een aantal Latijnsamerikaanse landen arbeidswetgeving tot stand die betrekking had op het verlenen van organisatierechten aan vakbonden, vaststelling van maximale werktijden, zwangerschapsverlof en verbetering van arbeidsomstandigheden. ${ }^{26}$ De uitvaardiging van sociale wetgeving dient niet alleen beschouwd te worden als het resultaat van een politieke krachtmeting tussen de oligarchie en de opkomende middenklasse, maar was ook een noodzakelijk antwoord op een sociaal/politiek probleem. Rond het begin van de jaren twintig kwam de trek van het platteland naar de grote steden op gang. Deze urbanisatie was het gevolg van de uitstoot van arbeidskrachten door een zich moderniserende agrarische sector en ging aan de industrialisatie vooraf. ${ }^{27}$ Een groeiend stadsproletariaat van rurale oorsprong, waarvoor onvoldoende werkgelegenheid voorhanden was en dat emplooi vond in de informele sector, vormde een sociale tijdbom. De geest zou in de fles gehouden kunnen worden door enige sociale concessies te doen en door de maatschappelijke krachten te kanaliseren in vakbonden

25 Rodolfo Stavenhagen heeft kritiek geleverd op de stelling dat de Latijnsamerikaanse ontwikkeling de verdienste is van een dynamische en vooruitstrevende middenklasse. In de eerste plaats is het dikwijls onduidelijk wat men precies onder de middenklasse verstaat. Men krijgt de indruk dat het een statistisch aggregat is van personen die noch tot de aristocratie van grootgrondbezitters, noch tot de landloze boeren behoren. In de tweede plaats trekt Stavenhagen de progressieve instelling van de zogenaamde middenklasse in twijfel: zaj zouden eerder geneigd zijn om zo veel mogelijk de levensstijl van de elite te imiteren.

Stavenhagen R. Seven fallacies about Latin America in: Petras J./Zeitlin M. (eds.) Latin America: Reform or Revolution? New York $1968_{\text {, pp. } 23-26 .}$

Deze terechte kanttekening sluit ewenwel niet uit dat politici die afkomstig waren uit het middenkader, uilt opportunistische overwegingen aansluiting zochten büj de arbeidersklasse en een progressieve politieke koers gingen volgen.

26 Het eerste land in Zuid Amerika, waar sociale wetgeving werd uitgevaardigd, was Uruguay tijdens de ambtsperioden van de progressieve president Battle y Ordoñez (1903-1907 en 1911-1915). Met de introductie van een wekelijkse rustdag, bescherming van werkende moeders en de befaamde "wet van de stoel" (elke werkmemer moest een stoel ter beschikking krijgen om uit te kunnen rusten van zijn werkzaamheden) liep Battle aanzienlijk wooruit op zijn collega's in de buurlanden. Vgl. Alba, a.w. pp. 241-242.

In Peru bewerkstelligde een algemene staking in 1919 de totstandkoming van een wet inzake de acht-urige werkdag. Voor een uitvoerige beschrijving wordt werwezen naar Blanchard P. The Origins of the Peruvian Labor Movement; 1883-1919, Pittsburgh 1982, pp. 148-159.

27 CEPAL (Comisión Económica para América Latina; Naciones Unidas) El Desamollo Social de América Latina en la Postguerra, Buenos Aires 1963, p. 63. 
die door de staat opgericht en gecontroleerd werden. In tegenstelling tot Europa, ging de sociale politiek en de vorming van legale vakorganisaties aan de industrialisatie vooraf." De opkomst van de middenklasse en het onvermogen om adequaat te reageren op sociale problemen hadden de machtspositie van de oligarchie aangetast. Mondiale gebeurtenissen die de export-economie ontwrichtten, gaven de traditionele elite evenwel de politieke genadeklap. Ten gevolge van de economische crisis van de jaren dertig en de Tweede Wereldoorlog daalden de prijzen van Latijnsamerikaanse exportprodukten dramatisch. Bovendien waren de Westerse landen niet langer in staat om te fungeren als leveranciers van industriële produkten. Structurele aanpassingen op economisch en op politiek terrein waren noodzakelijk om aan deze crisis het hoofd te bieden, maar de oligarchie had geen belang bij deze veranderingen en was evenmin bij machte om ze door te voeren. Het politieke machtsvacuúm dat zodoende aan het begin van de jaren dertig ontstond werd niet opgevuld door dle middenklasse maar door nationalistisch-populitische regimes. De specifieke betrekkingen tussen deze regimes en de vakbeweging zouden het karakter van de vakbeweging ingrijpend beïnvloeden.

\subsection{Nationalistisch-populistische regimes en de vakbeweging}

De opkomst van nationalistisch-populistische regimes is te verklaren tegen de achtergrond van structurele veranderingen van sociaal/economische en politieke aard die de Latijnsamerikaanse "anciens régimes" voor onoplosbare problemen hadden gesteld. Op de drempel van een nieuwe periode in de geschiedenis van Latijns Amerika presenteerden enkele maatschappelijke groeperingen - witte boorden-employés, georganiseerde werknemers en nationale ondernemers - zich nadrukkelijk als nieuwe "power contenders" ${ }^{30}$ Als sociale klasse waren deze groeperingen niet sterk genoeg om, ten opzichte van elkaar maar vooral ten opzichte van de economisch nog immer machitige agro-export elite, hun belangen te verdedigen. Derhalve waren zij afhankelijk van de politieke steun van de staat. ${ }^{31}$ Voor de nationalistischpopulistische regeringen betekende dit een unieke gelegenheid om hun politieke legitimatie te grondvesten op een brede coalitie van nationale (industriële) werkgevers, middenklasse en vakbeweging. ${ }^{32}$

29 Octavio lanni kenschetst de crisis van het internationalle kapitalisme in de jaren dertig als de voornaamste oorzaak van de ondergang van de oligarchie. Ianni O. Populismo y Relaciones de Clase in: Germani G./di Tella T. S./Lanni O. Populismo y contradicciones de clase en Latinoanérica, México 1973, pp: 97-98.

30 De term is afkomstig van Anderson Ch. W. Politics and Economic Change in Latin America, New York 1967, pp. 97-104;

31 De "politisering" van maatschappelijke groeperingen in reactie op hun zwakte als sociale klasse is een centraal thema in het werk van Touraine (1988), vgl, onder andere p. 45 en pp. 201-203.

32 Vgl. Robert R. Kaufman Industrial Change and Authoritarian Rule in: Collier D. (ed.) The New Authoritarianism in Latin America, Princeton 1979, p. 199. 
In economisch opzicht werden de nieuwe regeringen geconfronteerd met een acuut probleem: door de internationale economische crisis droogden de deviezen-bronnen snel op, zodat de invoer van industrieprodukten stagneerde. Teneinde tegemoet te komen aan de vraag naar industriële produkten, stimuleerde de staat actief de industrialisatie, waarbij de lokale fabricage van lichte consumptiegoederen de nadruk kreeg."3.

Op de iets langere termijn bleek dit economische beleid ook in politiek en ideologisch opzicht vruchten af te werpen. De industrialisatie illustreerde dat Latijnsamerikaanse landen de economische afhankelijkheid ten opzichte van Europa en de Verenigde Staten konden doorbreken en wakkerde nationalistische gevoelens aan. Het nationalisme fungeerde als het ware als een ideologisch bindmiddel om de disparate coalitiegenoten op wie de nationalistische/populistische regimes steunden, bij elkaar te houden. Bovendien leken tijdens de eerste fase van het industrialisatie-proces de klassentegenstellingen hun scherpe kanten te verliezen. De industrialisatie schiep werkgelegenheid en plaveide de weg voor geleidelijke loonsverhogingen om de binnenlandse markt te vergroten. ${ }^{3 *}$

Deze ogenschijnlijk coherente politiek kenmerkte zich in werkelijkheid door een aantal innerlijke tegenstrijdigheden die alle terug te voeren waren op het feit dat de vergroting van de onafhankelijkheid (ten opzichte van het Westen) op een illusie berustte. De importsubstitutie van lichte gebruiksartikelen vereiste de invoer van kapitaalgoederen en halffabrikaten en die kon uitsluitend gefinancierd worden met de opbrengsten uit de export. ${ }^{35}$ De voortdurende externe afhankelijkheid werd deels gecamoufleerd door een virulente nationalistische retoriek die soms in praktijk gebracht werd door de nationalisatie van vitale economische sectoren. ${ }^{36}$ Ook met behulp van dergelijke maatregelen konden de nationalistischpopulistische regeringen evenwel niet verhelpen dat de mogelijkheden om economische ontwikkeling en (her)verdeling van nationale rijkdommen te combineren begrensd werden door de grillige prijsschommelingen van Latijnsamerikaanse exportprodukten op de wereldmarkt. ${ }^{37}$ Zoals we hieronder nog zullen zien, ondermijnde de onmogelijkheid om

33 Dit wordt wel de horizontale fase van de import-substitutie-industrialisatie genoend.

Op de voortrekkersfunctie van de stat in landen waar de industrialisatie pas in een laat stadium plaatsvindt, wordt onder andere gewezen door: van Niekerk A.E. Populisme en politicke ontwikkeling in Latijns Amerika, Rotterdam 1972, p. 204 ("El Estado empresarial", de staat als ondernemer). Vergellijk verder Davis (1989), a.w. p. 45: "Late industrialization "requires" a strong public sector in the dewelopment process".

34 "It was hoped that industrialization would provide profits for the rich, jobs for the poor and consumer goods for everyone". Davis (1989), a.w. p. 47.

35 In dit verband plaatst Kaufman de terechte kanttekening dat de politieke maar niet de econoryische positic van de agrarische export-elite was aangetast. Kaufman (1979), a.w. p. 200.

36 Zo ging de Mexicaanse president Cardenas in 1938 over tot de nationalisatie van de complete olie-exploitatie.

37 Dat de combinatie van deze doelstellingen kenmerkend was voor populistische regimes wordt onder andere erkend door James Malloy: "An explicit assumption of all populist approaches has been that regimes could simultaneously spur development, incorporate many sectors in the political system, and broadly distribute the surplus". Malloy J.M. The Politics of Transition in Latin America, in: Malloy J.M./Seligson M.A. (edis.) Authoritarians and Democrats: Regime Transition in Latin America; Puttsburgh 1987, pp. 239-240. 
economische groei en sociaal/economische hervormingen tegelijkertijd te verwezenlijken op de langere termijn de positie van de nationalistisch-populistische regimes.

De ontwikkelingen in de relatie tussen staat en vakbeweging gedurende deze periode moeten gezien worden in het licht van een behoedzaam schipperen (door de staat) tussen de Scylla van de externe economische afhankelijkheid en de Charybdis van het verlies van politieke legitimatie. Nauwere samenwerking beantwoordde aan een bepaalde logica. Allereerst was voor een groeiend aantal werknemers in overheidsdienst de staat, in diens hoedanigheid van ondernemer, de natuurlijke onderhandelingspartner. De toenadering stond evenwel vooral in het teken van politieke steun in ruil voor economische concessies. De externe economische afhankelijkheid legde echter de vrijheid van de staat om naar eigen goeddunken de eisen van de vakbonden in te willigen, aan banden. Om nu de politieke steun van de vakbeweging enigszins los te koppelen van de economische tegenprestatie, trachtte de staat zijn greep op de vakbeweging te versterken en diens autonomie in te perken. Door het voeren van een controlepolitiek trachtte de staat als het ware de symmetrie in de wederzijdse afhankelijkheidsrelatie tussen staat en vakbeweging te doorbreken.

Van cruciaal belang voor het welslagen van deze controlepolitiek was de omstandigheid dat de vakbeweging in hogere mate afhankelijk was van de ondersteuning door de staat dan andersom. Voor de vakbeweging zat er niet veel anders op dan de patronage van de staat te accepteren. De hierboven gesignaleerde urbanisatietendens leidde tot een overbezetting van de arbeidsmarkt, hetgeen werkgevers in de gelegenheid stelde om veeleisende werknemers te ontslaan en te vervangen door werkwilligen uit de vrijwel onuitputtelijke arbeidsreserve. Overheidsprotectie tegen ontslag was voor de vakbeweging van levensbelang.

Op grond van het bovenstaande lijkt de voorlopige conclusie gerechtvaardigd dat de controle over de vakbeweging deel uitmaakte van de strategie van de staat om tegen de achtergrond van de knellende economische afhankelijkheid wat meer armslag te verkrijgen, zonder dat dit gepaard ging met verlies aan politieke legitimatie. De zwakke onderhandelingspositie van de vakbeweging speelde hierbij de staat in de kaart.

De vervlechting tussen staat en vakbeweging nam verschillende vormen aan. In Brazilië werden gedurende de "Estado Novo" van de populistische dictator Getulio Vargas, vakbonden door de staat zelf opgericht. Arbeidsconflicten werden vermeden, doordat arbitragetribunalen eenzijdig de arbeidsvoorwaarden vaststelden. ${ }^{38}$ De nauwe verwevenheid tussen politiek en vakbeweging kwam in Mexico voornamelijk tot uitdrukking in het feit dat vakbondsleiders hun werkzaamheden combineerden of afwisselden met het bekleden van functies in de politieke partij die voort gekomen is uit de Mexicaanse revolutie en nu reeds meer dan zestig jaar

38. Vergelijk Alain Touraine: ". l'action syndicale est done destinee a exercer une pression sur elle (i.e. la justice de travail) plutôt que sur les entreprises". Touraăne (1988), a.w. p. 263. 
de alleenheerschappij uitoefent. ${ }^{\text {s }}$ Deze functievermenging werd nog in de hand gewerkt door het feit dat vanaf 1936 de vakcentrale CTM (Confederatie van Mexicaanse Arbeiders) als "corporatistische zuil" officieel deel uitmaakte van de regeringspartij en permanent én derde van het aantal zetels van de regeringspartij kreeg toegewezen. ${ }^{40}$

In Argentinië tenslotte hadden de betrekkingen tussen staat en vakbonden een wat minder geformaliseerd en hiërarchisch karakter dan in Mexico en Braziliē. De populistische leider Perón wierp zich graag op als beschermheer van de stedelijke immigranten, de "descamisados", door persoonlijk arbeidsconflicten in het voordeel van de werknemers te beslechten. $\mathrm{De}$ vakcentrale CGT fungeerde als instrument om de steun van de arbeidersklasse aan Perón ten tijde van politieke crises te mobiliseren, maar was in de regulliere arbeidsverhoudingen niet het verlengstuk van de staat of een politieke partij en kon derhalve een zekere mate van autonomie bewaren. ${ }^{4 /}$

Resumerend kunnen we stellen dat de vervlechting tussen staat en vakbeweging waartoe vóor de jaren dertig al een eerste aanzet was gegeven, door nationalistisch-populistische regimes geïnstitutionaliseerd werd. Onder invloed van specifieke economische en politieke factoren zochten staat en vakbeweging toenadering tot elkaar maar dit betekende voor de vakbeweging het verlies van haar autonomie.

\subsection{Crisis van de nationalistisch-populistische regimes en opkomst van de militairen}

Tegen het einde van de jaren vijftig, begin jaren zestig geraakten nationalistisch-populistische regeringen in een aantal Latijnsamerikaanse staten in een diepe crisis die uiteindelijk tot hun politieke ondergang zou leiden. Om deze ingrijpende gebeurtenis wat beter te kunnen begrijpen, is een korte uitweiding over de politieke en economische context noodzakelijk. Rond 1950 had de horizontale fase van de import-substitutie-industrialisatie reeds haar grenzen bereikt, aangezien de relatief kleine markt voor consumptiegoederen spoedig verzadigd was. Albert Hirschman heeft op heldere wijze de verdiensten en de beperkingen van de economische politiek die ten grondslag lag aan de import-substitutie-industrialisatie, in kaart gebracht: ${ }^{42}$ Het monetaire beleid en de tariefpolitiek van de nationalistisch-populistische regeringen begunstigde de lokale produktie van gebruiksartikelen. De overwaardering van de nationale

39. Gedoeld wordt op de PRI (Partij van de Geirnstitutionaliseerde Revolutie) die tot tweemaal toc in haar bestaan een naamsverandering heeft ondergaan: in 1929 opgericht als Partij van de Nationale Revolutie (PNR), werd zij in 1936 omgedoopt tot Partij van de Mexicaanse Revolutie (PRM) om in 1946 haar definitieve naaum te krijgen.

40. Hellman J.A. Mexico in Crisis, London 1978, p. 106.

41 Vergelijk di Tella Statemate or Coexistence in Argentina in: Petras/Zeitlin (1968), a.w. p. 259.

42. Hirschman A. O. The Political Economy of Import-Substituting Industrialization in Latin America, in: Nisbet Ch. T. Latin America: Problems in Economic Developmen; New York 1969, pp. 237-266. 
munt maakte de import wan kapitaalgoederen aantrekkelijk en bewerkstelligde tegelijkertijd een versluierde inkomensoverdracht van de exportsector naar de industriële ondernemers, zonder dat de nog immer machtige exportsector direct belast hoefde te worden. ${ }^{43} \mathrm{De}$ nationale industrieën werden beschermd tegen concurrentie uit het buitenland door middel van kwantitatieve importbeperkingen en door het heffen van invoertarieven. Aan dit economische beleid, even simpel als doeltreffend, kleefden echter ook een aantal bezwaren. De overwaardering van de munt benadeelde de nationale export, zodat flinke tekorten op de betalingsbalans een regelmatig terugkerend fenomeen waren. Bovendien leidde het kunstmatige protectionisme van de industriële sector tot relatief dure produkten van een povere kwaliteit, hetgeen de inflatie aanwakkerde. Men was geneigd om deze negatieve bijeffecten voor lief te nemen, zolang de industrialisatie de nodige dynamiek vertoonde, maar toen de economische groei stagneerde droegen zij bij tot het ontstaan van politieke en sociale onrust. Hirschman heeft overtuigend aangetoond dat het lot van de import-substitutie-industrialisatie niet bezegeld was door de uitputting van de horizontale fase. Vooral de verdieping van het industrialisatieproces door middel van lokale produktie van kapitaalgoederen en de export van industriële goederen kenschetst hij als geschikte strategieën om de structurele obstakels te overstijgen." Tegelijkertijd onderkent Hirschman dat dergelijke impulsen om de industrialisatie nieuw leven in te blazen verstrekkende aanpassingen van de economische politiek vergden en op weerstand stuitten bij de nationale werkgevers die verwend waren door de overheidsprotectie. Daarnaast bleek de kapitaalsaccumulatie die vereist was om de nieuwe fase in het industrialisatieproces te financieren, moeilijk te verenigen met de inkomenspolitiek van nationalistisch-populistische regeringen die de vakbeweging te vriend wilden houden.

Gedeeltelijk voortbouwend op de economische analyses van Hirschman heeft de Argentijnse politicoloog Guillermo O'Donnell in enkele originele en baanbrekende essays getracht de ondergang van de populistische regeringen en de daaropvolgende opkomst van bureaucratische/autoritaire regimes te verklaren. Allereerst herleidt hij de crisis van het populisme tot de groeiende kloof tussen de economische prestaties en de eisen van de georganiseerde arbeidersbeweging: ${ }^{\text {ss }}$ Waar de regering, met het oog op bestrijding van de inflatie en de besparing voor nieuwe investeringen, er bij de vakbeweging op aandrong om de looneisen te matigen, waren de vakbonden niet bereid om hun eisen aan te passen aan de verslechterende economische situatie. Met de opmerkelijke uitzondering van Mexico, waar we later nog uitvoerig op zullen terugkomen, bleek de controle over de vakbeweging in landen als Argentinië en Brazilië op het kritieke moment ontoereikend om de vakbeweging tot terughoudendheid

43 Hirschman, a.w. p. 261.

44 Hirschman, a.w. pp. 253-265.

45 O'Donnell G. Modemization and Bureaucratic-Authoritarianism: Studies in SouthAmerican Politics, Berkeley 1973, pp. 70 e:v. O'Donnell spreckt van een "demand-performance gap". 
te manen zonder dat de staat de politieke rugdekking verloor ${ }^{\text {t5 }}$ De behoefte van de populistische regeringen aan de continuering van de vakbondssteun beperkte aanzienlijk hun manoeuvreerruimte om het economische beleid te wijzigen. De schoorvoetende tegemoetkoming aan de vakbondseisen joeg opnieuw de inflatie aan en leidde tot een verscherping van de economische crisis, hetgeen wederom politieke en sociale weerstanden opriep etc. De nationalistisch-populistische regimes konden deze neerwaartse spiraal niet doorbreken, aangezien dit een keuze impliceerde tussen verdergaande politieke en sociale hervormingen en stimulering van de economische groei, terwijl deze regimes juist hun politieke toekomst geïnvesteerd hadden in een combinatie van deze doelstellingen.

In latere essays heeft $O^{\prime}$ Donnell zijn oorspronkelijke bevindingen nog aangescherpt en verfijnd om een helder licht te werpen op de drijfveren die een technocratische elite en diens militaire bondgenoten ertoe aanzetten om staatsgrepen te plegen. ${ }^{47} \mathrm{Net}$ als in de jaren dertig en veertig waren internationale ontwikkelingen van grote invloed op de politieke koerswijzigingen in Latijns Amerika. De na-oorlogse internationale hoogconjunctuur leidde tot de expansie van multi-nationale ondernemingen die op zoek waren naar nieuwe investeringsmogelijkheden. De Latijnsamerikaanse landen leken geschikte gegadigden. De structurele "bottlenecks" in het industrialisatieproces, waarmee deze landen kampten konden overwonnen worden door een verdieping van de produktiestructuur: kapitaalgoederen die voorheen geïmporteerd werden, zouden voortaan lokaal geproduceerd worden. Dit vereiste evenwel forse kapitaalsinjecties, waarin buitenlandse geldschieters konden voorzien.

Deze economische belangenverstrengeling bracht $O^{\prime}$ Donnell tot een tweeledige verklaring van de opkomst van bureaucratische/autoritaire regimes. Aan de ene kant waren de staatsgrepen op te vatten als een reactie van de elite op een dreigende revolutie van de arbeidersklasse die door de populistische regeringen niet beteugeld kon worden. De vrees voor een dergelijke gang van zaken kan niet los gezien worden van de Cubaanse revolutie en de uitbreiding van guerrilla-activiteiten aan het begin van de jaren zestig. ${ }^{48}$ Aan de andere kant dienden de militairen de juiste sociaal/economische en politieke condities te scheppen voor de introductie van een nieuwe fase in het industrialisatieproces: de verdieping van de produktiestructuur. De broodnodige buitenlandse kapitaalinvesteringen konden slechts aangetrokken worden, indien de staat een gunstig maar vooral voorspelbaar investeringsklimaat kongaranderen. Multi-nationale ondernemingen moesten aantrekkelijke winstmarges en sociale vrede in het vooruitzicht gesteld worden. De eliminatie van de vakbeweging als politieke en economische machtsfactor diende in dit perspectief een dubbel doel. In de eerste plaats

46 O'Donmell noemt expliciet "...the popular sector's increasing autonomy of corporatist controls imposed by populism. ${ }^{\circ}$ O'Donnell G. Reflections on the Pattems of Change in the Bureancratic-Authoritarian State in: Latin American Research Review, (XIII, No. 1; 1978), p. 10.

47 Zie wooral het eerdergenoemde Reflections on the Pattems of Change in the Bureaucratic-Authoritarian State, pp. 3-38.

48. Zo ook: Hirschman A.O. The turn to athoritarianism in Latin America and the search for its economic determinants in: Collier a.w. p. 71. 
vormde een veeleisende vakbeweging op zich al een obstakel voor het proces van kapitaalsaccumulatie. In de tweede plaats stelde de uitschakeling van de vakbeweging de influx van buitenlandse investeringen die deze kapitaalsaccumulatie mogelijk zou maken, veilig, aangezien het bijdroeg tot een stabielere sociale en politieke orde en bovendien de staat de handen vrijliet om een consistent economisch beleid te voeren."

Met name O'Donnell's "verdiepings-hypothese" heeft vrij veel kritiek ontlokt." Wellicht met uitzondering van Argentinië ten tijde van het generaalsbewind van Ongania (1966-1970) en, in een later stadium, Braziliè, zou de verdiepings-hypothese niet opgaan. In landen als Chili, Uruguay en Argentinië (gedurende het militaire regime van 1976 tot 1982) vond geen verdieping van de industrialisatie plaats maar, integendeel, een ontmanteling van de industriêle sector ten gevolge van een eenzijdige nadruk op de export van traditionele goederen.

O'Donnell mag dan de aard en de consistentie van de economische politiek van de militaire regimes niet geheel juist hebben getaxeerd, de grote verdienste van zijn theorie schuilt in het feit dat hij een plausibele verklaring geeft woor een ingrijpende politieke koerswijziging in Latijns Amerika en daaraan inherente veranderingen in de betrekkingen tussen staat en vakbeweging. Daarbij moet men O'Donnell nageven dat de economische politiek van de militaire regimes op enkele punten opmerkelijke overeenkomsten vertoonde en dat de verwezenijiking van deze componenten zich niet verdroeg met een in economisch en politiek opzicht machtige vakbeweging.

Op korte termijn moest de economische crisis bezworen worden door de beteugeling van de inflatie en de correctie van de tekorten op de betalingsbalans. Bij het terugdringen van de inflatie lieten de militaire regimes zich leiden door de orthodoxe recepten van het Internationale Monetaire Fonds en gingen zij over tot forse besnoeiingen op de overheidsuitgaven, inkrimping van de geldhoeveelheid en bevriezing van de arbeidslonen. Devaluatie van de munteenheid zou de exportpositie van de Latijnsamerikaanse landen verbeteren en dientengevolge de betalingsbalans-problemen oplossen. ${ }^{51}$

$\mathrm{Na}$ deze harde saneringsmaatregelen, zo verzekerden de militairen, gloorde een gouden toekomst. De oriëntatie op de export en de toevloed van buitenlandse investeringen zouden nieuwe impulsen geven aan het bedrijfsleven en de daaruit voortvloeiende economische groei

O'Donnell (1978), a.w. pp. 12-13.

50 Zie de bijdragen van Hirschman, Kaufman en José Serra (Three mistaken theses regarding the connection between industrializution and authoritorian regines, pp. 99-163) aan de bundel van Collier (1979). Paul Cammack gaat zelfs zover te stellen dat verwerping van de "verdiepings-hypothese" de coherentie van het gehele model (van O'Donneli) aant ast. Cammack $P$. The political econony of contenporary regimes in Latin America: from bureaucratic authoritarianism to restructuring in: O'Brien $\mathrm{Ph}$./Cammack $\mathrm{P}$. (eds.) Generals in retreat. The crisis of military nule in Latin America; Manchester 1985, p. 9.

51. Zie voor een beknopt overzicht van de - korte termijn -economische politiek van de militaire regimes: Hartllyn J./Morley S.A. Bureatcratic-Authoritarian Regimes in Comparative Perspective in: Hartlyn J./Morley S.A. (eds.) Latin American Political Economy: Financial Crisis and Political Change; Westview Press 1986, p. 39. 
zou uiteindelijk de gehele bevolking ten goede komen. Maar eerst moesten materiele offers gebracht worden.

De onderdrukking van de vakbeweging maakte deel uit wan een breed opgezet offensief tegen linkse politieke krachten die, in de ogen van de nieuwe mach thebbers, de Latijnsamerikaanse landen op de rand van de morele afgrond hadden gebracht. De doctrine van de Nationale Veiligheid vormde de ideologische fundering van de repressie, waarvan de ernst recht evenredig was aan de mate waarin de heersende klassen zich bedreigd hadden gevoeld door de ontketende arbeidersklasse. ${ }^{52}$ De poging om de vakbeweging volstrekt te de-politiseren stond in het teken van de huiver die de militairen in het algemeen tentoonspreidden ten aanzien van elke vorm van politieke representatie. Zij gaven de voorkeur aan "technische" boven politieke samenwerking met sociale groeperingen. ${ }^{33}$

Zodra de werknemers van hun militante vertegenwoordigers "verlost" waren, trachtten de militairen hen te betrekken in, op corporatistische leest geschoeide samenwerkingsverbanden tussen werkgevers, werknemers en autoriteiten. ${ }^{54}$ Aangezien lonen en andere arbeidsvoorwaarden veelal van boven opgelegd werden door middel van wetsdecreten, dienden deze overlegorganen als buffer tussen de autoriteiten en de werknemers, wier onvrede groeide naarmate hun materiële positie verslechterde, en vervulden zij verder louter een decoratieve functie.

Resumerend kunnen we stellen dat de opkomst van militaire regimes radical een einde maakte aan de "symbiotische" relatie die populistische regeringen hadden opgebouwd met de vakbeweging. De combinatie van bloedige repressie en een orthodox economisch beleid dat kapitaalsaccumulatie stimuleerde ten koste van inkomenswerdeling, zou in een aantal staten de vakbeweging als economische en politieke machtsfactor vrijwel elimineren.

\subsection{De ondergang van de militaire regimes en het herstel van de democratie}

In 1990 viel het militaire bewind van Pinochet in Chili als laatste dominosteen van het eens haast onaantastbaar geachte bastion van millitaire regimes in Latijns Amerika. Hoe valt deze toch betrekkelijk snelle ondergang te verklaren? Ongetwijfeld vormde het gewelddadige karakter van deze regimes, in eerste instantie een machtig wapen, op de wat langere termijn

52 Vergelijk O'Donnell (1978), a.w. p. 7 en Cardoso F.H. On the Characterization of Authoritarian Regimes in Latin America in: Collier (ed.) 1979, aw. pp. 55-56: "Above all, when leftist political forces were strong and well rooted in society, the initial phases of the military regime are highly repressive".

Dit is een sterke aanwijzing dat niet alleen economische maar ook ideologische motieven de militairen en hun handlangers aanzetten tot het plegen van coups. Vergelijk de dubbele verklaring die O'Donnell geeft voor de opkomst van Bureaucratisch-A whoritaire regimes.

53 In dit opzicht onderscheidden de Bureaucratisch-Autoritaire regeringen zich, volgens Cardoso, essentieel van fascistische regimes die juist wel politieke mobilisatie aanmoedigden. Cardoso (1979), a.w. p. 36.

54 "As in the past, corporative links are established within the trade unions (between workers and management) and between them and the state, and where these links were historically weak (as in Chile), the military regimes encourage them". Cardoso, (1979) a.w. p. 37. 
een destabiliserende factor. Waar de directe politieke tegenstanders, soms met instemming van brede lagen onder de bevolking al in een vroeg stadium uitgeschakeld waren, strekte de repressie later er vooral toe om de gehele bevolking te intimideren. Het volstrekt willekeurig gebruik van geweld ondermijnde de politieke legitimatie die toch al een wankele basis had."

Toch wordt de smadelijke afgang van de militaire regimes vooral toegeschreven aan het feit dat zij hun pretenties met betrekking tot het voeren van een efficiënt economisch beleid niet konden waarmaken. ${ }^{56}$ Hoewel deze verklaring wellicht wat al te generaliserend is - de militaire regimes van Brazilië en uiteindelijk ook Chili beriepen zich er met enig recht op dat zij de economie uit het slop hadden gehaald - hadden alle militaire regeringen twee kenmerken gemeen die eventuele positieve prestaties overschaduwden. In de eerste plaats leidde de economische politiek tot schevere inkomensverhoudingen die een sociale ontwrichting tot gevolg hadden. In de tweede plaats zadelden de militaire regeringen hun democratische opvolgers op met een grote buitenlandse schuldenlast.

Een uitvoerige analyse van de oorzaken en de gevolgen van de buitenlandse schuldencrisis valt buiten het bestek van dit proefschrift. ${ }^{\text {st }}$ Opgemerkt dient te worden dat militaire regimes niet de enigen waren die voor de verleiding bezweken om op grote schaal leningen af te sluiten bij Westerse particuliere banken. Ook democratisch geregeerde landen als Mexico en Venezuela staken zich blijmoedig in de schulden, zolang de wereldinflatie hoger was dan het rentepeil. Geheel Latijns Amerika werd aan het begin van de jaren tachtig pijnlijk verrast door het "schaar-effect" van hogere rentestanden - het gevolg van een krappe monetaire politiek in de Westerse landen - en protectionistische maatregelen die het Westen nam in het licht van een wereldwijde recessie. ${ }^{58}$ In het geval van de militaire regimes droeg de schuldencrisis evenwel bij tot een versnelde terugkeer van de militairen naar de kazernes, niet alleen omdat zij van een solide economisch beleid hun paradepaardje gemaakt hadden waaraan zij hun legitimatie ontleenden, maar ook omdat zij niet tijdig de economische politiek aanpasten. Dit gebrek aan flexibiliteit kwam volgens Foxley deels voort uit het politieke isolement, waarin de militairen verkeerden, en had deels te maken met de stroeve besluitvormingsprocedures, een kenmerk van logge, bureaucratische structuren. ${ }^{59}$

56 Foxley A. Economic and Political Transition in South America in: Galjart B./Silva P. (eds.) Democratization and the State in the Southem Cone, Amsterdam 1989, p. 68. Hartlyn/Morley (1986), a.w. p. 40.

57 In een gedegen overzichtsessay bespreekt Stephen $S$. Golub niet minder dan 21 titels die betrekking hebben op dit onderwerp (Golub Stephen S. The Political Economy of Latin American Debt Crisis in: Latin American Research Review, Vol. 26, No. 1 1991, pp. 175-215). De visie op de buitenlandse schuldencrisis wordt sterk beinvloed door de politieke voorkeur van de verscheidene auteurs. Niettemin wijten zowel Susan George (A Fale worse than Debt; New York 1988), een representante van de links-progressieve "school", als de meer rechts georiënteerde Pedro Pablo Kuczynski (Latin American Debt; Baltimore 1988) het ontstaan van de crisis voor een belangrijk deel aan het economisch wanbeleid van regeringen in de schulden-landen.

58 Vergelijk Kuczynski (1988), a.w. p. 73.

59 Foxley,(1989) a.w. pp. 68-69. Deze opvatting strookt overigens niet met de visie van Kaufman en Stallings (Debt and Democracy in Latin America; Boulder, Colorado 1989). Deze auteurs menen dat democratieën 
Halverwege de jaren tachtig vormden in een groot aantal Latijnsamerikaanse landen de fragiele democratieën die onmiddellijk geconfronteerd werden met een economische crisis, een erfenis van hun voorgangers, het decor tegen de achtergrond waarvan de vakbeweging opnieuw haar positie ten opzichte van staat en werkgevers moest bepalen. $\mathrm{Na}$ jaren van onderdrukking, lijkt de vakbeweging, soms tegen wil en dank, weer een sleutelrol in te gaan nemen in het Latijnsamerikaanse krachtenveld. In dit licht bezien, moet de cruciale vraag of de vakbeweging, gegeven de vaak bittere ervaringen in het verleden, zich meer zal distantiëren van de politiek, vooralsnog ontkennend beantwoord worden. Zeker: er is een tendens te bespeuren, vooral onder vakbonden van werknemers in economisch dynamische sectoren, om zich te bevrijden van de knellende bevoogding door de staat. De neiging van werkgevers en vakbonden om, buiten de officiële, door de wet voorgeschreven procedures om, arbeidsconflicten onderling te beslechten, onderstreept deze ontwikkeling. ${ }^{60}$ Toch lijkt het mij niet juist om deze tendens aan te voeren als een overtuigend bewijs dat de vakbeweging in Latijns Amerika definitief het pad der de-politisering is ingeslagen.

Twee factoren dragen er, naar het mij voorkomt, toe bij dat het patroon van nauwe betrekkingen tussen staat en vakbeweging voorlopig nog wel in stand zal blijven. In de eerste plaats voorziet arbeidswetgeving in sommige landen - Mexico is een goed voorbeeld - nog immer in formele procedures van geschillenbeslechting, waarbij aan de publieke autoriteiten een beslissende stem wordt toegekend. Dit institutionele raamwerk waarborgt blijvende staatsinterventie in arbeidsverhoudingen, dwingt vakbonden, ook op het niveau van de onderneming, om in contact te komen met de autoriteiten en fixeert als het ware de eenmaal gegroeide verhoudingen tussen staat en vakbeweging. ${ }^{\text {bi }}$

In de tweede plaats moet niet uit het oog verloren worden dat de nauwe vervlechting tussen staat en vakbeweging niet uitsluitend negatieve kanten voor laatstgenoemde heeft gehad. Weliswaar heeft de vakbeweging door deze vervlechting aan politieke onafhankelijkheid ingeboet, maar de nauwe samenwerking met de staat heeft de vakbeweging in economisch

in een overgangsfase doorgaans het zwakst presteren op hel gebied van het cconomisch beleid, aangezien zij plegen toe te geven aan populistische druk. Autoritaire regimes kunnen harde bezuinigingsmaatregelen doorwoeren, terwijl gevestigde democratieèn de flexibiliteit bezitten om orthodoxe overtheidsbezuinigingen te combineren met inkomensverdeling.

60 Vergelij.k Cordlova (1981), a.w. pp. 3-4.

61 Deze conserverende werking van de arbeidswetgeving wordt onderkend door Geraldo von Potobsky, Las Onganzaciones Sindicales in: Cordova (1981), a.w. p. 26.

In zijn kritiek op de "labour aristocracy"- thesis, verwijst Carrière naar de studie van E. Jelin en J.C. Torre (Los nuevas trabajadores en Annerica Latüna: wna reflexión sabre la lesis de la aristocracia obnera, Desarrollo Economico, Buenos Aires, vol. 22 (1982) No. 85) die aantonen hoe de staat onderhandelingen tussen werkgever en vakbond kan doorkruisen: "The classic model of an "embourgeoisified" worker, one drawn in by management to share in the benefits of high productivity, presupposes at the very least an ability on the part of management and workers to reach agreement about the distribution of productivity benefits between themselves: a luxury which neither group was allowed in Argentina, where the State intervened heavily in the conditions of collective bargaining to restructure labour's price and market conditions in the search for a new "economic strategy". Carrière (1989), a.w. p. 11 . 
opzicht soms ook gewin opgeleverd. Vakbonden in Latijns Amerika kennen een lange traditie van politieke onderhandelingen. In dit licht bezien, zou de volledige afschaffing van het proces van "political bargaining" ook binnen de gelederen van de vakbeweging wel eens op weerstand kunnen stuiten.

Door het duistere intermezzo van de militaire heerschappij, heeft de politieke wisselwerking tussen staat en vakbeweging een nieuwe dimensie gekregen die onder andere door Hirschman in een tamelijk recent essay wordt gesignaleerd. In het bewastzijn dat inwilliging van looneisen de inflatie zal aanwakkeren, waardoor de nieuwe democratieën in diskrediet zullen geraken, heeft de vakbeweging in Argentinie en Braziliè zich bereid getoond om de eisen te matigen. ${ }^{62}$ Deze opstelling die duidt op een verantwoord gebruik van politieke macht, heeft de basis gelegd voor sociale vrede, de zogenaamde "concertacion".

De zojuist geschetste verhouding tussen staat en vakbeweging roept herinneringen op aan de betrekkingen tussen de vakbeweging en populistische regimes, maar én belangrijk verschil springt onmiddellijk in het oog: waar de vakbeweging gedurende de jaren veertig en vijftig het politieke bondgenootschap met de staat werd opgedrongen, ten detrimente van haar ontwikkeling tot een autonome sociale beweging, lijkt de vakbeweging nu in staat om zelf een afweging te maken tussen politieke steun aan een democratisch regime en behartiging van de belangen van de eigen achterban. Deze evolutie vormt een aanwijzing dat de vakbeweging een grotere mate van onafhankelijkheid heeft verworven ten opzichte van de staat.

Dat de politieke matrix, waarbinnen de vakbeweging functioneert, nog steeds actueel is, valt ten diepste te herleiden tot, wat Touraine treffend heeft geformuleerd als: "La double fonction du syndicalisme". Afgezien van haar "normale" functie als pleitbezorger van de (georganiseerde) arbeidersklasse, draagt de vakbeweging in Latijnsamerikaanse landen mede de verantwoordelijkheid voor de algehele ontwikkeling van het land. ${ }^{64}$ Als ik Touraine goed begrijp, dan ziet hij het perspectief voor een grotere autonomie van de Latijnsamerikaanse vakbeweging vooral in een versterking van haar functie als belangenbehartiger van haar achterban: "On voit ainsi se constituer, de manière limitée mais visible, un mouvement ouvrier, sans pour autant que disparaisse la participation dépendente du syndicalisme à des politiques de développement qui s'appuient sur une base multiclassiste et qui ont des objectifs nationaux plus que de classe".

62 Hirschman A.O. The Political Economy of Latin American Development Seven Exercises in Retrospection in: Latin American Research Review, Vol. XXII No. 1 (1987), p. 22 .

63 Vgl Hirschman (1987), a.w. p. 23, en zie ook Carriere (1989) a.w. pp. 10 en 13. Hirschman wijst erop dat de "concertacion" de weg plaveide voor inventieve monetaire hervormingen (het Plan Austral in Argentinie van 1985 en het Plan Cruzado in Brazilië van 1986) die overigens op een fiasco vitliepen omdat de presidenten Alfonsin resp. Sarney geen weerstand konden bieden aan de verleiding om hun popullariteit te verhogen en daarom de grondslagen van de plannen werlieten. Vergelijk Stephan S. Golub, (1991), a.w. p. 205.

64 Touraine (1988), a.w. p. 283: "Le syndicalisme a plus nettement qu'en Europe une double fonction: acteur de la sociêté industrielle, ill est aussi un acteur du développenent national".

65 Touraine (1988), a.w. p. 284. 


\section{Chili: de ILO-reactie op de vakbondspolitiek van het regime- Pinochet}

\section{Inleiding}

Op 11 maart 1990 kwam een einde aan het regime van Augusto Pinochet dat ruim 16 jaar geduurd had. Deze militaire dictatuur had een buitengewoon slechte naam op het gebied van de rechten van de mens. Jarenlang hebben internationale organisaties in lijvige rapporten de trieste balans opgemaakt van standrechtelijke executies, folteringen, arrestaties en detenties zonder vorm van proces en van schendingen van fundamentele burgerrechten, zoals het recht van vergadering en van vereniging.

Vooral de vakbeweging was het mikpunt van de staatsrepressie. Zo werd in een rapport van de Inter-Amerikaanse Commissie voor de Rechten van de Mens onomwonden gesteld dat "If there has been any sector in Chile which has been the subject of permanent harassment and persecution, it has been the labor union sector."'

Het offensief tegen de wakbeweging had zowel een ideologische als een economische oorzaak. In ideologisch opzicht werd met name de vakcentrale CUTCh (Enige Centrale van Chileense Arbeiders) volstrekt geïdentificeerd met de Volksfront-regering van Pinochet's voorganger, de socialistische president Salvador Allende. Deze laatste had, naar het oordeel van de militairen, het land aan de rand van de politieke, morele en economische afgrond gebracht. De militaire Coup van 11 september 1973 werd dan ook voorgesteld als een ultieme reddingsoperatie, volgens de coupplegers toegejuicht door de meerderheid van de Chileense bevolking, die een einde moest maken aan de "voortwoekerende Marxistische kanker" . ${ }^{2}$ De Doctrine van de Nationale Veiligheid, het ideologische credo van de militairen, schreef de totale oorlog tegen het internationale communisme voor, plaveide de weg voor een permanente machtsovername door de militairen en legitimeerde het gebruik van geweld en de schending

1 Organization of American States (OAS), Report on the Situation of Human Rights in Chile. OAS/Ser. L/V/II.66, Doc. 17, 27-09-1985, p. 236.

2 Deze voorstelling van zaken, compleet met de onsmakelijke metafoor, treft men aan in talloze militaire communiques. Vgl. Loveman B. Mititany Dictatorship and Political Opposition in Chite, 1973-1986, in. Journal of Interamerican Studies, 1986-1987, no, 4, p. 2. 
van mensenrechten. ${ }^{3}$ Gegeven de nauwe banden tussen de Volksfront-coalitie en de vakbeweging, lag het woor de hand dat de repressie ook tegen laatstgenoemde was gericht. Maar de felle gebetenheid van de nieuwe machthebbers op de vakbeweging had, zoalls gezegd; ook een economische reden. Bij zijn aantreden werd Pinochet geconfronteerd met een rampzalige economische situatie die vooral tot uitdrukking kwam in een torenhoge inflatie." Pogingen om de inflatie te bestrijden sorteerden geen effect, zodat Pinochet zich genoodzaakt zag om het deskundige advies in te winnen van een aantal neo-liberale economen die gepromoveerd waren aan de Universiteit van Chicago. In navolging van hun geestelijke leidsmannen, Friedrich won Hayek en Milton Friedman - Nobelprijswinnaar voor Economiebeleden deze zogenaamde "Chicago Boys"t een onwrikbaar geloof in de werking van het vrije marktmechanisme. De economische malaise ten tijde van Allende was in hun ogen te herleiden tot de instandhouding van een topzware, niet-rendabele publieke sector aan de ene kant en de monopolisering van de arbeidsmarkt door een overmachtige vakbeweging aan de andere kant.

De "Chicago Boys" presenteerden een twee fasen-plan om de Chileense economie te saneren. Op korte termijn moest de inflatie een halt worden toegeroepen en met dit oogmerk schreven zij een shock-therapie voor die drastische overheidsbezuinigingen en loonsbevriezingen behelsde. Zodra de inflatie beteugeld was, zou de economie vanzelf weer aantrekken, op voonwaarde dat het Chileense bedrijfsleven zich op de export zou richten en dat de staat zich zoveel mogelijk zou onthouden van interventie in de economie. Binnen een dergelijk scenario was geen plaats ingeruimd voor een machtige vakbeweging. Elke loonvorming die niet beantwoordde aan de wetten van vraag en aanbod, zou namelijk binnen het kader van een volledig open economie die de "Chicago Boys" voor ogen stond, een verslechtering van Chili's concurrentiepositie op de internationale markt tot gevolg hebben.'s

De vakbondspolitiek van de regering-Pinochet en de ILO-reactie hierop vormen het hoofdbestanddeel van het onderhavige hoofdstuk. Aan de hand van een korte analyse van de historisch gegroeide verhouding tussen staat, politieke partijen en vakbeweging (2) kan aangetoond worden dat de Coup van 1973 een radicale breuk opleverde met een tamelijk open en democratische traditie.

De indeling van de overige paragrafen volgt in grote lijnen de accentverschuivingen die in de loop der jaren hebben plaatsgevonden in de vakbondspolitiek van het regime.

3 Over de leer wan de Nationale Veiligheid is veel gepubliceerd, vgl. onder andere G. Arriagada, Ideology and Politics in the South American Militany (Argentina, Brazil, Chile and Unuguay), Wilson Center Paper No. 55 en Rouquie A. Military and the State in Latin America, New York 1985. Op het laatste navrante aspect, legitimatie van mensenrechtenschendingen, wordt vooral gewezen door: Arriagada G. Pinochet, The Politics of Power, Boston 1988, p. 23 en door O'Brien/Roddick J. Chile: The Pinochet Decade, London 1983, p. 43.

4 In 1973 bedroeg, volgens de berekeningen van het $\mathrm{IMF}_{*}$ de inflatie $352 \%$ op jaarbasis.

5 Een beknopte maar heldere analyse van de wooronderstellingen en het beleid wan de Chicago Boys kan men vinden in O'Brien/Roddick, a.w. met name de hoofdstukken 6 en 7. 
Een strikt chronologische behandeling kan daarbij niet gevolgd worden. Globaal genomen voerde het regime gedurende de eerste zes jaar ten aanzien van de vakbeweging een tweesporenbeleid. Links-georiënteerde organisaties en vakbondsleden werden ongemeen hard onderdrukt (3). De niet-Marxistische segmenten van de vakbeweging werden geduld, maar moesten opereren binnen een strak institutioneel kader (4). De continuïteit van deze vakbondspolitiek werd eind 1974-1975 onderbroken door een wat constructievere, op corporatistische leest geschoeide benadering van luchtmachtgeneraal Diaz Estrada (5). Nadien begon de regering in toenemende mate gebruik te maken van economische instrumenten om de macht van de vakbeweging te beteugelen (6).

De nieuwe arbeidswetgeving ("Plan Laboral") van 1979 was het logische uitvloeisel van de economische politiek (7). Groeiend verzet van de kant van de vakbeweging werd door het regime voortdurend afgeschilderd als politieke agitatie (8). Vanaf 1983 speelde de vakbeweging een belangrijke rol binnen een brede oppositie die de weg plaveide voor de overgang naar de democratie (9). De verhouding tussen staat en vakbeweging sinds het herstel van de democratie komt kort aan de orde in een epiloog (10). Het hoofdstuk wordt afgesloten met een evaluatie en een conclusie (11).

\section{De verhouding tussen staat en vakbeweging in Chili in historisch perspectief}

De Chileense vakbeweging onderscheidt zich in twee opzichten van vakbewegingen in andere landen van het continent. In de eerste plaats hebben Marxistische partijen nergens zo'n sterke invloed gehad binnen de vakbeweging als in Chili - hoewel ook in Chili deze invloed nooit exclusief is geweest. In de tweede plaats heeft de vakbeweging er immer naar gestreefd om haar positie van strijdbare onafhankelijkheid ten opzichte van de staat te bewaren.

De redenen voor deze militante en autonome traditie van de vakbeweging die de Chileense politieke verhoudingen in de 20e eeuw diepgaand zou beïnvloeden, zijn complex. De oorsprong van het politieke radicalisme van de vakbeweging moet volgens sommige auteurs gezocht worden in de structuur van de Chileense economie die van oudsher in hoge mate afhankelijk is geweest van de export van mijnbouwprodukten. ${ }^{6}$ Onder invloed van specifieke arbeidsomstandigheden en - verhoudingen ontwikkelden werknemers in de mijnbouw en hun organisaties een autonome en klassebewuste visie. Deze visie sloeg over op werknemers in de agrarische en industriële sector en leidde uiteindelijk tot een opvallende zwenking naar links van de gehele Chileense politieke cultuur. Populistische pogingen om de vakbeweging onder controle te brengen leden schipbreuk, aangezien de machthebbers de eenmaal gegroeide politieke loyaliteiten tussen de vakbeweging en Marxistische partijen niet konden verbreken en omdat

6 Vgl. Bergquist Ch. Labor in Latin America, Stanford 1986, pp. 22 en 37. Petras J. and Zeitlin M. Miners and Agrarion Radicalism in: Petras and Zeillin (eds.) Latin America: Reform or Revolution 7; New York 1968, p. 238. Touraine A. La Parole et le Sang, Paris 1988, p. 262 , 
de uitgevaardigde wetgeving juist zowel de autonomie van de vakbeweging als diens betrekkingen met de linkse politieke partijen versterkte.

\subsection{Mijnbouw als woedingsbodem voor een radicale vakbeweging}

Evenals in andere Latijnsamerikaanse landen werden de eerste initiatieven tot de oprichting van werknemersorganisaties ontplooid in de strategische sectoren van de economie: het vervoer en de export. Deze sectoren kwamen tot grote bloei na de Chileense overwinning op Bolivia en Peru in de zogenaamde Nitraatoorlog (1879-1883) die Chill een aanzienlijke gebiedsuitbreiding - de provincies Tarapaca en Antofagasta, beide rijk aan salpeter - opleverde. De ontginning en de export van salpeter zou gedurende een halve eeuw de motor vormen van de Chileense economie. Van 1890 tot 1918 nam de produktie van salpeter toe van 1 miljoen tot 3 miljoen ton per jaar en gedurende deze periode fluctueerde het aandeel van de salpeterinkomsten in de totale exportopbrengst tussen 60 en $80 \%$ ?

Toch kleefden er enkele ernstige bezwaren aan deze eenzijdige samenstelling van het exportpakket. De Chileense economie bleek extreem gevoelig voor internationale conjunctuurschommelingen, een tendens die nog versterkt werd door het cyclische patroon van de vraag naar salpeter: ${ }^{B}$ Bovendien vergde de exploitatie van salpeter grote kapitaalinvesteringen, zodat de Chileense staat zich genoodzaakt zag om deze uit te besteden aan buitenlandse ondernemingen." Zoals we aanstonds zullen zien, hadden beide omstandigheden hun weerslag op de politieke koers van de vakbeweging.

Het dagelijks bestaan op de salpetervelden was zwaar, ongezond en niet van gevaar ontbloot. ${ }^{10}$ Het produktieproces bestond uit verschillende fasen, waarvoor mijnwerkers met specifieke professionele deskundigheden werden ingezet. Voor zijn persoonlijke veiligheid moest elke mijnwerker dus kunnen blindvaren op het vakmanschap van zijn collega's. Deze onderlinge afhankelijkheid versterkte het gevoel van lotsverbondenheid, hetgeen de basis legde voor hechte werknemersorganisaties. Rond de eeuwwisseling ontstonden, allereerst in de Noord-Chileense havensteden, kort daarna op de salpetervelden, de zogenaamde "mancomunales". De diverse functies van deze werknemersorganisaties, een typisch Chileens verschijnsel, weerspiegelden de behoeften van hun leden. In geval van ziekte of invaliditeit voorzagen zij in sociale uitkeringen en in dit opzicht had de mancomunal dus het karakter

7 Bergquist, a.w. pp. 25 en 30.

8 Jorge Barria S. El Mowimiento obrero en Chile, Sintesis historico-social, Santiago 1971, pp. 15-16.

9 In 1901 was $55 \%$ van het kapitaal dat in de salpeterproduktie geinvesteerd was, wan Britse herkomst; de rest wan Europa nam $30 \%$ voor zijn rekening, terwijl het Chileense aandeel in de investeringen slechts $15 \%$ bedroeg. Brom: Pinto Santa Cruz A. Chile, un caso de desarrollo frustrado, Santiago 1962, p. 55.

10 Bergquist wijdt een witvoerige en beeldrijke beschrijving aan "the Life and Work on the Nitrate Pampa", a.w. pp. 37-47. Veel van zijngegevens ontleent hij aan de ongepubliceerde dissertatie van Arthur Lawrence Stickell, Mignation and Mining Labor in Northem Chle in the Nitrate Era, 1880-1930; Indiana University 1979. 
van een wederzijdse bijstandsvereniging. Maar al snel namen zij het voortouw bij het organiseren van stakingen en ondersteunden de arbeiders bij het formuleren van hun eisen. Hoewel de mijnwerkers in financieel opzicht het nog niet zo slecht hadden, werd hun koopkracht regelmatig aangetast door hoge inflatie. "Daarbij kregen zij hün lonen dikwijls niet uitbetaald in harde munt maar in coupons die zij konden inwisselen voor levensmiddelen bij de bedrijfswinkel. ${ }^{12}$ De inflatie en het ficha-systeem waren dan ook de belangrijkste grieven die ten grondslag lagen aan grote stakingsacties. ${ }^{13}$

De meedogenloze repressie van de kant van de staat en de werkgevers verzwakte tijdelijk de werknemersorganisaties, maar leidde op de langere termijn begrijpelijkerwijs tot hardere en radicalere standpunten. ${ }^{34}$ Het feit dat de meeste ondernemingen in de salpeterproduktie in buitenlandse handen waren, droeg bij tot de groeiende animositeit tussen werkgevers en arbeiders. Buitenlandse kapitalisten toonden over het algemeen weinig begrip voor de Chileense werknemerscultuur. Bovendien leefde onder de mijnwerkers sterk het gevoel dat de vreemde werkgevers uitsluitend het land beroofden van zijn natuurlijke rijkdommen en zich niet bekommerden om de opbouw van de Chileense economie. ${ }^{\text {is }}$

Het politieke radicalisme bleef niet beperkt tot de Noord-Chileense havensteden en salpetervelden, maar zou zich geleidelijk over heel Chili verspreiden. Gedurende de periodieke recessies zagen de mijnwerkers zich genoodzaakt om elders emplooi te zoeken. Tijdens hun omzwervingen kwamen de mijnwerkers in contact met fabrieksarbeiders en boeren; met wie zij ervaringen uitwisselden en die zij deelgenoot maakten van hun radicale denkbeelden. ${ }^{16}$ Om deze netwerken van informele contacten om te smeden tot een hecht georganiseerde vakbeweging, was de steun van politieke partijen onmisbaar. Politieke partijen, en wel met

11. Vgl. Barria, a.w. p. 16 en Bergquist, a.w. p. 29.

12 Dit zogenaamde ficha-systeem werd in het leven geroepen om de mijnwerkers aan de onderneming te binden, vgl. Monteón M. Chile in the Nitrate Era, Madison. Wisconsin 1982, p. 89.

13 Vergelijk het overzicht van belangrijke stakingen in: Roddick J. Chile, in: Carrière J./Haworth N. and Roddick J. (eds.) The State, Industral Relations and the Labour Moventem in Latin America, Hampshire 1989, p. 179. De grote stakingen van 1890 , georganiseerd door de havenarbeiders, 1907 (Salpetermijnen; Iquique) en 1918-1919 werden uitgeroepen als protest tegen de chronische inflatie. Beide eerstgenoemde stakingen hadden bovendien de afschaffing van het ficha-systeem op het oog.

14 Het bloedbad in Iquique in 1907, watar tussen de 600 en 3000 mijnwerkers en han familieleden omkwamen, zou een nationaal symbool van werknemers-onderdrukking worden. Een uitvoerige beschrifving wan deze staking en de trieste gevolgen treft men aan in Monte6n, a.w. p. 103-106.

15 "Foreigners were scooping out the irreplaceable wealth of Chile at great profit to themselves. Little that nitrate workers saw could be said to redound to the nation's benefit," Bergquist, a.w. p. 57 . De indruk van de mijnwerkers was niet zonder grond, indien men bedenkt dat buitenlandse ondernemingen ongeveer de helft wan de winsten in de salpeterproduktie wisten te "repatriëren". Bergquist, a.w. p. 34.

"Les mineurs furent constamment un foyer de radicalisation dont l'action s'étendit, au delà des mines mèmes, sur les paysans des régions voísines". Touraine (1988), p. 262. De politieke invloed van de mijnwerkers op werknemers in andere sectoren had een persistent karakter.Zo vonden Petras en Zeitlin een sterke correlatie tussen agrarische gemeenschappen die diclit bij mijnen gelegen waren en de steun voor de progressieve presidentskandidaat Allende bij de verkiezingen van 1958. Petras/Zeitlin, a.w. p. 243. 
name de socialisten, konden de bittere ervaringen van de arbeidersklasse in een breder politiek kader plaatsen, door inflatie en werkloosheid te kenschetsen als de onvermijdelijke gevollgen van de salpetereconomie. In samenwerking met de mancomunales, verzorgden zij de uitgave van kritische arbeiderskranten die een breed lezerspubliek trokken. ${ }^{17}$ Tenslotte konden politieke partijen natuurlijk in het Parlement aandringen op verbetering van de miserabele situatie van de arbeidersklasse. In 1921 werden de betrekkingen tussen vakbeweging en socialisten geformaliseerd, door het besluit van de FOCh (Federatie van Chileense Arbeiders) om het lidmaatschap van de federatie te koppelen aan dat van de POS (Partij van Socialistische Arbeiders).

Zo werden aan het begin van de jaren twintig de contouren zichtbaar van een strijdbare, autonome vakbeweging die niet langer genegeerd kon worden door de politieke machthebbers.

\subsection{De mislukte poging tot institutionalisering}

In het licht van de bedreiging die een militante vakbeweging, gesteund door linkse politieke partijen, vormde voor gevestigde politiek/economische structuren en belangen, zochten de traditionele machthebbers naar wegen om de vakbeweging onder controle te brengen. Het was president Alessandri, aanvoerder van de Liberale Alliantie, die in 1921 het initiatief nam tot het uitvaardigen van arbeidswetten. Parlementsleden van de Conservatieve Partij wisten jarenlang de aanvaarding van deze wetgeving te traineren door het indienen van talloze amendementen, totdat de arbeidswetten, onder druk van reformistische militairen die Allessandri hadden afgezet, in september 1924 van kracht werden.

De Codigo Laboral vormde een wonderlijk amalgama van conservatieve en liberale initiatieven. Met name de organisatiestructuur droeg een conservatief stempel. Werknemers binnen eén onderneming konden zich verenigen in een sindicato industrial, waarvan het lidmaatschap woor alle werknemers verplicht was, zodra de meerderheid voor de organisatie stemde. Daarnaast werden vakverenigingen van beroepsgenoten, de zogenaamde sindicatos profesionales, erkend maar federaties die gehele bedrijfstakken omvatten, waren verboden. De Liberale bijdrage kwam tot uitdrukking in de zware staatsinterventie in de arbeidsverhoudingen. Het Ministerie van Arbeid oefende toezicht uit op de registratie, de financiën en de verkiezingen van vakbonden. In geval van een arbeidsconflict moesten eerst uitvoerige conciliatie - en arbitrageprocedures beproefd worden, alvorens een vakbond een staking kon

17 De legendarische vakbondsleider en socialistisch politicus Recabarren had een manie om nieuwsbladen op te richten. De bekendste was "El Despertar de los Trabajadores" (Het Ontwaken van de Arbeiders).

18 Zie voor de connecties tussen vakbeweging en politieke partijen: Bergquist, a.w. pp. 53 en 61 :Roddick, a.w. pp. 190-191. 
uitroepen. Uitsluitend de ministeriële Junta de Conciliacion was bevoegd om toestemming te geven voor een legale staking."

Met het uitvaardigen van deze wetgeving had de regering overduidelijk het doel voor ogen om de vakbeweging te versnipperen. Door het recht op collectieve onderhandelingen uitsluitend toe te kennen aan ondernemingsvakbonden, leek de staat de mogelijkheden van de vakbeweging om de krachten te bundelen en in economisch opzicht een vuist te maken tegen de werkgevers, te ontnemen. Voorzover de autoriteiten ook het oogmerk hadden om de vakbeweging te deradicaliseren en de eigen invloed te vergroten, sorteerden de arbeidswetgeving en de vakbondspolitiek echter een averechts effect. De arbeidswetgeving had tot gevolg dat de vakbeweging gedurende de jaren dertig in toenemende mate ging opereren op twee niveaus. Binnen de ondernemingswakbonden waren de sociale afstanden tussen kader en basis gering, zodat de klasse-solidariteit intact bleef en de vakbonden betrekkelijk immuun waren voor pogingen wan de werkgever of de autoriteiten om hen tot grotere volgzaamheid te bewegen. ${ }^{20}$

De vakbeweging stond voor de opgave om de lokale acties te coördineren teneinde pressie te kunnen uitoefenen op de staat. Met dit doel voor ogen werd in 1936 de vakcentrale $C T C h$ (Confederatie van Chileense Arbeiders) opgericht. De CTCh onderhield nauwe betrekkingen met de linkse politieke partijen die kort daarvoor zelf een ingrijpende reorganisatie hadden ondergaan. ${ }^{21}$ De Communistische en Socialistische Partij brachten hun eigen organisatorische netwerken in stelling om zowel de contacten tussen de sindicatos industriales onderling als de banden tussen de lokale bonden en de vakcentrale te verstevigen. Bovendien verleenden de politieke partijen vakbonden waardevolle juridische assistentie bij het doorgronden van de ingewikkelde arbeidswetgeving. Ongewild werkte de arbeidswetgeving een verdere toenadering tussen vakbeweging en politieke partijen in de hand.

Het militaire regime van Ibañez y Campo (1927-1931), noch de regering van Alessandri die van 1932 tot 1938 een tweede ambtstermijn vervulde, konden vat krijgen op deze solide alliantie. Op lokaal niveau maakten de ondernemingsvakbonden gebruik van het institutionele raamwerk, zolang zij hiervan profijt konden trekken: de illegale stakingen overtroffen in aantal veruit de legalle stakingen, een tendens die zich zou doorzetten in de volgende decennia. Op nationaal niveau slaagden de vakcentrales er regelmatig in om de basis te mobiliseren voor nationale stakingen om zodoende druk uit te oefenen op de staat. Aangezien de publieke autoriteiten binnen het systeem van industriële verhoudingen een belangrijke plaats innamen, lag het ook wel voor de hand dat de vakbeweging zich met zijn eisen tot de staat zou richten.

19 Zie voor een overzicht wan de wetgeving: Roddick, aw, pp. 200-201; Bergquist, a.w. p. 67 en Angell A. Politics and the Labour Movement in Chile, London 1972.

20 Vgl. Touraine, a.w. p. 286" "La participation aux rendivications s'appuie, dans l'entreprise, sur l'esprit de communauté. Dans celle-ci existe une solidarite primaỉre, qui entraîne une relation très directe entre les. ouvriers et leurs dirigeants syndicaux.."

21 De Communistische Partij was in 1922 voortgekomen uit de POS, terwijl een aantal socialistische splintergroeperingen zich in 1933 verenigd hadden in de Chileense Socialistische Partij. Ziv voor nadere details Barria (1971), a.w. pp. 81-86. 
Maar de vakbeweging liet zich niet verleiden tot het aangaan van al te nauwe betrekkingen met de staat die de weg zouden openen naar grotere controle, al was het alleen maar omdat de staat niet bij machte was om een duurzame verbetering van de materiële positie te garanderen. ${ }^{2 x}$

Het bondgenootschap tussen de vakbeweging en de linkse politieke partijen kreeg een geheel nieuwe betekenis, toen in 1939 de Communistische en de Socialistische Partij een regeringscoalitie wormden met de Radicale Partij, het zogenaamde "Frente Popular".

\subsection{Het streven naar eenheid}

Tijdens de regeringsperiode van het Frente Popular (1939-1946) ondervond de vakbeweging de spanning die diens dubbele hoedanigheid - als drager van politieke verantwoordelijkheid en als pleitbezorger van de arbeidersklasse - met zich meebracht. De CTCh stelde zich coöperatief op en drong binnen de eigen gelederen aan op sociale rust om de industrialisatiepolitiek van de regering te bevorderen. ${ }^{27}$ Waar populistische regeringen er nimmer in geslaagd waren om de vakbeweging aan zich te binden, legde de vakbeweging zichzelf beperkingen op in de eigen handelingsvrijheid, nu de politieke bondgenoten van het eerste uur aan de macht waren gekomen.

In zekere zin herhaalde de situatie zich in de periode 1970 - 1973, toen de vakbeweging zich geplaatst zag voor een vergelijkbaar dilemma: moest de socialistische regering van president Allende onvoorwaardelijk gesteund worden of diende de vakbeweging primair de belangen van de eigen achterban te behartigen ${ }^{24}$ Er was echter één belangrijk verschil. In de tussenliggende decennia waren de politieke verhoudingen binnen de vakbeweging gewijzigd. Geleidelijk aan waren andere politieke partijen - eerst de Radicale Partij, vanaf het midden van de jaren vijftig de Christen Democraten - erin geslaagd om het machtsmonopolie van de Marxistische partijen binnen de vakbeweging te doorbreken en hadden zich een vaste

22 Nigel Haworth en Jacqueline Roddick verklaren het mislukken van populistische experimenten in de Chileense politiek uit het feit dat diens radicale antecedenten de vakbeweging ervan weerhielden om te bezwijken voor de verleidingskunsten wan populistische regeringen. Haworth N./Roddick J. Tres cambios de Rumbo en la Poltica Laboral del Gobiemo Mititar en Chile in: Gallitelli B. y Thompson A.A. (eds) Sindicalismo y Regimenes Militares en Angentina y Chile, Amsterdam 1982, p. 299.

In haar bijdrage aan de studie van Carrière et al. heeft Roddick dit standpunt nog enigszins toegelicht: "In Chile, attempts to organize a Brazilian or Argentinian style State corporarist model were doomed by the prior existence of strong traditions of organisation of workers (...)" - particularly as the State was unable to offer substantial and durable economic concessions (...)

Roddick, a.w. p. 199 (cursivering HwdW)

23 De CTCh was vertegenwoordigd binnen de overheidsinstantie CORFO (Staatscorporatie voor Investeringen). Vergelijk Roddick (1989), a.w. p. 213 en Barria, a.w. p. 89.

24 . Francisco Zapata schetst dit dilemma in zijn studie: Las relaciones entre el Movimiento Obrero y el Gobiemo de Salvador Allende, Méjico 1974. 
vakbondsaanhang verworven. Deze meer evenwichtige verdeling van politieke loyaliteiten bleek een effectieve waarborg tegen al te innige betrekkingen met een regering van welke politieke signatuur dan ook. ${ }^{25}$

Maar de zojuist geschetste ontwikkeling wierp een nieuw probleem op: de intensieve politieke competitie binnen de vakbeweging leidde soms tot sectarisme en maakte de vakbeweging kwetsbaar voor verdeel-en-heers-tactieken van de kant van de autoriteiten. Zo trachtte de Radicale president Gonzalez Videla (1946-1952) politieke munt te slaan uit de splitsing van de CTCh in een socialistische en een communistische vleugel, een splitsing die gezien moet worden tegen de achtergrond van een algehele verwijdering tussen socialisten en communisten tijdens de Koude Oorlog. In 1948 verbood hij de Communistische Partij op grond van de Wet voor de Verdediging van de Democratie, om vervolgens de socialistische fractie te paaien door hen kabinetsposten in het vooruitzicht te stellen. ${ }^{26}$ Hoewel deze poging om een wig te drijven in de vakbondsgelederen uiteindelijk faalde, zou zij de vakbeweging tijdelijk aanzienlijk verzwakken.

De oprichting van de CUTCh (Enige Centrale van Chileense Arbeiders) in 1953 bezegelde het herstel van de eenheid. Nog meer dan zijn voorganger de CTCh, ontwikkelde de CUTCh zich tot een platform dat rechtstreeks met de staat onderhandelde over de economische politiek. Confrontaties met conservatieve regeringen in de jaren vijftig en het begin van de jaren zestig die, met het oog op een strak anti-inflatie beleid, de arbeiderslonen zoveel mogelijk probeerden te drukken, konden niet uitblijven. Hoewel de resultaten van deze krachtmetingen, en daarmee het prestige van de CUTCh, sterk wisselden, kwam de eenheid gedurende deze periode niet in gevaar. ${ }^{2}$

Fricties tussen de aanhangers van de verschillende politieke partijen binnen de vakbeweging ontstonden weer tijdens de regeringsperioden van de Christen Democraat Frei en diens opvolger Allende. De algehele ideologische polarisatie tussen Christen Democraten en Marxisten gaf soms aanleiding tot bittere conflicten in de vakbeweging tussen (kritische) aanhangers van de zittende regering en sympathisanten van de oppositie. ${ }^{28}$

Toch zouden deze conflicten niet tot een schisma binnen de CUTCh leiden. In vakbondskringen leefde sterk het besef dat de eenheid, ondanks politieke meningsverschillen, behouden moest blijven. Zo stuitte de poging van de Christendemocratische regering aan het eind van de jaren zestig om een nieuwe organisatiestructuur te introduceren door aan federaties die

25 Roddick wijst op de wetmatigheid in de Chileense politiek dat regeringspartijen telkens cen gedeelte van hun vakbondsaanhang aan de oppositie plegen te verliezen en leidt hieruit af dat: "There is no possibility of an "official trade unionism' ever enjoying any popular success." Roddick (1989), a.w, p. 234.

26 Vergelijk Barria, a.w. pp. 98-99 en Roddick, a.w. p. 215.

27 Zie voor een beschrijving van deze periode: Angell, aw. pp. 221-222.

28 De grote stakingen tegen de regeringen van Frei en Allende hadden vooral thun oorsprong in de vakbonden in de kopermijnen, waar de Christendemocratische en de Mrarxist ische aanhang elkaar ongeveer in evenwicht hìeld. Deze protestuitingen getuigden miet alleen wan het behoud van strijdbare onafhankelijkheid ten opzichte van regeringen die de vakbeweging gunstig gezind waren, maar stelde ook de coherentie binnen de vakbeweging sterk op de proef. 
een gehele bedrijfistak onvatten het recht toe te kennen om collectieve arbeidsovereenkomsten af te sluiten, op de felle weerstand van de gehele vakbeweging. Aangezien de Christen Democraten de indeling van de federaties wensten te koppelen aan de politieke gezindheid, getuigde het verzet van de vakbeweging wan het inzicht dat een dergelijke strategie interne verdeeldheid zou zaaien en de afhankelijkheid van de vakbeweging ten opzichte van de politieke partijen zou vergroten. Met al zijn tekortkomingen was de sindicato industrial dan toch te prefereren: de vijf-koppige samenstelling van de uitvoerende comités werkte de eenheid in de hand, aangezien de bestuursleden veroordeeld waren tot onderlinge samenwerking. ${ }^{*}$

Tijdens de regering-Allende bleef de vakbeweging zoeken naar een evenwicht tussen samenwerking met de regeringspartijen en het innemen van een zekere distantie, waarbij grote waarde gehecht werd aan de interne eenheid. Pinochet's bewering dat vakbeweging en politiek volledig verstrengeld waren, is dan ook een vertekening van de realiteit en lijkt eerder een alibi om de hevige repressie te rechtvaardigen.

\section{Onverbloemde repressie}

De Coup bracht grote ontreddering in vakbondskringen. De meeste bedrijfsbonden hadden eén of meer vakbondsleiders verloren die vermoord, gevangen genomen of verbannen waren. Bovendien gingen de autoriteiten over tot de ontbinding van de vakcentrale CUTCh en tot de ontmanteling van enkele grote federaties die bekend stonden als aanhangers van Allende. De gecombineerde effecten van een harde staatsterreur en een (daanuit voortvioeiende) organisatorische verzwakking maakten elke poging tot verzet bij voorbaat tot mislukken gedoemd.

\subsection{Internationale reactie}

De verontrustende berichten uit Chili leidden internationaal tot heftige verontwaardiging. Afkeurende resoluties van de Algemene Vergadering van de Verenigde Naties effenden de weg voor de oprichting van een Ad Hoc-Comite dat speciaal belast werd met het onderzoek naar de mensenrechtensituatie in Chili en daarover diende te rapporteren aan de VNCommissie inzake de Rechten van de Mens. ${ }^{30}$ Binnen het kader van de Organisatie van

29 Vergelijk Roddick (1989), a.w. p. 222: "Anti-communism found little echo within a labour rellations system based in practice on the co-operation of communists and other parties in the five-member executive of the sindicato industrial."

30 Resolutie 8 (XXXI) van 27-02-1975 vain de Commissie vormde de juridische grondslag van het Ad Hoc-Comite. Bij Commissie-Resolutie 11 (XXXV) van 6-03-1979 werd het Comite van zijn taak ontheven en wervangen door een Speciale Rapporteur wiens mandaat jaarlijks verlengd werd op basis van resoluties van de Algemene Vergadering. 
Amerikaanse Staten (OAS) vervulde met name de eerdergenoemde Inter-Amerikaanse Commissie voor de Rechten van de Mens (LACHR) een prominente rol. Verscheidene malen bezochten de Commissieleden Chili om ter plekke poolshoogte te nemen, waarna zij in kritische rapporten verslag uitbrachten aan de Algemene Vergadering. ${ }^{31}$

Gezien het feit dat vooral de vakbeweging het slachtoffer was van de repressie, was het van evident belang hoe de ILO zou reageren. Eind september 1973 dienden internationale vakverenigingen, bij wie de gelaedeerde Chileense vakbonden waren aangesloten, gezamenlijk een klacht in bij de Directeur van het Internationale Arbeidsbureau. Het Comité inzake de Vrijheid van Vakvereniging nam de klachten in behandeling en verzocht de regering om informatie. $^{32}$

Nadat in november nieuwe klachten waren ingediend, kwam het Comite tot de conclusie dat de complexiteit van de zaak een grondig onderzoek vergde. Op aanbeveling van het Comite verzocht de Raad van Beheer de Chileense regering hem toestemming te verlenen om de zaak over te dragen aan de Onderzoeks- en Bemiddelingscommissie inzake de Vrijheid van Vakvereniging. ${ }^{33}$ Op 9 mei 1974 bewilligde de regering in het verzoek, zodat de Raad van Beheer op 1 juni de Commissie kon aanstellen.

De Commissie ging voortvarend te werk. Van 28 november tot 19 december 1974 bezocht de Commissie Chili. Op grote schaal hoorden de Commissieleden ooggetuigen en stelden werkgevers, overheidsfunctionarissen en vakbondsvertegenwoordigers van verschillende politieke denominaties in de gelegenheid om hun lezing van de feiten te geven. Naar aanleiding van het bezoek, formuleerde de Commissie begin 1975 haar eerste voorlopige bevindingen. Om tot een gefundeerd eindoordeel te komen, moest de Commissie eerst het overvloedige materiaal grondig bestuderen. Pas op 8 mei 1975 kon de Commissie haar eindrapport aan de Raad van Beheer overleggen. ${ }^{34}$

Nadat de Raad van Beheer in november 1975 de Chileense regering had verzocht te rapporteren over de ontwikkeling van de vakbondssituatie, kon het Comité inzake de Vrijheid van Vakvereniging de taak wederom van de Commissie overnemen.

De Commissie stond uitvoerig stil bij de juridische grondslagen van het onderzoek en bij de afbakening van haar eigen mandaat. Met betrekking tot de juridische basis van het onderzoek, stelde de Commissie vast dat Chili Conventie no. 87, noch Conventie no. 98 had geratificeerd en uit dien hoofde dan ook niet gebonden was aan die bepalingen. Niettemin

31 C. Medina Quiroja geeft in The Battle of Human Rights, Dordrecht 1990, pp. 262-315 een degelijk overzicht van de werkzaamheden wan de Commissie. In het Commissie-Rapport van 1985 treft men een samenvatting. aan van de belangrijkste bewindingen van de Commissie over de gehele periode.

32 Case No. 765,139 e Rap. $\$ \$ 553-568$.

33 Case No. 765,142 e Rap. $\$ 271$. De toestemming van de regering was noodzakelijk, aangezien Chili geen van beide sleutelconventies inzake de vrijheid van vakvereniging had geratificeerd.

34 ILO; The trade union situation in Chile: Repont of the Fact-Finding and Conciliation Commission om Freedom of Association, Geneva, 1975 (provisional edition). Hierna aan te geven als: "Report". 
was Chili, alls lidstaat van de ILO, gehouden om bepaalde beginselen te respecteren die op grond van gewoonterecht zelfs voorrang hadden boven Conventies. Tot die beginselen behoorde het principe van vrijheid van vakvereniging. ${ }^{35}$ De Chileense regering had erin toegestemd dat de zaak werd overgedragen aan de Commissie, zodat zij nu kon overgaan tot het formuleren van conclusies en aanbevelingen.

Vervolgens bakende de Commissie haar eigen mandaat af. De Commissie had uitsluitend de klachten onderzocht die betrekking hadden op schending van het recht van vereniging en op schending van burgerrechten, woorzover deze de uitoefening van vakbondsrechten aantastten, sinds de regeringswisseling. Hiermee weerlegde zij het argument van de regering dat de vigerende vakbondspolitiek beoordeeld diende te worden in het licht van de gebeurtenissen voor 11 september 1973 die tot ontwrichting van de natie en het militaire ingrijpen hadden geleild. De Commissie kon zich geen oordeel aanmeten over hoogst controver-siële politieke aangelegenheden. Gebeurtenissen die aan de Coup vooraf waren gegaan, zou de Commissie uitsluitend in beschouwing nemen, indien zij direct verband hielden met regeringsmaatregelen met betrekking tot de verschillende aspecten van vakverenigingsvrijheid. ${ }^{37}$

Het was duidelijk, zo ging de Commissie verder; dat de ware bedoeling van de regeringswisseling het doorvoeren van een drastische verandering van de situatie, zoals die zich had ontwikkeld tijdens de Unidad Popular-regering, was geweest. Het optreden van de nieuwe regering had grote gevolgen gehad voor de vakbeweging, wier leiders voor een belangrijk deel lid waren van de Volksfront-partijen. Uit het vergaarde bewijsmateriaal was genoegzaam gebleken dat de regering elk verzet tegen haar politiek van de kant van de vakbeweging wenste uit te bannen of te voorkomen. ${ }^{3 s}$

\subsection{Moord op of executie van vakbondsleiders}

Betrouwbare informatie over het exacte aantal vakbondsleiders dat kort na de Coup was gedood, is niet beschikbaar." Vast staat evenwel dat sinds 11 september 1973 vele vakbondsleiders waren omgekomen, hetzij door executie, met of zonder proces; hetzij door

36 Report, \$467.

37 Report, $\$ 470$.

38 Report; $\$ 472$.

39 Het OAS-Rapport (1985, $\$ 111)$ bevat een lijst wan 45 vakbondsfunctionarissen die "vermist" waren, maar uit de formulering ("among the labor union officials that are missing...") blijkt al dat deze lijst niet uitputtend is. Barrera en Valenzuela geven aan dat, ten gevolge van executie, detentie, verbanning of ontslag, de vakbeweging veell, zo niet de meerderheid van haar meest ervaren kaderleden verloor. Barrera $\mathrm{M}$ /Valenzuela J.S. The Development of Labor Movernent. Opposition in: Valenzurela J.S./Valenzuella A. Mititary Rulle in Chile, Baltimore and London 1986, p. 235. 
toepassing van de Wet inzake Voortvluchtigen (Ley de Fuga), hetzij als gevolg van martelingen. ${ }^{\text {*n }}$

Bij wijze van steekproef, had de Commissie de regering een lijst van 110 personen, van wie beweerd werd dat zij gedood waren, voorgelegd, met het verzoek om nadere informatie te verschaffen. De regering had de dood van 33 vakbondsleiders bevestigd. Volgens de regering waren 9 van hen omgekomen in gevechten met het leger, 10 waren geëxecuteerd en 14 waren gedood terwijl zij probeerden te ontsnappen." De regering ontkende dat de vakbondsleiders waren geëxecuteerd vanwege hun vakbondsactiviteiten. ${ }^{42}$

Een cruciaal element bij de beoordeling van doodvonnissen vormde het feit dat, krachtens de staat van beleg, gewone rechters vervangen waren door militaire tribunalen, wier objectiviteit ernstig in twijfel getrokken werd. ${ }^{43} \mathrm{De}$ Commissie maakte in het bijzonder bezwaar tegen het vluchtige karakter van de procedure, de afwezigheid van toereikende waarborgen voor de verdediging van de verdachte, het gebrek aan mogelijkheden om in beroep te gaan en de toepassing met terugwerkende kracht van bepalingen die uitgevaardigd waren op grond van de staat van beleg." Voorts meende de Commissie dat zij niet stilzwijgend voorbij kon gaan aan gevallen, waarin martelingen de doodsoorzaak waren geweest. ${ }^{45}$

Concluderend stelde de Commissie dat de regering er niet in alle gevallen in geslaagd was om te bewijzen dat de dood van de vakbondsleiders geen verband hield met hun vakbondsactiviteiten. Ook al heerste er in de periode vlak na de Coup alom verwarring, de omstandigheden toonden aan dat de waarborgen die noodzakelijk waren om de eerbiediging van mensenrechten met betrekking tot de persoonlijke veiligheid te verzekeren, in ernstige mate waren aangetast, met alle onherstelbare gevolgen vandien. ${ }^{46}$

\subsection{Arrestatie en detentie van vakbondsleiders}

$\mathrm{Al}$ in haar voorlopige beschouwingen had de Commissie melding gemaakt van het grote aantal vakbondsleiders dat onmiddellijk na de Coup gearresteerd was. Het ontbreken van de normale

40 Report, \$ 495. De Ley de Fuga (Wetsdecreet no. 5, 12-09-1973) bepalde dat "indien de veiligheid van de aangevallene (d.w.z. de militairen) dit wereist, kan de aanvaller geëxecuteerd worden tijdens de handeling". Arriagada (1988, p.6) wijst op de schokkende praktijk om dit Wetsdecreet toe te passen indien voortwluchtige politieke gevangenen niet terstond gehoorzaamden aan een stop-bevel.

41 Report, \$ 496.

42 Report, \$ 497.

43 De IACHR gaf aan dat verscheidene aspecten van de procedure die gevolgd werd door deze tribunalen in strijd waren met internationale normen inzake de vereisten wan een eerlijk proces. Vgl Medina, a.w. p. 268.

44 Report, \$ 498.

45 Report, \& 499.

46 Report, $\$ 500$. 
gerechtelijke waarborgen gaf reden te vrezen dat een aantal van hen blootgesteld was aan slechte behandeling of strenge bestraffing.

De regering beaamde de arrestaties maar voegde hieraan toe dat de vakbondsleiders gearresteerd waren, omdat ze misdrijven hadden gepleegd, zoals verboden wapenbezit en het deelnemen aan gevechten met de strijdkrachten, of omdat ze extremisten waren.

Wederom had de Commissie een lijst met 120 namen opgesteld, met het verzoek aan de regering om informatie te verschaffen over deze mensen. De regering had de arrestatie van 54 van hen bevestigd. De meerderheid was veroordeeld op grond van de Wet inzake de Staatsveiligheid of de Wet inzake de Wapencontrole. ${ }^{4}$ Verder had de Commissie een onderhoud gehad met zeven vakbondsleiders die in voorlopige hechtenis waren, zonder dat er een formele aanklacht tegen hen was ingediend. Zij waren gedetineerd op grond van de Staat van Beleg om verder ondervraagd te worden of omdat zij geacht werden een gevaar op te leveren voor de nationale veiligheid."49

Volgens de Commissie kleefden er in het algemeen twee ernstige bezwaren aan de detenties. In de eerste plaats waren sommige vakbondsleiders die door de autoriteiten gearresteerd waren, sindsdien spoorloos verdwenen. Het starten van een amparo-(habeas corpus)procedure om meer te weten te komen over het lot van de "verdwenen" vakbondsleiders mocht niet baten. Het Hoogste Gerechtshof had namelijk verscheidene malen amparoprocedures niet ontvankelijk verklaard in geval van detenties die bevolen waren tijdens en op grond van de Staat van Beleg. Bovendien, zo verzekerde de President van het Hoogste Gerechtshof, beoogde de amparo-procedure een waarborg te bieden tegen onrechtmatige detentie die was opgelegd door de rechter. De procedure had niet de strekking om een onderzoek in te stellen tegen detenties die bevolen waren door de uitvoerende autoriteiten. ${ }^{\text {so }}$ In de tweede plaats had de Commissie uit verscheidene betrouwbare bronnen vernomen dat gedetineerde vakbondsleiders mishandeld waren."

Concluderend stelde de Commissie vast dat vakbondsleiders, gelijk alle andere mensen, de plicht hadden om de wet te respecteren en dat zij niet vrijgesteld waren van vervolging indien zij de wet overtraden. Niettemin was de Commissie van mening dat het ontbreken van toereikende waarborgen het mogelijk had gemaakt dat vakbondsleiders het slachtoffer waren geworden van onjuiste beslissingen, waardoor zij onderworpen waren aan onrechtvaardige behandeling. Dit gebrek aan waarborgen, zo ging de Commissie verder, had

47 Report, $\$ 501$.

48 Report, $\$ 503$.

49 Report: 504 .

50 Vgl. UN-Doc. A/33/331, 186-188. Het Ad Hoc-Comité merkte op dat de Chileense wetgeving, zoals geinterpreteerd door de rechter, niet de voorziening kende, waar art.9, lid 4 van het Internationaal Verdrag inzake Burgerrechten en Politielke rechten op doelt. Dit artikel-lid luidt: "Een ieder wie door arrestatie of gevangenhouding zijn vrijheid is ontnomen, heeft het recht voorziening te vragen bij de rechter, opdat die rechter binnen korte termijn beslist over de wettigheid van zijn gevangenhouding en zijn invrijheidstelling beveelt, indien zijn gevangenhouding onrechtmatig is:

51 Report; $\$ 507$. 
klaarblijkelijk een gevoel van onveiligheid en angst in het leven geroepen dat de uitoefening van vakbondsrechten in negatieve zin beïnvloed had.

\subsection{De ontbinding van de CUTCh}

Eén van de meest opzienbarende wapenfeiten van het regime-Pinochet was de ontbinding van de CUTCh in november 1973 . Het ingrijpende karakter van deze maatregel kan moeilijk overschat worden, als men bedenkt dat de CUTCh als enige invloed kon uitoefenen op de arbeidspolitiek van de regering. ${ }^{5 x}$

Als rechtvaardiging had de regering aangevoerd dat de CUTCh was verworden tot een politiek instrument in handen van de Marxistische partijen, dat uitsluitend politieke belangen had gediend die niet strookten met de belangen van de arbeiders.

Leiders van de CUTCh hadden ministeriële posten bekleed. Tijdens de verkiezingen voor de Nationale Raad van de CUTCh in 1971 moesten kandidatenlijsten gesteund worden door politieke partijen. Tussen de CUTCh en de regering-Allende waren verstrekkende afspraken gemaakt over collectieve onderhandelingen en stakingen. Deze feiten toonden genoegzaam aan dat de CUTCh politiek ontaard was. ${ }^{54}$

De Commissie plaatste enige kanttekeningen bij deze voorstelling van zaken. Het oordeel of de vakcentrale voldoende onafhankelijk opereerde om haar werkzaamheden te vervullen, kwam toe aan de arbeiders. Zij dienden, zo nodig, geschikte maatregelen te nemen in overeenstemming met de reglementen, de zaak aanhangig te maken bij de rechter of zelfs de betrokken vakbondsleiders naar huis te sturen. Tijdens de verkiezingen van het kader van de CUTCh in 1972 hadden de leden zich in meerderheid uitgesproken voor leiders die behoorden tot de partijen van Unidad Popular. Hieruit zou men kunnen afleiden dat de vakbondsleiders het vertrouwen van de basis hadden, ware het niet dat de resultaten van de verkiezingen door sommige partijen waren aangevochten.s

Was de ontbinding van de CUTCh, alle omstandigheden in aanmerking genomen,nu wel of niet gerechtvaardigd; zo luidde de hamvraag.

Om te beginnen voelde de Commissie zich geroepen in dit verband het belang van de ILC-Resolutie van 1952 betreffende de onafhankelijkheid van de vakbeweging te benadrukken. ${ }^{56}$ Deze Resolutie komt er, kort weergegeven, op neer dat vakbonden politieke activiteiten mogen ontplooien, mits zij hun bevoegdheden niet te buiten gaan door zich uitsluitend met politieke activiteiten bezig te houden. Met het aanhalen van deze resolutie

53 Vgl. UN-Doc. A/33/331, \$666.

54 Report, $\$ 474-476$.

55 Report, $\$ \$ 480$ en 481 .

56 Report, $\$ 482$. Deze Resolutie is in hoofdstuk 1 uitwoerig aan de orde geweest. 
hield de Commissie zich nogal op de vlakte, aangezien zij niet aangaf of de CUTCh, naar de mening van de Commissie, de eigen bevoegdhedensfeer had overschreden.

Van doorslaggevende betekenis achtte de Commissie dat het oordeel over politieke uitwassen van de kant van vakbonden woorbehouden was aan de gerechtelijke autoriteiten. Deze regel maakte deel uit van een allgemeen principe dat, met het oog op het waarborgen van de onpartijdigheid, het toezicht op vakbondsactiviteiten die, naar beweerd werd, een inbreuk maakten op de wet of de vakbondsreglementen, uitgeoefend diende te worden door de rechter. . $^{\text {it }}$

In het licht van deze overwegingen, kwam de Commissie tot de conclusie dat de ontbinding van de CUTCh door de regering niet in overeenstemming was met de beginselen van vrijheid van vakvereniging. ${ }^{58}$

\subsection{De ontmanteling van overige "marxistische" vakverenigingen}

Een aantal grote (con)federaties die nauwe banden hadden onderhouden met de regeringAllende, bleef aanvankelijk in juridische zin nog voortbestaan, maar zij werden ernstig in hun functioneren belemmerd. Vooral werknemers en vakbonden in de agrarische sector hadden te lijden onder de overheidsrepressie. Twee van de drie confederaties in deze sector, "Ranquil" en de Verenigde Confederatie van Boeren en Arbeiders, werden gereduceerd tot een papieren bestaan en de meeste federaties en bonden die bij deze confederaties waren aangesloten, werden ontbonden."

Een beproefd middel om vakverenigingen het opereren onmogelijk te maken, was de confiscatie of bezetting van vakbondslokalen. Met name de Confederatie van Employés in Private Ondernemingen (CEPCh) en de Nationale Federatie van Bonden in de Metaalnijverheid was het gebruik van de eigen vakbondslokalen ontzegd. Andere vakorganisaties, zoals de Nationale Federatie van Textiel- en Kledingwerkers (FENATEX) en de Nationale Federatie voor de Bouw, de Houtbewerking en Bouwmaterialen (FIEMC) waren niet langer gerechtigd om lidmaatschapsgelden te vergaren.

De beide vakcentrales voor onderwijzend personeel, SUTE en ANESE, werden na de Coup onder toezicht gesteld van speciale comités die de opdracht hadden om te onderzoeken in hoeverre de centrales hun bevoegdheden te buiten waren gegaan. Verder bleek de regering van plan te zijn SUTE te vervangen door een college van onderwijzers die door de regering waren aangesteld ${ }^{\text {.0 }}$

58 59. Report; 487. Barrera en Valenzuela (a.w. p. 235) stellen dat beide confederaties $61,5 \%$ van alle agrarische
bonden vertegenwoordigden.

60 Naar aanleiding vam laatstgenoende maatregel owerwoog de Commissie dat het onderwijzend personeel zelf diende te beslissen door welke organisaties zij vertegenwoordigd wenste te worden; Report, $\$ \$ 490$ en 
De Commissie was van oordeel dat al deze situaties aantoonden dat specifieke gevallen van schending van vakbondsrechten waren voorgevallen, waartegen de regering had behoren op te treden. ${ }^{\text {Gi }}$

$\mathrm{Na}$ jarenlang een kwijnend bestaan te hebben geleid, werden op 17 oktober 1978 zeven federaties alsnog bij Wetsdecreet ontbonden. ${ }^{22}$ Hun rechtspersoonlijkheid werd herroepen en hun bezittingen werden overgedragen aan de Staat. De regering stelde dat de ontbinding noodzakelijk was om de burgers te beschermen tegen ondermijnende activiteiten. Bovendien bleek uit het gedrag van de vakbonden dat hun acties en doeleinden geïnspireerd waren op Marxistische beginselen.

Alle zeven organisaties gingen in beroep bij het Hof van Appèl van Santiago. Het Hof verwierp het beroep op procedurele gronden en het Hoogste Gerechtshof bevestigde de uitspraak: de zeven bonden hadden geen bescherming gevraagd tegen handelingen van de administratie, maar hadden het Hof verzocht het Wetsdecreet te toetsen aan de Grondwet en het niet-toepasselijk te verklaren. Hiervoor was de procedure echter niet bestemd. ${ }^{\text {*3 }}$ Het Comité was niet geporteerd voor deze uitspraak. Ontbinding van vakbonden door de regering, in de uitoefening van haar wetgevende bevoegdheden voorzag, evenmin als ontbinding door middel van een administratieve procedure, in voldoende waarborgen voor de verdediging. Uitsluitend de rechter is bevoegd om een vakbond te ontbinden. ${ }^{\text {A }}$

\subsection{Ontslag en diskwalificatie van vakbondsleiders}

Met name gedurende de periode september-december 1973 waren veel vakbondsleiders ontslagen of door de autoriteiten gedwongen om als vakbondsleider af te treden. Over de ontslaggrond was elke twijfel uitgesloten: de regering beweerde openlijk dat vakbondsleiders waren ontslagen in verband met het ontplooien van illegale praktijken. Vertegenwoordigers van de oppositie daarentegen hielden vol dat de ontslagen verband hielden met de krachtige inzet van vakbondsleiders of met hun lidmaatschap van UP-partijen. De Commissie achtte deze laatste factor uitsluitend van doorslaggevende betekenis in bepaalde organisaties in

491.

61 Report, $\$ \$ 492 \operatorname{en~} 493$.

62 De getroffen organisaties waren: de Confederatie "Ranquil" Arbeiders, de Nationale Federatie van Bonden in de Metaalnijwerheid, de Vakbond van Bouwvakarbeiders wan Santiago, FENATEX, FIEMC en de Nationale Federatie vain Mijnwerkers. Volgens de IACHR waren bij deze federaties 550 vakbonden aangesloten, die eveneens ontbonden werden. OAS-Rapport (1985), $\mathrm{p}_{\text {* }}$ $225 \& 48$.

63. Case No. 823, 197 e Rap. $\$ 424$.

64 Case No. 823, 197 e Rap. \& 425 en $207 \mathrm{e}$ Rap. \$ 175. 
de staatssector en stelde bovendien dat deze ontslaggrond niet op uniforme wijze was gehanteerd.

De wetgeving verruimdle aanzienlikk de mogelijkheden om werknemers te ontslaan Zo werden op grond van Wetsdecretem nos. 6 en 22 alle dienstbetrekkingen in de publieke sector geconverteerd in tijdelijke aanstellingen en konden ambtenaren en werknemers van staatsondernemingen zonder enige nadere opgave van redenen ontslagen worden. In de particuliere sector voorzag Wetsdecreet no. 32 in een aantal aanvullende ontslaggronden (naast de bestaande gronden die opgenomen waren in de Codigo Laboral) die op zichzelf, naar het oordeel van de Commissie, gerechtvaardigd waren. Niettemin kende het Wetsdecreet de mogelijkheid dat vakbondsleden ontslagen werden op grond van het ontplooien van bepaalde activiteiten die onder de vorige regering, om welke reden dan ook, geen grond opleverden voor ontslag.

Van evident belang was de vraag hoe de nieuwe ontslagwetgeving zich verhield tot de, van oudsher in de Chileense wetgeving erkende regel dat vakbondsleiders immuniteit genoten tegen ontslag (de zogenaamde fuero sindical). In de particuliere sector was de "fuero sindical" uitdrukkelijk buiten toepassing verklaard in geval van ontslagen die gevallen waren op grond van Wetsdecreet no. 32 .

De gerechtelijke procedure die de regering in het leven had geroepen om ontslagen op hun redelijkheid te beoordelen, kon de toets der kritiek niet doorstaan. Tegen de uitspraken van speciale rechtbanken, waarin, naast een vertegenwoordiger van de strijdkrachten, een rechter en een arbeidsinspecteur zitting hadden, stond geen hoger beroep open. ${ }^{6}$

Hoewel sommige ontslagen, als sanctie op daden die door vakbondsleiders gepleegd waren, gerechtvaardigd waren; was de Commissie ervan overtuigd dat zowel autoriteiten als werkgevers zich bediend hadden van het ontslagmechanisme om zich te ontdoen van vakbondsleiders die behoorden tot het vorige regime of, naar hun mening, te voortvarend hun taken hadden uitgeoefend. ${ }^{\circ}$

\section{Bevriezing van de gedoogde vakbeweging}

Het spreekt vanzelf dat de repressie ook in getalsmatig opzicht gevolgen had voor de vakbeweging. Over de terugloop in de aanhang van de vakbeweging bestaat evenwel geen

66 Voor een beknopt overzicht van deze wetgewing wordt verwezen naar OAS-Rapport (1985), pp. 221 en 222.

67 Report, 511. Eén van de meest verraderlijke clausules betrof de mogelijkheid om werknemers te ontslaan die zich schuldig hadden gemaakt aan deelname aan illegale stakingen. De clausule gaf werkgevers "carte blanche" om zich van militante vakbondsleden en -leiders te ontdoen, aangezien vrijwel geen enkele staking in de voorafgaande decaden legaal was, vgl. Barrera/Valenzuela, a.w. p. 236. 
consensus: ${ }^{*}$ Aangenomen wordt dat de meerderheid van de vakbonden - vooral de gematigde bonden met een christendemocratische signatuur - kon blijven functioneren, zij het op een wat lager actieniveau. ${ }^{\text {th }}$ Deze "gedoogde" vakbonden moesten hun strategie echter drastisch wijzigen. Allereerst werd de steun van de traditionele bondgenoten, de politieke partijen, node gemist. In hun ijver om het marxisme te bestrijden, gingen de militairen direct over tot de ontmanteling van de gehele politieke cultuur. Het Parlement werd ontbonden en de niet-marxistische partijen werden op reces gestuurd.

In de tweede plaats was het ontplooien van vakbondsactiviteiten aan strenge restricties onderhevig. Toch lieten de autoriteiten het institutionele kader in grote lijnen intact. Op de langere duur zou de vakbeweging hier haar voordeel mee doen.

\section{I Vakbondswerkiezingen}

Sedert 11 september 1973 waren vakbondsverkiezingen verboden. Krachtens Wetsdecreet no. 198 dat uitgevaardigd was in december 1973 , werd de ambtstermijn van zittende vakbondsleiders automatisch verlengd. Opengevallen plaatsen moesten opgevuld worden door werknemers die het langst bij een bedrijf werkzaam waren. Mocht deze opvolging naar anciënniteit geen uitkomst bieden, dan kon, conform art: 9 van het Decreet, de Minister van Arbeid nadere aanwijzingen geven. Deze regeling gaf soms aanleiding tot misbruik, waar de Minister van Arbeid de neiging vertoonde om, zonder de betrokken vakorganisatie te raadplegen, gunstelingen aan te stellen. ${ }^{72}$ In de publieke sector werden vakbondsleiders aangesteld door de gouverneur na consultatie van het betrokken hoofd van de overheidsdienst en op basis van een voordracht van drie personen door de vakorganisatie.

De Commissie drong er bij de regering op aan om het recht van vakorganisaties om hun vertegenwoordigers in volledige vrijheid te kiezen, te erkennen. ${ }^{73}$

70. Ruiz Tagle baseen zich op de officiele statistieken van het Ministerie van Arbeid die aangeven dat de aanhang van de vakbeweging tussen 1973 en 1977 met 2;4\% is geslonken, vgl. Ruiz Tagle J. Sindicalismo y Estado en el Regimen Mititar Chileno, Santiago 1986, p. 15. Campero verwijst naar het onderzock van P. Frías (Dinerssiones Cuantitativas de la Afiliación Sindical, CED Santiago, 1984) die de daling van de vakbondsaanhang tussem 1973 en 1983 taxeert op $17,1 \%$ (in 1973 was $28,4 \%$ van de beroepsbevolking aangesloten bij een vakbond, in 1983 nog maar $11,3 \%$ ). Hieruit zou men kunnen opmaken dat de getalsmatige verzwakking van de vakbeweging wooral plaatswond na 1977 , ware het niet dat de officiéle cijfers naar alle waarschijnlijkkheid opzettelijk geflatteerd zijn, vgl. Campero G. El Sindicalisno Chileno en el Regimen Militar (1973-1984) in: García R. (ed.) "Chile: 1973-1984", Stockholm 1985, pp. 176-177.

71 Vgl. Barrera/Valemzuela, a.w. p. 235: "Despite the severity of the repression, most organizations (...) were spared from dissollution and confiscation of their assets."

72 UNN-Doc. $A / 33 / 331, \$ 639$.

73 Report, $\$ 518$ jo. $\$ 530$. 
Volslagen onverwacht kondigden de autoriteiten op 27 oktober 1978 nationale vakbondsverkiezingen aan. Kandidaatstelling vooraf, een bestendige praktijk binnen de Chileense vakbeweging, was praktisch uitgesloten, aangezien de verkiezingen vier dagen later dienden plaats te vinden. De verkiezingen die geregeld werden in Wetsdecreet no. 2376, hadden als doelstelling de vakbeweging te voorzien van een volledig nieuw kader en stonden in het teken van de depolitisering. Vrijwel algemeen wordt aangenomen dat de regering niet slaagde in deze opzet. De verkozen vakbondsleiders waren weliswaar jong en onervaren, maar gekant tegen het militaire regime en zij legden in grote lijnen dezelfde ideologische voorkeuren aan de dag als hun voorgangers. ${ }^{\text {7q }}$

Er kleefden nogal wat bezwaren aan de bepalingen wan het decreet, zo meende het Comité. Zo kende het decreet een tijdelijke bepaling dat zittende vakbondsleiders uitgesloten waren van de kandidatuur. Deze uitsluiting was niet alleen in strijd met de beginselen van vrijheid van vakvereniging, maar beroofde de organisaties ook van ervaren leiders. ${ }^{7 s}$ Verder moesten de aspirant-leiders tenminste vijf jaar werkzaam zijn in de onderneming en twee jaar lid zijn van de vakbond, mochten zij niet veroordeeld zijn wegens een misdrijf of overtreding, noch verwikkeld zijn in een tegen hen lopend strafrechtelijk onderzoek en moesten zij, bij hun ambtsaanvaarding, plechtig zweren dat zij geen politieke activiteiten zouden ontplooien. Al deze voorwaarden stonden op gespannen woet met het beginsel van vrijheid van vakvereniging. Het Comite nam kennis van de belofte van de Minister van Arbeid dat enkele vereisten het verbod van herverkiezing en de uitshiting wegens het ontplooien van politieke activiteiten bij de volgende verkiezingen niet meer zouden gelden. ${ }^{76}$

\subsection{Vakbondsvergaderingen}

Op grond van Wetsdecreet no. 198 werden restricties gesteld aan het houden van vergaderingen. Vakbondswergaderingen mochten uitsluitend gehouden worden om informatie uit te wisselen en interne aangelegenheden te bespreken. Bovendien moest de politie op de hoogte gebracht worden van de agenda en van de plaats waar de vergadering werd gehouden. Vakbondsleiders gaven als hun mening te kennen dat deze kennisgeving niet zuiver een formaliteit was, maar in feite neerkwam op het verkrijgen van voorafgaande toestemming. ${ }^{n}$

74. Vgl O'Brien/Roddick, a.w. p.81; Barrera/Valenzuela a.w. pp. 250-251 en Hurtado-Beca C. Chile 1973-1981: Desaniculacion y Reestnctiracidin Autoriaria del Movimiento Sindical in: Gallitelli B. y Thompson A.A. (eds) Sindicalisho y Reginenes Militares en Angentina y Chile, Ansterdam 1982, pp. 245 en 256.

75 Case No. 823 , 190 e Rap. \$ 191.

76 Case No. 823, 190e Rap. \$ 193.

77 Zie cok UN-Doc. A/33/331, 644. Het Ad Hoc-Comite makte bovendien nog melding van de bepaling dat vakbondsvergaderingen bijgewoond dienden te worden door een vertegenwoordiger van de autoriteiten, opdat geverifieerd kon worden of de vakbond zich wel hield aan de voorschriften. 
De Commissie verzocht de regering om het recht van organisaties om vergaderingen te houden zonder controle van de autoriteiten, te garanderen. Tijdens deze vergaderingen moesten alle kwesties die van belang waren voor de leden, vrijelijk besproken kunnen worden. ${ }^{78}$

Wetsdecreet no. 2544 dat in februari 1979 werd uitgevaardigd en $\$ 4$ van Wetsdecreet no. 198 verving, leek op het eerste gezicht een verbetering. Vakbonden mochten buiten werkuren in hun eigen hoofdkwartieren vergaderen. Indien zij niet de beschikking hadden over eigen ruimte, dan konden zij ook in privé-lokalen vergaderen, mits zij vantevoren het dichtstbijzijnde politiebureau daarvan in kennis stelden. Deze merkwaardige construetie, waarbij de vrijheid van vergadering afhankelijk gesteld werd van de beschikking over eigen vakbondslokalen, werd door het Comité niet geaccepteerd.

\subsection{Collectieve onderhandelingen en stakingen}

Op grond van Proclamatie no. 36 die op 18 september 1973 was afgekondigd, waren collectieve onderhandelingen opgeschort en stakingen strikt verboden. Elke inbreuk op het stakingsverbod kon bestraft worden door de militaire gerechtshoven, wegens schending van de Wet inzake de Interne Veiligheid van de Staat.

De Minister van Arbeid verklaarde nadrukkelijk dat collectieve onderhandelingen slechts waren opgeschort, met het oog op de penibele economische situatie: Indien in 1975 het inflatiepercentage terug gebracht zou zijn tot 50 of $60 \%$, zouden collectieve onderhandelingen weer toegelaten worden. In oktober 1974 was een systeem van driemaandelijkse loonaanpassing ingevoerd. Bovendien waren tripartiet adviescomités in het leven geroepen die in bepaalde gevallen hogere lonen konden adviseren. Sommige comités waren er in geslaagd om arbeidsaangelegenheden op informele basis te bespreken en hadden ook verbeteringen in de beloning verkregen. ${ }^{\text {.0 }}$

De Commissie was zich bewust van de ernstige situatie waarin de Chileense economie verkeerde. Juist werknemers, wier salarissen duidelijk laag waren, ondervonden de negatieve effecten van deze situatie aan den lijve. Onder deze omstandigheden wenste de Commissie te benadrukken dat de restricties op het recht om collectief te onderhandelen slechts van tijdelijke aard dienden te zijn. Zij hoopte dan ook dat de praktijk van het collectieve onderhandelingen zonder uitstel hervat zou worden. Bij wijze van tijdelijke maatregel zouden de adviescomités kunnen opereren. Deze comités dienden bij de aanpassing van lonen in het bijzonder toe te zien op de verbetering van de levensstandaard van arbeiders en hun gezinnen. ${ }^{81}$

79 Case No. 823, 1944e Rap. $\$ 143$ en 146.

80 Report, $\$ 521$.

81 Report, $\$ 534$. 
In april 1977 kregen de beslissingen van de adviescomités de status van collectieve overeenkomsten, mits ze met eenstemmigheid genomen waren en de regering niet binnen een periode wan 60 dagen een bezwaar had ingediend.

Het Comité had de nieuwe voorzieningen grondig onderzocht en kwam tot de slotsom dat zij op geen enkele wijze ontsloegen van de verplichting dat de regering haar goedkeuring moest hechten aan collectieve overeenkomsten. Deze goedkeuring was in strijd met het gehele systeem van vrijwillige onderhandelingen. ${ }^{\text {to }}$

Bij Constitutionele Wet no, 3 van 1976 werd bepaald dat arbeidsconflicten door middel van verplichte arbitrage beslecht zouden worden en dat het stakingsrecht werd afgeschaft." Het Comite leverde kritiek op deze wetgeving. Een stakingsverbod was weliswaar toelaatbaar tijdens collectieve onderhandelingen, tijdens het van kracht zijn van een collectieve overeenkomst of voor ambtenaren of werknemers die essentiële diensten verrichtten, maar een algeheel verbod op de uitoefening van het stakingsrecht was in strijd met de beginselen van vrijheid van vakvereniging. ${ }^{\text {ss }}$

Vakbonden bleven naar creatieve oplossingen zoeken om het rigide stakingsverbod te ontduiken. Zo weigerden de koper-mijnwerkers van de Chuquicamata-mijn in september 1978 om hun maaltijden te nuttigen in de bedrijfskantine, hetgeen in praktijk neerkwam op een hongerstaking. De protestactie was ingegeven door de onvermurwbare opstelling van de werkgever CODELCO die niet wenste in te gaan op het verzoek om loonsverhogingen. De onderneming had de "oproerkraaiers" ontslagen en de regering had de staat van beleg in de provincie Lota afgekondigd. Het recht van vergadering en zelfs de bewegingsvrijheid werden aan banden gelegd. De regering beweerde dat sommige opstandige elementen politieke voordelen hadden willen verwerven die niets te maken hadden met verbetering van de arbeidswoorwaarden. Het Comité merkte op dat het afkondigen van de staat van beleg wel erg zware beperkingen van de vakbondsactiviteiten met zich mee had gebracht. ${ }^{86}$

82 Barrera en Valenzuela (a.w. p. 240) wijzen op de geringe betekenis wan de tripartiet comités, die duidelijk het corporatistische stempel van Diaz Estrada droegen (zie onder, $\$ 5$ ): "the tripartite committees turned out to be mere window dressing for international consumption in which (...) the gowernment tried to consilidate a form of purely superstructural unionism."

83 Case No. 823,176 e Rap. $\$ 22$ en 23.

84 Bij de presentatie van de wet kwalificeerde de Minister van Arbeid de staking als een instrument van de klassenstrijd, waarvan het rechtskarakter niet door de meest geavanceerde wetgevende organen en evenmin door eminente rechtsgeleerden erkend werd. Het VN-Ad Hoc-Comité merkte fijntjes op dat de uitoefening van het stakingsrecht wel degelijk erkend werd in het Wetswoorstel van 01-05-1975 (zie hieronder; \$ 5). UNDoc. A $/ 33 / 331_{\text {и }} \$ 653$.

85 Case No. 823 , 185 e Rap. $\$ 38$.

86 Case No. 823,190 e Rap. \$ 178 en 179. 


\section{Een periode van dooi in de verhouding tussen regime en vakbeweging: het intermezzo "Diaz Estrada"}

In het licht van de groeiende internationale kritiek - vooral van de kant van de ILO - stelde de regering pogingen in het werk om een constructievere vakbondspolitiek te voeren. ${ }^{87}$ Luchtmachtgeneraal Diaz Estrada die in juli 1974 benoemd was tot Minister van Arbeid, probeerde een opening te creëren naar de gematigde - Christendemocratische - vakbondsleiders.

Diaz ontvouwde zijn opvattingen in een wetsontwerp dat diende als blauwdruk voor een ingrijpende wijziging van de Codigo Laboral. Dit wetsontwerp was enerzijds schatplichtig aan het Christendemocratische gedachtengoed met betrekking tot de positie van de vakbeweging en droeg anderzijds de sporen van de corporatistische staatsideologie. ${ }^{88}$ Van oudsher hadden de Christen Democraten aangedrongen op in economisch opzicht krachtige vakverenigingen, waarvan alle werknemers in de desbetreffende bedrijfstak verplicht lid zouden zijn. Grotere economische slagvaardigheid achtten zij een probaat tegengif tegen politiek radicalisme.

Het corporatisme, dat altijd op een zekere mate van populariteit heeft kunnen rekenen binnen militaire kringen in Chili, gaat uit van harmonieuze verhoudingen tussen kapitaal en arbeid, op basis van een gemeenschappelijk belang: de verbetering van het produktieproces. Staatsinmenging in arbeidsverhoudingen is onvermijdelijk, aangezien de autoriteiten in geval van eventuele arbeidsconflicten zo snel mogelijk moeten ingrijpen en tevens erop toe moeten zien dat werkgevers en vakbonden het hogere belang van de nationale gemeenschap voor ogen houden.

Het wetsontwerp werd voorgelegd aan de Onderzoeks- en Bemiddelings-Commissie. Mocht de regering evenwel gemeend hebben met ditwetsontwerp de ILO gunstig te kunnen stemmen, dan kwam zij bedrogen uit. In het commentaar overheerste een kritische toon.

Het corporatistische karakter van de wetgeving kwam met name tot uiting in Artikel 2 van het ontwerp dat het wezen en de functies van vakorganisaties omschreef. Conform dit artikel dienden vakverenigingen instituten te zijn voor onderlinge samenwerking tussen degenen die betrokken waren bij produktie. Hun fundamentele opdracht moest zijn het bevorderen van de economische en sociale vooruitgang van hun leden, het steunen van de economische

87 Vooral Barrera en Valenzuela (a.w. p. 239) wijzen op de opmerkelijke "coincidentie" dat de introductie van de soepele vakbondspolitiek samenviel met het bezoek van de ILO-Onderzoeks Commissie aan Chili. Zie tevens Haworth en Roddick, a.w. p. 314.

88 Een goede verhandeling over de complexe ideologische grondslagen van de vakbondspolitiek van Diaz treft men aan in Roddick en Haworth, aw. pp. 310-315. De visie van. Falabella die de Christen Democraten een voorkewr voor corporatistische structuren toedicht, lijkt mij ongenuanceerd. In tegenstelling tot de corporatisten zijn de Christen Democraten nimmer voorstander geweest van een grote staatsinwloed in arbeidsverhoudingen. Vgl. Falabella G. Labour in Chile under the Jumia, 1973-1979, London 1981, p. 23. 
en sociale vooruitgang van de gemeenschap en het deelnemen aan projecten en mechanismen die voor dat doel in het lewen waren geroepen. Handelingen van vakbonden die niet strookten met genoemde doelstellingen, zouden geacht worden strijdig te zijn met letter en geest van de wet.

De Commissie signaleerde het gevaar dat vakbonden op grond van dit artikel gedwongen zouden kunnen worden om zich te sehikken naar de economische en sociale politiek van de regering. Een strikte interpretatie zou waarschijnlijk inbreuk maken op art. 3 van Conventie no. 87 dat aan vakorganisaties het recht toekent om hun eigen activiteiten te organiseren, zonder enige inmenging van de kant van de autoriteiten. ${ }^{\infty}$

De Christendemocratische voorkeur voor economisch krachtige vakbonden die een gehele bedrijfstak omspanden, manifesteerde zich in de organisatiestructuur van de vakbeweging (artt. $5 \mathrm{t} / \mathrm{m} 8$ ). In beginsel konden twee soorten vakbonden worden opgericht: ondernemingsvakbonden in een onderneming die meer dan 300 werknemers in dienst had (art.6) en bonden die een gehele bedrijfstak in een provincie omvatten (art. 8). In het laatste geval moest de bond tenminste 100 leden tellen en minstens $25 \%$ van de werknemers van de bedrijfstak in kwestie vertegenwoordigen. Werknemers die besloten hadden toe te treden tot een ondernemingsbond, konden niet meer lid worden van een bedrijfstak-bond. Tenslotte konden in speciale gevallen andere soorten bonden opgericht worden maar deze oprichting kon uitsluitend plaatsvinden na goedkeuring van het Ministerie van Arbeid.

De Commissie overwoog dat deze bepalingen op verschillende wijzen inbreuk maakten op het, in art. 2 van Verdrag no. 87 geformuleerde recht van werkgevers en werknemers om zich aan te sluiten bij organisaties naar hun eigen keuze of deze op te richten. $\mathrm{Zij}$ sloten onder andere de vorming van organisaties van werknemers die eenzelfde beroep uitoefenen, uit. Ook de vereiste toestemming van het Ministerie van Arbeid stond op gespannen voet met art. 2. Tenslotte kon het relatief hoge minimumaantal dat vereist was om een organisatie op te richten, een obstakel vormen voor de oprichting van organisaties. ${ }^{\text {91 }}$

De voorkeur voor een strakke, verticale organisatiestructuur die de vereniging van en contacten tussen werknemers van verscheidene economische sectoren vrijwel uitsloot, kwam tot uitdrukking in de regeling van (con)federaties. Artikelen $11 t / m 13$ bepaalden dat vakbonden bïnen één bedrijfstak een federatie konden vormen, met dien verstande dat tenminste $25 \%$ van de vakbonden in die bedrijfstak akkoord gingen met de oprichting van die organisatie. De federaties binnen én bedrijfstak konden zich wederom verenigen in een confederatie. Ook hier gold het vereiste van de instemming van $25 \%$ van de federaties. Het wetsontwerp verbood impliciet de vorming van een nationale vakcentrale.

Bij haar analyse van deze bepalingen verwees de Commissie naar de uitspraken van het Comitế van Deskundigen. Het Comité had zich in kritische zin uitgelaten over het restrictieve karakter van wetgeving die de oprichting van een vakcentrale verbood. Bovendien had het

91 Report $_{*} \$ 41.8$ p. 95. 
Comité het verbod op het vormen van federaties van agrarische bonden en industriële bonden, van bonden in de publieke sector en bonden in de private sector en het verbod op het vormen van federaties van bonden van verschillende bedrijfstakken in strijd geacht met de beginselen van Verdrag no. 87. Tenslotte was het vereiste van een minimumaantal van bonden of federaties om secundaire of tertiaire organisaties te vormen, niet in overeenstemming met het Verdrag. ${ }^{92}$

De staatsinmenging in interne vakbondsaangelegenheden verkreeg een wettelijke grondslag in Artikel 18 dat bepaalde dat vakorganisaties onderworpen waren aan het toezicht van de Arbeidsdienst. $\mathrm{Zij}$ moesten alle informatie verschaffen waar de Dienst om verzocht.

De Commissie overwoog dat Verdrag no. 87 externe controle over vakbondsaangelegenheden niet uitsloot, indien de verdenking gerezen was dat de vakbond zich schuldig had gemaakt aan onwettige praktijken. Het verdiende echter de voorkeur dat deze controle werd uitgeoefend door de gerechtelijke autoriteiten. Regeringscontrole over vakbondsfondsen diende in principe beperkt te blijven tot periodieke inzage in de boekhouding. Indien de autoriteiten de bevoegdheid hadden om op ieder willekeurig moment, los van geconstateerde onregelmatigheden of onwettig gedrag, onderzoek te verrichten of inlichtingen in te winnen, borg dit het gevaar in zich van ongeoorloofde inmenging in interne vakbondsaangelegenheden. ${ }^{33}$

Van belang was ook artikel 22 dat de vereisten opsomde, waaraan een vakbondsleider moest voldoen. De vakbondsleider moest onder andere werkzaam zijn in de onderneming of de bedrijfstak, waarbinnen de vakbond was opgericht.

De Commissie kwam tot de conclusie dat het ontslag van een vakbondsleider in dergelijke gevallen met zich meebracht dat hij niet langer zijn ambt kon uitoefenen. Dit kon de actievrijheid van de organisatie en haar recht om vrijelijk haar vertegenwoordigers te kiezen aantasten en zelfs de inmenging van werkgevers aanmoedigen. De Commissie achtte het noodzakelijk dat dergelijke bepalingen versoepeld werden door de kandidatuur van mensen die werkzaam waren geweest in de desbetreffende bedrijfstak toe te laten en door bovendien het vereiste van werkzaamheid in de bedrijfstak voor een aanzienlijk deel van de vakbondsleiders te laten varen.

Het wetsontwerp erkende het stakingsrecht en betekende wat dit betreft dan ook een verbetering ten opzichte van de voorgaande situatie. Titel $I V$ inzake werkhervatting en verplichte arbitrage ontkráchtte echter de essentie van het recht. Op grond van art. 54 kon

92 Report, $\$ 418$ p. 96.

93 Report, $\$ 418$ p. 96.

94. Report, \& 418 p. 97. In een herziene versie van het wetsontwerp was gedeeltelijk rekening gehouden met de opmerkingen van de Commissie. Zo kwamen, op grond van art. 236 , sub b van dit wetsontwerp, ook werknemers die minder dan twee jaar met pensioen waren, woor vakbondsleiderschap in aanmerking, vgl. Report, $\$ 422$. 
de regering een werkhervatting eisen in geval van stakingen die "de economische of sociale belangen van de bevolking" aantastten.

De Commissie stelde dat voorzieningen die in dergelijke algemene termen waren vervat, in zeer verschillende omstandigheden konden worden toegepast in plaats van in gevallen van werkelijke noodtoestand. $\mathrm{Zij}$ zouden daardoor een hindernis kunnen zijn woor de vrije uitoefening van vakbondsrechten. ${ }^{.5}$

De vakbondspolitiek van Diaz Estrada heeft zich nimmer in een grote populariteit mogen verheugen, zodat diens wetsontwerp ook niet de status van studeerkamerproject ontsteeg. De meer autoritaire segmenten binnen het militaire regime meenden dat Diaz "too soft on the unions" was en drongen aan op nog meer staatsinvloed binnen de vakbeweging. De meeste vakbondsleden daarentegen voelden zich bekneld door het strakke organisatorische keurslijf dat hun werd opgedrongen. ${ }^{*}$

Van doorslaggevende betekenis was evenwel dat de benadering van Diaz zich niet verdroeg met de economische politiek van de "Chicago Boys", wier invloed binnen de regering gestadig toenam. De bedrijfstakgewijze organisatiestructuur werkte de monopolisering van de arbeidsmarkt in de hand en zou het vrije krachtenspel in de arbeidsverhoudingen doorkruisen. Bovendien zou de staatsinterventie in vakbondsaangelegenheden, waarin het wetsontwerp voorzag, op den duur de vakbeweging toch weer de gelegenheid bieden om druk uit te oefenen op de autoriteiten. Om aan te tonen tot wat voor ongewenste consequenties dit zou leiden, hoefden de "Chicago Boys" slechts te verwijzen naar de periode-Allende."

Diaz werd in maart 1976 ontslagen als minister van arbeid en vervangen door Sergio Fernandez, een "Chicago Boy" die een persoonlijke gunsteling van president Pinochet was. Het zou meer dan drie jaar duren, alvorens de regering opnieuw een poging ondernam om de collectieve arbeidsverhoudingen in een institutioneel wettelijk kader te regelen.

\section{Pinochet en de vakbeweging na 1976: de verschuiving van "militaire" naar "economische" repressie}

Vanaf 1976 stelde de regering-Pinochet pogingen in het werk om het geschonden imago op het gebied van de rechten van de mens te verbeteren. Zo maakte de regering in haar correspondentie met internationale organisaties gewag van wetgeving die arrestatie en detentie met de nodige waarborgen beoogde te omkleden. Wetsdecreet no. 146 (10 februari 1976) voorzag in het onaangekondigde bezoek van hoge functionarissen van de rechterlijke en uitvoerende macht aan detentiecentra. Met behulp van dergelijke "verrassings"-tactieken zouden

95 Report, $\$ 419$.

96 Roddick en Haworth (a.w. p. 314) merken op dat Diaz de vakbeweging wilde "drillen"-als een militaire organisatie en daarbij nit het oog verloor dat aansluiting bij een vakbond plaats vindt op basis van vrijwilligheid.

97 Vergelijk Roddick en Haworth, a.w. pp. 300 en 313. 
misstanden eenvoudig ontdekt kunnen worden, maar de hoogwaardigheidsbekleders hadden geen aanwijzingen dat gedetineerden werden mishandeld.

Vol trots kondigde de regering de Constitutionele Wet no. 3 betreffende de rechten van de mens aan. Deze wet beperkte de duur van de preventieve hechtenis: politiele autoriteiten hadden de plicht om gearresteerden binnen een termijn wan 48 uur voor de rechter te geleiden (met een mogelijke termijn-verlenging door de rechter tot vijf dagen). Voorts was het verboden om personen in bewaring te stellen in gebouwen die niet voor dat doel bestemd waren. De verdachte had recht op een eerlijk proces ten overstaan van een onpartijdige rechter en kon aanspraak maken op juridische bijstand. Tenslotte kende de wet nog een curatieve voorziening: elke burger wiens constitutionele waarborgen geschonden of veronachtzaamd waren, kon via een snelle en doeltreffende procedure bij de bevoegde beroeps-rechter het herstel van zijn rechten verkrijgen.

Ook de ontmanteling van de gehate Geheime Dienst, DINA (Nationale Inlichtingen Departement) in 1977 kan opgevat worden als een signaal van Pinochet in de richting van de internationale gemeenschap dat hij de verbetering van de mensenrechtensituatie serieus nam. De DINA werd vervangen door de CNI (Nationale Informatie Centrum), wiens taken op het gebied van veiligheid uitsluitend informatief van aard waren, aldus de regering. ${ }^{n 00}$ Tenslotte kondigde Pinochet op 12 april 1978 een algemene amnestie af. Op grond van deze amnestie zouden alle personen, waaronder veel vakbondsleden, die door militaire tribunalen veroordeeld waren, vrijgelaten worden. Bovendien zouden ballingen mogen terugkeren, met uitzondering van actieve Marxisten en personen die in het buitenland lastercampagnes tegen Chili hadden gevoerd. ${ }^{101}$

Droegen al deze fraaie voorzieningen nu ook concreet bij tot een verbetering van de situatie van de rechten van de mens? Aangenomen moet worden dat zij deels een louter kosmetisch effect hadden. Zo merkte de IACHR terecht op dat de met veel tam-tam gepresenteerde Constitutionele Wet no. 3 op het terrein van de voorlopige hechtenis een achteruitgang betekende. In de Constitutie van 1925 werd namelijk strikt de hand gehouden aan de 48-uurs termijn. ${ }^{102}$ Ook de verzekering van regeringszijde dat de rechterlijke macht onafhankelijk opereerde, hetgeen voldoende garanties bood voor een eerlijk proces, werd zowel door de VN-organen als door de IACHR herhaaldelijk in twijfel getrokken. ${ }^{103}$

98 Case No. 823,159 e Rap. 54.

99 Case No. 823, 161e Rap. 40.

100 Case No. 823, $176 \mathrm{e}$ Rap. $\$ 38$.

101 Case No. 823, 185e Rap. $\$ 63-64$.

102 OAS, Inter-American Yearbook on Humant Rights. 1985, Dordrecht 1987, p. 748.

103 De LACHR maakte gewag van Wetsdecreet no. 1, waarin de rechterlijke onafhankelijkheid erkend werd, "in zoverre de huidige situatie van het land dat toelaat woor een betere verwezenlijking van de doelstellingen van de Junta." Inter-American Yearbook, a.w. p. 826.

Het Ad Hoc-Comité was zelfs van mening dat de onafhankelijkheid van de rechterlijke macht "pure theorie" was, vgl. UN-Doc. A/33/331, 212 onder (c). 
De vervanging van de DINA door de CNI kwam uiteindelijk neer op een naamsverandering. Vergelijking van de beide wetsdecreten die ten grondslag lagen aan de totstandkoming van de organisaties, wijst uit dat de CNI in grote lijnen dezelfde bevoegdheden had als zijn voorganger.

Specifiek met betrekking tot de "verdwijning" van vakbondsmensen voelde het ILO-Comite zich geroepen om te wijzen op de discrepantie tussen theorie en praktijk. Juist in 1976 waren veel klachten ingediend over het feit dat gearresteerde vakbondsmensen onvindbaar waren in de detentiecentra van het land: ${ }^{\text {:os }}$

Toch kan niet ontkend worden dat de repressie vanaf 1977 een minder systematisch en grootschalig karakter had. Men moet hier niet uit afleiden dat het regime zijn leven gebeterd had, maar veeleer dat het besloten had tot een verandering van tactiek. Vooral in relatie tot de vakbeweging nam de regering in toenemende mate halar toevlucht tot een geraffineerder en efficiënter wapen: de economische politiek. .06 $^{106}$

Zoals in de inleiding al kort is aangegeven, schreven de Chicago Boys in eerste instantie een shock-therapie voor teneinde de inflatie te bestrijden, om zich vervolgens volledig te kunnen concentreren op het herstel van het marktmechanisme. Beide maatregelen hadden, althans op korte termijn, funeste gevolgen voor de nationale industrie. Door het plotselinge wegvallen van elke vorm van protectie, konden vele Chileense firma's de concurrentieslag met buitenlandse ondernemingen niet volhouden. ${ }^{107}$ Voorts verloor de staat, ten gevolge van de drastische overheidsbezuinigingen, al snel zijn belangrijke positie als werkgever. Beide ontwikkelingen hadden vanzelfsprekend repercussies voor de werkgelegenheid (vgl. Tabel 1).

Tot op zekere hoogte was hoge werkloosheid een onvermijdelijk neveneffect van de economische politiek, maar in de literatuur wordt gesuggereerd dat de autoriteiten de werkloosheid doelbewust als wapen hanteerden om de vakbeweging te verzwakken. ${ }^{108}$ In drie opzichten had de werkloosheid nadelige gevolgen voor de positie en het opereren van de vakbeweging. In de eerste plaats leidde het tot een verwijdering tussen werkenden en

104 Arriagada, a.w. p. 33. Weliswaar had de DINA, in tegenstelling tot de CNI, een onbeperkte bevoegdheid on mensen te arresteren en vast te houden, maar Wetsdecreet no. 1878 verleende oolk de CNI het recht om in geval van ontdekking op heterdaad tot arrestatie over te gaan. De vereiste goedkeuring van de Minister van Binnenlandse Zaken hoefde slechts a posteriori verleend te worden. Vgl. UN-Doc: $A / 33 / 331, \$ 140$.

105 Case No. 823, 161 e Rap. 43.

$106 \mathrm{Vgl}$. Oscar Catalán Aravena, Ontmanteling en Herstel van de Vakbeweging in: Catalán Aravena O./Gunder Frank A. (red.) Chili onder Pinochet, Amsterdam 1984, p. 84: "De massale militaire repressie werd langzamerhand vervangen door een ekonomische repressie via de mechanismen van de vrije markt, hetgeen de mogelijkheid bood de arbeiders te kontroleren met een meer selektieve militaire repressie."

107 De inwoertarieven werden gereduceerd van $100 \%$ tot $10 \%$. Falabella, a:w. p. 8 .

108 Vgl. vooral Ruiz Tagle, a.w. p. 8 en Falabella, a.w. p. 15: "...the Junta has created a reserve army, which employers are training according to their manpower needs, which they can effectively use to divide class and people." 
werklozen, zodat de interne cohesie van de arbeidersklasse werd aangetast. ${ }^{100}$ In de tweede plaats bemoeilijkte de hoge werkloosheid het streven van de vakbeweging om in de politiek wederom een sleutelrol te verwerven. ${ }^{110}$. Werknemers legden zich vooral toe op het behoud van koopkracht en werkgelegenheid en hadden minder aandacht voor ideologische en politieke vraagstukken.

Tenslotte, en dit is waarschijnlijk het belangrijkste punt, maakte de hoge werkloosheid werknemers terughoudend om zich aan te sluiten bij vakbonden en tot collectieve actie over te gaan, aangezien zij vreesden voor ontslag. Wij zullen onze analyse toespitsen op dit laatste aspect.

Het spreekt voor zich dat werkgevers, in het licht van een slappe arbeidsmarkt, eenvoudig werknemers konden ontslaan. Zij werden hierin evenwel van harte gesteund door de autoriteiten. In de periode van 1978 tot 1982 werden ingrijpende wijzigingen in de ontslagwetgeving doorgevoerd die de, toch al uitgeholde bescherming wolledig teniet deden.

Economische adviseurs van de regering vertoonden de neiging om ontslagwetgeving en uitwoering van deze wetgeving te presenteren als technische maatregelen die noodzakelijk waren met het oog op de sanering van de economie. Privileges van (bijvoorbeeld) vakbondsleiders konden niet gehandhaafd worden, aangezien dergelijke beschermings-constructies zich niet verdroegen met de noodzakelijke flexibilisering van de arbeidsmarkt.

Tabel 1. Ontwikkelingen in het werkloosheidpercentage, 1970-1982

Open $\quad$ Reëel( $\left({ }^{111}\right)$ Open Reëel

$\begin{array}{llllll}1970 & 5,7 & - & 1977 & 12,7 & 18,6 \\ 1971 & 3,8 & - & 1978 & 13,6 & 17,9 \\ 1972 & 3,1 & - & 1979 & 13,8 & 17,7 \\ 1973 & 4,8 & - & 1980 & 12,0 & 17,3 \\ 1974 & 9,2 & - & 1981 & 10,8 & 17,3 \\ 1975 & 14,5 & 16,8 & 1982 & 19,6 & 30,2 \\ 1976 & 14,4 & 19,4 & & & \end{array}$

Bron: Bertha Teitelboim, Indicadores Económicas y sociales. Series Anuales 1960-1982; Santiago: Programa de Economia del Trabajo 1983, p. 26.

109 De onderlinge solidariteit liep ook schade op ${ }_{n}$ doordat de inkomensverschillen sterk toenamen: werknemers van dynamische, export-gerichte ondernemingen verdienden aanzilenlijk beter dan werknemers die voor de lokale markt produceerden. Vgl. Ruiz Tagle, a.w. p. 10.

110 Dit aspect wordt met name benadrukt door Campero G. Los trabajadores y el sindicalismo en la próxima decada in: Martner G. (coord) Chile hacia el 2000; Desaflos y opciones, Caracas 1988, pp. 239-240.

111 In het reële werkloosheidpercentage zijn de werkwerschaffingsprogramma's PEM (Programa de Empleo Minimo) en POJH (Programa de Ocupación para Jefes de Hogar) werdisconteerd. Deze projecten die volledig door de overheid gefinancierd werden, voorzagen in de mogelijkheid dat werklozen tegen een salaris van resp. $\$ 30$ en $\$ 60$ per maand, publielke werkzaamheden verrichtten. 
Met Wetsdecreet no. 2200 van 15 juni 1978 dat Boek I en Boek II van de Arbeidswet van 1931 verving, werd de toon gezet. De kern van dit decreet was dat de werkgever eenzijdig het arbeidscontract kon wijzigen, waarbij hij maandelijks $10 \%$ van zijn personeel kon ontslaan. Wenste hij nog meer werknemers te ontslaan, dan had hij de toestemming van de Ministers van Arbeid en van Economische Zaken nodig. Overigens vormde dit laatste nauwelijks een beletsel voor collectief ontslag. Zo hechtte de Minister op 17 december 1979 zijn goedkeuring aan het ontslag van het totale werknemersbestand van de onderneming Textil Andina. ${ }^{\text {III }}$ In relatie tot de "fuero sindical" was het vooral van belang dat Decreet no.2200 de ontslaggronden voor vakbondsleiders verruimde. Zo bepaalden artt. 15 en 22 dat "het leiding geven aan of het participeren in illegale werkonderbrekingen "een grond voor ontslag opleverde.

Wetsdecreet no. 2200 was geen lang leven beschoren. Op 14 augustus 1981 werd Wet no. 18018 afgekondigd die het voorgenoemde decreet op een aantal punten ingrijpend wijzigde. Deze wet herriep volledig de befaamde "ley de inmovilidad" (Wet no. 16445 van 8 april 1966), waarvan art. 1 bepaalde dat een werkgever uitsluitend in verband met een gerechtvaardigde reden een arbeidscontract kon beëindligen. Voortaan hoefde de werkgever slechts aan te voeren dat het ontslag "in het belang van de onderneming" was. ${ }^{14}$ Voorts verleende de wet werkgevers volledige vrijheid in geval van collectieve ontslagen. De voorafgaande toestemming van de autoriteiten was niet langer noodzakelijk.

De intentie van de regering om werknemers iedere vorm van bescherming te ontnemen kwam ook tot uiting in de rechterlijke reorganisatie. Bij Wetsdecreet no. 3643 dat op 1 mei 1981 in werking trad, werden de speciale arbeidsgerechten afgeschaft. Arbeidskwesties zouden voortaan onder de jurisdictie van de normale civiele rechter vallen. Deze maatregel riep internationaal veel verontwaardiging op. Door arbeidszaken over te laten aan civiele rechters, miskende de regering het bijzondere karakter van het arbeidsrecht, aangezien burgerlijke rechters plegen uit te gaan van tegengestelde beginselen, zoals gelijkheid van partijen en volledige contractsvrijheid. ${ }^{115}$

Het moge duidelijk zijn dat bovengenoemde wetgeving de werknemers betrekkelijk weerloos maakte tegenover de werkgever. Vakbondsleden verkeerden evenwel, naar eigen zeggen, in een nog kwestbaarder positie, daar zij als eersten in aanmerking kwamen voor ontslag als sanctie op het ontplooien van collectieve actie. Autoriteiten en werkgevers daarentegen beweerden dat ontslagmaatregelen zonder aanziens des persoons werden toegepast. Voor internationale organen was de cruciale vraag aan wellke lezing zij meer geloof dienden te hechten. Aan de hand van een drietal cases kan geillustreerd worden dat zowel

112 UN-Doc. A/35/522, 363 .

113 Deze ontslaggronden waren ook al opgenomen in eerdere decreten, maar met de uitvaardiging van Decreet no. 2200 beoogden de autoriteiten de regeling een permanent karakter te geven.

114 Deze dubieuze ontslaggrond werd trouwens bij Wet no. 18372 van 1984 weer afgeschaft. De IACHR achtte dit een aanzienlijke verbetering, vgl. OAS-Rapport (1985), p. 234.

115 Vgl. OAS-Rapport (1985), p. 231. 
bet ILO-Comité als de VN-Rapporteur regelmatig tot de conclusie kwamen dat vakbondsleiders en -leden discriminatoir behandeld werden bij (massa)ontslagen. ${ }^{146}$

Een schrijnend geval, dat door het ILO-Comité en door de VN-Rapporteur werd gesignaleerd, betrof het ontslag en de diskwalificatie van Daniel Lillo, voorzitter van de Nationale Vereniging voor Douanebeambten in Valparaiso. In maart 1979 was Lillo van zijn ambt ontheven en tijdelijk - ontslagen door de regionale gouverneur op grond van Wetsdecreet no. 349, aangezien hij, in strijd met de waarheid, tegenover de pers beweerd zou hebben dat hij een vergadering had bijgewoond. Het Comité stelde uitdrukkelijk dat ontslag en diskwalificatie van vakbondsleiders in de publieke sector door de uitvoerende macht niet in overeenstemming was met de beginselen van vrijheid van vakvereniging. ${ }^{117}$ Nadat Lillo, door rechterlijke tussenkomst, weer in dienst was genomen, werd hij in 1980 opnieuw ontslagen, ditmaal op grond van Wetsdecreet no. 3410 (28 mei 1980). Dit decreet verleende de President van de Republiek de bevoegdheid om de publieke administratie te reorganiseren, met name door middel van reductie van personeel, zonder dat hij rekening hoefde te houden met privileges van vakbondsleiders. De toepassing van dit decreet met terugwerkende kracht beroofde Lillo van verworven rechten en stelde de autoriteiten alsnog in de gelegenheid om hem te bestraffen voor het ontplooien van vakbondsactiviteiten. ${ }^{418}$

Een vakorganisatie die veel te lijden had van de wakbonds-vijandige houding van de regering, was de ANEF (Nationale Vereniging van Staatsemployés). In 1980 had het Directoraat van Industrie en Handel verscheidene leiders van de ANEF ontslagen. De betrokkenen beweerden dat hun ontslag verband hield met hun vakbondsactiviteiten, maar de Minister van Economische Zaken hield vol dat het ontslag te maken had met de reorganisatie van de dienst. Het Comité overwoog dat het niet bevoegd was om te oordelen over de wenselijkheid van ontslag om financiële of economische redenen. Toch benadrukte het Comité het belang van een goede bescherming tegen ontslag, vooral met het oog op het nemen van maatregelen tegen ontslagen die, onder de dekmantel van economische overwegingen, in feite een vakbondsdiscriminatoir karakter hadden. ${ }^{119}$

Massa-ontslagen in de onderneming Panal-Textiel vormden voor het Comité de aanleiding om te veronderstellen dat de ontslagen verband hielden met een kort daarvoor beëindigd,

116 Deze gevallen zijn slechts een kleine selectie uit bet grote aantal ontslagzaken, waarbij het MLO-Comite en de VN-Rapporteur in hoge mate aannemelijk achtten dat ontslagen verband hielden met het ontpllooien van legitieme vakbondsactiviteiten. Vgl. UN-Doc. A/35/522, \$384-385 (pharmaceutische industrite, onderwijs) en Case $\mathrm{Na}, 823,190 \mathrm{e}$ Rap. $\$ \$ 194205$ (koper, publieke sector).

117 Case No. 823, 202e. Rap. 302 .

118 UN-Doc. A/35/522, 367.

119 Case No. 823, 207e Rap. \&181 en 217e Rap. \$549. Dat de argwaan van het Comité omtrent de onderliggende motieven terechtwas, bleek toen het Directoraat al spoedig aanstalten maakte om de lastige vakbondsleiders. door nieuwe employés te verwangen. UN-Doc. A/37/564; $\$ 221$. 
langdurig arbeidsconflict tussen de werkgever en de vakbond. Nadat het Comite overwogen had dat de staking eén van de meest essentiële middelen voor werknemers is om hun belangen te behartigen, kwam het tot de conclusie dat de ontslagen activisten kennelijk het slachtoffer waren geworden van anti-vakbondsdiscriminatie. ${ }^{300}$

\section{Het Plan Laboral: essentiële kenmerken en praktische consequenties}

De nieuwe arbeidswetgeving ("Plan Laboral") die gepresenteerd werd als blijk van de goede intentie van de regering om de arbeidsverhoudingen te normaliseren, kwam mede tot stand onder invloed van groeiende internationale druk. Ditmaal was het de dreiging van een totale handelsboycot, geinitieerd door de Amerikaanse vakcentrales AFL/CIO, die Pinochet aanzette tot het ondernemen van actie. ${ }^{121}$

Het Plan Laboral dat op 30 juni 1979 van kracht werd, droeg in veel opzichten het keurmerk van de "Chicago Boys". Waar de ondernemingsvakbond het exclusieve recht werd toegekend om collectieve onderhandelingen te voeren, stond het Plan Laboral duidelijk in het teken van de decentralisatie. Twee angstvisioenen van de "Chicago Boys" werden hiermee verdreven. In de eerste plaats verijdelde de sterke decentralisatie de gevreesde monopolievorming. In de tweede plaats belemmerde de isolatie van de vakbonden binnen de eigen onderneming de vorming van politieke netwerken.

Het systeem van collectieve onderhandelingen op het niveau van de onderneming beantwoordde aan de doelstelling om de werking van het marktmechanisme te bevorderen: de hoogte van de lonen zou immers direct gerelateerd zijn aan de produktiviteit van de onderneming. ${ }^{122}$ Toch school er iets paradoxaals in de voorkeur van de "Chicago Boys" voor het Plan Laboral: hoe konden de kampioenen van het economisch liberalisme zich nu verenigen met een systeem dat voorzag in een strakke, van boven opgelegde organisatiestructuur en in forse staatsinterventie in vakbondsaangelegenheden? ${ }^{12}$ De verklaring moet gezocht worden in de omstandigheid dat het maatschappij-model van de "Chicago Boys" een gedisciplineerde

120 Case No. 823, 217e Rap. $\$ \$ 499$ en 510. De VN-Rapporteur sloot zich wan harte bij deze conclusie aan, UN-Doc. A/37/564, \$226.

121 Zie hierover uitwoerig Barrera/Valenzuela, a.w. pp. 249-253.

122 Vgl. Barrera M./Henriquez H./Selamé T. Sindicatos y Estodio en el Chile actual, Genève 1985, p. 63; Hurtado, a.w. p. 250.

123 O'Brien en Roddick (1983, a.w. p. 80) brengen deze paradox scherp onder woorden: "In all these measures, Pintera (de Minister van Arbeid, onder wiens verantwoordelijkheid het Plan Laboral werd uitgevaardigd) was presumably remembering Hayek's dictum that economic liberty, the free operation of the market, is more fundamental than any other liberty. He may also have been influenced by Hayek's belief that the state does not intervene in individual affairs if it does no more than lay down ground rules, setting up an automatic system in which individualls are free to operate, so long as they obey these guidelines. Chile's workers were not such subtle philosophers. They drew the obvious conclusion that the new Labour Plan was a massive state intervention in union affairs designed to favour employers at the workers" expense." 
arbeidsbevolking vereiste. Gegeven de strijdbare en onafhankelijke traditie van de Chileense wakbeweging, kon deze doelstelling uitsluitend verwezenlijkt worden met behulp van een autoritair regime. ${ }^{124}$ Het Plan Laboral bezegelde de gelegenheidsalliantie tussen het liberale kapitalisme en de Chileense dictatuur en nergens manifesteerde deze alliantie zich zo sterk als in de restricties van het stakingsrecht. ${ }^{125}$

Het Plan Laboral riep tegenstrijdige reacties op. Sommige werkgevers en aanhangers van de vrije markt-economie uit de wetenschappelijke hoek prezen de consistentie van het Plan met de economische politiek. ${ }^{126}$ Binnen vakbondskringen was men het er echter vrijwel unaniem over eens dat de wetgeving verworpen diende te worden.

In een brief van 31 augustus 1979 had het Internationale Verbond van Vrije Vakverenigingen een vernietigend oordeel uitgesproken over Wetsdecreten nos. 2756 en 2758 die tezamen het leeuwendeel van het Plan Laboral vormden. Mede naar aanleiding van deze brief besloot het Comité de wetten aan een kritisch onderzoek te onderwerpen. Bovendien bezocht een Direct contact-missie van 1 tot 8 december 1980 Chili, met het doel om een indruk te krijgen van de praktische consequenties van het Plan. Eén van de meest fundamentele kritiekpunten van de Missie gold het feit dat werknemersorganisaties bij het opstellen van de wetgeving niet geraadpleegd waren. In dit verband achtte de Missie het nuttig om ILO-Aanbeveling no. 113, inzake Consultatie op Industrieel en Nationaal Niveau (1960) in herinnering te roepen. Verder bevestigden de bevindingen van de Missie de conclusies van het Comite dat de wetgeving op tal van punten in strijd was met de internationale normen op het gebied van de vrijheid van vakvereniging. ${ }^{127}$

\subsection{Bepalingen betreffende de organisatie van de vakbeweging}

Wetsdecreet no. 2756 (29 juni 1979) had betrekking op de organisatiestructuur, de oprichting van en het toezicht op vakbonden.

\subsubsection{Oprichting}

De artikelen 10 en 11 behelsden een tamelijk ingewikkeld stelsel van percentages en getalscriteria waaraan vakbonden in oprichting moesten voldoen. Een vakbond binnen een onderneming moest minimaal 25 leden tellen die tenminste $10 \%$ van de werknemers die werkzaam waren in die onderneming, vertegenwoordigden. Indien de onderneming uit

124 Barrera et al. (1985), a.w. p. 24 .

125 Valenzuela a.w. p. 258 Deze restricties komen hieronder aan de orde.

$126 \mathrm{Vgl}$. UN-Doc. A/34/583, \$280 en 291 .

127 Case No. 823, 207e Rap. \$\$ 161-165. Vgl. voorts UN-Doc. A/36/594, \$404. 
verscheidene vestigingen bestond, moesten 25 leden tenminste $40 \%$ van de werknemers vertegenwoordigen. Niettemin konden 250 werknemers, die werkzaam waren binnen eenzelfde onderneming, ongeacht het percentage, een vakbond oprichten. In ondernemingen die minder dan 25 werknemers in dienst hadden, konden acht werknemers die $50 \%$ van het personeelsbestand vertegenwoordigden, een vakbond oprichten. 75 leden waren vereist voor een vakbond die werknemers van meer dan één onderneming omvatte.

Het Comite overwoog dat de $10 \%$-eis vooral in hele grote ondernemingen een belemmering kon opleveren voor de oprichting van vakbonden. Het Comite was echter in dit geval niet in de gelegenheid om te beoordelen of de toepassing van de voorziening in praktijk tot problemen zou leiden: ${ }^{128}$.

Conform artt. 13 en 14 konden vakbonden rechtspersoonlijkheid verkrijgen door hun statuten over te leggen aan de autoriteiten. Niettemin was de Arbeidsinspectie bevoegd binnen een periode van 90 dagen bezwaren in te dienen tegen de oprichting van een vakbond vanwege het niet voldoen aan de formalateiten of indien het statuut niet in overeenstemming was met de wet.

Het Comité merkte op dat het in dit geval aanbeveling zou verdienen dat de beslissing van de arbeidsinspectie en de mogelijke intrekking van de rechtspersoonlijkheid aangevochten konden worden voor de rechter. ${ }^{12}$

\subsubsection{Regels met betrekking tot het functioneren van vakbonden, extern toezicht}

Titel $\mathrm{IV}^{\mathrm{V}}$ van Wetsdecreet no. 2756 bevatte bepalingen omtrent het aantal vakbondsleiders, de vereisten voor verkiesbaarheid en verkiezingsprocedures. Het Comité benadrukte dat gedetailleerde wetgeving dienaangaande niet in overeenstemming was met het recht van werknemers om hun vertegenwoordigers te kiezen. Wat betreft de vereisten voor verkiesbaarheid, merkte het Comité met belangstelling op dat sommige voorwaarden - het verbod op herverkiezing en de eis dat vakbondsleiders zich niet zouden inlaten met politieke activiteiten - verdwenen waren. ${ }^{130}$ Toch bleven sommige bezwaren overeind. Zo was het Comité van mening dat een veroordeling wegens het plegen van een misdrijf of overtreding en a fortiori een strafrechtelijke vervolging - geen grond mocht opleveren voor uitsluiting van de kandidatuur, indien dit feit geen bedreiging vormde voor de goede uitoefening van vakbondstaken. Opnieuw wees het Comité op de onwenselijkheid van de koppeling tussen

128 Case No. 823,197 e Rap. 379.

129 Case No. 823,197 e Rap. $\$ \$ 380$ en 381 . Ditmaal kwam de regering tegemoet aan de kritick van het Comitê: een amendement op het Plan Laboral bepaalde dat vakorganisaties, in gevall van een negatieve beschikking van de Arbeidsinspectie, in beroep konden gaan bijy de rechter. Het Comite nam hiervan met belangstelling kennis. Vgl. Case No. 823,202 e Rap. $\$ 298$.

130 In dit verband kan gewezen worden op de toezegging wan de Minister van Arbeid ter gelegenheid van de vakbondsverkiezingen in oktober 1978 , zie boven p. 22 . 
vakbondsleiderschap en werkzaamheid in de onderneming. Deze koppeling bleef in de nieuwe wetgeving gehandhaafd..$^{\text {.31 }}$

Titel $V T$ verleende verstrekkende bevoegdheden aan het Arbeids-Directoraat op het gebied van controle van boekhouding en administratie. Vakbondsleiders die niet binnen een periode van 30 dagen voldeden aan een verzoek om inzage, werden automatisch van hun taak ontheven en mochten gedurende een periode van drie jaar niet verkozen worden. Onder verwijzing naar de uitspraken van het Deskundigen-Comité stelde het Comité met nadruk - mede gezien de ernstige consequenties die het niet-voldoen aan het onderhavige Wetsdecreet had voor de vakbond - dat inspectie en informatieverschaffing op willekeurig verzoek van de autoriteiten het gevaar van inmenging in de interne administratie van vakbonden in zich borg. ${ }^{132}$

7.1.3 Ontbinding van vakbonden; totstandkoming van (con)federaties; toepasselijkheid van het Wetsdecreet

Titel VII van Wetsdecreet no. 2756 voorzag in de mogelijkheid dat vakbonden door de rechter werden ontbonden, op verzoek van het Arbeidsdirectoraat, een vakbondslid, de werkgever of elke andere persoon die er belang bij had. Het Comité constateerde dat deze voorziening een verbetering betekende ten opzichte van de Arbeidswet van 1931 en zeker niet in strijd was met het beginsel dat vakbonden niet ontbonden dienden te worden door de administratie. ${ }^{133}$

De oprichting en het functioneren van (con)federaties was geregeld in Titel VIII. Met name de VN-Rapporteur merkte op dat de loutere erkenming van het bestaansrecht van (con)federaties een stap vooruit betekende. ${ }^{134}$ Niettemin was voor (con)federaties vrijwel uitsluitend een decoratieve functie weggelegd, aangezien art. 59 hun uitdrukkelijk verbood om deel te nemen aan collectieve onderhandelingen. Ik kom hier in de volgende paragraaf op terug.

Wat betreft de toepasselijkheid van het Wetsdecreet, bepaalde art. 74 uitdrukkelijk dat de wet niet gold voor personen die werkzaam waren bij de overheid. Het Comité herinnerde

131 Case No. 823, 197e Rap. 383 en 384.

132 Case No. 823, 197 e Rap. \$8 385 en 386.

133 Case No. 823, 197e Rap. $\$ 388$. Het milde oordeel van het Comitê staat in scherp contrast met de kritiek van de IACHR en de VN-Rapporteur. $Z$ ij hebben erop gewezen dat de inschakeling van de rechter cen loosgebaar was, aangezien de ontbindings-procedure een administratief karakter had die niet de waarborgen bood waar art. 4 van ILO-Conventie no. 87 op doell, vgl. OAS-Rapport (1985), p. 227 en UN-Doc. A/34/583, 278.

134 UN-Dac. A/34/583, 279 . 
de regering eraan dat ambtenaren, evenals werknemers in de private sector, in staat moesten zijn om organisaties op te richten die de beroepsbelangen van hun leden konden verdedigen ${ }^{\text {to }}$

\subsection{Collectieve onderhandelingen}

Wetsdecreet no. 2758 (29 juni 1979) had betrekking op collectieve onderhandelingen. Het Comité nam met belangstelling kennis van het feit dat het systeem van collectieve onderhandelingen wederom in ere hersteld was, maar overwoog dat een aantal bepalingen kritiek opriep.

\subsubsection{Beperkingen "ratione personae"}

Allereerst constateerde het Comité dat het recht op het voeren van collectieve onderhandelingen niet voor alle werknemers was weggelegd. Zo sloot art. 5 lid 1 van Wetsdecreet no. 2756 vakorganisaties in de bouwnijverheid uit van het recht op collectieve onderhandelingen. Bovendien was het sluiten van collectieve arbeidsovereenkomsten niet toegestaan in staatsondernemingen, in ondernemingen die voor meer dan de helft gefinancierd werden door de staat en in openbare nutsbedrijven die door private ondernemingen werden gerund (Wetsdecreet no. 2758, art. 3). In dit verband verwees het Comite naar de ILO-Conventie inzake Arbeidsverhoudingen in de Publieke Sector (no. 151). Art. 7 van deze Conventie bepaalde dat er matregelen genomen moesten worden om de ontwikkeling van mechanismen voor het onderhandelen over de arbeidsvoorwaarden tussen de autoriteiten en ambtenarenorganisaties te bevorderen. ${ }^{136}$

Het uitgangspunt van het Plan Laboral om het recht op collectieve onderhandelingen strikt te reserveren voor werknemers van een onderneming, impliceerde dat arbeiders die niet in een onderneming werkzaam waren, geen legale mogelijkheden hadden op het voeren van collectieve onderhandelingen. Vooral de havenarbeiders die van oudsher op tijdelijke contractbasis werden aangenomen om stukwerk te verrichten, ondervonden de nadelen van de nieuwe wetgeving. Jarenlang slaagden hun vakbonden erin om uniforme arbeidsvoorwaarden af te dwingen voor de gehele bedrijfstak. Aan deze trotse traditie maakte Wet no. 18032 (25 september 1981) een abrupt einde. De wet bepaalde dat de arbeidsverhoudingen in deze branche beheerst dienden te worden door individuele arbeidscontracten. Onderhandelingen voor alle werknemers in de bedrijfstak zouden, volgens de regering, namelijk tot de gevreesde kartelvorming leiden en onaanvaardbare kosten met zich meebrengen voor consumenten, werklozen en de staat.

135 Case No. 823, 197e Rap. \& 392.

136 Case No. 823 , 197e Rap. 406 . 
Het Comité benadrukte dat wetgeving geen belernmeringen mocht opleveren voor onderhandelingen op bedrijfstak-niveau. Om de onafhankelijkheid van werkgevers en werknemers op dit gebied optimaal te garanderen, zou het aanbeveling verdienen dat partijen in onderling overleg het niveau, waarop onderhandelingen plaats dienden te vinden, zouden vaststellen. ${ }^{137}$

\subsubsection{Beperkingen "ratione materiae"}

Collectieve arbeidsovereenkomsten strekten in de optiek van de opstellers van het Plan Laboral vooral tot de vaststelling van de materiële positie van de betrokken werknemers. Inspraak over de bedrijfsvoering kon niet het voorwerp van collectieve onderhandelingen zijn. Evenmin kon, zo bepaalde art. 12 van Wetsdecreet no. 2758 , een vakorganisatie binnen het kader van een CAO met de werkgever afspraken maken over de doorbetaling van stakende werknemers. ${ }^{\text {iss }}$

Daarbij had de collectieve dimensie van de $\mathrm{CAO}$ een beperkte draagwijdte, aangezien uitsluitend leden van de vakbond die partij was bij de $\mathrm{CAO}$, rechten aan de overeenkomst konden ontlenen.

Ruiz Tagle onderkent in deze bepalingen de onderliggende doetstelling om de alleenheerschappij van de werkgever over het produktieproces te bewaren en de onderlinge solidariteit tussen vakbondsleden en niet-vakbondsleden tegen te werken ${ }^{199}$

\subsubsection{Het voorgeschreven onderhandelingsniveau}

De doelstelling van het Plan Laboral om de vakbeweging te fragmentiseren, kwam vooral tot uiting in de artikelen 4 en 7 van Wetsdecreet no. 2758 die bepaalden dat collectieve onderhandelingen uitsluitend plaats konden vinden op het niveau van de onderneming. ${ }^{140}$ (Con)federaties konden met andere woorden geen collectieve onderhandelingen voeren. Het Comite zag zich genoodzaakt om erop te wijzen dat deze restrictie tot ernstige problemen in de ontwikkeling van de industriële verhoudingen zou kunnen leiden. Vooral kleine vakbonden die, vanwege hun gebrek aan macht, de belangen van hun leden zelf onvoldoende konden behartigen, zouden gedupeerd worden. ${ }^{\text {A1 }}$

137 Case No. $1096,217 \mathrm{e}$ Rap. 300.

138 Specifiek met betrekking tot deze bepaling, overwoog het Comitê dat dergelijke aangelegenheden niet op voorhand van collectieve onderhandelingen mochten worden uitgesloten, Case No. 823, 197e Rap. \$412.

139 Ruiz Tagle, a.w. p. 13.

140 Vooral Ruiz Tagle (a.w. pp. 12-13) schetst het verband tussen de onderhawige regeling en de fragmentisering van de wakbeweging die naadloos aansloot bij de economische politiek.

141 Case No. 823, 197 e Rap. $\$ 8$ 407-409. 
De regering repliceerde dat er voor (con)federaties wel een adviesfunctie was weggelegd, maar dat het systeem van onderhandelingen op het niveau van de onderneming in het leven was geroepen om monopolievorming binnen de vakbeweging tegen te gaan. Het Comité hield voet bij stuk door te stellen dat een a priori-verbod aan het adres van (con)federaties om deel te nemen aan collectieve onderhandelingen niet getolereerd kon worden. Eventuele misbruiken die het gevolg waren van monopolievorming moesten recht gezet worden door de gerechtelijke autoriteiten. ${ }^{142}$

Fundamentele kritiek op de onderhavige regeling kwam ook van de kant van de VNRapporteur. Zijn principiële afwijzing die gestoeld is op het speciale karakter van het arbeidsrecht in vergelijking met het verbintenissenrecht, verdient integraal te worden geciteerd: "The decree-laws under consideration, by reducing the bargaining power of workers, encourage a return to the civil-law notion of the contract in which labour is subject to the laws of the market, in other words, to a negation of the specifity of labour law. ${ }^{\mathrm{m} 43}$

Dat de regering zelfs de adviserende werkzaamheden van (con)federaties niet wenste te tolereren, kwam tot uiting naar aanleiding van een klacht van het IVVV (Internationaal Verbond van Vrije Vakverenigingen). Vier leiders van confederaties die eerste graadsvakbonden uitsluitend geadviseerd hadden bij hun collectieve onderhandelingen, werden bestraft met een boete. Het Comité sprak de hoop uit dat de boetes zouden worden kwijtgescholden, waarbij het zijn standpunt inzake het recht van (con)federaties om deel te nemen aan collectieve onderhandelingen in herinnering bracht. ${ }^{144}$

Halverwege 1980, nadat de wettelijke erkenning van het recht op collectieve onderhandelingen én jaar van kracht was geweest, kon een eerste inventarisatie gemaakt worden hoe het Plan Laboral in de praktijk functioneerde. De uitkomst was niet bemoedigend: naar schatting 600.000 werknemers hadden toegang gehad tot het systeem van collectieve onderhandelingen, hetgeen impliceerde dat zo'n $84 \%$ van de arbeidsbevolking van collectieve onderhandelingen was uitgesloten. Zowel de VN-Rapporteur als de ILO-Direct contact-missie schreven de povere resultaten toe aan het feit dat werknemers in een groot aantal economische sectoren niet konden voldoen aan de stringente wettelijke voorwaarden inzake het minimum aantal werknemers dat vereist was voor de oprichting van een vakbond. ${ }^{145}$

142 Case No. 823, 194 e Rap. $\$ 155$.

143 UN-Doc. A/34/583, 285 .

144 Case No. 1109,217 e Rap. \$482.

145 Vgl. UN-Doc. A/36/594, \$ 405 en Case No. 823, 207e Rap. \$165. 


\subsection{Stakingen}

Formeel werd het stakingsrecht erkend in het Plan Laboral. Maar de kring van werknemers die het recht mochten uitoefenen, was zeer beperkt en de talrijke vereisten, waaraan de procedure moest voldoen, begunstigden de werkgever ten detrimente van de stakende vakorganisatie.

Allereerst verbood ant. 6 van Wetsdecreet no. 2758 stakingen in ondernemingen in de openbare nuts-sector en in ondernemingen waar een werkonderbreking ernstige gevolgen zou hebben voor de nationale gezondheid, de bevoorrading van de bevolking, de economie van het land of de nationale veiligheid. Ieder jaar zou een lijst van deze ondernemingen worden opgesteld op basis van een gezamenlijk besluit van de Ministers van Arbeid, Defensie en van Economische Zaken. Een verplichte arbitrage-procedure zou in deze ondernemingen van toepassing zijn, in geval van onenigheid. Volgens de regering stonden in 197932 ondernemingen die voor het grootste deel behoorden tot de vervoerssector, op deze lijst. ${ }^{145}$ In het algemeen gaf het Comite toe dat in ondernemingen die sleutelposities innamen in het bedrijfsleven van het land en waar werkonderbrekingen dientengevolge ernstige schade zouden berokkenen aan de nationale gemeenschap, stakingen beperkt of zelfs helemaal verboden konden worden, mits adequate waarborgen de stakingen zouden vervangen. Toch voelde het Comité zich geroepen om erop te wijzen dat een stakingsverbod in ondernemingen die strikt genomen geen essentiële diensten verrichtten het bovengenoemde beginsel van zijn betekenis beroofde. In het onderhavige geval zou de lijst die de regering ieder jaar opstelde, wel eens onaanvaardbaar lang kunnen zijn. ${ }^{147}$

Voorts kon men uit art. 52, in samenhang met art. 4 en 7, afleiden dat ook (con)federaties niet mochten staken. ${ }^{148}$

De voorgeschreven stakingsprocedure bevatte tal van obstakels die de strekking hadden om stakende werknemers te ontmoedigen. Zo kon de werkgever op grond van art. 58 tijdens een staking onderkruipers in dienst nemen. Verder bepaalde art. 62 dat werknemers die na 60 dagen staken niet aan de slag gingen, geacht werden vrijwillig ontslag te hebben genomen. In dit verband merkte het Comite op dat het inzetten van onderkruipers, in geval van een legale staking, uitsluitend gerechtvaardigd was, indien de werkonderbreking in de getroffen diensten of industrieën zou leiden tot een situatie van acute crisis. In dit specifieke geval

146 Uit informatie, ontleend aan het OAS-Rapport (1985, p. 228) blijkt dat de lijst in 1982 al was uitgebreid tot 41 ondernemingen.

147 Case No. 823, 197e Rap. \$\$ 410 en 411. Naar aanleiding van een latere zaak, waarin de uitwoerige lijst wederom ter discussie stond, merkte het Comité op dat van sommige ondernemingen die op de lijst voorkwamen, toch niet gezegd kon worden dat zij essentiële diensten werleenden in de strikte zin van het woord. Op de lijst stond cok de fameuze onderneming CODELCO in de kopermijn-sector en men mag, gelet op de andere ondernemingen van de lijst; aannemen dat het Comitte onder andere zinspeelde op deze onderneming. Cases Nos. 1183 en 1205,233 e Rap. 8484.

148 Art. 52 luidde (voorzover van bellang): "Alleen de absolute meerderheid van de werknemers die betrokken zijn geweest bij de collectieve onderhandelingen, kan tot cen staking besluiten". (cursivering HvdW) 
zou de gecombineerde toepassing van genoemde voorzieningen (artt. 58 en 62) de positie van werknemers en hun organisaties bij de verdediging van hun belangen aanzienlijk verzwakken. Verder stelde het Comitê dat art. 62 een substantiële restrictie van het stakingsrecht impliceerde, aangezien het in praktijk de stakingsduur tot een maximum van 60 dagen beperkte. ${ }^{1 \oplus 0}$

Op grond van art. 65 kon de President van de Republiek een werkhervatting voor de periode van 90 dagen decreteren, indien een staking de volksgezondheid, bevoorrading, nationale economie of nationale veiligheid ernstig in gevaar bracht. Bovendien bepaalde art. 86 van het Wetsdecreet dat de President, in geval van een illegale staking die schade toebracht aan de ondernemingen, genoemd in art.6, de werkhervatting kon bevelen, waarbij hij de hulp van civiele en militaire autoriteiten kon inroepen. In deze gevallen zouden de werknemers weer aan het werk moeten gaan onder de voorwaarden die van toepassing waren op het moment dat tot de illegale werkonderbreking besloten was. Het Comité moest de nadruk leggen op het feit dat recruteringsmaatregelen tijdens stakingen zich dikwijls voor misbruik leenden en dat deze maatregelen in het algemeen onwenselijk waren, tenzij zij genomen werden met het oog op de voortzetting van essentiële diensten in uitzonderlijk ernstige situaties. ${ }^{1.50}$

Het oordeel wan de VN-Rapporteur met betrekking tot het stakingsrecht was werkelijk vernietigend. Afgaande op de bepalingen van Wetsdecreet no. 2758, kon men niet volhouden dat Chileense werknemers dit recht genoten. Voor grote groepen werknemers was het recht volstrekt illusoir, terwijl de werknemers die in beginsel wel gerechtigd waren om te staken, van dit recht zouden afzien, aangezien de uitoefening meer schade dan voordelen opleverde..$^{.51}$ De praktijk stelde de Rapporteur in het gelijk: slechts $3 \%$ van de collectieve onderhandelingen die tussen 1979 en 1981 gevoerd werden, mondden uit in een staking. ${ }^{1.2}$ Toch vonden in 1980 , vooral in de kopermijn El Teniente, enkele zeer grote stakingsacties plaats, waarbij de stakers uiting gaven aan hun onbehagen over de regeringspolitiek. Het was een teken dat de vakbeweging zich voorbereidde op gestructureerd verzet.

\section{Groelend verzet en nieuwe repressie (1980-1983)}

In het licht van de opzettelijke "versplinterings"'-politiek, trachtte de vakbeweging de krachten te bundelen om gezamenlijk de autoriteiten het hoofd te bieden. Tot op zekere hoogte werkte

149 Case No. 823 , 197 e Rap. $\$ \$ 41.5416$

150 Case No. 823 , 197 e Rap. $\$ 417$ en 418 . Het LACHR merkte met betrekking tot de onderhavige regeling op dat "there is no meed to mention the abuses and arbitrary acts that such a provision may give rise to." OAS-Rapport (1985), p. 229.

151 UN-Doc. A/34/583, \$ 292.

152 Cijfers ontleend aan Barrera et al. (1985), a.w. pp. 68-70. 
het Plan Laboral dit streven naar eenheid in de hand. Door het herstel van het systeem van collectieve onderhandelingen, kregen vakbondsleiders de kans om hun organisatorische capaciteiten te ontplooien; confrontaties met de werkgever verscherpten het (klasse)bewustzijn en droegen bij tot een vergroting van de onderlinge solidariteit. Met andere woorden: waar het Plan Laboral het oogmerk had om vakbonden te isoleren en te reduceren tot economische belangenorganisaties, schiep het juist de condities voor de ontwikkeling van een grootschalige, sociaal-politieke beweging.

Tegen het einde van de jaren zeventig trad een vijftal vakcentrales voor het voetlicht, die niet langer door de autoriteiten genegeerd konden worden. De UDT (Democratische Unie van Arbeiders) was voortgekomen uit de Groep van Tien, een informeel platform van christendemocratische vakbondsleiders die gedurende de eerste jaren na de Coup "on speaking terms" waren met de autoriteiten en Chill vertegenwoordigden bij de ILO. De CNS (Nationale Vakbonds-Coördinatie) herbergde de meer links-georiënteerde vakorganisaties en werknemers: de socialisten en de linkervleugel van de Christendemocratische Partij. Hoewel deze centrale niet officieel was aangesloten bij een internationale vakvereniging, onderhield zij nauwe betrekkingen met zowel het IVVV als met het Wereld Vakverbond. De kleine vakcentrale FUT (Verenigd Front van Arbeiders) was geïnspireerd op sociaal-christelijke beginselen en was aangesloten bij de CLAT (Latijnsamerikaanse Centrale van Arbeiders).

Liepen de scheidslijnen tussen bovengenoemde centrales min of meer parallel aan de verschillen tussen de Chileense politieke partijen en internationale ideologische stromingen, twee andere centrales - de CEPCh-(Confederatie van Chileense Employes in de Particuliere Sector) en de CTC (Confederatie van Werknemers in de Kopersector) hadden geen (partij)politieke bindingen. ${ }^{1 \mathrm{~s}}$

Aan het begin van de jaren tachtig tekende zich binnen de vakbeweging een organisatorische en functionele tweedeling af die herinneringen opriep aan de strategie die de vakbeweging na de Tweede Wereldoorlog had gevolgd. Op het niveau van de onderneming voerden vakbonden actie voor de verbetering van de arbeidswoorwaarden. Op nationaal niveau trachtten vakcentrales verandering te brengen in de regeringspolitiek.

Afgezien van het feit dat de communicatie tussen beide niveaus, vanwege het ontbreken van een middenkader, soms moeizaam verliep, stuitten de vakcentrales op de rabiate tegenwerking van de overheid.

Een beproefde manier voor vakbonden om hun ongenoegen over de regeringspolitiek kenbaar te maken was het houden van 1 mei-demonstraties. Aan het begin van de jaren tachtig werden deze demonstraties stelselmatig verboden, met het excuus dat de vakbondsleden zich schuldig

153 Zie over deze paradoxale ontwilkeling, Ruiz Tagle, a.w. p. 21 en Barrera et al. (1985), pp. 16 en 147.

154 Voor een beknopt overzicht van de belangrijkste vakcentrales wordt verwezen naar: Ruiz Tagle, aw. pp. 18 en 19 en OAS-Rapport (1985), p. 238. 
maakten aan verstoring van de openbare orde. Bovendien vonden op grote schaal arrestaties plaats. ${ }^{\text {Iss }}$

Het Comité veroordeelde het repressieve optreden van de autoriteiten, waar het stelde dat het houden van bijeenkomsten en het uiting geven aan eisen van sociaal-economische aard ter gelegenheild van de viering van de Eerste Mei, traditionele vormen van vakbondsactie waren. ${ }^{\text {136 }}$

Het offensief van de autoriteiten was vooral gericht tegen de CNS die, niet geheel ten onrechte, werd beschouwd als de erfopvolger van de ontbonden CUTCh. ${ }^{157}$ Het meest geduchte wapen, waarvan de regering zich bediende om de vakcentrale het opereren onmogelijk te maken, was Wetsdecreet no. 2347 van 17 oktober 1978 . Art. 1 van dit Wetsdecreet verklaarde elke vakbondsvertegenwoordiging, in het openbaar of in rechte, door personen die daartoe niet de wettelijke bevoegdheid bezaten, in strijd met de openbare orde en de staatsveiligheid. Art. 2 bedreigde vrijheidsstraffen tegen overtreders.

De autoriteiten beschikten nog over een tweede troef om kritische vakbondsleiders op veilige afstand te houden. Door elke rechtstreekse benadering van de regering te kwalificeren als politieke actie en vervolgens het ontplooien van politieke activiteiten te verbieden, beoogden de autoriteiten de vakbondsleiders te ontmoedigen.

Het verbod op het ontplooien van politieke activiteiten door vakbondsleden was uitvoerig geregeld in de nieuwe Constitutie die op 11 maart 1981 van kracht werd. Verwees art.8 van de Grondwet nog naar "subversieve" activiteiten, art. 19, lid 15 gebood vakbondsleden zich te onthouden van het ondernemen van elke actie die eigen is aan politieke partijen. Bovendien bepaalde art. 23 dat de functies van een vakbondsleider onverenigbaar waren met het actieve lidmaatschap van een politieke partij. De VN-Rapporteur gaf aan dat vakbondsactie en politiek niet gescheiden konden worden en merkte kritisch op dat het genot van vakbondsrechten blijkbaar voorbehouden was aan hen die voortdurend hun aanhankelijkheid aan de regering betuigden. ${ }^{158}$

Het gehele juridische arsenaal werd in stelling gebracht toen tien vakbondsleiders van de CNS in juni 1981 de euvele moed hadden om de regering een "Pliego Nacional" te presenteren, waarin de autoriteiten verzocht werd om arbeidswetgeving en algemene vakbondspolitiek nog eens in heroverweging te nemen. De reactie van de autoriteiten was stereotiep. Allereerst probeerde de Minister van Binnenlandse Zaken de vakbondsleiders te laten vervolgen op grond van Wetsdecreet no. 2347. Nu de CNS geen legale organisatie was, hadden

155 Zo had de VN-Rapporteur uit betrouwbare bron vernomen dat op 1 mei 1981 alleen al in Santiago 141 demonstranten gearresteerd waren. UN-Doc. A/36/594, $\$ 439$.

156 Case No. 1046, 211 e Rap. \$321.

157 Ruiz Tagle, a.w. p. 18.

158 UN-Doc. $A / 36 / 594, \$ 414-417$. In vergelijkbare - kritische - zin het LO-Comité, naar aanleiding van Wetsdecreet no. 2755 dat ook een verbod op het ontplooien van politieke activiteiten imhield, Case No. 823 , $197 \mathrm{e}$ Rap. $\$ 387$. 
de leiders niet de bevoegdheid om de vakcentrale te vertegenwoordigen. Tegelijkertijd overwoog de minister om de vakbondsleiders te laten diskwalificeren, een mogelijkheid waarin art. 8 van de Grondwet voorzag. Het offensief tegen de CNS ging vergezeld van een lastercampagne in het regeringsgezinde dagblad "El Mercurio", waarin de vakcentrale werd afgeschilderd als een communistische mantelorganisatie en werd aangedrongen op flinke straffen. ${ }^{198}$

Twee vakbondsleiders, Manuel Bustos en Alamiro Guzmán, werden veroordeeld wegens het "misdrijf" van illegale vertegenwoordiging, meermalen gepleegd en zaten een vrijheidsstraf van zes maanden uit. Nadat zij van de uitspraak in hoger beroep waren gegaan, trok de regering op 14 juni 1982 haar aanklacht in. ${ }^{160}$ Naar aanleiding van deze kwestie benadrukte het Comité dat de strafrechtelijke veroordeling en detentie van vakbondsleiders die verband hileld met het ontplooien van legitieme vakbondsactiviteiten, de vrije uitøefening van vakbondsrechten in gevaar bracht. ${ }^{161}$

Het conflict tussen regering en CNS escaleerde, nadat de vakcentrale in december 1982 een demonstratie had georganiseerd om te protesteren tegen de stijgende kosten wan het levensonderhoud en de werkloosheid. Twee leiders van de CNS, Manuel Bustos en Hector Cuevas, werden gearresteerd en prompt het land uitgezet.

Verbanning - naar het onherbergzame noorden van het land - en uitzetting waren twee sancties waarvan de regering zich gedurende de jaren tachtig in toenemende mate ging bedienen om zich van politieke tegenstanders te ontdoen. Meestal werden deze maatregelen genomen op grond van Overgangsbepaling 24 van de Grondwet, waartegen geen beroep op de rechter open stond.

Met betrekking tot de uitwijzing, merkte het Comité op dat een dergelijke maatregel een ernstige inbreuk op de mensenrechten en tevens op de vrijheid van vakvereniging was, aangezien het de gehele vakbeweging verzwakte. Wat betreft de verbanning, stelde het Comite dat de beperking van de bewegingsvrijheid van een vakbondslid, zodat hij niet langer zijn taak kon uitoefenen, onverenigbaar was met een normaal genot van vakbondsrechten. Het Comité drong er daarom op aan dat deze maatregelen omkleed waren met toereikende juridische waarborgen. ${ }^{162}$

Het ontplooien van politieke activiteiten kon ook nog repercussies hebben voor de eenmaal verleende rechtspersoonlijkheid van vakbonden.

159 El Mercurio, 07-07-1981 en 20-08-1981.

160 Een uitvoerige beschrijving van de gehele affaire vindt men in: UN-Docs. A/36/594, $\$ \$ 410-417$ en $\$ \$ 428-430$; A. $/ 37 / 564,218$.

161 Case No. 823,217 e Rap. $\$ 513$.

162 Case No. 1170,226 e Rap. $\$ 384$ en 386.

Cases Nos. 1183 en 1205,233 e Rap. $\$ 510$. 
Het Internationale Verbond voor Vrije Vakverenigingen diende begin 1983 bij de ILO een klacht in vanwege het feit dat het Ministerie van Economische Zaken de rechtspersoonlijkheid van de AGECh (Beroepsvereniging voor Onderwijzers van Chili) had herroepen. De vereniging had zich ingelaten met politieke activiteiten, hetgeen op grond van de Constitutie en van art. 1 van Wetsdecreet no. 2755 verboden was. De vereniging was in beroep gegaan en de rechtbank had de beschikking van de Minister vernietigd.

Om te beginnen stelde het Comité het herroepen van de rechtspersoonlijkheid op eén lijn met het ontbinden van een vakbond, hetgeen betekende dat ook de onderhavige maatregel uitsluitend door de rechter genomen kon worden. Verder wenste het Comité de aandacht van de regering te vestigen op het feit dat het niet voldoende was dat de wet aan vakbonden het recht toekende om bij de rechter beroep aan te tekenen tegen de ontbinding of het herroepen van de rechtspersoonlijkheid. De beroepsprocedure moest ook schorsende werking hebben, zodat de gewraakte maatregel pas na verloop van de beroepstermijn van kracht werd of nadat zij door de rechter bekrachtigd was. ${ }^{163}$

\section{De protestbeweging in de jaren tachtig als opmaat tot het herstel van de democratie}

De repressieve politiek van het regime-Pinochet riep steeds meer tegenstand op. In 1983 ontpopte de vakbeweging zich tot de voortrekker van een brede volksoppositie, waarvan vrouwen, studenten en inwoners van krottenwijken ("poblaciones") deel uit maakten, en drong er bij de politieke partijen op aan om hun onderlinge grieven bij te leggen. De vakbeweging gaf zelf het goede voorbeeld door op 1 juni 1983 de CNT (Nationale Arbeiders Commando) op te richten, een koepelorganisatie, waarin de vijf in de vorige paragraaf genoemde, centrales vertegenwoordigd waren. Het was een uiting van het besef dat de economische politiek geen onderscheid maakte naar politieke signatuur, maar de gehele arbeidersbevolking trof. Het communiqué, waarmee de CNT naar buiten trad, bevatte een aantal eisen - herstel van de democratie, intrekking van Overgangsbepaling 24 en erkenning van het recht van dissidenten on gebruik te maken van de media - die strikt genomen buiten het kader van vakbondsaangelegenheden vielen. Om deze eisen kracht bij te zetten, werden in 1983 en 1984 nationale protestdagen georganiseerd die elkaar in rap tempo opvolgden.

Toch nam de vakbeweging, na aanvankelijk successen te hebben gevierd, geleidelijk aan in betekenis af. Verscheidene factoren waren hier debet aan. Allereerst ontleende de vakbeweging haar speciale positie aan het vermogen om, door middel van een algemene staking, de regering onder druk te zetten. In het licht van de hoge werkloosheid, bleven stakingen evenwel een riskante aangelegenheid. Nadat de CTC in september 1983 in de kopermijnen een staking had uitgeroepen, reageerde de regering onmiddellijk met het ontslag van 1800 werknemers. Slechts eenmaal (oktober 1984) viel een nationale protestdag samen 
met een landelijke staking die het hele openbare leven lam legde. Een week later werd de Staat van Beleg afgekondigd. ${ }^{114}$

In de tweede plaats had de toenadering tussen vakbeweging en politieke partijen niet uitsluitend positieve effecten. De partijen benutten de politieke opening die Pinochet in 1983 creëerde vooral om oude en nieuwe meningsverschillen uit te vechten. Het belangrijkste twistpunt tussen linkse oppositie (met name de communisten) en christendemocraten gold de vraag of Pinochet met geweld dan wel uitsluitend met vreedzame middelen bestreden moest worden. Gegeven de nauwe samenwerking tussen politieke partijen en vakbeweging, had de politieke tweespalt zijn weerslag op de eenheid binnen de vakbeweging. ${ }^{\text {1t5 }}$ Tenslotte werd de vakbeweging, vooral na de afkondiging van de Staat van Beleg in november 1984, opnieuw geconfronteerd met brute repressie.

Tijdens de jaren tachtig veranderde de repressie overigens enigszins van karakter. "Verdwijningen" en standrechtelijke executies vonden slechts zelden plaats. De repressie nam veeleer de gestalte aan van massale arrestaties, verbanningen en plotselinge legerrazzia's in de "poblaciones" om de inwoners te intimideren. ${ }^{160}$

Een complicerende factor was voorts dat de autoriteiten in toenemende mate de neiging vertoonden om, vooral in geval van zeer ernstige schendingen van mensenrechten, iedere betrokkenheid te ontkennen. In 1982 was het Comite hiermee al geconfronteerd, zowel bij de moord op de vakbondsleider Tucapel Jimenez als bij de doodsbedreigingen die geuit werden aan het adres van de vakbondsleider Hernán Mery. In beide gevallen waste de regering haar handen in onschuld. Het Comité was niet onder de indruk van de repliek van de regering: een klimaat van geweld dan wel van onveiligheid en vrees vormde een ernstige hindernis voor de vrije uitoefening van vakbondsrechten. De autoriteiten dienden strenge maatregelen te nemen om activiteiten die een dergelijk klimaat schiepen, uit te bannen. ${ }^{67}$

In reactie op de grote protestmanifestaties, voerde de regering een systematisch "ontmoedigings"beleid, waarbinnen drie componenten vielen te onderscheiden. In de eerste plaats namen de autoriteiten hun toevlucht tot preventieve maatregelen, door stakingen en demonstraties op voorhand te verbieden en door vakbondslokalen aan de vooravond van protestmanifestaties te doorzoeken. In de tweede plaats traden veiligheidsagenten en militairen

164 Gegewens over de wisselende successen van de vakbeweging gedurende deze periode zijn ontleend aan Arriagada (1988), a.w. pp. $56-60$.

In Chili's vakbeweging contra Pinochet (Intermediair, 07-03-1986, p. 41-45) heb ik me wat optimistischer uitgelaten over de bijdrage van de vakbeweging aan het herstel van de democratie.

165 De spanming ontlaadde zich toen begin 1984 de UDT (die inmiddels was omgedoopt tot CDT) uit de CNT trad. Vgl. Campero (1985), a.w. pp. 185-187.

166 Vgl. OAS-Rapport (1985), p. 237 en Arriagada (1988, a.w. pp. 63-64) die op grond van informatie varn het Vicariaat van Sollidariteit aantoont dat tussen 1982 en 1986 het aantal arrestaties verzewenvoudigde!

167 Case No. $1117,217 \mathrm{e}$ Rap. $\$ 493$.

Case No. 1162,222 e rap. $\$ 129$. 
tijdens de demonstraties over het algemeen hard op. Tenslotte werden gerichte strafmaatregelen genomen tegen de kopstukken van de vakbeweging, zoals de charismatische leider van de CTC, Rodolfo Seguel.

\subsection{Preventieve maatregelen}

De internationale vakverenigingsfederaties beklaagden zich tegenover de $\mathrm{LO}$ erover dat de autoriteiten er een gewoonte van maakten om, aan de vooravond van nationale protestdagen, vakbondslokalen binnen te dringen. Blijkbaar waren zij op zoek naar belastend bewijsmateriaal of andere informatie. Het Comité wees de regering erop dat het beginsel van de onschendbaarheid van vakbondslokalen noodzakelijkerwijs met zich meebracht dat de autoriteiten deze lokalen niet mochten betreden zonder huiszoekingsbevel. ${ }^{168}$

In een latere uitspraak lichtte het Comité dit standpunt nader toe. Het huiszoekingsbevel moest door de gewone rechter zijn uitgevaardigd, nadat de rechter zich ervan vergewist had dat er redelijke gronden bestonden om aan te nemen dat er bewijs in het betreffende lokaal voorhanden was dat aanleiding zou kunnen geven tot een vervolging wegens een strafrechtelijk vergrijp. Bovendien moest de huiszoeking beperkt worden tot de doeleinden, waarvoor het huiszoekingsbevel was afgegeven. ${ }^{168}$ In een brief van 26 april 1985 refereerde het IVVV aan een brutale aanval van tien gemaskerde en gewapende mannen op het vakbondslokaal van de Confederatie van Bouwvakarbeiders. Vakbondsleiders waren mishandeld en hun persoonlijke bezittingen en identiteitskaarten waren gestolen. De regering ontkende iedere betrokkenheid. Het IVVV legde echter interessant bewijsmateriaal over waaruit de connectie tussen regering en para-militaire groep genoegzaam bleek: op 15 april had de Minister van Binnenlandse Zaken een proces aangespannen tegen vier vakbondsleiders wegens overtreding van de Staatsveiligheids-wet. Als bewijsmateriaal presenteerde de Minister de documentatie die tijdens de para-militaire actie was geconfisceerd. De regering moest haar betrokkenheid wel toegeven. Het Comité volstond met het benadrukken van het belang van de bescherming van vakbondsiokalen en drong er bij de regering op aan om de schuldigen op te sporen. ${ }^{170}$

Als rechtvaardiging voor het a priori-verbod van demonstraties heeft de regering telkens aangevoerd dat er geen sprake was van vreedzame vakbondsdemonstraties, aangezien vakbondsleiders niet deelnamen aan deze evenementen en zij niet om vakbondsredenen gehouden werden. De regering beweerde dat de protestdemonstraties ontaardden in zeer gewelddadige handelingen, warbij bezittingen werden beschadigd en winkels werden

168 Case No. $1200,230 \mathrm{c}$ rap. $\$ 610$. In de ILC-Resolutie inzake Vakbondsrechten en hun verhouding tot burgerlijke vrijheden (1970) wordt het recht op bescherming van vakbondseigendommen aangemerkt als ến van de essentielle voorwaarden voor de normale uitoefening van vakbondsrechten.

169 Case No. 1309, 238 e Rap. \$ 361.

170 Case No. 1309 , 239e Rap. 335 en 241 e Rap. $\$ 765$ en 797. 
geplunderd (lezing van de gebeurtenissen op 14 juni 1983). In deze omstandigheden kon het Comité uitsluitend de contradicties opmerken tussen de verslagen van de klagende instanties en de regering met betrekking tot aard, achtergronden en doeleinden van de Nationale Protestdag. ${ }^{17 \pi}$

Dat het Comite overigens niet bereid was om de preoccupatie van de autoriteiten met de handhaving van orde en gezag als alibi te accepteren, bleek naar aanleiding van een verbod in 1983 aan het adres van de CNS om een 1 mei-bijeenkomst te houden op de Plaza de los Artesanos. Volgens de regering zou de bijeenkomst de openbare orde kunnen verstoren en bovendien was de CNS niet "representatief" genoeg om openbare bijeenkomsten te organiseren. Het Comité overwoog dat de CNS, als organisatie die de belangen van werknemers behartigde en verdedigde, het recht genoot om openbare vergaderingen en demonstraties te organiseren. Verder stelde het Comité zich op het standpunt dat, indien de autoriteiten besloten om een demonstratie te verbieden teneinde ordeverstoringen te voorkomen, zij met de organisatoren dienden te overleggen om de demonstratie op een andere plaats te houden. Bij gebrek aan een dergelijk voorafgaand overleg, maakte de regering inbreuk op vakbondsrechten. Tenslotte betreurde het Comité het dat de uitoefening van het demonstratierecht - een wezenlijke component van vakbondsrechten - ernstig onderdrukt was door grootscheepse arrestaties en fysieke bedreigingen. ${ }^{172}$ :

In die gevallen, waarin protestmanifestaties vergezeld gingen van een staking, was het Comité in de gelegenheid om zijn ideeën inzake de toelaatbaarheid van politiek getinte stakingen te ontvouwen.

De Nationale Protestdag van 4 september 1985 viel samen met een staking in de publieke sector. Naar aanleiding van de arrestatie van de stakingsleiders, merkte het Comité op dat vakverenigingen, ook in de publieke sector, proteststakingen moesten kunnen uitroepen, met het oog op de verdediging van de sociale en economische belangen van hun leden. ${ }^{173}$ Deze belangen, zo voegde het Comite er in een volgend rapport aan toe, betroffen niet alleen de verbetering van arbeidsvoorwaarden maar ook het zoeken van oplossingen voor vraagstukken van economisch- en sociaal-politieke aard. Met deze opmerking leverde het Comité kritiek op de Chileense wetgeving (Wetsdecreet no. 2758, artt. 45-55) die bepaalde dat stakingen uitsluitend uitgeroepen konden worden met het oog op de vernieuwing van collectieve arbeidsovereenkomsten. ${ }^{174}$

171 Case No. 1212,230 e Rap. $\$ 633$ en 233 e Rap. $\$ 541$.

172 Case No. 1200,230 e Rap. $\$ 611$ en 614.

173 Case No. 1309, 241e Rap. $\$ 800$.

174 Case No. 1309, 243e Rap. $\$ 482$. Het Comité scherpte de eigen formulering nog aan in dezelfde "Case", $238 \mathrm{e}$ Rap. $\$ 360$, waar het vakbonden uitdrukkelijk het recht toekende proteststakingen te organiseren om kritiek uit te oefenen op de sociale en economische politiek van de regering. 


\subsection{Het optreden van de autoriteiten tijdens de demonstraties}

Tijdens de nationale protestdagen vonden regelmatig harde confrontaties plaats tussen demonstranten en ordetroepen.

Het harde optreden van veiligheidsagenten tijdens de nationale protestdagen van 11 mei en 14 juni 1983 eiste twee resp. vier slachtoffers. Aanvankelijk had de regering toegezegd om een onderzoek in te stellen, maar vervolgens ging de regering tot de aanval over door het Comité te beschuldigen wan inmenging in interne aangelegenheden. De protestdagen, zo verkondigde de regering, hadden niets te maken met vakbondsactiviteiten: zij hadden een politiek karakter en waren ontaard in ordinaire rellen. Niet de veiligheidsagenten maar de leiders van de protestbeweging die zich onverantwoordelijk hadden gedragen, hadden de dood van de demonstranten op hun geweten, aldus de regering. Het Comité merkte laconiek op dat de regering zelf blijkbaar ook haar twijfels had over het optreden van de veiligheidsagenten, getuige het feit dat zij een onderzoek had ingesteld. Vervolgens stelde het Comité met nadruk dat een onderzoek naar de beschuldigingen met betrekking tot de dood van mensen wel degelijk binnen haar mandaat viel, aangezien de demonstraties, volgens de klagers, vakbondsactiviteiten waren. ${ }^{178}$ :

Na een nieuwe demonstratie op 4 september 1984 had de regering een beschuldiging van het IVVV die een gedetailleerde beschrijving had gegeven van de arrestatie, "verdwijning" en dood van het vakbondslid Aguirre Ballesteros, eenvoudig afgedaan door te stellen dat de politie hem niet had gearresteerd en dat de doodsoorzaken nog niet waren vastgesteld. Het Comité nam geen genoegen met deze algemene verklaring: gezien het zeer ernstige karakter van de beschuldigingen, moest de regering de omstandigheden van de dood ophelderen en de schuldigen opsporen en bestraffen. ${ }^{176}$

Talloze klachten bereikten de ILO over telefonische doodsbedreigingen aan het adres van bekende vakbondsleiders. Het Comité stelde dat een vakbeweging, waarin vakbondsleiders, in vrijheid en onafhankelijkheid, de belangen van de werknemers kunnen behartigen, zich niet kon ontwikkelen indien vakbondsleiders bedreigd werden en in voortdurende angst leefden. Het Comité drong er bij de regering op aan om gerechtelijke stappen te ondernemen met het oog op het beëindigen van dergelijke intimidaties die onzekerheid zaaiden in vakbondsgelederen. ${ }^{17}$

175 Case No. 1200, 230 e Rap. \$616/233e Rap. \$71.

Case No. 1212, 230 e Rap. $\$ 641 / 233$ e Rap. $\$ 541$.

176 Case No. 1309,238 e Rap. $\$ 359$.

177 Case No. 1309,254 e Rap. $\$ 339$. 


\subsection{Sancties tegen de verantwoordelijke vakbondsleiders}

Autoriteiten en werkgevers trachtten met name het verzet van de vakbeweging te breken door gerichte sancties te treffen tegen de vakbondsleiders die verantwoordelijk waren voor de organisatie van de protestmanifestaties. Arrestaties, gevolgd door gevangenisstraf of verbanning, ontslagen en diskwalificaties van vakbondsleiderschap vonden op grote schaal plaats naar aanleiding van de nationale protestdagen. Dikwijls waren deze sancties gelkoppeld: een strafrechtelijke vervolging en veroordeling leverde een grond op voor ontslag, terwijl ontslag weer aanleiding kon zijn om een functionaris uit zijn ambt te zetten. Soms werden klachten ingediend in verband met afzonderlijke sancties, hetgeen het Comite in de gelegenheid stelde om zijn standpunt dienaangaande te verfijnen.

Detentie schiep nog immer de gelegenheid voor het uitoefenen van kwalijke praktijken. Zo had een afvaardiging van het IVVV die na de nationale protestdag van 14 juli 1983 Chili had bezocht, uit de eerste hand vernomen dat de vakbondsleiders, Maria Rozas, José Anselmo Navarrete en Sergio Troncoso zwaar gefolterd waren. De regering ontkende de aanklachten. Het Comité achtte de informatie van de regering ontoereikend en verzocht haar een onafhankelijk onderzoek in te stellen, met het oog op de opheldering van de feiten en het ondernemen van gerechtelijke stappen tegen de folteraars. ${ }^{178}$

Afgezien van dergelijke "incidenten", was het opmerkelijk dat, halverwege de jaren tachtig; zowel strafrechtelijke als ontslag-procedures gevoerd werden ten overstaan van de rechter. Dit wees op een lichte verbetering van het rechtsstatelijke gehalte, maar wierp tegelijkertijd de cruciale vraag op of de rechter, gegeven de gebrekkige nationale wetgeving, wel bij machte was om eventueel onrecht te herstellen.

Tot tweemaal toe, beide keren naar aanleiding van een strafrechtelijke veroordeling, oefende het Comité openlijk kritiek uit op de nationale wetgeving en op de uitspraak van de rechter die de wetgeving had toegepast.

Het eerste geval had betrekking op havenarbeiders die hun baan verloren hadden in verband met de overtreding van de Staatsveiligheids-wet. Het Comité overwoog dienaangaande dat de gedupeerden heel goed gearresteerd en veroordeeld konden zijn voor activiteiten die de nationale wetgeving strafbaar stelde, maar die volgens algemeen erkende beginselen beschouwd konden worden als normale en wettige vakbondsactiviteiten..$^{10}$ In de tweede zaak stond de veroordeling van - onder andere - de befaamde vakbondsleider Manuel Bustos centraal. Bustos werd gestraft vanwege het feit dat hij op 7 oktober 1987 zijn achterban had aangezet tot een illegale staking. Het Comite gaf te kennen dat een dergelijk veroordeling in strijd was met het beginsel van vrijheid van vakvereniging. In dit verband wees het Comité 
erop dat de wet handelingen die beschouwd werden als legitieme vakbondsactiviteiten, niet strafbaar diende te stellen. ${ }^{\text {so }}$

Een goed voorbeeld van het opleggen van gekoppelde sancties was de strafrechtelijke vervolging, het ontslag en de diskwalificatie van Rodolfo Seguel, de leider van de CTC, die tussen 1983 en 1986 verwikkeld was in langdurige gerechtelijke procedures. Seguel werd op 15 juni 1983, daags na een grote protestmanifestatie, gearresteerd op verdenking van het aanzetten tot omverwerping van het legitieme bewind (Wet op de Staatsveiligheid, artt. 4 (a) en (c) en art. 11). Nadat Seguel meer dan een maand in preventieve hechtenis had doorgebracht, trok de regering haar aanklacht in. Het Comité uitte zijn zorg over de lange periode van voorarrest. ${ }^{191}$ De zaak was hier evenwel niet mee afgedaan. Seguel's werkgever, CODELCO, maakte dankbaar van de gelegenheid gebruik om deze lastige werknemer te ontslaan en richtte zich vervolgens tot de rechter met het verzoek Seguel uit zijn ambt te zetten. Op zijn beurt tekende Seguel bij de rechter bezwaar aan tegen zijn ontslag. Nadat de Rechtbank van Rancagua zich onbevoegd had verklaard om een oordeel te vellen over de diskwalificatie - een dergelijke kwestie behoorde namelijk tot de competentie van het Arbeidsdirectoraat -, werd Seguel tijdelijk van zijn functie ontheven door het Generale Arbeidsdirectoraat. Inmiddels was Seguel in beroep gegaan tegen de beslissing van de rechter in eerste aanleg die het ontslag had goedgekeurd. Seguel werd door de appèl-rechter in het gelijk gesteld, maar uiteindelijk bevestigde het Hoogste Gerechtshof het vonnis van de eerste rechter. ${ }^{\text {ine }}$

De beslissing van het Hoogste Gerechtshof ontlokte aan het Comité een belangwekkende uitspraak met betrekking tot de beperkte mogelijkheden van de nationale rechter om schendingen van (vakbonds)rechten te repareren. Na vastgesteld te hebben dat Seguel het slachtoffer was geworden van anti-vakbondsdiscriminatie, oordeelde het Comite dat de inschakeling van de rechter in een ontslagprocedure niet noodzakelijkerwijs een voldoende garantie tegen anti-vakbondsmaatregelen vormde. De macht van de rechter was immers beperkt tot het op correcte wijze toepassen van de nationale wetgeving. ${ }^{186}$

$\mathrm{Nu}$ het ontslag van Seguel onherroepelijk was geworden, was de weg vrij voor diens definitieve diskwalificatie als vakbondsleider. In 1986 verklaarde het Arbeidlsdirectoraat inderdaad zijn (her)verkiezing als vakbondsleider nietig. Het Comité sprak zijn afkeuring uit over deze maatregel en verwees daarbij naar de bezwaren van de ILO tegen een koppeling tussen vakbondsleiderschap en het werkzaam zijn in een onderneming. ${ }^{184}$

180 Case No. 1309, 246e Rap. $\$ 300$ en 254e Rap. $\$ 342-343$.

181 Case No. 1212 , 230e Rap. 658 .

182 Een uitvoerige beschrijwing van de ingewikkelde rechtsgang treft men aan in: UN-Docs. A/38/385, $\$ 285$ en $A / 39 / 631,8323-328$.

183 Case No. 1309, 241e Rap. \$ 803.

184 Case No. 1309,244 e Rap. $\$ 333$. 
Voorzover ontslagen kort volgden op grote stakingen en protestmanifestaties, had het Comite geen moeite om het vakbonds-discriminatoire karakter van deze maatregelen vast te stellen. Naarmate de uitingen van verzet in intensiteit en in frequentie afnamen, konden autoriteiten en werkgevers beter hun ware bedoelingen verhullen, door financiële of organisatorische motieven voor ontslagen aan te voeren. Zo vond in 1986 een grote afslankingsoperatie plats in het onderwijs die gepaard ging met massa-ontslagen, waarvan ook een groot aantal nationale en lokale leiders van onderwijsvakbonden het slachtoffer werd. Het Comité achtte zich niet bevoegd om over een dergelijke reorganisatie een oordeel uit te spreken. Niettemin uitte het zijn bezorgdheid over de genomen maatregelen, waarbij het verwees naar ILO-Aanbeveling no. 143 inzake de Bescherming en Faciliteiten voor Vakbondsleiders in de Onderneming. Deze Aanbeveling bepleitte onder andere de erkenning van voorrang voor vakbondsleiders met betrekking tot het behoud van hun baan in geval van vermindering van het personeelsbestand. ${ }^{\text {us }}$

\section{Epiloog}

De laatste jaren van het regime-Pinochet traden er weinig veranderingen op in de vakbondspolitiek. Het Comité inzake de Vrijheid van Vakvereniging bleef alert op verstoringen van demonstraties, stakingsverboden, ontslagen van vakbondsleiders etc.

Twee gebeurtenissen die kort na elkaar in 1988 plaatsvonden, verscherpten nog de animositeit tussen autoriteiten en vakbeweging. Allereerst vatte de regering de heroprichting van de CUTCh in augustus 1988 op als een nieuwe provocatie aan het adres van het regime. Het beginselprogramma van de nieuwe CUTCh bevatte namelijk, naast de roep om intrekking van het Plan Laboral en herstel van vakbondsrechten, ook politieke punten, zoals de verwerping van de transformatie van het Paaseiland tot een Amerikaanse legerbasis en kritiek op de overdracht van nationale rijkdommen aan multi-nationale ondernemingen. ${ }^{186}$

In de tweede plaats gaf het referendum van oktober 1988, waarbij de Chileense bevolking in de gelegenheid werd gesteld om zich uit te spreken over al of niet continuering van het bewind van Pinochet, aanleiding tot nieuwe sociale onrust. De regering bestempelde demonstraties en stakingen bij de spoorwegen als politieke agitatie, waarbij vooruit gelopen werd op de uitslag van het referendum. ${ }^{187}$

185 Case No. 1309, 253e Rap. \& 298.

186 Vergelijk de analyses van het beginselprogramma in de nieuwsbladen: "La Epoca", 2907-1988 en "Tercera", 08-08-1988.

187 Vgl. Case No. 1309, $259 \mathrm{e}$ Rap. $\$ 386$ en 397 . Het Comite herhaalde zijn standpunt dat stakingen niet alleen uitgeroepen konden worden met het oog op verbetering van de arbeidswoorwaarden, maar tevens als middel konden fungerem om een oplossing te vinden voor alle kwesties die van direct belang waren voor de werknemers (\$ 412). 
De uitslag van het referendum - 54\% van de Chilenen zag geen heil in voortzetting van de militaire dictatuur - betekende een gevoelige nederlaag voor Pinochet en gaf de verenigde oppositie de morele steun in de rug om naar een vreedzame overgang naar de democratie te streven. Op 14 december 1989 behalde de presidentskandidaat van de oppositie, de christendemocraat Patricio Aylwin, de absolute meerderheid van de stemmen en op 11 maart 1990 aanvaardde hij zijn ambt. Het was het einde van een duister tijdperk.

De vakbondspolitiek van de regering-Aylwin valt buiten het bestek van dit proefschrift, zodat met enkele opmerkingen volstaan kan worden. De nieuwe arbeidswetgeving die op 1 augustus 1991 van $k r a c h t$ werd, ademt een liberale sfeer. ${ }^{\$}$ Werknemers hebben een grote mate van vrijheid om vakorganisaties op te richten en hoeven daarbij slechts formele plichtplegingen te vervullen (Titel I, Hfdst.I en II). Vakbondsfunctionarissen genieten ontslagbescherming en kunnen uitsluitend (tijdelijk) uit het ambt geweerd worden, indien zij veroordeeld zijn tot een lange gevangenisstraf (artt. 13 en 25). Van belang is tevens dat (con)federaties collectieve onderhandelingen kunnen voeren en dat CAO's afgesloten kunnen worden voor een gehele bedrijfssector (art.110). Enige bederkingen kan men hebben tegen de handhaving van het stakingsverbod in ondernemingen, waar een werkonderbreking ernstige schade kan toebrengen aan de volksgezondheid, de voedselbevoorrading, de nationale economie of de nationale veiligheid (art. 160). De ministeriële beschikking, waarbij dergelijke ondernemingen jaarlijks worden aangewezen, is echter met de nodige waarborgen omgeven en het is nog te vroeg om te beoordelen hoe de toepassing van deze bepaling in de praktijk uitwerkt.

\section{Evaluatie en conclusies}

De repressieve vakbondspolitiek van het regime-Pinochet heeft van meet af aan ongezouten kritiek ontlokt van de zijde van de ILO, zo kan de algemene conclusie van de voorgaande analyse luiden. De meeste pogingen om de economische en politieke macht van de vakbeweging te kortwieken, werden gekenschetst als schendingen van vakbondsrechten. In eerste instantie heeft de Onderzoeks- en Bemiddelings-Commissie een uitvoerig onderzoek ingesteld. Vervolgens heeft het Comite inzake de Vrijheid van Vakvereniging diens taak overgenomen. Het Comité heeft zich niet beperkt tot de afhandeling van klachten, maar ook de wetgeving van kritisch commentaar voorzien. Tenslotte hebben Direct contact-missies zich ter plaatse van de situatie op de hoogte gesteld en zowel met regeringsvertegenwoordigers als met tegenstanders van het regime overlegd om een verbetering te bewerkstelligen. op weg naar het einde? in: Intermediair, 08-12-1989, pp. 17-25:

189 Wet no. 19069 van 22-07-1991 betreffende vakorganisaties en collectieve onderhandelingen. Int. Labour Office, Labour Law Documents, Geneva 1992-1, pp. 1-30. 
De ILO heeft hiermee het instrumentarium dat haar ter beschikking staat om toe te zien op de naleving van vakbondsrechten optimaal benut. De band tussen de $1 \mathrm{LO}$ en Chili is immers uiterst fragiel: aangezien Chili Conventie no. 87 noch Conventie no. 98 heeft geratificeerd, kan de regering uitsluitend aangesproken worden op naleving van haar statutaire verplichtingen. De Preambule van het Statuut bestempelt vrijheid van vakvereniging als één van de fundamentele beginselen van de ILO. Het Comité inzake de Vrijheid van Vakvereniging heeft hieruit afgeleid dat elke lid-staat van de ILO de vrijheid van vakvereniging dient te respecteren. ${ }^{190}$

De kritiek van de ILO heeft zich toegespitst op drie categorieën van repressieve maatregelen tegen de vakbeweging die men als volgt kan classificeren: schendingen van fundamentele rechten van de mens, aantasting van het institutionele kader van de vakbeweging en inperking van vakbondsactiviteiten.

Allereerst zjjn fundamentele mensenrechten van met name sympathisanten van de regeringAllende en andere politiek actieve vakbondsleden geschonden. Sinds de Internationale Arbeidsconferentie in haar befaamde Resolutie van 1970 bepaald heeft dat de afwezigheid van burgerrechten elke betekenis aan het concept van vakbondsrechten ontneemt, hebben de ILO-organen die belast zijn met het toezicht op de naleving van vakbondsrechten, onbekommerd schendingen van fundamentele mensenrechten van vakbondsmensen aan de kaak gesteld. De ILO heeft dan ook moord op of doodsbedreigingen aan het adres van vakbondsmensen, folteringen, "verdwijningen" en arrestatie en detentie zonder vorm van proces in scherpe bewoordingen veroordeeld.

In de tweede plaats hebben de autoriteiten de vrijheid van (vak)organisatie in hoge mate aan banden gelegd. Dikwijls liep de existentie van vakbonden als zodanig gevaar, doordat de uitvoerende macht zich het recht voorbehield om haar toestemming voor de oprichting van vakbonden te weigeren of vakbonden te ontbinden. Bovendien werd de vrijheid van de vakbeweging om gestalte te geven aan de eigen organisatiestructuur, vrijwel volledig teniet gedaan, doordat de wet dienaangaande dwingende voorschriften bevatte. Beide soorten maatregelen konden, naar het oordeel van de ILO, de toets der kritiek niet doorstaan. De vrijheid van vakorganisatie impliceert ook dat democratisch gekozen vakbondsleiders vrijelijk hun ambt moeten kunnen uitoefenen. Pogingen van de autoriteiten om, door middel van ontslag, diskwalificatie of arrestatie, de vakbeweging van haar kader te beroven, werden door de ILO gekenschetst als inbreuken op de vrijheid van vakvereniging.

Tenslotte heeft de regering de vakbeweging in haar functioneren belemmerd door strenge restricties te stellen aan de activiteiten die vakbonden mochten ontploolen. De vrijheid van vergadering en van demonstratie werd uitgehold. Het recht op het voeren van collectieve onderhandelingen werd, na aanvankelijk volledig verboden te zijn geweest, zowel ratione

190 In de Philadelphia-Verklaring van 1944 die integraal deel witmaakt van de Preambule, wordt vrijheild van vakwereniging gekenschetst als eén van de fundamentele beginselen van de ILO. Het Comité deed zijn uitsprakik in zijn Eerste Rapport, 32 . 
materiae als ratione personae strak geclausuleerd. De uitoefening van het stakingsrecht werd wrijwel volledig illusoir gemaakt. Met de normen van de sleutelconventies als leidraad, heeft de ILO zich in kritische zin uitgelaten over deze beperkingen.

Afgezien van de commentaren die de $I L O$ geleverd heeft op concrete wetsartikelen en naar aanleiding van bepaalde incidenten, heeft zij zich af en toe vitgelaten over de globale (economische) politiek, voorzover deze consequenties had voor de positie van de vakbeweging. Wat dit betreft hebben de toezichtsorganen van de ILO zich wat terughoudender opgesteld dan de organen van de OAS en de VN, maar dit is niet verwonderlijk, aangezien beide laatste organisaties geacht worden een onderzoek in te stellen naar de algehele mensenrechtensituatie. De incidentele uitweidingen over de politieke achtergronden getuigen van een ruime taakopvatting en vormen een bewijs dat de ILO oog heeft voor de politieke context, waarbinnen schendingen wan vakbondsrechten plaatsvinden.

Twee aspecten verdienen nog een korte bespreking. Het eerste heeft betrekking op de neiging van het regime-Pinochet om zich te rechtvaardigen door de repressie voor te stellen als legitieme sancties op (subversieve) politieke activiteiten van vakbonden en hun leden. Aanvankelijk hielden de toezichtsorganen wan de ILO zich nogal op de vlakte. Naar aanleiding van de ontbinding van de CUTCh verschool de Commissie zich achter de weinig verhelderende ILC-Resolutie inzake de Toelaatbaarheid van Politieke Activiteiten en gispte de maatregel vooral omdat zij niet door de rechter genomen was. In het woetspoor van de VN-Rapporteur nam de ILO vanaf 1980 terzake een geprononceerder standpunt in. Zo accepteerde het Comité bijwoorbeeld niet het op voorhand verbieden van vergaderingen en demonstraties vanwege hun politieke karakter en evenmin het verbinden van de voorwaarde aan de kandidaatstelling van een vakbondsleider-in-spé dat hij zich zou onthouden van politieke activiteiten. De meeste duidelijkheid schiep het Comité met betrekking tot de toelaatbaarheid van "politieke" stakingen: stakingen kunnen uitgeroepen worden met het oog op het ventileren van kritiek op de sociaaleconomische politiek van de regering.

Het belang van een dergelijke stellingname kan moeilijk overschat worden. Enerzijds bevestigt het Comite het standpunt van de ILO dat vakbonden politieke activiteiten mogen ontplooien en geeft het bovendien een indicatie omtrent de grenzen die vakbonden daarbij in acht moeten nemen. Anderzijds weerlegt het Comité het alibi van de regering om inbreuk te maken op vakbondsrechten. Vooral in een land als Chili waar politiek engagement de vakbeweging een tweede natuur is, hetgeen meestal heeft geleid tot spanningen tussen staat en vakbeweging, heeft een helder standpunt grote waarde.

Het tweede aspect betreft de positie van de nationale rechter.

Zoals in het eerste hoofdstuk van deze studie al betoogd is, kent de ILO bij het opleggen van sancties aan vakbonden en hun leden groot gewicht toe aan het oordeel van de rechter. De inschakeling van de rechter is geen loos gebaar. De rechter is, beter dan een internationale organisatie, in staat de feiten te beoordelen en de politieke achtergronden te peilen. Bovendien 
kan de rechter schendingen van vakbondsrechten door de uitvoerende macht corrigeren. Deze corrigerende functie boet evenwel aanzienlijk aan belang in, indien de nationale wetgeving die de rechter moet toepassen, in het licht van de internationale arbeidsnormen gebreken vertoont.

In het concrete geval van Chili heeft het Comité dit probleem terdege onderkend. Vooral in 9 kwam naar voren dat kritiek op wetgeving tevens kritiek op rechterlijke uitspraken die gebaseerd zijn op die wetgeving, impliceert. Voorzover mij bekend, heeft het Comité eenmaal het ontslag van Seguel - uitdrukkelijk bepaald dat inschakeling van de nationale rechter onvoldoende waarborgen bood, aangezien hij gehouden is om de nationale wetgeving toe te passen.

In een groot aantal landen plegen rechters internationaalrechtelijke normen toe te passen, soms zelfs met voorrang boven nationaal recht. De Chileense constitutionele wetgeving en de internationale verplichtingen, waaraan Chili gebonden is, bieden in dit opzicht echter weinig perspectief. Zo kan de Chileense rechter de ILO-Conventies inzake vrijheid van vakvereniging niet toepassen, om de simpele reden dat Chili deze verdragen niet geratificeerd heeft. Afhankelijk van de Chileense Constitutie, zou rechterlijke toepassing van internationale normen inzake de vrijheid van vakvereniging mogelijkerwijze op een andere manier kunnen geschieden. Te denken valt aan toepassing van de VN-Mensenrechtenverdragen, waar Chili wel partij bij is of aan rechterlijke toepassing van de beginselen inzake vrijheid van vakvereniging als regel van internationaal gewoonterecht.

Het ligt buiten het bestek van dit hoofdstuk om nader in te gaan op deze mogelijkheden; in het slothoofdstuk van deze studie kom ik hier nog uitvoerig op terug. Volstaan kan worden met de opmerking dat de "case law" van de ILO geen enkele aanwijzing bevat dat de rechter van deze mogelijkheden gebruik maakt.

Bij wijze van slotconclusie kunnen we stellen dat de toezichthoudende activiteiten van de ILO met betrekking tot de vakbondssituatie tijdens het regime van Pinochet respect afdwingen. Natuurlijk is het effect van deze activiteiten moeilijk meetbaar. Toch zijn er aanwijzingen dat de constante internationale pressie de regering van Pinochet gedwongen heeft om verantwoording af te leggen van de gevoerde (vakbonds)politiek, het moreel van de oppositie gesterkt heeft en daardoor bijgedragen heeft tot het herstel van de democratie. 



\section{Staat en vakbeweging in Colombia}

\section{Inleiding}

De verhouding tussen staat en vakbeweging in Colombia heeft zich ontwikkeld volgens een patroon dat weinig kenmerkend is voor de grote Latijnsamerikaanse landen, Weliswaar concentreerde de vakcentrale CTC (Confederatie van Colombiaanse Arbeiders) zich gedurende de jaren dertig op "political bargaining" met de regering, maar aan deze strategie lag, in tegenstelling tot bijvoorbeeld Brazilië en Mexico, geen populistische alliantie ten grondslag. Bovendien kwam aan de samenwerking tussen autoriteiten en vakbeweging abrupt een einde, toen de politieke bondgenoot van de CTC, de Liberale Partij, na de Tweede Wereldoorlog een smadelijke verkiezingsnederlaag leed tegen de Conservatieve partij. De politieke machtsomwenteling had verstrekkende gevolgen voor de positie van de vakbeweging. Nieuwe arbeidswetgeving verordende dat collectieve onderhandelingen voortaan plaats zouden vinden op het niveau van de onderneming. De sterke versplintering verijdelde dat de vakbeweging eensgezind de sociaal/economische politiek van de regering ter discussie stelde. Op centraal niveau was de vakbeweging politiek verdeeld: de UTC (Unie van Colombiaanse Werknemers) onderhield tamelijk nauwe betrekkingen met de Conservatieve Partij, terwijl de CTC de Liberale Partij trouw bleef. De vakcentrales en vakbondsbasis opereerden op gescheiden niveaus; van onderlinge beinvloeding was nauwelijks sprake. Sterke versplintering, politieke verdeeldheid en gebrek aan interne democratie tastten de slagvaardigheid van de vakbeweging aan en verzwakten haar positie als maatschappelijke en politieke machtsgroepering.

Onder de druk van de verslechterende economische situatie streefde de vakbeweging in de loop van de jaren zestig naar eenheid en begon in toenemende mate de regeringspolitiek onder vuur te nemen. Het groeiende verzet van de vakbeweging werd door de autoriteiten beantwoord met restricties van vakbondsrechten. Kon de regering voorheen volstaan met het aangeven van nauwe wettelijk marges, waarbinnen vakbonden hun activiteiten konden ontplooien en met incidentele correcties, indien die marges overschreden werden, gaandeweg verschoof het accent binnen de vakbondspolitiek van controle naar repressie. De controverse tussen staat en vakbeweging maakte deel uit van een patroon van groeiende maatschappelijke en politieke conflicten. Verscherpte sociale tegenstellingen en een drugsmafia die vrijwel straffeloos kan opereren hebben bijgedragen tot een klimaat van structureel politiek geweld, 
waarin de "rule of law" steeds meer terrein verliest. Een complicerende factor is dat de regering nauwelijks meer in staat lijkt te zijn om leger en veiligheidsagenten die op $z^{\prime} n$ minst zijdelings betrokken zijn bij ernstige schendingen van vakbonds- en mensenrechten, in bedwang te houden.

In dit hoofdstuk zullen allereerst de sociale, economische en politieke ontwikkelingen in Colombia geschetst worden, tegen de achtergrond waarvan het specifieke karakter van de Colombiaanse vakbeweging verklaard kan worden (2 en 3).

Vervolgens zal ik in drie afzonderlijke paragrafen uitvoerig stilstaan bij de verschillende fasen in de vakbondspolitiek die de regering heeft gevoerd in reactie op de groeiende strijdbaarheid van de vakbeweging. Vanzelfsprekend zullen wetgeving en rechtspraktijk worden geanalyseerd aan de hand van de kritische kanttekeningen van de ILO. Tenslotte wil ik in een synthetische beschouwing de toezichthoudende werkzaamheden van de ILO met betrekking tot Colombia waarderen in het licht van de beschikbare informatie over de mensenrechtenen vakbondssituatie in Colombia en van de algemene ILO-normen inzake de vrijheid van vakvereniging. (7)

\section{De invloed van de koffie-economie op de sociale en politieke ontwikkelingen in Colombia}

De verbouw en export van koffie stonden aan de basis van de ietwat verlate, maar zeer spectaculaire economische ontwikkeling van Colombia. Het aandeel van koffie in de totale exportopbrengst van Colombia steeg tussen 1905 en 1929 van $39 \%$ naar $69 \%{ }^{1}$

De koffieteelt was vooral in handen van kleine en middelgrote boeren. Uitgestrekte "woeste gronden" (terrenos baldíos), in eigendom van de staat, wachtten op exploitatie. Met name de hellingen van het Andes-gebergte leenden zich bij uitstek voor de verbouw van koffie, maar waren niet geschikt voor grootschalige produktie. ${ }^{2}$ Ondernemende kolonisten (colonos) die een karig bestaan leidden in de hooglanden van de provincies Antioquia en Caldas, daalden

1 Pécaut D. Colombia in: Carrière J./Haworth $\mathrm{N}$, and Roddick J. (eds.) The State, Industrial Relations and the Labour Movennent in Latin America, Hampshire 1989, p. 263.

Export van balen koffie (60-killo):

$1913 \quad 1$ miljoen

1921 miljoen

$1930 \quad 3$ miljoen

19374 miljoen

Bron: Ch. Bergquist Labor in Latin America, Stanford 1986, p. 295.

2 Vgl. Mc Greevy W.P. An Economic History of Colombia, 1845-1930, Cambridge 1971, p. 231: "Intermediate or steep slopes on which 80 per cent of all coffee-plantings are located offer the best ecological conditions for coffee but do not lend themselves to production in large units." 
af naar het middelgebergte om het maagdelijk oerwoud in cultuur te brengen. ${ }^{3}$ Zo ontstond gedurende de eerste drie decennia van de twintigste eeuw een kaste van kleine en middelgrote koffieboeren die verantwoordelijk was voor ongeveer de helft van de koffieproduktie."

De sociaal/economische voorspoed van deze koffieboeren en hun bijdrage aan de industriële ontwikkeling èn aan de vorming van een stabiele democratie zijn in de literatuur soms wat te rooskleurig voorgesteld. "Toegegeven moet worden dat de "koffie-bonanza" zich aanvankelijk voltrok tegen de achtergrond van een tamelijk stabiel politiek klimaat. De Conservatieve Partij had tijdens de bloedige Oorlog van de Duizend Dagen (1899-1902) de Liberale Partij verslagen en leek, geruggesteund door de Katholieke Kerk, verzekerd van de politieke hegemonie. ${ }^{6}$ Op de langere termijn zouden evenwel juist de sociale spanningen in de koffiezone de politieke stabiliteit ondermijnen.

De groei van de koffiesector bevorderde ontegenzeggelijk de industrialisatie. Het aandeel van de koffieboeren in deze ontwikkeling is echter omstreden. Mc Greevy beweert dat een evenwichtiger inkomensverdeling in de koffiesector de markt voot verbruiksartikelen die lokaal geproduceerd konden worden, vergrootte. Vooral de textielsector in Antioquia zou garen gesponnen hebben bij de stijgende welvaart van de koffieboeren? Andere auteurs wijzen er evenwel op dat de koffieboeren te zeer verpauperd waren om te fungeren als koopkrachtige consumenten. ${ }^{8}$ In het licht van deze tegenwerpingen moet de industriële ontwikkeling waarschijnlijk worden toegeschreven aan andere factoren. Handelsondernemingen streken

3 Deze migratie is onder andere helder beschreven door Catherine LeGrand Labor Acquisition and Social Conffict in the Colonibian Frontie, 1850-1936 in: Journal of Latin American Studies, 16 (1984), pp. $29-32$.

4. In het licht van de gebrekkige statistische gegevens, lopen de schattingen over het grondbezit in de koffiezone enigszins uiteen. Bergquist (a.w. pp. 301-303) baseert zich op het onderzoek van de VN-Commissie voor Latijins Amerika (CEPAL) en de FAO (El café en América Latina. Problemas de la productividad y perspectivas. 1. Colombia y El Salvador, Mexico 1958) en komat tot de conclusie dat in $195594 \%$ van het totale aantal boerenbedrijven minder dan 10 hectare grond in bezit had. $80 \%$ van deze bedrijven was het eigendom wan de familie die het land bewerkte.

Vernon Lee Fluharty (Dance of the MiWiow, Pittsburgh 1957, p. 202) stelt dat $87 \%$ van de bedrijven minder dan 5000 koffiestruiken had (5000 koffiestruiken komt overeen met een oppervlakte van 2 hectare), Specifiek met betrekking tot het grondbexit in de provincie Tolima, geeft D. Meertens (Jonkers en Boeren, de wrijd on het land in Colombia, Amsterdam 1979, p. 106) aan dat in $192378,1 \%$ van de "fincas" (koffiebedrijven) minder dan 5000 koffiestruilken had.

5 Een exponent vam deze "klassieke" benadering is Parsons J. Antioqueño Colonization in Westem Colombia, Berkeley 1949.

Vgl. Pécaut (1989), a.w. p. 263: "Paradoxically, these (socio/economic) transformations took place at a time when political structures in Colombia remained unchanged." Bergquist wijdt in zijn dissertatie Coffee and Conflict in Colombia (Durham, N.C., 1978) uit over de Oorlog van de Duizend Dagen.

7 Mc Greevy, a.w. p. 236 .

8 Fluharty, a.w. pp. 203-206 en vooral Palacios M. Coffee in Colombia, Cambridge 1980, pp. 196-197: "The intense commercialization of agriculture (...) did not, as is so often axiomatically affirmed, create a rural middle class with sufficient size and purchasing power to stimulate ind ustrial investment. (...) The integration of the small producer into the money economy was superficial." 
vooral de winsten uit de koffie-export op en investeerden deze winsten in industriêle projecten:" Daarbij stegen de overheidsinkomsten door het heffen van invoer-en uitvoerrechten en door de Amerikaanse herstelbetalingen die Colombia schadeloos moesten stellen voor het verlies van het Panama-kanaal. ${ }^{\text {to }}$ In de loop van de jaren twintig begon de overheid in toenemende mate te investeren in de aanleg van een deugdelijk spoorwegennet. ${ }^{14}$ De verbetering van de infrastructuur strekte primair on de geisoleerde en verspreid liggende percelen waar koffie verbouwd werd te verbinden met de koffiebranderijen en uitvoerhavens. Tegelijkertijd had zij enkele gunstige neveneffecten op de industriële ontwikkeling. De transportkosten van ruwe grondstoffen, waarvan de textielindustrie in hoge mate afhankelijk was, daalden aanmerkelijk en bovendien leverde de groei van de werkgelegenheid in de vervoerssector een nieuwe markt op voor industriële produkten. ${ }^{12}$

Welke consequenties hadden de geschetste ontwikkelingen nu voor de positie van de georganiseerde arbeidersbeweging?

Bij de plotselinge en versnelde economische groei konden sociale conflicten niet uitblijven. Vooral in de export-enclaves die in handen waren van buitenlandse ondernemingen zoals de United Fruit Company en Tropical Oil, liepen de spanningen hoog op. Stakingen werden door werkgevers en autoriteiten gekenschetst als ondermijning van orde en gezag en werden met harde hand neergeslagen. ${ }^{13}$ De acties van militante spoorwegarbeiders en havenwerkers sorteerden dikwijls succes, aangezien zij de zenuwknopen van het economische verkeer konden uitschakelen. Deze stakingen waren evenwel spontane erupties van onvrede en werden zelden georganiseerd door vakbonden. Bovendien was koffie de strategische sector van de Colombiaanse economie. Aangezien de ontwikkelingen in de koffiesector de koers van de Colombiaanse vakbeweging in hoge mate bepaald hebben, is het noodzakelijk om dieper in te gaan op de lotgevallen van de koffieboeren.

De koffiezone was het toneel van bittere sociale conflicten. Naarmate de koffieprijzen stegen en de bevolking toenam, verscherpte de concurrentie in de strijd om het land. Grootgrondbezitters in de provincie Cundinamarca trachtten te profiteren van de explosieve groei van de koffiesector. Met de hulp van lokale autoriteiten probeerden zij hun arealen uit te breiden door kolonisten van het land te verdrijven, waarbij zij zich dikwijls beriepen op dubieuze eigendomstitels. ${ }^{\text {i4 }}$ Met deze handelwijze verzekerden de grootgrondbezitters

9. Vgl. Pecaut, a.w. p. 263 .

10 Fluharty, a.w. p. 31.

11 Overheidsinvesteringen in publieke werken (vooral de vervoerssector) stegen tussen 1923 en 1928 van \$ 6,3 miljoen naar $\$ 62$ miljoen per jaar, Bejarano J.A. El Despegue Cafetero (1900-1928) in: Ocampo J.A. (ed.) Historia econónica de Colombia, Bogotá 1987, p. 196.

12 Bejarano, a.w. pp. $1811 \cdot 182$.

13 In 1928 riep de United Fruit Company de hulp van het leger in om een staking van bananenwerkers in de Santa Marta-plantage te breken. Garcia Marquez heeft de confrontatie die honderden werknemers het leven kostte, op aangrijpende wijze beschreven in zijn magnum opus "Honderd jaar eenzaamheid".

14 Voor details zie Palacios a.w. met name hoofdstuk 9: "Sociopolitical elements in antioqueño colonization." 
zich bovendien van de broodnodige arbeidskrachten." Tegelijkertijd voltrok zich een ontwikkeling in de andere richting: de drang om te delen in de welvaart die de uitdijende koffiesector in het vooruitzicht stelde, maakte landarbeiders en pachters steeds onwilliger om diensten te verrichten voor hun werkgever of pachtheer. Ook zij mengden zich in de strijd om het land. ${ }^{16}$

In de loop van de jaren twintig en dertig wonnen de kleine koffieboeren dikwijls het pleit: Met grote hardnekkigheid keerden zij terug naar de percelen die zij gedwongen verlaten hadden en voerden gerechtelijke procedures tegen de grootgrondbezitters, waarbij zij menigmaal de Colombiaanse wetgeving aan hun zijde vonden."

Met dit al had de strijd om het land, een prelude op de "Violencia" die de Colombiaanse maatschappij in de jaren vijftig en zestig zou teisteren, bij uitstek een individualistisch karakter. Voor elke landarbeider en pachter betekende het bezit van een eigen stukje grond de bekroning van een jarenlange worsteling. Zodra dit ideaal evenwel verwezenlijkt was, verloor de koffieboer zijn strijdbare instelling. In tegenstelling tot de werknemers in de export-enclaves, appelleerde de klassenstrijd in het geheel niet aan de conservatief ingestelde koffieboeren. Gedurende de jaren twintig hadden linkse politieke partijen, zoals de PSR (Revolutionaire Socialistische Partij) en de UNIR (Nationale Unie van Revolutionair Links) aanvankelijk succes in de koffiezone, maar zij zagen hun aanhang drastisch slinken, naarmate landarbeiders en pachters zich steeds meer opwerkten tot kleine en middelgrote grondbezitters."

Niet alleen de linkse politieke partijen, ook de vakbeweging kon geen vat krijgen op de koffieboeren, aangezien een collectieve belangenbehartiging niet aansloot bij hun individualistische opstelling. De onmacht van de vakbeweging om de koffieboeren te incorporeren, zou op de langere termijn ingrijpende gevolgen hebben.

$15 \mathrm{Vgl}$. LeGrand, a.w. p. 35: "The cumulative effect (of the monopolization of immense extensions of territory) was to block peasants from access to the most desirable land, thus encouraging them to sell their labor power."

16 Bergquist (1986), a.w. p. 325 .

17 Wooral een vitspraak van het Colombianse Hoogste Gerechtshof in 1926 stak de koffieboeren een hart onder de riem. Het Hof overwoog dat vitsluitend de oorspronkelijke akte warbij de eigendom wan eem stuk land werd oyergedragen, bewijskracht had Grootgrondbezitters konden een dergelijke akte meestall niet overleggen (LeGrand, a.w. p. 43). Kolonisten beschikten evenmin over zo'n akte, maar zij werden beschermd als "bezitters te goeder trouw" als zij het land in cultuur hadden gebracht (vgl. Palacios, a.w. pp. 172-173).

18 De de-radicalisering in de koffiesector wordt vrijwel algemeen onderkend in de literatuur. Vgl. Bergquist (1986), aw. pp. 310-312; Hartlyn J. The impact of puttertis of industrialization and of popular sector incorporation on political regime type: a case study of Colombia in: Studies in Comparative International Development, 1984 Vol. XIX, p. 35; H. Rojas Ruiz El frente nacional: solución politica a um problema de desarrollo? in: Rodrigo Parra S. (ed.) La dependencia externa y el desarrollo político en Colombia, Bogota 1970, p. 109 en Pearce J. Colombia; Inside the Labyrinth, London 1990, p. 41: The decline of peasant millitancy has been traced to this transformation of combative workers into conserwative freeholders." 


\section{De periode van "political bargaining" (1930-1945)}

Zoals in de vorige paragraaf al is aangegeven, speelden vakbonden tot aan het begin van de jaren dertig nauwelijks een rol van betekenis. De verkiezingsoverwinning die de Liberale Partij in 1930 behaalde op de intern verdeelde Conservatieve partij zou daar verandering in brengen.

Allereerst verzorgde de regering arbeidswetgeving die vakbonden en werknemers beschermde tegen de werkgever. ${ }^{19}$ Vervolgens stimuleerden de autoriteiten in 1936 de oprichting van de vakcentrale CTC, waarmee zij intensief zouden gaan samenwerken. De vervlechting tussen de Liberale Partij en de CTC strekte beiden tot voordeel, Voor de Liberale Partij was de versterking van de politieke legitimatie de voornaamste drijfveer om toenadering te zoeken tot de vakbeweging. ${ }^{20}$

In ruil voor de politieke steun van de CTC aan de Liberalle Partij, intervenieerde de president vaak hoogstpersoonlijk in arbeidsconflicten ten gunste van de vakbonden. ${ }^{21}$

Toch was deze vakbondspolitiek die voor de vakbeweging mogelijkheden bood voor "political bargaining" $\left({ }^{22}\right)$, in Colombia, in tegenstelling tot andere Latijnsamerikaanse landen, geen lang leven beschoren. Op een aantal essentiële punten week de economische en politieke situatie in Colombia namelijk af van die van andere landen in Latijns Amerika. De Grote Crisis van 1929 had de export- en importcapaciteit van de Colombiaanse economie aanzienlijk aangetast. Een krachtig overheidsingrijpen in de economie was onvermijdelijk met het oog op het bezweren van de economische en de daaruit voortvloeiende politieke crisis. Maar in tegenstelling tot bijvoorbeeld Brazilië en Mexico, waar de staat een doelgerichte industrialisatiepolitiek voerde en zich opwierp als belangrijk ondernemer, had de staatsinterventie in Colombia een bescheiden en tijdelijk karakter. Binnen de economische en politieke elite heerste een opmerkelijke eensgezindheid met betrekking tot de noodzaak om de export-sector, en wel met name de export van koffie die de voorgaande decennia de motor van de Colombiaanse economie was geweest, nieuw leven in te blazen. ${ }^{23}$ De staat fungeerde

19 Wet no. 83 van 1931 verleende werknemers het recht om zich te organiseren en stelde geldboetes op elke poging om de uitoefening wan dit recht te dwarsbomen.

20 Urrutia Montoya M. Historia del Sindicatismo en Colombia, Medellin 1976, p. 135.

21 Vooral president Lopez Pumarejo (1934-1940 en 1942-1945) dlankte zijjn populariteit in vakbondskringen aan dergelijke spectaculaire interventies.

Pecaut D. l'Ordre er la Volence, Paris 1987, pp. 150-151.

22 Zoals al eerder in dit proefschrift is vermeld, is de term afkomstig van James Payne, Labor and Politics in Pent: The System of Political Bargaining, New Haven 1965.

23 Deze consensus hing samen met het feit dat de koffiesector in Colombiaanse handen was. De winsten uit de koffie-export werden geinvesteerd in de transport-sector of in de industrie. In Colombia ontstonden nauwelijks conflicten tussen een agro-export "bourgeoisie" die met handen en voeten gebonden was aan de buitenlandse clièntele en een ontluikende industriële "bourgeoisie" van nationale herkomst:

Pécaut (1987), a.w. pp. 56 en 57. Bergquist (1986), a.w. p. 304. Cardoso F.H. and Folletto E. Dependency and Development in Latin America, Berkely 1979, pp. 97 en 98. 
als "crisis-manager", verdeelde de geslonken deviezenwoorraad en symboliseerde de nationale eenheid in een moeilijke periode, maar diende zijn economische politiek vooral af te stemmen op de verwezenlijking van de genoemde doelstelling: het herstel van de export-economie. In 1936 hadden de opbrengsten uit de koffie-export wederom het niveau van 1928 bereikt, hetgeen toe te schrijven was aan de monetaire politiek van de overheid, de produktieverhogingen in Colombia en de produktiebeperkingen in Braziliê, waardoor Colombia een groter deel van de wereldmarkt kon veroveren. ${ }^{34}$ Intussen had de industrie geprofiteerd van de devaluaties en de protectionistische maatregelen die de overheid in eerste instantie had genomen om de export te bevorderen en de betalingsbalans in evenwicht te houden. Particuliere ondernemers gingen zich toeleggen op de verbreding van de import-substitutie-industrialisatie - een bittere noodzaak na het uitbreken van de Tweede Wereldoorlog, aangezien de toevoer van industriële produkten uit Europa en de Verenigde Staten nagenoeg stagneerde en richtten met dat doel belangenorganisaties op. ${ }^{25}$ Nu de economie zich leek te herstellen, was de staatsinterventie overbodig geworden. De economische elite had aan het begin van de jaren dertig geprofiteerd van het actieve overheidsingrijpen( ${ }^{36}$ ), maar drong er nu bij de staat met succes op aan om zich terug te trekkenuit de economie. Aan het eind van de oorlog had het liberale ontwikkelingsmodel zijn plaats in de Colombiaanse economische politiek heroverd: "laissez faire" was het wachtwoord van de economische elite.

De protectie van de vakbeweging door de staat correspondeerde volstrekt niet met de liberale economische politiek. De bourgeoisie schilderde de vakbeweging af als een "blauwe boordenaristocratie" die begunstigd werd door de arbeidswetgeving. De voortdurende concessies van de staat aan de looneisen van de vakbonden bedreigden de economische ontwikkeling en vertraagden het doorvoeren van een sociale politiek voor de overige volksklassen. ${ }^{27}$ Bovendien leefde onder de elite de vrees dat de vakbeweging haar innige contacten met de regeringspartij zou misbruiken om niet alleen in economisch maar vooral ook in politiek opzicht steeds meer macht te verwerven, ${ }^{28}$

24 Pecaut (1987), a.w. pp. 104 en 121.

25 De bekendste van deze organisaties was de, in 1942 opgerichte, Nationale Vereniging van Industrièlen (ANDI).

26 Daniel Pécaut verwoordt het als wolgt: "Ces dernières (i.e. les fractions Economiques dirigeantes) n'ont accepté l'interventionisme etatique que comme un instrument sur l'usage duquel ils ont leur mot a dire." P'ecaut (1987), aw. pp. 204-205:

27 Pécaut (1987), a.w. pp. 277-278. Met de arbeidswetgeving die overigens vooral negatieve consequenties had voor de vakbeweging, zoals we hieronder nog zullen zien, werden Wetsdecreet no. 2350 van 1944 en Wet no. 6 van 1945 bedoeld. Deze Wetten regelden onder andere de "ftiero sindicall" (de bescherming van vakbondsleiders tegen ontslag) en een aantal sociale voorzieningen, zoals de vaststelling van maximumwerktijden, de uitkering van ongevallenpremies etc.

28 Ongetwijfeld was deze vrees tijdens de Tweede Wereldoorlog overtrokken. De CTC, gebrand op het behoud van haar geprivilegeerde positie, legde een voorbeeldig conformisme aan de dag, repte met geen woord over de klassenstrijd en speelde het politieke spell volgens de institutionele regels. De Communistische Partij die de nodige invloed binnen de CTC uitoefende, drong zelfs aan op een alliantie met de nationale bourgeoisie, 
Ondanks het feit dat de nieuwe arbeidswetgeving in de ogen van de elite nog teveel bescherming bood aan de vakbeweging, plaveide zij de weg voor een vakbondspolitiek die wel congruent was aan het liberale economische ontwikkelingsmodel en waarbij het mes zowel aan de pollitieke als aan de economische kant sneed. De hoeksteen van Wetsdecreet no. 2350 van 1944 en Wet no. 6 van 1945 was een grondige herziening van de organisatiestructuur. Voortaan zouden collectieve onderhandelingen uitsluitend plaats vinden op het niveau van de onderneming tussen de werkgever en de vakbond van die onderneming ("sindicato de base"). De hoogte van de arbeidslonen zou niet langer afhankelijk zijn van de pressie die de vakbeweging kon uitoefenen op de staat maar zou tot stand komen volgens de Wetten van het vrije marktmechanisme en recht evenredig zijn aan de economische vitaliteit van de onderneming in kwestie. Doordat de werkgever de aangewezen onderhandelingspartner voor de vakbond was en doordat de versnipperde organisatiestructuur zich eenvoudig niet leende voor het onderhouden van contacten op centraal niveau met de autoriteiten, zouden de vakbonden automatisch hun politieke engagement verliezen en zich uitsluitend toeleggen op het behartigen van de sociaal/economische belangen van hun leden.

De tweede belangrijke pij]er van het nieuwe vakbondsbeleid was de uitbreiding van het concept van "publieke diensten", waarin stakingen verboden waren. Met deze maatregel trachtte de heersende elite met succes de strijdvaardigheid van enkele grote vakbonden in de vervoerssector te breken. ${ }^{20}$

De beoogde de-politisering van de vakbeweging zorgde voor enige vertraging in de praktische verwezenlijking van de wetgeving. De Liberale Partij was niet bereid om zonder slag of stoot het verlies van haar politieke bondgenoot, de CTC, te accepteren en vreesde niet ten onrechte trouwens - dat de Conservatieve Partij zou proberen om invloed te verwerven in de "a-politieke" ondernemingsvakbonden. Pas nadat de Liberale partij in 1945 een gevoelige verkiezingsnederlaag had geleden en plaats had moeten maken voor de Conservatieve Partij, kon het verbod van vakbondspluralisme op centraal niveau worden opgeheven. ${ }^{20}$

De CTC werd niet geheel ontmanteld maar was geen schim meer van de vakcentrale die zich voor en tijdens de oorlog had mogen verheugen in de steun van de regeringspartij

teneinde gezamenlijk de opbouw van de Colombiaanse economie ter hand te nemen. Pecaut (1987) a.w. pp. $210-229$.

Toch was, zoals Pécaut terecht opmerkt, de enkele dreiging wan een politieke machtsovername voor de elite voldoende om de verstrengeling tussen stalat en vakbeweging met groot wantrouwen te bezien: "Mais la menace vient surtout de l'influence que les syndicats pourcaient conquérir a lintérieur du parti liberal, par la prise de parole ou par la défection (..)." (cursivering HvdW) Pecaut (1987), aw, p. 211.

De "wilde" staking van de vakbond van rivierarbeiders FEDENAL, in 1945 (zie voor details Urrutia, a.w. pp. 190-192), de radicalisering van de CTC vlak na de oorlog en de atantrekkingskracht die de grillige populist Jorge Eliécer Gaitan had woor de vakbondsbasis, gaven voedsel aan de angst van de elite.

29 Vgl. Pécaut (1987), aw, p. 212: "(\%) extension de la notion de service public à certaines activités privées, telle la navigation sur le Rio Magdalena - ce qui revient a priver la trop remuante Fedenal du droit de grève."

30. Het verbod van vakbondspluralisme op het nivean van de onderneming is, zoals we nog zullen zien, tot op de dag van vandaag van kracht. 
en moest bovendien de concurrentie van een nieuwe vakcentrale, de UTC, dulden. Deze UTC die veel ondernemings-vakbonden in de industriêle sector onder haar leden telde en het produkt was van pogingen in katholieke kringen om een tegenwicht te creëren tegen de, door de communisten geïnfiltreerde CTC, onderhield weliswaar betrekkingen met de clericale Conservatieve Partij, maar van een nawwe verstrengeling, zoals die tussen de CTC en de Liberale Partij had bestaan, was toch geen sprake. Allereerst symboliseerde de UTC de afsluiting van het tijdperk van "political bargaining".

Ongetwijfeld strookte de vernieuwde vakbeweging uitstekend met de wensen van de economische en politieke elite in Colombia, maar het zou onjuist zijn on haar totstandkoming uitsluitend toe te schrijven aan de eensgezinde en doeltreffende politiek van de machthebbers. Het feit dat de vakbondspolitiek van de regering nawwelijks tegenstand ondervond van de kant van de arbeidersbevolking, kan uitsluitend verklaard worden tegen de achtergrond van bepaalde demografische en sociale ontwikkelingen. Opnieuw zouden de werknemers in de koffie-sector een stempel drukken op de koers van de vakbeweging.

Tegen het eind van de Tweede Wereldoorlog was de samenstelling van de beroepsbevolking in Colombia aan grote veranderingen onderhevig. Het liberale ontwikkelingsmodel had niet alleen een grondige wijziging van de vakbondsstructuur tot gevolg, maar leidde ook tot op zekere hoogte tot het terugdraaien van progressieve landhervormingen die in 1936 door president Lopez Pumarejo door middel van het uitvaardigen van wetgeving tot stand waren gebracht. Wet no 100 van 1945 verbood pachters om meerjarige gewassen - waaronder koffie te verbouwen; hetgeen hen beroofde van hun belangrijkste bron van inkomsten. In het algemeen noopte het proces van groeiende landconcentratie kleine boeren om hun land te verlaten en hun geluk te gaan beproeven in de stad. Tenslotte intensiveerde het uitbreken van de "Violencia" $\left({ }^{32}\right)$ de migratie van het platteland naar de steden. ${ }^{33}$

31 Vergelijk Pécaut (1987) a.w. p. 293: "Alors que la crise de VEtat interventionniste entraine avec elle la crise des formes d'action de la CTC, la suprématie de lidéologie libérale du developpement sons-tend la constitution d'un syndicalisme lié a l'entreprise et négociant dans ce cadre: le syndicalisme catholique reprếsente un premier pas dians cette direction."

Enige bladzijden verder merkt Pecaut op: 'Nous l'avont cependant suggếré plus haut, elle (i.e. la naissance de PUTC) traduit aussi ta crise du modele de political bargaining' a quioi la CTC a lie son sort depuis 1936." Pecaut, a.w: pp. $297-298$.

32. De moord op de populaire presidentskandidaat Jorge Gaitân op 9 april 1948 in Bogotả markeert het begin van de Violencia. De moord had een complete volksopstand tot gevolg. Binnen 24 war verspreidden de gewelddadigheden zich over een groot gedeelte van het land.

De Violencia is een uiterst gecompliceerd fenomeen. Een uitvoerige behandeling van deze tragedie die Colombia meer dan twintig jaar heeft geteisterd, ligt buiten het bestek wan dezie studie. Aan de Violencia lagen vooral sociale conflicten op het platteland ten grondslag die evenwel vertaald en gekanaliscerd werden in een machtsstrijd tussen de Conservatieve en de Liberale Partij. Verwezen wordt naar de werken van Gurmain G./Fals Borda O./Umaña Luna E. La Violencia en Colombia, Bogota 1962, Leal Buitrago P Estado y Poltica en Colombia, Bogotá 1984 en Oquist P. Violence, Conflict and Politics in Colombia, New York 1980. 
Aanvankelijk hadden de industriele ondernemingen onvoldoende emplooi voor deze verse stroom van arbeidskrachten, maar de industriële groei van na de Oorlog stelde velen in de gelegenheid om een drastische omscholing door te maken. Charles Bergquist schetst hoe de a-politieke vakbeweging naadloos aansloot bij de conservatieve mentaliteit van deze nieuwe werknemers: "It (i.e. the flight of rural workers from the Violence to the security of the cities) also furnished the growing industrial sector of the Colombian economy with a flood of cheap, and culturally conservative, new workers. These workers, embued with Catholic precepts and individualist values, proved especially receptive to the blandishments of the new unionism. They furnished the economic cadres for the UTC:

De maatschappelijke omstandigheden en de politieke en economische krachtsverhoudingen in Colombia leidden tot een specifieke vakbondssituatie die afweek van andere Latijnsamerikaanse landen, zo kan de voorlopige conclusie luiden. In tegenstelling tot bijvoorbeeld Braziliề en Mexico, waar de staat directe controle uitøefende over een sterk gecentraliseerde vakbeweging, trachtte de Colombiaanse regering de macht van de vakbeweging te beknotten door haar juist te versnipperen in bedrijfsgebonden vakbonden. Dit beleid werd in 1950 gecodificeerd in de Código Sustantivo del Trabajo en heeft ongeveer twintig jaar lang aan zijn doel beantwoord.

De toezichthoudende organen van de ILO hebben de regering regelmatig gewezen op de discrepanties tussen de arbeidswetgeving en de rechtspraktijk in Colombia enerzijds en de internationale normen op het gebied van de vrijheid van vakvereniging anderzijds. Hun kritische kanttekeningen en de reacties van de regering vormen het onderwerp van de volgende paragrafen. ${ }^{35}$

33. In 1938 wertegenwoordigde de plattelandsbevolking nog $70,9 \%$ van de totale bevolking. In 1951 was dit percentage teruggelopen tot $61,1 \%$. De bewolking van plaatsen met meer dan 10,000 inwoners groeide gedurendle die periode van 15,4 naar $25,5 \%$, die van plaatsen met meer dan 100,000 inwoners van 7,1 naar $14,7 \%$ :

Cijfers zijn ontleend aan Pécaut (1987), a.w. p. 240.

34. Bergquist (1986), aw, p. 368. Met deze overweging brengt Bergquist de sociale ontwrichting in de koffie-sector in verband met de dociele houding van de valkbeweging. Ook Pecaut (1989, a.w. pp. 282-293) onderkent dat de rurale oorspriong wan veel werknemers in de industriële sector van invloed is geweest op de voorkeur voor "a-politieke" vakbonden en de politieke radicalisering van de vakbeweging heeft belemmerd.

35 Met name de analyse van de arbeidswetgeving levert enkele problemen van chronologische aard op. De Colombiaanse arbeidswetgeving is een bonte verzameling van waarborgen en rechten enerzjjds en controle. en repressie-instrumenten anderzijds. Hoewel sommige bepalingen nog steeds van kracht zijn, zijn zij als controlemiddlell in onbruik geraakt. Aangeżen Colombia echter pas in 1976 de ILO-Verdragen mos. 87 en 98 geratificeerd heeft; heeft het Comite van Deskundigen pas vauaf die datum aanmerkingen kunnen maken op de Colombianse arbeidswetgeving. Ik heb ervoor gekozen om de ontwikkeling van de vakbondssituatie in Colombia in te delen in drie periodes en het (recente) commentaar van het Comité te koppelen aan de vakbondspolitiek die voor elk van deze periodes kenmerkend was. 
De Código Sustantivo del Trabajo (hierna: CST) die, hoewel verscheidene keren aangevuld en aangepast door Wetsdecreten, tot op de dag van vandaag van kracht is, vormt de juridische basis voor de driehoeksverhouding tussen staat, werkgevers(-organisaties) en vakbonden. Deze Arbeidswet bekrachtigde het beleid van de regering ten aanzien van de vakbeweging dat in de loop van de Tweede Wereldoorlog gestalte begon te krijgen en al enigszins uitgestippeld was in Wetsdecreet no. 2350 (1944) en Wet no. 6a (1945). Het ingrijpen in de organisatiestructuur vormde het belangrijkste element van de vakbondspolitiek (4.1). Deze organisatiestructuur kon uitsluitend in stand gehouden worden, indien aan vakbonden, wier existentie de structuur dreigde te doorkruisen, rechtspersoonlijkheid werd geweigerd (4.2). Hoewel de organisatiestructuur op zichzelf al het ontplooien van politieke activiteiten ontmoedigde, achtten de autoriteiten het noodzakelijk om het verbod van politieke activiteiten expliciet in de Arbeidswet op te nemen. Deze bepalingen komen in 4.3 en 4.4 aan de orde. In 4.5 wordt uiteengezet hoe de autoriteiten rechtstreeks controle trachtten uit te oefenen over de vakbonden. Tenslotte wordt in 4.6 aandacht besteed aan de stakingsverboden in de publieke sector.

\subsection{De onganisatiestructuur van de vakbeweging}

Art. 356 van de CST noemt de ondernemingsvakbond (de zgn. "sindicato de base") naast andere vormen van vakorganisaties, waarbij werknemers zich kunnen aansluiten. ${ }^{36}$ Deze nevenschikking van organisatievormen verhult het belang van de sindicato de base. Krachtens art. 357 CST geniet de sindicato de base een voorkeurspositie bij collectieve onderhandelingen, bij vertegenwoordiging in alle arbeidsverhoudingen en bij het aanwijzen van (vakbonds)leden in bemiddelings- en arbitragetribunalen ${ }^{37}$ Voorts bepaalt art. 357 dat binnen een onderneming slechts één sindicato de base mag opereren, met andere woorden: de Colombiaanse Wet

36 De andere organisatievormen zijn:

a. de bedriffstak-bond, die samiengesteld is uit werknemers die in eenzelfde industriële bedriffistak werkzaam zajini.

b. de beroepsgenoten-bond ("gremial") die bestaat uit werknemers die eenzelfde beroep, ambt of specialisme uitoefenen.

c. een restcategorie: bonden die bestaan uit werknemers die verschillende beroepen uitoefenen.

37 Ook in numeriek opzicht is de sindicato de base sinds de Tweede Wereldoorlog enorm in belang toegenomen. In 1980 maakten de sindicatos de base $53,8 \%$ van het totale aantal valkbonden uit (tegen $34,2 \%$ in 1947). De "gremiales" en de bedrijfstak-bonden namen in 1980 resp. $37,5 \%$ en $8,6 \%$ woor hun rekening. De laatste jaren schijnt het percentage "gremiales" gegroeid te zijn, ten koste van de sindicatos de base. Bron: Londoño Botero R. La Estructura Sindical Colombiana en la Decada del 70 in: Sindicalisma y Folitica Económica Gomez Buendía H./Londoño Botero R./Perry Rubio G. (editores), Bogotå 1986, p. 107. 
kent een verbod van vakbondsparallellisme of, anders gezegd, een verplicht vakbondsmonopolie op het niveau van de onderneming.

De wettelijk geregelde organisatiestructuur lijkt op het eerste gezicht vakbonden voldoende ruimte te bieden om de krachten te bundelen en de positie ten aanzien van werkgevers en autoriteiten te versterken. Allereerst hebben "sindiactos de base" en "gremiales" het recht om zich te verenigen in (con)federaties. ${ }^{30}$ In de tweede plaats lijkt het verplichte vakbondsmonopolie juist een goede waarborg tegen een overmatige versmippering van (kleine) vakbonden binnen én onderneming. Deze garanties zijn echter door andere regelingen uitgehold en, zoals nu aangetoond zal worden, grotendeels illusoir.

De vrijheid van vakbonden om zich te organiseren in (con)federaties is een gratuite gebaar, aangezien (con)federaties op grond van art. 417 lid 1 niet mogen staken. Bovendien geldt een minimum-aantal van 10 vakorganisaties voor de oprichting van een lokale of regionale federatie en van 20 vakorganisaties voor de oprichting van een nationale federatie. ${ }^{* 0}$ Beide laatstgenoemde regelingen beogen uiteraard een bundeling van krachten van de vakbeweging tegen te gaan.

Het Comité van Onafhankelijke Deskundigen heeft, vanaf het moment dat Colombia Verdrag no. 87 ratificeerde $\left({ }^{4}\right)$, de bovengeschetste wettelijke ingrepen in de organisatiestructuur van kritisch commentaar voorzien. Het Comité acht het verbod van vakbondspluralisme op het niveau van de onderneming en de vereiste minima voor de oprichting van een federatie niet verenigbaar met het, in art. 2 van het verdrag verankerde, recht van werknemers om zich aan te sluiten bij een organisatie naar eigen keuze. ${ }^{42}$ Het stakingsverbod aan het adres van (con)federaties strookt niet met het recht van vakorganisaties om de eigen activiteiten to organiseren, aldus het Comite..$^{33}$

In een poging om de Colombiaanse wetgeving te rechtvaardigen in het licht van de internationale normen op het gebied van de vakverenigingsvrijheid, volgt de regering een tweetal redeneringen. Tot halverwege de jaren tachtig beroept de regering zich in haar commentaren

38 Het verbod op vakbondsparallellisme ten aanzien van vak-centrales werd in 1949 bij Wetsdecreet opgeheven. Moncayo en Rojas zien deze maatregel als een doelbewuste poging van de toenmalige regering-Ospina Perez om de macht van de CTC die in de luwte van het vakbondsmonopolie tot bloei was gekomen, te breken, de weg te plaveien voor de arkenning van de rechtspersoonlijkheid wan de UTC en, in het algemeen, door het woeren van een verdeel- en heerspolitiek, de macht van de wakbeweging te beteugelen. Moncayo V.M./Rojas F. Luchas Obreras y Poltica Laboral en Colombia, Bogotá 1978, pp, 89-94.

$39 \operatorname{CsT}_{\text {, arti. } 417-426 .}$

40 Deze maatregel dateert van een later tijdstip (Wetsdecreet no. 1469 van 1978, artt. 27 en 28). Aangezien hij thematisch thuishoort bij de categorie "staatsinterventies in de organisatiestructuur", heb ik besloten hem op deze plaats aan de orde te stellen en af te ziem van een strikt chronologische behandeling.

41. De ratificatie van het verdrag werd op 16-11-1976 geregistreerd.

42. Direct Requests 1981, pp. 6-7 en Direct Requests 1983, pp $7-8$.

Art. 6 van Verdrag no. 87 verklaart art. 2 van overeenkomstige toepassing voor (con)federaties.

Direct Requests 1981, p. 7; Direct Requests 1983, p. 8. 
op de aanmerkingen van het Comite, op de specifieke nationale situatie. Het betrekkelijk lage ontwikkelingspeil van de Colombiaanse industrie brengt met zich mee dat de meeste bedrijven een gering aantal werknemers in dienst hebben. Een versnippering van vakbonden op het niveau van de onderneming zou de betrokken werknemers eerder schaden dan baten, aangezien het een bevredigende regeling van de arbeidswoorwaarden voor alle werknemers van de onderneming in de weg zou staan. ${ }^{4}$ Bovendien kan men zich afvragen of zeer kleine vakbonden niet extra vatbaar zijn voor bevoogding door de werkgever. ${ }^{45}$

Ook (con)federaties dienen een aanzienlijk aantal werknemers te vertegenwoordigen teneinde de krachten te bundelen en slagvaardig te kunnen optreden. ${ }^{46}$ Daarbij merkt de regering nog op dat een ontwikkelingsland uitsluitend een coherente arbeidspolitiek kan voeren, indien de arbeidersklasse een gesloten front vormt. Men krijgt de indruk dat de regering verwijten aangaande het voeren van een versnipperingspolitiek een slag voor wil zijn door zichzelf juist te presenteren als een groot voorvechter van vakbondseenheid.

Wordt het feit dat Colombia een ontwikkelingsland is in het voorgaande aangevoerd als argument om de vakbeweging wat extra te steunen, bij het stakingsverbod voor (con)federaties hanteert de regering het juist als excuus voor de restrictieve maatregel. De nationale economie van een land dat nog geen bevredigend ontwikkelingspeil heeft bereikt, zou teveel schade lijden, indien men (con)federaties, die immers een groot aantal vakorganisaties vertegenwoordigen, zou toestaan te staken. De regering voegt hier nog de belerende opmerking aan toe dat de ILO rekening dient te houden met het ontwikkelingsniveau van de lid-staten, aangezien het nemen van veel maatregelen afhankelijk is van de beschikbare middelen en de duurzaamheid van de nationale economie.

Het Comité toont zich niet onder de indruk van de repliek van de regering. Na kennis genomen te hebben van de argumenten, dringt het bij de regering erop aan de Wet te wijzigen en het stakingsrecht zo min mogelijk te beperken.

Met betrekking tot de rechtvaardiging van ingrepen in de organisatiestructuur, lijkt de regering in de Memoria van 1986 van tactiek te zijn veranderd. In de eerste plaats wijst zij erop dat de vakbeweging zelf, tijdens besprekingen over wetswijzigingen in 1984, zich bepaald geen voorstander heeft getoond van de opheffing van het verbod van vakbondsparallellisme, noch van de reductie van het aantal vakorganisaties, benodigd voor de oprichting van een federatie. In de tweede plaats strookt de dikwijls beweerde en ook door de ILO gesuggereerde versnippering van de vakbeweging niet met de werkelijkheid. De CUT, die in november 1986 is opgericht, is een samenwerkingsplatform van de vier grote centrales. Bovendien verhoedt het verbod van co-existentie van twee of meer sindicatos de base binnen én onderneming

44 Memoria sobre el Convenio No. 87, 1982, p. 3.

45 Memoria sobre ell Convenio No. 87, 1986, $p_{i} 7$.

46 Memoria sobre el Convenio No. 87, 1984, p. 11.

47 Memoria 1982, p. 7.

48. Observation 1985, onder (3). 
niet dat binnen die onderneming werknemers lid zijn van bedrijfstak-bonden en gremiales. Tenslotte opereren er bedrijfstak-bonden die het gehele nationale grondgebied bestrijken."

Vooral voor de beide laatste argumenten toont het Comite zich wel gevoelig. In zijn Observation van 1987 erkent het dat de door de regering geschetste feitelijke organisatievormen tot op zekere hoogte de negatieve effecten van een stringente organisatiestructuur verzachten. ${ }^{\text {so }}$

Niet alleen de restricties van het recht op federatievorming, maar ook de aantasting van de positie van de ondernemings-vakbond doet de vraag rijzen of de bewering van de regering dat zij juist de positie van de vakbeweging wenst te versterken (zle hierboven, p. 159) wel helemaal oprecht is.

Art: 471 lid 1 CST bepaalt dat de arbeidswoonwaarden van een Collectieve Arbeidsovereenkomst gelden voor alle werknemers van een onderneming, indien de $\mathrm{CAO}$ is overeengekomen met een vakbond die meer dan éen-derde van de werknemers van de onderneming vertegenwoordigt. Deze bepaling lijkt inderdaad te duiden op een bescherming van de ondernemingsvakbond; maar valt moeilijk te rijmen met art. 481 CST dat de werkgever het recht toekent om, buiten de vakbond om, accoorden (zogenaamde "pactos collectivos") te sluiten met nietgeorganiseerde werknemers.

De ILO heeft verscheidene klachten ontvangen van vakorganisaties die stelden dat de praktijk van het sluiten van "pactos" de onderhandelingspositie van vakbonden ernstig ondermijnde, vooral gezien de uitlatingen van ambtenaren van het Ministerie van Arbeid dat een CAO niet gesloten kon worden, indien er al een "pacto" bestond, maar dat, omgekeerd, het van kracht zijn van een CAO geen beletsel vormde voor het sluiten van "pactos".: De regering ontkende dat het Ministerie van Arbeid actief het sluiten van "pactos collectivos" bevorderde en refereerde daarbij aan het grote aantal CAO's dat jaarlijks in Colombia werd afgesloten. ${ }^{52}$ Onder verwijzing naar art. 4 van Verdrag no. 98 dat regeringen verplicht om matregelen te nemen teneinde vrijwillige onderhandelingen tussen werkgevers- en werknemersorganisaties aan te moedigen, en de Aanbeveling inzake Collectieve Overeenkomsten, 1951 (no. 91) nam het Comité inzake de Vrijheid van Vakvereniging het volgende standpunt in: in bepaalde gevallen kan de directe onderhandeling tussen een onderneming en diens werknemers, waarbij representatieve organisaties gepasseerd worden, afbreuk doen aan het beginsel dat onderhandelingen tussen werkgevers- en werknemersorganisaties aangemoedigd en bevorderd dienen te worden.

49 Memoria 1986, pp. $1-2$

50 Observation 1987, onder (1). De regering heeft nog niet gereageerd op de aanmerkingen op de stakingsrestricties. In de Observation van 1989 zijn de aanmerkingen op het verplichte vakbondsmonopiolie verdwenen en refereert het Comité uitshuitend aan de stakingsverboden aan het adres wan (con)federaties.

51 Zie o.a. Case No. 734, 143 e Rap. $\$ 61$.

52 Case No: 734, 143e Rap. $\$ 62$.

53 Case No. 734, 143e Rap. $\$ \$ 63$ en 65. Case No. 919, 194e Rap. $\$ 358$. 
Het spreekt voor zichzelf dat de wettelijk opgelegde organisatiestructuur een dode letter zou zijn, indien de staat niet over de macht zou beschikken orn een vakbond die deze organisatiestructuur zou dreigen te doorkruisen, het bestaansrecht te ontzeggen.

Art. 366 van de CST verleent de Minister van Arbeid de bevoegdheid om een vakbond, waarvan de statuten in strijd zijn met de Grondwet, de Wetten of de goede zeden, rechtspersoonlijkheid te weigeren. . $^{\text {. }}$

Het Comite van Deskundigen is van mening dat deze bevoegdheid in feite neerkomt op een vereiste van voorafgaande toestemming die in strijd is met art. 7 , in samenhang met art. 2 van Verdrag no. 87. Een dergelijk vereiste kan yoor een betrokken vakbond extra nadelig uitpakken, nu de erkenning van rechtspersoonlijkheid, krachtens art. $372 \mathrm{CST}$, onontbeerlijk is voor zijn functioneren. ${ }^{55}$ Deze kwestie is aanleiding geweest tot een spiegelgevecht tussen Comité en regering. In haar Memoria van 1982 gaat de regering volledig voorbij aan de inhoudelijke kritiek van het Comité door een exposé te geven over de juridische status van de rechtspersoon, in vergelijking tot de natuurlijke persoon ${ }^{56}$ Niet tevreden met dit ontwijkende antwoord, vraagt het Comitế de regering concreet aan te geven of en zo ja, welke beroepsmogelijkheden openstaan tegen een weigering van rechtspersoonlijkheid. ${ }^{57}$ De regering verwijst naar de herziene Wet inzake Administratieve Geschillen $\left({ }^{(58}\right)$, die voorziet in administratief beroep (art. 50) en, indien de administratieve beroepsmogelijkheden zijn uitgeput, in een rechtsgang tot de Raad van State (art: 85). ${ }^{87}$ Het Comité besteedt nauwelijks aandacht aan de administratieve beroepsmogelijkheden en geeft te kennen dat een beroep bij de rechter uitsluitend adequate waarborgen biedt, indien de rechter niet alleen zich ervan kan vergewissen dat de Wet correct is toegepast, maar ook de zaak inhoudelijk kan beoordelen en de gronden waarop de beschikking rust, kan vaststellen in het licht van de bepalingen van Verdrag no. $87 . .^{\circ}$ In reactie op deze Observation geeft de regering aan dat de rechter een inhoudelijk onderzoek moet instellen naar de verenigbaarheid van de beschikking met de Wet, naar de zorguldigheid van de motivering en tevens moet nagaan of de Minister van Arbeid al of niet zijn bevoegdheden heeft overschreden. ${ }^{61}$ Het Comite constateert dat de rechter in ieder geval de beschikking inhoudelijk kan beoordelen en lijkt zich hiermee voorlopig tevreden te stellen.

54 Zie ook art. 5 van Wetsdecreet no. 1469 (1978). Art. 423 CST verklaart art. 360 van overeenkomstige toepassing voor (con)federaties.

55 Direct Requests, 1981, pp. 6-7.

56. Memoria 1982, p. 4 .

57 Direct Requests 1983, p. 8.

58 Codigo Contencioso Administrativo (Decreto No. 1. de 1984), in werking getredèn op 01-03-1984.

59 Memoria 1984, p. 11.

60 Observation 1985, onder (1).

61 Memoria 1986, $\mathrm{p}_{n} 4$

62 Observation 1987, onder (1). 


\subsection{Het verbod van (partij)politieke activiteiten}

Het vaste voornemen van de economische en politieke machthebbers na de Tweede Wereldoorlog om definitief af te rekenen met de nawwe vervlechting tussen staat en vakbeweging (met name tussen de Liberale regering en de CTC) en het systeem van "political bargaining" te vervangen door een louter sociaal/economische belangenbehartiging, komt onverbloemd naar voren in art. 378 van de CST. Dit artikel verbiedt "alle vakorganisaties zich te mengen in partij-politiek (...), door zich te laten vertegenwoordigen in partijcongressen of -besturen, (...) door politieke partijen financieel te steunen, (...) of door kandidaten voor te dragen voor politieke verkiezingen": ${ }^{3}$

De verantwoordelijkheid voor de bestrijding van misbruiken door vakbonden die hun voornaamste doelstelling - de economische en sociale vooruitgang van hun leden - uit het oog dreigen te verliezen, dient bij de rechterlijke macht teliggen, zo luidt het standpunt van het Comité van Deskundigen: ${ }^{6}$ Aanvankelijk gaat de regering niet inhoudelijk in op de (on)toelaatbaarheid van een verbod van politieke activiteiten, maar weidt zij uit over de scheiding der machten en de daarmee corresponderende taakverdeling. De uitvoerende macht, in casu de minister van arbeid, moet proberen te voorkomen dat de vakbond zich inlaat met politieke activiteiten, aangezien de bescherming van vakbonden en hun leden - de ratio van het verbod van politieke activiteiten - een snelle en doeltreffende actie vergt. Indien de vakbond in het kwaad volhardt, kan de minister overgaan tot repressieve maatregelen, krachtens art 380 , lid 1 sub 2 , nadat hij de goedkeuring van de rechter heeft verkregen. Het Comite negeert de uiteenzetting over de drie machten-leer en dringt er bij de regering op aan de Wet te wijzigen. ${ }^{60}$ De regering verzekert het Comite dat art. 379 CST niet de ideologische keuze van vakbonden wil beïnloeden, noch hun wil beletten over politieke aangelegenheden een standpunt in te nemen. De bepaling beoogt uitsluitend een grenswervaging tussen politiek en vakbondskwesties tegen te gaan, aangezien vakbonden die een verlengstuk vormen van een politieke partij hun onpartijdigheid tegenover de publieke opinie en hun leden verliezen. ${ }^{7 ?}$ In het bijzonder keert het artikel zich tegen het gebruik van vakbondscontributies voor subsidièring van politieke partijen, aangezien deze contributies hier stellig niet voor bestemd zijn.

Het verweer van de regering kan het Comité niet overtuigen. Nadat de regering verzuimd heeft om in haar Memoria van 1988 op de aanmerkingen van het Comité te reageren, blijft

63 De artt. 12 en 50 van Resolutie no. 4 van 1952 en art. 16 van Wetsdecreet no. 2655 (1954) hebben een gelijke strekking.

64 Direct Requests 1981 , p. 7 onder (2).

65 Memoria 1982, pp. 5-6.

66 Observation 1985, onder (3).

67 Memoria 1985, p. 11 .

68 Memoria 1986, p. 6. 
het Comité in zijn Observation van 1989 hameren op de noodzaak om het verbod van politieke activiteiten uit de Wet te schrappen.

\subsection{Nationaliteitsvereisten in verband met vakbondslidmaatschap}

Het verbod op het ontplooien van politieke activiteiten komt, althans tot op zekere hoogte, voort uit de vrees van de autoriteiten voor ondermijning van de bestaande maatschappelijke en politieke orde. Eenzelfde angst voor subversie ligt ten grondslag aan het stellen van nationaliteitsvereisten in verband met vakbondslidmaatschap, zodat het voor de hand ligt om deze problematiek op deze plaats te behandelen.

Conform art. 384 CST moet minimaal $2 / 3$ van het ledenbestand van een vakbond Colombiaan zijn. Het Comité van Deskundigen kenschetst deze bepaling als strijdig met het recht van werknemers, zonder enig onderscheid, om zich aan te sluiten bij organisaties van hun eigen keuze. ${ }^{\text {To }}$

De Colombiaanse regering verwijst wederom naar de bijzondere positie, waarin ontwikkelingslanden verkeren. Aan de ene kant moet juist een ontwikkelingsland werknemers in de gelegenheid stellen om zich te verenigen teneinde hun belangen te verdedigen. Aan de andere kant beschikken buitenlandse werknemers niet over een gedegen kennis van de economische situatie van het land, zodat de staat moet voorkomen dat zij, door het uitoefenen van onevenredig zware pressie, het economische ontwikkelingsbeleid doorkruisen."

De Memoria van 1984 bevat enkele overwegingen, waartussen iedere samenhang ontbreekt. Om te beginnen deelt de regering mee dat er slechts weinig buitenlandse werknemers in Colombia zijn en dat de Grondwet uitdrukkelijk het genot van enkele burgerrechten aan Colombiaanse staatsburgers toekent. Vervolgens verwijst de regering naar de toepasselijke artikelen van de Grondwet die de verkrijging van het Colombiaanse staatsburgerschap regelen. ${ }^{2}$ Uiteindelijk komt de ware reden boven water: de regering acht het niet opportuun dat, gegeven de actuele politieke situatie in de wereld, vreemdelingen, onder de dekmantel en ten detrimente van vakorganisaties, subversieve activiteiten ontplooien."

Merkwaardig genoeg stelt het Comité de kwestie in zijn volgende "Observations" niet meer aan de orde. Wel signaleert het Comité de verplichting om Colombiaan te zijn als voorwaarde voor verkiesbaarheid voor vakbondsleiderschap en tekent hier in het licht van art. 3 van Verdrag no. 87 bezwaar tegen aan. ${ }^{74}$ Vooralsnog heeft de regering nog niet gereageerd op deze kritiek.

69 Rep. of the Committee of Experts, Observation 1989, p. 145.

70 Direct Requests 1981, p. 6 .

71 Memoria 1982, p. 2.

72 Art. 8 van de Nationale Grondwet voorziet in twee mogelijkheden: door geboorte en door naturalisatie.

73 Memoria 1984, p. 10.

74 Observation 1985 , onder (2). 


\subsection{Toezichthoudende bevoegdheden van de autoriteiten}

Zoals uit het woorafgaande blijkt, hebben de Colombiaanse autoriteiten vooral door middel van ingrepen in de organisatiestructuur geprobeerd de macht van de vakbeweging te beteugelen. Daarnaast heeft de stat er zorg voor gedragen dat hij rechtstreekse controle kon uitoefenen op de vakbeweging en heeft deze controlebevoegdheden verankerd in de arbeidswetgeving. De autoriteiten bezitten verstrekkende bevoegdheden met betrekking tot de goedkeuring van reglementen en vakbondsverkiezingen en op het gebied van toezicht op de interne administratie en tijdens vakbondsvergaderingen.

Conform artt, 369 en 370 CST moet elke wijziging der statuten ter goedkeuring worden voorgelegd aan de minister van arbeid. ${ }^{7 s}$ Art. 486 CST verleent functionarissen van het Ministerie van Arbeid de bevoegdheid om van werkgevers, werknemers en vakbondsleiders informatie te verlangen en inzage te eisen in de boeken, registers en andere documenten. Bovendien mogen zij, zonder voorafgaande waarschuwing en op ieder moment, werkplaatsen en vakbondslokalen betreden en vergaderingen bijwonen. Deze controlerende maatregelen, zo vervolgt het artikel, strekken tot doel om de overtreding van bepalingen betreffende arbeidswoorwaarden en betreffende bescherming van werknemers in de uitoefening van hun beroep en van hun verenigingsrechten, te beletten. Specifiek met betrekking tot vergaderingen waarin gestemd wordt over het uitroepen van een staking, bepaalt art. 444, lid 2 CST dat de autoriteiten vantevoren gewaarschuwd moeten worden, opdat zij aanwezig kunnen zijn en de ontwikkeling van de gang van zaken in de gaten kunnen houden. Tenslotte moeten, krachtens art. 21 van Resolutie no. 4 (1952), de resultaten van vakbondsverkiezingen ter goedkeuring worden voorgelegd aan de administratieve autoriteiten.

Deze bepalingen, zo concludeert het Comité van Deskundigen, verlenen de autoriteiten wel erg ruime bevoegdheden om zich te mengen in het recht van vakorganisaties om hun eigen regels op te stellen, hun vertegenwoordigers in volledige vrijheid te kiezen, hun administratie en activiteiten te organiseren en hun programma's te formuleren. ${ }^{76}$

De regering erkent dat zij controle uitoefent over vakbondsactiviteiten maar acht deze interventie noodzakelijk om ervoor te zorgen dat vakbondsrechten juist ontzien worden. In een land waar grote belangenconflicten heersen en waar de vakbeweging nog onvoldoende kracht bezit, is een dergelijke controle onontbeerlijk. De goedkeuring achteraf van de resultaten van vakbondsverkiezingen ligt in dezelfde lijn. De staat moet erop toezien dat vakbondsleiders de noodzakelijke kwaliteiten en integriteit bezitten om hun functie uit te kunnen oefenen." In november 1982 ontvangt de ILO een brief van één van de grote vakcentrales, de CGT, waarin gewag gemalakt wordt van modelstatuten, waaraan vakbonden zich strikt moeten

75 Met betrekking tot de statuten van (con)federatics stelt art. 425 CST bovendien nog vast wat zij moeten behelzen: de ambtstermijn woor vakbondsleiders en de verkiezingsprocedure, de quorum-regeling en de tijdstippen voor vergaderingen en de verantwoording van de nitgaven.

76 Direct Requests 1981, p. 8 .

77 Memoria 1982, pp. 9-10. 
houden. ${ }^{78}$ Het Comité van Deskundigen is van mening dat bepaalde procedurele kwesties beter door de vakbonden zelf geregeld kunnen worden dan door de Wet en vraagt de regering om nadere uitleg."

Het antwoord van de regering bevat niet veel nieuws. Trouw aan haar Hobbesiaanse levensvisie schetst de regering hoe sommige personen, gedreven door ambitieuze en egoïstische motieven, de doelstellingen van de vrijheid van vakvereniging perverteren, teneinde uitsluitend zichzelf te bevoordelen. Vakbondsleden moeten in bescherming genomen worden tegen deze aantasting van hun rechten en de overheid is de enige die, als objectieve en rechtvaardige scheidsrechter, deze bescherming kan bieden..$^{\text {so }}$

Nadat het Comite van Deskundigen in zijn Observations van 1985 de regering er nogmaals op gewezen heeft dat het recht van vrije vergadering aan zo min mogelijk restricties onderhevig dient te zijn en dat het interne beleid beter aan vakbonden zelf kan worden overgelaten, gaat de regering onvermoeibaar voort haar bevoogdende opstelling toe te lichten en te rechtvaardigen. Men dient scherp te onderscheiden tussen vormen van inmenging die de rechten van vrije vergadering en vereniging beogen te doorkruisen aan de ene kant en de gerechtvaardigde en noodzakelijke interventie van de autoriteiten aan de andere kant. Art. $354 \mathrm{CST}$, beoogt de bescherming tegen eerstgenoemde vorm te waarborgen, door gevangenisstraf en hoge geldboetes te stellen op het verhinderen of verstoren van legitieme vergaderingen of het uitoefenen van vakbondsrechten. Hoe kunnen ambtenaren van het Ministerie van Arbeid die belast zijn met de taak om elke verstoring van de uitoefening van vakbondsrechten te sanctioneren, hun functie vervullen, als zijgeen informatie kunnen inwinnen, noch vakbondslokalen kunnen betreden, noch vergaderingen kunnen bijwonen, zo luidt de retorische vraag van de regering. Het verdient in dit verband aanbeveling om juridische normen meer naar de geest dan naar de letter te beoordelen, omdat het verwondering wekt dat, op grond van Verdrag no. 87, de interventie van de autoriteiten die er juist op moeten toezien dat iedereen de Wet respecteert, gekwalificeerd wordt als "onbehoorlijk". ${ }^{81}$

De impasse tussen regering en Comité wordt niet opgelost. Het Comité herhaalt zijn standpunt dat (met name) art. 486 CST buitensporige interventie-mogelijkheden verschaft aan de autoriteiten die in strijd zijn met art. 3, lid 2 van Verdrag no. 87, bepalende dat de autoriteiten zich moeten onthouden van elke inmenging die de rechten, erkend in het Verdrag, beperkt. ${ }^{32}$

78 Resolutie no. 4 van 1952 regelt in detail de samenstelling van het witwoerend comité van een vakbond, de verkiezingsprocedure, het quorum voor de jaarvergadering etc.

79 Direct Requests 1983 , p. 9.

80 Memoria 1984, pp. 14-15.

81. Memoria 1985 , pp. 9-10.

82 Observation 1987, onder (2). Uit de Obserwation van 1989 blijkt dlat er zich geen nieuwe ontwikkelingen hebben voorgedaan. 
Hoewel de in de Wet vastgelegde controle-bevoegdheden van de overheid al sinds 1950 van kracht zijn zijn zij vooral sinds het begin van de jaren zeventig in toenemende mate onderhevig aan kritiek van de zijde van de vakbeweging. ${ }^{2 a}$

In 1972 ontving de ILO een klacht van drie vakorganisaties die werknemers van de Nationale Colombiaanse Luchtvaartmaatschappij AVANCA vertegenwoordigden. Tussen de maatschappij en de drie organisaties waren conflicten gerezen naar aanleiding van collectieve onderhandelingen. Deze conflicten hadden geleid tot prikacties en weigering van de werknemers om overuren te maken. De vakorganisaties stelden dat AVIANCA hen had beschuldigd van sabotage en dat de Minister van Arbeid, zonder de zaak nader te onderzoeken, inzage in de administratie had geëist, vakbondsfondsen had bevroren en de rechtspersoonlijkheid van de betrokken organisaties geschorst had. Met betrekking tot de controle van de boekhouding en de daaruit voortvloeiende bevriezing van de fondsen overwoog het Comité inzake de Vrijheid wan Vakvereniging dat speciale onderzoeken uitsluitend in uitzonderlijke gevallen - bijwoorbeeld in geval van geconstateerde of veronderstelde malversaties - gerechtvaardigd waren. Buitensporige inmenging in de administratie van vakbonden en de schadelijke en wellicht onrechtmatige publicatie van informatie die misschien vertrouwelijk was, moest zoveel mogelijk vermeden worden. ${ }^{84}$

Kan de zojuist beschreven "case" wellicht nog beschouwd worden als een incident, klachten van een latere datum hebben veeleer betrekking op restricties van het recht van vrije vergadering en toezichthoudende maatregelen van de autoriteiten in het algemeen. Klachten over het vereiste van voorafgaande toestemming voor het houden van een vakbondsbijeenkomst bereikten de ILO in 1973 en in $1981 .{ }^{\mathrm{as}}$ In het laatste geval, waarin ook nog gerefereerd werd aan de verplichte goedkeuring van het vakbondsbudget, volstond het Comité inzake de Vrijheid van Vakvereniging met te constateren dat het Comite van Deskundigen de zaak in behandeling had en sprak het zijn vertrouwen uit dat de regering de wetgeving in overeenstemming zou brengen met Verdrag no. 87.

83 Dit maakt deel wit wan een algemeen patroon van een escalatie van spanningen tussen staat en vakbeweging. Naarmate de vakbeweging zich in de loop war de jaren zestig mondiger en onafhankelijker ging opstellen, reageerde de regering met het doorvoeren van meer repressieve maatregelen, hetgeen weer tot een grotere verwijdering tussen staat en vakbeweging leidde etc. Hieronder kom ik hier nog uitvoerig op terug.

84 Case No. 719,138 e Rap. $\$ 67$.

85 Case No. 734 , 143e Rap. $\$ 57$ resp. Case No. $1065,214 \mathrm{e}$ Rap. $\$ 402$. De klachten zijn in nogal vage termen gesteld en or walt niet goed uit op te maken of zij verwijzen naar vergaderingen met een besloten of met een openbaar karakter. Het Comité inzake de Vrijheid van Vakvereniging wijdt aan beide mogelijkheden een korte overweging en stelt met betrekking tot openbare bijeenkomsten dat restricties toegestaan zijn met het oog op de handhaving van de openbare orde, mits de toestemming maar niet willekeurig geweigerd wordt. Case No. 734, $143 \mathrm{e}$ Rap. $\$ 60$.

86 Case No. 1065,214 e. Rap. $\$ 416$. Dit is naturijijk een mooi woorbeeld van de nauwe samenwerking en de takverdeling tussen beide Comités. Om een goed beeld te krijgen van de vakbondssituatie in een land en een coherent beleid ten aanzien van dat land te voeren, is het noodzakelijk dat de toezichthoudende organen regelmatig contact hebbem, verwijzen naar elkaars werkzaamheden en, zo nodig, elkaar bepaalde vraagstukken die meer tot de competentie van de ander behoren, toespelen. 


\subsection{Stakingswerboden in de publieke sector}

Zoais hierboven al gesteld werd, beoogde de staat met de introductie en uitbreiding van het begrip "publieke diensten", waarin stakingen verboden waren, turbulente vakbonden in economisch belangrijke sectoren hun machtigste wapen uit handen te slaan. ${ }^{g 7}$

Deze strategie die het sluitstuk vormde van de controle-politiek ten opzichte van de vakbeweging, is verankerd in de Nationale Grondwet en de CST die naar elkaar verwijzen. De term "publieke diensten" geeft licht aanleiding tot verwarring, omdat zij, ten onrechte, suggereert dat uitsluitend werknemers in overheidsdienst het moeten stellen zonder stakingsrechten. Art. 430 CST helpt eventuele misverstanden uit de wereld: onder "publieke diensten" moeten alle georganiseerde activiteiten verstaan worden die behoeften van algemeen belang beogen te bevredigen, of deze activiteiten nu, direct of indirect, gerealiseerd worden door de staat of door private (rechts)personen. De regering heeft geopteerd voor een opsomming van activiteiten die in ieder geval tot de publieke diensten gerekend moeten worden, zonder dat deze opsomming uitputtend is. Onder "publieke diensten" vallen onder andere de activiteiten van: vervoersondernemingen en nutsbedrijven (art. 430 CST onder (b)), gezondheids- en welzijnsinstellingen (resp. onder (c) en (d)), bedrijven voor de melkvoorziening, marktplaatsen en slachthuizen (onder (e)), bedrijven die de exploitatie, de bewerking en de distributie van zout verzorgen (onder (g)) en bedrijven die zich bezighouden met de exploitatie, de raffinage, het transport en de distributie van olie en zijn bijprodukten, voorzover de activiteiten van deze bedrijuen zich richten op de brandstofvoorziening van het land (art. 430 CST onder (h)). Later is de categorie activiteiten die expliciet bestempeld worden, als "publieke diensten" nog door Wetsdecreten aangevuld. ${ }^{\text {g }}$

Het stakingsverbod aan het adres van werknemers in publieke diensten heeft geleid tot pittige discussies tussen de Colombiaanse regering en de ILO, waarbij telkens de vraag centraal heeft gestaan in hoeverre de categorieën die de regering heeft aangewezen, op te vatten zijn als "essentiële diensten", waarin de ILO stakingsverboden toelaatbaar acht.

Voordat Colombia Verdrag no. 87 had geratificeerd, was het Comité inzake de Vrijheid van Vakvereniging bij de afhandeling van klachten al enkele malen in de gelegenheid geweest

87 De introductie van het begrip "publieke diensten" dateert uit 1920 (Ley Nr 21). Deze Wet kwalificeerde onder andere de spoorwegen, het riviertransport en de nationale mijnen als publieke diensten. Het was bepaald geen toeval dat vakbonden in deze sectoren een hoge organisatiegraad hadden bereikt en zeer strijdbaar waren. Urrutia, a.w. p. 177.

88 Art. 18 van de Nationale Constitutie bepaalt: "Het stakingsrecht wordt erkend, behalve in publieke diensten. De Wet regelt de uitoefening van het recht". A.rt, 430 CST, gewijzigd door art. 1 wan Buitengewoon Decreet no. 753 van 1956 stelt vervolgens in de aanhef: "In overeenstemming met de Nationale Constitutie zijin stakingen in publieke diensten verboden".

89 Wetsdecreet no. 1593 van 1959, bijvoorbeeld, schaarde de banksector onder de "publieke diensten". Recentelijk (najaar 1992) heeft het Comité inzake de Vrijheid van Vakwereniging hierover nog zijn ongenoegen uitgesproken: de banksector is geen "essentiele dienst", waarin stakingen verboden kunnen worden en verplichte arbitrage-procedures toelaatbaar zijn. Case No. 1631, 284e Rap. \$398. 
om het parcours te verkennen en een normatieve lijn uit te zetten. Zo trok het Comite het essentielle karakter van een aantal sectoren - de olie (verwerkende)-industrie $\left({ }^{\infty}\right)$, de banksector( $\left.{ }^{91}\right)$; het onderwijs $\left({ }^{92}\right)$ - in twijfel. In latere zaken nam het Comité een meer uitgesproken standpunt in, door te verklaren dat sommige sectoren - de luchtvaartbranche $\left({ }^{n}\right)$ en de gasdistributie $\left({ }^{(4)}\right)$ - onmogelijk aangemerkt konden worden als essentiële diensten. Nadat Colombia in 1976 Verdrag no. 87 had geratificeerd konden deze casuistische uitspraken vervlochten worden in een algemene toetsing wan de toepasselijke Colombiaanse wetgeving. In de Direct Requests van 1981 laat het Comité van Deskundigen geen ruimte voor twijfel. Gelet op de door de ILO gehanteerde maatstaf van een essentiële dienst - de onderbreking ervan zou het bestaan of het welzijn van de gehele bevolking of een deel daarvan in gevaar brengen - kan een aantal van de in de Wet genoemde diensten niet als zodanig worden aangemerkt. Het Comité verwijst met name naar de vervoerssector, de veeteeltproduktie, de markten, de ontginning en distributie van zout, de raffinage en distributie van olie, de gaslevering en de banksector. .5

De regering voert een uitgebreid verweer. In de Memoria stelt de regering dat het moderne leven tal van behoeften van de bevolking met zich meebrengt, behoeften die de regering moeilijk kan negeren door een onderbreking in de bevrediging ervan toe te staan. Bij de afweging van het algemeen belang en het specifieke belang van werknemers om te kunnen staken, moet het laatste voor het eerste wijken. Een te beperkte opvatting van het begrip "essentiële diensten" zou de nationale economie en dus uiteindelijk ook de arbeidersklasse zelf schade berokkenen. ${ }^{\circ}$

In twee aanvullende rapporten tracht de regering haar standpunt nader toe te lichten. $\mathrm{Na}$ eerst een overzicht te hebben gegeven van de relevante wetgeving, benadrukt de regering dat stakingsverboden in essentiële diensten beoordeeld dienen te worden in het licht van de ontwikkelingsproblematiek. De in de Código genoemde activiteiten bezitten een essentieel karakter in een land dat op weg is zich te ontwikkelen. ${ }^{97}$ In de Memoria van 1984 borduurt de regering voort op hetzelfde patroon, maar ditmaal plaatst zij de problematiek in een ruimer perspectief. De regering verzoekt het Deskundigen-Comité om de naleving van verdragen tegen de achtergrond van de specifieke sociaal/economische omstandigheden in een land te beoordelen. Zo kan de restrictie van het stakingsrecht in een gering aantal essentiële diensten voor rijke landen geen enkel bezwaar opleveren, terwijl dit een land dat de barrières

Case No. 363, 74e Rap. $\$ \$ 229 \cdot 230$.

91

92

93

94

95

96

97 
van de onderontwikkeling tracht te overbruggen, voor onoverkomelijke problemen plaatst. ${ }^{\text {ps }}$ Colombia, zo vervolgt de regering, heeft er al vele malen op aangedrongen om de criteria, op grond waarvan het Comité van Deskundigen de naleving van geratificeerde verdragen beoordeelt, te herzien. Een wat lankmoediger interpretatie van de normen kan meer recht doen aan de vooruitgang die geboekt is bij de naleving van verdragen.

Aan de andere kant lijkt het niet juist, zo stelt de regering verder, dat het Comite verplichtingen aan het verdrag ontleent, waarin het verdrag niet voorziet, zoals nu gebeurt met de staking in de essentiële diensten. Nergens rept Verdrag no. 87 over stakingen en evenmin bepaalt het wat precies onder essentiële diensten moet worden verstaan. Destaking maakt in feite deel uit wan het proces van collectieve onderhandelingen en dit proces vormt het onderwerp van een aparte Conventie, namelijk no. 98. Mocht het Comite niettemin unit een verdrag verplichtingen afleiden, dan is bet van belang dat het de naleving ervan analyseert in het licht van de realiteit, waarmee staten te maken hebben en dat het Comite vaststelt dat diensten die voor ontwikkelde landen niet essentieel zijn, dit wel degelijk zijn voor ontwikkelingslanden. ${ }^{\infty}$

Het Comité neemt kennis van de argurnenten van de regering, maar accepteert deze niet als excuus voor een, uit het oogpunt van de internationale normen gebrekkige arbeidswetgeving. De toezichthoudende organen van de $\mathrm{LO}$ hebben het stakingsrecht immer beschouwd als één van de belangrijkste middelen voor werknemers en hun organisaties om hun belangen te behartigen. Restricties van het recht zijn slechts toelaatbaar in essentiële diensten en niet in de gehele publieke sector. ${ }^{100}$

Aangezien de regering in haar volgende Memoria's geen aandacht besteedt aan de problematiek, blijft het Comité hameren op de noodzaak van Wetswijziging. ${ }^{101}$

\section{De geleidelijke teloorgang van de controle-politiek (1965-1977)}

De hierboven uitvoerig geschetste vakbondspolitiek heeft ongeveer twee decennia lang aan haar doel beantwoord. De vakbeweging schikte zich in die periode in haar lot en beperkte zich voornamelijk tot het voeren van loononderhandelingen met de werkgevers op het niveau van de onderneming. Colombia maakte gedurende het begin van de jaren vijftig een economische bloeiperiode door die voor een belangrijk deel samenhing met de na-oorlogse hausse

98 Het is een excuus dat de Colombiaanse regering graag hanteert. In Case No. 490 ging de regering zelfs zover te beweren dat alle diensten in een ontwikkelingsland essenticel waren. Case No. 490, 101e Rap. $\$$ 305 .

99 Memoria 1984, pp. 12-13. Het voortdurende pleidooi van de Colombiaanse regering voor een rekkelijke interpretatie van de normen is natuurlij]k van eminent belang, angezien het de door de ILO gekoesterde uniwersaliteit van de vrijheid van vakvereniging ter discussie stelt. Zie hierover hoofdstuk 1 van deze studie, p. 19-28.

100 Observations 1985, onder (3).

101. Observation 1987, onder (3) en Observation 1989, p. 145. 
van de grondstoffenprijzen, maar gedeeltelijk ook beschouwd werd als de vrucht van het liberale ontwikkelingsmodel en de verzwakking van de vakbeweging.

Ondanks de "Violencia" die voornamelijk het platteland teisterde, werd de machtspositie van de elite, zoals immer gesymboliseerd door de monopolisering van het politieke toneel door de Conservatieve en de Liberale Partij, niet of nauwelijks aangetast. Het militaire bewind van Rojas Pinilla (1953-1957) betekende slechts een onderbreking, zeker geen einde van de heerschappij van de Liberale en de Conservatieve Partij. ${ }^{10 z}$

Aan het begin van de jaren zestig was een kentering in de opstelling van de vakbeweging te bespeuren De opzettelijke loskoppeling van staat en vakbeweging die gestalte had gekregen in de arbeidswetgeving van 1950, bleek enkele onvoorziene consequenties te hebben. Hoewel de vakbonden in de industriële sector veroordeeld waren tot de belangenbehartiging van hun leden op het niveau van de onderneming en zij nauwelijks machtsmiddelen bezaten om politieke pressie uit te oefenen, leerden zij gaandeweg een optimaal gebruik te maken van het instrument dat hun wel ter beschikking stond: de staking. ${ }^{103}$ In de loop van de jaren zestig nam het aantal stakingen en de gemiddelde duur ervan sterk toe. ${ }^{104}$ De structurele opbouw van de industriële sector begunstigde de langdurige werkonderbreking. De economische groei van de jaren vijftig had de monopolievorming in de industriële sector in de hand gewerkt. De vakbonden in dergelijke grote ondernemingen konden langdurig blijven agiteren, omdat stakingen de economische levenswatbaarheid van het bedrijf niet bedreigden, nu het (vrijwel) de markt monopoliseerde. ${ }^{105}$

102 Rojas stond een ontwikkeling in de verhouding tussen staat en vakbeweging naar Peronistisch model voor ogen. Geïnspireerd door corporatistische idealen, streefde hij juist een sterk gecentraliseerde organisatiestructuur van de vakbeweging na. De sindicatos de base dienden wervangen te worden door grote wakorganisaties die cen gehele bedrijfstak omvatten. De arbeidsvoorwaarden dienden in naww overleg met de staat te worden vastgesteld, zodat de staat controle kon uitoefenen en tegelijkertijd de eer kon opstrijken voor de verbetering van de positie van de werknemers. De vakbeweging diende met andere woorden woor een deel te fungeren als machtsbasis en als politieke legitimatie van het bewind. Aangezien deze politiek do arbeidsverhoudingen in Colombia nauwelijks beinwloed heeft, blijft zij verder in dit proefschrift onbesproken. Vigl. Fluharty, a.w. pp. $245-249$.

103 Pécaut (1989, a.w. p. 295) signalleert een verband tussen een verschuiving naar "links" en het gebruik van het stakingswapen: "This correlation between a "left" orientation and the use of strikes should be seen in the context of a kind of trade unionism moving towards a class identity. A liberal approach to development had, for a long period, favoured trade union fragmentation, especially in industry, but it also meant that the unions would become used to confront employers face to face."

104 Aantal stakingen:

1962: 36; 1963: 69; 1964: 75; 1965: 84 .

Aantal betrokken werknemers:

1962: 48.800; 1963: 110.000; 1964: 118.000; 1965: 171.000.

Gemiddelde duur van de staking (in dagen):

1962: 9; 1963: 17; 1964: 29; 1965: 24.

Bron: Urrutia, a.w. p. 238.

Urrutia, a.w. pp. 182-186. 
Het groeiend verzet van de vakbeweging moet wellicht ook gezien worden als een uiting van frustratie over het "heren-accoord" tussen de Liberale en de Conservatieve Partij: in 1958 vormden de partijen het Nationale Front, waarbij zij overeenkwamen dat het presidentschap gedurende een periode van zestien jaar afwisselend door een vertegenwoordiger van de Liberale en van de Conservatieve partij bekleed zou worden. ${ }^{106}$ De weerstand tegen deze volstrekte monopolisering van het politieke bedrijf dat van de democratie een schijnvertoning maakte, manifesteerde zich in kiezers-absenteïsme en in een daling van de populariteit van de traditionele vakcentrales CTC en UTC. De communistische stroming binnen de CTC zag zich genoodzaakt uit de vakcentrale te treden en een nieuwe, marxistisch georiënteerde vakcentrale - de CSTC - op te richten. ${ }^{107}$ :

De geleidelijke radicalisering van de vakbeweging noopte de staat om de eigen vakbondspolitiek aan een kritisch onderzoek te onderwerpen. Hoe kon de staat de greep op de vakbeweging versterken en de stakingsgolf keren? De strategie van de autoriteiten bestond uit een drietal elementen. In de eerste plaats verklaarde de staat elke staking die niet beschouwd kon worden als een uitvloeisel van mislukte collectieve onderhandelingen, illegaal door haar te kwalificeren als een politieke staking. In de tweede plaats probeerde de staat de staking te vervangen door een systeem van (verplichte) arbitrage. Arbeidsconflicten dienden door middel van bemiddeling en arbitrage te worden beslecht, waarbij de stem van de overheid van doorslaggevende betekenis was in de tripartiet samengestelde arbitragetribunalen. En tenslotte trachtte de staat politiek onwelgevallige vakbonden en vakcentrales het legaal functioneren onmogelijk te maken door hun rechtspersoonlijkheid te weigeren.

\subsection{Het verbod van de "politieke" staking}

In 1963 riep de CTC op tot een 24 uurs-staking om te protesteren tegen (onder andere) de passieve houding van regeringsambtenaren ten aanzien van onrechtmatige speculaties, de groeiende werkloosheid, de sluiting wan ondernemingen en de terroristische aanslagen. De regering verklaarde de staking illegaal op grond van art. 450, lid 1 sub (b) CST en ontnam, bij wijze van sanctie, de participerende vakbonden hun rechtspersoonlijkheid voor een periode van twee maanden. ${ }^{108}$

Namens de gedupeerde vakbonden, diende (het Wereld Vakverbond) een klacht in bij de ILO. Het Comite inzake de Vrijheid van Vakvereniging overwoog, onder verwijzing naar

106 Een beknopt overzicht van de achtergronden en de betekenis van het Nationale Front geeft Kline H.F. The National Front: Historical Perspective and Overview in: Berry R.A./Hellman R.G./Solatin M. Politics of Compromise, Coaltion Govemnent in Colombia, New Brunswick, New Jersey 1980, pp. 59-83.

107 vgl. Romero Vidal M. De la factoria a la microempresa: el desmonte del sindicalismo in: Giraldo J. et al (eds.) Movimientos sociales ante la crisis en Sudanérica, Bogotá 1986, pp. 138-139.

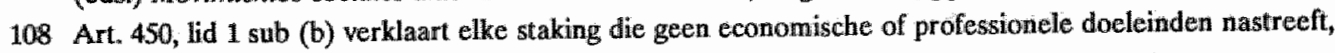
illegaal. 
eerdere zaken, dat de staking primair gericht was tegen de regeringspolitiek en een protest vormde tegen bepaalde feitelijke situaties. De staking was niet het uitvloeisel van een arbeidsconflict in de strikte zin van het woord. Het Conité adviseerde de Raad van Beheer er nota van te nemen dat het stakingsverbod was ingegeven door het feit dat de doelstellingen een beroepsmatig noch een economisch karakter hadden. ${ }^{109}$

\subsection{De introductie van de werplichte arbitrage}

Reeds de oorspronkelijke versie van de CST kende de verplichting voor vakbonden om in geval van een arbeidsconflict eerst een bemiddelingsprocedure te beproeven, alvorens een staking uit te roepen. ${ }^{110}$ Het Comité inzake de Vrijheid van Vakvereniging vond deze regeling uit het oogpunt van vrijheid van vakvereniging niet laakbaar, aangezien de vakbond, na het mislukken van het vreedzame overleg, alsnog haar toevlucht kon nemen tot een staking." Met het oog op de groeiende arbeidsonrust aan het begin van de jaren zestig, besloot de regering het pad te effenen voor de verplichte arbitrage. ${ }^{112}$ Wetsdecreet no. 2351 van 1965 liet vakorganisaties nog de vrije keuze tussen arbitrage en het uitroepen van een staking, met dien verstande dat, indien de vakorganisatie voor de arbitrage geopteerd had, de arbitrale uitspraak bindend was. Het jaar daarop werd een Wetsdecreet uitgevaardigd dat de Minister van Arbeild de bevoegdheid verleende om, na verloop van 40 dagen, een staking te beëindigen door het arbeidsconflict te onderwerpen aan verplichte arbitrage. ${ }^{113}$ Wet no. 48 van 1968 vormde het sluitstuk van de legislatieve inspanningen om de staking door verplichte arbitrage te vervangen. In de eerste plaats verruimde de Wet de bevoegdheden van de Minister van Arbeid door hem toe te staan op ieder moment, dat wil zeggen los van het feit of er al of niet een staking gaande was, de vorming van een arbitragetribunaal voor te stellen dat een bindende uitspraak zou doen over de eisen van de werknemers. In de tweede plaats kon de President van de Republiek besluiten elk arbeidsconflict aan een arbitragetribunaal voor te leggen, indien hij van mening was dat de staking de belangen van de nationale economie bedreigde. ${ }^{114}$

109 Case No. 363, 74e Rap. 233-235.

Het standpunt van het Comite is nogal behoudend, gezien het feit dat de RO proteststakingen tegen de sociaal/economische politiek wan de regering legitiem acht (vgl hoofdstuk 1 van deze studie). Het lijkt me in het onderhavige geval toch duidelijk dat sommige bezwaren - de groeiende werkloosheid en de sluiting van ondernemingen - ten nauwste samenhingen met de economische politiek van de regering. In het laatste hoofdstuk van dit proefschrift kom ik nog uitvoerig terug op deze ongerijmdheid in de jurisprudentie van de ILOO.

110 Art. 450, lid 1 sub (c) CST.

111 Case No. 363, 74e Rap. \$233.

112 De verschillende stadia zijn door Moncayo en Rojas nauwkeurig geanalyseerd. A.w. pp. 200-229.

113 Wetsdecreet no. 939, art. 2.

114 Wet no, 48 van 1968 , art. 3 lid 4. 
Aangezien de regelingen nog steeds van kracht zijn, heeft het Comite van Deskundigen deze aan een kritisch onderzoek kunnen onderwerpen. Gelet op de vaste "jurisprudentie" van de $\amalg O$, is het vanzelfsprekend dat het Comité bedenkingen heeft tegen de gedwongen conversie wan stakingen in arbitrage, waarin Wetsdecreet no. 939 en Wet no. 48 voorzien. De vervanging van stakingen door verplichte arbitrage is alleen toegestaan in essentiële diensten in de strikte zin van het woord. ${ }^{115}$

De regering tracht de kritiek van het Comite te pareren. Men moet de verplichte arbitrage opvatten als een bescherming van de werknemers, wier belangen geschaad worden door lange werkonderbrekingen die het gevolg zijn van de onverzoenlijke opstelling van de partijen. De staat heeft de plicht om te bemiddelen in arbeidsconflicten en dient daarbij het welzijn van de werknemers tot leidraad te nemen. ${ }^{146}$

Op 20 juni 1982 wordt bij Wetsdecreet de noodtoestand opgeheven. Het DeskundigenComité meent hieruit te mogen opmaken dat onder andere de Wetsdecreten nos. 2351 en 939 zijn ingetrokken en beperkt zich in zijn Direct Requests dan ook tot kritiek op Wet no. $48 .{ }^{113}$

Tijdens een Direct contact-missie blijkt de mening van het Comité op een misverstand te berusten: de Wetsdecreten nos. 2351 en 939 blijven van kracht, aangezien zij uitsluitend de arbeidswetgeving wijzigen en geen verband houden met de uitzonderingstoestand. ${ }^{118}$ Met betrekking tot de bevoegdheid van de president om aan stakingen door middel van het instellen van arbitrageprocedures een eind te maken, geeft de regering te kennen dat de president alleen na een positief advies van de Arbeidskamer van de Hoge Raad van deze bevoegdheid gebruik mag maken. Wat dit laatste punt betreft, komen regering en Comité niet nader tot elkaar, maar de Memoria van 1986 werpt wel een nieuw licht op de interventie door de Minister van Arbeid in stakingen. Een zorgvuldige lezing van art. 448 CST leert dat het Ministerie van Arbeid, na 10 dagen staking en vervolgens met intervallen van 20 dagen, een arbitragetribunaal $k a n$ instellen en dat over de arbitrale uitspraak door de werknemers gestemd zal worden. De procedure noch de uitspraak worden met andere woorden aan de werknemers door de autoriteiten opgedrongen. ${ }^{120}$ Het Comité neemt kennis van deze uitleg en verzoekt de regering aan te geven of Wetsdecreet no. 939 van 1966 herroepen is of niet langer wordt toegepast. ${ }^{121}$

Het systeem van de verplichte arbitrage heeft zich, ondanks de verwoede pogingen van de regering om de verdiensten ervan te benadrukken, nimmer in een grote populariteit binnen

115 Direct Requests 1981, p. 7 .

1.16 Memoria 1982 , p. 8.

117 Direct Requests 1983 , p. 9.

118 Informe de Misión, p. 21. De regering bevestigt deze visic: Memoria 1984, p. 7.

119 Memoria 1984 , p. 14

120 Memoria 1986, pp. 6-7.

121 Observation 1987, onder (3). In zijn Observation van 1989 herhaalt het Comite zijn verzoek. 
vakbondskringen mogen verheugen. Al in 1966 dienden twee Colombiaanse federaties een klacht in bij de ILO, waarin zij stelden dat Wetsdecreet no. 939 een inbreuk maakte op het stakingsrecht. Het Comité inzake de Vrijheid van Vakvereniging onderkende het gevaar dat de Minister van Arbeid, gebruik makend van de bevoegdheden die het Wetsdecreet hem verleende, de actiemogelijkheden van vakbonden kon beperken. Het Comité adviseerde de regering dan ook om Wetsdecreet no. 939 aan een nader onderzoek te onderwerpen in het licht van het beginsel van vakverenigingswrijheid. ${ }^{22}$ In 1981 bereikte de ILO opnieuw een klacht, waarin het systeem van verplichte arbitrage als zodanig bekritiseerd werd. Het Comité inzake de Vrijheid van Vakvereniging stemde in met de bezwaren van de klagers, maar volstond met te verwijzen naar de rapporten van het Deskundigen-Comité dat, zoals hierboven al is aangegeven, de regering regelmatig over deze kwestie ter verantwoording heeft geroepen. ${ }^{\text {2as }}$

Het grootse bezwaar van de vakbeweging gold evenwel het uit het arbitrage-systeem voortgevloeide leerstuk van de "contrapliegos patronales" (tegen-voorstellen van de werkgever) dat door de rechtspraak ontwikkeld is. Op grond van de Collombiaanse wetgeving blijven condities van een collectieve arbeidsovereenkomst van kracht, nadat éen der partijen de overeenkomst heeft opgezegd.12a Het kwam regelmatig woor dat werknemers een staking uitriepen en vervolgens, nadat 40 dagen verstreken waren en de Minister van Arbeid aanstalten maakte om een arbitrage-tribunaal in het leven te roepen, hun eisen schielijk introkken om te ontkomen aan verplichte arbitrage. ${ }^{125}$ Aan deze praktijk werd abrupt een einde gemaakt door het Hoogste Gerechtshof dat art. 3, lid 2 van Wet no. 48 van 1968 in strijd met de Grondwet verklaarde, voorzover het bepaalt dat een arbitragetribunaal uitsluitend hoeft te oordelen over eisen van werknemers. Het tribunaal moest ook een uitspraak doen over de "contrapliegos patronales", aldus het Hof. ${ }^{125}$ In 1970, het jaar van de uitspraak, dienden werknemersorganisaties een klacht in bij de LO, waarin zij stelden dat de door de jurisprudentie gesanctioneerde praktijk stakingsrechten op onrechtmatige wijze beperkte: werknemers konden zich immers niet aan verplichte arbitrage onttrekken. Het Comité inzake de Vrijheid van Vakvereniging deelde deze visie niet. Het enkele feit dat arbitragetribunalen ook over tegen-voorstellen van de werkgever oordeelden, impliceerde niet dat deze arbitrage een verplichtend karakter had. ${ }^{127}$

122 Case No. $490,99 \mathrm{e}$ Rap. $\$ \$ 41-42$.

123 Case No. 1065,214 e Rap. $\$ 402$ en $\$ 416$.

124 Wetsdecreet no. 616 wan 1954.

125 Moncayo Y Rojas, atw: $\mathrm{p}_{\text {. }} 221$.

126 Arrest van het Hof, 12-06-1970.

127 Case No: 641, 130e Rap. \$\$ 7-16. Het is de vraag of deze overweging van het Comite nuet te formalistisch is en het standpunt van het Deskundigen-Comité doorkruist. Gelet op de uitspraak van het Hof, hadden stakende werknemers immers inderdaad geen andere keuze dan zich neer te leggen bij de instelling wan een arbitrage-tribunaal dat over het arbeidsconflict zijn finale oordeel uitsprak. 


\subsection{De weigering wan rechtspersoonlijkheid als repressief instrument}

Zoals in 4 al gesteld werd, heeft de Colombiaanse regering zich lange tijd bediend van de weigering van rechtspersoonlijkheid als instrument om te voorkomen dat de van boven opgelegde organisatiestructuur doorkruist werd. Vanaf het midden van de jaren zestig kreeg dit instrument daarnaast nog een andere functie: de regering trachtte hiermee het legaal opereren van vakbonden wier doelstellingen en activiteiten niet correspondeerden met de regeringsideologie, onmogelijk te maken.

De meest geruchtmakende zaak die aan de ILO ter beoordeling werd voorgelegd, betrof het jarenlang traineren van de inwilliging van het verzoek om rechtspersoonlijkheid van de vakcentrale CSTC. ${ }^{128}$ Volgens de CSTC was de weigering ingegeven door ideologische motieven. De regering sprak deze bewering niet tegen, maar wenste toch vooral te benadrukken dat de statuten van de CSTC niet in orde waren. Met name art. 417 CST - het stakingsverbod aan het adres van (con)federaties - en art. 422 CST - het vereiste dat vakbondsleiders op het moment van hun verkiezing minimaal éen jaar werkzaam moesten zijn in de sector, waarvoor de vakbond werd opgericht - werden met voeten getreden. Bovendien had de CSTC tijdens haar oprichtingscongres de leden openlijk opgeroepen om de Wet te overtreden, hetgeen regelrecht in strijd was met art. $379 \mathrm{CST}\left({ }^{12}\right)$ en stonden enkele leiders van de CSTC onder arrest op verdenking van ondermijning van de openbare orde.

Aan de beweerde tekortkomingen van de statuten besteedde het Comité weinig aandacht. Het stakingsverbod ex art. $417 \mathrm{CST}$ was niet in overeenstemming met de beginselen inzake de vrijheid van vakvereniging. Wat betreft het vereiste dat vakbondsleiders werkzaam moesten zijn in de sector waarvoor de vakbond werd opgericht, bracht het Comité de regering in herinnering dat het een dergelijk voorschrift onverenigbaar achtte met het recht van vakorganisaties om hun vertegenwoordigers in volledige vrijheid te kiezen. ${ }^{130}$ De beide overige argumenten die de regering had aangevoerd, vergden een uitvoeriger afweging door het Comité. Aan de ene kant verwees het Comité naar art. 8 van Verdrag no. 87 dat stelt dat werknemersorganisaties bij de uitoefening van rechten de Wet van het land dienen te eerbiedigen. Maar de controle of de vakorganisatie al of niet de Wet had overtreden, diende a posteriori te geschieden en was voorbehouden aan de rechter. De weigering om een vakbond te registreren, zo vervolgde het Comite, op grond van het feit dat de autoriteiten, vantevoren en naar eigen inzicht, de registratie politiek onwenselijk achtten, was in strijd met de bepalingen van Verdrag no. 87. ${ }^{131}$ Het verzoek van de CSTC om erkenning van rechtspersoonlijkheid belandde bij de Raad van State en werd in 1974 (10 jaar na indiening!) uiteindelijk ingewilligd. ${ }^{132}$

128 De Case (No. 514) dateert wit 1964.

129 Art. 379 sub (f) verbiedt vakbonden campagnes of bewegingen te stimuleren die wettelijke woorschriften overtreden of handelingen van de wettige autoriteiten weerstreven.

130 Deze kwestie komt in de volgende paragraaf nog aan de orde.

131 Case No. 514, $129 \mathrm{e}$ Rap. $\$$ 112-116.

132 Case No. $514,147 \mathrm{e}$ Rap. $\$ 27$. 
Nadien zijn met een zekere regelmaat klachten ingediend bij de ILO aver de weigering van rechtspersoonlijkheid. In 1988 bracht de vakcentrale CUT de kwestie inzake de erkenning van rechtspersoonlijkheid wederom onder de aandacht van de ILO. De buitengewoon omslachtige erkenningsprocedure zou leiden tot onaanvaardbare vertragingen bij de toekenning van rechtspersoonlijkheid. Bovendien zouden sommige functionarissen van het Ministerie van Arbeid zich door werkgevers laten omkopen om de verzoeken van vakorganisaties niet in te willigen. Het Comite inzake de Vrijheid van Vakvereniging erkende de problemen, drong bij de regering aan op een vereenvoudiging van de procedure teneinde de erkenning van vakbonden te stroomlijnen en verwees de zaak ter verdere afhandeling naar het DeskundigenComite ${ }^{134}$ Op zijn beurt verzocht het Deskundigen-Comité de regering om de wetgeving te wijzigen met het oog op het verhelpen van de tekortkomingen in de procedure. ${ }^{\text {ass }}$

\section{De laatste 16 jaar (1977-1993): van "controle" naar "repressie"}

In de loop van de jaren zeventig bleek de regering steeds minder in staat de groeiende radicaliteit en onafhankelijkheid van de vakbeweging te verhullen. Zoals hierboven al werd aangegeven bij de bespreking van het systeem van werplichte arbitrage, waren legislatieve kunstgrepen niet langer toereikend om de vakbeweging te controleren. Het onbehagen over de dalende levensstandaard $\left({ }^{136}\right)$ en het groeiende politieke bewustzijn die zich voornamelijk manifesteerden op het niveau van de "sindicatos de base", begonnen door te dringen in de hogere echelons van de grote vakcentrales. Schoorvoetend gaven de UTC en de CTC gehoor aan de wensen van hun ledenorganisaties om een onafhankelijker standpunt in te nemen, aangezien hun regeringsgezinde opstelling een gevoelig Jedenverlies tot gevolg had. ${ }^{137}$ Halverwege de jaren zeventig zochten de grote vakcentrales; CTC, UTC, CSTC en CGT,

133 Zie onder andere Case No. 675, 128e Rap. \$\$20-21 en Case No. 734, 143e Rap. \$\$ 47-56. De regering wachtte zich ervoor om cok maar te zinspelen op politieke conflicten die ten grondslag zouden liggen aan de weigering en beriep zich op allerlei formalliteiten, waaraan de vakbonden in kwestie niet woldaan zouden hebben, om de eigen handelwijze te rechtvaardigen. Het Comite stelde zich op het standpunt dat het rechr om zonder voorafgaande toestemming vakbonden op te richten de betrokken werknemers weliswaar niet ontsloeg van de verplichting om bepaalde formaliteiten in acht te nemen, maar dat deze formaliteiten niet van dien aard mochten zijn dat zij in praktijk de oprichting wan vakbonden verhimderden. Case No, 675, 128e Rap. $\$ 20$ en Case No. 734, $143 \mathrm{e}$ Rap. $\$ 55$.

134 Case No. 1434, 259 Rap. $\$ \$ 662-664$.

135 Observation 1989 , p. 143.

136 Het reẻle loon van "obreros" (blauwe boorden) in de industrielle sector daalde tussen 1971 en 1975 van 261.7 tot 221,4 pesos op jaarbasis. Het reele loon van "empleados" (witte boorden) daalde gedurende dezelfde periode van 686,9 tot 538,3 pesos.

Bron: Gomez B./Londono B./Perry R, a.w. p. 67.

137 Tussen 1965 en 1974 daalde het ledenbestand van CTC en UTC vam $71,25 \%$ naar $60,65 \%$ van het totale aantal georganiseerde werknemers.

Bron: Moncayo y Rojas, a.w. p. 227. 
steeds meer toenadering tot elkaar, hetgeen culmineerde in een gezamenlijk besiuit om een nationale staking van 24 urur uit te roepen op 14 september $1977 . .^{138}$

Deze nationale staking markeert een caesuur in de geschiedenis van de verhouding tussen staat en vakbeweging in Colombia. $\mathrm{Zij}$ is het zichtbare teken dat de controle-politiek gefaald heeft. Vanaf 1978 groeit jaarlijks het aantal klachten dat bij de ILO wordt ingediend. Ook de aard van de klachten verandert: in toenemende mate hebben zij betrekking op zuiver repressieve maatregelen van de kant van de autoriteiten, zoals ontbinding van vakorganisaties, diskwalificaties en massa-ontslagen van vakbondsleiders en -leden, arrestaties en detenties en, uiteindelijk, zelfs martelingen, "verdwijningen" en moorden. Regelmatig vertrekken Direct contact-missies naar Colombia om poolshoogte te nemen en met de autoriteiten te overleggen hoe er een einde gemaakt kan worden aan het gewelddadige klimaat in het land. Aangezien de meeste repressieve maatregelen geen wettelijke grondslag hebben, zal het geen verbazing wekken dat, bij de beschrijving van deze meest recente periode, het accent verschuift van de bevindingen van het Deskundigen-Comité naar de activiteiten van het Comité inzake de Vrijheid van Vakvereniging. Laten wij evenwel eerst terugkeren naar de reacties van de regering op de Nationale Staking van 1977.

\subsection{Het algehele stakingsverbod als uitvloeisel van uitzonderingswetgeving}

Artikel 121 van de Grondwet verleent de president de bevoegdheid om de staat van beleg af te kondigen in geval van binnenlandse onrust. Hoewel Colombia vanaf 1947 vrijwel onafgebroken "in staat van beleg" is geweest, zïjn vooral de laatste vijftien jaar Wetsdecreten uitgevaardigd om elke vorm van sociaal of politiek protest te onderdrukken. ${ }^{130}$

Zo kondigde de regering op 25 augustus 1977 bij wijze van preventie Wetsdecreet no. 2004 af dat stakingen tijdens de noodtoestand verbood, op straffe van detentie. Bovendien leverde deelname aan een dergelijke staking, krachtens hetzelfde Decreet, een redelijke grond voor ontslag op. Naar aanleiding van de staking werden inderdaad honderden vakbondsleden ontslagen of gevangen genomen. Een groot aantal vakorganisaties, zowel van nationale als van internationale herkomst, wendde zich tot de ILO om zich te beklagen over deze inbreuk op vakbondsrechten. Geheel in overeenstemming met het eigen mandaat, sprak het Comite inzake de Vrijheid van Vakvereniging zich niet uit over de (on)verenigbaarheid van het Decreet met internationale normen in het algemeen, maar spitste zijn oordeel toe op het concrete geval. Had de nationale staking van 14 september een zuiver politiek karakter, zodat zij buiten de reikwijdte van de beginselen van vakverenigingsvrijheid viel? Of hadden de stakers uitsluitend hun gevoelens over sociaal/economische aangelegenheden kenbaar willen maken, hetgeen in de ogen van de ILO een legitieme vorm van vakbondsactiviteit is? ${ }^{140}$ Het Comité

138 Zie ower de achtergronden en het werloop van deze staking: Gomez B./Londono B./Perry R. a.w. pp. 123-127.

139 Vgl. Pearce, a.w. p. 197.

140 Case No. 889 , 177 e Rap. \& 326. 
constateerde dat de meningen verdeeld waren. De indieners van de klachten beschreven de staking als een protestactie in het licht van een ernstige verslechtering van de sociaal/economische situatie van de Colombiaanse arbeidersbevolking. De regering kenschetste de staking als een poging om de openbare orde te verstoren. Het Comité neigde emaar de visie van de klagers te onderschrijven door te wijzen op de hardhandige methoden die de regering gebruikt had, in antwoord op een 24-uurs staking die grotendeels de uitdrukking van ontevredenheid leek te zijn, nu zill georganiseerd was door alle belangrijke vertegenwoordigers van de Colombiaanse vakbeweging. ${ }^{141}$

Wetsdecreet no. 2004 is tot op heden nog niet ingetrokken, zodat ook het Comité van Deskundigen er zijn licht over heeft kunnen laten schijnen. Een tijdelijke opschorting van het stakingsrecht dient beperkt te zijn tot de onmiddellijke periode van de noodtoestand, aldus het Deskundigen-Comite ${ }^{142}$ In reactie op deze kritische kanttekening van het Comité legt de regering uit dat het achterliggende motief van het Wetsdecreet de noodzaak om het ononderbroken functioneren van essentiële diensten te waarborgen, is ${ }^{1{ }^{43}}$ Deze nogal geforceerde poging om de eigen wetgeving te persen in het maatpak van de internationale arbeidsnormen wordt door het Deskundigen-Comité onmiddellijk doorzien. Nadat de verwarring omtrent een eventueel intrekken van het Decreet na het opheffen van de staat van beleg in 1982 is opgehelderd - het Decreet blijft gewoon van kracht, zoals de regering zelf toegeeft $\left({ }^{144}\right)$ - dringt het Comite er telkens bij de regering op aan om de buitensporige restricties van het recht van vreedzame staking af te schaffen. ${ }^{145}$ Ondanks herhaalde verzoeken van het Comite, reageert de regering niet.

Naar aanleiding van de nationale staking van 14 november 1990 bevestigde het Comité inzake de Vrijheid van Vakvereniging zijn standpunt met betrekking tot de toelaatbaarheid van stakingen die gericht zijn tegen de overheid. De staking was uitgeroepen door de vier vakcentrales om te protesteren tegen de massa-ontslagen die het gevolg waren van grootschalige privatisering en tegen de ontoereikende loonaanpassingen voor de werknemers in de publieke sector na prijsstijgingen. De regering had de staking illegaal verklaard op grond wan de overweging dat de staking ondermijnende krachten in de kaart zou spelen en wegens de noodzaak om het recht op arbeid van de overgrote meerderheid van de Colombiaanse bevolking te waarborgen. Het Comitê overwoog dat, nu de staking gericht was tegen de schadelijke sociale gevolgen van de economische politiek, het verbod van de staking in strijd was met de vrijheid van vakvereniging. ${ }^{\text {s.6. }}$

141 Case No. 889, 177 e Rap. 328.

142 Direct Requests 1981 , p. 7.

143 Mémoria 1982, p. 8.

144 Memoria 1984 , p. 7 .

145 Observations 1985 en 1987, onder (3)/Observation 1989, p. 145.

146 Case No. 1562, 279e Rap. 514 


\subsection{Ontbinding van vakorganisaties en intrekking van rechtspersoonlijkheid}

Eén van de meest gehekelde en gevreesde instrumenten die de regering ter beschikking staan om "lastige" vakbonden te bestraffen is de ontbinding van vakorganisaties en de intrekking van hun rechtspersoonlijkheid. ${ }^{\text {tw7 }}$ Hoewel de ontbinding van vakorganisaties v66r de staking van 1977 al enkele malen het voorwerp was geweest van klachten $\left({ }^{148}\right)$, kreeg de kwestie juist naar aanleiding van deze staking grote actualiteitswaarde, aangezien art. 450 , lid 2 CST op een illegale staking de sanctie van intrekking van de rechtspersoonlijkheid voor een periode van twee tot zes maanden en zelfs ontbinding van de vakorganisatie stelt. De indieners van de klachten beschuldigden de regering van het intrekken van de rechtspersoonlijkheid van de Handwerkslieden-bond. ${ }^{149}$ Nadat de regering het Comité verzekerd had dat het Ministerie van Arbeid zich immer onthield van het intrekken van rechtspersoonlijkheid, aangezien dit een taak van de rechtsprekende macht was, verwees het Comité naar art. 450 dat wel degelijk het Ministerie bevoegdheden verleende om de rechtspersoonlijkheid in te trekken in geval van illegale stakingen. ${ }^{150}$ Onder verwijzing naar art. 4 van Verdrag no. 87 , voegde het Comite hier nog aan toe dat een recht op appel ten overstaan van de rechter niet voldoende was om het in dit artikel verankerde beginsel te respecteren. Zolang de administratieve beschikking nog niet door de rechter was bekrachtigd en de beroepstermijn nog niet verstreken was, moesten er geen gevolgen aan de beschikking verbonden worden.

Toen bleek dat de intrekking van de rechtspersoonlijkheid herroepen was en nadat de regering had toegezegd om een aanpassing van de wetgeving in overweging te zullen nemen, besloot het Comite de zaak verder te laten rusten."

Nationale stakingen naar het model van de proteststaking van september 1977 volgden elkaar in de loop van de jaren tachtig in rap tempo op. Naar aanleiding van een dergelijke staking op 21 oktober 1981 werd de rechtspersoonlijkheid van de vakcentrale CSTC en van de federaties FECODE (Colombiaanse Federatie van Onderwijzers) en FENALTRASE (Nationale Federatie van Werknemers in dienst van de Staat) tijdelijk ingetrokken. De juridische

147 Gezien het feit dat art. 372 CST het bezit van rechtspersoonlijkheid een absolute woorwararde acht woor het functioneren van vakorganisaties, komt intrekking van rechtspersoonlijkheid in praktijk op hetwelfde neer als ontbinding van de vakorganisatie.

148 Zie onder andere Case No. 363, 74e Rap. $\$ 224-225$.

In 1971 liep het nog met een sisser aff. Hoewel de regering de rechtspersoonlijkheid van enkele vakorganisaties had opgeschort, volstond het Comite inzake de Vrijheid van Vakvereniging met een berisping, aangezien de schorsingsmaatregelen inmiddels weer waren opgeheven. Case No. 664, 124te Rap. 112-113.

In de Cases Nos. 719 en 871 kwam het Comité wel toe aan een inhoudelijke beoordeling en verklaarde de intrekking van rechtspersoonlijkheid door de administratieve autoriteiten in sirijd met art. 4 wan Verdrag no. 87 .

Case No. 719, 138 e Rap. $\$ 89-70$ en Case No. 871, 168e Rap. $\$ 8$ 252-254.

149 Case $\mathrm{No}$. 889, 177 e Rap. $\$ 322$.

150 Case No. 889 , 187e Rap. $\$ 503$ en 508.

151 Case No. 889,190 e Rap. \$143. 
grondslag van dexe maatregel was niet art. 450 CST maar een apart Wetsdecreet no. 2933 dat uitgevaardigd was om aan gezagsondermijnende groepen die de staatsveiligheid, de Wet en de publieke orde in gevaar brachten, het hoofd te bieden. Het Comité inzake de Vrijheid van Vakvereniging benadrukte het absolute karakter van art. 4 van Verdrag no. 87. Ongeacht de vraag of de motieven van de regering de beslissing van de administratieve autoriteiten om de rechtspersoonlijkheid in te trekken, rechtvaardigden, kon men duidelijk uit de bewoordingen van art. 4 opmaken dat de administratieve autoriteiten de rechtspersoonlijkheid van een vakorganisatie niet mogen intrekken. Daarbij merkte het Comité nog op dat de rechter de intrekking van de rechtspersoonlijkheid moest beoordelen in het licht van de bepalingen van Verdrag no. 87.152 De regering trachtte zich te verweren door erop te wijzen dat het Hoogste Gerechtshof Wetsdecreet no. 2932 in overeenstemming had verklaard met de Constitutie en de Wet, maar het Comité toonde zich niet onder de indruk. Het verwees de zaak naar het Comité van Deskundigen, opdat dit laatste de legislatieve aspecten nader kon onderzoeken. ${ }^{13}$

Hoewel de discussie tussen het Comité van Deskundigen en de regering niet leidt tot een verzoening der standpunten, werpt zij wel een helder licht op het wettelijk systeem inzake het onderhavige onderwerp. Art. 380 CST bevat de algemene regeling met betrekking tot het intrekken van rechtspersoonlijkheid en de ontbinding van vakorganisaties. Zodra een vakorganisatie bepalingen van de Arbeidswet overtreedt, kan het Ministerie van Arbeid om te beginnen de organisatie een boete opleggen. Indien de organisatie in het kwaad volhardt, kan het Ministerie haar rechtspersoonlijkheid schorsen en, in laatste instantie, zelfs de rechter verzoeken om de rechtspersoonlijkheid definitief in te trekken en de vakorganisatie te ontbinden (art. 380, lid 1 sub d jo. art 380, lid 2 CST). Art. 450, lid 2 bevat een bijzondere regeling. De instantie die een staking illegaal heeft verklaard (i.e. het Ministerie van Arbeid) kan de rechtspersoonlijkheid van de verantwoordelijke organisatie intrekken voor een periode van twee tot zes maanden en uiteindelijk de organisatie ontbinden.

152 Casses Nos. 1083 en 1085,214 e Rap. $\$ 448$. De formulering van het Comite munt niet uit in logische consistentie. Geen enkel motief rechtvaardigt immers, gelet op de woorden wan art. 4 van Verdrag no. 87 , een dergelijke actie door de administratieve autoriteiten.

153 Case Nos. 1083 en 1085,217 e Rap. 185 .

Naar aanlleiding wan een nationale staking op 20 juni 1985, werd wederom de rechtspersoonlijkheid van een zestal vakverenigingsfederaties, waaronder de CSTC en FENALTRASE, tijdelijk ingetrokken. Het geschilpunt tussen de regering en het Comité spitste zich ditmaal toe op de vraag of de getroffen vakorganisaties over voldoende beroepsmogelijkheden beschikten om de maatregelen aan te vechten. De regering wees op de mogelijkheid om herziening te vragen bij de Minister van Arbeid en, indien deze negatief beschikt, in beroep te gaan bij de administratieve rechter. Het Comite voelde zich echter geroepen om erop te wijzen dat, nu het herzieningswerzoek in dit concrete geval geen succes had gesorteerd, de vakorganisaties niet wettig konden functioneren, zodat de beschikking van de autoriteiten in strijd was met art 4 van Verdrag no. 87.

Case No. 1343, 244 e Rap. $\$ \$ 365$ en 376. 
Het Comité van Deskundigen is van mening dat zowel de algemene als de bijzondere regeling op gespannen voet staan met art. 4 van Verdrag no. 87 en verwijst naar de aanbevelingen van het Comité inzake de Vrijheid wan Vakvereniging om de wetgeving aan te passen. ${ }^{\text {is }}$

De regering benadrukt de rol van de rechter bij het intrekken van rechtspersoonlijkheid en de ontbinding van vakorganisaties. Daarbij moet opgemerkt worden, zo vervolgt de regering, dat de regering op grond van art. 121 van de Grondwet tijdens een staat van beleg strafmaatregelen kan nemen om het gevaar te bezweren dat subversieve groepen, onder de dekmantel van vakorganisaties, de rechtsstaat proberen te ondermijnen. Deze maatregelen mogen echter nimmer de doelstelling van vakorganisaties, namelijk de behartiging van de belangen van hun leden, aantasten. ${ }^{\text {sss }}$

Tijdens een Direct contact-missie komt aan het licht dat de relevante wetsartikelen van de Código door Wet no. 26 van 1976 - de Goedkeuringswet van Verdrag no. 87 - gewijzigd zijn. ${ }^{156}$ In beginsel kan alleen de rechter de schorsing van de rechtspersoonlijkheid van een vakbond of haar ontbinding bevelen. De regering geeft toe dat de co-existentie van Wet no. 26 en de toepasselijke bepalingen van de Código enige verwarring heeft gezaaid, maar wenst te benadrukken dat er op de algemene regel slechts twee uitzonderingen bestaan: het Ministerie van Arbeid kan uitsluitend de rechtspersoonlijkheid van een vakbond opschorten of intrekken, indien het een staking illegaal heeft verklaard of indien een bepaling die is uitgevaardigd op grond van de staat van beleg, het Ministerie hiertoe uitdrukkelijk machtigt. ${ }^{19}$ ? De repliek van de regering kan het Comite van Deskundigen nog steeds niet overtuigen. Nadat het Comite in het Direct Request van 1985 heeft opgemerkt dat de meest recente editie van de CST nog steeds voorziet in de mogelijkheid dat de administratieve autoriteiten de rechtspersoonlijkheid van een vakbond opschorten of intrekken $\left({ }^{158}\right)$, verwijst het naar Case No. 1343. Het beroep op de rechter tegen een beschikking van het Ministerie van Arbeid heeft geen schorsende werking, zodat de betrokken organisaties niet kunnen functioneren, zolang de maatregel van kracht blijft. Het Comité dringt er dan ook bij de regering op aan om legislatieve stappen te ondernemen, zodat elke intrekking van rechtspersoonlijkheid door de administratieve autoriteiten onmogelijk wordt. ${ }^{199}$

Met het uitvaardigen van een nieuwe Grondwet (18 juli 1991) lijkt de regering tenslotte aan de wens van de ILO tegemoet te zijin gekomen. Art. 39 van de Grondwet bepaalt namelijk dat het intrekken of het schorsen van rechtspersoonlijkheid uitsluitend kan geschieden door de rechter. Naar aanleiding van een klacht ower de schorsing van de rechtspersoonlijkheid van een vakorganisatie door de administratieve autoriteiten die plaatsvond in nei 1991, sprak

154 Direct Requests 1981, p. 8.

155 Memoria 1982, p. 11.

156 Informe de Misión, december 1983, p. 22.

157 Memoria 1986, p. 7 .

158 Dit geldt zowel in het algemeen (art. 380, lid 2, (c)), als in het geval van de illegale staking (art. 450, lid 2 jo. art. 451). Direct Request, 1985.

159 Direct Request 1987. 
het Comitê inzake de Vrijheid van Vakvereniging dan ook de hoop uit dat dergelijke praktijken tot het verleden zouden behoren. ${ }^{160}$

\subsection{Ontslag en diskwalificatie van vakbondsleiders en leden}

Treft de ontbinding van een vakbond of het intrekken van diens rechtspersoonlijkheid een gehele organisatie, afzonderlijke vakbondsleden en leiders worden met name gedupeerd door ontslag of - in geval van vakbondsleiders - door ontzetting uit hun functie. Hoewel deze sancties in beginsel door verschillende instanties worden uitgevoerd - de werkgever en de overheid - zijn zij in de Colombiaanse "rechts"praktijk nauw verbonden. Diskwalificatie van vakbondsleiderschap leidt in veel gevallen tot ontslag, terwijl ontslag dikwijls het verlies van de leidersfunctie met zich meebrengt. Ik kom aanstonds op deze koppeling terug.

\subsubsection{Ontslag door de werkgever}

Een groot aantal van de klachten die in de loop der jaren bij de ILO tegen Colombia zijn ingediend, heeft betrekking op ontslag van vakbondsleden en -leiders of andere vormen van anti-vakbondsdiscriminatie door de werkgever. ${ }^{15 t}$

Voorts heeft de vakcentrale CUT in een commentaar op het rapport van de regering van 1988 inzake Verdrag no. 98 , de in haar ogen gebrekkige rechtsbescherming tegen antivakbondsdiscriminatie principieel aan de orde gesteld. De regering antwoordt dat het Ministerie van Arbeid zich serieus kwijt van zijn toezichthoudende taak door werkgevers die antivakbondsmaatregelen hebben genomen, te bestraffen met geldboetes die kunnen variëren van 1 tot 40 maal het minimumloon. ${ }^{162}$ Bovendien kan de strafrechter op grond van art. 309 Wetboek van Strafrecht eenieder die de uitoefening van vakbondsrechten belet, veroordelen tot gevangenisstraf van 1 tot 5 jaar en tot geldboetes van 1000 tot 50.000 pesos. Onder verwijzing naar art. 1 van Verdrag no. 98 acht het Comite van Deskundigen het noodzakelijk dat de geldboetes verhoogd worden met het oog op het zeer lage minimumloon

160. Case No. $1562,279 \mathrm{e}$ Rap. $\$ 514$.

161 Zie o.a. Case No. 490 , 99 e Rap. $\$ 43-45$ en 101 e Rap. $\$ 308-317$ en 103 e Rap. $\$ 48-57$.

Case No, 546, 1110 Rap. $\$$ 64-85 en 112e Rap. $\$ 37-46$.

Case No. 601, 117e Rap. \$\$ 54-65 en 120e Rap. \$ $\$ 70-75$.

Case No. 643, 125 e Rap. \$\$ 7-14.

Case No. 785, 150e Rap. \$\$ 7-19.

Case No. 994, 207e Rap. \$\$ 263-274.

Case No. 1073, 214 e Rap. $\$ \$ 366-377$.

Case No. 1101, 214e Rap. $\$ \$ 270-280$.

Case No. 1422,254 e Rap. $\$ \$ 87.107$.

162 Het Ministerie van Arbeid ontleent zijn toezichthoudende bevoegdheden aan ant 485 CST. 
en benadrukt het belang dat de strafrechtelijke sancties in praktijk ten uitvoer worden gelegd. ${ }^{10 x}$

Ondanks deze recente kritiek op de rechtsbescherming heeft de ILO in een aantal concrete gevallen de juridische waarborgen tegen ontslag van vakbondsleiders en -leden wel toereikend geacht. Zo deelde het Comite inzake de Vrijheid van Vakvereniging, naar aanleiding van massa-ontslagen bij de firma Hermega, de opinie van het Ministerie van Arbeid dat vakbondsleiders ontzien waren en vakbondsleden niet opzettelijk benadeeld waren ten opzichte van werknemers die niet waren aangesloten bij de vakbond. ${ }^{144}$ Verder stelde het Comite zich ermee tevreden dat onrechtmatige ontslagen van vakbondsleden bij Coca Cola door de interventie van de administratieve autoriteiten ongedaan waren gemaakt. ${ }^{165}$ In een recentere zaak (de klacht dateert uit 1988) liet het Comite blijken dat het de juridische waarborgen tegen anti-vakbondsdiscriminatie van de kant van de werkgever althans in theorie adequaat vond. ${ }^{166}$

Het vertrouwen van de ILO in de rechtsbescherming tegen discriminatoir ontslag van vakbondsleden in Colombia vindt mogelijk (mede) zijn oorsprong in bet feit dat de nationale Arbeidswet het fenomeen kent van de "fuero sindical": het is verboden vakbondsleiders te ontslaan. ${ }^{167}$ Hoewel slechts een klein aantal personen onder deze bescherming valt - krachtens art. 406 CST zijn maximaal vijf vakbondsleiders per vakbond, federatie of confederatie en hun vervangers gevrijwaard tegen ontslag - en de Wet in een ontsnappingsclausule voorziet art. 410 verwijst naar "gerechtvaardigde redenen voor ontslag" -, vormt het leerstuk van de "fuero sindical" een indicatie dat Colombia althans op dit punt de bescherming van vakbondsrechten au sérieux neemt.

\subsubsection{Ontslag als gevolg van sancties}

Het ontslagvraagstuk is aanzienlijk gecompliceerder, indien maatregelen van de autoriteiten direct of indirect het ontslag van vakbondsleiders of -leden tot gevolg hebben. In de eerste plaats kan de Wet direct bepaalde activiteiten met ontslag bestraffen. ${ }^{168}$ In de tweede plaats

163 Observations concerning ratified Convention No. 98, 1989, p. 267.

164 Case No. 490, $103 \mathrm{e}$ Rap, $\$ \$ 56-57$.

165 Case No: 1073 , 214e Rap. \$\$ 366-377.

166 Naar aanleiding van klachten over anti-vakbonds-maatregelen in de General CEAT-Company; stelde de regering dat de ontslagen werknemers in beroep hadden kunnen gaan bij de arbeidsrechter. Bowendien hadden ze een procedure kunnen aanspannen bij de strafrechter tegen de onderneming wegens schending vain vakbondsrechten. Het Comite inzake de Vrijheid van Vakwereniging stelde de regering in het gelijk. Case No. 1422, 214e Rap. \$\& 87-107.

167 De Fuero Sindical is geregeld in artt. 403-413 CST.

168 Zo verleent art. 450 , lid 2 CST de werkgever de wrijheid om werknemers die deelgenomen thebben aan een illegale staking te ontslaan, ongeacht de vraag of zij al of niet beschermd zijn door de "fuero sindical". 
kunnen sommige sancties - het niet inwilligen van een verzoek om rechtspersoonlijkheid te verkrijgen $\left({ }^{(15)}\right)$, de ontbinding van een vakorganisatie en de diskwalificatie van vakbondsleiderschap - ertoe leiden dat met name vakbondsleiders van hun "fuero sindical" beroofd worden. Deze sancties zijn op zichzelf al in strijd met de vrijheid van vakvereniging, zodat de toezichtsorganen van de ILO het blijkbaar niet nodig achten om apart aandacht te schenken aan de nadelige consequenties. Zo heeft het Comite van Deskundigen de diskwalificatie van vakbondsleiderschap, met inbegrip van het verlies van het recht om zich te organiseren, gekwalificeerd als strijdig met het recht van vakorganisaties om hun vertegenwoordigers in volledige vrijheid te kiezen (art. 3 van Verdrag no. 87), zonder nader in te gaan op het, direct met de diskwalificatie samenhangende, verlies van de "fuero sindical": ${ }^{120}$ De regering heeft verzuimd om op deze kritiek uitvoerig te reageren. Uitsluitend in de Memoria van 1984 wordt er een korte alinea aan gewijd: het opleggen van sancties aan vakbondsleiders aan wier schuld het te wijten is dat een vakbond te gronde gaat, dient uitsluitend ter bescherming van de degenen die bij de vakbond aangesloten zijn. ${ }^{17}$ Gezien de voortdurende herhaling van zijn

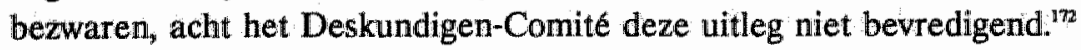

\subsubsection{Het verband tussen ontslag en vakbondsleiderschap}

Besteedt het Comite van Deskundigen geen aandacht aan de consequenties van diskwalificatie van vakbondsleiderschap - de sanctie brengt het verlies van de "fuero sindical" met zich mee, op de inverse relatie tussen beide sancties - het ontslag leidt tot verlies van vakbondsleiderschap - gaat het Comité wel dieper in. Zoals al eerder werd vermeld, knoopt de Colombiaanse Arbeidswet aan de kandidatuur voor vakbondsleiderschap de verplichting dat de vakbondsleider-in-spe minimaal zes maanden het vak of de werkzaamheden heeft uitgeoefend die karakteristiek zijn voor de desbetreffende vakbond. ${ }^{173}$

In de, eerder geciteerde, Case $N 0.719$ was het ontslag van 400 werknemers en van alle vakbondsleiders wan de drie organisaties die opereerden binnen de firma AVLANCA de rechtstreekse consequentie van hun deelname atan de illegale staking. Case No. 719, $138 \mathrm{e}$ Rap. 59.

169 Zie de hierwoor aangehalde Case No. 734, 143e Rap. $\$ 47$.

170 Direct Requests 1981, p. 8.

Art 380, lid 2 sub (c) CST bepaalt dat elke leider die verantwoordellijk is voor de ontbinding van zijn vakbond; zijn leidersfunctie verliest. Art. 380, lid 4 CST bepaalt dat de rechter een dergellijke persoon het recht om zich te organiseren kan ontzeggen.

171 Memoria 1984 , p. 15 .

172 Observations 1985 en 1987 , onder (2)/Observation 1989, p. 145 .

173 Art. 388, lid 1, sub (c), art. 432, lid 2 CST en art. 18 (c) van Resolutie no. 4 van 1952 hebben betrekking op "eerstegraads"-vakbonden. Art. 422 , lid 1, sub (c) CST stelt de verplichte minimum-termijn voor toekomstige vakbondsleiders van federaties op én jaar.

Zie voor het kritische commentaar van het Comite inzake de Vrijheid van Vakvereniging hierboven, p. 194 en Case $\mathrm{Nlo}$ 514, 129 e Rap. $\$ 113$. 
In eerste instantie volstaat het Comite met op te merken dat het wenselijk zou zijn om de voorwaarden voor verkiesbaarheid van leidersfuncties te versøepelen door bijvoorbeeld een aanzienlijk percentage vakbondsleiders te ontslaan van de verplichting om het vak uit te oefenen dat karakteristiek is voor de organisatie die zij willen leiden. ${ }^{1 \pi}$ De regering antwoordt dat het duidelijk is dat een organisatie geleid moet worden door personen die min of meer dezelfde activiteiten ontplooien en dezelfde belangen nastreven, aangezien anders een gemeenschappelijk doel moeilijk gesteld, laat staan gerealiseerd kan worden. Ter illustratie overweegt de regering dat men zich moeilijk kan voorstellen dat een werknemer uit de agrarische of maritieme sector kan oordelen over de belangen van een vakorganisatie in de metaalsector of in de bouw. ${ }^{175}$ In zijn Observation van 1985 benadrukt het Comite de connectie tussen ontslag en verlies van vakbondsleidersehap. Het Comité spreekt de hoop uit dat de regering de relevante wetsartikelen zal amenderen, om te voorkomen dat een ontslagen vakbondsleider zijn functie verliest en om personen die eertijds het vak van de organisatie hebben uitgeoefend, in de gelegenheid te stellen om mee te dingen naar vacante posten. ${ }^{176}$ In haar antwoord op het commentaar van het Comite, wijst de regering op art. 4 van Decreet no. 1469 van 1978: "De beëindiging van een arbeidsovereenkomst verbreekt als zodanig niet de band tussen werknemer en vakbond". Een werknemer die deel uit maakt van of zelfs een leidersfunctie bekleedt binnen een organisatie van beroepsgenoten (de zogenaamde "gremial") zal zijn band met de organisatie niet ten gevolge van ontslag verliezen, aangezien zijn lidmaatschap of leiderschap niet voortspruit uit de contractuele relatie met de werkgever maar uit het vak dat hij uitoefent en uit zijn vrije wil om te behoren tot die organisatie. ${ }^{17}$ Het Comité van Deskundigen laat zich niet misleiden door het gewiekste antwoord van de regering. De explicatie van de regering heeft uitsluitend betrekking op organisaties van beroepsgenoten ("gremiales"), niet op ondernemingsvakbonden, zo merkt het Comité terecht op. Met andere woorden: ontslag uit een onderneming impliceert wel degelijk het verlies van leiderschap over een sindicato de base. ${ }^{17 g}$

Voorzover bekend, is er slechts eenmaal een klacht ingediend over het verlies van leidersfuncties naar aanleiding van ontslagen. In 1982 bereikte de ILO een klacht over het ontslag van werknemers van het Nationale Instituut voor Statistiek, een ontslag dat naar alle waarschijnlijkheid nauw samenhing met het feit dat de betrokken werknemers vakbondsfunctionarissen waren. Het ontslag impliceerde het verlies van de functie. Het Comité inzake de

174 Direct Requests 1981, p. 8.

Direct Requests 1983, p. 9.

175 Memoria 1984, pp. 15-16.

176 Observation 1985, onder (2).

177 Memoria 1985, p. 10/Memoria 1986, pp. 5 en 6.

178 Observation 1987, onder (2). Uit de Observation van 1989 blijkt dat de regering haar standpunt in 1988 niet nader heeft toegelicht. 
Vrijheid van Vakvereniging achtte deze gang van zaken in strijd met het recht van organisaties om thun eigen vertegenwoordigers te kiezen."

\subsection{Arrestatie en (preventieve) hechtenis van vakbondsleden}

Het aantal arrestaties en detenties van vakbondsleden is dikwijls een goede graadmeter voor het repressieve klimaat in een land. In dit verband is het opmerkelijk dat wanaf het midden van de jaren zestig klachten over arrestatie en detentie bij de ILO werden ingediend: het is wederom een indicatie dat in deze periode de vakbondspolitiek zich geleidelijk begon te verharden als reactie op de meer onafhankelijke en strijdbare opstelling van de vakbeweging. De eerste arrestaties en detenties vonden plaats naar aanleiding van stakingen, werkonderbrekingen en fabrieksbezettingen die, achteraf bezien, de voorboden waren van de grote nationale stakingen aan het eind van de jaren zeventig en gedurende de jaren tachtig. De hechtenis was in deze periode doorgaans nog van korte duur. Het Comité inzake de Vrijheid van Vakvereniging volstond dan ook met de kanttekening dat maatregelen van preventieve hechtenis een ernstige inmenging in vakbondsaangelegenheden konden opleveren die aan kritiek onderhevig was, tenzij zijvergezeld gingen van toereikende gerechtelijke waarborgen die binnen een redelijke termijn werden toegepast.

Zoals hierboven al vermeld werd, reageerde de regering op de eerste grote nationale staking in 1977 met het uitvaardigen van een Wetsdecreet, waarin de staking verboden werd en de organisatoren gedreigd werden met gevangenisstraf. Het voornaamste bezwaar van het Comite inzake de Vrijheid van Vakvereniging gold het feit dat de procedures van het Decreet een vluchtig karakter hadden en onvoldoende omkleed waren met de waarborgen van een "eerlijk proces", zoals voorzien in het Internationale Verdrag inzake Burger- en Politieke Rechten, waarbij Colombia partij is. ${ }^{181}$

Op 6 september 1978 werd het Statuut van de Nationale Veiligheid bij Wetsdecreet no. 1923 ingevoerd. Een groot aantal vakverenigingen, zowel van nationale als van internationale herkomst, beklaagde zich tegenover de ILO erover dat het Statuut gerechtelijke procedures uitholde, gevangenisstraffen verhoogde en de werking van het militaire strafrecht uitbreidde over vergrijpen die door burgers begaan waren. De regering refereerde aan een uitspraak van het Hoogste Gerechtshof, waarin gesteld werd dat het Statuut toereikende gerechtelijke bescherming bood en beweerde dat het Statuut was uitgevaardigd om rebellie de kop in te

179 Case No. 1127, so 234-246.

180 Case No. 363, 774e Rap. \$\$ 214-215.

Case No. 514, 101e Rap. $\$ 462$.

Case No. 527, 103e Rap. 68 .

Case No. 664, 127 e Rap. $\$ 91$.

Case No. 701,139 e Rap. $\$ 482-489$ en 142 e Rap. $104-116$.

181 Case No. 889.177 e Rap. 330. 
drukken en illegaal wapenbezit te bestrijden. De klagende vakorganisaties meenden dat dit een voorwendsel was om de vakbeweging te onderdrukken.

Geconfronteerd met deze tegenstrijdige visies en met een aanzienlijke toename van het aantal klachten over arrestatie en detentie, heeft het Comité inzake de Vrijheid van Vakvereniging een consequent standpunt ontwikkeld, waarbij het de inschakeling van de rechter als Leitmotiv heeft genomen. In de eerste plaats accepteerde het Comité geen lichtvaardige beschuldigingen aan het adres van de autoriteiten. Zo kregen sommige vakorganisaties die zich beklaagden over arrestaties en detenties al in een vroeg stadium nul op het request, aangezien hun klachten, naar het oordeel van het Comite, in te vage termen vervat of onvoldoende onderbouwd waren. ${ }^{18 s}$

De functie van de inschakeling van de rechter was tweeërlei, zo gaf het Comité te kennen. Aan de ene kant zou een snelle voorgeleiding voor de rechter een einde maken aan de in juridisch opzicht schimmige situatie van de preventieve hechtenis en vooral een goede waarborg vormen tegen mishandeling tijdens deze preventieve hechtenis. ${ }^{124}$ Aan de andere kant was de rechter de aangewezen figuur om vast te stellen of de specifieke omstandigheden een veroordeling tot een vrijheidsstraf rechtvaardigden, Daarom drong het Comité er bij de regering op aan om zoveel mogelijk informatie te verstrekken over de redenen van de arrestaties en kopieën van de vonnissen over te leggen. ${ }^{185}$

Indien vakbondsleden tijdig voor de rechter waren geleid en door de rechter veroordeeld waren, stelde het Comité zich ermee tevreden dat de arrestatie en detentie niet het uitvloeisel was van hun vakbondslidmaatschap of hun vakbondsactiviteiten, maar een strafrechtelijke achtergrond hadden. ${ }^{186}$ Indien daarentegen de gerechtelijke procedure lang op zich had laten

182 Case No. $919,194 \mathrm{e}$ Rap. $\$ \$ 325$ en 336.

183 Case No. 919,217 e rap. $\$ 363$.

Case No. 1023 , 208e Rap. $\$ \$ 52-58$.

Case No. 1036, 21le Rap. $\$ \$ 54-59$.

Case No. 1072 , $214 \mathrm{e}$ Rap. $\$ \$ 40-45$.

Cases Nos. 1083 en 1085,217 e Rap. $\$ 183$.

184 Case No. $919,208 \mathrm{e}$ Rap. $\$ 260$.

In dit kader zijn de bevindingen van de VN-Werkgroep inzake Gedwongen en Onvrijwillige Verdwijningen die van 24 oktober tot 2 november 1988 Colombia bezocht, vermeldenswaardig. De Werkgroep beschilkte over aanwijzingen dat er een verband bestond tussen de "verdwijning" van personen en hun langdurige voorlopige hechtenis in militaire kampementen. Laatstgenoemde praktijk is in strijd met art. 394 van thet Colombiaanse Wetboek van Strafvordering dat de onmiddellijke voorgeleiding voor de rechter eisi vain personen die op heterdaad betrapt zijn. Bovendien zijn militaire kampementen geen algemeen erkende detentiecentra. Vgl. Report an the wist to Colombia by two members of the Working Group on Enforced or Involontary Disappearances (24-10-1988 tot 2-11-1988), E/CN.4/1989/18/Add. 1, §! 54 en 55 .

185 Case No. 919, 194ke Rap. $351-354$.

186 Case No. 919, 217 e Rap. $\$ 361$ en 362 .

Case No. 1343, 244 e rap. $\$ \$ 366$ en 377.

In het eerste geval (Case No, 919) was het feil dat de vakbondsleden in kwestie veroordeeld waren vanwege bun connecties met de guerrillagroeperingen M'19 en FARC en aanspraak konden maken op strafivermindering 
wachten of de rechter in het geheel niet was ingeschakeld neigde het Comité er snel toe om aan te nemen dat de arrestatie en detentie verband hielden met het ontplooien van (legitieme) vakbondsactiviteiten. ${ }^{\text {ist }}$

\subsection{Moord op en "verdwijningen" van vakbondsleden}

De ontbinding van vakbonden, arrestaties en detenties en ontslagen van vakbondsleiders en -leden gaan uit van de autoriteiten of van werkgevers. Doorgaans is het vrij eenvoudig om de verantwoordelijke instantie of persoon te traceren en dit vergemakkelijkt de taak van het Comite inzake de Vrijheid van Vakvereniging om tot een genuanceerd oordeel te komen. Met moord op en verdwijningen van vakbondsleiders en -leden ligt dit anders. Vooral de laatste tien jaar terroriseren para-militaire doodseskaders, misdaadsyndicaten die onder contract staan van of in ieder geval connecties hebben met de drugsmafia en linkse guerrillagroeperingen de bevolking van Colombia. Vakbondsleden en -leiders zijn dikwijls het slachtoffer van hun misdaden. In welke mate ook het leger geïnvolveerd is in de gewelddadigheden, is niet duidelijk. Elke structurele betrokkenheid van de militairen wordt natuurlijk door de autoriteiten categorisch ontkend.

De bloedige aanslagen op vakbondsleden en het algemene gewelddadige klimaat in Colombia vervullen de ILO met groeiende zorg. Toch kwam de uitbarsting van geweld niet geheel onverwachts. Voor 1985 hadden vakorganisaties bij de ILO al klachten ingediend over moord op en mishandeling van vakbondsleiders. Sommige van deze klachten hadden betrekking op het doden van boerenleiders in rurale gebieden; andere klachten wezen op de uitbreiding van het geweld van het platteland naar de stad en zinspeelden op een verband tussen de nationale stakingen en het geweld van de kant van de autoriteiten. Aan beide categorieën zal in het kort aandacht worden besteed.

\subsubsection{Het geweld op het platteland}

Het geweld op het platteland is in zekere zin de voortzetting en de erfenis van de Violencia van de jaren vijftig en zestig die nimmer volledig is uitgewoed. De opvattingen over de herkomst en de aard van het geweld van de vakorganisaties enerzijds en van de autoriteiten

of gratie op grond van de amnestieregelling van 1982 van invloed op het oordeel van het Comite. Case No. 919, 208 e Rap. $\$ \$ 256-257$.

187 In Case No. 1065 had het Comite duidelijke aanwijzingen dat José Joaquim Romero, een vakbondsleider van FENATRAMETAL, zonder vorm van proces werd vastgehouden in verband met het organiseren van een staking. (217e Rap. \$5 555-558) Nadat de regering had meegedeeld dat zijn zaak verder afgehandeld zou worden door de strafrechter, verzocht het Conitê de regering om het van de verdere ontwilkkelingen op de hoogte te houden (218e Rap. 571). 
anderzijds verschillen sterk en komen duidelijk naar voren in de zaken die het Comite inzake: de Vrijheid van Vakvereniging ter afhandeling zijn voorgelegd.

De boerenvakbond FANAL, wier gelederen de afgelopen tien jaar aanzienlijk zijn uitgedund ten gevolge van de laaghartige moordaanslagen, heeft er dikwijls op gewezen dat de moord op boerenleiders niet los gezien kan worden van haar pogingen om landhervormingen doorgevoerd te krijgen. De inzet van deze vakbondsleiders voor de boeren brengt hen onvermijdelijk in conflict met grootgrondbezitters die dikwijls openbare ambten bekleden en met steun van de publieke autoriteiten geen middel schuwen om de boeren en hun leiders de voet dwars te zetten. ${ }^{188}$

De reacties van de regering zijn telkens vrij stereotiep geweest. In de eerste plaats heeft de regering beweerd dat de moorden niets te maken hadden met vakbondsaangelegenheden Het Comité inzake de Vrijheid van Vakvereniging heeft hierop geantwoord dat het niet uitsluitend aan de regering is om uit te maken of een bepaald incident verband houdt met vakbondsactiviteiten, maar dat het Comité zelf in het licht van de omstandigheden en van de beschikbare informatie zich hier een oordeel over moet vormen. ${ }^{150}$ In een enkel geval komt het Comite, na een zorgvuldig onderzoek, inderdaad tot de conclusie dat een moord geen verband houdt met vakbondsactiviteiten. ${ }^{191}$

In de tweede plaats wijst de regering elke betrokkenheid van het leger of van de politie van de hand en tracht het Comité ervan te overtuigen dat met name de guerrillabeweging, die overigens nauwe contacten onderhoudt met de drugsmafia, verantwoordelijk is voor de moorden. ${ }^{192}$ De regering voegt hier nog aan toe dat Colombia geen dictatuur maar een democratisch geregeerd land is. Een dictatuur, zo vervolgt de regering, verbiedt vrije verkiezingen, vrije vakverenigingen en vrijheid van meningsuiting, maar een democratie, zoals Colombia, is juist gegrondvest op deze vrijheden en zal daarom volgens andere maatstaven beoordeeld moeten worden. ${ }^{193}$

Het Comité inzake de Vrijheid van Vakvereniging heeft zich nimmer laten verleiden tot een prematuur oordeel over de schuldvraag. Het heeft zich beperkt tot de observatie dat een klimaat van geweld een zeer ernstige bedreiging vormt voor de uitoefening van vakbondsrechten $\left({ }^{1 *}\right)$ of, anders geformuleerd, dat de vrijheid van vakvereniging uitsluitend

188 Zie o.a. Case No. 871,168 e Rap. $\$ \$ 238$ en 239.

Case No. 1155, 222e Rap. 268 en 269.

189

Zie o.a. Case No. 871, 168 e Rap. 240.

Case No, 919, 194te Rap. \$341.

Case No. 1155, 234e Rap. \$266.

Case No. 1252,234 e Rap. $\$ 277$.

190 Case No. 871 , 168e Rap. $\$ 241$.

191 Case Na. 1105, 217e Rap. $\$ 623$.

192 Zie o.a. Case No. 1155, 222 e Rap. $\$ 271-272$ en 234e Rap. $\$ \$ 266-267$.

Case No. 1252, 234e Rap. $\$ 277-278$.

193 Case No. 1252, 234e Rap. $\$ 277$.

194 Case No. 1155, 222 e Rap. \& 273. 
genoten kan worden onder de voorwaarde dat fundamentele mensenrechten, en wel in het bijzonder die mensenrechten die betrekking hebben op het recht op leven en op persoonlijke veiligheid, volledig gewaarborgd en gerespecteerd worden. ${ }^{\text {195 }}$ Met het oog hierop, heeft het Comité er telkens bij de regering op aan gedrongen om, in geval van moord op of mishandeling van vakbondsleiders, een onafhankelijk onderzoek door de rechter te laten instellen, teneinde de omstandigheden op te helderen en de schuldigen op te sporen en te bestraffen. ${ }^{19 \%}$

6.5.2 Moord op en mishandeling van vakbondsleden welke mogelijk verband houden met deelname aan nationale stakingen

In 1979 makten verscheidene internationale vakverenigingen de ILO attent op het feit dat de repressie ten aanzien van vakorganisaties overgewaaid was van het platteland naar de stedelijke centra. ${ }^{197}$ In feite verkondigden de klagers niet veel nieuws. Reeds de Nationale Staking van september 1977 had meer dan 100 mensenlevens geëist. Aangezien zich onder de slachtoffers geen vakbondsleden bevonden, achtte het Comité het niet in overeenstemming met zijn mandaat om de zaak verder te onderzoeken. ${ }^{196}$

Nieuwe klachten over mishandeling, martelingen en moord naar aanleiding van stakingen sorteerden niet het gewenste resultaat. Ondanks thet feit dat het Comite er herhaaldelijk bij de regering op aandrong om de klachten te onderzoeken, bleven de autoriteiten in gebreke om aan de verzoeken van het Comite te voldoen. Het Comite volstond met de regering te manen om in geval van preventieve hechtenis speciale voorzieningen te treffen teneinde de gedetineerden te beschermen tegen mishandelingen $\left({ }^{199}\right)$ of kwam tot de conclusie dat de klagers onvoldoende bewijsmateriaal hadden aangevoerd om hun beschuldigingen te schragen. ${ }^{200}$

\subsubsection{De escalatie van gewelddadigheden na 1985}

De aansporingen van het Comité inzake de Vrijheid van Vakvereniging aan het adres van de regering om gerechtelijke onderzoeken in te stellen naar klachten over moord op en

195 Case No. 1239, 233 e Rap. $\$ 212$.

Case No $1252,234 \mathrm{e}$ Rap. 282.

196 Case No. $871,202 \mathrm{e}$ Rap. $\$ 92$.

Case No. 919, 194e Rap. $\$ 349$.

Case No. 1155, 222 e Rap. 273.

Case No. 1252, 234e Rap. \$281.

197 Case No. 919, 194e Rap. \$325.

198 Case No. 889,190 e Rap. $\$ 142$.

199 Case No. 919,208 e Rap. $\$ 260$.

200 Cases Nos. 1083 en 1085, 217e rap. $\$ 177$ en 182. 
martelingen en verdwijningen van vakbondsleiders, vormen een constante in de "case law" van de ILO. De resultaten van deze onderzoeken zijn tot op heden ronduit teleurstellend geweest. Lange, tot mismoedigheid stemmende lijsten met namen van vakbondsleden die vermoord of gemarteld zijn of wier verblijfplaats onbekend is, zijn de afgelopen acht jaar bij de ILO ingediend. ${ }^{201}$ In enkele gevallen heeft de regering geprobeerd de ernst van de situatie te bagatelliseren door de moord op of de verdwijning van vakbondsleden te ontkennen $\left({ }^{(202}\right)$ of door erop te wijzen dat het aantal "verdwenen" vakbondsleden schromelijk overschat is. ${ }^{20}$ Soms neemt de regering haar toevlucht tot het vertrouwde excuus dat de moord of de verdwijning geen verband houdt met vakbondsactiviteiten. ${ }^{24}$ Daarbij zijn de gewelddadige activiteiten van de zogenaamde para-militaire groeperingen - een naam die overigens in de ogen van de regering ongelukkig gekozen is, aangezien het hier om gewone criminelen gaat die niet parallel opereren aan of getolereerd worden door het officiële legerniet uitsluitend gericht tegen vakbondsleden: het gehele land is het slachtoffer van hun misdaden. ${ }^{20 s}$

In de meerderheid van de gevallen stelt de regering, zoals ook het Comite erkend heeft, echter wel een strafrechtelijk onderzoek in. ${ }^{206}$ Dit onderzoek wordt dikwij]s door verschillende omstandigheden bemoeilijkt. Volgens de regering vormt het gebrek aan medewerking van de kant van de klagende vakorganisaties soms een beletsel voor de voortgang van het onderzoek. ${ }^{27}$ In dit verband heeft het Comité inzake de Vrijheid van Vakvereniging opgemerkt dat getuigen soms niet ter terechtzitting verschijnen uit angst voor represailles. ${ }^{208}$ Ongetwijfeld is het gebrek aan resultaten voor een deel ook toe te schrijven aan bepaalde strafprocessuele restricties. $\mathrm{Zo}$ schort art 473 van het Wetboek van Strafvordering de opsporingsbevoegdheid op, indien na verloop van een jaar nog geen verdachte is gevonden of indien er te weinig belastend bewijsmateriaal tegen de verdachte voorhanden is. ${ }^{20}$ Bovendien heeft met name de VN-Werkgroep erop gewezen dat de werkzaamheden van het Bureau van de Procureur Generaal, belast met de opsporing en vervolging van publieke functionarissen, aanzienlijk aan effectiviteit hebben ingeboet, sinds de ontmanteling van het

201 Zie met name Annex I bij Case No. 1343, 244e Rap./Case No. 1434, 259e Rap. $\$ 813$ en 614/Annex I (vermoorde of "verdwenen" vakbondsleden) en Annex II (vermoorde vakbondsleden) bij Cases Nos: 1434 en $1477,279 \mathrm{e}$ Rap.

202 Zie o.a. Case No, 1343, 246e Rap. $\$ 390$

203 Zie o.a. Case No. 1343, 248 e Rap. $\$ 497$

204 Case No. 1343, 251 e Rap. $\$ 330$.

205 Case No. 1343, 248 e Rap. $\$ 499$

206 Zie o.a. Case No. 1343, 246 e Rap. \& 395.

207 Met name de boerenorganisatie ANUC wordit gebrek alan coőperatie verweten. Zie Case No. 1343, 2460 Rap. $\$ 390$ en 251 e Rap. $\$ 328$.

208 Deze wretenschap ontleent het Comité aan het rapport van de Direct contact-missie die van 14 tot 18-07-1986 het land heeft bezocht. Case No. 1343, 246e Rap. 394. Vgl. ook het Rapport van de VN-Werkgroep; E/CN.4/1989/18/Add. 1, \$\$ 80-83.

2009 Case No. 1343, 248 e Rap. $\$ 497$. 
opsporingsapparaat van het Bureau. Verscheidene Procureurs-Generaal, wier inzet en doortastendheid bij de bestrijding van mensenrechtenschendingen onomstreden is, hebben zich bij de president van de republiek beklaagd ower deze personele amputatie.:

De buitengewoon ondoorzichtige situatie, de onmacht van de autoriteiten om de schuldigen van wandaden te vervolgen en de daaruit voortvloeiende toename van geweld zijn de belangrijkste aanleiding geweest voor de ILO om regelmatig Direct contact-missies samen te stellen. Met name de bevindingen van de laatste missie zijn van belang omdat zij althans enige opheldering verschaffen over de herkomst van slachtoffers en daders en enig inzicht bieden in de structurele achtergrondlen van het geweld. ${ }^{2 n}{ }^{21}$ Hoewel het geweld niet uitsluitend gericht is tegen vakbondsleden, hebben de aanstichters van het geweld het wel in het bijzonder gemunt op deze categorie, zoluidt de eerste conclusie van de missie. Daarbij is het opvallend dat vooral onder de leden van de links-georiënteerde vakcentrale CUT veel slachtoffers zijn te betreuren, maar dit maakt deel uit van een meer algemeen patroon dat met name mensen van linkse signatuur getroffen worden door het geweld. In militaire kringen en in conservatieve nieuwsbladen wordt wel beweerd dat de CUT nauwe banden onderhoudt met de guerrillabeweging, hetgeen een verklaring zou kunnen zijn voor het grote aantal slachtoffers binnen de gelederen van de CUT. Deze aantijging kan evenwel niet serieus genomen worden: van regeringszijde wordt officieel ontkend dat de CUT als instituut betrekkingen heeft met de guerrillabeweging.

Het geweld gaat voornamelijk uit van para-militaire groeperingen, waarvan er 138 verspreid over het gehele land opereren. Door niemand wordt tegengesproken dat deze groeperingen gefinancierd worden door grootgrondbezitters en drugs-baronnen die elke poging om economische of politieke hervormingen door te voeren tegenwerken, uit vrees voor een aantasting van hun rijkdommen en hun bevoorrechte positie. Dit verklaart waarom juist veel boeren en arbeiders het slachtoffer zijn van de gewelddadigheden. Veel van deze para-militaire groeperingen komen van origine voort uit de zogenaamde zelfverdedigings-commando's die in 1969 door het leger zijn opgericht in het kader van de strijd tegen de guerrilla-beweging. Hoewel de Minister van Justitie beweert dat deze commando's zijn ontmanteld, wordt er in de media nog regelmatig aan hun bestaan gerefereerd.

Wat betreft de betrokkenheid van de staat en van het leger bij de gewelddadigheden lopen de meningen uiteen. Niemand, ook niet de vakbondsleiders met wie de delegatieleden van de ILO een onderhoud hebben gehad, beweert weliswaar dat de staat of het leger als instituut zich schuldig maakt aan structureel geweld, maar de deelname van bepaalde elementen van de strijdkrachten aan de gewelddadigheden is volgens de CUT frequenter dan men bereid is om toe te geven. $\mathrm{Zij}$ worden zelden of nooit onderworpen aan disciplinaire

$210 \mathrm{E} / \mathrm{CN} .4 / 1989 / 18 /$ Add. 1, $\$ 30-32$. De onmacht van het strafrechtelijke apparaat komt duidelijk tot uitdrukking in thet feit dat in 1990 en 1991 van een lijst van 113 vermoorde vakbondsleden slechts in zeven gevallen de identiteit van de daders achterhaald kon worden, vgl. Cases Nos. 1434 en 1477,279 e Rap. $\$ 492$.

211. Deze missie vond plaats van 31-08-1988 tot 07-09-1988 en stond onder leiding van Philippe Cahier. Het rapport van de missie is als ANNEX II toegevoegd aan Case No. 1434, 259e Rap. 
maatregelen. De presidentiële adviseur inzake de rechten van de mens geeft daarentegen aan dat van de 700 politieke moorden die vanaf het begin van het jaar (1988) gepleegd zijn, slechts in 16 gevallen militairen in staat van beschuldiging zijn gesteld.".:

Het voornaamste verwijt aan het adres van de regering geldt haar passieve houding. De alom heersende straffeloosheid wakkert het geweld aan, enerzijds omdat familie en vrienden van slachtoffers hun dierbaren willen wreken en het recht in eigen hand nemen, anderzijds omdat de criminelen in het kwaad volharden nu zij toch geen strafvervolging hebben te vrezen. De Procureur Generaal zelf maakt melding van het stroef werkende justitiele systeem in Colombia. Rechters beschikken over onvoldoende materiële middelen, worden slecht betaald en staan zelf voortdurend bloot aan bedreigingen. Enkele raadsheren van het Hoogste Gerechtshof voegen hier nog aan toe dat het Colombiaanse recht (te) strenge eisen stelt aan de bewijsvoering.

Volgens de CUT hanteert het openbaar gezag bovendien een merkwaardige dubbele maatstaf. Politie en leger bestrijden de guerrillabeweging te wuur en te zwaard, terwijl zij de para-militaire groeperingen vrijwel ongemoeid laten.

Alle beschouwingen in overweging nemende, vraagt de Missie zich tenslotte af of er tekenen zijn die wijzen op een verandering in gunistige zin. Er zijn enkele lichtpuntjes, zo constateert de Missie. De aanstelling van een presidentiële adviseur voor de rechten van de mens en de creatie van een speciaal politie-corps dat belast is met het onderzoek naar de personen die zich schuldig maken aan gewelddadigheden, geven blijk van de goede wil van de regering. Bovendien signaleert de Missie een recente jurisprudentie van het Hoogste Gerechtshof, op grond waarvan militairen die ervan verdacht worden misdaden tegen burgers te hebben begaan, voortaan onder civiele rechtspraak zullen vallen. Verder heeft de regering actie ondernomen om in specifieke conflicthaarden, zoals de provincie Uraba, het overheidsgezag te versterken en de sociaal/economische situatie te verbeteren. Tenslotte wijst de Missie op het feit dat de opsporingsactiviteiten van het Openbaar Ministerie in 15 gevallen geleid hebben tot de aanhouding van verdachten, een cijfer dat iets gunstiger afsteekt bij de bevindingen van de voorlaatste Direct contact-missie in 1986.

Ondanks deze lichte vooruitgang, meent de Missie dat het wenselijk zou zijn dat de regering de effectiviteit en de middelen van de rechterlijke macht versterkt en krachtige maatregelen neemt om de para-militaire groepen te ontmantelen.

Het is zeer de vraag of de Direct contact-missie, afgaande op de berichtgeving van de regering, de situatie niet te rooskleurig afschildert. Vooral vanuit de hoek van NonGouvernementele-Organisaties komen voortdurend signalen dat het leger wel degelijk sterk geînvolveerd is in schendingen van vakbondsrechten en mensenrechten. Het rapport "Impunity" dat samengesteld is naar aanleiding van een Mensenrechten-missie van Pax Christi en de Nederlandse afdeling van Justitia et Pax naar Colombia van 28 oktober tot 11 november

212 Deze mededeling staat in scherp contrast met de berichtgeving van non-gouvernementele organisaties dat 385 van de 962 officieel geregistrcerde "verdwijningen" loegeschreven kunnen worden aan het leger of aan veiligheidstroepen, vgl. E/CN.4/1989/18/Add. 1, \& 73. 
1988, bevat tal van trieste ooggetuigenverslagen die wijzen op het feit dat militairen op $z^{\prime} n$ minst medeplichtig zijin aan moord op burgers. ${ }^{23}$ De militarisering van sommige zones, zoals Uraba, waarover de ILO-missie haar goedkeuring uitspreekt, werkt averechts: de militairen gedragen zich als wolven in schaapskleren en hun aanwezigheid leidt tot een toename van de repressie en het geweld. ${ }^{214}$

Amnesty International komt tot de conclusie dat het optreden van de paramilitaire groepen een integrerend onderdeel vormt van een contra-terreurprogramma van het Colombiaanse leger dat erop gericht is om tegenstanders te elimineren. Amnesty voert twee bewijzen aan. In de eerste plaats is het opmerkelijk dat er geen botsingen hebben plaatsgevonden tussen het leger en paramilitaire groepen. In de tweede plaats is er vrijwel niemand veroordeeld vanwege de duizenden politieke moorden. ${ }^{\text {as }}$

De ontmoedigende ervaringen van ASFFADES (Vereniging van Familieleden van Gedetineerde en Verdwenen Personen) bij hun pogingen om de verblijfplaats van hun dierbaren te traceren en het onderzoek van de Colombiaanse sectie van CAJ (de AndesCommissie van Juristen) naar de medeplichtigheid van politiefunctionarissen bij politieke moorden, wijzen tenslotte uit dat de passiviteit van de autoriteiten bij de vervolging van geweldplegers niet zozeer berust op machteloosheid als wel op politieke onwill. . $^{26}$

Niet alleen verscheidene NGO's, ook de VN-Werkgroep inzake Gedwongen en Onvrijwillige Verdwijningen is stelliger (dan de ILO) omtrent de betrokkenheid van militairen en veiligheidsagenten bij de schending van fundamentele mensenrechten. De belangrijkste conclusie van de Werkgroep verdient integraal geciteerd te worden: All in all, having carefully weighed the material available, the Working Group is of the view that, in the majority of the cases it has transmitted, circumstantial evidence strongly suggests or precise information clearly demonstrates involvement of units of the armed forces or security services in enforced or involuntary disappearances". ${ }^{117}$

213 Impunity in Colombia; A Publication of pax Christi Netherlands and the Dutch Commission Justitia et Pax, den $\mathbb{H a a g} 1989$, pp. $15,17,38,49,55,67$.

214 "Impunity", a;w. pp. $35-39$ en p. 55. Vgl: ook Pearce; a.w. p. 254, "Although most of the killings (in Uraba) were carried out by various death squads the heavy millitary presence and frequent roadblocks made it easy for armed assassins who had the army's support to move around $(.)^{\prime \prime}$

21 Amnesty International, Colombia: Una Crisis de Derechos Humanos, London april 1988, pp. 5,13 en 16. De presidentiele adviseur voor de rechten van de mens reageert furieus op de "aantijgingen" wan Amnesty: Tirado Mejia A. The Struggle against Violenice and Impunity: A Democratic Commitment, Bogota 1988. Amnesty voldoet evenwel niet aan diens eils tot rectificatic en herhaalt haar standpunt in het volgende rapport over Colombia. Amnesty International, Colombia; Human Rights Developments - "Death Squads" on the Defensive? London, sept. 1989 .

216 "Impunity", a.w. p. 75 resp. p. 82

217 E/CN.4/1989/18/Add 1 \& 126. 


\section{Evaluatie en conclusies}

Colombia biedt een goed voorbeeld van een staat die, na aanvankelijk gedurende een tamelijk lange periode de vakbeweging effectief gecontroleerd te hebben, onder invloed van veranderende politieke en economische omstandigheden in toenemende mate zijn toevlucht gezocht heeft tot repressieve maatregelen ten aanzien van die vakbeweging. De repressie van de kant van de overheid heeft (wellicht) bijgedragen tot het ontstaan van een algemeen gewelddadig klimaat, waarbinnen de vakbeweging zich slechts met de grootste moeite kan handhaven en afzonderlijke vakbondsleden hun leven dikwijls niet veilig zijn.

Hoewel een aantal controle-maatregelen inmiddels in onbruik is geraakt, zijn zij nog immer verankerd in de Colombiaanse arbeidswetgeving. Dit heeft de ILO in de gelegenheid gesteld om in retrospectief een oordeel te vellen over een vakbondspolitiek die met name gedurende de jaren vijftig en zestig haar vruchten heeft afgeworpen. Vooral de regeling van de vakbondsstructuur vertoont enige anachronistische trekjes en is bovendien niet erg consistent. Aan de ene kant zijn de numerieke eisen voor het oprichten van (con)federaties en de restricties van de bevoegdheden van (con)federaties inderdaad een effectieve hinderpaal voor een bundeling van krachten. Aan de andere kant past het verplichte vakbondsmonopolie op het niveau van de ondlerneming niet binnen een versnipperings-politiek: het weren van concurrentie versterkt immers juist de positie van de ondernemings-vakbond. ${ }^{218}$ Dit voordeel wordt echter grotendeels teniet gedaan door de mogelijkheid die de arbeidswetgeving de werkgever biedt om met niet-georganiseerde werknemers aparte contracten te sluiten (de zogenaamde "pactos collectivos", zie hierboven, p. 160).

Andere controle-maatregelen - de stakingsverboden in de publieke sector, de toezichthoudende bevoegdheden van de autoriteiten in vakbondsaangelegenheden en de verplichte arbitrage - hebben hun instrumentele functie niet verloren, maar bleken in de loop der jaren niet toereikend om de vakbeweging, wier weerbaarheid toenam, het hoofd te bieden. Deze controle-maatregelen zijn eveneens door de ILO van kritisch commentaar voorzien.

Wat betreft de repressieve maatregelen, voorzover deze bewijsbaar uitgaan van de autoriteiten, neemt het Comite inzake de Vrijheid van Vakvereniging het bekende standpunt van de ILO in dat het treffen van sancties ten aanzien van vakbonden of vakbondsleden voorbehouden is aan de rechter. De diskwalificatie van vakbondsleiders, de ontbinding van vakbonden en de arrestatie en detentie van vakbondsleden door de uitvoerende macht, dat wil zeggen zonder tussenkomst van de rechter, zijn uit het oogpunt van vakverenigingsvrijheid ontoelaatbaar.

In Colombia doet zich het probleem voor dat het in het algemeen moeilijk te bepalen is of en in hoeverre de autoriteiten de hand hebben in de ernstigste schendingen van vakbondsrechten, zoals moord op en verdwijningen van vakbondsleden. Het feit dat de autoriteiten niet (rechtstreeks) betrokken zijn bij schendingen van vakbondsrechten, ontslaat hen nog

218 Zoals ik in het eerste hoofdstuk van deze studie al heb aangegeven, is het verplichte vakbondsmonopolie juist kenmerkend voor een nauwe verstrengeling tussen de staat en een sterk gecentraliseerde vakbeweging. 
niet van de verplichting om een rechtsklimaat te scheppen, waarin mensen ongestoord hun rechten kuninen genieten, zo kan men het standpunt van de ILO parafraseren. Niet alleen de staat dient de rechten van de mens te respecteren, ook particulieren moeten in het maatschappelijke verkeer elkaars fundamentele rechten ontzien. Met andere woorden: de rechten van de mens hebben horizontale werking. De verplichting van een staat om op te treden tegen personen of groepen die anderen in de legitieme uitoefening van hun rechten dwarsbomen, kan opgevat worden als een reflex van deze horizontale werking.

Men kan zich in het specifieke geval van Colombia afvragen hoever de verantwoordelijkheid van de staat strekt. Heeft de staat, door repressie uit te oefenen tegen de vakbeweging en door politieke en economische hervormingen tegen te werken, niet het slechte voorbeeld gegeven en daardoor bijgedragen tot het algehele normverval? In hoeverre is er niet zozeer sprake van onmacht, als wel van onwil om het geweld tegen vakbondsleden (en andere pleitbezorgers van hervormingen) te bestrijden? Is de betrokkenheid van politie en leger bij de gewelddadigheden werkelijk zo incidenteel als de regering suggereert? ${ }^{219}$

De ILO legt deze vragen die van verscheidene kanten worden opgeworpen, goeddeels naast zich neer. De teneur van de uitspraken van de ILO is dat de Colombiaanse autoriteiten niet bij machte zijn om het geweld dat Colombia teistert, uit te roeien en alle steun verdient om de situatie ten goede te keren. De Direct contact-missies hebben dan ook vooral de opdracht om de regering eraan te herinneren dat haar inspanningen om het algemene klimaat van de rechten van de mens in Colombia te verbeteren, nauwlettend door de ILO worden gevolgd.

Na deze algemene conclusies wil ik nog aan een drietal aspecten nadere aandacht besteden. De beide eerste aspecten hebben betrekking op de problematiek van de universaliteit van de vrijheid van vakvereniging.

Zoals ik in het eerste hoofdstuk van deze studie ontvouwd heb, impliceert de universaliteit van het recht van vakverenigingsvrijheid dat vakbondsrechten onder alle omstandigheden, ongeacht de specifieke economische en politieke situatie, gerespecteerd moeten worden. $\mathrm{Bij}$ haar pogingen om controle-maatregelen te rechtvaardigen, stelt de Colombiaanse regering de universaliteit van het recht van vakverenigingsvrijheid voortdurend ter discussie door er bij de ILO op aan te dringen om verschillende maatstaven aan te leggen bij de beoordeling van de vakbondssituatie in landen die in een verschillende fase van economische ontwikkeling verkeren. De controle over de vakbeweging kan, zo kan men het standpunt van de regering

219 De al eerder genoem de Andes Commissie van Juristen geeft in een rapport dat in oktober 1988 is verschenen en de titel "The Right to Justice" draagt, aan dat de worzaken van de straffeloosheid van mensenrechtenschendingen gezocht moeten worden in het bestaan van de Doctrine van Nationale Veilighetd. De Commissie suggereert met deze uitspraak dat er een verband bestaat tussen de overheidsrepressie ten aanzien van vakbondsleden en andere pleitbezorgers van hervormügen aan het eind van de jaren zeventig en het begin van de jaren tachtig en het geweld, gepleegd door "derden", waarvan dezelfde groeperingen het slachtoffer zijiz. "Impunity", aw. p. 95. 
vertolken, met het oog op het voeren van een economische politiek die het land uit het stadium van de onderontwikkeling moet verlossen, noodzakelijk en te billijken zijn.

Het is opmerkelijk dat de ILO, bij monde van het Comite van Deskundigen, de repliek van de regering geen enkele consideratie waardig keurt. Het Comité neemt kennis van de opvattingen (inzake het niet-universele karakter van vakverenigingsvrijheid) van de regering de meest neutrale term uit het ILO-vocabulaire - en gaat over tot de orde van de dag, dat wil zeggen: het herhaalt zijn bezwaren tegen bepaalde inbreuken op het recht van vakverenigingsvrijheid.

Men kan zich afuragen of het Comite de repliek van de regering niet expliciet had moeten verwerpen. De tegenwerpingen van de Colombiaanse regering behelzen immers een principiële aanvechting van de opvattingen van de ILO dat de vrijheid van vakvereniging niet alleen universeel maar ook integraal, dat wil zeggen in alle constituerende onderdelen, geaccepteerd en gerespecteerd dient te worden. Naar het mij voorkomt, dient het feit dat het Comité niet een aparte overweging wijdt aan het alibi van de regering, evenwel niet opgevat te worden als een stilzwijgende instemming: door zijn bezwaren tegen met name de inbreuken op het stakingsrecht te handhaven, geeft het Comite impliciet te kennen dat het niet van plan is om flexibele maatstaven te hanteren op grond van het sociaal/economische ontwikkelingsniveau van een land.

Niet alleen met betrekking tot structurele controle-maatregelen, maar ook in geval van zeer ernstige schendingen van vakbondsrechten en mensenrechten beroept de Colombiaanse regering zich op de concrete politieke situatie. Het verweer van de regering dat een democratie als Colombia volgens andere maatstaven beoordeeld moet worden als een dictatuur( $\left.{ }^{20}\right)$, duidt erop dat (mogelijke) inbreuken op vakbondsrechten volgens de regering niet losgekoppeld kunnen worden van de context, waarin zij plaatsvinden. Dit verweer is derhalve wederom een aantasting van het universaliteitsprincipe. (Ernstige) schendingen van vakbondsrechten zijn in een democratie, weliswaar betreurenswaardige, maar zeldzame excessen die niet op eén lijn gesteld kunnen worden met de structurele repressie in een dictatuur.

Ook in dit geval gaat de ILO - ditmaal bij monde van het Comité inzake de Vrijheid van Vakvereniging - niet in op de repliek van de regering. Het Comité dringt bij de regering aan op het instellen van een gerechtelijk onderzoek en benadrukt dat de vrijheid van vakvereniging uitsluitend genoten kan worden onder de voorwaarde dat fundamentele mensenrechten volledig gewaarborgd en gerespecteerd worden, zonder een overweging te wijden aan het democratische gehalte van de Colombiaanse staat en samenleving. De tamelijk grote clementie die de ILO ten aanzien van Colombia aan de dag legt - in vergelijking tot bijwoorbeeld Chili, tijdens het regime van Pinochet - hangt niet samen met haar voorkeur voor een democratie boven een dictatuur, maar is het gevolg van het feit dat de ILO over onvoldoende aanwijzingen beschikt om te veronderstellen dat de betrokkenheid van de autoriteiten bij schendingen van vakbondsrechten in het geval van Colombia even groot is 
als in het geval van (bijvoorbeeld) Chill. Uitgaande wan de eigen taxatie van de feiten, blifft de ILO trouw aan het universaliteitsbeginsel door de vakbondssituatie in Colombia enigszins anders te beoordelen dan die in Chili. Het grote probleem schuilt hier in het feit dat, juist vanwege het gebrek aan bewijs dat het leger en/of de autoriteiten zich in Colombia schuldig maken aan ernstige schendingen van mensenrechten en vakbondsrechten, de ILO wat al te behoedzaam reageert en de regering te mild beoordeelt. We stuiten hier op het vraagstuk hoe de "fact finding"-procedures verbeterd kunnen worden, opdat de ILO tot een beter gefundeerd oordeel kan komen. Aangezien de verbetering van de fact finding-procedure de basis vormt voor een beter functioneren van de ILO bij het streven naar de universele naleving van vakbondsrechten, kom ik er in het laatste hoofdstuk van deze studie nog uitvoerig op terug.

Een laatste kanttekening betreft de belangrijke functie die de ILO toekent aan de nationale rechter bij het opleggen van sancties aan vakbondsleden en vakorganisaties. Op zichzelf hoeft de inschakeling van de nationale rechter nog niet een garantie te zijn dat de vrijheid van vakvereniging wordt gerespecteerd. Een rechter kan zich immers beperken tot het toepassen van; uit het oogpunt van internationale arbeidsnormen gebrekkige, nationale wetgeving en zodoende een inbreuk maken op vakbondsrechten.

Zie ik het goed, dan is de ILO zich van dit gevaar wel degelijk bewust. In het specifieke geval van Colombia heeft de ILO tot tweemaal toe erop gewezen dat de rechter niet alleen een door de uitvoerende macht opgelegde sanctie aan de nationale wetgeving moet toetsen, maar deze nationale wetgeving ook moet toepassen in het licht van de bepalingen van Verdrag no. 87. ${ }^{221}$ De ILO bereikt met deze uitspraken de grenzen van haar eigen mandaat, aangezien de vraag of en op welke wijze internationaal recht doorwerkt in de nationale rechtsorde, beantwoord wordt naar nationaal, constitutioneel recht.

Deze problematiek zal in het laatste hoofdstuk van deze studie uitvoerig aan de orde komen. De doorwerking van internationaal recht in de nationale rechtsorde zal in dat hoofdstuk in een breder perspectief worden geplaatst door een vergelijking van de situatie in de drie, in dit proefschrift behandelde landen. Op deze plaats wil ik volstaan met een drietal kanttekeningen die specifiek betrekking hebben op de Colombiaanse situatie.

In de eerste plaăts dient opgemerkt te worden dat Colombia een monistisch stelsel kent, hetgeen betekent dat internationale verdragsbepalingen binnen het bereik van de rechter liggen en dat de rechter deze bepalingen kan toepassen. ${ }^{222}$ Vereist is; en dit is mijn tweede

221 Observation 1985 , onder (1), zie p. 161, noot 60 van dit hoofdstuk.

Case Nos. 1083 en 1085,214 e Rap. 448 , zie p. 180 , noot 152 van dit hoofdstuk.

222 Merkwaardig genoeg heeft er lange tijd onzekerheid bestaan met betrekking tot de vraag of Colombia een monistisch of een diualistisch stelsel had (zie onder andere de discussie in het Colombiaanse dagblad El Tiempo, dd. 14-10-1977). In een rapport op basis van art. 40 van het Internationale Verdrag inzake Burgerrechten en Politieke Rechten aan het Comité voor de Rechten van de Mens stelt de regering, onder verwijzing naar Wet no. 7 wan 1944, dat internationale verdragen deel uit maken van de nationale wetgeving, zodra zij geratificeerd zijn. CCPR/C/1/Add.50 28-11-1979. Over de hiërarchische verhouding tussem 
kanttekening, dat de bepaling zich leent voor rechtstreekse toepassing. Gezien het feit dat de bepalingen van Verdrag no. 87 vakorganisaties beogen te beschermen tegen aantasting van hun rechten door de autoriteiten en deze bepalingen geen nadere uitwerking behoeven in nationale wetgeving, is het aannemelijk dat zij inderdaad rechtstreeks door de rechter kunnen worden toegepast. Enkele Westeuropese staten kennen aan (sommige) bepalingen van Verdrag no. 87 rechtstreekse werking toe. ${ }^{233}$ Aangezien de vraag of aan een internationale verdragsbepaling rechtstreekse werking toekomt, wederom beantwoord moet worden naar nationaal recht, vormt dit echter nog geen garantie dat ook de Colombiaanse rechter de bepalingen van Verdrag no. 87 rechtstreeks zal toepassen.

Zelfs indien de rechter terughoudend is om internationale verdragsbepalingen toe te passen - en dit is mijn laatste kanttekening - laten de subtiele bewoordingen van de ILO de rechter de ruimte om althans rekening te houden met het internationale recht: de rechter dient de nationale wetgeving toe te passen in het licht van de verdragsbepalingen. Deze formulering doet sterk denken aan de zogenaamde "reflex-werking" van het internationale recht binnen de nationale rechtsorde: de rechter dient nationale regelingen en overheidsbeschikkingen te interpreteren in het licht van internationaal gewoonterecht, besluiten van volkenrechtelijke organisaties en van (niet eenieder verbindende) verdragsbepalingen. ${ }^{224}$ Met respect voor de rechterlijke onafhankelijkheid en de staatssoevereiniteit, doet de ILO de rechter de mogelijkheid aan de hand om schendingen van vakbondsrechten te corrigeren op basis van internationale normen inzake de vrijheid van vakvereniging.

verdragsbepalingen en nationale wetgeving laat de regering zich ewenwel niet uit, vgl. ook $\mathrm{A} / 43 / 40$ (1988), $\$ 513$.

223 Leary V. Intemational Labour Conventions and National Law; The Hague/Boston/London, $1982 \mathrm{pp} .107-109$.

224 Onder anderen Heringa bezigt de term reflex-werking, ter onderscheiding van de echte rechistreekse werking, waaronder hij met name de toetsing van nationaal- wettelijke voorschriften verstaat.

Heringa A.W. Sociale Grondrechten, 's-Gravenhage 1989 , p. 261. 



\section{Staat en vakbeweging in Mexico}

\section{Inleiding}

In vergelijking met Chili en Colombia heeft de vrijheid van vakvereniging in Mexico de ILO door de jaren heen slechts in geringe mate verontrust. Binnen het kader van de rapportageprocedure heeft de kritiek van het Comité van Deskundigen zich vooral toegespitst op de wettelijk geregelde organisatiestructuur van vakverenigingen in de publieke sector. ${ }^{1}$ Verder zijn er dertien klachten tegen Mexico ingediend bij de ILO. Het Comité inzake de Vrijheid van Vakvereniging heeft de klagende organisatie slechts in twee zaken in het gelijk gesteld. ${ }^{2}$

De tamelijk gunstige en rustige indruk die men van de Mexicaanse vakbondssituatie verkrijgt door de "case-law" van de ILO te bestuderen, strookt niet met het beeld dat over het algemeen in de literatuur wordt geschetst. Hier ontwaart men de contouren van een vakbeweging die voor een groot deel (te) nauw gelieerd is aan de regeringspartij PRI (Partij van de Geïnstitutionaliseerde Revolutie) en daardoor over onvoldoende speelruimte beschikt om zelfstandig de belangen van de achterban te behartigen. Bij de politieke controle over de vakbeweging is coöptatie een sleutelbegrip: vakbondsleiders worden door de staat gepaaid met kleine concessies en gunsten in ruil voor matiging van (loon)eisen en een grotere inschikkelijkheid ten aanzien van het vigerende politieke systeem. ${ }^{3}$ De sociale afstanden tussen vakbondskader en basis in Mexico zijn doorgaans groot en het democratische gehalte binnen de vakbeweging is gering.

Naast deze indirecte, trapsgewijze controle pleegt de staat direct in te grijpen in arbeidsverhoudingen, een praktijk die geformaliseerd en gelegaliseerd wordt door het bestaan van tripartiet samengestelde arbeidsraden (Juntas de Conciliación y Arbitraje). Werknemers die van de staat onafhankelijke organisaties willen oprichten, kunnen rekenen op de eendrachtige tegenwerking van staat, werkgevers en gecontroleerde vakbeweging.

1 Mexico ratificeerde op 01-04-1950 de Conventie inzake de Vrijheid van Vereniging en de Bescherming van het Recht om zich te Organiseren (no. 87), maar is niet partij bij het Verdrag betreffende de Toepassing van de Beginselen van het Recht op Organisatie en op Collectieve Onderhandelingen (no. 98).

2 Cases Nos. 603 (121e, $129 \mathrm{e}$ en 133e Rap.) en 827 (157e, 160e en 165e Rap.). Hieronder worden de zaken uitwoerig behandeld.

3 Anderson B./Cockcroft J.D. Control and Coöptation in Mexican Politics, p. 378 in: Horowitz I.L. (ed.) Latin American Radicalism, New York 1959. 
In het licht van het bovenstaande rijst de vraag of de in de literatuur gesignaleerde controlepolitiek door de ILO gekwalificeerd wordt als een inperking van de vrijheid van vakvereniging. Het onderzoek dat uiteindelijk tot beantwoording van deze vraag moet leiden, kan onderverdeeld worden in twee componenten. Allereerst wordt onderzocht hoe en waarom de controle over de vakbeweging in Mexico tot ontwikkeling is gekomen, hoe deze controle zich manifesteert en op welke wijze zij de sociaal/economische en politieke machtsverhoudingen beïnvloed heeft. Deze vraagstukken staan centraal in 2 .

In 3 wordt vervolgens onderzocht van welke juridische instrumenten de staat zich bediend heeft om de controle in stand te houden en of deze instrumenten, gemeten naar de maatstaven die de ILO hanteert, te kwalificeren zijn als schendingen van de vrijheid van vakvereniging.

\section{De verhouding tussen staat en vakbeweging in historisch perspectief}

\subsection{Inleiding}

In het tweede hoofdstuk van dit proefschrift heb ik de nauwe vervlechting tussen staat en vakbeweging in Latijns Amerika geschetst tegen de achtergrond van economische en politieke ontwikkelingen. De crisis en ondergang van populistische regeringen wier legitimatie voor een belangrijk deel gefundeerd was in de steun van de georganiseerde arbeidersklasse, werden verklaard uit het onvermogen van deze regeringen om de vakbeweging blijvend aan zich te binden en om tegelijkertijd een regressieve loonpolitiek te voeren. Deze laatste maatregel werd noodzakelijk geacht met het oog op de intrede van een nieuwe fase in het industrialisatieproces. De autoritaire regimes die de populistische regeringen opvolgden, bekommerden zich niet om politieke legitimatie. Zij stelden zich ten doel om de politieke stabiliteit te herstellen teneinde buitenlandse investeerders te lokken wier activiteiten de economische groei zouden bevorderen. ${ }^{4}$

Het feit dat in Mexico geen breuk in het politieke systeem heeft plaatsgevonden en dat de continue regeringspartij, de PRI, legitimatie, politieke stabiliteit en economische groei heeft weten te combineren om het hoofd boven water te houden, moet geplaatst worden in het historisch perspectief van de Mexicaanse Revolutie. Van meet af aan heeft de controle van de vakbeweging deel uit gemaakt van de overlevingsstrategie van de PRI. Hierna (2.2 en 2.3) zal worden nagegaan welk effect de Revolutie op de toenadering tussen staat en vakbeweging heeft gehad en hoe de vakbeweging uiteindelijk in het politieke bestel geïncorporeerd is.

Na de Tweede Wereldoorlog heeft de PRI de voordien gekweekte goodwill gebruikt om de controle over de vakbeweging te verstevigen. Vrij algemeen wordt aangenomen dat de arbeidlersklasse een prijs heeft moeten betalen voor de economische groei en dat de controle door de regering tot op zekere hoogte succesvol is geweest. Over de mate waarin de 
vakbeweging offers heeft moeten brengen, bestaat evenwel geen eenstemmigheid. Als werkhypothese wordt aangenomen dat de daling van de reële lonen gedurende de eerste decennia na de oorlog in combinatie met een geringe frequentie van arbeidsconflicten een goede indicatie en graadmeter omtrent de mate van controle geeft. Deze hypothese wordt in 2.4 aan een nader onderzoek onderworpen. In 2.5 zal de wijze waarop de verhouding tussen staat en vakbeweging geëvolueerd is tegen de achtergrond van de economische en politieke crises van de twee laatste decennia worden besproken.

\subsection{De Mexicaanse Revolutie (1910-1917)}

Mexico's huidige politieke bestel is geworteld in een bloedige revolutie die in 1910 een einde maakte aan de 35 jaar durende alleenheerschappij van een verlicht despoot, Porfirio Diaz. Het regime van Porfirio Diaz (1875-1910) had Mexico na een uiterst turbulente periode politieke stabiliteit en een zekere mate van materiële welvaart gebracht. Diaz breidde het spoorwegennet uit, ging over tot intensieve exploitatie van de mijnen en ontving buitenlandse investeerders met open armen. Maar de politieke rust en economische welvaart hadden een keerzijde. De materiële voorspoed bleef beperkt tot een smalle toplaag. Concentratie van landbezit om de voedselproduktie en - export te stimuleren, impliceerde onteigening van gemeenschappelijke landbouwgronden en leidde tot verpaupering van de Indiaanse boerenbevolking. Arbeiders werkten van zonsopgang tot zonsondergang tegen een karig loon. Werknemersorganisatie werd ontmoedigd en stakingen werden met geweld beantwoord: ${ }^{s}$ Diaz duldde over het algemeen geen politieke oppositie. Verslaafd aan macht en omringd door een kliek van vertrouwelingen, de "cientificos" die geïnspireerd door Auguste Comte, politiek bedreven als exacte wetenschap, slaagde hij er lange tijd in de alleenheerschappij uit te oefenen. ${ }^{6}$

De eerste verzetsimpulsen gingen uit van vertegenwoordigers van de middenklasse die niet tot de coterie van Diaz behoorden en die hun politieke ambities gefrustreerd zagen door diens machtsmonopolie. Onder het motto "effectief stemrecht, geen herverkiezing" slaagde Francisco Madero in 1910 erin om Diaz af te houden van een nieuwe ambtstermijnt.

5 Zie woor en korte impressie ván de netelige positie, waarin de arbeidersklasse tijdens het Diaz-regime verkeerde: Spalding H.A. Organized Labor in Latin America, New York 1977, pp. 96-97.

6 Weliswaar werden er elke zes jaar verkiezingen gehouden, maar de uitslagen werden routineus vervallst. Bovendien waren politieke partijen werbodem. Porfurio Diaz "kocht" politieke loyaliteit door het uitdelen van publieke ambten. Zo stelde hij zelf de gouverneurs van de provincies aan, die op hun beurt de burgemeesters ("jefes políticos") van de gemeenten benoemden.

Vgl. Ruiz R.E. The Great Rebellion, Mexico 1905-1924, New York 1980, pp. 2829.

7 Diaz had in 1910 de verkiezingen gemanipuleerd; teneinde zujin presidentschap met nog zes juar te kunnen verlengen. Hij was echter niet in staat om de opstand van Madero te breken. Madero stelde de ministter van buitenlandse zaken, De la Barra, aan als interim-president en won vervolgens de presidentsverkiezingen van 1911. Ruif; a.w. pp. 150-151. 
Nationalisme, als reactie op het feit dat Diaz Mexico's rijkdommen had verkwanseld aan het buitenland, en anti-clericalisme tegen de bevoorrechte positie van de Katholieke kerk, maakten deel uit van het valag omlijnde beginselprogramma van de nieuwe politieke leiders. De verzetsbeweging kreeg een bredere reikwijdte en groeide uit tot een gewelddadige revolutie toen boeren in opstand kwamen tegen de grootgrondbezitters en zich achter het banier van Madero schaarden. In eerste instantie bundelden de liberale politici en de boeren de krachten om het hoofd te bieden aan de contra-revolutionaire krachten. De radicale opstelling van legendarische boerenleiders als Pancho Villa en Emiliano Zapata boezemde evenwel de gematigde politieke leiders angst in. Waar Madero en de zijnen slechts politieke veranderingen wensten zonder aan de maatschappelijke status quo te tornen, drong Zapata aan op ingrijpende landhervormingen en streefde hij naar een sociaal-economische omwenteling. ${ }^{8}$ Een confrontatie kon niet uitblijven.

Venustiano Carranza, de opvolger van Madero die in 1913 werd vermoord, bond de strijd aan met Pancho Villa en Zapata en sloot met dat oogmerk een verbond met de vakbeweging die zich rond de eeuwwisseling begon te profileren." In 1912 hadden anarcho-syndicalisten de Casa del Obrero Mundial (Huis van de Wereld Werknemer) opgericht. ${ }^{10} \mathrm{De}$ Casa meende te kunnen profiteren van de politieke veranderingen en organiseerde demonstraties om de regering te dwingen tot inwilliging van arbeiderseisen. Een ideologische tweespalt binnen de vakbeweging tussen katholieke "mutualistas", socialisten en anarchisten - een verdeeldheid die overigens kenmerkend was voor de vakbeweging in Latijns Amerika aan het begin van de eeuw - leidde ertoe dat de Casa slechts de spreekbuis was van een bescheiden percentage van de vakbeweging. Dit stelde de autoriteiten in staat om de protesten eenvoudig de kop in te drukken. In 1914 werd de Casa gesloten en werden haar leiders gearresteerd.

Obregon, een generaal van Carranza, onderkende evenwel het belang van de vakbeweging als politiek en militair bondgenoot in de strijd tegen de boerenopstandelingen. Hij heropende de Casa en sloot in 1915 namens de Constitutionalisten een officieel pact met de vakorganisatie: ${ }^{11}$ Deze alliantie zette de toon voor de toekomstige verhouding tussen staat en vakbeweging. Vanuit de optiek van de Constitutionalisten was het een meesterzet om een wig te drijven tussen de boeren en de vakbeweging: daarmee werd immers de vorming van een machtig volksfront voorkomen. Van minstens even groot belang was echter dat de

8 Riding A. Metico: Inside the Volcano, London 1987, p. 43.

9 Spoorwegmaatschappijen badden vel Amerikaanse werknemers in dienst die aangesloten waren bij vakorganisaties als de Industrial Workers of the World en de Knights of Labor. In navolging van hun Amerikaanse collega's en concurrenten, richtten Mexicaanse spoorwegarbeiders eveneens "broederschappen" en vakbonden op. Rufi, a.w. p. 65 .

10 Over de formatie en de anarchistische origine van de COM: Carr B. Onganised Labour and the Mexican Revolution 1975-1928, Oxford 1972, p. 4.

11 De fractie rondl Carranza en Obregon noem de zich "Constitutionalisten" om aan te geven dat zij de Grondwet van 1857 trouw wensten te blijven. 
wakbeweging zich liet misbruiken voor politieke doeleinden en daarmee al in een vroeg stadium een positie als autonome sociale machtsgroepering verspeelde. ${ }^{12}$

Met de steun van vakbondsleden die georganiseerd waren in de "Rode Bataljons" slaagde Carranza er in 1915 bij de plaats Celaya in om Zapata en Pancho Villa een beslissende nederlaag toe te brengen. Nu de strijd gestreden leek, was het moment aangebroken om de nieuwe revolutionaire orde constitutioneel vorm te geven. De Constitutie van 1917 voorzag in een federale staatsstructuur en een strikte scheiding der machten, waarbij aan de president overigens verstrekkende bevoegdheden werden toegekend. In sociaal/economisch opzicht leek artikel 123 van de Grondwet, wel bestempeld als de Mexicaanse Magna Charta van de arbeidersklasse, de vakbeweging te belonen voor haar loyale opstelling. De acht-urige werkdag, minimumnormen voor veiligheid en gezondheid, bescherming voor vrouwen en kinderen, zware boetes op onwettig ontslag en de afschaffing van de gehate bedrijfswinkels werden grondwettelijk vastgelegd. Zowel arbeiders als werkgevers verkregen het recht om zich te organiseren. Maar de vaststelling van de arbeidsvoorwaarden werd niet overgelaten aan het vrije krachtenspel tussen werkgevers en werknemers(organisaties). Het gedetailleerde grondwetsartikel voorzag namelijk ook in een gecompliceerde arbitrageprocedure, waarbij in geval van een arbeidsconflict de stem van de overheid van doorslaggevende betekenis was. Bovendien verkreeg de regering de bevoegdheid om te oordelen over de legaliteit van elke vakbondsactie en had zij het recht om aan nieuwe vakverenigingen rechtspersoonlijkheid te verlenen of te onthouden."

Daarmee werden de contouren van de controlepolitiek al zichtbaar in een op het eerste gezicht zeer progressieve Constitutie.

\subsection{De vakbeweging als verlengstuk van de politiek (1918-1940)}

Gedurende de jaren twintig kreeg de vervlechting tussen staat en vakbeweging nader gestalte. De positie van de vakbeweging vis à vis de staat moet worden gezien in het licht van een instabiel politiek klimaat waarin presidentskandidaten nog niet geruggesteund werden door een partij-politiek apparaat. Voor een president kon de steun van een hecht georganiseerde en strak geleide vakbeweging van doorslaggevende betekenis zijn om aan de macht te komen en deze te behouden. ${ }^{14} \mathrm{Al}$ te royale tegenprestaties op materieel gebied hoefde de vakbeweging niet te verwachten, aangezien werkgevers noch de staat in een fase van economische opbouw zich dergelijke gestes konden permitteren.

12 Vgl. Carr, a.w. p. 11: "The alliance with national politicians implied a heavy price, the destruction of the long-term autonomy and effectiveness of the labour movement."

13 Over het hybride karakter van art. 123 Grondwet, Spalding, a.w. p. 103.

14 Carr, a.w. p. 15: "The only permanent national organisation, centralised and highly disciplined, was the labour movement, which alone proved capable of mobilising significant sections of the population across the Republic." 
In 1918 richtte de vakbondsleider Luís Morones de vakcentrale CROM (Regionale Confederatie van Mexicaanse Arbeiders) op. Morones slaagde erin de CROM om te smeden tot een instrument, waarmee de vakbondsleden gemobiliseerd werden om de zittende president te steunen. Tegelijkertijd drong hij er bij de achterban op aan om de looneisen te matigen in het belang van de Mexicaanse natie..5 Intussen lukte het Morones en zijn collega-vakbondsleiders om zich aanzienlijk te verrijken. Werkgevers werden gechanteerd door rust aan het arbeidsfront afhankelijk te stellen van financiële vergoeding aan de vakbondsleiders. ${ }^{16}$ Vacante leidersposten werden tegen betalling vergeven. De staat wist de vakbondsleiders aan zich te binden door hun de mogelijkheid te bieden om een politieke carrière te maken. Morones zelf was de exponent van deze functievermenging, waarin de vervlechting tussen staat en vakbeweging tot uitdrukking kwam. Zijn benoeming tot minister van Industrie en Arbeid vormde de bekroning van een dubbelcarrière als corrupt vakbondsleider en paladijn van het politieke establishment. ${ }^{17}$

De jaren twintig stonden in politiek opzicht in het teken van de krachtmeting tussen Obregon (president van 1920-1924) en Plutarco Elías Calles (president van 1924-1929). De houding van beide ambtsdragers ten aanzien van de vakbeweging verschilde slechts gradueel. Weliswaar had Obregon een reputatie als "vriend van de arbeidersklasse" - de uiteindelijke versie van art. $123 \mathrm{GW}$ was op zijn aandringen aangenomen -, maar hij stond een neutrale "arbiters"-rol van de staat in arbeidsverhoudingen voor. Calles doorbrak deze neutraliteit door openlijk de ondernemers het hof te maken. Tijdens zijn ambtsperiode nam het aantal stakingen dramatisch af, hetgeen mogelijk kan worden verklaard doordat de regering, met de hulp van de CROM, de vakbondsbasis effectief controleerde. ${ }^{18}$

Met de oprichting van de Partij van de Nationale Revolutie in 1929 gaf Calles blijk over politiek inzicht te beschikken. De PNR gaf hem een instrument in handen om na zijn aftreden nog vijf jaar lang de feitelijke macht uit te oefenen. ${ }^{39}$ Toch kon ook Calles niet voorkomen

15 Trejo R. Historia del Movimiento Obrero en Mexico, pp. 22-29 in : Gonzalez Casanova P. (ed.) Historia del Movimiento Obrero en América Lacina, Vol. $1_{4}$ Mexico 1984.

16 Hansen R.D. The Politics of Mexican Development, Baltimore/London 1971, p. 197.

17 Spalding a.w. p. 106.

18 Aamkal "legale" stakingen van 1920-1928:

$\begin{array}{llll}1920 & 173 & 1925 & 51 \\ 1921 & 310 & 1926 & 23 \\ 1922 & 197 & 1927 & 15 \\ 1923 & 146 & 1928 & 7 \\ 1924 & 125 & & \end{array}$

Bron: Ruiz, a.w. p. 299.

Rulz" commentaar met betrekking tot de daling van het aantal stakingen: "The decline of strikes demonstrates not just the success of the official policy, to keep labor in place, but the consolidation of the CROM's political
monopoly." A.w. p. 299 .

19. Obregon werdl in 1929 herkozen, maar kort na zijn herverkiezing werd hij vermoord. Hoewel zijn betrokkenheid officieel nooit bewezen is, neemt men wel aan dat Morones die zelf aspiraties koesterde om president te worden, de hand heeft gehad in deze moord: De presidenten die Obregon's termijn tot 1934 moesten volmaken, 
dat aan het begin van de jaren dertig de Revolutie aan aantrekkingskracht begon in te boeten. De "krach" van 1929 had ook gevolgen voor de Mexicaanse economie en zaaide onrust binnen de gelederen van de arbeidersklasse. Door de infame corruptie van haar leiders taanden de populariteit en daarmee de invloed van de CROM. Vooral werknemers in economisch/strategische sectoren gaven de voorkeur aan autonome militante actie in plaats van zich aan te sluiten bij een door de overheid gecontroleerde vakcentrale. ${ }^{20}$ Bovendien groeide de onvrede in vakbondsgelederen doordat de uitvoeringswetgeving van art. 123 die door de Grondwet aan de afzonderlijke deelstaten was gedelegeerd, in veel gevallen op zich liet wachten. In deze laatste lacune werd voorzien door de uitvaardiging van de Federale Arbeidswet (Ley Federal del Trabajo) in 1931 die met name een uniformele regeling bracht inzake de beslechting van arbeidsconflicten door Arbeidsraden. De overheid stond nu voor de lastige opgave om de geleidelijk afkalvende politieke legitimatie te versterken.

In het onzekere tijdsgewricht halverwege de jaren dertig was de voordracht van Lazaro Cárdenas als presidentskandidaat een gouden greep. Cárdenas beschikte over persoonlijk charisma en presenteerde zich nadrukkelijk als een "vader" voor arbeiders en boeren. Stad en land reisde hij af om zich persoonlijk van de grieven van de bevolking op de hoogte te stellen. ${ }^{21}$ Tijdens zijn ambtsperiode (1934-1940) oordeelden Arbeidsraden in een overgrote meerderheid van de gevallen in het voordeel van de werknemers. ${ }^{22}$

Nadat de CROM vanaf 1930 haar aanhang geleidelijk aan had zien slinken, was de vakbeweging intern sterk verdeeld. Cárdenas moedigde Vicente Lombardo Toledano, een rijzende ster binnen de vakbeweging die zich strijdbaarder en onafhankelijker opstelde dan zijn voorgangers, aan om een nieuwe vakcentrale op te richten. Zo kwam in 1936 de CTM (Confederatie van Mexicaanse Arbeiders) tot stand. Dat Cárdenas bereid was om radicale maatregelen te nemen bleek in 1938, toen hij een arbeidsconflict tussen werknemers in de olie-industrie en buitenlandse ondernemingen aangreep als aanileiding om de Onteigeningswet toe te passen teneinde de gehele oliesector te nationaliseren. Deze laatste actie leverde Cárdenas' regering binnen conservatieve kringen het stempel "marxistisch" op.

Toch is deze kwalificatie onjuist. Cárdenas' opstelling ten aanzien van de vakbeweging had duidelijk populistische trekken. Weliswaar begunstigde hij de arbeidersklasse (en de boeren) meer dan zijn voorgangers hadden gedaan en zijn opvolgers zouden doen, maar hij

waren door Calles aangestelde stromannen. Vgl. Spalding; a.w. pp. 111-112.

20 Zo richtten spoorwegwerkers in 1931 de STFRM (Vakwerenigingwan Spoorwegarbeiders van de Mexicaanse Republiek) op die zich doelbewust distantieerde van de CROM. Het Statuut van de STFRM sprak zelfs een veroordeling wit over door werkgevers of door de stat gesteunde vakorganisaties.

21 In dit verband merkt Evelyn Stevens wat cynisch op dat de bewolking in dankbare herinnering aan de leider de luttele gevallen waarin actie werd ondernomen in het geheugen heeft gegrift, terwijl de ontelbare voorbeelden wan falen gemakshalve vergeten zijn. Stevens Evelyn P. Protest and Response in Mexico, Massachusetts 1974, p. 70.

22 Van de 2030 stakingen die tussen 1935 en 1940 platswonden, kwamien werknemersorganisaties in 1596 stakingen als owerwinnaar tevoorschijn. Spalding, a.w. p. 124. 
liet er geen misverstand ower bestaan dat vakbonden slechts druk mochten uitoefenen binnen de marges van het politieke systeem en dat zij hun bevoorrechte positie te danken hadden aan de welwillendheid van de staat. Onafhankelijke politieke actie werd niet getolereerd. Daarbij gaf Cárdenas te kennen dat vakbonden zich uitsluitend dienden in te spannen om de materiële welvaart van hun leden te bevorderen; deze opvatting sloot naadloos aan bij een economisch beleid dat gericht was op stimulering van de koopkracht. ${ }^{23}$

Cardenas wenste de vakbeweging ondergeschikt te maken aan en te integreren binnen de gevestigde politieke orde. Deze opzet manifesteerde zich in de reorganisatie van de PNR. in 1938. Cárdenas veranderde de naam van de partij in PRM (Partij van de Mexicaanse Revolutie) en richtte haar in naar corporatistisch model. Arbeiders, boeren, militairen en een restcategorie, bestaande uit ambtenaren en de middenklasse, zouden voortaan vertegenwoordigd worden door vier "zuilen"-organisaties die tezamen de PRM vormden. De CTM fungeerde als arbeiders-"zuil!", hetgeen impliceerde dat ieder lid van de CTM automatisch lid van de PRM was.

De nadruk op de behartiging van economische belangen en ondergeschiktheid aan het politieke stelsel vormden, kort samengevat, de beide peilers van Cárdenas' politiek ten aanzien van de vakbeweging; deze politiek was exemplarisch voor populistisch getinte regimes tijdens de eerste fase van de Import-Substitutie-Industrialisatie. ${ }^{24}$ Met dit beleid legde Cárdenas het fundament voor een stabiel politiek klimaat en een spectaculaire economische groei. ${ }^{25}$

\subsection{0-1970: een periode van politieke stabiliteit en economische groei}

De opvolgers van Cárdenas gaven prioriteit aan een snelle industriële ontwikkeling. Binnen deze economische politiek pasten geen royale gebaren in de richting van de vakbeweging. Winsten moesten worden gebruikt om de aanschaf van kapitaalgoederen te bekostigen met het oog op de verdieping van de produktiestructuur. De regering zag zich geplaatst voor de opgave om voor dit beleid de medewerking te verkrijgen van een vakbeweging die kort tevoren de economische en politieke protectie van de staat ten deel was gevallen. De autoriteiten slaagden in hun opzet. Kon tijdens de Tweede Wereldoorlog de loonstop die de CTM afkondigde nog beschouwd worden als een patriottistische daad, ook toen de conjunctuur weer aantrok en de economische groei inzette legde de vakbeweging een grote mate van zelfbeheersing aan de dag. ${ }^{26}$ Ondanks het feit dat reële lonen in de industriële sector

Spalding, $a_{4} w, p_{n} 120$.

Voor een algemene beschouwing over deze periode wordt werwezen naar hoofdstuk $2,3.2$, pp. 80-83. Aldus Allan Riding: "Cardenas prepared the country for its subsequent industrial take off and he turned the party into powerful instrument for the president." Riding, a.w. p. 55 .

Trejo, a.w. pp. 46 en 48. De dociele opstelling van de CTM had overigens wel tot gevolg dat een groot aantal werknemers(organisaties) uit de vakcentrale stapte en in 1947 een nieuwe overkoepelende organisatie, de CUT (Enige Centrale van Arbeiders) oprichtten. Onder andere de bonden van spoorwegarbeiders, electriciteiltswerkers, mijnwerkers en petroleumwerkers sloten zich bij de CUT aan. Ten gevolge van 
gedurende de jaren veertig en vijftig over het algemeen een dalende tendens vertoonden, bleef de rust op het arbeidsfront gehandhaafd.

De hier geschetste ontwikkeling roept de vraag op hoe Mexico in staat was om al in een vroeg stadium de "moeilijke" fase van de Import-Substitutie-Industrialisatie te betreden, zonder dat dit, zoals in Argentiniè en Brazilię, gepaard ging met sociale onrust en politieke spanningen. ${ }^{28}$ Gelet op bovenstaande verhandeling ligt het voor de hand om het antwoord te zoeken bij de efficiënte controle over de vakbeweging, waarmee Cárdenas een begin had gemaakt. Maar dit verklaart niet waarom de controle in Mexico - in tegenstelling tot Argentinie en Brazilië - gehandhaafd kon worden in een periode waarin het economisch en politieke tij zich tegen de vakbeweging keerde.

Controle berust op een combinatie van dwang en manipulatie. In Mexico waren de condities optimaal voor beide componenten. Aan de ene kant werd dwang op een geraffineerde en omzichtige wijze toegepast, doordat de autoriteiten het meestal aan de vakbonden zelf overlieten om hun achterban in het gareel te houden. Vakbondsleiders moesten in de gunst bij de regering staan en konden in dat geval rekenen op fraaie loopbaanperspectieven. Zodra zij evenwel een strijdbare en onafhankelijke koers volgden, grepen de autoriteiten in. Zo intervenieerde de regering in 1948 in de (te) onafhankelijke vakbond van de spoorwegarbeiders STFRM, arresteerde de leiders en stelde de corrupte en volledig met de overheid in de pas lopende Jesus Diaz de León aan. Sindsdien staat de controle door corrupte en aan de regering onderworpen vakbondsleiders in Mexico bekend onder de term "charrismo": het is een verwijzing naar de bijnaam van Diaz de León - El Charro (de cowboy) - die zich graag in cowboy-outfit hulde. Charrismo riep herinneringen op aan de praktijken van Luís Morones en de zijnen, met dit verschil dat het simultalan bekleden van vakbondsleidersposten en politieke functies door de organisatorische vervlechting van de CTM en de PRI - de Partij

owerheildsdruk en repressie ging de CUT al snel ten onder. Anderson R.D. Mexico, in: Greenfield/Maram (eds.) Latin American Labor Organizations, Westport 1987, p. 520.

27 Onderzoeken met betrekking tot de loonontwikkeling gedurende deze periode geven niet dezelfde uitkomsten. Hansen (aw. pp. 72-73) schat dat de reële lonen tussen $1940 \mathrm{en} 1950$ met een derde afnamen, terwijl Timothy King zelfs op een dalingspercentage wan $50 \%$ over dezelfde periode uilkomt. Timothy King, Mexico: Industrialization and Trade Policies since 1940, New York 1970, p. 26.

Spalding toont aan dat de stakingsactiviteit na 1940 afnam en een dieptepunt bereikte tussen 1947 en 1958. Bovendien kwam de vakbeweging tussen 1941 . en 1950 slechts in 301 gevallen als overwinnaar uit de staking tevoorschijin, terwijl werkgevers in 359 gevallen triomfeerden. Spallding, a.w. p. 139.

28 Vgl. Kaufman R. Mexico and Latin Anerican Auhoritarianism in: Reyna J.L./Weinert R.S. (eds.) Authoritarianism in Mexico, Philadelphia 1977, p. 208: "Why was it that Mexico, despite similar developmental patterms and tensions, did not collapse into the full-scale crisis characteristic of the south?"

29 De regeringsinterventie in de interne aangelegenheden van de STFRM was geen incident. Gedurende de jaren vijftig greep de regering regelmatig in, indien vakbondskandidaten haar miet aanstonden. Zo werden de verkiezingen wam enkele onafhankelijke kandidaten in de vakbond van werknemers in de olie-sector in 1958 op technische gronden ongeldig verklaard. 
van de Geinstitutionaliseerde Revolutie was in 1946 in de plaats getreden van de PRM bevorderd en geformaliseerd werd. ${ }^{\text {to }}$

De "charros" stelden uiltsluitend belang in vakbondsaangelegenheden, voorzover zij door de autoriteiten geroepen werden om hun achterban te bewegen tot loonmatiging; natuurlijk riep dit weerstanden op bij de basis. Individuele werknemers hoedden zich evenwel voor een te obstinate houding, omdat verwijdering uit een vakbond, door middel van de toepassing van "closed shop"-clausules, ontslag betekende. ${ }^{31}$ Alleen door hun krachten te bundelen en door zelf kandidaten voor leidersfuncties voor te dragen, konden vakbondsleden de machtspositie van de "charros" doorbreken maar hiermee haalden ze de gramschap van de autoriteiten op hun hals. Dit ondervond de Vallejista-beweging van spoorwegarbeiders, toen zij in 1958 een staking uitriep die het gehele openbare leven verlamde. De staking die voor een belangrijk gedeelte tot oogmerk had om voorgoed een einde te maken aan het "charro"-imperium, werd met, naar Mexicalanse maatstaven, ongewoon harde hand neergeslagen ${ }^{32}$

Toch kan het succes van de controlepolitiek niet uitsluitend worden verklaard uit de toepassing van al of niet subtiele dwang. Bij elke presidentsverkiezing bleven veel arbeiders hun stem uitbrengen op de PRI, waarmee zij hun lotsverbondenheid met en trouw aan een partij die althans eens voor hun belangen was opgekomen, tot uitdrukking brachten. Van haar kant greep de PRI iedere gelegenheid aan om te benadrukken dat zij haar wortels in de revolutie had en dat de revolutie gevoerd was om de boeren en arbeiders een betere toekomst te garanderen. De revolutionaire antecedenten mochten dan in de loop der jaren verfletst zijn, zij verschaften de PRI nog immer een bron van politieke legitimatie. Deze legitimatie vergemakkelijkte de controle, versterkte in combinatie met de controle de politieke stabiliteit en schiep de ideale condities voor kapitaalsaccumulatie en economische groei. ${ }^{33}$ Juist in dit opzicht onderscheidde Mexico zich van Argentinië en Brazilië, waar populistische regeringen de vakbeweging, door middel van controle en materiële concessies, weliswaar tijdelijk aan

30 "Affiliation with the CTM opens to an ambitious worker a wide range of patronage positions and sinecures well above a laborer's pay. The top leaders of the CTM are regularly assigned seats in the federal legislature, and; at the lower levels, salaried positions in local and state government, on regional committees, as labor representatives to government agencies, arbitration boards and the like are available to the tried and true CTM man". Judith Adler Hellman, Mexico in Crisis" London 1978 , p. 106.

31 Op de "closed shop" als instrument van controle wordt later in dit hoofdstuk nog uitwoerig ingegaan.

32 Do exacte toedracht van deze dramatische gebeurtenis die de ILO-"case-law" gehaald heeft wordt in de juridische analyse nader vit de doeken gedaan.

33 De opwatting dat de Revolutie de legitimatie wan de PRI voortdurend gewoed theeft en dikwijls heeft gefungeerd als een middel om de bittere pil van een straffe economische politiek te vergulden, vindt algemene bijual in de literatuur. Vgl. Kaufman, a.w. p. 212;

Needler M.C. Matican Politics: the Containment of Conflict, New York 1968, p. 73;

Padgett, Vincent L. The Mexican Political System, Boston 1966, met name hoofdstuk 1;

Reyma, Jose L. Redefining the Authoritarian Regime in: Reyna/Weimert (eds.) Aluthoritarianisin in Mexico, Philadelphia 1977, p. 159 
zich wisten te binden, maar waar de ideologische bagage van deze regimes te mager bleek om ook in een periode van tegenvallende economische prestaties verzekerd te zijn van de loyale steun van de bonden. ${ }^{34}$

De PRI ontleende haar politieke legitimatie evenwel niet uitsluitend aan de manipulatie van versleten revolutionaire symbolen. Gedurende de jaren zestig begonnen industriële werknemers geleidelijk aan te profiteren van de economische groei. Over de vraag of de vakbeweging in economisch opzicht vooral schade heeft ondervonden van haar inkapseling in het politieke bestel, dan wel op de langere termijn de vruchten heeft geplukt van haar coöperatieve opstelling, bestaat in de literatuur enige controverse. Sommige auteurs benadrukken dat de economische expansie een zware sociale tol heeft geëist. Weliswaar werd de neerwaartse trend in de ontwikkeling van de reële lonen gedurende de jaren zestig tijdelijk onderbroken, maar lonen bleven aanzienlijk achter bij ondernemerswinsten. ${ }^{35}$ Roxborough onderkent dat een dergelijke globale constatering een betrekkelijk geringe waarde heeft voor de vaststelling van de invloed van de vakbeweging, aangezien niet gedifferentieerd wordt tussen georganiseerde en ongeorganiseerde werknemers. Hij baseert zijn bewering dat de inkomenspositie van georganiseerde werknemers er sinds de Tweede Wereldoorlog op vooruit is gegaan, op onderzoeksresultaten van Michael Everett. ${ }^{36}$ Zapata benadert het vraagstuk uit een andere invalshoek, maar komt in grote lijnen tot dezelfde conclusie als Roxborough. Hij erkent dat de reële lonen van industriële werknemers er de laatste vijftig jaar op achteruit zijn gegaan, maar voegt hier onmiddellijk aan toe dat dit geen adequate methode is om de successen van de vakbeweging te meten. Met name georganiseerde werknemers hebben gunstige secundaire arbeidsvoorwaarden verkregen in de vorm van huisvesting, onderwijs, gezondheidszorg en sociale zekerheid. ${ }^{37}$ Een nadere verfijning die door sommige auteurs binnen de categorie van georganiseerde werknemers wordt aangebracht, werpt weer een ander licht op de gevolgen van de nauwe connecties tussen staat en vakbeweging. Organisaties van werknemers in economisch strategische sectoren - spoorwegarbeiders, mijnwerkers en werknemers in de olie-sector - hebben zich niet aangesloten bij de CTM en hebben als autonome bonden voor hun achterban aanzienlijk hogere lonen weten te bedingen dan de gemiddelde loonstijgingen in de gehele industriële sector. ${ }^{\text {\$H }}$ Dit zou een aanwijzing kunnen zijn voor de stelling dat de afhankelijke positie van de CTM ten opzichte van de staat de leden uiteindelijk benadeeld heeft, ofschoon natuurlijk direct de vraag rijst of de

Zie hierover O'Donnell G. Modemization and Bureaucratic-Authoritarianism, Berkeley 1973, pp. 95-97. Vgl. Kaufman, a.w. p. 213; Reyna, a.w. p. 160.

36 Roxborough I.A. Unions and Politics in Mexico. The Case of the Antomobile Industry. Cambridge 1984, p. 27. Everett M.D. The Role of the Mexican Trade Unions, 1950-1963, Ph.D. diss., Economics, Washington University; St. Louis 1967.

37 Zapata F. Labor and Politics: The Mexican Paradox in: Epstein E.C. Labor Autonomy and the State in Latin America, Boston 1989, p. 176. Hansen bevestigt deze indirecte welvaartstijging: "A further factor which may have improved the standard of liwing of some of the Mexican labor force while not influencing wages was a rise in the level of public services." Hansen, a.w. p. 73.

Anderson, a.w., p. 520. Spalding, a.w. p. 141. 
positieverbetering van de spoorwegarbeiders etc. te maken heeft met hun economische belang of toe te schrijuen is aan de autonome opstelling van hun bonden.

Een ondubbelzinnige conclusie valt uit bovenstaande gegevens niet te trekken. In het licht van de versterking van de politieke legitimatie is het vooral van belang dat de PRI, door kleine concessies te doen $\left({ }^{32}\right)$, er meestal in geslaagd is om werknemers te suggereren dat de overheid hun welzijn ter harte gaat. Deze indruk wordt nog versterkt - en in dit opzicht zijn Zapata's bevindingen interessant - doordat de staat secundaire arbeidsvoorwaarden pleegt te verschaffen. In dit perspectief moet ook de wisselwerking tussen legitimatie, politieke stabiliteit en economische groei die door sommige auteurs gesignaleerd is, gezien worden." Mexicaanse werknemers hebben hun vertrouwen in en steun aan overheid en officiële vakbeweging zeker tot aan het eind van de jaren zestig gegrondvest in het vooruitzicht om te delen in de algemene economische welvaart. De oorspronkelijke politieke stabiliteit bevorderde met andere woorden niet alleen de economische groel, maar omgekeerd versterkte de economische groel wederom de legitimatie en daarmee de stabiliteit van het bestel. Pas tegen het eind van de jaren zestig werd zowel de legitimatie als de controlepolitiek ten gevolge van economische en politieke omwentelingen aan een serieuze test onderworpen.

\subsection{0 -1992: De alliantie tussien staat en vakbeweging onder groeiende druk}

De drie decennia na de oorlog brachten niet iedereen geluk en voorspoed. Achter de façade van economische groei en politieke stabiliteit gingen grote sociale problemen schuil. Weliswaar profiteerde de middenklasse enigszins van de materiële welvaart, maar het inkomensaandeel van de armste $50 \%$ van de Mexicaanse families nam gestadig af. $^{42}$ Deze verpaupering stond in schril contrast met de spilzucht van een kleine elite. Onvrede over deze sociale misstanden die absoluut niet correspondeerden met het gunstige imago van Mexico in de buitenwereld, leidde tot de studentendemonstraties in 1968 die met harde hand werden neergeslagen. ${ }^{\text {s3 }}$

President Echeverría (1970-1976) stond voor de opgave om het gevaar van een ernstige legitimiteitscrisis te bezweren. In politiek opzicht streefde hij naar meer openheid en een

39 Kaufman morkt dienaangaande op dat ook tijdens de jaren zestig "all 'concessions' turned out on closer examination to be marginal reforms at the very most." Kaufman, a.w. p. 221.

40 What labor did not obtain in salaries it obtained collectively through benefits provided directly by the state rather than by entrepreneurs." Zapata, a.w. p. 176. Zo participeren weel werknemers in het Mexicaanse Instituut voor Sociale Zekerbeid en verschaft de overheid goedkope huisvesting door middel van het huisvestings-fonds INFONAVIT.

41 Levy D./Szekely G. Mexico: Panadoxes of Stability and Change, Boulder (Col.) 1987, p. 24. Vgl. ook Flansen, a.w. pp. 179-180:

42 Het aandeel in de totale inkomsten van de armste $50 \%$ van de Mexicaanse families daalde van $19,1 \%$ in 1950 tot 15,5\% in 1963. De mate van inkomensongelijkheid was in Mexico gedurende de jaren zestig groter dan in de meeste andere Latijnsamerikaanse landen. Hansen, a:w. p. 74.

Over de oorzaken en het verloop wan de studentendemonstraties zie: Adler Hellman, a.w. pp. 134-144. 
grotere betrokkenheid van boeren en arbeiders æan de basis. Zijn pogingen om de verstarde overlegstructuren binnen de officiële vakbeweging te doorbreken en het stimuleren van de oprichting van onafhankelijke vakbonden pasten in dit beleid. In economisch opzicht besloot Echeverría een einde te maken aan de "desarrollo estabilizador", de periode van eenzijdige nadruk op economische groei. Een rechtvaardiger inkomensverdeling maakte hij tot inzet van zijn presidentschap: de stijgende overheidsuitgaven kwamen voor een belangrijk deel ten goede aan de welzijns-sector. Bovendien stegen gedurende Echeverría's ambtsperiode de arbeidslonen."

Deze op Keynes geïnspireerde economische politiek was gedoemd te mislukken. Het geheim van het Mexicaanse "Wirtschaftswunder" school voor een belangrijk deel in de bereidheid van buitenlandse en binneniandse geldschieters om te investeren in produktieve sectoren. Door Echeverria's radicale retoriek en zijn economische maatregelen slonk het vertrouwen in het Mexicaanse investeringsklimaat. De groeiende overheidsbestedingen leidden tot flinke begrotingstekorten en dit wakkerde, in combinatie met de stijgende consumentenvraag die het gevolg was van de toegenomen koopkracht, de inflatie aan. Voorts stagneerde de export van industriële produkten ten gevolge van de permanente overwaardering van de peso. Een forse devaluatie bleek niet te vermijden. Vooral de instabiliteit van de nationale munt en de groeiende inflatie leidden tot een massale kapitaalvlucht die het failliet van Echeverria's economische politiek bezegelde. ${ }^{45}$

Even leek het erop dat Echeverria's opvolger, Lopez Portillo, een ernstige economische crisis kon afwenden, toen Mexico begon te profiteren van de stijgende olieprijzen aan het eind van de jaren zeventig. De toestroom van oliedollars verleidde particuliere ondernemers en consumenten echter tot de onverantwoorde aanschaf van luxeprodukten en kapitaalgoederen die gefinancierd werden met buitenlandse leningen, in blind vertrouwen op de permanente kredietwaardigheid. Ook de overheid legde zichzelf niet de noodzakelijke financiële zelfbeheersing op, zodat de buitenlandse schuld van zowel de private als de publieke sector gestadig toenam.

De euforie was van korte duur. Aan het begin van de jaren tachtig begonnen de olieprijzen te zakken. Aangezien de import niet onmiddellijk aan de geslonken valutastroom kon worden aangepast, groeide de buitenlandse schuld in korte tijd tot astronomische hoogten. In augustus 1982 zag de Mexicaanse minister van financiën, Jesus Silva Herzog, zich genoodzaakt om aan de Amerikaanse regering uitstel van betaling te vragen. Het betekende het begin van de internationale schuldencrisis.

44. Tussen 1970 en 1976 stegen de overheidsuitgaven wan $21 \%$ naar $34 \%$ van het BNP. Het aandeel wan de lonen en salarissen in het nationale inkomen steeg over dezelfde periode van $35,5 \%$ naar $40 \%$.

Bron: Ayala J./Ruzz Durán C. Development and Crisis in Mexico: A Stmcturalist Approach in: Hartlyn J./Mlorley S.A. Latin Americam Political Ecionomy: Financial Crisis and Political Change, Boulder 1986, p. 245.

45 Voor een wat witwoeriger owerzicht van de economische ontwikkelingen ten tijde van de regering-Echeverría wordt verwezen naar: Philip G. Mexican Politics under Stress: Alusterity and After in: Philip G. (ed.) Politics in Mexico, London 1985 , p. 57. 
Sindsdien hebben de presidenten De la Madrid (1982-1988) en Salinas de Gortari (1988-beden) een streng bezuinigingsbelleid gevoerd. De sterke inkrimping van de overheidssector, de loonsbevriezingen en de herprivatisering van bedrijven zijn vooral gericht op de sanering van de economie en het tot stilstand brengen van de inflatie, een opzet waarin de regering inmiddels redelijk geslaagd is. Aan de constante druk wan particuliere banken en internationale organisaties als het IMF om de schulden af te betalen, kon slechts worden voldaan indien Mexico de beschikking zou hebben over voldoende deviezen; met dit oogmerk heeft de regering getracht om, door middel van devaluaties en exportdiversificatie, de positie van Mexico op de internationale markt te verstevigen. Hoewel de macro-economische problemen nog niet zijn opgelost, lijken de vooruitzichten op economisch herstel gunstig. ${ }^{46}$

Maar de paardeniddelen waarvan de regering zich bediend heeft, hebben grote maatschappelijke kosten met zich gebracht en hebben verstrekkende repercussies gehad voor de verhouding tussen staat en vakbeweging. De officiële vakbeweging heeft alle reden om ontevreden te zijn over de regeringspolitiek. Zowel de vakbondsbasis als het kader hebben de wrange vruchten wan het beleid geplukt. In materieel opzicht hebben werknemers aanzienlijk moeten inleveren, op directe wijze door de gecombineerde effecten van loonsbevriezingen en inflatie en op indirecte wijze door de bezuinigingen van de overheid op welzijnssectoren. ${ }^{47}$ Aan de ene kant heeft dit het vertrouwen van de werknemers in de PRI geschaad, hetgeen met name valt af te meten an de marginale overwinning van Salinas tijdens de laatste presidentsverkiezingen en het ongekende succes van zijn belangrijkste rivaal, Cuauhtémoc Cárdenas, de leider van het populistische Nationale Democratische Front: ${ }^{48}$ Aan de andere kant heeft binnen de CTM de verslechtering van de materiële positie geleid tot een verwijdering tussen kader en vakbondsleden aan de basis die zich in toenemende mate begonnen af te vragen of de CTM zich wel voldoendle inzet voor hun belangen. De afgelopen 20 jaar heeft de CTM veel leden verloren, tijdens het bewind van Echeverría vooral aan onafhankelijke, militante bonden, gedurende de jaren tachtig ook aan meer gedweeë vakcentrales die in het kader van een verdeel-en-heers politiek door de staat begunstigd werden. ${ }^{49}$

46. Vgl. Wijnbergen van S. Mexico: een uitdaging, in NRC-Handelsblad 16-03-1989.

47 Het atandeel in het budget van de federale overheid dat besteed wordt aan onderwijs, gezondheidszorg en social welzijn is gedaald van $14,9 \%$ in 1982 tot $9,2 \%$ in 1987 . Middlebrook Kevin J. The Sounds of Silence: Onganised Labour's Response to Economic Crisis in Mexico in: Journal of Latin American Studies, Vol, 21 (May 1989), p. 199

48 Salinas verwieri bij de verkiezingen in juli $198850,7 \%$ van de stemmen, terwijl Cardenas officieel $31,1 \%$ van de stemmen kreeg toegewezen. De verkiezingen gaven aanleiding tot een grootscheepse rel, toen Cárdenas de PRI beschuldigde van verkiezingsfraude en de overwinning opeiste. Vgl. Rohter L. Kam Salinas Mexico medden? in: Intermediair, 09-12-1988, p. 7.

49 Zie over de opkoinst en bloei van omathankelijke vakbonden tijdens het begin wan de jaren zeventig Contreras Suarez E. y Silva Ruiz G. Los recientes movimientos mexicanos pro independencia sindical y el reformismo obrero in: Revista Mexicana de Sociologia Año XXXXIV (1972), pp. 845-876. 
Het vakbondskader heeft ook in politiek opzicht, terrein verloren. Dit is onder andere het gevolg van de politieke hervormingen die Lopez Portillo in 1977, na het mislukte economische experiment van Echeverria, heeft doorgevoerd om het politieke systeem voor verdere erosie te behoeden. ${ }^{\text {so }}$ De verlaging van de kiesdrempel en de permanente reservering van 100 zetels in de Kamer van Afgevaardigden voor de leden van de oppositie waren vooral bedoeld als concessie aan de politieke partijen ter linker-en ter rechterzijde wan de PRI en als signaal aan de bevolking om het open en concurrerende karakter van het politieke bestel te benadrukken. Maar tegelijkertijd betekende dit dat de PRI zelf de beschikking had over minder politieke posten die vergeven konden worden aan vakbondsleiders als beloning voor trouwe dienst. ${ }^{\text {si }}$ De CTM heeft zich van meet af aan verzet tegen de politieke hervormingen die werden opgevat als een aantasting van de eigen politieke machtspositie..2

Geconfronteerd met de groeiende druk van onderaf en met de vijandige houding van de staat, heeft de CTM getracht zich militanter en onafhankelijker op te stellen dan voorheen. De vakcentrale faalde in haar opzet. In 1983 en 1984 dreigde de CTM een algemene staking af te kondigen om de regering te dwingen tot het sluiten van een formeel accoord dat met name het voorstel behelsde om de lonen te koppelen aan de prijsstijgingen. President De la Madrid wees de eisen beslist van de hand en week niet af van zijn bezuinigingsbeleid. Na deze nederlagen koos de CTM wederom voor een meer verzoenende opstelling, waarbij de vakcentrale erin slaagde om op bescheiden schaal enige concessies van meer structurele aard te verwerven. Tot meer dan een belastinghervorming, een wijziging in de marges van de winstuitkering en de toezegging dat de regering veranderingen in het sociale zekerheidssysteem en in de federale arbeidswetgeving in overweging zou nemen, kon de CTM De la Madrid niet bewegen.

In december 1987 werd de CTM en werkgeversorganisaties een sociaal pact - het Economische Solidariteitspact (PSE) - opgedrongen. ${ }^{54}$ Inflatiebestrijding was de voornaamste doelstelling van het PSE. In dit opzicht wierp het pact zoveel vruchten af dat het in december 1988

Middlebrook refereert aan de begunstiging door de overheid van de CROC (Revolutionaire Confederatie van Arbeiders en Boeren) en van de bedaagde CROM. Middlebrook (1989), a.w. p. 203.

50 De politieke legitimiteitscrisis manifesteert zich vooral in het hoge absenteisme-percentage tijdens verkiezingen. Bij de kamer verkiezingen van 1979 was de opkonst slechts 49,2\%1 Middlebrook Kevin J. Political Change and Political Reform in an Authoritarian Reginne: The Case of Mexico, Washington DC. 1981, p. 27.

51 Daar komt nog bij dat de PRI zich nog maar nauwelijks kan handhaven als grootse politieke partij. De terugval van de PRI werkt ook door in de lagere bestuurlijke niveaus, waar functies van oudsher open stonden woor loyale wakbondsleiders

52 Middlebrook (1981), a.w. pp. 18-19 en 55. In zijn latere bijdrage aan bet Journal of Latin American Studies toont Middliebrook met concrete voorbeelden aan dat vooraanstaande CTM-kandidaten tijdens de Kamerverkiezingen van 1988 gepasseerd zij. Hij wekt de suggestic dat de regering dit met opzet heeft gedaan om zich van de CTM te distantiëren. Middlebrook (1989), a.w. p. 201.

53 Vgl. Middlebrook (1989), a.w. p. 209.

54 Nestor de Buen wijst erop dat dit sociale pact en zäjn opvolger niet het produkt zijn van onderhandelingen maar eenzijdlig door de staat zijn opgelegd. De Buen N. Mexico in: Blanpain R. (Ëd. in Chief) Imtemational Encyclopaedia for Labour Law and Industrial Relations, Deventer/Bioston $199 \mathbf{1}_{\text {, p. }} 161$. 
geprolongeerd werd. De oorspronkelijke bedoeling om de lonen aan de prijzen te koppelen werd evenwel al in februari 1988 verlaten en de reẻle lonen bleven een dalende tendens vertonen.

Stakingscijfers illustreren de terughoudendheid van de officiële vakbeweging om de economische politiek van de regering met krachtige middelen te weerstreven. ${ }^{\text {ss }}$

Hoe kan men dit gebrek aan strijdbaarheid nu verklaren? Ongetwijfeld heeft de economische recessie de bereidheid van werknemers om in verzet te komen in negatieve zin beînvloed. De arbeidsmarkt was krap en de vrees voor ontslag was gegrond. De belangrijkste oorzaak schuilt waarschijnlijk in het feit dat de CTM geen militante traditie kent. De CTM is decennialang gewend geweest aan "beschaafde" onderhandelingen met werkgevers en de staat, waarbij een discrete verwijzing naar groeiende onrust onder de achterban of het enkele dreigen met een staking voldoende was om de onderhandelingspartners te bewegen tot het doen van enige economische of politieke concessies. Hoewel de CTM immer een ondergeschikte positie heeft ingenomen ten opzichte van de staat, heeft aan de relatie tussen staat en vakbeweging gedurende de drie eerste decennia na de oorlog een wederzijds voordeel, een "quidd pro quo" ten grondslag gelegen. De CTM zorgde voor sociale rust binnen haar gelederen en verzekerde de PRI van politieke rugdekking. In ruil daarvoor verwierf de vakcentrale politieke macht en beperkte sociaal/economische voordelen voor haar leden. Nu de autoriteiten niet langer bereid - en wellicht niet bij machte - zijn om de vakbeweging te begunstigen, blijkt de CTM niet in staat om van strategie te veranderen. ${ }^{56}$

Vakbonden van werknemers in economisch strategische sectoren die een sterke onderhandelingspositie innemen ten opzichte van hun werkgevers, vertonen in toenemende mate de neiging om zich te distantiëren van de staat. Bovendien slagen zij erin om zich te verlossen van het juk van de corrupte vakbondstop $\left({ }^{57}\right)$, waarbij zij, opvallend genoeg, soms de

55. Aantal officieel erkende stakingen van 1982 tot 1987 :

$\begin{array}{ll}1982 & 222 \\ 1983 & 489 \\ 1984 & 423 \\ 1985 & 165 \\ 1986 & 306 \\ 1987 & 1174\end{array}$

Bron: Middlebrook (1989), a.w. p. 204.

56. Zle Philip, A.w. pp. 64-65 en vooral Middlebrook (1989), a.w. p. 209: "Incremental intra-elite bargaining may have been appropriate during Mexico's long era of sustained economic growth, but it has proved much less successfuil in crisis conditions."

57 Dat het vakbondskader van de officiële vakbeweging corrupt is, wordt algemeen onderkend: "De Mexicaanse bonden, naast de CTM vooral ook de bond van oliewerkers en de onderwijsbond, konden gedurende lange tijd ongehinderd aan hun eigen, zonder uitzondering corrupte, imperiums werken." Vooral de oliewerkersbond thad een slechte reputatie: "Aanzienlijke delen van de winst van het staatsoliebedrijf Pemex verdwenen in de kas van de oliewerkersbond in ruil voor arbeidsrust. De bond had steevast recht op twee procent van alle contracten die Pemex afsloot en had verder totale zeggenschap over het personeelsbeleid; met uitzondering wan het topkader." 
medewerking van de staat verkrijgen. Zo had Salinas' spectaculaire coup tegen la Quina, de machtige leider van de olievakbond STPRM, injanuari 1989 de instemming van een groot aantal vakbondsleden. ${ }^{\text {s8 }}$

Mogelijkerwijs vormt deze grote schoonmaak van Salinas de voorbode van een definitieve ontmanteling van de officiële vakbeweging, hetgeen overigens nog niet wil zeggen dat de Mexicaanse vakbonden een grotere vrijheid zullen verwerven ten opzichte van de staat. $\mathrm{Er}$ zijn aanwijzingen dat de regering de indirecte controle over de vakbeweging tracht te vervangen door directe controle. 9

\section{Juridische controlemechanismen ter beoordeling van de ILO}

\subsection{Inleiding}

De Mexicaanse autoriteiten hebben gebruik gemaakt van een grote verscheidenheid aan economische, politieke en juridische middelen om de controle over de vakbeweging te verwezenlijken en te bestendigen. In 2 lag het accent op de economische en politieke aspecten van de controle. Aangezien de ILO zich voornamelijk op basis van wetgeving en in klachten ter discussie gestelde beleidsmaatregelen een oordeel kan vormen over de vraag of vakbondsrechten geschonden zijn, verschuift de aandacht in 3 naar de juridische controlemechanismen.

In 2 is hier en daar al gerefereerd aan het onderscheid tussen directe en indirecte controlemechanismen. De Mexicaanse autoriteiten plegen regelmatig rechtstreeks in te grijpen in arbeidsconflicten. In hoeverre deze interventies nu op gespannen voet staan met de

Reinoud Roscan Abbing, Macht arbeiders taant in past-rewolutionair Mexico in NRC-Handelsblad, 17-04-1993.

De werkelijke drijfveren van Salinas om de macht wan la Quina te breken zijn overigens nogal complex. La Quina werd gearresteerd op verdenking van wapenhandel en belastingontduiking. Hoewel deze verdenkingen gegrond waren, stak er waarschijnlijk nog iets anders achter. Er deden geruchten de ronde dat La Quina de verkiezingscampagne van Cárdenas had gefinancierd. Bovendien had het kader van de STPRM in het najaar van 1988 openlijk kritiek geleverd op administratieve herwormingen in de pefroleumindustrie.

In dit licht kan de arrestatie ook gezien worden als een terechtwijzing wegens politieke trouwbreuk en als een poging om de STPRM tot grotere politieke volgzaamheid te bewegen. Vooral de aanstelling door Salinas van een meer plooibare opvolger wijst in deze richting. Vgl. Latin American Weekly Report WR-89-04, 26-01-1989; New York Times, 11-01-1989, p. 6.

59 Buve geeft aan dat Salinas zich wenst te ontdoen van de partij-bonzen (de "PRI-nosaurussen") en de corrupte vakbondsleiders, maar hij plaatst twee relativerende kanttekeningen. Allereerst zal Salinas behoedzaam moeten opereren, aangezien de PRI-nosaurussen en de wakbondsleiders de peilers wormen van een sterk partij-apparaat. In de tweede plaats onderkent Buve dat Salinas, juist door de krachtige aanpak van bastions van corruptie, de reputatie van "sterke man" heeft verworven. Buve voorspell dat Salinas de beproefide autoritaire instrumenten wit de Mexicaanse politiek hard nodig zal hebben, indien hij er miet in slaagt on de midden-en lagere klassen te laten profiteren van de economische groei.

Buve R. Mexico onder Carlos Salinas de Gortari: een revolutie van bovenaf in: Intermationale Spectator, mei 1992 , pp. 301-304. 
uitoefening van het stakingsrecht, wordt onderzocht in 3.2 Van indirecte of trapsgewijze controle, waaraan uitvoerig aandacht wordt geschonken in 33, is sprake indien de autoriteiten het veeleer aan de vakbonden - en wel met name aan het vakbondskader - overlaten om de vakbondsleden te bewegen tot een opstelling die de staat welgevallig is.

De Mexicaanse geschiedenis kent enkele voorbeelden, waarin segmenten van de vakbeweging in verzet kwamen tegen de overheersing door de staat. Het conflict tussen de Nationale Bond van Spoorwegpersoneel, STFRM, en de staat dat zijn oorsprong had in een dergelijke verzetsimpuls, en de reactie van de ILO staan centraal in 3.4. Tenslotte komt in 3.5 aan de orde hoe de $\mathrm{KLO}$ zich opgesteld heeft ten aanzien van pogingen van de Mexicaanse regering om, door zich te verschuilen achter de rechter, de verantwoordelijkheid voor schendingen van vakbondsrechten te ontlopen.

\subsection{Staatsintenenties in arbeidsconflicten}

Een eminente rol bij de beslechting van arbeidsconflicten is weggelegd voor de tripartiet samengestelde Raden voor Conciliatie en Arbitrage, hierna "Arbeidsraden" * ${ }^{*}$ Over het rechtskarakter van deze organen en hun plaats in het publiekrechtelijke bestel bestond vooral in de eerste jaren, nadat de Mexicaanse Constitutie van kracht was geworden, onduidelijkheid. De naam suggereert een bemiddelende functie en is in zekere zin misleidend. Op grond van een uitspraak van het Hoogste Gerechtshof in 1924, zijn de meeste rechtsgeleerde auteurs het erover eens dat de raden opereren als "echte" arbeidsgerechten."

In het verlengde van het voorgaande kunnen we ons afvragen of de Arbeidsraden onafhankelijk functioneren van de uitvoerende macht en niet gevoelig zijn voor politieke beïnvloeding. Op z'n zachtst gezegd is hier ruimte voor twijfel. Op het eerste gezicht lijkt de tripartiet samenstelling te duiden op een evenwichtige belangenvertegenwoordiging, hetgeen een onpartijdige opstelling lijkt te garanderen. In haar standaardwerk over de Mexicaanse vakbeweging heeft Marjorie Ruth Clark er evenwel op gewezen dat Arbeidsraden in hoge mate geneigd zijn zich te laten leiden door het standpunt van de vertegenwoordiger van de autoriteiten. In de meeste gevallen staan werkgevers en werknemersvertegenwoordigers namelijk lijnrecht tegenover elkaar, zodat de stem van de regeringsvertegenwoordiger van

De Spaanse term "Jinta de Conciliacion y Arbitraje" verwijst naar de functie van het orgaan, maar niet natar

het terrein watrop het werkzaam is. Vandaar mijn voorkeur voor de term "arbeidsraden".
61 Vl. 10 Buen, a.w. $\$ 454-472$.

In deze befaamde uitspraak owerwoog het Hof dat de "Junta's" kennis konden nemen van zowel individuele verkllsarde bovendien dat de Juntave arbeudsconficten en dat de beslissingen in rechte konden worden afgedwongen. Het Hof waretu met het oplossen van vraagstukken inzake de arbeidsovereenkomst in al bechte M.R. La onganización obrena en Mexico, México 1979 , p. 199. 
doorslaggevende betekenis is. ${ }^{62}$ Bovendien zijn de Arbeidsraden financieel geheel afhankelijk van de Staat.

De tendens dat Arbeidsraden fungeren als het verlengstuk van de staat is versterkt door de zogenaamde "federalisatie" van de arbeidsrechtspraak. Arbeidsraden maken deel uit van een organisatorisch netwerk dat opgebouwd is op basis van de administratieve indeling van het land. Zo kent elke deel-staat een eigen Arbeidsraad en opereren binnen de deelstaten lokale Arbeidsraden. Aan de hiërarchische top staat de Federale Arbeidsraad die zetelt in de hoofdstad. Aanvankelijk bedoeld als een forum ter beslechting van geschillen die hun oorsprong hadden in het Federale District of in industriële ondernemingen die zich uitstrekten over verscheidene deelstaten, heeft de Federale Raad in de loop der jaren steeds meer bevoegdheden toebedeeld gekregen. Tegenwoordig oefent de Federale Raad, op grond van art. 123, sectie XXXI van de Grondwet, exclusieve jurisdictie uit met betrekking tot geschillen in een groot aantal industrieën, waarin de Staat een wezenlijk belang heeft. ${ }^{\text {*a }}$ De achterliggende motieven van deze centralisatietendens worden duidelijk in het licht van de neiging van de Federale Arbeidsraad om belangen van de overheid in hoge mate te laten meewegen bij de besluitvorming. ${ }^{64}$

Met name op het gebied van de collectieve arbeidsconflicten zijn de Arbeidsraden gebonden aan de strakke procedurele en inhoudelijke voorwaarden die de Federale Arbeidswet (Ley Federal del Trabajo, hierna LFT) stelt aan een legale staking. Aangezien in deze studie vakbonden en collectieve arbeidsverhoudingen centraal staan, zullen we ons concentreren op dit aspect van de totale taakuitoefening van de Arbeidsraden.

De spilfunctie van de Arbeidsraden bij collectieve arbeidsconflicten blijkt uit het feit dat de vakbond elke intentie om een staking uit te roepen, indien aan bepaalde eisen niet tegemoet wordt gekomen, via een Arbeidsraad aan de werkgever kenbaar moet maken. Voor het uitroepen van een staking moet een bepaalde termijn in acht genomen worden die begint te lopen vanaf het moment dat de Arbeidsraad de werkgever op de hoogte heeft gebracht. ${ }^{\text {s. }}$ Vervolgens stelt de Arbeidsraad een datum vast voor een gezamenlijke bijeenkomst waarin een poging ondernomen zal worden om tot een vreedzame oplossing van het conflict te komen. Indien deze bemiddelingspoging geen succes sorteert, kan de staking worden uitgeroepen.

62 Clark, a.w. p. 207.

63 De Buen, a.w. 471 geeft en integrale opsomming.

64 Vgll. De Buen a.w. $\S 465$ : "The State is interested, directly or indirectly in this (i.e. the jurisdictional control of conflicts that affect enterprises and services that are still of federal competence) and the Federal Board submissively directs its attention to this interest a priori over the Constitution and the laws."

65 Deze termijn bedraagt zes dagen voor particuliere ondernemingen en tien dagen woor ondernemingen in de publieke sector.

66 Conform art. 927, lid 2 LFT heeft absentie wan de werknemers tijdens deze bijeenkomst tot gevolg dat de stakingstermijn niet begint te lopen. 
Vanaf het begin van de staking kan ledere belanghebbende gedurende een periode van 72 uur de Arbeidsraad verzoeken om de staking nietig te verklaren. ${ }^{67}$ De Arbeidsraad kan uitsluitend tot een dergelijke kwalificatie komen op grond van de overweging dat de vakbond niet voldaan heeft aan de wettelijke vereisten. Naast de zogenaamde meerderheidsclausule de staking moet de instemming hebben van de meerderheid van de werknemers van de onderneming - en de formele vereisten inzake de kennisgeving, moet de vakbond met het uitroepen van de staking vooral het nastreven van wettelijk toegestane belangen voor ogen hebben gehad. Art. 450 LFT brengt restricties aan in de doelstellingen die aan een staking ten grondslag kunnen liggen. Allereerst herhaalt dit artikel het tamelijk abstract geformuleerde vereiste van art. 123 Grondwet dat de doelstelling van een staking moet zijn om een machtsevenwicht na te streven teneinde de rechten van "arbeid" en "kapitaal" met elkaar in overeenstemming te brengen. Vervolgens wordt de staking als pressiemiddel gekoppeld aan de herziening en (niet) naleving van collectieve arbeidscontracten. Tenslotte voorziet art. 450 LFT nog in de mogelijkheid van solidariteitsstakingen. Een oordeel van de Arbeidsraad dat de staking nietig is, heeft verstrekkende consequenties. Allereerst moeten de stakende werknemers binnen 24 uur bun werkzaamheden hervatten, op straffe van ontslag. Bovendien hoeft de werkgever hun geen loon uit te betalen over de periode dat de staking geduurd heeft.

Indien de staking legaal wordt geacht of indien een verzoek tot nietigverklaring niet binnen de voorgeschreven 72-uurs termijn plaatsvindt, kan de vakbond zich tot de Arbeidsraad wenden met een verzoek om arbitrage. De Arbeidsraad onderzoekt vervolgens of het conflict toe te schrijven is aan de werkgever of aan de stakende vakbond. In het eerste geval dient de werkgever aan de eisen van de stakers tegemoet te komen en moet hij loon uitkeren over de periode dat de staking geduurd heeft. Indien daarentegen de werkgever geen schuld treft, wordt het conflict beëindigd en moeten de stakers terugkeren naar hun werkzaamheden, zonder dat zij recht hebben op loon over de stakingsperiode.

Collectieve arbeidsconflicten zijn aan een tamelijk strakke wettelijke regulering onderworpen, zo kunnen we uit het bovenstaande concluderen. Maar staan de gehele procedure en in het bijzonder de interventies van de Arbeidsraden nu ook op gespannen voet met de ILO-normen op het gebied van de vrijheid van vakvereniging? Vooropgesteld moet worden dat het stakingsrecht in de Grondwet verankerd is en daadwerkelijk wordt uitgeoefend. Vakbonden zijn weliswaar verplicht om eerst de weg van de vreedzame geschillenbeslechting te beproeven, maar kunnen vervolgens een staking uitroepen. Bindende arbitrale uitspraken komen uitsluitend tot stand, nadat de vakbond in vrijheid voor arbitrage door een Arbeidsraad gekozen heeft. Van een gedwongen arbitrageprocedure, die de ILO in strijd acht met het stakingsrecht, is met andere woorden geen sprake.

De wettelijke vereisten, waaraan een Arbeidsraad op verzoek van een belanghebbende een staking moet toetsen om zich een oordeel te vormen over het legale karakter, zijn

67 Het begrip "belanghebbende" wordt ruim opgevat: in praktijk kan, naast de werkgever en andere werknemers of vakbonden, elke "derde" zich van deze procedure bedienen. 
misschien in het licht van de internationale arbeidsnormen erg rigide. Men kan zich afvragen of de doeleinden die volgens de wet met een staking mogen worden nagestreefd niet te beperkt zijn. Art. 450 LFT bevat duidelijk een limitatieve opsomming en rept met geen woord over de door de ILO erkende mogelijkheid om een staking uit te roepen teneinde protest aan te tekenen tegen de sociaal/economische regeringspolitiek. Hoe dit ook zij: het Comite van Deskundigen heeft geen aanleiding gezien om de Mexicaanse regering op dit punt ter verantwoording te roepen.

Sommige auteurs zijn van mening dat het stakingsrecht niet zozeer wordt uitgehold door de wettelijke vereisten zelf als wel door de wijze waarop Arbeidsraden deze vereisten plegen te interpreteren. De Arbeidsraden zouden dikwijls de regeringspolitiek tot uitgangspunt nemen en tot het oordeel komen dat de staking sehadelijk is voor het evenwicht tussen arbeid en kapitaal - het multi-interpretabele criterium dat opgenomen is in wet en Grondwet. Dergelijke beweringen zijn moeilijk te staven, aangezien in officiële statistieken met geen woord gerept wordt over het aantal illegale of nietige stakingen. ${ }^{69}$ Voorts is in de literatur de suggestie opgeworpen dat vakbonden, met het oog op het grote aantal negatieve beschikkingen van de Arbeidsraden, een terughoudend gebruik maken van het stakingswapen. Gezien het feit dat procedures bij de Arbeidsraden vaak lang plegen te duren en de werknemers, zo de staking achteraf nietig wordt verklaard, aanzienlijke inkomsten kunnen derven, zouden vakbonden zich maar neerleggen bij de vreedzame oplossing die de Arbeidsraad in zijn functie van conflict-bemiddelaar voorstelt. ${ }^{70}$ Deze indirecte dwang om zich te conformeren aan de directieven van de autoriteiten is een subtiele ondermijning van het stakingsrecht. Tegelijkertijd valt het effect van een dergelijke vorm van zelf-censuur op de stakingsfrequentie moeilijk te meten. Spalding wijst er weliswaar op dat in 1957 van de 13.364 arbeidsconflicten die voorgelegd werden aan de Arbeidsraden er slechts 193 uitmondden in een staking, terwijl in 1970 maar 206 stakingen werden uitgeroepen, hoewel de raden over 26.377 conflicten moesten oordelen. ${ }^{71}$ Maar hij maakt niet duidelijk wat nu precies de oorzaken van deze lage stakingsfrequentie is geweest.

Vast staat slechts dat het aantal stakingen gedurende de laatste vijftig jaar, enkele uitzonderingen daargelaten, gering is geweest en dat de stakingsfrequentie de laatste tijd

68 Vgl. Kevin J. Middlebrook (1989) p. 211: "In evaluating collective labour-management conflicts and strike petitions, the board's decisions generally conform to the incumbent government's overall labour policy." Spalding, a.w. p. 139: "(...) arbitration boards have usually declared stoppages by militant unions or those seeking benefits above the guidelines to be either illegal or non-existent."

69 Vgl Roxborough die slechts tot de conclusie komt dat. "A sizeable but unknown number of strikes are

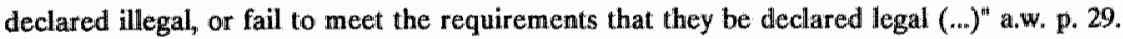

Incidentele data zijn wel beschikbaar. Zo werden tijdens de regering van Avila Camacho (1940-1946) wan de ruim 300 stakingen er 39 nietig en 211 illegaal verklaard. Bron: Iglesias S. Sindicalismo y Socialismo en Mérico, México 1970, p. 132 .

70 Spalding, a.w. p. 135.

71 Spalding, a.w. p. 139 . 
een dalende tendens vertoont. Enkele auteurs vatten dit gegeven op als een aanwijzing voor een stevige staatscontrole over de vakbeweging, een controle die mede in stand wordt gehouden met behulp van het gehele systeem van Arbeidsraden. ${ }^{n}$

Voor de ILO is van doorslaggevende betekenis of zij klachten ontvangt die de aandacht vestigen op eventuele inbreuken op het stakingsrecht. Dit is nauwelijks het geval. Slechts eenmaal werd indirect verwezen naar een uitspraak van de Arbeidsraad van de staat Chihuahua die een staking nietig had verklaard op grond van de overweging dat de vakbond de meerderheidsregel niet in acht had genomen. ${ }^{3}$ De staking was uitgeroepen om de werkgever te dwingen een aantal ontslagen vakbondsleden wederom in dienst te nemen en de Arbeidsraad overwoog dat de stemmen van deze werknemers niet konden worden meegeteld om te verifièren of aan de meerderheidsregel de hand was gehouden. Aangezien het Comité zich evenwel beperkte tot de constatering dat de vakbondsleden ten onrechte waren ontslagen en het slachtoffer waren geworden van anti-vakbondsdiscriminatie, was een oordeel over de juistheid van de uitspraak van de Arbeidsraad niet relevant. ${ }^{24}$

Er zijn aanwijzingen dat het stakingsrecht in Mexico aan restricties onderhevig is, maar op grond van het bovenstaande kunnen we slechts gelaten constateren dat de ILO over te weinig aanknopingspunten beschikt om tot een dergelijk oordeel te komen.

\subsection{Indirecte of trapsgewijze controle}

Indirecte of trapsgewijze controle veronderstelt een dubbele binding: het vakbondskader wordt gecoöpteerd door de staat, terwijl de vakbondsleiders op hun beurt de basis onder controle houden. De technieken die dle staat hanteert om de loyale medewerking van Mexicaanse vakbondsleiders te verkrijgen zijn hiervoor al besproken. De vraag hoe de coöptatie van vakbondsleiders zich verhoudt tot beginselen inzake interne vakbondsdemocratie, staat centraal in 3.3.1.

De controle van het vakbondskader over de basis kan uitsluitend gerealiseerd worden, indien aan twee, onderling nauw samenhangende woorwaarden is voldaan. Allereerst moet de vakbondsleiding de beschikking hebben over sancties om dissidente vakbondsleden te treffen. In de Mexicaanse praktijk blijkt het verplichte vakbondslidmaatschap op straffe van ontslag een geducht wapen te zijn om de basis in het gareel te houden. In de tweede plaats

Vgl. Gonzalez Casanowa P. Democracyin Mexico, Oxford 1970, p. 15. Voorts Zapata, a.w, p. 181: "The general decline in strikers is evidence in support of the thesis of increased state control over labor demands in recent
years."

Case No. 603, 129e Rap. \$ 78 .

Case No. $603,129 \mathrm{e}$ Rap. $\$ 82$. 
dienen de door de staat gecontroleerde vakbonden geen concurrentie te duchten van onafhankelijke vakbonden, met andere woorden: zij moeten een monopoliepositie genieten. ${ }^{\text {s }}$

De aparte wettelijke regelingen voor werknemers en vakbonden in de publieke en in de particuliere sector maken de Mexicaanse situatie op dit gebied tamelijk complex. In de publieke sector voorzien afzonderlijke wetsbepalingen in verplicht vakbondslidmaatschap en in de vestiging van vakbondsmonopolies. Het Comité van Deskundigen heeft de onderhavige wetsbepalingen van kritiseh commentaar voorzien. In de particuliere sector worden beide doelstellingen - verplicht vakbondslidmaatschap en vakbondsmonopolie - dikwijls verenigd in en verwezenlijkt door "closed shop"-clausules.

\subsubsection{Coöptatie van vakbondsleiders als mogelijke inbreuk op de interne vakbondsdemocratie}

De loyale steun van vakbondsleiders aan de autoriteiten is immer een hoeksteen geweest van de politiek van de Mexicaanse overheid om de vakbeweging te controleren. Het hoeft nauwelijks betoog dat het uitoefenen van invloed door de overheid op de aanstelling van vakbondsleiders met het doel om zich van deze steun te verzekeren, een inbreuk vormt op het fundamentele recht van vakorganisaties om in volledige vrijheid de eigen vertegenwoordigers te kiezen. ${ }^{76}$

In de literatuur wordt melding gemaakt van drie methodes die, binnen de Mexicaanse context; op gespannen voet staan met beginselen inzake de interne vakbondsdemocratie.

Allereerst wordt gewezen op de vrij frequent voorkomende praktijk dat vacante leidersposten opgevuld worden door personen die niet gekozen zijn door de vakbondsleden, maar benoemd zijn door de hiërarchische top van (bijvoorbeeld) de CTM. ${ }^{n}$ Een variant hierop is de coöptatie in de strikte zin van het woord: aspirant-leiders worden voorgedragen en benoemd door de zittende leiders. ${ }^{78}$

In de tweede plaats wordt soms gerefereerd aan de neiging van de autoriteiten om loyaliteit te belonen met materiële voordelen of met het verlenen van politieke betrekkingen. ${ }^{7}$ Hoewel

75 De monopoliepositie van de "gecontroleerde" vakbonden is in Mexico zeker niet absoluut. Zoals in de vorige paragrafen al is aangegeven, hebben in Mexico immer onafhankelijke vakbonden geopereerd en is hun aantal de laatste jaren nog toegenomen. In de nuvolgende paragrafen zullen we ons buigen over de instrumenten die de staat en de gecontroleerde vakbeweging gehanteerd hebben on de monopoliepositie van de laatste te versterken en onafhankelijke vakbonden het functioneren onmogelijk te maken.

76. Dit recht wordt gewaarborgd in art: 3 wan Conventie no. 87.

77 Vgl. Spalding, a.w. p. 107.

78. Hansen (a.w. p. 113) noemt beide varianten: "Looking beneath the PRI's methods of selecting its official candidates for public office to the working of the party's labor and agrarian sectors themselwes, we note a similar pattern of co-opted or imposed leadership and the consequent upward-flowing obligations and loyalities." (cursivering HwdW)

79 Brandenburg F. The Making of Modem Mexico, New York 1964, p. 154: For two decades, the union boss has kept the rank and file in line, loyal to the Revolutionary regimes. His reward, besides the permanence 
art. 3 van Verdrag no. 87 niet expliciet refereert an de mogelijkheid dat vakbondsleden een vakbondsleider afzetten die niet langer hun vertrouwen geniet, lijkt deze mogelijkheid de logische pendant van het recht van werknemers om in volledige vrijheid hun vertegenwoor. digers te kiezen.

De meest directe interventie van de autoriteiten in de verhouding tussen vakbondskader en - basis, tenslotte, vindt plaats in de vorm van een weigering van de Arbeidsraden, meestal op technische gronden, om de verkiezing van democratisch gekozen en onafhankelijke kandidaten te erkennen. Gegeven de veelvuldige verwijzingen in de literatur naar de gebrekkig functionerende vakbondsdemocratie in Mexico, wekt het verbazing dat dit thema in het kader van de ILO-klachtenprocedure nauwelijks aan de orde is gesteld. De spoorwegstaking van 1958 werd, zoals we hieronder nog zullen zien, mede uitgeroepen met het oogmerk om een einde te maken aan het imperium van de "charro"-leiders, maar deze kwestie werd als zodanig niet ter beoordeling aan het Comité voorgelegd. Slechts in é̉n zaak zinspeelde een klagende vakorganisatie op de corrupte instelling van vakbondsleiders in een concurrerende vakbond. De beschuldiging was slechts een ondergeschikt facet van een klacht tegen een onderneming die de oprichting en het functioneren van een onafhankelijke vakbond dwarsboomde en werd door het Comité niet nader onderzocht.". Een verklaring voor het gebrek aan klachten met betrekking tot het ondemocratisch functioneren van vakbondsleiders binnen de eigen vakbond zou kunnen zijn dat werknemersorganisaties klachten kunnen indienen bij het Comité inzake de Vrijheid van Vakvereniging, maar dat individuele werknemers noch fracties binnen een vakbond rechtsingang hebben tot deze procedure.

In het kader van de rapportageprocedure heeft het Comité van Deskundigen aanmerkingen gemaakt op het verbod van herverkiezing van vakbondsleiders in de publieke sector dat verankerd is in art. 75 van de Federale Wet voor Werknemers in Dienst vản de Staat. De Mexicaanse regering heeft getracht om deze wettelijke voorziening te billijken door aan te geven dat zij een waarborg vormt voor een goede roulatie van vakbondsleiderschap en de interne vakbondsdemocratie bevordert. In verscheidene Latijnsamerikaanse landen, zo stelt de regering, blijven vakbondsleiders voortdurend in functie. Dikwijls heulen zij samen met de werkgevers en remmen de vakbeweging in haar ontwikkeling. ${ }^{22} \mathrm{Er}$ nog van afgezien dat een dergelijke uitspraak uit de mond van een regering van een land dat berucht is om zijn gesloten, ondemocratische vakbeweging enige bevreemding wekt, is de mededeling niet goed

of his tenure, somelimes comes in the form of a legislative office."

81 Case No. 827, $157 \mathrm{e}$ Rap. $\$ 207$. De veronachtzaming van deze kwestie door het Comite past in het algemene beleid wan de ILO om zich nict te mengen in geschillen tussen vakbonden: "Inter-union rivalry is outside the scope of Convention No. $98^{\prime \prime}$, Digest of Decisions, Geneva 1985, $\$ 669$

Memoria del Gobierno de México sobre el Convenio No. 87, 1970 (ongepubliceerd), $p_{i} 4$. 
te rijmen met de praktijk in de particuliere sector, waar herverkiezing eerder regel dan uitzondering is.

Naast deze repliek, heeft de regering zich beijverd om de onderhavige wetsbepaling te plaatsen tegen een historische en politieke achtergrond. Bij de toepassing van internationale verdragen, zo betoogt de regering, moet immer rekening gehouden worden met specifieke nationale omstandigheden. Welnu, de gehele problematiek van de herverkiezing van officiële gezagsdragers ligt, historisch gezien, buitengewoon gevoelig in Mexico. De inzet van de bloedige Mexicaanse Revolutie was immers onder andere het totstandbrengen van een verbod van presidentiële herverkiezing teneinde een einde te maken aan het meer dan 30-jarige presidentschap van een tiran en teneinde herhaling van een dergelijke ongewenste situatie te voorkomen. Er zijn met andere woorden praktische, politieke en historische redenen aan te voeren, waarom herverkiezing van vakbondsleiders in Mexico niet getolereerd kan worden. ${ }^{s 4}$

In de "Memoria's" van 1978 en 1982 beroept de regering zich op een wonderlijk argument, waar zij stelt dat art. 75 geen inbreuk maakt op het vrije stemrecht van werknemers, maar veeleer het recht van scheidende vakbondsleiders inperkt. ${ }^{85}$

Het Comité van Deskundigen heeft zich niet kunnen verenigen met de opvattingen van de regering. Het heeft de regering te kennen gegeven dat de ILO-organen die belast zijn met het toezicht op de nalleving van de Conventies, unaniem het verbod van herverkiezing in strijd achten met art. 3 van Conventie no. 87 , met de aantekening dat een verbod op grond van de procedureregels van vakbonden geaccepteerd wordt.

Het standpunt van het Comité lijkt mij juist, maar het blijft wonderlijk dat de ILO kritiek heeft geoefend op een wettelijke bepaling die, althans volgens de regering, interne vakbondsdemocratie pleegt te bevorderen, terwijl nu juist het gebrek aan deze democratie in Mexico een alom gesignaleerd probleem is.

83 Vgl. Zapata, a.w. p. 178: "While it is not clear how election procedures for the higher posts actually function, reelection is typical."

In dit verband kan gewezen worden op de unieke positie die de inmiddels hoog bejaarde Fidel Velazquez inneemt binnen de CTM. Sinds 1950 is Velazquez ononderbroken secretaris-generaal van de CTM gewest en met zijn diepe loyaliteit jegens de PRI en zijn wirulent anti-communistische gezindheid heeft hij in hoge mate een persoonlijk stempel op de vakcentrale gezet.

84 Memoria 1970, p. 3. Gedoeld wordt natuurlijk op de dictatuur van Porfirio Diaz (1875-1910).

85 Memoria 1978, pp. 8-10; Memoria 1982, pp. $20-22$.

86 Observation 1987; Report of the Committee of Experts 1989, pp. 192-193. Deze laatste toevoeging is natuurlijk een uitwerking van art. 3 , lid 1 van Conventie no. 87 dat vakorganisaties het recht toekent om hun interne aangelegenheden, waaronder verkiezingen, te regelen. 


\subsubsection{Vakbondsmonopolies in de Mexicaanse wetgeving en rechtspraktijk}

Het onderscheid tussen werknemers in de particuliere en in de publieke sector is in de Grondwet verankerd. "Apartado A" wan art. $123 \mathrm{Gw}$. heeft betrekking op werknemers in de particuliere sector, terwijl "Apartado B" van toepassing is op werknemers in de publieke sector.

\subsubsection{Het wettelijk voorgeschreven vakbondsmonopolie in de publieke sector}

Van meet af aan heeft de kritiek van het Comité van Deskundigen zich toegespitst op de wettelijke regeling inzake vakorganisaties binnen de publieke sector. Vooral het bij wet ingestelde vakbondsmonopolie in deze sector heeft het moeten ontgelden. Alvorens we de gezichtspunten van regering en Comité in deze ontvouwen, moeten we in het kort ingaan op de vraag welke werknemers onder het regime van de Federale Wet voor Werknemers in Dienst van de Staat (Ley Federal de los Trabajadores en el Servicio del Estado; hierna LFTSE) vallen die in een dergelijk vakbondsmonopolie voorziet. Het wisselende standpunt van de regering heeft aanleiding gegeven tot misverstanden.

In een Memoria van 1958 verzekerde de regering het Comité dat uitsluitend ambtenaren in dienst van de centrale overheid onderworpen waren aan de LFTSE, terwijl werknemers van gedecentraliseerde organen en van genationaliseerde ondernemingen onder de werking van de reguliere Arbeidswet vielen. ${ }^{\text {}}$ "Nadat de kwestie gedurende meer dan twintig jaar onbesproken was gebleven, kwam de regering op deze restrictieve interpretatie terug. In een Memoria van 1982 wijdde de regering een uitvoerige beschouwing aan de essentie van de overheidstaak en kwam vervolgens tot de conclusie dat het onderscheid tussen de staat als ondernemer en de staat als publieke macht niet van doorslaggevende betekenis kon zijn voor de beoordeling van de vraag of de arbeidsverhoudingen bij CAO geregeld konden worden of dwingend voorgeschreven moesten worden in de wet. Uiteindelijk diende de Federale regering van geval tot geval na te gaan of de uitoefening van de publieke taak vereiste dat een specifieke categorie werknemers onder de werking van een apart wettelijk regime werd gebracht.

Bij de nationalisatie van de banken in 1985 bleek dat deze casuïstische benadering in de praktijk ertoe leidt dat de reikwijdte van de LFTSE stelselmatig wordt uitgebreid. Bankemployés, zo verklaarde de regering in reactie op een "Direct Request" van het Comite, zouden voortaan onder de specifieke regeling van de LFTSE vallen; de LFT had als "lex generalis" slechts aanvullende werking. ${ }^{\text {.9 }}$ Het Comité betreurde met name de vestiging van

89 Memoria 1986, pp. 2-4. 
een vakbondsmonopolie ten gunste van de Federatie van Vakbonden in het Bankwezen die het gevolg is van deze wetgevende maatregel. ${ }^{\infty}$

Het vakbondsmonopolie in de publieke sector is verankerd in verscheidene artikelen van de LFTSE die vooral gericht zijn aan het adres van de Federale Arbeidsraad die belast is met de registratie van vakbonden in deze sector. De hoofdregel van art. 68 LFTSE is imperatief gesteld: "In elke overheidsafdeling zal slechts én vakbond (sindicato) opereren." De Federale Arbeidsraad dient, zo vervolgt het artikel, in het geval dat verscheidene groepen werknemers elkaar het recht betwisten om officieel als "sindicato" erkend te worden, het verzoek om. registratie van de groep die de meeste werknemers telt, in te willigen. In de volgende artikelen wordt de materie vanuit verschillende invalshoeken belicht, maar zij komen inhoudelijk op hetzelfde neer. ${ }^{91}$

Het Comité van Deskundigen heeft de onderhavige bepalingen van meet af aan in strijd geacht met art. 2 van Conventie no. 87, aangezien de betrokken werknemers bij wet (cursivering in het origineel) beroofd worden van hun recht om organisaties naar eigen keuze en zonder voorafgaande goedkeuring van de autoriteiten op te richten. Bovendien voldoet de Mexicaanse wetgeving niet aan art. 7 van de Conventie, aangezien vakorganisaties in de publieke sector die geen meerderheidspositie innemen, geen rechtspersoonlijkheid kunnen verwerven. ${ }^{92}$

Maar de kritiek van het Comité beperkt zich niet tot deze bepalingen. De artikelen moeten, naar het oordeel van het Comite, bezien worden in samenhang met art. 69 LFTSE dat werknemers in de publieke sector die eenmaal zijn toegetreden tot een vakbond, verbiedt om deze vakbond weer te verlaten, tenzij zij geroyeerd worden. Dit artikel bemoeilijkt de oprichting van nieuwe vakbonden en resulteert, in gecombineerde toepassing met art. 68 , 71,72 en 73 , in de vestiging van een vakbondsmonopolie bij wet.

90 Report of the Committee of Experts 1989, p. 192.

91 Zo bevat ant, 71 LFTSE een richtsnoer woor de werknemersgroep die cen wakbond wil oprichteru. De groep moet minstens 20 werknemers omvatten en er mag bimen de overheidsdienst niet reeds cen vakorganisatie bestaan die meer leden tell.

Ant 72 verplicht de Federale Arbeidsraad om, in geval van een verzock tot registratie, te verifièren of in de desbetreffende owerheidsdienst al een wakbond bestaat en of de vakbond die het verzoek indient de meeste werknemers vertegenwoordigt:

Tenslotte bepaalt ant 73 dat de Federale $\mathbb{R}$ aad de registratie van een vakbond dient te annuleren, zodra een andere werknemersorganisatie aantoont dat zij de meerderheid van de werknemers in de owerheidsdienst representeert.

92 Report of the Comittee of Experts 1958.

Art. 374 LFT bepaalt dat de verwerving van rechtspersoonlijkheid automatisch gekoppeld is aan de registratie van een vakorganisatie.

93 Report of the Committee of Experts 1958, sub (7); Analisis comparativo compillementario de la Memoria del Gobierno de México (ongepubliceerd), p. 6 .

Zoals bekend, maakt de ILO onderscheid tussen wettelijk opgelegde vakbondsmonopolies en feitelijke monopolies die op vrijwillige basis tot stand komen en neergelegd worden in een CAO. 
Op het eerste gezicht is de overweging van het Comité niet geheel helder - hoe kan immers de oprichting van nieuwe vakbonden bemoeilijkt worden, indien de co-existentie van verscheidene vakbonden in één organisatie-eenheid bij wet verboden is? Maar het standpunt wint aan duidelijkheid in het licht van de nadere explicatie van de regering.

De regering heeft namelijk in de loop der jaren eengroot aantal argumenten aangevoerd om aan te tonen dat de wetgeving niet in strijd is met de vrijheid van vakvereniging, maar het verweer spitst zich toe op de stelling dat vakbondspluralisme in de publieke sector niet bij wet verboden is. Binnen én afdeling mogen wel degelijk verscheidene organisaties opereren, hetgeen al blijkt uit het feit dat rechtspersoonlijkheid wordt ontzegd aan de minderheids-vereniging die al is opgericht

Slechts én organisatie kan geregistreerd worden en uit dien hoofde rechtspersoonlijkheid verkrijgen. Aan deze organisatie verleent de Mexicaanse wet de kwalificatie "sindicato", om haar te onderscheiden van andere coalities die minder werknemers vertegenwoordigen. ${ }^{95}$ Minderheidsorganisaties kunnen ernaar streven om de meerderheid te verwerven en zich tot de autoriteiten wenden met het verzoek om geregistreerd te worden, zodra zij hierin geslaagd zijn. Op grond van art. 73 LFTSE zal de Federale Arbeidsraad dan de registratie van de voormalige meerderheidsorganisatie moeten annuleren. Art. 69 LFTSE, zo verduidelijkt de regering, staat er namelijk niet aan in de weg dat werknemers ook lid zijn van een andere organisatie die al binnen de afdeling in kwestie bestaat. Dit impliceert dat werknemers, tezamen met nieuwe collega's die nog niet lid zijn van de geregistreerde vakbond, door middel van een dubbel lidmaatschap, de numerieke verhoudingen kunnen beïnvloeden en de registratie van een andere vakbond kunnen bewerkstelligen."

Vervolgens brengt de regering een doelmatigheidsargument in stelling. De aanwijzing van cén "sindicato" die bevoegd is om te fungeren als gesprekspartner van de werkgever/overheid, dient een dubbel doel. Aan de ene kant moet de staat weten met wie hij zich heeft te verstaan, indien zich een conflict voordoet. Een bonte verscheidenheid aan vakbonden met wie verschillende arbeidswoorwaarden zijn overeengekomen, vergroot de kans op conflicten en belemmert de staat in zijn taakuitoefening. Aan de andere kant versterkt de bundeling van krachten in én organisatie de onderhandelingspositie van de vakbond tegenover de overheid.

Tenslotte beroept de regering zich op het feit dat de ILO zelf regelmatig het begrip "meest representatieve vakbond" hanteert. In dit verband verwijst de regering naar een tweetal uitspraken van het Comitê inzake de Vrijheid van Vakvereniging, waarin de aanwijzing van de meest representatieve vakbond als exclusieve onderhandelingspartner niet in strijd wordt

95 Memoria 1982, p. 14.

96 Memoria 1978, pp. 3-4. Het argument wordt therhaald in Memoria 1982, p. 29.

97 Memoria 1970, p. $2_{*}$ Memoria 1986, p. 10. 
geacht met Conventie no. 87, mits in enkele waarborgen is voorzien. van 1986 refereert de regering nog aan de Verklaring van Philadelphia (1946), waarin gesteld wordt dat de lid-staten van de ILO zich verplichten om afgevaardigden te benoemen "in overeenstemming met de meest representatieve vakverenigingen.

Dit uitvoerige pleidooi, waarin doelmatigheids-en rechtmatigheidsoverwegingen elkaar afwisselen, vermag het Comité niet te overtuigen. Inderdaad is het verlenen van bepaalde voorrechten op het gebied van collectieve onderhandelingen, overleg met de autoriteiten en vertegenwoordiging in internationale gremia aan meerderheidsvakbonden niet in strijd met de Conventie. Waar het op aan komt is dat naast deze meerderheidsvakbond, minderheidsverenigingen moeten kunnen bestaan die ténminste hun leden mogen vertegenwoordigen en, conform de formulering van art. 10 van Conventie no. 87, de belangen van hun leden kunnen "bevorderen en verdedigen". Welnu, de coalities van werknemers, waaraan de regering voortdurend refereert, genieten deze rechten blijkbaar niet. Art. 67 LFTSE bepaalt namelijk dat uitsluitend geregistreerde vakbonden de belangen van hun leden mogen "bestuderen, verbeteren en verdedigen", terwijl art. 77 aan deze bonden het exclusieve recht toekent om hun leden te beschermen en te vertegenwoordigen ten overstaan van de autoriteiten of de Federale Arbeidsraad. ${ }^{100}$ Gezien het feit dat de regering in haar Memoria's in vruchteloze herhalingen van het eigen standpunt vervalt, besluit het Comité in de "Observation" van 1987 zijn strategie te wijzigen. Het verzoekt de regering om, met concrete voorbeelden, aan te geven of er vakverenigingen bestaan in overheidsdiensten war een "sindicato" al geregistreerd is, welke rechten deze verenigingen genieten en of het wel eens voorkomt dat een dergelijke vereniging erin slaagt om de status van "sindicato" te verkrijgen, indien er al een andere vakbond geregistreerd is. ${ }^{\text {tal. }}$

Een "Memoria" van 1988 bevat geen nieuwe gezichtspunten. Wederom zinspeelt de regering op de mogelijkheid, zonder overigens aan te geven of deze situatie zich in praktijk wel eens voordoet, dat een minderheidsvereniging aandringt op een nieuwe telling van de leden, opdat vastgesteld wordt welke organisatie de meeste werknemers vertegenwoordigt. Met engelengeduld legt het Comité uit dat een dergelijke wisseling van de wacht nog niet een doorbreking van het wettelijk opgelegde vakbondsmonopolie impliceert en dringt er nogmaals bij de regering op aan om de LFTSE in overeenstemming te brengen met de waarborgen, waarin Conventie no. 87 voorziet. ${ }^{102}$

98 Memoria 1982, p. 20. De regering doelt op Case No. 303, \$292 en Case No. 316, 94. De waarborgen die het Comité noemt zijn de wolgende: a) de aanwijzing moet geschieden door een onafhankelijk orgatan; b) de representatieve vakbond moet gekozen zijn door de meerderheid van de werknemers in de betrokken dienst of onderneming; c) de organisaties die niet voldoende stemmen hebben verkregen, dienen het recht te hebben om binnen een vastgestelde termijn een nieuwe verkiezing te vragen; d) deze termijn kan doorgaans het beste op twaalf maanden gesteld worden.

99 Memoria 1986, p. 12 .

100 Report of the Committee of Experts 1973.

101 Observation 1987.

102 Report of the Committe of Experts 1989, pp. 192 en 194. 
De regering tracht het verbod van uittreding (art.69 LFTSE) te rechtvaardigen met een beroep op de letterlijke tekst van Conventie no. 87. Een zorgvuldige lezing van deze Conventie leert, aldus de regering, dat geen enkele bepaling expliciet gewijd is aan het recht van werknemers om de vakbond, waartoe zij behoren, te verlaten. Blijkbaar komt het Comité, door middel van analoge interpretatie, tot een andere conclusie, maar de regering deelt het standpunt van het Comité niet. Interpretatiegeschillen dienen, op grond van art. 37, lid 1 van het Statuut van de $\mathrm{LO}$, beslecht te worden door het Internationale Gerechtshof. A contrario kan men hieruit afleiden, zo vervolgt de Mexicaanse regering; dat het Comité niet de bevoegdheid bezit om een interpretatie van Conventies dwingend voor te schrijven. ${ }^{\text {seo }}$

Het Comité reageert laconiek op de beweringen van de regering. In zijn "Observation" van 1987 benadrakt het dat het recht om zich aan te sluiten bij een organisatie van eigen keuze wel degelijk ook het recht impliceert om de organisatie weer te verlaten. ${ }^{104}$

De officieel erkende "sindicatos" kunnen toetreden tot de Federatie van Werknemers in Dienst van de Staat (FSTSE) die op grond van art. 78 LFTSE, met uitsluiting van andere federaties, door de staat wordt erkend. Het vakbondsmonopolie op federaal niveau is met andere woorden gefixeerd ten gunste van éen federatie. Daarnaast verklaart art. 84 LFTSE de voorzieningen van de Federale wet voor "sindicatos" van overeenkomstige toepassing op de FSTSE. Terecht merkt Freyre Rubio op dat deze bepalingen de vorming van andere federaties die de machtspositie van de FSTSE en daarmee de controle van de staat over werknemers en vakorganisaties in de publieke sector zouden kunnen aantasten, volstrekt uitsluiten. ${ }^{105}$

Het Comité van Deskundigen heeft de regering voortdurend te kennen gegeven dat het bezwaar maakt tegen het wettelijk decreteren van een vakbondsmonopolie op federaal niveau. ${ }^{106}$ Niet alleen hebben werknemers en werkgevers het recht om zich aan te sluiten bij een vakorganisatie van hun eigen keuze, ook vakorganisaties dienen over de vrijheid te beschikken om toe te treden tot de (con)federatie van hun voorkeur. ${ }^{107}$

Het Comité van Deskundigen huldigt het standpunt dat het wettelijk voorgeschreven vakbondsmonopolie in de publieke sector in Mexico niet strookt met de vrijheid van vakvereniging, zo kunnen we uit het voorgaande afleiden. Zoals we in 3.3.2.2 zullen zien, contrasteert deze principiële stellingname met de terughoudendheid van de ILO ten aanzien van monopolies en "closed shop"-clausules in de particuliere sector.

103 Memoria 1986, pp. 12-14.

104 Observation 1987.

105 Freyre Rubio J. Las Organizaciones Sindicales, Obreras y Burocráticas Contemporaneas en México, México 1985 , p. 166.

106 Zie 0.al. Rep. of the Committee of Experts 1989, p. 194.

107 Art. 6 van Conventic no. 87 verklaart de waarborgen van de artt. 2,3 en 4 van overeenkomstige toepassing op federaties en confederaties van werknemers en werkgevers. 
Artikel 360 van de Federale Arbeidswet noemt vijf typen vakorganisaties:

I) de zogenaamde gremiales, die gevormd worden door werknemers die eenzelfde beroep of specialisme uitoefenen;

II) de empresa, vakbonden van werknemers die werkzaam zijn bij dezelfde onderneming; III) industriales van werknemers die werkzaam zijn bij twee of meer ondernemingen van eenzelfde industriële bedrijfstak;

IV) nacionales de industria die gevormd worden door werknemers die in dienst zijn van én of meer ondernemingen, behorende tot eenzelfde bedrijfstak en gevestigd zijn in twee of meer deel-staten, en

V) oficios varios bestaande uit werknemers die verscheidene beroepen uitoefenen. ${ }^{\text {10s }}$

Ondernemingsvakbonden ("sindicatos de empresa") hebben duidelijk de overhand boven de "gremiales". Voorts is er een centralisatietendens waarneembaar in de groei van de nationale industriële bonden -categorie IV ${ }^{100}$

In tegenstelling tot de publieke sector, schrijtt de Mexicaanse wetgeving in de particuliere sector geen vakbondsmonopolie voor. Integendeel: Art. 388 LFT bepaalt uitdrukkelijk dat binnen ến onderneming verscheidene vakbonden kunnen functioneren. Verder stelt art. 358 LFT dat niemand verplicht kan worden om zich al of niet aan te sluiten bij een vakbond. Aan de andere kant werkt de Federale Arbeidswet zowel vakbondsmonopolies als verplicht vakbondslidmaatschap in de hand door "closed shop"-clausules toe te staan. Zo bepaalt art. 395 LFT dat in een CAO kan worden vastgelegd dat de werkgever uitsluitend leden van de vakbond die partij is bij de $C A O$, in dienst kan nemen. Ook de contractuele verplichting van de werkgever om werknemers die de vakbond verlaten hebben of als lid geroyeerd zijn, te ontslaan, wordt in het Mexicaanse recht erkend. ${ }^{110}$

De "closed-shop" als machtsinstrument in de handen van de officiële, door de Staat gesteunde vakbeweging om zich van dissidente werknemers te ontdoen, is uitvoerig in de

108 De wettelijke erkenning van deze laatste categorie waarborgt dat ook werknemers in kleine gemeenten zich kunnen organiseren. Art. 364 LFT bepaalt namelijk dat een vakbond minimaal 20 leden moet tellen. In kleine Mexicaanse gemeenten komt het dikwijls voor dat er geen twintig werknemers zijn die eenzzelfde beroep uitoefenen of die werkzaam zijn bij dezelfde onderneming. In dit licht bezien is het begrijpelijk dat, conform art. 360 LFT, "sindicatos de oficios varios" slechts opgericht kunnen worden binnen een gemeente, indien in die gemeente mindler dan 20 werknemers werkzaam zijn die eenzelfde beroep uiteefenon.

109 Zie over deze centralisatietendens: Freyre Rubio, a.w. p. 222.

110 Vgl. H. Barbagelata Introduction aux Insitutitons du Droit du Travail en Amérique Latine, Leuven 1980, p. 238 . 
literatuur gedocumenteerd. ${ }^{111}$ Sommige Mexicaanse rechtsgeleerden achten art. 395 LFT zelfs in strijd met de art. 123, sub XVI van de Mexicaanse Grondwet en art. 358 LFT, aangezien het inbreuk zou maken op het recht van de individuele werknemer om niet tot een vakbond te behoren. ${ }^{\text {.12 }}$ De Buen deelt deze visie niet. Hij wijst erop dat de "closed shop"clausule strikt genomen de werknemer niet verplicht om lid te worden en te blijven van een vakbond. De uitoefening van het recht om zich niet aan te sluiten of uit te treden heeft voor de werknemer "slechts" repercussies voor zijn dienstverband. ${ }^{\text {1s }}$

In het licht van de problematiek van vakbondsmonopolies rijst met name de vraag of "closed shop"-clausules de oprichting en het functioneren van concurrerende vakbonden in een onderneming beletten en zodoende de wettelijke waarborgen op het gebied van vakbondspluralisme uithollen. Deze vraag kan uitsluitend beantwoord worden nadat we inzicht hebben verkregen in de wettelijke procedures die tot doel hebben om de organisatie van vakbonden binnen een onderneming te reguleren. Vervolgens zal, aan de hand van enkele ILO-"cases", worden nagegaan hoe deze procedures in praktijk worden toegepast door de Arbeidsraden. In het bijzonder zal worden bekeken welke gevolgen de Arbeidsraden verbinden aan "closed shop"-clausules.

De Mexicaanse wet kent het verschijnsel van de meest representatieve vakbond. Indien verscheidene vakbonden binnen één onderneming aanspraak maken op het recht om een collectieve arbeidsovereenkomst af te sluiten met de werkgever, dan zal de CAO met de vakbond die de meeste leden telt binnen de onderneming, van kracht zijn, zo bepaalt art. 388, lid 1 LFT. De CAO is, op grond van art. 386 LFT, vervolgens van toepassing op alle werknemers van de onderneming.

In de tweede plaats moeten vakbonden om rechtspersoonlijkheid te verkrijgen geregistreerd worden door het Secretariaat van Arbeid en Sociale Voorzieningen, indien zij onder federale jurisdictie vallen en door Arbeidsraden, indien zij onder lokale jurisdictie vallen (art. 365 LFT). Art. 366 LFT bepaalt dat registratie slechts geweigerd kan worden, indien de vakbond niet de door de wet voorgeschreven doelstellingen nastreeft, indien de vakbond niet is opgericht door het minimaal vereiste aantal werknemers of indien bepaalde documenten niet zijn overgelegd aan de autoriteiten.

In de nu volgende ILO-"cases" zal worden aangetoond op welke wijze deze procedures die als zodanig niet in strijd zijn met ILO-normen, in combinatie worden gehanteerd om

111 Vgl. Davis Ch. L. Working Class Mobilization and Political Control - Venezuela and Mexico, Kentucky 1989, pp. 64-65; Lauth H.J. Gewerkschaften in Mexico: zwischen Partizipation wnd Kontrolle in: Briesemeister D./2immerman K. (Hrsg) Mexico Heufe, Politik, Wintschaft, Kultur, Frankfurt am Main 1992, p. 78; Grayson G.W. The Mexican Labor Machine: Powe, Politics and Patronage, Washington D.C. 1989, p. 56; Reyna, a.w. p. 26; Roxborough, a.w. p. 110; Stevens, a.w. p. 106.

112 De Buen noemt als woornaamste aanhanger van deze visie de prominente Mexicaanse rechtsgeleerde Mario de la Cueva, a.w. \$ 521 . Art. 123, sub XVI van de Grondwet refereert aan het recht wan vakbondsleden om de organisatie te verlaten.

113 De Buen, a.w. \$ 522: "However, if not enrolled, the worker will lose the possibility of job attainment and, conversely, will be unemployed upon exercising his right to resign." 
onafhankelijke vakbonden te dwarsbomen en de monopoliepositie van officiële vakbonden veilig te stellen.

De eerste zaak die betrekking had op de monopoliepositie van vakbonden binnen een onderneming, was Case No. $394{ }^{\text {1M4 }}$ Werknemers van een onderneming in Chihuahua wensten een ondernemingsvakbond op te richten en een $\mathrm{CAO}$ af te sluiten met de werkgever. In overeenstemming met art. 365 LFT en art. 390 LFT richtten zij zich met beide verzoeken tot de Centrale Arbeidsraad van Chihuahua. ${ }^{115}$ De Arbeidsraad verwierp beide verzoeken met het argument dat de onderneming al een $\mathrm{CAO}$ had afgesloten met de plaatselijke afdeling van een nationale industriebond. De aspirant-ondernemingsvakbond ging vervolgens in beroep bij de rechter en deze stelde hem in het gelijk: Naar het oordeel van de beroepsrechter had de Arbeidsraad ten onrechte het bestaan van een CAO opgevat als een hinderpaal voor de registratie van de ondernemingsvakbond. Allereerst had de Arbeidsraad ex art. 366 moeten vaststellen dat de vakbond aan alle wettelijke vereisten voor registratie had voldaan. Vervolgens had de Arbeidsraad op grond van art. 388, lid 1 moeten onderzoeken welke vakbond de meeste werknemers binnen de onderneming vertegenwoordigde en uit dien hoofde het recht bezat om collectieve onderhandelingen te voeren met de werkgever. ${ }^{116}$

De zaak werd terugverwezen naar de Arbeidsraad en de ondernemingsvakbond verkreeg alsnog de gewenste registratie. Het Comité inzake de Vrijheid van Vakvereniging stelde vast dat de rechter door toepassing van wettelijke bepalingen de registratie had veilig gesteld en dat de uitkomst van de gevolgde procedure in overeenstemming was met de, in art. 2 jo. art. 7 van Verdrag no. 87 verankerde, vrijheid van organisatie. Het besloot derhalve de zaak niet verder te onderzoeken. ${ }^{117}$

In Case No. 460 stond wederom de registratie van een vakbond ter discussie. Werknemers van twee ondernemingen in de houtverwerkende sector trachtten een industriebond op te

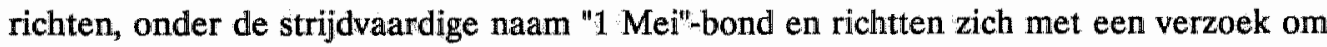
registratie tot de Arbeidsraad van Parral. In tegenstelling tot de vorige zaak, voerde de Arbeidsraad niet het bestaan van een $C A O$ als rechtsgrond aan voor de weigering van de registratie, maar beriep zich op art. 360 LFT. Dit artikel, aldus de Raad, verbond aan de oprichting van een industriebond de essentiële voorwaarde dat de leden eenzelfde beroep uitoefenden en dit was bij de leden van de "1 Mei"-bond niet het geval. ${ }^{118}$ De "1 Mei"-bond tekende beroep aan tegen de uitspraak van de Raad en de rechter stelde de appellanten in het gelijk. De Arbeidsraad had blijk gegeven van een volstrekt verkeerde opvatting van

114 Case No. 394, 84e Rap. $\$ \$ 13-22$,

115 Art. 390 LFT bepaalt dat vakbonden hun eisen schriftelijk moeten indienen bij een Arbeidsraad, teneinde de Arbeidsraad in de gelegenheid te stellen om te bemiddelen bij de totstandkoming van een CAO.

116 Case No. 394, 84e Rap. $\$ 20$.

117 Case No. 394, 84e Rap. $\$ 22$.

118 Case No. 460 , 94e Rap. 839. 
art. $360 \mathrm{LFT}$, aangezien dit artikel juist bepaalde dat de leden van een industriebond niet eenzelfde beroep behoefden uit te oefenen. Door het verzoek om registratie te weigeren, had de Raad de waarborgen van artt. 1, 9 en 123, sub XVI van de Grondwet (die voorzien in de vrijheid van vakvereniging) geschonden. ${ }^{119}$

Maar de "1 Mei"-bond ondervond niet alleen de tegenwerking van de autoriteiten. De werkgevers van beide ondernemingen hadden een aantal vakbondsleden ontslagen en éen van de ondernemingen had, achter de nig van de werknemers om, een $\mathrm{CAO}$ afgesloten met een andere bond om het volwaardig functioneren van de " $1 \mathrm{Mei}^{\text {"-bond }}$ te belemmeren. Volgens de klagende organisatie was de begunstigde vakbond gelieerd aan de CTM en stond zij onder controle van de onderneming. ${ }^{120}$

Het Comite handelde de twee aspecten van de zaak separaat af. Allereerst stelde het zich tevreden met een afschrift van de positieve beschikking met betrekking tot de registratie die na de rechterlijke uitspraak alsnog haar beslag had gekregen. ${ }^{12}$ Vervolgens nam het Comite kennis van de regeringsversie dat de CTM-bond al een CAO had afgesloten met de onderneming voordat de " 1 Mei"-bond geformeerd was. Gezien het feit dat de klagende werknemers, naar het oordeel van het Comité, niet aannemelijk hadden gemaakt dat zij door deze gang van zaken in de uitoefening van hun vakbondsrechten beperkt waren, overwoog het Comite dat de kwestie niet voor nadere bestudering in aanmerking kwam. ${ }^{122}$

Aan Case No. 827 lag, duidelijker dan bij de voorgaande zaken, een conflict ten grondslag tussen een onafhankelijke vakbond en een vakbond die door de onderneming en de autoriteiten gecontroleerd werd. Jarenlang waren de werknemers van de Spicer Company geringeloord door de Nationale Bond van Werknemers in de Metaalverwerkende Industrie. Deze organisatie vertoonde alle trekken van een vakbond die beheerst werd door autoritaire en corrupte vakbondsleiders: zij verbood vergaderingen, verkocht permanente banen aan de hoogst biedende en spande met de onderneming samen om weerbarstige werknemers te ontslaan. ${ }^{12}$

Om voorgoed een einde te maken aan deze wantoestand, besloten de werknemers een eigen, onafhankelijke bond op te richten en zich aan te sluiten bij de Nationale Bond van Werknemers in de IJzer-, Staal-en Aanverwante Produkten-industrie. Het Secretariaat van Arbeid en Sociale Voorzieningen weigerde de registratie van deze vakbond om niet nader genoemde redenen. Vervolgens startte de nieuwe vakbond ten overstaan van de Federale Arbeidsraad een procedure tegen de Nationale Bond van Werknemers in de Metaalverwerkende Industrie om deze het recht op het voeren van collectieve onderhandelingen te betwisten. Spicer Company en de aangeklaagde bond beweerden dat de klagende bond geen rechtsper-

119 Case No. 460, 94e Rap. \$1. De klacht werd door het Internationale Verbond van Christelijke Vakwerenigingen ingediend bij de ILO, voordat de rechter in hoger beroep de uitspraak van de Arbeidsraad had vernietigd.

120 Case No. 460, 94e Rap. $\$ 40$.

121 Case No. 460, 10le Rap. $\$ 65-66$.

122 Case No. 460, 101e Rap. \$\$ 70-71.

123 Volgens de lezing van de klagende organisatie: Case No. 827, 157e Rap. $\$ 207$. 
soonlijkheid bezat en daarom geen rechtsingang had tot de Federale Raad, maar de Raad verwierp deze exceptie, erkende de rechtspersoonlijkheid van de nieuwe vakbond en zette de procedure inzake de vaststelling van de meest representatieve vakbond in gang. ${ }^{\text {12x }}$

Inmiddels was het conflict tussen Spicer Company en de nieuwe vakbond op de spits gedreven. Dreigementen van de kant van de onderneming om vakbondsleden te ontslaan werden waar gemaakt, nadat de nieuwe vakbond een staking had uitgeroepen om de negatieve houding van Spicer Company jegens de vakbond aan de kaak te stellen. Vervolgens intervenieerde het Secretariaat van Arbeid om de strijdende partijen te verzoenen. Een accoord tussen Spicer Company, de Nationale Bond van Werknemers in de Metaalverwerkende Industrie en een onderhandelingscomité dat optrad namens de stakers, maakte een eind aan de staking. ${ }^{125}$ Met dit al was het geschil tussen de rivaliserende vakbonden naar de achtergrond verdrongen. De klagende organisatie beweerde dat de onderneming met de Bond van Werknemers in de Metaalverwerkende Industrie tijdens de staking en zonder de werknemers te consulteren een nieuwe CAO had gesloten. Maar de regering repliceerde dat de nieuwe vakbond, zonder opgave van redenen, de aanspraak op het recht om collectieve onderhandelingen had laten varen, zodat de oorspronkelijk rechten van de oude vakbond herleefden.120 Bovendien liet het accoord dat een einde had gemaakt aan de staking de werknemers de vrije keuze om zich aan te sluiten bij de Bond van Werknemers in de Metaalverwerkende Industrie of ongeorganiseerd te blijven.

Nu de Federale Arbeidsraad het verzoek om registratie van de Nationale Bond van Werknemers in de IJzer, Staal- en Aanverwante Produkten-industrie had gehonoreerd en deze organisatie blijkbaar uit eigen beweging besloten had niet meer mee te dingen naar de status van meest representatieve vakbond, besloot het Comite dat de kwestie niet verder onderzocht behoefde te worden. ${ }^{128}$

De situatie die aanleiding gaf tot Case No. 492, fungeerde als lakmoesproef voor het wettelijk erkende vakbondspluralisme en dwong het Comité inzake de Vrijheid van Vakvereniging om stelling te nemen ten aanzien van de "closed shop"-problematiek.

In juli 1966 richtte de Veracruz-Afdeling van de Bond van Werknemers in Tijdelijke Dienst bij Petroleos Mexicanos (PEMEX) zich tot de ILO met een klacht die betrekking had op de onmogelijkheid om vakbondsmonopolies te doorbreken. Onomwonden stelden de klagers dat art. 395 LFT (het "closed shop"-artikel), in samenhang met de CAO die van kracht was tussen PEMEX en de olievakbond, STPRM, werknemers in tijdelijke en in vaste dienst van het recht beroofden om andere vakbonden op te richten, "aangezien zij onmiddellijk ontslagen werden en hun het recht werd ontzegd om weer in dienst van de petroleumindustrie

124 Case No. 827,160 e Rap. $\$ 262$.

125 Case No. 827 , 157 e Rap. 213 en 160e Rap. $\$ 262$.

126 Case No. 827, 160e Rap. 264 .

127 Case No. 827 , 160e Rap. $\$ 265$.

128 Case No. 827,165 e Rap. $\$ 11$ en 15. 
te treden. Art. 4 van de $\mathrm{CAO}$, zo gingen de klagers verder, verplichtte de onderneming om werknemers zonder nadere explicatie te ontslaan, indien een verzoek van de vakbond die partij was bij de $\mathrm{CAO}$, daartoe strekte. Bovendien beschuldigde de klagende instantie PEMEX ervan vakbondscontributies in te houden ten bate van de vakbond die de CAO had ondertekend, ondanks het feit dat de tijdelijke werknemers geen lid waren van die vakbond. ${ }^{\text {*o }}$ In reactie op de beschuldigingen, gaf de regering haar visie op het wettelijke systeem en de toepasselijke CAO-bepalingen. Conform art. 386 LFT was een CAO bindend voor alle werknemers van een onderneming, ongeacht of zij all of niet lid waren van de vakbond die de CAO had afgesloten. Art. 395 LFT stond het opnemen van "closed shop"-clausules in CAO's toe. Volgens artikel 4 van de CAO dat van kracht was tussen PEMEX en STPRM, verplichtte de werkgever zich tot het in dienst nemen van vakbondsleden in geval van een vaste betrekking. Tijdelijke vacatures werden, ex art. $5 \mathrm{CAO}$, vervuld door personen die voorgedragen waren door de vakbond. Weinu, het inhouden van vakbondscontributies van de tijdelijke werknemers was juridiseh verdedigbaar, omdat de werknemers onder de CAO vielen en bovendien voorgedragen waren door de vakbond. ${ }^{131}$ Het was niet juist, zo vervolgde de regering, dat de CAO-bepalingen, in samenhang met de wettelijke "closed shop"-artikelen, de vrijheid van vakvereniging aantastten, aangezien zij de oprichting van andere vakbonden niet verhinderden. ${ }^{132}$ Deze laatste bewering is moeilijk te rijmen met een uitspraak van de Federale Arbeidsraad, waaraan de klagende organisatie refereerde. De STPRM had zich met een verzoekschrift tot de Arbeidsraad gericht, teneinde de registratie van de Minatitlan-Afdeling van de Bond van Tijdelijke Werknemiers in dienst van PEMEX ongedaan te maken. De Raad had het verzoek ingewilligd, waarbij het onder andere het argument van de STPRM scheen te hebben aanvaard dat een clausule in de bestaande CAO de oprichting van andere vakbonden in de bedrijfstak verbood. ${ }^{133}$

Begrijpelijkerwijs raakte het Comité inzake de Vrijheid van Vakvereniging het spoor enigszins bijster door de verhaspeling van Afdelingen: de klagende organisatie - de VeracruzAfdeling - had immers beweerd, zonder deze beschuldiging overigens nader toe te lichten, dat zij niet de gewenste registratie had verkregen. Nu verwezen de klagers plotseling naar het lot van een zuster-afdeling, wier al toegekende registratie blijkbaar herroepen was. ${ }^{\text {b4 }}$

129 Case $\mathrm{No}^{4}, 42,96 \mathrm{Rap}, 105$. Aanhalingstekens in het origineel.

130 Case No. $492,96 \mathrm{e}$ Rap. $\$ 107$.

131 Case No. 492, 96e Rap. 111 en 115.

132 Case No. 492, 96e Rap. $\$ 113$

133 Case No. 492, 96e Rap. \$117.

134 Case No, 492, 96 e Rap, \$118. Het Comité besteeddle aan dit aspect geen aandacht. Hoewel de casus daarover niets vermeldt, ligt het voor de hand dat procedurele voorschriften aan een verdere afhandeling in de weg stonden. Nationale organisaties zijn namelijk uitsluttend ontvankelijk, indien zij een rechtstreeks belang hebben bij de aangekaarte kwestie. Welnu, de Veracruz-Afdeling had niet een rechtstreeks belang bij het intrekken van de registratie van de Minatitlan-aldeling. Vgl. International Labour Office, Freedon of Association. Digest of Decisions, Geneva 1985, \$ 34 . 
Met betrekking tot de verplichte contributies en het privilege van de STPRM om nieuwe werknemers voor te dragen, stelde het Comité vast dat deze bepalingen vastgelegd waren in een $\mathrm{CAO}$ en niet het resultaat waren van wetgeving. Vervolgens volstond het Comite met het weergeven van het algemene ILO-standpunt inzake "closed shops" dat uit Verdrag no. 87 noch een toestemming, noch een verbod van deze clausules mocht worden afgeleid, aangezien dergelijke kwesties in overeenstemming met de nationale praktijk geregeld moesten worden. In het licht van dit standpunt en gegeven het feit dat de klachten over de weigering van registratie onvoldoende onderbouwd waren, besloot het Comité deze aspecten van de zaak niet verder te onderzoeken. ${ }^{\text {13s }}$

Tenslotte kan melding gemaakt worden van een dispuut tussen rivaliserende vakbonden, waarbij de rollen exact omgedraaid waren. In Case No. 603 was sprake van een onafhankelijke vakbond wiens positie ondermijnd werd door de werkgever. Deze laatste probeerde, geruggesteund door de autoriteiten, de vakbond te vervangen door een meer plooibare concurrent.

In de zomer van 1969 verliepen de onderhandelingen tussen de firma Embotelladora del Norte en de ondernemingsvakbond over het sluiten van een nieuwe CAO stroef. Er werd afgesproken dat partijen tien dagen de tijd zouden nemen om een accoord te sluiten, maar luttele dagen na afloop van deze termijn ontsloeg de firma 121 vakbondsleden. Intussen sloot de werkgever heimelijk een CAO af met een nieuwe, aan de CTM gelieerde vakbond die zonder mankeren geregistreerd was door de Arbeidsraad van Chihuahua, en nodigde de ontslagen werknemers uit om weer in dienst te treden, op voorwaarde dat zij zich zouden aansluiten bij deze vakbond. Verontwaardigd over deze gang van zaken, kondigde de gedupeerde vakbond een stakin ${ }_{b}$ aan bij de Arbeidsraad en tekende tevens verzet aan tegen de registratie van de nieuwe vakbond. De Arbeidsraad verklaarde de staking evenwel nietig en liet de registratie van de andere vakbond onverlet. ${ }^{136}$ Appèlprocedures mochten de betrokken vakbond niet baten, want de rechter in hoger beroep bekrachtigde uiteindelijk de oorspronkelijke uitspraak van de Arbeidsraad. ${ }^{137}$

Het Comite overwoog dat niet de wettigheid van de staking ter discussie stond, maar dat de Arbeidsraad zich had moeten buigen over de vraag of de daaraan voorafgaande ontslagen wel rechtmatig waren geweest. Vervolgens kwam het Comité tot de slotsom dat de firma zich schuldig had gemaakt aan onoirbare praktijken die niet alleen de afzonderlijke werknemers/vakbondsleden hadden getroffen maar ook hadden geleid tot de complete verdwijning van een vakorganisatie. ${ }^{138}$ De uitkomst van deze zaak is in zoverre wat onbevredigend dat uit de casus niet blijkt of de interventie van het Comité tot eerherstel van de betrokken vakbond heeft geleid.

135 Case No. 492, 96e Rap. $\$ 121$.

136 Case No. 603, 121e Rap. $\$ 60$. Vergelijik ook hierboven, p. 222.

137 Case No. 603,129 e Rap. $\$ 81$.

138 Case No. 603,133 e Rap. $\$ 80$. 
Een korte analyse van de besproken zaken is op haar plaats. Hoewel de casusposities verschillen, hebben zij enkele belangrijke kenmerken gemeen. In alle zaken stelde een onafhankelijke vakbond pogingen in het werk om voet aan de grond te krijgen binnen een onderneming of zich daarin te handhaven. Telkens ondervond de vakbond daarbij de tegenwerking van de onderneming of van de autoriteiten die probeerden om de monopoliepositie van een andere vakbond, ten detrimente van de onafhankelijke vakbond, veilig te stellen.

Wat betreft de opstelling van de autoriteiten, is het opmerkelijk dat in minimaal vier gevallen (Cases Nos. 394, 460, 492 en 603) de autoriteiten de vakbondsvoorkeur van de onderneming deelden en de registratieprocedure gebruikten om de onafhankelijke vakbond het bestaansrecht te ontzeggen. Dit is een aanwijzing dat de staat streeft naar een feitelijk monopolie van dociele vakbonden en levert munitie op voor de Buen's these dat de staat met behulp van de registratieprocedure de vakbeweging tracht te controleren. ${ }^{139}$

In Case No. 827 was de opstelling van de autoriteiten ambivalent. Het Secretariaat van Arbeid weigerde de registratie, terwijl de Federale Arbeidsraad de concurrerende vakbonden een eerlijke kans beoogde te geven door de procedure inzake de vaststelling van de meest representatieve vakbond te starten. Over de drijfveren van de onafhankelijke vakbond om zich terug te trekken, tasten we in het duister: misschien waren de werknemers geïntimideerd door de agressieve houding van de onderneming. De Case vermeldt hier verder niets over. In twee gevallen (Cases Nos. 394 en 460) verkreeg de onafhankelijke vakbond alsnog, door tussenkomst van de rechter, de gewenste registratie. Eenmaal achtte het Comité een klacht van een onafhankelijke vakbond over anti-vakbondsmaatregelen door de werkgever gegrond (Case No. 603). Zoals gezegd, bleek uit de Case niet of de interventie van het Comite tot gevolg had dat de gedupeerde vakbond weer in vrijheid kon opereren.

Case No. 492, tenslotte, is veruit de belangrijkste. De "closed shop"-clausule die in deze zaak ter discussie stond, is binnen de Mexicaanse arbeidsverhoudingen een wijd verbreid fenomeen. Met behulp van de "closed shop"-constructie kan een vakbond op zeer efficiënte wijze een monopoliepositie binnen een onderneming verwerven. In de onderhavige casus gaf de STPRM op overduidelijke wijze blijk van haar intentie om concurrentie te weren door in de CAO te bedingen dat elke poging om een andere vakbond op te richten een grond zou opleveren voor ontslag. De uitspraak van het Comite in deze Case acht ik niet gelukkig. Toegegeven: de weigering van de registratie van de klagende vakbond door de Arbeidsraad die het bedoelde beding had gehonoreerd, was nauwelijks met feiten gestaafd. Bovendien kon het Comite, op grond van de eigen procedurele voorschriften, het intrekken van de registratie ten detrimente van de zuster-afdeling niet aan een nader onderzoek onderwerpen.

139 De Buen, a.w. p. 146: "By means of this mechanism (i.e. registration), the state controls union life. For those unions incorporated into the corporative system, registrations are generously granted, as well as entries of their board of directors. If, on the contrary, the interested parties do not coincide with the political line of the government, registration and entries are refused."

Vgl. tevens Grayson, aw. p. 55: "(...) the ministry of Labor and Social Welfare can reward or punish organizations by either accepting or denying their registration requests." 
De CAO-bepaling in kwestie verplichtte echter de werkgever om werknemers te ontslaan, zodra zij aanstalten maakten om een vakorganisatie op te richten. Het CAO-beding was dan ook in flagrante strijd met art. 1 van Conventie no. 98 dat werknemers in hun dienstbetrekking toereikende bescherming beoogt te bieden tegen anti-vakbondsmaatregelen. Naar mijn mening had het Comite, zonder het algemene standpunt van de ILO inzake "closed shops" geweld aan te doen, dit oneigenlijke gebruik van de "closed shop"-constructie kunnen kwalificeren als een ontoelaatbare inbreuk op essentiële vakbondsrechten.

Doorgaans hebben "closed shop"-clausules een meer verhulde concurrentie-werende werking. Zo maakt de "closed shop"-construetie die expliciet door art. 395 LFT wordt toegelaten, de existentie en het functioneren van andere vakbonden niet per se onmogelijk maar wordt het opereren daarvan wel bemoeilijkt. Werknemers die zich willen aansluiten bij een andere vakbond, zijn ummers verplicht om een dubbel lidmaatschap aan te gaan. ${ }^{140}$ Bovendien kan de concurrerende vakbond de status van tweederangs-organisatie eigenlijk niet ontstijgen, aangezien hij niet kan wedijveren met de bond die op grond van de "closed shop"-clausule alle werknemers tot zijn ledenbestand mag rekenen. Aangezien de ILO "closed shop"-clausules in het algemeen wenst te aanvaarden, accepteert zij deze consequentie blijkbaar ook.

Het is hier niet de plaats om het algemene ILO-standpunt inzake "closed shop"-clausules aan een kritisch onderzoek te onderwerpen. In het laatste hoofdstuk kom ik hier nog uitvoerig op terug.

Binnen de context van de Mexicaanse arbeidsverhoudingen volsta ik met een tweetal afrondende kanttekeningen. Allereerst is het opmerkelijk dat de ILO tal van inperkingen op de vrijheid van vakvereniging - verplichting tot het aangaan van een dubbel lidmaatschap, gebrek aan open concurrentie bij de vaststelling van de meest representatieve vakbond, etc. terecht kritiseert, voorzover deze inperkingen voortvloeien wit wettelijke regelingen, om deze vervolgens zonder problemen te tolereren, indien zij het produkt zijn van contractuele clausules. In de tweede plaats draagt de $I L O$, door vast te houden aan haar standpunt inzake "closed shops", bij tot de handhaving van oude organisatiestructuren die de controle van de staat over de vakbeweging vergemakkelijken.

\subsection{De Vallejista-beweging in verzet tegen de controle-politiek}

In de historische analyse is gewag gemaakt van enkele confrontaties tussen opstandige elementen binnen de vakbeweging en de autoriteiten. Hoewel deze conflicten een incidenteel karakter hadden en slechts een tijdelijke rimpeling in de ogenschijnlijk harmonieuze verhouding tussen staat en vakbeweging veroorzaakten, toonden zij aan dat de wenselijkheid van een nauwe relatie tussen staat en vakbeweging niet door alle vakbondsleden en organisaties onderschreven werd. Bovendien bleek uit de dikwijls heftige reacties van de autoriteiten dat 
zij, zodra de controlepolitiek faalt, geneigd zijn om hun toevlucht te nemen tot repressieve maatregelen. Dit is een aanwijzing voor de juistheid van de veronderstelling dat controle en repressie complementaire dimensies zijn van een integrale politiek die de strekking heeft om de groei en bloei van een autonome vakbeweging te verijdelen. ${ }^{141}$

De conflicten hadden noch dezelfde oorsprong, noch hetzelfde verloop, In sommige gevallen kwam de vakbondsbasis in verzet tegen de "charros" die hun organisatie overheersten de hieronder te bespreken Vallejista-beweging is een schoolvoorbeeld. In andere gevallen trachtten werknemers het imperium van de officiele vakbeweging te ondermijnen door onafhankelijke organisaties op te richten. ${ }^{142}$ Het onderscheid is overigens van secundair belang: de belangrijkste drijfveer die aan beide categorieën conflicten ten grondslaglag, was de onvrede van bepaalde segmenten binnen de vakbeweging over het functioneren van de vertegenwoordigers van de officiële vakbeweging die optraden als zetbazen van de staat. Indirect gold hun protest dus de controle-politiek van de Mexicaanse autoriteiten.

Om twee redenen zullen we ons concentreren op de Vallejista-beweging die tegen het eind van de jaren vijftig een dramatische krachtmeting aanging met de staat en de vertegenwoordigers van de officiële vakbeweging. In de eerste plaats is het de enige confrontatie met een nationale draagwijdte geweest die aanleiding heeft gegeven tot een klachtenprocedure bij de ILO. In de tweede plaats heeft geen enkele andere protestbeweging de controlepolitiek van de staat zo pregnant en principieel ter discussie gesteld. Zoals we hieronder zullen zien, had de confrontatie ontegenzeggelijk een politieke ondertoon, een omstandigheid waarvan de autoriteiten dankbaar gebruik maakten om de beweging in diskrediet te brengen. In ILO-verband stond begrijpelijkerwijs de vraag centraal in hoeverre vakbonden van hun rechten gebruik mochten maken om "politiek"' te bedrijven.

De Vallejista-beweging moet geplaatst worden tegen de achtergrond van groeiende sociale onrust die tegen het einde van de jaren vijftig ontstond ten gevolge van de daling van de reële lonen. ${ }^{143}$ Toch was het van meet af aan duidelijk dat militante leden van de STFRM niet uitsluitend geïnteresseerd waren in loonsverhogingen. In de loop van de jaren vijftig

141 Davis (a.w. p. 77) merkt daar het volgende over op" "In order to understand the effectiveness of cooptation, we need to consider the other side of the coin, threatened or actual repression. To refuse cooptation is to risk repression."

142 Verscheidene voorbeelden van lokale inter-wakbondsdlisputen zijn al aan de orde geweest in het kader wan het stuk over vakbondsmonopolies. Een interessante krachtmeting op nationaal niveau tussen cen officiële vakbond (de SNE, Nationale Bond van Federale Electriciteitswerkers) en een autonome organisatie (de STERM, Bond van Electriciteitswerkers van de Mexicaanse Republiek) vond plaats aan het begin van de jaren zeventig. De STERM verkoos met legale middelen actie te woeren en het conflict werd in den minne geschilkt door de fusie wan beide opponenten in de SUTERM (Enige Bond van Electriciteitswerkers van de Mexicaanse Republiek). Voor details wordt verwezen malar Handelman H. The Politics of Labor Protest" in Mexico, Journal of Interamerican Studies and World Affairs, Vol 18 No. 3, August 1976 "pp. 279-290.

143 Tussen 1957 en 1958 steeg het aantal grote industriële stakingen sprongsgewijs van 193 naar 740 . Handelman, a.w. p. 273. 
hadden zij verscheidene pogingen ondernomen om de "charro"-leiders af te zetten, maar hun inzet had niet het gewenste resultaat opgeleverd. De controverse kwam tot een climax toen de "charros" begin 1958 kritiekloos de mededeling van de werkgevers aanvaardden dat loonsverhogingen in verband met verliezen in de spoorwegenbranche niet tot de mogelijkheden behoorden. Afgevaardigden van dissidente fracties uit het gehele land kwamen bijeen, schaarden zich achter de radicale vakbondsman Demetrio Vallejo en stelden een manifest op. In dit manifest drongen de dissidenten aan op substantiële loonswerhogingen, eisten het aftreden van het door de "charros" gedomineerde uitvoerende comité van de STFRM en dreigden met het uitroepen van estafette-stakingen, indien aan hun eisen niet tegemoet werd gekomen. Al spoedig bleek dat de werkgevers niet te vermurwen waren, zodat een groot gedeelte van de spoorwegarbeiders eind juni 1958 het werk neerlegde. President Ruiz Cortines (1952-1958) besloot in dit snel escalerende conflict te bemiddelen en de stakende arbeiders halverwege tegemoet te komen. Deze partiële overwinning werd extra luister bijgezet door het aftreden van het uitvoerende comité van de STFRM, hetgeen de weg plaveide voor Demetrio Vallejo die dan ook met grote meerderheid tot Secretaris-Generaal van de STFRM verkozen werd.

Vallejo had zich tevreden kunnen stellen met de resultaten en de regering erkentelijk kunnen zijn vanwege haar welwillende houding, maar nederige dankbaarheid was niet éen van Vallejo's karaktereigenschappen. Eind 1958 drongen de nieuwe vakbondsleiders opnieuw aan op herziening van de CAO's. Zij vroegen een geringe loonsverhoging en herinnerden de werkgevers aan hun, in de CAO vastgelegde verplichting om zorg te dragen voor betaalbare huisvesting. ${ }^{144}$ Vallejo liet deze eisen vergezeld gaan van grondige analyses van de misstanden in de spoorwegsector. De onderbetaling van spoorwegarbeiders, zo stelde Vallejo, had een structureel karakter, aangezien de regering ernaar streefde om de vervoerskosten zo laag mogelijk te houden, teneinde de ondernemers te bevoordelen. Met name deze analyses vervulden de regering met grote zorg daar zij fundamentele kritiek inhielden op het algehele economische beleid. ${ }^{145}$

Vallejo's militante opstelling gaf aanleïding tot een lastercampagne in de pers. Vallejo werd afgeschilderd als een agent van Moskou en beschuldigd van pogingen om de constitutionele orde omver te werpen ${ }^{* 6} \mathrm{Hij}$ liet zich hierdoor niet intimideren en kondigde voor maart 1959 opnieuw een grootschalige staking aan om de spoorwegmaatschappijen te dwingen tot het aanvaarden van uniforme arbeidsvoorwaarden. Vallejo overspeelde zijn hand. De staking vond plaats tijdens de Heilige Week en dupeerde het publiek dat niet over vervoer beschikte

144 Stevens wijst erop dat deze eisen zeer gematigd waren, vooral indien men bedenkt dat het genot van betaalbare huiswesting een in de Constitutie verankerd grondrecht is. Stevens, a.w. p. 113.

145 Handelman haalt de woorden van en onafhankelijke vakbondsleider aan die de ommekeer in het karakter van het conflict haarscherp signaleert: "the movement had ceased to be a (purely) economic labor conflict with management and had become a political dispute with the government." Handelman, a.w. p. 277. Zie ower deze lastercampagne in détail Stevens, a.w. pp. 114-119. 
om uitstapjes te kunnen maken." Gesteund door de publieke opinie gingen de autoriteite over tot de tegenaanval. De gebeurtenissen volgden elkaar in een rap tempoop. De Federal Arbeidsraad verklaarde de staking illegaal op grond van het feit dat Vallejo de beslissin niet had woorgelegd aan de achterban. Toen een meerderheid van de spoorwegarbeider desondanks aanstalten maakte om de staking door te zetten, greep het leger in en dwon de stakers het werk te hervatten. Een groot aantal vakbondsleiders en duizenden werknemer werden gearresteerd. De gehele top van de STFRM werd afgezet en vervangen door mee gezagsgetrouwe leiders. Vallejo werd, na verscheidene jaren in voorlopige hechtenis te hebbei doorgebracht, uiteindelijk berecht en veroordeeld tot een gevangenisstraf van 11 jaar. De staking was gebroken en de orde was hersteld.

In 1963 diende het Wereld Vakverbond een klacht in bij de ILO, waarin de arrestatie van de vakbondsleiders en de gerechtelijke veroordeling werden gekenschetst als een schending van vakbondsrechten en wel met name als een inbreuk op het stakingsrecht. ${ }^{148} \mathrm{De}$ Mexicaanse regering repliceerde, kort gezegd, dat de vakbondsleiders de wet hadden overtreden en zich schuldig hadden gemaakt aan subversieve praktijken. Het Comité inzake de Vrijheid van Vakvereniging begon met het formuleren van een algemeen standpunt: in geval van arrestaties van vakbondsleden, rustte op de regering de verplichting om feiten en omstandigheden aan te dragen waaruit bleek dat de arrestaties geen verband hielden met vakbondsactiviteiten maar het gevolg waren van handelingen, buiten de sfeer van vakbondsactiviteiten, die hetzij de openbare orde verstoorden, hetzij een politiek karakter hadden. ${ }^{49}$ Vervolgens nam het Comitê nota van de gerechtelijke uitspraken. Het Hoogste Gerechtshof bekrachtigde de vonnissen van de rechter in eerste instantie en van de appèlrechter, en achtte het genoegzaam bewezen dat Vallejo en zijn collega's zich schuldig gemaakt hadden aan het politieke delict, zoals omschreven in art. 145 van de Federale Strafwet. Dit artikel stelt het aanzetten van anderen tot de verstoring van de rechtsorde strafbaar. Vallejo en de zijnen hadden, zo lichtte het Hof zijn beslissing toe, de spoorwegarbeiders geïnstrueerd om het werk niet te hervatten, ondanks het feit dat de staking illegaal was verklaard. Met deze handelwijze hadden zij niet het oogmerk gehad om voordelen te verwerven voor de arbeidersklasse, maar hadden zij de vakbeweging misbruikt om de juridische en politieke structuur van de staat te ondermijnen. ${ }^{150}$ Het Comité nam kennis van deze uitspraak en stelde vast dat Vallejo en de andere vakbondsleiders wolledig de waarborgen van een eerlijk proces hadden genoten; het concludeerde dat de zaak niet voor verdere behandeling in aanmerking kwam. ${ }^{\text {si }}$

147 Stevens, a.w. pp. 120-121.

148 Case No. 358, 99e Rap. $\$ 28-63$. De klacht werd in 1963 ingediend door het Wereldvakverbond, de internationale federatie van vakwerenigingen waarbij de STFRM was aangesloten, omdat pas in dat jaar Vallejo en de andere vakbondsleiders terecht stonden voor hun daden.

149 Case No. 358 , 99 e Rap. $\$ 42$.

150 Case No. 358, 99 e Rap. 53-55.

151 Case No. 358,99 e Rap. $\$ 59$ en 60. 
Men kan een gevoel van onvrede over deze beslissing moeilijk onderdrukken; dit is vooral toe te schrijven aan de gebrekkige motivering van de uitspraak van het Comite. Vooropgesteld moet worden dat het Comitế natuurlijk gebonden is aan de feiten, zoals die door de rechter zijn vastgesteld. Het Comité dient de juridische kwalificatie van die feiten wel te toetsen aan de beginselen inzake de vrijheid van vakvereniging. Gelet op de bewoordingen van art. 8 , lid 2 van Conventie no. 87, moet het Comité daartoe onderzoeken of de wet, dan wel de toepassing van de wet inbreuk maakt op de garanties, waarin deze Conventie voorziet. Dit kan pas vastgesteld worden aan de hand van de vraag of vakbondsleden binnen de eigen bevoegdhedensfeer zijn gebleven.

In het concrete geval hadden de eisen die ten grondslag lagen aan de stakingen loonsverhogingen, onvrede over het vakbondskader - oorspronkelijk uitsluitend betrekking op vakbondsaangelegenheden. Pas in het laatste stadium leek de staking vooral bedoeld om druk uit te oefenen op de staat. Maar overschreden de stakers hiermee de grens van de eigen bevoegdhedensfeer? Er is ruimte voor twijfel. Aan de ene kant kan men aanvoeren dat de stakers niet uitsluitend een verbetering van de eigen materiële positie voor ogen stond en dat zij de staking niet alleen als instrument hanteerden om de overheid te dwingen ten gunste van de werknemers in een arbeidsconflict te interveniëren. Uitgaande van de dichotomie, politiek als instrument vs. politiek als doel, die de ILO als onderscheidend criterium hanteert om te bepalen of politieke actie geoorloofd is, kan men volhouden dat de staking inderdaad een overwegend politiek karakter had. ${ }^{152}$ Anderzijds spitsten de protesten zich toe op structurele misstanden in de relatie tussen staat en vakbeweging en had de staking dus betrekking op kwesties die de vakbeweging wel degelijk ten nauwste aangingen. ${ }^{153}$ Op grond van de maatstaf die het Comite in deze zaak zelf aanlegt - "houdt de arrestatie verband met vakbondsactiviteiten $?^{\prime \prime}$ - is het verdedigbaar dat de stakers legitieme vakbondsactiviteiten ontplooiden en dat de arrestatie onrechtmatig was.

Hoe dit ook zij: door zich te refereren aan de uitspraak van de rechter, onderschreef het Comité diens opvatting dat de staking een politiek doel had gediend en dat dit doel gelegen was in de ondermijning van de staat. ${ }^{1.54}$ Een nadere toelichting van dit oordeel was op haar plaats geweest, al was het maar om het ILO-standpunt inzake de toelaatbaarheid van het

152 Zie over dit onderscheid, hoofdstuk 1, p. 29.

153 "In effect, by ousting the oligarchical leadership of the STFRM, by claiming the right to strike without "permission", and by using work stoppages as a weapon for placing severe pressure on the state (rather than a symbolic gesture), Vallejo was challenging the government's time-fionored control over the Mexican labor movement." Handelman, a.w. p. 279. (corsivering Hwdw)

154 Over het (ongeoorloofde) politieke karakter van de staking kan men twisten, zoals ik geprobeerd heb om aan te tonen.

Of de stakers ook subversieve intenties hadden, lijkt mij op z'n zachtst gezegd discutabel, allthans niet voldoende bewezen. In het arrest van het Hof opgenomen kwalificaties als "communistische elementen" en "pogingen om de Staat omwer te werpen en te vervangen door een socialistisch regime" lijken mij ter onderbouwing. van het bewezenverklaarde weinig substantieel en horen eerder thuis in de boulevardpers dan in een weloverwogen rechterlijk oordeel. Vgl. Case No. 358, 99e Rap. $\$ 53$ en 54 . 
ontplooien van politieke activiteiten door vakbonden aan de hand van een concreet geva nog eens te verduidelijken.

\subsection{De ILO en de nationale rechter: de rechterlijke witspraak is niet onaantastbaar}

In de zaak die in 3.4 uitvoerig is behandeld, werd het Comite gevraagd een oordeel te vellen over een kwestie die al tot in hoogste instantie voor de nationale rechter had gespeeld. In breder perspectief rijst de vraag hoe het Comité de eigen competentie ziet on kennis te nemen van een klacht en hierover een standpunt te ontvouwen, índien de kwestie nog onderwerp is van een lopende gerechtelijke procedure of nadat een nationale rechter in hoogste ressort er een uitspraak over heeft gedaan. De klachten die tegen Mexico zijn ingesteld, verwijzen regelmatig naar rechterlijke uitspraken en zij hebben het Comité dan ook de gelegenheid geboden om de eigen opvattingen terzake weer te geven.

Drie klachten hadden, net als Case No. 358, mede betrekking op strafrechtelijke veroordelingen van vakbondsleden. In Case No. 492 was een vakbondsleider, Esguerra, beschuldigd van en veroordeeld wegens fraude en poging tot moord, aangezien hij werknemers die in hongerstaking waren gegaan, belet zou hebben om medische zorg te ondergaan. ${ }^{15 s}$ In Case No. 773 achtte de rechter genoegzaam en overtuigend bewezen dat twee boerenleiders, Palomino en Sanchez Torres, zich schuldig hadden gemaakt aan resp. illegale landbezetting en sabotage van een waterleidinginstallatie. ${ }^{156}$ In Case No. 827 , tenslotte, was een vakbondsleider, Escamilla, gearresteerd en berecht wegens fraude en verduistering van vakbondsfondsen. Kort na het vonmis was hij weer op vrije voeten gesteld. ${ }^{157}$ Telkens was het twistpunt of de sancties waren opgelegd vanwege het plegen van strafbare feiten, dan wel of zij verband hielden met het ontplooien van legitieme vakbondsactiviteiten. De slotconclusies van het Comité in Case No. 492 en Case No. 773 waren gelijkluidend. Het Comité stelde vast dat de vakbondsleden de waarborgen van een eerlijk proces hadden genoten, bestudeerde de feitelijke omstandigheden aan de hand van de ter beschikking staande informatie en kwam tot de slotsom dat de rechter redelijkerwijze tot de conclusie had kunnen komen dat de vakbondsleden zich schuldig gemalkt hadden aan het plegen van strafbare feiten. ${ }^{158}$ De overwegingen van het Comité in Case No. 492 en Case No. 773 verschillen in zoverre van diens conclusie in Case No. 358 dat het Comite in laatstgenoemde zaak nauwelijks aandacht besteedde aan de strafrechtelijke kwalificatie van de feiten die Vallejo

155 Case No. 492, 118e Rap. \$102.

156 Case No. 773, $147 \mathrm{e}$ Rap. $\$ \$ 110-112$.

157 Case No. 827 , 160 e Rap. $\$ 267$.

158 Case No. 492, 124e Rap. \$ 78-79.

Case No. 773 , $147 \mathrm{e}$ Rap. 116

In Case No. 827 had het Comité geen moeite met de rechterlijke uitspraak, maar kritiseerde het de lichtwaardige preventieve detentiemaatregel. Vgl. $160 \mathrm{e}$ Rap. $\$ 274$. 
en de zijnen telaste waren gelegd en zich tevreden stelde met de omstandigheid dat Vallejo de waarborgen van een eerlijk proces had genoten. Twee elementen die het Comite onderscheidt in een gerechtelijke procedure, komen met name in Case No. 492 en Case No. 773 naar voren. In de eerste plaats hecht het Comite eraan dat vakbondsleden in de gelegenheid gesteld worden om hun zaak voor te leggen aan een onpartijdige nationale instantie. In de tweede plaats fungeert de tekst van een vonnis als bron van informatie, op basis waarvan het Comité kan verifiëren of er wellicht toch een schending van vakbondsrechten heeft plaatsgevonden. Uit dit laatste kunnen we opmaken dat het Comitê zich niet onder alle omstandigheden klakkeloos neerlegt bij de uitspraak van de nationale rechter, maar zich het recht voorbehoudt om tot een afwijkend oordeel te komen. Dit bleek in de hierboven behandelde Case No. 603, waarin het Comité als zijn mening te kennen gaf dat de rechter ten onrechte een staking nietig had verklaard, terwijl hij geroepen was om een uitspraak te doen over de daaraan voorafgaande massa-ontslagen van vakbondsleden: ${ }^{160}$

De principiële vraag of een internationale organisatie überhaupt wel competent is om rechterlijke uitspraken te toetsen, heeft aanleiding gegeven tot een diepgaande controverse tussen de Mexicaanse regering en het Comité. De Mexicaanse regering heeft zich verscheidene malen op het standpunt gesteld dat de ratificatie van Verdrag no. 87 door Mexico het Comité niet het recht verleent om zich een oordeel aan te meten over een rechterlijke uitspraak. De redenering van de regering komt op het volgende neer. De Mexicaanse staatsinrichting kent een strikte scheiding van machten. Dit impliceert dat de uitvoerende macht bereid noch bevoegd is om invloed uit te oefenen op de uitkomst van een gerechtelijke procedure. ${ }^{161}$ Vervolgens chargeert de regering de toezichthoudende activiteiten van het Comite door deze te bestempelen als "inmenging in de activiteiten van de rechter" en "herziening van rechterlijke uitspraken". Tenslotte vergelijkt de regering het Comité met de (Mexicaanse) uitvoerende macht en beweert dat "inmenging" en "herziening" de onafhankelijkheid van de rechterlijke macht aantasten, het beginsel van de scheiding der machten schenden en een inbreuk op de nationale soevereiniteit opleveren. ${ }^{162}$ Bovendien, zo voegt de regering als een soort "obiter

159 De toetsing die door het Comite verricht werd, was uiterst marginaal: "It appears from the Court rulings that Mr. Vallejo and the other persons (...) were sentenced on account of various offences contemplated in the Penal Code." Case No. No. 358, $99 \mathrm{e}$ Rap. 80 . (cursivering HvdW)

160 Case No. 603 , 129e Rap. $\$ \$ 81-82$ en $84 ; 133$ e Rap. $8 \$ 81-82$.

Het is interessant om erover te speculeren of het feit dat in deze zaak niet een strafrechtelijke, maar cen arbeidsrechtelijke kwestie ten grondslag lag aan de klacht, mogelijkerwijs van invloed is geweest op het oordeel van het Comite. Voor de competentie van het Comite om een rechterlijk oordeel te toetsen maakt het niet wit welk rechtsgebied door de rechter wordt bestreken. Nu de uitspraken van lret Comité niets dienaangaande vermelden, mogen we er vanuit gaan dat het onderscheid niet van belang is.

161 Zie Case No. 492, 110 e Rap. \$144; Case No. 603, $121 \mathrm{e}$ Rap. 83 en 133 e Rap. \& 72; Case No. 773, 147e Rap. 107 .

Vgl. Case No. 492, 118e Rap. \& 106 en 124e Rap. \& 74; Case No. 827, 160e Rap. 257. 
dictum" nog toe, zou dit vakbondsleden in een bevoordeelde positie brengen ten opzichte van anderen die niet van een dergelijke extra rechtsgang kunnen profiteren. ${ }^{\text {tas }}$

Met deze argumentatie lijkt de Mexicaanse regering te suggereren dat het Comité zich ten onrechte de rol aanmeet van een internationale rechterlijke instantie in hoogste ressort. Deze voorstelling van zaken strookt niet met de werkelijkheid. De procedure die het Comité volgt, heeft een quasi-judicieel karakter en heeft daarnaast tot doel om de staat te overreden om, zo nodig, wet en rechtspraktijk in overeenstemming te brengen met de internationale normen op het gebied van de vrijheid van vakvereniging." ${ }^{164}$ Een aanwijzing hiervoor kan men al ontlenen aan het feit dat de bevoegdheid van het Comité om een klacht in behandeling te nemen niet afhankelijk is van het antwoord op de vraag of nationale rechtsmiddelen uitgeput zijn. "wes Deze "exhaustion of local remedies-rule" heeft zich ontwikkeld tot een regel van internationaal gewoonterecht en heeft als ratio dat justitiabelen zich dienen te onderwerpen aan het recht en de procedures van de staat, waarmee zij een bepaalde binding bebben, alvorens zij hun toevlucht zoeken tot internationale rechtsbescherming tegen deze staat. ${ }^{106}$ Uit het feil dat het Comité zich, althans in theorie $\left({ }^{167}\right)$, niet aan de "local remedies rule" wenst te houden, kan men afleiden dat het niet de pretentie heeft om te fungeren als een internationale rechter ${ }^{168}$

163 Case No. 492, 124e Rap. \& 74.

164 Dit laatste aspect zou men "conciliatoir" kunnen noemen. Dat het accent toch voornamelijk op de quasi-judicielle werkzaamheden van het Comite ligt, wordt onder andere benadrukt door de ILO zelf, ygl. Int. Labour Office, ILO principles, standards and procedures conceming freedom of association, Geneva 1985, $\mathrm{p}, 10$.

$\checkmark \mathrm{gl}$. voorts: Simamba B.H. The Jurisdiction of the ILO to hear complaints regarding trade union freedom in: XXI CILSA 1988, p. 413.

165 Vgl. Digest of Decisions, \& 33 en specifiek met betrekking tot Mexico, Case No. 460,101 e Rap. $\$ 76$. In dit opzicht verschilt het Comité van bijvoorbeeld een internationaal klachten-tribunaal dat wel gebonden is a an de regel dat nationale rechtsmiddelen uitgeput moeten zijn, zo voegt het Comite in Case No. 460 er nog aan toe.

166 Van Dijk P. Toetsing wan Overheidshandelen door de Nationale en lntertationale Rechter en het Vereiste van een Procesbelang, "s-Cravenhage 1976, p. 240.

167 "in theorie", want in praktijk hecht het Comite well degelijk waarde aan het feit dat een bepaalde kwestie die in een klacht ter discussice stat, nog "sub judice" is "dan wel vatbaar is voor hoger beroep. Zo wachtte het Comité in Case No. 696 (138e Rap, \& 11) en in Case No. 358 (98e Rap. $\$ 59$ ) de uitspraak van resp. de beroeps-rechter en het Hoogste Gerechtshof af, alvorens het een oordeel gaf. In Case No. 460 (94e Rap. \$77) achtte het Comite de omstandigheid dat de klagers geen gebruik hadden gemaakt van de mogelijkheid om in hoger beroep te gaan van een rechterlijke beslissing, een reden on de zaak niet verder voort te zetten. Deze pragmatische houding relativeert de bewering van het Comite dat het zich niet gebonden acht aan de "local remedies rulle".

168 Men mag deze redenering niet omdraailen door te beweren dat de "local remedies rulle" uitshuitend toepassing vindt in strikt judiciele procedurès. Zowel het Internationaal Verdrag inzake Burgerrechten en Politieke Rechten (hierna: BUPO-Verdrag) als het Internationaal Verdrag inzake de Uilbanning van Alle Vormen van Rassendiscriminatie (hierna: Rassenverdrag) woorzien in een individuele klachtenprocedure van quasijudiciele aard. Art. 5, lid 2 sub b van het Facultatieve Protocol bij het BUPO-Verdrag bepaalt dat het Mensenrechten-Comite zich ervan dient te wergewissen dat de betrokken klager alle beschikbare nationale 
Het Comite heeft overigens expliciet de hierboven ontvouwde visie van de regering weerlegd door nauwkeurig de grenzen van het eigen mandaat te markeren. Het staat vast, zo geeft het Comite de regering toe, dat de ILO geenszins de competentie bezit om uitspraken van nationale rechters te herzien. Het Comite is ook niet bevoegd om te beslissen welke interpretatie gegeven dient te worden aan de wetten van de staat. ${ }^{109}$ Het wenst uitsluitend te onderzoeken of de wetgeving, dan wel de toepassing van de wetgeving in overeenstemming is met de beginselen inzake de vrijheid van vakvereniging die Mexico door zijn lidmaatschap van de ILO heeft erkend. ${ }^{170}$

Naar het mij voorkomt, getuigt deze formulering van diplomatieke tact en wijsheid. Aan de ene kant etaleert het Comité een realistische kijk op de beperktheid van de eigen mogelijkheden die zijn positie en de procedure nu eenmaal met zich brengen. Daarnaast toont het respect voor de nationale soevereiniteit en de interne rechtsstatelijke ordening, verworvenheden die staten doorgaans met grote verbetenheid tegen aantasting plegen te verdedigen. Aan de andere kant geeft het Comité de Mexicaanse regering duidelijk te verstaan dat men zich met een beroep op de onafhankelijkheid van de rechter niet kan vrijwaren tegen elke vorm van kritiek.

Hoe men deze opvattingen moet plaatsen tegen de achtergrond van de algemene beoordeling van de nationale rechtspraktijk door de ILO, komt uitvoerig aan de orde in het laatste hoofdstuk.

\section{Conclusies}

Staatscontrole over vakbonden is een moeilijk grijpbaar fenomeen. In de historische en politicologische literatuur over Mexico wordt er veelvuldig aan gerefereerd, maar het blijkt niet zo eenvoudig om juridische verschijningsvormen van een controlepolitiek als zodanig te herkennen, laat staan om deze te kwalificeren als een inbreuk op fundamentele vakbondsrechten. Voorzover controlemechanismen verankerd zijn in wetgeving - hetgeen in Mexico met name het geval is bij het verplichte vakbondsmonopolie in de publieke sector - heeft het Comité van Deskundigen de onderhavige bepalingen van kritisch commentaar voorzien.

Doorgaans zijn de wettelijke bepalingen op zichzelf evenwel niet in strijd met de internationale normen inzake de vrijheid van vakvereniging, maar scheppen zij voor de

rechtsmiddelen heeft uitgeput. Art. $14_{b}$ lid 7 sub a luidt exact hetzelfde.

Cançado Trindade merkt met betrekking tot het BUPO-Verdrag hierover op: "(...) the preparatory work of the Cowenamt and the Protocol clearly indicated, that the human rights committee is not strictly a judicial body, a court, and does not thereby need to apply the local remedies rule with the same rigour as, say, the European Commission of Human Rights in its earlier years."

Cançado Trindade A.A. Exhaustion of Local Remedies under the UN Covenant on Civil and Political Rights and its Optional Protocol in: 28 International and Comparative Law Quarterly, Oct. 1979, p. 759.

169 Case No. 696, 138e Rap. $\$ 13$.

170 Case No. 827,160 e Rap. $\$ 269$. 
autoriteiten slechts de gelegenheid om, langs informele weg, controle vit te oefenen over vakbonden en hun leden. ${ }^{17}$ In dergelijke gevallen is het Comite inzake de Vrijheid van Vakvereniging wat betreft de informatievoorziening afhankelijk van klagende organisaties. Slechts een gering aantal klachten is in de loop der jaren bij de ILO ingediend. Hierboven heb ik de suggestie opgeworpen dat dit wellicht valt toe te schrijven aan het feit dat individuele vakbondsleden noch fracties binnen een vakbond gerechtigd zijn om klachten in te dienen. Een meer algemene verklaring zou kunnen zijn dat een efficiènte controlepolitiek het aantal. klachten tot een minimum reduceert. Apathie en vrees voor repressie van de kant van de autoriteiten, werkgevers of de officiële vakbeweging zouden werknemers ervan kunnen weerhouden om onafhankelijke vakbonden op te richten en zich, in geval van tegenwerking, met een klacht tot de ILO te richten.

Maar zelfs indien een klacht wel de ILO bereikt, blijkt het Comite inzake de Vrijheid van Vakvereniging niet snel geneigd om de klager in het gelijk te stellen. Drie factoren die hierboven in afzonderlijke paragrafen zijn uitgewerkt, zijn hier mijns inziens debet aan. Allereerst is het Comite niet bereid om vakbondsmonopolies die het gevolg zijn van contractuele "closed shop"-clausules aan een kritisch onderzoek te onderwerpen. Dit hangt overduidelijk samen met het terughoudende ILO-standpunt inzake "closed shops",

In de tweede plaats blijkt het Comite, in geval van een conflict tussen autoriteiten en vakbonden dat voortvloeit uit een protest tegen de controlepolitiek, vrij snel aan te nemen dat de vakbonden de grenzen wan hun bevoegdheden hebben overschreden.

Een laatste verklaring zou kunnen zijn dat kwesties die in klachten aan de orde werden gesteld, in een eerder stadium al onderworpen waren geweest aan het oordeel van de nationale rechter. Hoewel het Comité het principiële standpunt inneemt dat rechterlijke uitspraken niet immuun zijn voor een kritische beschouwing, blijkt het zich in de praktijk veelal te conformeren aan de beslissing van de mationale rechter.

Aan het eind van dit hoofdstuk rijst de vraag of het betreurenswaardig is dat de Mexicaanse controlepolitiek eigenlijk grotendeels aan het kritisch oordeel van de ILO ontglipt. Natuurlijk verraadt elk antwoord op deze vraag de persoonlijke opvattingen van de schrijver over de errist en het abjecte karakter van controle. Toch wil ik een poging wagen om éen en ander in een meer objectief perspectief te plaatsen. Het lijkt mij verantwoord om een uitspraak van de ILO inzake de vervlechting tussen staat en vakbeweging tot uitgangspunt te nemen en de Mexicaanse vakbondssituatie vervolgens te toetsen aan deze overweging. Punt 6 van de ILC-Resolutie inzake de Onafhankelijkheid van de Vakbeweging (1952) luidt als volgt: "Regeringen dienen, bij het zoeken naar de medewerking van vakbonden om hun sociale en economische politiek te verwezenlijken, te erkennen dat de waarde van deze medewerking in hoge mate rust op de vrijheid en onafhankelijkheid van de vakbeweging als enen essentiële

171 Freyre Rubio maakt een duidelijk onderscheid tussen de publieke en de particuliere sector en stelt dat de controlemechanismen in laatstgenoemde sector een informeel karakter hebben. Freyre Rubio, a.w. p. 222. 
factor bij de bevordering van sociale vooruitgang. $\mathrm{Zij}$ moeten niet proberen om de vakbeweging te transformeren in een instrument ter nastreving van politieke doeleinden. ${ }^{\text {"172 }}$

Twee auteurs hebben in recente publicaties de verhouding tussen staat en vakbeweging in Mexico bondig getypeerd. Aan De Buen ontleen ik de volgende uitspraak: "In the political order the so-called 'Labour Sector' is corporately integrated into the Revolutionary Institutional Party (PRI) and is subordinated in an absolute manner by the Government, regardless of the political, economical or social line put into movement" ${ }^{173}$ Een opmerking van HansJoachim Lauth heeft dezelfde strekking: "Die CTM ist jedoch weiterhin funktional in das politische System eingebunden, jetzt weniger als Ausgleichsgewicht gegenüber anderen Sektoren oder als Mobilisierungsfaktor bzw. Stimmenlieferant, sondern eher als Stabilitätsgarant im ökonomischen ModernisierungsprozeB. ${ }^{m{ }^{m / 4}}$ Beide auteurs lijken te suggereren dat de Mexicaanse autoriteiten de vakbeweging nog immer trachten te gebruiken als een verlengstuk van de (economische) politiek, waardoor het vrije opereren van de vakbeweging in het gedrang komt. Indien we nu deze situatie vergelijken met de door de ILO gepostuleerde onafhankelijkheid van de vakbeweging, dan is het mijns inziens inderdaad onbevredigend dat de ILO onvoldoende de Mexicaanse regering ter verantwoording heeft geroepen voor haar controlepolitiek.

172 Zie voor een uitwoerige bespreking van dit onderdeel van de Resolutie, hoofdstuk 1, p. 39 .

173 De Buen, a.w. p. 138.

174 Lauth, a.w. p. 81. 


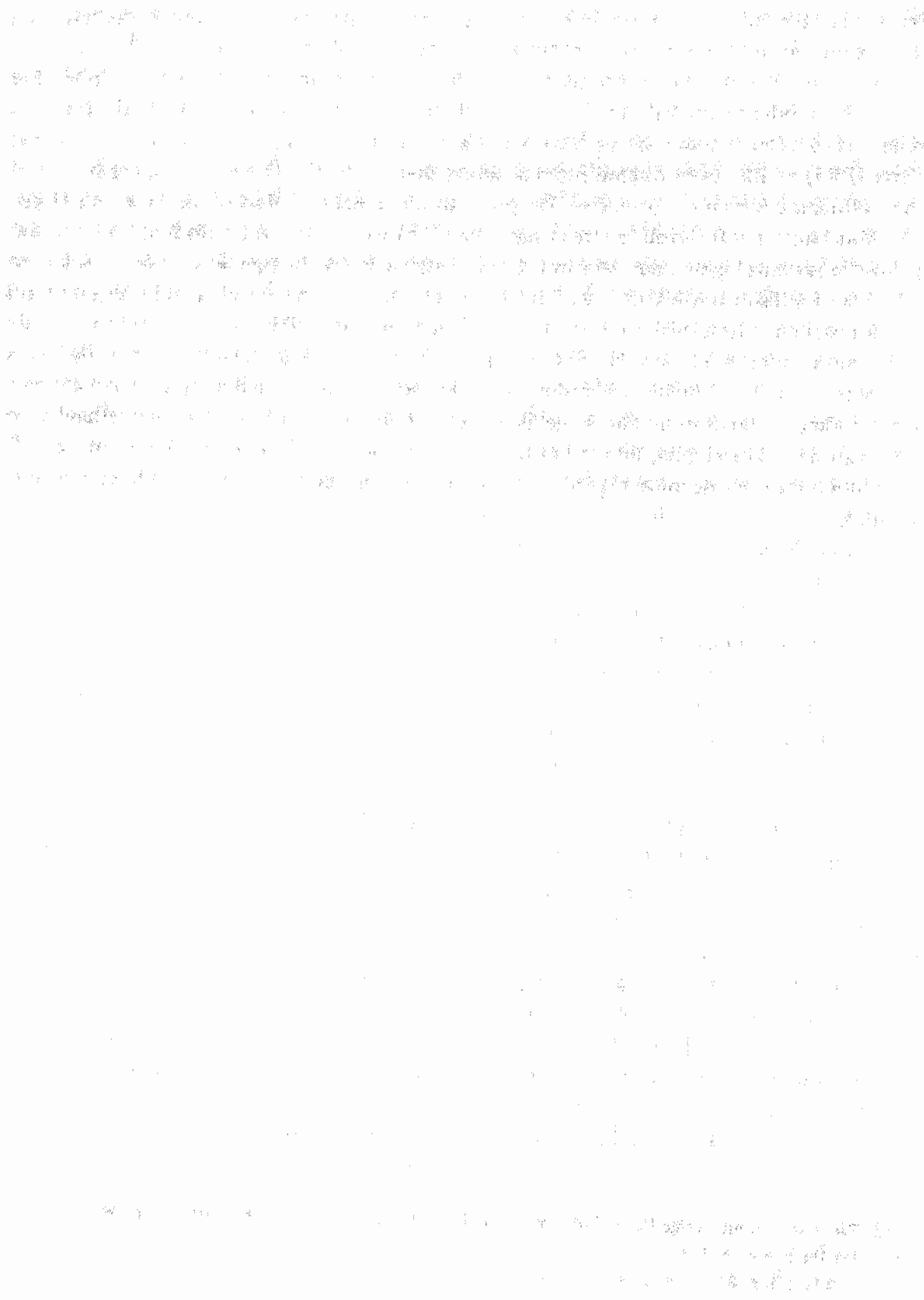




\section{De ILO-jurisprudentie gewikt en gewogen}

\section{$1 \quad$ Inleiding}

$\mathrm{Na}$ de uitvoerige analyses van de vakbondssituatie in de drie geselecteerde Latijnsamerikaanse landen en de reacties van de ILO, is nu het moment aangebroken om de balans op te maken. Een korte karakteristiek van de verhouding tussen staat, vakbeweging en politieke partijen in Chili, Colombia en Mexico kan ons daarbij behulpzaam zijn.

De relatie tussen staat en vakbeweging in Chili gedurende het regime van Pinochet werd gekenmerkt door extreme polarisatie. Naar Latijnsamerikaanse maatstaven onafhankelijk en tamelijk militant, werd de Chileense vakbeweging plotseling geconfronteerd met hevige repressie, waaraan zowel ideologische als economische motieven ten grondslag lagen. Geleidelijk aan wist de vakbeweging zich te herstellen van de opgelopen schade en maakte aanstalten om actief verzet te plegen tegen het autoritaire bewind. De vakbeweging heeft daarmee een belangrijke bijdrage geleverd aan de restauratie van de democratie.

De ILO heeft van meet af aan de massale schendingen van fundamentele vakbondsen mensenrechten onderkend en ondubbelzinnig partij gekozen voor de vakbeweging. Wellicht het meest opmerkelijke aspect in de uitspraken van de $\Pi \mathrm{LO}$ heeft betrekking op het ontplooien van politieke activiteiten. De ILO heeft het alibi van de regering-Pinochet dat de repressie opgevat moest worden als een legitieme reactie tegenover een wakbeweging die zich te buiten ging aan politieke actie, nooit aanvaard. Politiek en vakbondsactiviteiten liggen in elkaars verlengde en zijn vaak moeilijk te scheiden, aldus de ILO.

In Colombia overheersten, althans gedurende de twee eerste decennia na de Tweede Wereldoorlog, betrekkelijk harmonieuze arbeidsverhoudingen. De arbeidswetgeving dicteerde dat vakbonden zich op het niveau van de onderneming uitsluitend dienden in te zetten voor de sociaal/economische belangen van hun leden. Arbeidsconflicten werden doorgaans in de kiem gesmoord door verplichte conciliatie- en arbitrageprocedures.

De ILO heeft deze wettelijk verankerde controlemechanismen gekwalificeerd als strijdig met de internationale arbeidsnormen op het gebied van de vrijheid van vakvereniging. In politiek opzicht was de vakbeweging een verschijnsel in de marge. De grote vakcentrales CTC en UTC mobiliseerden hun aanhang voor resp. de Liberale Partij en de Conservatieve 
Partij. De nawwe verbondenheid met de traditionele politieke partijen en de onderlinge verdeeldheid verzwakten de vakbeweging.

In de loop van de jaren zeventig begon de vakbeweging, daartoe geprangd door de verslechterde economische situatie, zich allengs te distantiëren van haar oorspronkelijke politieke bondgenoten. Deze strijdbare opstelling ten opzichte van de autoriteiten culmineerde in 1977 in een algemene staking, waarop gematigd repressief gereageerd werd.

Ernstiger is dat vooral de afgelopen tien jaar vakbondsmensen in toenemende mate het slachtoffer zijn geworden van geweld van de kant van de zogenaamde doodseskaders. In hoeverre deze doodseskaders in contact staan met militairen en politie en in hoeverre de autoriteiten rechtstreeks verantwoordelijk zijn voor de gewelddadigheden is niet geheel duidelijk: ILO en NGO's verschillen op dit punt van mening.

Ook in Mexico tenslotte hebben zich weinig conflicten voorgedaan tussen staat en vakbeweging. In vergelijking met Colombia bestaan er tot op de dag van vandaag nauwe banden tussen staat en vakbeweging die zich vooral manifesteren in de organisatorische vervlechting van de regeringspartij PRI en de grootste vakcentrale CTM.

De autoriteiten bedienen zich voornamelijk van indirecte mechanismen om controle uit te oefenen over de vakbeweging. Vakbondsleiders maken dikwij]s deel uit van het politieke establishment en dragen er zorg voor dat de eisen van de vakbonden stroken met de regeringspolitiek. Concurrentie van onafhankelijke vakbonden wordt meestal effectief gedwarsboomd door de praktische toepassing van "closed shop"-clausules. Daarnaast plegen de autoriteiten direct te interveniëren in arbeidsverhoudingen via de Arbeidsraden.

In de jurisprudentie van de ILO komt het zojuist geschetste controle-patroon nauwelijks tot uitdrukking. Op zich is dit niet zo verbazingwekkend. De ILO beschikt over twee kenbronnen om inbreuken op de vrijheid van vakvereniging op het spoor te komen: (arbeids)wetgeving en klachten. Met uitzondering van de wetgeving inzake vakorganisaties in de publieke sector, waar de controle een meer formeel karakter heeft, voldoen de Mexicaanse wetten aan de internationale normen op het gebied van de vrijheid van vakvereniging. Bovendien heb ik in het hoofdstuk over Mexico aangegeven dat een effectieve controle haast per definitie uitsluit dat van de kant van de gecontroleerde vakbeweging klachten worden ingediend. De gecontroleerde vakbeweging fungeert als een "black box", waarover niet of nauwelijks informatie beschikbaar is. Pas op het moment dat de controle faalt, doordat vakbonden zich aan de bevoogding door de autoriteiten trachten te ontworstelen, worden klachten ingediend. Deze klachten geven als het ware de contouren van de "black box" aan.

De spaarzame klachten die de ILO bereikt hebben, zijn voor het Comité inzake de Vrijheid van Vakvereniging in de meeste gevallen geen aanleiding geweest om de klagende organisatie in het gelijk te stellen en daarmee, althans op indirecte wijze, controlemechanismen te kwalificeren als inbreuken op de vrijheid van vakvereniging. Voor een deel valt dit toe te schrijven aan de interpretatie die de toezichthoudende organen van de ILO geven aan de
internationale arbeidsnormen. 
Welke conclusies kunnen nu uit het bovenstaande getrokken worden? In de inleiding heb ik de hypothese opgeworpen dat de ILO waarschijnlijk weinig moeite zou hebben om repressie te kenschetsen als schending van vakbondsrechten, terwijl controle veel moeilijker of wellicht in het geheel niet te onderkennen zou zijn als een inbreuk op de vrijheid van vakvereniging. Met name de "case study" van Colombia toont aan dat deze hypothese een te simplistische voorstelling van zaken geeft. Aan de ene kant is de LLO immers wel degelijk in staat om formele, in wetgeving verankerde controle-instrumenten te beoordelen in het licht van de beginselen inzake de vrijheid van vakvereniging. Aan de andere kant heeft de ILO er duidelijk moeite mee om, in geval van "informele" repressie, de mate van betrokkenheid van de autoriteiten vast te stellen.

De cruciale vraag die in dit slothoofdstuk centraal staat, is welke verklaring(en) gegeven kan (kunnen) worden voor de gevolgtrekking dat de ILO blijkbaar moeilijk staten ter verantwoording kan roepen wegens schending van vakbondsrechten in geval van informele vormen van controle en repressie.

In de drie landenhoofdstukken zijn vier onderwerpen belicht die, hetzij afzonderlijk, hetzij gezamenlijk een aanzet kunnen geven tot een verklaring. Aan een aantal van deze onderwerpen - met name de onder I, II en IV genoemde - ligt een bepaalde vooronderstelling ten grondslag: juist omdat staten als Mexico en Colombia bekend staan als democratische rechtsstaten, slagen zij er goed in om bepaalde vormen van informele controle of repressie te verhullen. Het democratisch aureool scheidt een rookgordijn af dat de wereldgemeenschap -en in het bijzonder internationale organisaties - het zicht beneemt op de werkelijke vakbonds-situatie en, meer in het algemeen, de situatie van de rechten van de mens.

I) Het eerste onderwerp dat ik aan de orde wil stellen, heeft betrekking op de problematiek van de toelaatbaarheid van politieke activiteiten. Veelvuldig is al opgemerkt dat de toezichthoudende organen van de $\mathrm{LO}$ erin geslaagd zijn om aan de diplomatieke en nietszeggende ILC-Resolutie gestalte te geven door in concreto aan te geven welke grenzen vakbonden bij het ontplooien van politieke activiteiten in acht moeten nemen. $O p$ basis van de analyses in de voorgaande hoofdstukken, krijgt men evenwell de indruk dat, met name bij politieke stakingen, de toezichthoudende organen niet altijd dezelfde maatstaven hanteren. Het Comité inzake de Vrijheid wan Vakvereniging bleek, naar aanleiding van politieke stakingen in Mexico en in Colombia all snel geneigd om, met de regering, aan te nemen dat een staking niet tot doel mocht hebben om kritiek uit te oefenen op regeringspolitiek. In latere uitspraken daarentegen, waarin politieke stakingen in (wederom) Colombia en Chili ter discussie stonden, was het Comité wel bereid om tegen de autoriteiten gerichte stakingen te bestempelen als een legitieme uitoefening van vakbondsrechten.

De koppeling van de uiteenlopende uitspraken aan de specifieke landen geeft voedsel aan een gewaagde hypothese. Het is denkbaar dat de ILO de toelaatbaarheid van politieke activiteiten relateert aan de politieke situatie in een land. Men zou zich kunnen voorstellen dat de ILO de neiging vertoont om zich toegeeflijker op te stellen ten aanzien van politieke 
activiteiten van een vakbeweging, naarmate diens normale manoeuvreerruimte meer is ingeperkt door een autoritair regime (zoals in Chili gedurende het regime van Pinochet). Omgekeerd zou de ILO in een politiek conflict tussen staat en vakbeweging wellicht minder snel de zijde van de vakbeweging kiezen, indien in de staat in kwestie harmonieuze arbeidsverhoudingen overheersen en de ILO, terecht of ten onrechte, de indruk heeft dat de vrijheid van vakvereniging er voldoende gerespecteerd wordt.

Deze hypothese moet grondig onderzocht worden, aangezien een bevestiging van de juistheid een tweetal verstrekkende consequenties heeft. In de eerste plaats stelt het aanleggen van werschillende maatstaven op basis van de politieke context op pregnante wijze de universele geldigheid van het recht op staking ter discussie. In de tweede plaats kan een dergelijke opvatting van de ILO impliceren dat een vakbond die door middel van een staking de versluierde controle-politiek aan de kaak wil stellen, niet hoeft te rekenen op veel steun van de zijde van de ILO.

II) Het tweede aspect betreft de rol die de nationale rechter inneemt in de uitspraken van de ILO. Het is al verscheidene keren gesignaleerd dat de toezichthoudende organen van de ILO een cruciaal onderscheid plegen te maken tussen sancties die opgelegd worden door de uitvoerende macht en sancties die het gevolg zijn van een rechterlijke uitspraak. Dikwijls lijkt een rechterlijke tussenkomst op zich zelf al voldoende om aan te nemen dat de vrijheid van vakvereniging niet in het geding is. Dit standpunt is geworteld in belangrijke noties zoals machtenscheiding en onafhankelijkheid van de rechterlijke macht en valt op zich ook wel te billijken. Maar nog afgezien van de vraag of de rechterlijke macht daadwerkelijk onafhankelijk is, kan er twijfel rijzen of de nationale rechter het vermogen heeft dan wel bereid is om eventuele schendingen van vakbondsrechten door de uitwoerende macht te corrigeren. Deze twijfel is met name gerechtvaardigd, indien de nationale wetgeving in het licht van de internationale arbeidsnormen gebreken vertoont. Rechterlijke correctie kan dan uitsluitend plaatsvinden, wanneer de rechter zijn toevlucht kan nemen tot internationaalrechtelijke bepalingen en de nationale wet buiten toepassing kan laten.

De onderhavige problematiek is aan de orde geweest in de drie landen-hoofdstukken, maar zal in dit slothoofdstuk in een breder perspectief worden geplaatst. Onderzocht zal worden over welke mogelijkheden de nationale rechter in de drie landen beschikt om internationaal recht toe te passen, in hoeverre de rechter in de praktijk van deze mogelijkheden gebruik maakt en of de ILO, in geval wan twijfel, geneigd is om de rechterlijke toepassing te toetsen aan de relevante internationale normen.

Een al te terughoudende opstelling in deze kan namelijk tot gevolg hebben dat de regering zich verschuilt achter de uitspraak van de rechter en dat mogelijke schendingen van vakbondsrechten onvoldoende aan de oppervlakte komen.

III) De beide voorgaande onderwerpen heb ik gegoten in de vorm van hypotheses die nog een nader onderzoek vergen. Bij het derde onderwerp - de problematiek van vakbondsmonopolies - kunnen we uitgaan van min of meer vaststaande gegevens. Op basis van eerdere analyses - 
zie met name het hoofdstuk over Mexico - mogen we aanmemen dat vakbondsmonopolies de politieke controle over de gehele vakbeweging vergemakkelijken. Bovendien staat vast dat de ILO in de praktijk gegroeide vakbondsmonopolies - in tegenstelling tot wettelijk opgelegde monopolies - niet in strijd acht met de vrijheid van vakvereniging.

We zullen ons moeten afvragen of dit onderscheid in toelaatbaarheid tussen opgelegde en "spontane" vakbondsmonopolies te rechtvaardigen is. Om dit te kunnen beoordelen moet een afweging gemaakt worden tussen de belangen van vakbonden die een monopoliepositie genieten en van vakorganisaties wier existentie gedwarsboomd wordt door vakbondsmonopolies. We zullen daarbij te rade gaan bij de opinies in de literatuur en de jurisprudentie van nationale en internationale rechters.

IV) Vormen de drie voorgaande aspecten een mogelijke verklaring voor het onvermogen van de ILO om informele controle-patronen op het spoor te komen en te beoordelen in het licht van de internationale arbeidsnormen, het laatste onderwerp heeft betrekking op informele repressie. Het is objectief vast te stellen dat er een discrepantie bestaat tussen de opvattingen van de ILO en NGO's over de mate van betrokkenheid van de autoriteiten bij ernstige schendingen van vakbondsrechten in Colombia. Natuurlijk is het onmogelijk om met zekerheid te zeggen welke opvatting meer overeenstemt met de realiteit. Well lijkt mij het standpunt verdedigbaar dat een dergelijke discrepantie in het algemeen onwenselijk is. Aan elke poging om een verbetering in de mensenrechten- of vakbondssituatie te bewerkstelligen, dient een goede taxatie van de feitelijke toedracht van schendingen ten grondslag te liggen. Gebrek aan eensgezindheid op dit punt tussen externe waarnemers kan een malafide regering in de kaart spelen. Maar ook een regering die te goede trouw wil meewerken aan een verbetering van de situatie, is meer gebaat bij een duidelijke standpuntbepaling van de internationale gemeenschap. Verwarring over met name de mate van betrokkenheid van (politiële en militaire) autoriteiten bij schendingen van de mensenrechten, kan de internationale steun verzwakken en de regering belemmeren bij de opsporing en vervolging van de schuldigen.

Bovenstaande overwegingen geven richting aan een nader onderzoek. We zullen moeten nagaan hoe het te verklaren is dat de inzichten van NGO's en de ILO vooral in geval van informele repressie uiteenlopen. Vervolgens kunnen we ons dan verdiepen in de vraag op welke wijze(n) ernaar gestreefd kan worden dat de standpunten meer op eén lijn komen.

2 Politieke activiteiten van de vakbeweging in Chili, Colombia en Mexico. De twijfelachtige universaliteit van een norm

\subsection{Inleiding}

In hoofdstuk 1 van deze studie is uitvoerig aandacht besteed aan de universaliteit van de vrijheid van vakvereniging. Aldaar heb ik getracht om aan te tonen dat de toezichthoudende organen van de ILO, bij de beoordeling van de vraag of staten de vrijheid van vakvereniging 
respecteren, voor alle staten gelijke maatstaven aanleggen. Daarbij wordt de rechtspositie van vakbonden tot uilgangspunt genornen en wordt geabstraheerd van de specifieke politieke en sociaal/economische context.

Bij de analyse van de ILO-uitspraken in de drie landenhoofdstukken is verscheidene malen gebleken dat de toezichthoudende organen van de ILO dit standpunt ook in praktijk brengen Zo deelde het Comité van Deskundigen niet de opvatting van de Colombiaanse regering dat de vaststelling van de categorie "essentiële diensten"; waarin stakingsverboden legitiem zijn, gerelateerd moet worden aan het sociaal/economische ontwikkelingsniveau van de staat in kwestie. Evenmin honoreerde het Deskundigen-Comite het beroep op een specifieke politiek/historische ontwikkeling dat wan de zijde van de Mexicaanse regering werd aangevoerd om het verbod op herverkiezing van vakbondsleiders te rechtvaardigen. ${ }^{2}$

Het zojuist geschetste universaliteitsconcept wordt ondermijnd indien de ILO op vergelijkbare (vakbonds)situaties verschillend reageert, afhankelijk van de sociaal/economische of politieke achtergrond watrtegen de gebeurtenissen zich afspelen. In deze paragraaf beoog ik aan te tonen dat de ILO bij de beoordeling van de vraag in hoeverre vakbonden politieke stakingen mogen organiseren, verschillende maatstaven hanteert. In het licht van de universaliteitsproblematiek zal dus onderzocht moeten worden of de gesignaleerde differentiatie toe te schrijwen is aan de neiging van de toezichthoudende organen van de ILO om, bij de vraag of een politieke staking toelaatbaar is, rekening te houden met het algehele politieke klimaat in een staat.

De methode die ik gekozen heb om deze vraag te onderzoeken, vereist enige toelichting. Uit de "case law" van de ILO met betrekking tot Chili, Colombia en Mexico zullen de gevallen, waarin het ontplooien van politieke activiteiten door vakbonden ter discussie stond, geselecteerd worden en in het kort worden weergegeven. Speciale aandacht zal geschonken worden aan vergelijkbare gebeurtenissen - met name het organiseren van politieke stakingen -, aangezien men hierop, uitgaande van het universaliteitsconcept van de ILO, een gelijklüdende reactie mag verwachten. Een diepgaande vergelijking van de verscheidene politieke stakingen wordt bemoeilijkt door de omstandigheid dat de voorgeschiedenis, de aan de stakingen ten grondslag liggende eisen en het verloop van geval tot geval verschillen en details hierover eigenlijk niet beschikbaar zijn. De toezichthoudende ILO-organen plegen evenwell tot op zekere boogte te abstraheren van de concrete situatie en deze abstractie biedt de mogelijkheid om de uitspraken naar aanleiding van min of meer vergelijkbare situaties op hun consistentie te toetsen.

In 2.5 zullen de incidentele uitspraken geplaatst worden in het bredere perspectief van de algemene opvattingen van de ILO inzake de toelaatbaarheid van politieke stakingen. Daarbij zal de nadruk komen te liggen op een vergelijking van de recente "bloemlezing" van de uitspra-

1. Vgl. Hoofidstuk 4, pp. 168-169.

2 Vgl. Hoofdstuk 5, p. 225. 
ken van de ILO met gelijksoortige edities van eerdere datum. ${ }^{3}$ Met deze exercitie verwacht ik uitsluitsel te krijgen over de juistheid van een alternatieve verklaring voor het hanteren van verschillende maatstaven met betrekking tot de toelaatbaarheid van politieke stakingen. De uitspraken die hieronder aan een nader onderzoek zullen worden onderworpen, liggen in tijd nogal uiteen. Het is dan ook denkbaar dat de verschillende oordelen met betrekking tot de politieke staking niet zozeer toe te schrijven zijn aan het feit dat de ILO flexibele criteria aanlegt naar gelang de politieke context, waarbinnen de staking plaatsvindt; maar eerder de vrucht zijn van een verandering in de rechtsopvattingen van de ILO dienaangaande. In dat geval komt het universaliteitsconcept dat aan het begin van deze paragraaf is uiteen gezet, niet in gevaar. Dit concept accentueert immers de ruimtelijke dimensie van de universele geldigheid van de rechten van de mens. Het sluit niet uit dat opvattingen met betrekking tot de inhoud van de rechten van de mens in de loop der tijd kunnen veranderen, mits alle staten maar op voet van gelijkheid beoordeeld worden naar de norm die op een bepaald moment wordt onderschreven.

Indien we kunnen aantonen dat het standpunt van de ILO inzake de toelaatbaarheid van politieke stakingen in de loop der jaren is gewijzigd, kunnen we ons tenslotte nog afvragen of dit standpunt vakbonden voldoende ruimte laat om door middel van een staking kritiek uit te oefenen op regeringspolitiek. In de evaluatie en conclusie (2.6) zal ik trachten mijn persoonlijke visie hierop uiteen te zetten.

\subsection{De scherpe politieke tegenstellingen tussen de Chileense vakbeweging en het militaire regime van Pinochet}

De brute repressie van de militairen jegens de vakbeweging die volgde op de staatsgreep van september 1973, was gewortell in de overtuiging van het regime van Pinochet dat de vakbeweging zich welbewust had laten misbruiken voor de politieke doeleinden van een Marxistische regering die het land aan de rand van de afgrond had gebracht. De Onderzoeks" en Bemiddelingscommissie heeft zich wijselijk niet laten verleiden tot het uitspreken van een oordeel over de politieke betrekkingen tussen de vakbeweging en de regering Allende." Naar aanleiding van het voornaamste "wapenfeit" van het militaire regime, de ontbinding van de vakcentrale CUTCh, ontweek de Commissie eigenlijk de vraag of de centrale zich al of niet teveel had ingelaten met politieke activiteiten. Zij beperkte zich tot het plaatsen van enkele algemene kanttekeningen - dat vakbondsleden tot op zekere hoogte de vrije keuze hadden om politieke activiteiten te ontplooien en contacten te leggen met politieke partijen, maar dat ze hierin de juiste maat moesten vinden. Waar het op aan kwam, was dat de rechter

3 Zoals bekend, zijn de uitspraken van het Comite inzake de Vrijheid van Vakvereniging en het Comite vam Deskundigen gecodificeerd in de "Digest of Decisions", resp. de "General Survey".

4 Zie Hoofdstuk 3, p. 102. 
die te oordelen heeft ower politieke grensoverschrijdingen van vakbonden, niet was ingeschakeli en dat makte de ontbinding van de CUTCh onaanvaardbaar.s

Ook het Comité inzake de Vrijheid van Vakvereniging kon, met het oog op de afscherming van de vrije politieke speelruimte van vakbonden tegen repressieve inbreuken door d autoriteiten, aanvankelijk volstaan met te signaleren dat de correcte juridische procedure: niet gevolgd waren. Het a priori uitsluiten van politiek actieve kandidaten van vakbondsleider schap $\left({ }^{\circ}\right)$, het ontslag van politiek links-georiënteerde vakbondsleiders, zonder tussenkoms van de rechter(?) en het herroepen van de rechtspersoonlijkheid van een politiek actieve vakvereniging $\left({ }^{8}\right)$ : het waren allemaal maatregelen die op formele gronden, ontleend aar de beginselen inzake de vrijheid van vakvereniging, konden worden aangevochten. Het Comité behoefde zich met andere woorden niet te bekommeren over de vraag of de vakbondsleder wel binnen de marges van het politiek toelaatbare waren gebleven.

De grote protestmanifestaties en -stakingen die halverwege de jaren tachtig plaatsvonden, brachten hier verandering in. De regering verdedigde het verbod van een grootschalige staking in de publieke sector op 4 september 1985 en de in aansluiting hierop genomen repressieve matregelen tegen de stakingsleiders met een beroep op Wetsdecreet no. 2758. De arikelen 45-55 van dit decreet bepaalden dat stakingen uitsluitend uitgeroepen konden worden met het oog op de vernieuwing van collectieve arbeidsovereenkomsten. Het Comité achtte deze interpretatie van het stakingsrecht duidelijk te restrictief in het licht van de beginselen van vakverenigingsvrijheid en stelde hier het eigen standpunt tegenover. De belangen, ter verdediging waarvan vakbonden stakingen uitriepen, betroffen niet alleen de verbetering van arbeidsvoorwaarden of collectieve eisen van een beroepsmatig karakter, maar strekten zich ook uit tot het zoeken naar oplossingen voor vraagstukken van economisch/ en sociaal/politieke aard. ${ }^{9}$

2.3 Colombia: het wettelijke verbod op (partij-)politieke activiteiten en de "politieke" stakingen van 1963 en 1977

Vanaf het moment dat Colombia de ILO-Verdragen nos. 87 en 98 ratificeerde (1976), is het Comité van Deskundigen met de Colombiaanse regering in een discussie verwikkeld over de (on)verenigbaarheid van art. 378 Arbeldswet - het verbod aan het adres van vakbonden om zich in te laten met politieke activiteiten - met de internationale arbeidsnormen. ${ }^{10} \mathrm{De}$ kritiek van het Deskundigen-Comite is niet zo opzienbarend, aangezien het hiermee trouw

5

6

7

8

9

10 Een samenvatting van de discussie vindt men op pp. 162 en 163 van Hoofdstuk 4. 
de ILO-opvatting, neergelegd in de ILC-Resolutie, vertolkt dat een algeheel verbod van politieke activiteiten wenselijk noch praktisch is.

Interessanter is het om de beide stakingen van 1963 en 1977 onderling te vergelijken, aangezien het Comité inzake de Vrijheid van Vakvereniging hier blijk geeft van een subtiele "changement d'opinion" die nogal verstrekkende consequenties heeft." De stakingen vertoonden markante overeenkomsten: beide hadden een nationale reikwijdte en waren niet direct het uitvloeisel van een arbeidsconflict met werkgevers. Zij hadden het karakter van protestacties en waren uitgeroepen om pressie uit te oefenen op de overheid. Aan beide stakingen lagen zowel politiek getinte als sociaal/economische motieven ten grondslag.

Naar aanleiding van een klacht over het verbod van de staking van 1963, gaf het Comité een kort exposé over het soort stakingen dat niet onder de bescherming van de internationale arbeidsnormen viel. Klachten over het verbod van stakingen die niet een beroepsmatig karakter hadden, stakingen die uitgeroepen waren om druk op de regering uit te oefenen ter beslechting van een politieke kwestie en stakingen die gericht waren tegen de regeringspolitiek en niet het gevolg waren van een arbeidsconflict, werden door het Comité niet verder afgehandeld. Welnu, het stond vast dat de staking gericht was tegen de regeringspolitiek en niet het uitvloeisel was van een arbeidsconflict, zodat het verbod van de staking niet strijdig was met de beginselen van vakverenigingsvrijheid. ${ }^{12}$

Opmerkelijk is nu dat het Comite 14 jaar later zich een stuk kritischer uitliet over het verbod van de staking van 1977 , ondanks het feit dat deze qua karakter weinig verschilde van de zojuist beschrevene. ${ }^{13}$ Dit was het directe gevolg van het feit dat het Comité uitdrukkelijk de bijkomende voorwaarde dat de staking het uitvloeisel moest zijn geweest van een arbeidsconflict, had laten vallen. Met andere woorden: proteststakingen die uitsluitend bedoeld waren om lucht te geven aan onvrede over sociale en economische aangelegenheden die effect hadden op vakbondsbelangen, waren toelaatbaar. ${ }^{14}$

Aanstonds zal onderzocht worden hoe deze uitspraken zich verhouden tot de algemene opvattingen van de ILO inzake de "politieke" staking. De voorlopige conclusie kan luiden dat het Comite, door de band met een onderliggend arbeidsgeschil door te snijden, de mogelijkheden van vakbonden om door middel van een staking de aandacht van de autoriteiten te vestigen op de eigen positie, verruimd heeft.

11 Voor een analyse van beide stakingen, zie Hoofdstuk 4, pp. 171-172 resp. 177-178.

12 Zie Case No. 363, 74 e Rap. \$\$ 233 en 234 en de kritische noot (109) wan Hoofdstuk 4 op p. 172 .

13 Vgl. Hoofdstuk 4, p. 178.

14 Case No. 889,177 e Rap. $\$ 326$. 


\section{Politieke conflicten tussen staat en vakbeweging in Mexico. De nationale spoonwegstaking van 1958-1959}

De Mexicaanse Vakvereniging van Spoorwegpersoneel (STFRM) voerde gedurende de jar wijftig een radicale, onafhankelijke koers en distantieerde zich nadrukkelijk van de nationa vakcentrale CTM die in hoge mate door de staat gecontroleerd werd. ${ }^{15}$ De spanning tuss staat en vakbond culmineerde in maart 1959 in een nationale spoorwegstaking, waarbij h treinverkeer volledig werd lamgelegd. De autoriteiten verboden de staking maar de leide negeerden het verbod en riepen de vakbondsleden op de staking voort te zetten. In react hierop werden de stakingsleiders, onder wie de Secretaris-Generaal van de STFRM, Demetr Vallejo, gearresteerd en door de rechter veroordeeld tot lange gevangenisstraffen. Het vonn van de appelrechter werd bekrachtigd door het Hoogste Gerechtshof. De veroordeling berust। op het feit dat het Hof het wettig en overtuigend bewezen achtte dat Vallejo en de zijne zich onder andere schuldig hadden gemaakt aan het politieke delict, zoals omschreven i art. 145 van het Federale Wetboek van Strafrecht, kort gezegd: poging tot omverwerpin van de staat. Ondanks het feit dat de staking verboden was en ondanks de verzoenende opste ling van de Minister van Arbeid, hadden de stakingsleiders koppig aangedrongen op voortzel ting, zo lichtte het Hof de eigen beslissing nader toe. "Communistische elementen" hadde: zich in het geschil gemengd en de stakingsleiders hadden politieke orders uitgevoerd. Alle wees erop dat de actie niet ondernomen was om voordelen voor de arbeidersklasse te verwer ven, maar gericht was op ondermijning van het staatsgezag voor subversieve doeleinden.'

In het Mexico-hoofdstuk heb ik mijn teleurstelling over het feit dat het Comité inzakı de Vrijheid van Vakvereniging zich klakkeloos refereerde aan het oordeel van het Hof, zonde dit nader toe te lichten, niet verheeld. Nu doet zich de gelukkige omstandigheid voor da de uitspraak van het Comite in de Vallejo-kwestie in tijd vrijwel samenviel met de afhandeling van de klachten over het verbod van de eerste politieke staking in Colombia (zie hierboven p. 259). Deze synchronie stelt ons in de gelegenheid om, aan de hand van de duidelijke criteria die het Comité in de Colombiaanse zaak heeft geformuleerd, het standpunt in de kwestie. Vallejo te reconstrueren.

Het conflict tussen de STFRM en de autoriteiten mondde uit in een strafrechtelijke veroordeling. De cruciale vraag, waarvoor het Comité zich dan ook geplaatst zag, was of de rechterlijke uitspraak inbreuk maakte op de waarborgen, waarin Verdrag no. 87 voorziet. ${ }^{\text {" }}$ In de uitspraak waren de specifieke politieke activiteiten die de STFRM ontplooid had en de (strafbare) gezagsondermijning versmolten: door pressie op de staat uit te oefenen (door

Zie voor nadere details hoofidstuk 5, pp. $240-243$.

Case No. 358 , 198 e Rap. $\$ \$ 33-55$. Voor een uitvoeriger behandeling van de rechtszaak wordt verwezen
naar hoofdstuk 5 , p. 242 .

17

$$
\text { naar hoofdstuk } 5 \text {, p. } 242 \text {. }
$$

Een dergelijk onderzoek geschiedt op basis van art. 8, lid 2 van Verdrag no. 87 dat bepaalt dat wetgeving vakbondsactiviteiten. 
middel van een staking) hadden de vakbondsleiders van de STFRM de delictsomschrijving van art. 145 van het Federale Wetboek van Strafrecht vervuld. Het Comité zou volstaan kunnen hebben met een onderzoek naar de vraag of de instaat van beschuldiging gestelde vakbondsleiders met het ontplooien van politieke activiteiten de eigen bevoegdhedensfeer hadden overschreden. In geval van een bevestigend antwoord zou de rechterlijke toepassing van de strafwet, gelet op de bewoordingen van art. 8 , lid 2 van Verdrag no. 87, immers niet aangemerkt kunnen worden als een schending van legitieme vakbondsactiviteiten.

In de analyses van de geruch tmakende spoorwegstaking wordt benadrukt dat de staking weliswaar haar oorsprong had in een arbeidsconflict tussen de STFRM en de spoorwegmaatschappijen, maar geleidelijk aan het karakter had gekregen van een zuiver politieke krachtmeting tussen autoriteiten en vakvereniging. ${ }^{18}$ Welnu, het Comité had, onder verwijzing naar de relevante passages in Case No. 363 (Colombia), kunnen overwegen dat de staking een overwegend politiek karakter had, nu zij geen rechtstreeks verband (meer) hield met een arbeidsconflict tussen vakbond en werkgever. Mitsdien kon de vakbond ook geen aanspraak maken op de bescherming die Verdrag no. 87 beoogt te verlenen.

Wat men ook inhoudelijk van dit standpunt mag vinden - ik kom daar in 2.6 nog kort op terug - het is in elk geval consistent met de opvattingen die de ILO aan het begin van de jaren zestig inzake politieke stakingen huldigde.

\subsection{Onderlinge vergelijking van de uitspraken en plaatsing in het bredere perspectiefvan de ILO- opvattingen}

De uitspraken van het Comité inzake de Vrijheid van Vakvereniging met betrekking tot politiek getinte stakingen in de drie landen leveren interessant vergelijkingsmateriaal op en illustreren hoe het Comité te werk gaat. Het Comité geeft de contouren aan van de activiteitensfeer van de vakbeweging. Indien vakbonden of vakbondsieden de grenzen van deze sfeer overschrijden door zich bijvoorbeeld te veel in te laten met politiek, dan kunnen zij niet verwachten dat de $L O$ hen in bescherming neemt tegen eventuele sancties van de kant van de autoriteiten, aangezien dergelijke activiteiten niet vallen onder de vrijheid van vakvereniging.

Op grond van de analyse in de vorige paragrafen lijkt het aannemelijk dat het Comite, bij de beoordeling van de toelaatbaarheid van politieke stakingen, de grenzen heeft verlegd. De vier besproken stakingen mogen qua achtergrond en verloop verschillen, zij hebben in elk geval twee belangrijke kenmerken gemeen en op deze kenmerken stoelt het Comité zijn oordeel. Aan alle vier de stakingen lagen grieven tegen een regeringspolitiek ten grondslag en geen der stakingen was het rechtstreekse uitvloeisel van een arbeidsconflict. Bij de eerste politieke staking in Colombia in 1963 huldigde het Comité nog de enge opvatting. Het Comité achtte het verbod van deze staking niet in strijd met de vrijheid van vakvereniging, aangezien de staking gericht was tegen de regeringspolitiek en geen verband hield met een arbeidsconflict. 
In 2.4 heb ik getracht om aan te tonen dat het Comite ook in de Vallejo-zaak stilzwijgeni van dit standpunt uitging.

De proteststakingen in Colombia van 1977 en in Chili van 1985 die evenmin iets te maker hadden met arbeidsconflicten, werden evenwel door het Comité gekenschetst als rechtmatig uitoefeningen van vakbondsrechten. Tussen 1963 en 1977 moet het Comite derhalve var mening zijn veranderd.

Het is interessant om na te gaan of deze wijziging van het standpunt terug te vinder is in de compilaties van uitspraken van het Comite. Dit blijkt inderdaad het geval te zijn In de Digest of Decisions van het Comite van 1976 wordt het verbod van een staking dif gericht is tegen de regeringspoltieken niet het gevolg is van een arbeidsconflict, niet in strijo geacht met de vrijheid van vakvereniging." Zoals we gezien hebben, is dit exact de formulering van het Comite naar aanleiding van de Colombiaanse staking van 1963. In het licht van deze casuspositie, lijkt mij Betten's conchusie dat het Comité destijds een verbod van een werkonderbreking uit protest tegen bijwoorbeeld een sociaal/economische politiek, maar die niets te maken had met een arbeidsconflict, door de vingers zag, geheel juist. ${ }^{20}$

In de Digest van 1985 is de koppeling met het arbeidsconflict verdwenen. Het Comité overweegt dat de belangen van werknemers die zij door middel van een staking trachten te verdedigen, niet beperkt zijn tot "betere arbeidsvoorwaarden en het nastreven van collectieve eisen met een professioneel karakter, maar ook gelegen kunnen zijn in het zoeken naar oplossingen voor vraagstukken van sociaal/politieke en economische aard" ${ }^{21}$ Ook het Deskundigen-Comité erkent dat vakbonden de mogelijkheid dienen te hebben om hun toevlucht te zoeken tot proteststakingen, in het bijzonder om kritiek uit te oefenen op een sociaal/economische regeringspolitiek. ${ }^{22}$

Wat is nu precies de draagwijdte en betekenis van deze standpuntswijziging van de ILO? De "oude" opvatting weerspiegelde de instrumentele visie dat het voeren van politieke actie door een vakbond - in casu het uitroepen van een staking - dienstbaar moest zijn aan de beslechting van een geschil tussen werkgever en vakbond. Zo de vakbond er niet in slaagde

19 ILO, Digest of Decisions of the Freedom of Association Cominitee, 2nd edition, Geneva 1976, $\mathrm{p}$ 112. Naast de Colombiaanse zaak (Case No. 362), worden het Verenigd Koninkrijk-Aden (Case No. 178, 36e Rap \$ 56) en Argentiniè (Case No. $192,49 \mathrm{e}$ Rap $\$ 168$ ) genoend.

20 Betten L. The Right to Sirike in Community Law, Den Haag 1985, p. 201.

21 ILO, Digest of Decisions, 3rd edition, Genewa 1985, \$368. Verwezen wordt naar Case No. 1081.(Peru) 214e Rap. 262 en Case No. 1089 (Opper Volta) 217 e Rap. $\$ 239$.

22 ILO, Freedom of Association and Collective Bangaining; General Sunvey by the Committee of Experts on the Application of Conventions and Recommendations, Geneva 1983, p. 67.

Hoefer-van Dongen heeft de uitspraken van het Comitê inzake de Vrijheid van Vakvereniging en van het Deskundigen-Comitc onderling vergeleken en zij constateert dat het Deskundigen-Comite meer ruimte laat voor politieke stakingen dan het Vakverenigings-Comite. Gezien de vrijwel gelijkluidende formuleringen die beide Comites gebruiken, lijkt mij deze conclusie inmiddels achterhaald. Hoefer-van Dongen P. The Right to Strike within the Framework of the ILO, 24 NILR 1977, p. 115. 
om de werkgever tot inwilliging van eisen te bewegen, dan kon hij altijd nog proberen om de schaal en daarmee de effecten van de staking op de economie en het openbare leven te vergroten, teneinde de overheid ertoe te brengen om druk uit te oefenen op de werkgever. De overheid fungeerde in deze optiek als hefboom tussen vakbond en werkgever, niet als zelfstandig mikpunt van vakbondseisen. Door de koppeling van de staking en het arbeidsconflict, was de hantering van het stakingsmiddel enkel ter beïnvloeding van overheidspolitiek in de ogen van de ILO niet toelaatbaar.

De "nieuwe" opvatting sluit beter aan bij de realiteit dat regeringen zich dikwijls plegen in te laten met de vaststelling van arbeidsvoorwaarden en dat overheidspolitiek consequenties heeft voor de positie van werknemers. ${ }^{23}$ De ILO onderkent immers dat uitsluitend de overheidspolitiek, los van een arbeidsconflict tussen vakbond en werkgever, een aanleiding kan vormen tot het uitroepen van een staking. Maar niet alle politieke vraagstukken kunnen ten grondslag liggen aan het uitroepen van een staking. Er moet een verband bestaan tussen de bekritiseerde (sociaal/economische) politiek en de professionele belangen van de vakbondsleden. Het Deskundigen-Comité laat er geen twijfel over bestaan dat een zuiver politieke staking - bijvoorbeeld een staking die gericht is tegen de opening van een kerncentrale of, binnen de Nederlandse context, tegen het lidmaatschap van de NAVO-buiten de reikwijdte van de beginselen van vakverenigingsvrijheid valt. ${ }^{24}$

Met Betten ben ik nieuwsgierig of de huidige opvatting van de ILO nog ruimte laat voor een verbod van stakingen die een regering beogen te dwingen om een bepalde politiek die verband houdt met werknemersbellangen, te wijzigen. ${ }^{25}$ Bertrams' standpunt dat een politieke staking die meer is dan een uiting van protest en gevoerd wordt ter afdwinging van eisen, onrechtmatig is, deel ik niet. ${ }^{25}$ Een staking is per definitie een drukmiddel. Naar het mij voorkomt haalt men de angel uit het stakingswapen door stakende werknemers het recht te ontzeggen om druk uit te oefenen (op de overheid). ${ }^{27}$ Toegespitst op de Nederlandse situatie acht ook Rood het uitoefenen van druk op de Kamer in verband met wetswoorstellen

23 Dit geldt in ieder geval woor landen, waar van ouddsher nauwe betrekkingen bestaan tussen staat en vakbeweging - Latijnsamerikaanse staten zijn een goed woorbeeld. Bertrams bespeurt ook in Westeuropese staten cen tendens wan groeiende owerheidsbemoeienis met arbeidswoonwaarden. Bertrams R.I.V.F. Een rechlswengelijkende beschouwing over de politieke staking, NJB 1982, p. 889.

24 General Survey, 816 . Het tweede voorbeeld is ontleend aan Bertrams, a.w. p. 890.

25. Betten, a.w. p. 201.

26. Bertrams, a.w. p. 898.

27 In het befaamde NS-Werkstaking-arrest owerwoog de Hoge Ramd dat de collectieve acties wan de Bonden zich "richttem tegen de overheid in die zin dat zij ten doel hadden regering en parlement onder druk te zetten ten einde te verhinderen dat (...) in de arbeidsvoonwaarden van (o.a.) de werknemers in dienst van NS zou worden ingegrepen." (cursivering HvdW) Toetsend aan het Europees Sociaal Handwest, kwam de HR vervolgens tot de belangwekkende slotsom dat dergelijke acties (nog) onder art. 6 lid 4 ESH vielen. Met andere woorden: het enkelle feit dat de bonden pressie beoogden uit te oefenen op de overheid was nog geen reden om hen de rechtsbescherming wan het ESH te onthouden. HR 30-05-1986, NJ 1986, 688 
door middel van een werkstaking geoorloofd, mits de staking van korte duur is. Een langdur actie zou immers onzorgvuldig en daarom onrechtmatig zijn jegens de werkgever, nu d laatste niet bij machte is de eisen van de actievoerders in te willigen. ${ }^{28}$

Gelet op het bovenstaande, lijkt het mij aannemelijk dat de ILO geen bezwaren zal hebt tegen een politieke staking die ertoe strekt om pressie uit te oefenen op de overheid i haar beleid te wijzigen, zolang dit beleid maar consequenties heeft voor de profession, belangen van de stakers.

\subsection{Evaluatie en conclusie}

In de inleiding is de vraag opgeworpen of de ILO, bij de beoordeling van de toelaatbaarhe van politieke stakingen, zich wellicht laat leiden door de politieke achtergrond, waarteg: deze stakingen zich afspelen. Op grond van bovenstaande analyse moet deze vraag mij inziens ontkennend beantwoord worden. Gebleken is dat het standpunt van de ILO in c loop der jaren gewijzigd is, in de zin dat vakbonden ruimere mogelijkheden hebben gekrege om een politieke staking te voeren. Raadpleging van de Digest wees uit dat de uitsprake van het Comitê inzake de Vrijheid van Vakvereniging naar aanleiding van de eerste politiek staking in Colombia (1963) en de staking van de STFRM volledig strookten met het algemer ILO-standpunt van dat moment. Anderzijds stemden de latere uitspraken van het Comit met betrekking tot de stakingen in Colombia en Chili wederom volledig overeen met $d$ inmiddels gewijzigde opvatting. Met andere woorden: er is geen enkele aanwijzing dat he Comité differentieert op basis van de specifieke politieke context in een staat.

Deze constatering valt in tweeërlei opzicht positief te waarderen. Allereerst vloeit de noodzaa om vaste en duidelijke maatstaven te hanteren voort - het is in de inleiding al genoemd uit de ILO-interpretatie van de universaliteit van vakverenigingsvrijheid. Binnen de optiel dat vakbonden, ongeacht het sociaal/economische of politieke klimaat waarbinnen zij opereren over bepaaide fundamentele rechten beschikken, is geen plaats voor bet aanleggen var zwevende criteria die juist wel rekening houden met deze sociaal/economische en politieke
variabelen.

In de tweede plaats kan worden vastgesteld dat de ILO de grenzen van de bevoegdheden. sfeer van vakorganisaties verlegd heeft ten faveure van die vakorganisaties. De oorspronkelijke opvatting van de ILO inzake politieke stakingen was mijns inziens inderdaad te benepen. Zij miskende dat een sociaal/economische regeringspolitiek grote gevolgen kan hebben voor de loonontwikkeling en arbeidswoorwaarden en dat werknemers er derhalve belang bij kunnen hebben om die politiek te beïnvloeden. Specifiek in relatie tot de STFRM-casus was het teleurstellend dat het Comité op geen enkele wijze steun bood aan een vakbond die, door middel van een staking, zich trachtte te verzetten tegen een versluierde controle-politiek.

Rood M.G. Akties en loonpolithek, SMA 1980, pp. 351-352. 
Deze laatste kanttekening werpt overigens onmiddellijk de vraag op of het huidige standpunt wel toereikend is om bescherming te bieden aan vakbonden die met behulp van een staking kritiek willen oefenen op politieke misstanden van meer structurele aard. Op het eerste gezicht lijkt de ILO vooral stakingen die gericht zijn tegen sociaal/economische politiek op het oog te hebben. Bij nader inzien acht ik deze interpretatie van het ILO-standpunt toch te beperkt. Waar het op aan komt is of de stakende vakbond met politieke middelen belangen van werknemers tracht te behartigen. De vrijheid van vakvereniging die juist door een controlepolitiek in gevaar wordt gebracht, lijkt mij bij uitstek een werknemersbelang. De ILO zal dan ook stakingen die de strekking hebben om inbreuken op de vrijheid van vakvereniging aan de kaak te stellen, moeten kwalificeren als een rechtmatige uitoefening van vakbondsrechten. Het huidige standpunt van de ILO inzake politieke stakingen laat hiertoe voldoende ruimte. ${ }^{\text {P }}$

\section{De nationale rechter en de ILO-normen inzake de vrijheid van vakvereniging}

\subsection{Inleiding}

Uitspraken van nationale rechters, waarin schendingen van mensenrechten ter discussie staan, zijn voor internationale organisaties van eminent belang. Aan de hand van deze uitspraken kan de internationale organisatie namelijk een beeld krijgen van de mate, waarin de rechtspraktijk van een staat overeenstemt met internationale normen. Deze signaalfunctie van de rechterlijke uitspraak dient men te plaatsen tegen de achtergrond van het feit dat nationale wetgeving slechts een grove indicatie biedt omtrent de naleving door de staat van internationale normen op het terrein van de rechten van de mens. In positieve zin kan de rechtspraktijk afwijken van de nationale wetgeving, doordat de rechter, onder bepaalde voorwaarden, nationale regels kan modelleren aan de hand van internationale normen en, zo nodig nationaal recht zelfs ten faveure van de internationale normen buiten toepassing kan laten. Hierbij moet onmiddellijk aangetekend worden dat de rechter de voorwaarden, waaronder dit kan geschieden, niet in eigen hand heeft. De rechterlijke armslag om internationaalrechtelijke normen toe te passen is namelijk enerzijds begrensd door de verplichtingen die de staat op international terrein op zich heeft genomen en anderzijds bepaald door de, veelal in de constitutie verankerde, wijze waarop het internationale recht

29 Ben Israël verwijst naar een zaak van het Comite inzake de Vrijheid van Vakvereniging (Case No. 857 (Ver. Koninkrijk/Antigua), 187e Rap. \$263), waarin het Comite zich onbevoegd acht om te oordelen over politieke aangelegenheden die geen verband houden met de ütoefening van de vrijheid van vakvereniging. Dergelijke Klachten moeten evenwel ten gronde onderzocht worden, om te bexien of de wrijheid van vakvereniging mogelijk toch in thet geding is, zo woegt het Comite eraan toe. Op grond van deze uitspraak lijkt het mij verdedigbaar dat het Comite stakingen die het oogmerk hebben een regering te dwingen om valkbondsrechten te eerbiedigem, toelaatbaar acht.

Ben Israel R. Intemational Labour Standards: The Case of Freedom to Strike, Deventer 1988, p. 96. 
binnen de nationale rechtsorde functioneert. In negatieve zin kan de rechtspraktijk afwijk van de nationale wetgeving; indien de wet die op zichzelf strookt met internationale norme (aanzienlijke) ruimte laat voor rechterlijke interpretatie. De toepassing van de wet kan een dergelijk geval conflicteren met internationale normen. ${ }^{30}$ In beide gevallen is er spral van een discrepantie tissen wetgeving en praktijk en in beide gevallen zal de internationa organisatie dan ook niet kunnen volstaan met de raadpleging van de wetgeving, maar die zij de rechtspraak aan een nader onderzoek te onderwerpen.

Er bestaat een potentiele spanning tussen de noodzaak om rechterlijke uitspraken t beoordelen op han verenigbaarheid met internationale normen en het, in de inleiding gesigne leerde ontzag van de ILO voor de nationale rechter. In deze paragraaf wil ik nagaan of $d$ toezichthoudende organen van de ILO bereid zijn om eventuele egards voor de rechterlijk macht ondergeschikt te maken aan hun primaire verantwoordelijkheid om, door middel vas raadpleging van rechterlijke uitspraken, een helder beeld te krijgen van de national (rechts)praktijk.

Voor de ILO vormt het eigen normenstelsel op het gebied van de vrijheid van vakvereni ging het referentiekader. We dienen dan ook te bekijken welke mogelijkheden de rechter van de drie onderzochte landen ter beschikking staan om aan deze internationale normen gestalte te geven en of de rechters van deze mogelijkheden gebruik maken. Dit onderzoek vormt het hart van het onderhavige hoofdstuk en is gesplitst in twee onderdelen. In 3.3 worden de marges aangegeven, waarbinnen de rechter kan opereren. Zeer in het kort zullen de internationale verplichtingen, waaraan achtereenvolgens Chili, Colombia en Mexico binnen het kader van de ILO gebonden zijn om in eigen land de vrijheid van vakvereniging te eerbiedigen, de revue passeren. Voorts zal in deze paragraaf de positie van het internationale recht binnen de nationale rechtsorde in genoemde landen geschetst worden. Vervolgens verschuift in 3.4 het perspectief naar de praktische toepassing van internationale normen door rechters in Chili, Colombia en Mexico. Binnen de beperkte opzet van dit onderzoek is het natuurlijk ondoenlijk om een totaalbeeld te geven van de rechterlijke hantering van internationale normen in de genoemde landen. De jurisprudentie van de toezichthoudende organen van de ILO die betrekking heeft op de (on)verenigbaarheid van rechterlijke uitspraken met de ILO-normen inzake de vrijheid van vakvereniging, vormt het uitgangspunt. Een theoretische reflectie op de verhouding tussen de nationale en de internationale rechtsorde en de, daaraan ten grondslag liggende, problematiek van monisme en dualisme kan niet gemist worden en gaat logisch vooraf aan beide paragrafen. Deze beschouwing vormt het onderwerp van 3.2. Tenslotte wil ik in 3.5 trachten aan te geven hoe de ILO, met respect voor de interne constitutionele verhoudingen en de nationale soevereiniteit, de signaalfunctie van de

30 Een toespeling op een dergelijke situatie treffen we aan in art. 8 van Verdrag no. 87 dat bepaalt dat niet alleen de wetgeving maar ook de toepassing erwan in overeenstemming moet zijn met de normen inzake de wrijheid van wakvereniging. 
rechterlijke uitspraak optimaal kan benutten om een betere naleving van de internationale normen inzake de vrijheid van vakvereniging na te streven.

\subsection{De verhouding tussen internationaal en nationaal recht. Monisme versus dualisme}

Binnen de theorievorming rond de verhouding tussen internationaal en nationaal recht zijn, globaal genomen, twee stromingen te onderscheiden: het dualisme en het monisme. ${ }^{31} \mathrm{De}$ dualisten gaan uit van een strikte scheiding tussen de nationale en de internationale rechtsorde. Nationale en internationale rechtsregels vloeien voort uit verschillende rechtsbronnen en hebben betrekking op verschillende rechtssubjecten. Aangezien beide soorten normen een verschillend werkingsgebied hebben, kunnen zij elkaar per definitie niet "bijten". Op de staat rust de verplichting om de internationale normen om te zetten in nationaal recht. Zodra deze transformatie heeft plaatsgevonden, heeft de internationale regel dezelfde status als (andere) nationaalrechtelijke normen.

De pleitbezorgers van het monisme nemen daarentegen de integratie van de internationale en de nationale rechtsorde tot uitgangspunt. Dit impliceert dat er zich situaties kunnen voordoen, waarin zowel normen van internationale als van nationale oorsprong aanspraak maken op toepassing en deze normen zullen niet altijd harmoniëren. Teneinde de eventuele conflicten tussen nationale en internationale regels op te lossen, veronderstellen de monisten dat er een hiërarchische verhouding tussen de nationale en de internationale rechtsorde bestaat, waarbij door de meeste aanhangers van het monisme het primaat verleend wordt aan het internationale recht. ${ }^{32}$

Men doet er goed aan zich te realiseren dat bet onderscheid monisme - dualisme een theoretisch concept en derhalve een simplificatie van de werkelijkheid is ${ }^{37}$ Geen enkele staat kent een zuiver monistisch, dan wel een zuiver dualistisch stelsel. Dualisme en monisme zijn de beide polen van een continuüm, waarop elke staat een plaats inneemt. ${ }^{34}$ In de praktijk zal elke staat een oplossing moeten vinden voor enkele vraagstukken die direct samenhangen met de verhouding tussen nationaal en internationaal recht. Deze vraagstukken vallen als volgt te rubriceren $\left({ }^{35}\right)$ :

31 Voor een beknopt maar helder overzicht wordt verwezen naar: Lardy P. La force obligatoire du droit intemational en droit interne; Paris 1966, pp. 15-34.

32 Het primaat wan het internationale recht volgt niet dwingend uit de theorie van het monisme. Lardy toont dit aan door het gedlachtengoed van de eminente Oostenrijkse rechtsfilosoof Hans Kelsen te ontwouwen. Hoewel Kelsen in zijin magnum opus. "Reine Rechtslere uiteindelijk op grond van niet-juridische argumenten de woorkeur geeft aan het internationale recht, acht hij het primaat wan het nationale recht logisch verdedigbaar. Kelsen H. Reine Rechtslere; Wenen 1960, pp, 343-345/Lardy; a.w. p. 27.

33 Jacobs F.G. and Roberts S. (eds.) The Effect of Treaties in Domestic Law; Uitgave van United Kingdom National Committee of Comparative Law (UKNCCL), Vol.7, London 1987 , p. XXIV.

34 Henkin L. International Law: Politics, Values and Functions; RCADI 1989 (IV), pp. 90-93.

35 De rubricering is deels ontleend aan Henkin, a.w. p. 93. 
- Maakt internationaal recht "automatisch" deel uit van de nationale rechtsorde of mi de wetgever matregelen nemen opdat het internationale recht de rechtsorde $k$ penetreren?

- Gesteld dat het internationale recht automatisch geïncorporeerd is, kan de justitiabs dan, ten overstaan van een nationale rechter, met succes hierop een beroep doen? $\mathrm{M}$ andere woorden: heeft het internationale recht rechtstreekse werking?

- Welke plaats neemt het internationale recht in binnen de constitutionele hiërarchi Kan de nationale rechter, met een beroep op het internationale recht, nationale wett buiten toepassing laten?

- Maakt de staat in kwestie, met betrekking tot bovengenoemde elementen, nog ondersche in rechtsbron - verdrag of gewoonte?

Aan elk van deze vraagpunten zal ik een korte paragraaf wijden.

\subsubsection{Automatische incorporatie of transformatie}

Het onderscheid tussen dualisme en monisme heeft betrekking op de mate waarin een natic nale wetgever maatregelen moet nemen om het internationale recht binnen de national rechtssfeer te loodsen. Men moet dit niet opvatten als een simpele tegenstelling: $d$ statengemeenschap kan niet worden ingedeeld in monistische cosmopolieten die juichen het internationale recht over zich heen laten stromen en dualistische kluizenaars die he internationale recht het liefst buiten de deur zouden houden. Een korte uiteenzetting ove de statelijke praktijk illustreert dat geen enkel land volledig monistisch of dualistisch is, maa dat er veeleer sprake is van grijze kleurschakeringen.

Toegespitst op verdragen, behoren in sommige "monistische" landen - Frankrijk, Nederland, de Verenigde Staten, de meeste Latijnsamerikaanse landen - verdragen, na ratificatie, automatisch tot het nationale recht, maar is tijdens of na de ratificatie wel enige vorm van parlementaire goedkeuring verplicht voorgeschreven. ${ }^{36}$ In een tweede categorie "dualistische" landen, waartoe Italië en Duitsland behoren, fungeert de Goedkeuringswet als een soort polsstok: als zodanig sorteren verdragen geen effect in de nationale rechtsorde, maar eenmaal overgeheveld door de Goedkeuringswet, zijn zij in onversneden vorm toepasselijk. In een derde categorie landen, waaronder het Verenigd Koninkrijk en Denemarken, dient elk verdrag getransformeerd te worden in nationale wetgeving. De internationale (verdrags-)bepaling ontleent haar werking binnen de nationale rechtsorde uitsluitend aan het feit dat zij gehuld
is in nationalle klederdracht.

Blijken de technieken om het internationale recht in de nationale rechtsorde te laten infiltreren in landen met een monistisch en landen met een dualistisch stelsel slechts gradueel

Jacobs and Roberts, a.w. p. XXV. 
van elkaar te verschillen, de grensvervaging tussen monisme en dualisme komt tevens tot uitdrukking in het feit dat ook in landen met een monistisch stelsel de doorwerking van het internationale recht berust op regels van nationale, constitutionele aard. Het internationale recht schrijft een manistisch, noch een dualistisch stelsel dwingend voor, maar laat, integendeel, de staat de vrijheid om te bepalen op welke wijze hij zijn verdragswerplichtingen ten uitvoer legt, mits hij ze maar nakomt. De supra-nationale rechtsorde van de Europese Gemeenschappen vormt de meest in het oog springende uitzondering op deze regel. Blijkens de jurisprudentie van het Europese Hof "dringen verdragsbepalingen zonder hulp van enige nationale maatregel binnen in de interne rechtsorde, voor zover zij zich naar hun aard daartoe lenen, d.w.z. rechtstreeks of direct werken". Transformatie van verdragsbepalingen verdraagt zich niet met de communautaire rechtsorde.

\subsubsection{De problematiek van de rechtstreekse werking}

De automatische incorporatie van internationaal recht in de binnenlandse rechtsorde van monistische staten impliceert nog niet dat justitiabelen zich in rechte met succes op internationale normen kunnen beroepen. De rechter dient namelijk eerst vast te stellen of de norm in kwestie zich voor directe toepassing leent. De moeilijkheid bij de bepaling of een internationale norm al of niet rechtstreekse werking bezit; schuilt in het feit dat er geen consistent patroon van criteria is, op grond waarvan dit met zekerheid woorspeld kan worden. ${ }^{40}$ Rechters plegen hier verschillende maatstaven te hanteren. In geval van verdragsbepalingen hebben rechters soms getracht de bedoeling van de verdragsluitende partijen te achterhalen." Aangezien de opvattingen van de verdragsluitende partijen vaak moeilijk uit de verdragsdocumenten te destilleren waren, zijn rechters in toenemende mate zich gaan baseren op objectieve criteria, zoals de inhoud, strekking, aard en bewoordingen van de bepaling. ${ }^{42}$ Als vuistregel kan men aanhouden dat normen die een concrete verplichting aan het adres van de staat behelzen om zich te onthouden van inbreuken op rechten van burgers, in beginsel voor directe toepassing in aanmerking komen. Normen die een nadere uitwerking van de kant van de overheid vergen, zullen daarentegen door de rechter als niet rechtstreeks werkend buiten

38 Van Dijk P./van Hoof G.J.H. De Europese Conventie in Theorie en Praktijk; Nijmegen 1982, p. 12.

39 Kapteyn P.J./VerLoren van Themaat P. Inleiding tot het Recht van de Europese Gemeenschappen, Deventer 1987, p. 33 .

De auteurs ontlenen de formulering aan: Arrest EHvI 3-4-1968, 28-67, Jur. XIV, p. 203.

40 Leary V. Intemational Labour Conventions and National Law; the Hague/Boston/London 1982, p. 65.

41 Vergelijk met betrekking tot de Amerikaanse jurisprudentie, Leary, a.w. p. 59. Zie tevens Tammes A.J.P "Een ieder verbindende" verdragsbepalingen in: NJB 1962, pp. 94-95.

42 Jacobs A. De rechustreekse werking van intemationale nomen in her sociaal rechu. Preadvies voor de Vereniging van Arbeidsrecht; Alphen aan de Rijn 1985, p. 12. 
beschouwing worden gelaten, met name indien de norm voorziet in een zekere beleids ruimte: ${ }^{\text {s3 }}$ Sommigen dringen aas op een nadere verfijning van de objectieve toets, waarbi zij het, mijns inziens verdedigbare, standpunt innemen dat niet alleen de internationale norm: maar ook de concrete rechtstoestand die aan de norm wordt getoetst, bij de vaststelling vas de rechtstreekse werking in de beoordeling betrokken moet worden. ${ }^{4}$

Het zou te ver voeren om binnen het kader van deze algemene oriëntatie dieper op dezt boeiende discussie in te gaan. Ons interesseert primair de vraag of de door de $\amalg$ O ontwikkeld, normen inzake de vrijheid van vakvereniging voor rechtstreekse werking in aanmerking komen Aan de hand van een dergelijk onderzoek kan ook fraai geillustreerd worden dat het aanlegger van verschillende maatstaven tot verschillende uitkomsten kan leiden.

Art. 1 van ILO-Verdrag no. 87 bepaalt dat "Each Member of the International Labour Organisation for which this Convention is in force undertakes to give effect to the following provisions." Rechters die de intentie van de verdragsluitende partijen tot richtsnoer nemen, zouden rechtstreekse werking aan de bepalingen van dit verdrag kunnen onthouden, nu de onderstreepte passage zinspeelt op nadere uitwerking door de staten. Naar inhoud en strekking lenen de bepalingen van dit verdrag zich evenwel bij uitstek voor directe toepassing. $\mathrm{Zij}$ verlangen immers van de overheid geen andere prestatie dan dat zij zich onthoudt van inbreuken op de vrijheid van organisatie die in het Verdrag wordt gewaarborgd.

Enkele Westeuropese staten achten bepalingen van het Verdrag rechtstreeks toepasselijk, waaruit blijkt dat zij aan de bewoordingen "undertakes to give effect" zelfstandige betekenis ontzeggen. Zo heeft de Zwitserse Federale Raad art. 4 - het verbod aan het adres van de administratieve autoriteiten om werkgevers- en werknemersorganisaties te ontbinden - van rechtstreekse toepassing verklaard. ${ }^{45}$ Leary verwijst verder naar de handelingen der Staten Generaal in Nederland, waaruit zou blijken dat Nederland rechtstreekse werking toekent aan art. 3 dat betrekking heeft op de activiteiten van werkgevers- en werknemersorganisaties. ${ }^{46}$

43 Heringa tekent hierbij aan dat "nadere implementatie" en "beleidsruimte" slechts indicaties geven omtrent het niet-rechtstreeks werkende karakter wan de norm. Hij betoogt dat de rechter de internationale norm wel degelijk als toetssteen kan gebruiken - en derhalve rechitstreekse werking kan verlenen - indien de overheid de hem toegestane beleidsruimte duidelijk overschreden heeft. Heringa A.W. Sociale Grondrechten; Den Haàg 1989 , pp. 229 en 252 .

44 Jacobs trekt hieruit de verstrekkende maar logische conclusie dat men niet kan spreken van DE rechtstreekse werking. Van geval tot geval zal bekeken moeten worden of een internationale norm zich entoe leent om direct toegepast te worden. Jacobs, a.w. p. 14. Instemmend Heringa, a.w. pp. 243-244.

45. Leary, aw: p. 107.

46 Leary, a.w. p. 108. Deze opvatting is echter bepaald niet gemeengoed, getuige de uitspraak van de President van de Haagse Rechtbank die zowel aan Verdrag no. 87 , als aan Verdrag no. 98 rechtstreekse werking ontzegde. Pres. Rb 's-Gravenhage, 19-12-1980, NJCM-Bulletin 1981, p. 412 en Pres. Rb. s-Cravenhage, 21-011982, NJ 1984, 487.

Koopmans gaat zelfs zover om alle ILO-Verdragen te rangschikken onder de opdrachten aan de wetgever. Koopmans T. Conpendum wan het Staatsrecht, Deventer 1987, p. 63. In kritische zin daarover: Jacobs, a.w. p. 23. 
Tenslotte acht Italië art. 2 dat werkgevers en werknemers het recht toekent om organisaties op te richten en zich daarbij aan te sluiten, "self-executing"."

Wat betreft Verdrag no: 98 moeten we differentiëren. Art. 4 is mijns inziens een schoolvoorbeeld van een niet-rechtstreeks werkende bepaling, waar het de bevoegde autoriteiten consigne geeft om, in overeenstemming met de nationale omstandigheden, maatregelen te treffen, teneinde collectieve onderhandelingen te bevorderen. Art. 1 en art. 2 van Conventie no. 98 beogen vakbondsleden in bescherming te nemen tegen antivakbondsdiscriminatie van de kant van de werkgever (met name ontslag), resp. werknemersen werkgeversorganisaties te vrijwaren tegen inmenging in elkanders aangelegenheden. Art. 3 verwijst naar de beide voorgaande artikelen, waar het de overheid opdraagt om, zo nodig, procedures in het leven te roepen teneinde de bedoelde bescherming te waarborgen. Op zichzelf is deze laatste bepaling een instructienorm aan het adres van de autoriteiten, waaraan burgers niet direct rechten kunnen ontlenen. Rechters in landen met een monistisch stelsel hoeven naar mijn mening evenwel niet machteloos toe te zien als de wetgever verzuimd heeft om de maatregelen, waar art. 3 op doelt, te treffen. Gelet op het feit dat de artikelen 1 en 2 slechts een negatieve verplichting behelzen en in het licht van de imperatieve bewoordingen van deze bepalingen - "Workers (and employers) shall enjoy adequate protection" - kunnen deze rechters de bescherming zelf bieden. ${ }^{48}$ Met andere woorden: rechtstreekse werking van de artt. 1 en 2 van Verdrag no. 98 lijkt mij verdedigbaar.

Met nadruk zij gesteld dat bovenstaande bespiegelingen over het rechtstreeks werkende karakter van internationale normen op het gebied van de vrijheid van vakvereniging slechts een grove indicatie beogen te geven. Het is namelijk uiteindelijk de rechter die beslist of een internationale norm zich leent voor directe toepassing.

\subsubsection{De hiërarchie tussen internationale normen en nationaal recht}

De vraag of, in geval van onderlinge strijdigheid, aan de internationale norm dan wel aan de nationale rechtsregel voorrang moet worden verleend, doet zich uitsluitend voor in landen met een monistisch stelsel. In landen met een dualistisch stelsel is de hoge afkomst van de internationale norm immers in het vergeetboek geraakt, nu deze te vondeling is gelegd tussen de nationale rechtsregels en niet meer van zijn alledaagse broertjes te onderscheiden is. Op grond van het beginsel "lex posterior derogat lege priori" zal een in nationale wetgeving omgezette internationale norm dan ook moeten wijken voor een nationale wet van latere datum.

47 Leary, a.w. pp. 108-109.

48 Een complicerende factor hierbij is dat in een dergelijk geval rechtstreekse toepassing tevens het toekennen wan horizontale werking impliceert, maar dit is nu eenmaal inherent aan de meeste arbeidsverdragen en daarvoor zal de rechter ook niet mogen terugdeinzen. $V_{g l}$ Jacobs, a.w. pp. 17-18. 
De situatie is niet anders in staten met een monistisch stelsel die aan internationale norme dezelfde status geven als aan nationale wetten. Met name de Amerikaanse Constitutie verlee keurig voorrang aan verdragsbepalingen boven wetten van deelstaten, maar zwijgt over $\mathrm{d}$ verhouding tussen verdragen en federale wetten. De opvatting dat federale wetten va een latere datum dienen te prevaleren boven verdragen, is weliswaar door sommige auteu fors bekritiseerd, maar wordt wel door de Amerikaanse rechter in praktijk gebracht. ${ }^{\text {so }}$

In sommige landen, bijvoorbeeld Frankrijk en Zwitserland, heerst het verdrag over d nationale wet, ongeacht de chronologische volgorde waarin ze zijn uitgevaardigd. Zoals bekenc kunnen in Nederland verdragen zelfs de Grondwet opzij zetten. Wat belet de rechter da om met gulle hand het internationale recht toe te passen?! De naîeve charme van een derge lijke "cri de coeur" wordt onmiddellijk overschaduwd door de rechterlijke terughoudlendheir om aan verdragen voorrang te verlenen boven nationale wetgeving. Respect voor de machten scheiding ligt hieraan ten grondslag. Zolang de wetgever geen noodzaak ziet om de national wetgeving bij te stellen, moet de rechter niet eigenmachtig via de achterdeur de internationals regel binnenlaten om de nationale wet te overmeesteren, zo wordt geredeneerd. Door midde van een verzoenende wetsinterpretatie in het licht van de internationale norm kan de rechte gestalte geven aan het internationale recht, zonder dat hij daarmee de nationale wet hoef af te vallen. ${ }^{\text {s1 }}$ Doorgaans wordt de rechter evenwel niet geconfronteerd met een titanenstrijo tussen een internationale norm en een daarmee strijdige nationale wet (in formele zin), maar krijgt hij te oordelen over lagere wetgeving of bestuurlijk optreden dat uit het oogpunt van het internationale recht onaanvaardbaar is. In dergelijke gevallen kent de rechter meestal minder schroom om het internationale recht te laten prevaleren..$^{52}$

Verdragsconforme wetstoepassing, toetsing van lagere wetgeving en overheidshandelen aan internationale normen: het zijn toepassingsmodaliteiten die de rechter in de gelegenheid stellen om het internationale recht in zijn oordeel te betrekken, zonder dat hij het, in zijn ogen, sacrosancte terrein van de nationale wetgever hoeft te betreden. Daarbij komt het vraagstuk van de voorrang tussen nationaal en internationaal recht in een iets ander daglicht te staan, nu blijkt dat het internationale recht niet altijd ten koste van nationale wetgeving hoeft in te breken in de nationale rechtsorde.

49 Sommige federale Latijnsamerikaanse staten, voor wier grondwetten de Amerikaanse Constitutie model heeft gestaan, kennen eenzelfde constructie. Ik kom daar in 3.3 .3 nog wat uitvoeriger op terug.

50 Leary, a.w. pp. 118-119.

51 Deze verdragsconforme wetstoepassing biedt natuurlijk geen soelaas, indien de wet overduidelijk in strijd is met de internationale norm en geen ruimte biedt voor een andere interpretatie.

Vgl. Cassese A. Modem Constihutions and Intemational Law, RCADI 1985 (III), p. 398 en Leary, a.w. n.
117.

52 Jacobs, a.w. p. 19. Hierbij moet owerigens wel opgemerkt worden dat Jacobs' bespuegelingen betrekking hebben op de Nederlandse rechter. 
Niet alleen (rechtstreeks werkende) verdragsbepalingen, maar ook internationaal gewoonterecht kan in aanmerking komen om toegepast te worden door de nationale rechter. Dit gegeven is van belang, omdat, zoals we in de volgende paragrafen zullen zien, de ILO aan het beginsel van vakverenigingsvrijheid de status van internationaal gewoonterecht toekent.

Welke plaats het international gewoonterecht wordt toegemeten binnen de nationale rechtsorde, hangt af van de constitutionele orde van de staat in kwestie en verschilt dan ook van land tot land. Cassese geeft een bruikbaar overzicht van de positie van een groot aantal constituties in deze. ${ }^{53}$ Een uitgebreide bespreking van deze materie valt buiten het kader van dit proefschrift. In 3.3 .1 besteed ik aandacht aan de positie van het internationaal gewoonterecht binnen de Chileense rechtsorde. Voorlopig wil ik volstaan met enkele tentatieve opmerkingen.

In de eerste plaats vormt het feit dat een staat voor een monistische of dualistische benadering heeft geopteerd met betrekking tot verdragsbepalingen, geen enkele garantie dat die staat eenzelfde attitude heeft ten aanzien van internationaal gewoonterecht. Het komt voor dat verdragsbepalingen getransformeerd moeten worden in nationale wetten, terwijl regels van internationaal gewoonterecht automatisch deel uitmaken van de nationale rechtsorde..$^{54}$

In een gering aantal staten, en dit is mijn tweede kanttekening, is het internationaal gewoonterecht niet alleen geincorporeerd in de nationale rechtsorde, maar wordt er bovendien aan deze regels voorrang verleend boven nationale wetten. ${ }^{5 s}$ De constituties van de meeste landen kennen evenwel een veel bescheidener, zo al enige, betekenis toe aan het internationaal gewoonterecht. Zo kunnen in Frankrijk en Nederland, staten die toch een welwillende houding innemen ten opzichte van verdragsbepalingen, nationale wettelijke voorschriften niet getoetst worden aan het internationaal gewoonterecht. ${ }^{36}$ Dit betekent overigens niet dat het internationaal gewoonterecht geheel buiten het bereik van de rechter valt. Allereerst heeft de Hoge Raad in het Nyugat-arrest slechts de toetsing van wettelijke voorschriften aan het internationaal gewoonterecht willen uitsluiten. De doorwerking van het internationaal gewoonterecht in

Cassese, a.w. pp. 368-393:

54 Een goed voorbeeld hierwan is het Verenigd Koninkrijk. Higgins R. "United Kingdom" in Jacobs F.G./Roberts S. (eds.), a.w. p. 125 .

55 Cassese noemt met name Italië, Japan, Griekenland en Duitsland. Cassese, a.w. p. 371.

56 In Frankrijk wordt alleen in de Prambule van de Grondwet wan 1946, waaraan de Grondwet van 1958 refereert, werwezen naar andere bronnen van international recht (dan verdragsrecht). Zie Rochère de la J.D. "France in: Jacobs/Roberts, aw. p. 39 .

In Nederland heeft de Hoge Raad in het bekende Nyugat-arrest (HR 06-03-1959 NJ 1962, 2) het toetsingsverbod aan het internationaal gewoonterecht a contrario afgeleid uit de bewoordingen vain art. 66 (oud) Grondwet, dat correspondeert met het huidige art. $94 \mathrm{GW}$. De wetgever heeft bij de herziening van de Grondwet in 1983 niet de gelegenheild te baat genomen om het internationaal gewoonterechi te revalueren. 
de Nederlandse rechtsorde stond evenwel niet ter discussie. ${ }^{57}$ Niets belet de Nederlar rechter derhalve bestuurlijk optreden dat het uitvloeisel is van, in een nationale wet voorzi beleidswrijheid, te toetsen an internationaal gewoonterecht. In de tweede plaats kar rechter het nationale recht, waaronder wettelijke woorschriften, interpreteren in het licht het internationaal gewoonterecht. In navolging van Panhuys reserveert Heringa voor d werking van het internationale recht de term "reflexwerking": het nationale recht onderg als het ware een kleurspoeling door het internationale recht. ${ }^{50}$ Zo kan het internatior gewoonterecht een nuttige functie vervullen bij de nadere duiding van vage begrippen "redelijkheid", "billijkheid", "algemeen belang"."

Maar de Nederlandse rechter, en dit is mijn laatste kanttekening, blijkt niet altijd e scheutig om aan internationaalrechtelijke normen op het gebied van de rechten van de $m$ de status van internationaal gewoonterecht te verlenen. Twee uitspraken van de Hoge $\mathbf{R}_{\mathbf{i}}$ vormen een interessante illustratie van deze rechterlijke terughoudendheid. Het arrest ' 7 november 1984, waarin de HR weigerde om een formele wet aan de Universele Verklar van de Rechten van de Mens te toetsen, lag nog geheel in de lijn van het Nyugat-arre: In het arrest van 23 november 1984 was evenwel geen formele wet in het geding, maar vro eiser de rechter om bestuurshandelingen te toetsen aan de Universele Verklaring. $\mathrm{De} \mathrm{Hc}$ Raad maakte geen onderscheid en verwierp het beroep, waarbij hij letterlijk de passage het eerstgenoemde arrest herhaalde. ${ }^{2}$ Daarmee liet de Hoge Raad in het midden of Universele Verklaring opgevat kon worden als internationaal gewoonterecht en op de rechterlijke gemakzucht schoten zowel de annotator Alkema als Heringa hun kritische pij]

Vgl. Deegens in zijn noot onder het Nyugat-arrest: "Wij mogen ervan uitgaan dat er ongeschreven vollkenre bestaat dat uit eigen kracht binnen de Nederlandse rechtssfeer geldt." Zo ook Erades L. De verhouding tus. volkenrecht en nationaal recht in Nederland; NJB, 18-03-1950, no. 11, p. 218: "Men is het er algemeen o eens, dat de Nederlandse rechter costumier volkenrecht mag en moet toepassen."

58 Jacobs, a.w. p. 19.

59 van Panhuys H.F. Reflecties ower volkenrechwelijke reftexen im: NJB 1963, no. 5, pp. 73-80. Heringa, a.w, 261.

De term "reflexwerking" wordt overigens in werschillende betekenissen gebezigd. Vierdag en Verzijl gebruik het begrip ter adstructie van de rechten en plichten die burgers "als reflex" ontlenen aan een internation: staatsverplichting, met name indien deze verplichting condenseert in het witwaardigen van nationale wetgevi
ter uitwoering van een verdrag.

Vierdag E.W. The legal nature of the rights grawted by the intemational covenant on economic, social a cultural nights, NXTL 1978 , pp. $69-105$.

Verzill in: W.11443 (1926), pp. 1-2.

60 Heringa, a.w. p. 261. Jacobs, a.w. p. 19.

61. HR 07-11-1984, NJ 1985, 247: "Voor zover belanghebbendes klachten berusten op de opvatting dat de recht de wet dient te toetsen aan de Universele Verklaring van de Rechten van de Mens, falen zij $j_{\text {, }}$ omdat , Uniwersele Verklaring niet kan worden aangemerkt als een besluit als bedoeld in art. 67 van de destij. geldende Grondwet, nu de onderhavige resolutie niet berust op een bij of krachtens verdrag opgedrag
bevoegdheid om voor Nederland bindende besluiten te nemen (...).

HR 23-11-1984, NJ 1985, 604. 
af. Om te beginnen stelde Alkema zich op het standpunt dat de Universele Verklaring zich ontwikkeld had tot regels van internationaal gewoonterecht. Vervolgens gaf hij de Hoge Raad toe dat de Verklaring dus niet "een ieder verbindend" verdragsrecht in de zin van art. 93 en $94 \mathrm{Gr}$.w. was en niet als toetssteen voor formele wetgeving kon dienen. Daar in het onderhavige arrest evenwel niet formele wetgeving, maar (onrechtmatig) overheidshandelen ter discussie stond, had de Hoge Raad wel acht behoren te slaan op de Universele Verklaring, nu deze gekwalificeerd kan worden als "recht" in de zin van art. 99 Wet RO.

Met bovenstaande bespiegelingen heb ik beoogd een globaal inzicht te verschaffen in de ingewikkelde materie van de verhouding tussen nationaal en internationaal recht. In de volgende paragrafen spits ik dit vraagstuk toe op de hantering van internationale arbeidsnormen op het gebied van de vrijheid van vakvereniging door de nationale rechters van Chili, Colombia en Mexico en de (kritische) reactie van de ILO hierop.

3.3 De internationale verplichtingen van de staat en de constitutionele bepalingen inzake het internationale recht als uitgangspositie voor de nationale rechter

Zoals ik in de inleiding al heb aangegeven, markeren twee coördinaten de mogelijkheden van de nationale rechter om gestalte te geven aan het internationale recht. In de eerste plaats is de rechter afhankelijk van de internationale verplichtingen van de staat. In de tweede plaats is de rechter gebonden aan de constitutionele bepalingen inzake de doorwerking van internationaal recht in de nationale rechtsorde.

\subsubsection{Chili}

Chili heeft geen van beide sleutelconventies (nos. 87 en 98) geratificeerd, maar is, op grond van het lidmaatschap van de ILO, gehouden om de fundamentele beginselen van de organisatie te respecteren. Nota bene naar aanleiding van een grondig onderzoek naar de vakbondssituatie in Chili, heeft de Onderzoeks- en Bemiddelingscommissie inzake Vrijheid van Vakvereniging erop gewezen dat het beginsel van vakverenigingsvrijheid zich ontwikkeld heeft tot een regel van internationaal gewoonterecht dat zelfs voorrang heeft boven verdragen. ${ }^{* 4}$ De vraag die nu voorligt, is welke plaats het Chileense rechtsstelsel toekent aan internationaal gewoonterecht.

Zie noot E.E. Alkema, NJ 1985, 604, p. 1990.

Heringa (a.w. p. 269) gaat nog een stap verder door, in tegenstelling tot Alkema, ook niet-een ieder verbindende verdragsbepalingen te kwalificeren als "recht" in de zin van art. $99 \mathrm{RO}$.

64 Report of the fact finding and Conciliation Commission on Freedom of Association on the Trade Union Situation in Chile, Geneva 1975, 466 . 
In een belangwekkend maar inmiddels nogal gedateerd artikel heeft Benadava erop gewe dat Chili de doctrine van de automatische incorporatie omarmde en dat nationale rech derhalve verplicht waren om algemeen aanvaarde regels van international recht toe passen. ${ }^{\text {ss }}$ Onder "algemeen aanvaarde regels" diende in ieder geval internation gewoonterecht te worden verstaan. Bovendien werd aan internationaal recht priori verleend boven nationaal recht. ${ }^{67}$ Het Chileense Hoogste Gerechtshof had het primaat het internationale recht uitdrukkelijk gegrondvest in de noodzaak om particulieren de rech te verlenen die hun oorsprong hebben in de internationale rechtsorde. ${ }^{.8}$

Deze loffelijke houding ten opzichte van het internationale (gewoonte-) recht was tijd, het militaire bewind van Pinochet ver te zoeken, zoals in 3.4.1 nader geillustreerd zal word Cassese wijst erop dat de Grondwet van 1980 die de Constitutie van 1925 heeft vervang. geen enkele verwijzing bevat naar het internationale gewoonterecht. Hoewel Chili zich w dit betreft in het gezelschap van veel andere landen bevindt; wijt Cassese de constitutiont veronachtzaming van het internationale gewoonterecht in dit geval aan de argwaan jege en het gebrek aan interesse in de internationale gemeenschap.

\subsubsection{Colombia}

In tegenstelling tot Chili, heeft Colombia de ILO-verdragen nos. 87 en 98 geratificeerc Met betrekking tot de positie van het internationale recht in het algemeen en internationa verdragen in het bijzonder binnen de Colombiaanse rechtsorde heeft er lange tijd gro verwarring bestaan en tot op de dag van vandaag is de kwestie niet geheel opgehelder Gedurende de jaren vijftig en zestig placht de Colombiaanse regering de ILO te verzekere dat ILO-verdragen, eenmaal goedgekeurd door het Parlement, deel uit maakten van o nationale rechtsorde en dat de rechter voorrang moest verlenen aan verdragsbepalinges voorzover zij directe werking hadden, boven alle daarmee strijdige nationale wetgeving.

Lijnrecht hiertegenover stond de bewering van Alfonso Plata-Castilla dat Colombia ee zuiver dualistisch systeem kende, hetgeen impliceerde dat alle verdragsbepalingen getransfor meerd moesten worden in nationale wetgeving. Volgens hem berustten de eerdere uitsprake van de regering op de misvatting dat een parlementaire Goedkeuringswet toereikend wa om het verdrag effect te laten sorteren binnen de nationale rechtsorde: het verdrag moes

Santiago Benadava, Las relaciones entre Derecho Intentacional y Derecho Intemo ante los tribunales chilenos 59 Revista de Derecho, Jurisprudencia y Ciencias Sociales 1-2 (Enero-Abril 1962), p, 2.

Benadawa, a.w. p. 7 .

Bermadava, a.w. p. 27 .

Benadava, a.w p. 5, waar hij verwijst naar de zaak Lauritzen v. Fisco:

Cassese, a.w. pp. 381-382.

Leary, a.w. pp. $26-27$. 
omgezet worden in substantiële wetgeving; de enkele goedkeuring van het Parlement was niet afdoende. ${ }^{n}$

In het kader van de rapportageprocedure op basis van art. 40 van het BUPO-Verdrag, weerlegde de regering de opvatting van Plata-Castilla door; onder verwijzing naar Wet no. 7 van 1944, het Mensenrechten-Comite mee te delen dat verdragen, zodra zij geratificeerd waren, automatisch geïncorporeerd waren in de nationale rechtsorde. Dit betekende dat de bepalingen van het BUPO-Verdrag konden worden ingeroepen voor de rechter, zo vervolgde de regering. ${ }^{2}$ Over de hiërarchische verhouding tussen internationale normen en nationaal techt blijft echter onduidelijkheid bestaan. De leden van het Mensenrechten-Comité hebben expliciet vragen gesteld met betrekking tot de verhouding tussen het BUPO-Verdrag enerzijds en de Constitutie, wetten en decreten anderzijds, maar kregen hierop geen antwoord. ${ }^{\text {th }}$

\subsubsection{Mexico}

Sinds 1950 is Mexico partij bij ILO-Verdrag no. 87, maar het land heeft Verdrag no. 98 tot op heden niet geratificeerd.

Evenals Colombia, huldigt Mexico het principe van de automatische incorporatie van internationale verdragen en dit beginsel is expliciet opgenomen in de Constitutie van $1917 .^{74}$ Deze ogensehijnlijk welwillende houding ten opzichte van het internationale (verdrags)recht wordt enigszins overschaduwd door het gebrekkige begrip dat de regering gedurende lange tijd ten toon heeft gespreid met betrekking tot de problematiek van de rechtstreekse werking en door de hiërarchische gelijkschakeling van verdragen met federale wetten. Aan beide punten zal ik in het kort aandacht besteden.

In haar contacten met het ILO-Comité van Deskundigen pleegde de regering zich, tot 1970, uitsluitend te beroepen op art. 133 van de Constitutie om aan te geven dat de nationale wetgeving overeenstemde met ILO-verdragen. De regering leek een blinde vlek te hebben voor de problematiek van de rechtstreekse werking. Het Deskundigen-Comité nam geen genoegen met deze summiere uitleg: verdragsbepalingen die een nadere uitwerking van de kant van de wetgever of de uitvoerende macht vergden, konden niet direct rechten of verplichtingen voor particulieren in het leven roepen. ${ }^{5}$ In 1970 bezigde de Mexicaanse regering voor het eerst de term "autoaplicativa" ("self-executing"), waarmee zij in ieder geval aantoonde

71 Alfonso Plata-Castilla, Intemational Labour Standards and Colombian Legislation, 99 Int. Labour Review (1969), p. 142 .

72 Het vereiste van de rechtstreekse werking werd niet genoemd. CCPR/C/1/Add.50, 28-11-1979 onder (3).

73 CCPR/A/43/40 (1988), onder 511 en 513 .

74 Art. 133 wan de Mexicaanse Constitutie luidt, voorzover hier van belang: "'. verdragen, die in overeenstemming zijn met de Constitutie, afgesloten zjjn door de President van de Republiek en goedgekeurd zijn door de Senaat, wormen de Hoogste Wet van het land".

75 Algemene Observatie van het Deskundigen-Comitê; 1952; geciteerd door Leary, a.w. p. 101. 
dat zij zich bewust was van het feit dat art. 133 van de Constitutie geen voldoende gara voor toepassing van een verdragsbepaling in de nationale rechtsorde opleverde, tenzi] bepaling rechtstreekse werking had."

Over de hiërarchische verhouding tussen verdragsbepalingen en nationale wetgeving kur we kort zijn. Uit art. 133 van de Grondwet valt ondubbelzinnig af te leiden dat verdra ondergeschikt zijn aan de Constitutie, op gelijke voet staan met federale wetten en voorr hebben boven wetgeving van deel-staten. Dit impliceert dat verdragsbepalingen, op gri van het "lex posterior"-beginsel, buiten toepassing moeten blijven, indien zij botsen met federale wet van latere datum."

Welke gevolgen heeft het bovenstaande nu voor de toepassing door de rechter van Verd no. 877 In het Mexico-hoofdstuk is gebleken dat de kritiek van het Deskundigen-Comité z geconcentreerd heeft op de Federale Wet voor Werknemers in Dienst van de Staat. Di Federale Wet dateert uit 1963, zodat de rechter constitutioneel verplicht is om aan dezev voorrang te verlenen boven de daarmee strijdige verdragsbepalingen. Voor het over stemmen de nationale wetsbepalingen inzake de vrijheid van vakvereniging, naar de menj van de ILO, behoorlijk overeen met de internationale arbeidsnormen. De noodzaak i concrete bestuurshandelingen rechtstreeks te toetsen aan de bepalingen van Verdrag 1 87 ontbreekt, nu de Constitutie (art. 123) en de Federale Arbeidswet voldoende waarborg bieden. ${ }^{\text {to }}$ De woornaamste functie van het verdrag binnen de Mexicaanse rechtsorde is c het de rechter kan dienen als inspiratiebron. De rechter dient rechtshandelingen en wett te beoordelen in het licht van de verdragsbepalingen. Of de rechter ook daadwerkelijk vi deze mogelijkheid gebruik maakt, zal blijken in 3.4.3.

\subsection{De hantering van internationale (arbeids)normen door de rechter in de praktijk}

In de vorige paragraaf is aangegeven welke internationale verplichtingen de drie onderzoch landen zijn aangegaan met betrekking tot de bescherming van de vrijheid van vakverenigir op hun grondgebied en hoe de internationale normen, theoretisch gezien, kunnen doorwerke in de nationale rechtsorde. $\mathrm{Nu}$ moet nog onderzocht worden of de rechter daadwerkelij internationale normen op het terrein van de vrijheid van vakvereniging in zijn oordeel me laat wegen.

76 Leary, a.w. p. 102

77 César Sepulveda, La Sitwación de los Tratados en el Orden Legal Mexicana in Comunicaciones Mexicanas al VT Congreso Internacional de Derecho Comparado (1962), p. 210

78 Sepulveda, a.w. p. 213. In het mij ter beschikking staande materiaal ben ik geen voorbeelden tegen gekomen wan rechitstreekse toepassing van Verdrag no. 87 . 
Het spreekt vanzelf dat de rechter uitsluitend schendingen van mensenrechten van de kant van de uitwoerende macht kan corrigeren, indien hij in de gelegenheid is om kennis te nemen

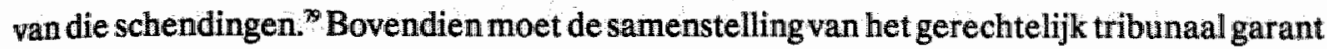
staan voor een onpartijdige afhandeling van de zaak.

Het feit dat deze garanties met name gedurende de eerste jaren van de regering-Pinochet ontbraken, rechtvaardigt op zichzelf al de ernstige twijfel omtrent het rechtstatelijk karakter van dit regime. Verscheidene malen hebben de toezichthoudende organen van de ILO kritiek uitgeoefend op het gebrek aan adequate rechterlijke controle op schendingen van vakbondsrechten door de autoriteiten. In sommige gevallen werden vraagtekens geplaatst bij de onpartijdigheid van het tribunaal en - dientengevolge - de efficiëntie van de procedure. ${ }^{\text {so }}$ In andere gevallen werd de rechter in het geheel niet geraadpleegd. ${ }^{\text {gI }}$

Zoals in het Chili-hoofdstuk al uiteen is gezet, trachtte Pinochet, naarmate de jaren verstreken, het geschonden blazoen van de mensenrechten te restaureren. De inschakeling van de rechter moest de indruk wegnemen dat de mensenrechtenpolitiek in het algemeen en het beleid ten aanzien van de vakbeweging in het bijzonder op willekeur gebaseerd was. Maar al snel bleek dat de positie van de rechter bij de eerbiediging van fundamentele rechten marginaal was. De in het licht van de internationale normen gebrekkige nationale wetgeving en het onvermogen (of de onwil?) om internationale normen in het oordeel te betrekken, speelden de rechter parten. Een klacht over het ontslag en de daaruit voortvloeiende diskwalificatie van vakbondsleiderschap van Rodolfo Seguel stelde het Comité inzake de Vrijheid van Vakvereniging in de gelegenheid om het eigen standpunt in deze te ontwouwen. ${ }^{22}$ Tot in hoogste instantie was het ontslag in stand gehouden, waarbij de rechter zich beriep op Wetsdecreet no. 2200 dat in samenhang met de Staatsveiligheidswet no. 1.2927 van 1958 het oproepen tot werkonderbreking in ondernemingen die van nationaal belang zijn, strafbaar stelde. Het Comité was echter van oordeel dat het ontslag verband hield met het ontplooien van legitieme vakbondsactiviteiten en derhalve een vakbondsdicriminatoir karakter had. De cruciale overweging luidde als volgt: "Het feit dat een gerechtelijke autoriteit in de ontslagprocedure intervenieert, vormt op zichzelf nog geen voldoende waarborg tegen antivakbondsactiviteiten, aangezien de bevoegdheid van de rechters in kwestie beperkt is tot de vaststelling dat de nationale wetgeving correct is toegepast". "Twee opvattingen liggen

79 Haba noemt de mogelijkheid tot gerechtelijke interventie een onontbeerlijk vereiste om een aanvaardbaar

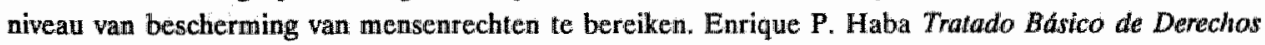
Humanos, Tomo II, San José 1986, p. 533.

80 Hoofdstuk 3, pp. 103 en 108.

81 Hoofdstuk 3, p. 104 (arrestatie en detentie van wakbondsleden); p. 106 (ontbinding vakbond); p. 136 (huiszoeking zonder rechterlijk bevel).

82 Zie Hoofdstuk 3, p. 140. De gehele kwestie nam drie jaar (1983-1986) in beslag.

83 Case No. 1309, 241e Rap. \&803. 
in deze uitspraak besloten. In de eerste plaats deugt, naar het oordeel van het Comite nationale wetgeving op dit punt niet, hetgeen ons niet hoeft te verbazen, gezien het feit het Comite al eerder aanmerkingen had gehad op ontsllagprocedures die gebaseerd wa op dit Wetsdecreet. Van veel groter belang is evenwel dat het Comite de nodige scepsis etal met betrekking tot de mogelijkheden van de Chileense rechter om nationale wetgevin interpreteren in het licht van de internationale arbeidsnormen of, zo nodig, die wetgev ten faveure van de internationale normen buiten toepassing te laten. Dit sceptische standp lijkt mij realistisch.

De negatieve houding van de Chileense rechter ten opzichte van het internationale re kan geillustreerd worden aan de hand van een uitspraak van het Hoogste Gerechtshof oktober 1984) die uitvoerig door Cassese geanalyseerd is. ${ }^{84}$ Eiseres in het geding had gest dat de verbanning van haar vader door de autoriteiten in strijd was met art. 12 van het BUP Verdrag. ${ }^{25}$ Het Chileense Hof had geweigerd om dit beroep te honoreren. Chili is pa: bij het BUPO-Verdrag sinds 1972 en de ratificatie werd op 30 november 1976 bij Wetsdecr bekrachtigd. De publicatie van dit Wetsdecreet was echter achterwege gebleven en h ontleende het Hof het eerste argument aan om het Verdrag buiten toepassing te laten, aany zien publicatie een vereiste was om aan een wet verbindende kracht te verlenen. Verd kon het Verdrag nimmer direct rechtsgevolgen sorteren binnen de nationale rechtsorde, omc enerzijds het Chileense recht expliciet nadere wettelijke implementatie van een verdrag verg en, anderzijds, art. 2, lid 2 BUPO-Verdrag niet in automatische incorporatie van het Verdr: voorzag. Dit laatste vereist enige nadere toelichting. Lid 2 van art. 2 BUPO-Verdrag bepaz dat iedere staat alle wettelijke of andere maatregelen dient te nemen die nodig zijn om ( rechten van het Verdrag tot gelding te brengen. Blijkbaar legde het Hof deze verdragsbepali aldus uit dat de verdragspartijen nimmer beoogd hadden dat het verdrag direct, dat wil zegge zonder uitvoeringswetgeving, in de nationale rechtsorde kon doorwerken. Terecht gispt Casse: in een kritische noot deze legalistische interpretatie van het Hof. Men kan uit de bewoordinge van art. 2, lid 2 de wijze waarop de verdragsbepalingen ten uitvoer moeten worden geleg، niet afleiden. Men kan daarentegen op basis van deze bepaling wel verdedigen dat de rechte de nationale wetgeving moet interpreteren op een wijze die toepassing van het verdrag o nationaal niveau mogelijk maakt. Het Hof had zich met andere woorden niet mogen late weerhouden door de formaliteit van publicatie om uitvoering te geven aan de bepalinge
van het verdrag.

Art. 12. BUPO-Verdrag regelt, woorzover hier wan belang, het recht on zich in eigen land vrij te verplaatsen
zich or te vestigen, benevens het recht or het

Cassese, a.w. pp. 458-459, noot 113. Bovendien merkt Ce verlaten en er terug te keren.

dat Chill de transformatie-leer huldigt, moeilijk te rijmen is op dat de opvatting wam het Hoogste Gerechtshol aan het Mensenrechten-Comite dat het BUPO-Verdrag, na geratifice verzering van de Chileense rapporteur deel uitmaakt van de Chileense rechtsordle. (CCPR, na geratificeerd en bekrachtigd te zijin, automatisch 
Hoewel in het zojuist geschetste geval een verdragsbepaling en niet een bepaling van internationaal gewoonterecht ter discussie stond, geeft het arrest een betrouwbare indicatie omtrent de algemene attitude van de Chileense rechterlijke macht ten tijde van Pinochet ten opzichte van het internationale recht. De bereidheid om aan het internationale recht op creatieve wijze gestalte te geven, leek in die periode niet groot, zo kan de conclusie luiden.

\subsubsection{Colombia}

De toezichthoudende organen van de ILO hebben zich in het geval van Colombia tweemaal een oordeel kunnen vormen over een gerechtelijke (beroeps)procedure.

In 1982 nam het Comite inzake de Vrijheid van Vakvereniging een klacht in behandeling over het intrekken van de rechtspersoonlijkheid van een aantal federaties van vakverenigingen. De Minister van Arbeid en Sociale Zaken had deze maatregel genomen naar aanleiding van een subversieve staking en op grond van Wetsdecreet no. 2932 dat uitgevaardigd was met het oogmerk om misbruik van vakbonden voor subversieve doeleinden te bestrijden. De gedupeerde federaties hadden beroep aangetekend bij de rechter, maar intussen bleef de sanctie van kracht. Het Comité overwoog dat gedurende de beroepstermijn schorsende werking moest worden verleend en dat de sanctie uitsluitend opgelegd kon worden door de rechter die in de gelegenheid moest zijn om de achtergronden van het rechtsgeschil te beoordelen in het licht van de bepalingen van Verdrag no. $87 . .^{87}$

Een dergelijke expliciete verwijzing naar verdragsbepalingen komen wij ook tegen in de Observation van 1985 van het Comité van Onafhankelijke Deskundigen. Hier stond de procedure inzake de erkenning van rechtspersoonlijkheid van vakbonden centraal. De Colombiaanse regering had in haar rapport van 1984 erop gewezen dat op grond van art. 85 van de Wet Administratieve Geschillen (1984) tegen een negatieve beschikking van de administratieve autoriteiten om rechtspersoonlijkheid te verlenen, beroep open stond bij de rechter. Het Comite van Deskundigen nam kennis van deze mededeling, maar overwoog dat een dergelijk beroep uitsluitend een toereikende waarborg bood, indien de rechter niet alleen kon vaststellen dat de wet op juiste wijze was toegepast, maar ook de gronden, waarop de administratieve beschikking berustte en de inhoudelijke aspecten van de zaak kon toetsen in het licht van de bepalingen van Verdrag no. $87 .{ }^{\text {.8 }}$

Welke betekenis moeten wij nu toekennen aan deze uitspraken? Van belang is dat in beide gevallen de Colombiaanse wetgeving op zeer gespannen voet stond met de verdragsbepalingen. Voor een verdragsconforme toepassing bood de wet de rechter weinig of geen ruimte. Men zou de uitspraken van de ILO-organen kunnen opvatten als een aanspo-ring aan het adres van de rechter om op vermetele wijze direct de verdragsbepalingen toe te passen en de nationale wetgeving buiten beschouwing te laten. Maar het is, gelet op de in 3.3.2 
ontvouwde, schemerige verhouding tussen nationaal en internationaal recht in Colombi zeer de vraag of de rechter hiertoe uberhaupt bevoegd is. Het lijkt mij correcter om 1 veronderstellen dat de overwegingen van de $1 \mathrm{LO}$-organen eerder uitdrukking geven aan ee wenselijkheid, dan dat zij refereren aan een reële optie. Ook het klemmende beroep d: de ILO naar aanleiding van deze zaken deed op de wetgever om de wetgeving in overeer stemming te brengen met de verdragsbepalingen, wijst in deze richting $\left({ }^{*}\right)$ : de wetgever mot aan zijh verplichtingen voldoen, opdat de rechter tot een uitspraak kan komen die strook met de internationale normen. Van de rechter mag niet verwacht worden dat hij, geconfron teerd met een overduidelijk conflict tussen de nationale wetgeving en een internationale norm aan de laatste vanzelfsprekend voorrang zal verlenen.

\subsubsection{Mexico}

De ILO heeft in het geval van Mexico verscheidene malen concrete rechterlijke uitspraker onderzocht op hun verenigbaarheid met de internationale normen inzake de vrijheid var vakvereniging.

In de discussie tussen het Comité inzake de Vrijheid van Vakvereniging en de Mexicaanse regering stond de principiële vraag centraal of internationale organisaties überhaupt wel competent zijn om rechterlijke uitspraken te toetsen. Het standpunt van de regering kwam, kort weergegeven, op het volgende neer. ${ }^{90}$ De ILO was niet bevoegd om zich te mengen in de activiteiten van de rechter en a fortiori was het haar niet toegestaan om uitspraken van Mexicaanse rechters te herzien. Ter staving van dit verbod beriep de regering zich op de onafhankelijkheid van de rechterlijke macht, het beginsel van de scheiding der machten en de nationale soevereiniteit. ${ }^{\text {.n }}$.

Het Comité deelde de opvatting van de regering dat toezichthoudende organen van een internationale organisatie niet bevoegd zijn om rechterlijke uitspraken te herzien. Evenmin, zo vervolgde het Comite, bezitten zij de competentie om te beslissen welke interpretatie gegeven dient te worden aan de wetgeving van een staat. Onmiddellijk voegde het Comité hier evenwel aan toe dat herziening, noch interpretatie aan de orde waren. Het Comite wenste uitsluitend te onderzoeken of de wetgeving, dan wel de roepassing van de wetgeving strookten met de internationale normen en beginselen op het gebied van de vrijheid van vakvereniging."

De repliek van het Comite is volstrekt juist. Voorzover de redenering van de regering de strekking heeft om, met een beroep op de onafhankelijkheid van de rechter, diens uitspraken te vrijwaren tegen een kritisch onderzoek van de kant van internationale organisaties, getuigt zij van een gebrekkig inzicht in het internationale recht. De begrippen "machtenschei-

89

90

91

92

Zie: Cases Nos. 1083-1085, 214 e Rap. $\$ 449$ en Observation 1985, onder (1), laatste alinea.

Voor een uitvoeriger analyse wordt werwezen naar het hoofdstuk 5, pp. 245-247.

Case No. 492, 118e Rap. $\$ 106$ en Case No. 827, 160e Rap. $\$ 257$. 
ding" en "onafhankelijke rechter" behoren tot het domein wan het nationale recht. De staat is als entiteit verantwoordelijk om zijn internationale verplichtingen na te komen en kan zich tegenover een internationale organisatie niet beroepen op de interne competentie-afbakening. Ook de rechter kan, met andere woorden, de staat aansprakelijk laten zijn door bijwoorbeeld het internationale recht verkeerd te interpreteren of internationale normen ten onrechte buiten beschouwing te laten, ${ }^{93}$

Welke gevolgen heeft dit standpunt nu gehad voor de beoordeling van de uitspraken van de Mexicaanse rechter die het Comité onder ogen heeft gekregen? De meeste klachten hadden betrekking op strafrechtelijke veroordelingen van vakbondsleden. De klagende organisaties beweerden dat de vakbondsleden ten onrechte veroordeeld waren wegens het uitoefenen van legitieme vakbondsactiviteiten. Het Comité stelde hen in alle gevallen in het ongelijk. Zinspelend op art. 8, lid 1 van Verdrag no. 87, waarin gesteld wordt dat de uitoefening van vakbondsrechten geen vrijbrief oplevert voor de overtreding van de wet, concludeerde het Comité dat de rechter in redelijkheid had kunnen aannemen dat de vakbondsleden zich schuldig hadden gemaakt aan strafrechtelijke vergrijpen. Toetsing van het rechterlijk oordeel bracht met andere woorden het Comité tot het inzicht dat de Mexicaanse rechtspraktijk althans in deze gevallen in overeenstemming was met de beginselen inzake vrijheid van vakvereniging. Ook de vernietiging van een negatieve beschikking op een verzoek om registratie van de klagende instantie kon de goedkeuring van het Comité wegdragen. ${ }^{95}$

Een markante uitzondering op deze serie fraaie rapportcijfers vormt Case No. 603. De rechter had een staking illegaal verklaard en was daarbij geheel voorbij gegaan aan het feit dat de staking was uitgeroepen als protest tegen massa-ontslagen van vakbondsleden. Onder verwijzing naar art. 1 van Verdrag no. 98 suggereerde het Comité dat de rechter hiermee verzuimd had om de vakbondsleden adequate bescherming te bieden tegen anti-vakbondsmaatregelen van de kant van de werkgever. ${ }^{\circ 6}$ Het interessante aan deze kwestie is dat de nationale wetgeving niet ter discussie stond. De rechter had, door een foutieve benadering van de rechtsvraag, ten onrechte nationale wetgeving die op zichzelf in het licht van de internationale normen voldoende waarborgen bood, buiten beschouwing gelaten en zodoende internationale normen inzake de vrijheid van vakvereniging geschonden.

Uit het bovenstaande kan geconcludeerd worden dat de ILO er niet voor terug deinst om rechterlijke uitspraken te toetsen aan de internationale normen op het gebied van de

93 Vgl. Mc Nair A.D. Law of Treaties, London 1961, p. 346: "... a State has a right to delegate to its judicial department the application and interpretation of treaties. If, however, the courts commit errors in that task or decline to give effect to a treaty or are unable to do so because the necessary change in, or addition to, the national law has not been made, their judgments involve the State in a breach of treaty."

94 Case No. 492, 118e Rap. 108 en 124e Rap. $\$ 88,79 /$ Case No. 773, 147e Rap. $\$ 116 /$ Case No. 827,160 e Rap. \$274. In Case No. 358, 98e Rap. \&59 kwam het Comite tot eenzelfde conclusie, maar in dit geval was de toetsing van het rechterlijk oordeel, in tegenstelling, tot de andere zaken, zeer marginaal, vgl. hoofdstuk 5, p. 245.

95 Case No. $696,138 \mathrm{e}$ Rap. $\$ 14$.

96 Case $\mathrm{No}_{\text {. }} 603$, 129e Rap. 81-82 en 84; 133e Rap. 8182. 
vrijheid van vakvereniging. Het is opmerkelijk dat in geen der rechterlijke beslissingen o positief gewaardeerd werden door het Comité, expliclet gerefereerd werd aan internationa normen. Dat boeft niet te betekenen dat de rechter zich bij de toepassing van het recht ni heeft laten inspireren door deze normen. Voor de ILO is het resultaat - de wetgeving , de toepassing daarvan moeten stroken met de internationale normen - van doorslaggeven betekenis. In de, althans in Mexico, zeldzame gevallen waarin de toepassing van het rec. niet verenigbaar is met de internationale normen, is het Comite voldoende alert om de regeri hierop te attenderen.

\subsection{Evaluatie en conclusies}

In bovenstaande paragrafen heb ik geprobeerd om een beeld te schetsen van de mogelijkhede en de bereidwilligheid van rechters in de drie Latijnsamerikaanse landen om internationaa rechtelijke normen in hun oordeelsvorming te betrekken. Speciale aandacht is geschonke aan de toepassing van de ILO-normen inzake de vrijheid van vakvereniging en de kritisch reflectie van de toezichthoudende organen van de ILO op deze rechterlijke arbeid. Het belan van het rechterlijk optreden vloeit voort uit het feit dat de internationale en de nationali rechtsordes niet versmolten zijn. De staat weet zich op het internationale vlak gebonden aa bepaalde verplichtingen maar beschikt over de nodige vrijheid on deze verplichtingen binnel de eigen rechtsorde ten uitvoer te léggen. Elk van de drie "machten" heeft een specifiekı verantwoordelijkheid om gestalte te geven aan de internationale normen, waaraan de staa

gebonden is. Een primaire taak rust op de schouders van de wetgever: hij moet er zorg voo. dragen dat de nationale wetgeving overeenstemt met de internationale normen. Maar waa de wetgever tekort is geschoten kan de rechter soms corrigerend optreden door de nationale wetgeving buiten beschouwing te laten en internationale normen rechtstreeks toe te passen Anderzijds is het niet uitgesloten dat de rechter aan op zichzelf aanvaardbare wetgeving een uitleg geeft die niet strookt met internationale normen. Deze autonome verantwoordelijkheid van de rechter komt ook tot uitdrukking in de woorden van Jenks die, toegespitst op de vrijheid van vakvereniging, stelt dat een onberispelijke wetgeving nog geen garantie hoeft te zijn voor een behoorlijke eerbiediging van vakbondsrechten in de praktijk. Aan de andere kant zal een gebrekkige wetgeving nog niet altijd een onomstotelijk bewijs vormen dat het ook in de praktijk droevig gesteld is met de vakverenigingsvrijheid." ${ }^{97}$

Voor de internationale organisatie brengt dit mee dat zij niet alleen de nationale wetgeving, maar ook rechterlijke uitspraken aan een nawweurig onderzoek dient te onderwerpen om een betrouwbare indruk te krijgen van de mate, waarin een staat aan zijn internationale verplichtingen voldoet. 
Hoe voltrekt deze wisselwerking tussen wetgever, rechter en internationale organisatie zich $\mathrm{nu}$ in de drie Latijnsamerikaanse landen? Wij dienen hïer duidelijk te differentiëren. Uit het onderzoek is gebleken dat de nationale wetgeving in Chili tijdens het regime van Pinochet op tal van punten regelrecht in strijd was met de internationalle normen op het gebied van de rechten van de mens. Bovendien werd het isolement van Chili ten opzichte van de internationale rechtsgemeenschap weerspiegeld in het feit dat de rechter hetzij niet in staat was, hetzij niet bereid bleek te zijn om internationale normen in zijn oordeel te betrekken. Dit bracht de ILO tot de conclusie dat de inschakeling van de rechter, voorzover dit al plaatsvond, geen garantie bood voor een toereikende bescherming van vakbondsrechten.

De Colombiaanse wetgeving staat, evenals de Chileense zij het in iets mindere mate, op gespannen voet met ILO-normen inzake de vrijheid van vakvereniging. De rechter beschikt in Colombia, althans in theorie, evenwel over ruimere mogelijkheden dan zijn Chileense collega om internationaalrechtelijke normen toe te passen, gezien de ratificatie van de sleutelconventies en de prominente plaats die het internationale recht inneemt binnen de Colombiaanse rechtsorde. Niettemin heeft de ILO tweemaal laten doorschemeren dat zij de kans dat de rechter aan internationale normen voorrang verleent boven daarmee strijdige nationale wetgeving niet erg groot acht. ${ }^{98}$

In Mexico tenslotte is de rechter het best toegerust om tot een beslissing te komen die in overeenstemming is met de ILO-normen. De nationale wetgeving strookt in grote lijnen met deze normen en bovendien brengt het stelsel van automatische incorporatie het internationale recht binnen handbereik van de rechter. Toch blijkt met name uit de "case law" van het Comité inzake de Vrijheid van Vakvereniging dat de $\mathrm{LO}$ zich niet laat verblinden door deze fraaie façade. Telkens neemt het Comité de moeite om rechterlijke uitspraken aan een nauwgezet onderzoek te onderwerpen en in eén geval heeft het een rechterijjke beslissing, gewogen tegen de ILO-normen, te licht bevonden."

Uit bovenstaande gegevens zijn twee conclusies te trekken. In de eerste plaats lijkt de zelfstandig-corrigerende functie van de nationale rechter in de onderzochte landen nauwelijks

98 Op zich vormen twee uitspraken, waarvan bovendien de duidelijkheid nog te wensen overlaat, een magere basis voor een dergelijke verstrekkende conclusie. De Colombialanse regering heeft evenwel ongewild de terughoudende opstelling van de Colombiaanise rechter ten aanzien van het internationale recht geacesntueerd door in het rapport aan het VN-Mensenrechten-Comite erop te wijzen dat de rechter in feder geval een keer bepalingen van het BUPO-Verdrag had toegepast. Hoewel deze mededeling natuurlijk niet vitsluit dat de rechter andere bronnen van internationalal recht in zijn oordeel betrekt, geeft zij een indicatie omtrent: de passieve houding van de rechter op dit gebied. CCPR/A/43/40 (1988), p. 120 .

99 Zoals in het Mexico-hoofdstuk en hierboven gesteld is, vond dit "nauwgezette onderzoek" niet plaats in Case No. 358. Deze zaak die ik ook in de paragraaf over polilieke activiteiten wan vakbonden wan kritisch commentaar heb voorzien, moet waarsichijnlijk worden beschouwd als cen betreurenswatardige "uitschieter". $\mathrm{Nu}$ het Comite in andere zaken die betrekking hadden op Mexico wel de moeite heeft genomen om het rechterlijk oordeel aan een nader onderzoek te onderwerpen, dient aan de summiere toetsing in de bedoelde zaak mijns inziens geen bijzondere betekenis te worden werbonden. 
tot ontplooing te zijn gekomen. ${ }^{100}$ Waar de rechterlijke uitspraak in harmonie is met c internationale normen, zoals in veel gevallen in Mexico, is dit het gevolg van het feit $d$ de nationale wetgeving al in overeenstemming is met deze normen. Hoogstens zal de rechte bij de uitleg van nationale wetgeving, het internationale recht als inspiratiebron gebruike maar dit valt uit de "case law" van de ILO niet duidelijk op te maken. In dit licht is ht begrijpelijk dat de ILO meestal geen genoegen neemt met de verzekering van een regerin dat het stelsel van automatische incorporatie voldoende waarborgen biedt voor de nalevin door de staat van ILO-verdragsbepalingen, zeker niet indien de nationale wetgeving of gespannen voet staat met internationale normen. ${ }^{101}$ Eerbied voor de nationale wetgevin zal de rechter er dikwijls van weerhouden om, in geval van strijd, aan internationale normes de voorrang te verlenen en een gebrekkige wetgeving vormt voor de ILO dan ook een ernstig aanwijzing dat ook de rechtspraktijk niet (geheel) zal corresponderen met de international normen.

In de tweede plaats bijkt de ILO zich er terdege van bewust te zijn dat; omgekeerd correcte nationale wetgeving nog niet een garantie is dat de rechtspraktijk in alle gevaller zal overeenstemmen met de internationale normen inzake de vrijheid van vakvereniging. Het risico dat de rechter de wetgeving interpreteert op een wijze die niet strookt met de internationale normen, vergt een voortdurende wakkzaamheid van de kant van de toezichthoudende organen, met name van het Comité inzake de Vrijheid van Vakvereniging. Deze bestendige praktijk relativeert de, soms door de ILO aan de dag gelegdle voorkeur voor transformatie in wetgeving boven automatische incorporatie. Waar het stelsel van automatische incorporatie een grotere afstand van de rechter ten opzichte van de nationale wetgeving suggereert dan hij zelf meestal bereid is te nemen, verbult, omgekeerd, een beroep op transformatie van verdragsbepalingen in wetgeving dat de rechter doorgaans over een zekere mate van interpretatieve vrijheid beschikt. In beide gevallen kan slechts de verschuiving

100 Enrique Haba gaat zelfs zover te suggereren dat de rechters in de meeste Latijnsamerikaanse landen "mentaal geblokkeerd" zijn on internationaalrechtelijke normen rechistreeks toe te passen, alle plechtige loyaliteitsverklaringen aan het internationale recht ten spijt. Haba Enrique $\mathbb{P}$. Tratado Bósico de Derechos Humanos, Tomo I, San Jose 1986; p. 452.

$101 \mathrm{Vgl}$. Leary, aw; pp. 31 en 157.

102 Leary constateert deze woorkeur en levert er kritiek op door de positie van de rechtzoekende burger tot uitgangspunt te nemen. In landen met een stelsel van automatische incorporatie kan de justitiabele in ieder geval voor de rechter een beroep doen op verdragsbepalingen. In een dualistisch stelsel is de weg naar de rechter afgesloten. Particulieren moeten hum heil zoeken bij de wetgewer, een instantie waarop een individu niet of nauwelijks invloed kan uitcefenen. Leary, a.w. pp. 156-158.

Toch valt de sympathie voor het transformatiesysteem wel te verklaren, gezien het feit dat, buiten de geavanceerde controlemechanismen bij de vrijheid van valkvereniging; de toezichthoudende organen van de $I L O$ weinig mogelijkheden hebben om rechterlijke uitspraken te controleren. Het Comite van Deskundigen beperkt zich voornamelijk tot bestudering van wetgeving en toegegeven moet worden dat in landen met een transformatiestelsel meer duidelijkheid bestaat omtrent de verenigbaarheid van deze wetgeving met
internationale arbeidsnormen. 
wan het controlemoment naar de rechterlijke uitspraak een betrouwbare aanwijzing opleveren voor de naleving door de staat van internationale normen in de praktijk.

Hoe ver mag de ILO nu gaan bij het controleren van rechterlijke uitspraken? Terecht heeft het Comite inzake de Vrijheid van Vakvereniging te kennen gegeven dat het zich niet bevoegd acht om een rechterlijke uitspraak te herzien. Net zomin als de ILO zelfstandig nationale wetgeving mag wijzigen die zij in strijd acht met de internationale normen, kunnen rechterlijke uitspraken herzien worden. Dit zou, naar de huidige stand van het internationale recht, een ontoelaatbare inbreuk op de nationale soevereiniteit van een staat betekenen. De ILO moet volstaan met een toetsing van de rechterlijke uitspraak aan de internationale normen inzake de vrijheid van vakvereniging en dient de regering van een eventueel geconstateerde discrepantie op de hoogte te brengen. De nationale autoriteiten moeten zich vervolgens beraden over de stappen die genomen moeten worden om de schending van het internationale recht ongedaan te maken.

Mijn conclusie is dat het geavanceerde controlesysteem op het gebied van de vrijheid van vakvereniging de ILO in de gelegenheid stelt om zich een oordeel te vormen over de naleving van internationale normen in de (rechts)praktijk en dat de toezichthoudende organen van deze mogelijkheid een voortvarend gebruik maken. De ILO onderkent dat het van groot belang is om rechterlijke uitspraken nauwkeurig te analyseren, omdat zij een signaalfunctie vervullen omtrent de mate waarin de rechtspraktijk in overeenstemming is met de internationale normen op het gebied van de vakverenigingsvrijheid. Terecht laat de ILO zich niet misleiden door de begrippen "scheiding der machten" en "onafhankelijkheid van de rechterlijke macht" die soms door staten als bezwerende formules worden gehanteerd om toetsing van rechterlijke uitspraken tegen te gaan. Deze begrippen kunnen niet als alibi fungeren voor een gebrekkige naleving van internationaalrechtelijke verplichtingen.

\section{Vakbondsmonopolies revisited. Een kritische beschouwing over het ILO-standpunt inzake "closed shops"}

\subsection{Inleiding}

Vakbondsmonopolies kunnen bij wet zijn ingesteld en kunnen in de praktijk ontstaan. Het onderscheid is van groot belang, aangezien de ILO beide situaties verschillend pleegt te beoordelen. Zowel in het eerste hoofdstuk (over de ILO en de verhouding tussen staat en vakbeweging) als in de hoofdstukken over Colombia en Mexico is gebleken dat de toezichthoudende organen van de ILO in de wet verankerde vakbondsmonopolies in strijd achten met de vrijheid om organisaties naar eigen keuze op te richten en zich daarbij aan te sluiten (art. 2, Verdrag no. 87) ${ }^{103}$ De ILO heeft daarbij op zijn minst de suggestie gewekt dat 
dergelifke vakbondsmonopolies de onafhankelijkheid van de vakbeweging ingevaar brengen. Tegen vakbondsmonopolies die ontstaan zijn in de praktijk, maakt de ILO geen bezwaar. ${ }^{\text {106 }}$

Het is interessant dat in Mexico beide vormen naast elkaar voorkomen. De wet bepaalt dat in de publieke sector per overheidsdienst slechts één vakbond kan functioneren. In particuliere ondernemingen worden vakbondsmonopolies dikwijls verwiezenlijkt door het opnemen van "closed shop"-clausules in een CAO.

In de voorgaande hoofdstukken is al enkele malen de vraag opgeworpen of een dergelijk onderscheid in benadering en beoordeling naar juridische grondslag door de ILO wel in alle gevallen gerechtvaardigd is. In deze paragraaf beoog ik te onderzoeken of vakbondsmonopolies, voorzover zij het uitvloeisel zijn van "closed shop"-constructies, op gespannen voet staan met het recht van vakverenigingsvrijheid. Daartoe zal eerst in 4.2 worden aangegeven welke individuele en collectieve - rechten van werknemers en vakbondsleden ten gevolge van "closed shop"-clausules onder druk komen te staan. Vervolgens zal ik in 4.3 nagaan of de belangen die met behulp van clausules inzake verplicht vakbondslidmaatschap gediend worden, voldoende gewicht in de schaal leggen om een inperking van de in 4.2 genoemde rechten te rechtvaardigen. Hierbij zal ik in het bijzonder aandacht besteden aan de, binnen het kader van de Internationale Arbeidsconferentie (hierna: ILC), gevoerde discussies die betrekking hadden op deze belangenafweging.

Indien kan worden aangetoond dat vakbondsmonopolies die het gevolg zijn van "closed shop"-bepalingen, onverenigbaar zijn met het recht van vrijheid van vakvereniging, dan vloeit hier rechtstreeks uit voort dat het door de ILO gemaakte onderscheid tussen wettelijke en feitelijke vakbondsmonopolies niet houdbaar is. De ILO heeft dit onderscheid onder meer trachten te verdedigen door erop te wijzen dat wettelijke en feitelijke vakbondsmonopolies voortkomen uit verschillende intenties van de staat resp. de vakbeweging. In $4.4 \mathrm{ga}$ ik dieper in op de vraag of deze veronderstelling wel geheel gegrond is, voorzover het de vergelijking tussen de motieven die ten grondslag liggen aan wettelijke en op "closed shop"-clausules gebaseerde vakbondsmonopolies, betreft. Tenslotte wil ik in 4.5 , na een korte samenvatting, een voorstel voor een herziening van het ILO-standpunt inzake de "closed shop" doen, een herziening die naar mijn mening beter aansluit bij de internationale normen op het gebied van de vrijheid van vakvereniging.

4.2 De verhouding tussen "closed shop"-clausules en de positieve en negatieve coalitievrijheid

Een "closed shop"-clausule is een bepaling in een $\mathrm{CAO}$, waarbij de werkgever zich verplicht om uitsluitend vakbondsleden in dienst te nemen en te houden. ${ }^{105}$ In deze paragraaf staat

104 Zie hoofdstuk 1, pp. 63-64; hoofdstuk 5, p. 237.

105 Er kan onderscheid gemaakt worden tussen de closed shop in engere zin (of pre-entry shop), waarbij de werkgever zich verplicht om, in geval van een vacature, te recruteren uit het ledembestand van de vakbond en de whion shop (of postentry shop), waarbij de werkgever de handen wrij heeft om aan te stellen wie hij 
de vraag centraal of dergelijke bepalingen de vrijheid van vakvereniging van werknemers en van andere vakbonden (dan de vakbond die de CAO heeft afgesloten) kunnen aantasten.

Voor een werknemer betekent een "closed shop"-clausule dat het lidmaatschap van een vakbond een voorwaarde is voor het verkrijgen en het behoud van een dienstbetrekking. Ontduiking van dit verplichte vakbondslidmaatschap leidt in beginsel tot het ontslag van de betrokken werknemer. De "closed shop"-clausule heeft met andere woorden repercussies binnen een privaatrechtelijke rechtsverhouding en dit werpt de prealabele vraag op of het recht van vakverenigingsvrijheid horizontale werking heeft. ${ }^{106}$ Aan deze kwestie hoeven wij weinig woorden te wijden. De ILO laat er geen twijfel over bestaan dat dit het geval is. Art. 1 van Verdrag no. 98 verplicht lid-staten werknemers in bescherming te nemen tegen antivakbondsmaatregelen van de kant van de werkgever. Deze staatsverplichting is een afgeleide van de horizontale werking van het recht op vakverenigingsvrijheid. ${ }^{107}$

Verplicht vakbondslidmaatschap verdraagt zich per definitie niet met de negatieve coalitievrijheid, het recht van individuele werknemers om ongeorganiseerd te blijven. Zoals in het eerste hoofdstuk van deze studie al is aangegeven, omvat de vrijheid van vakvereniging, volgens de ILC, niet de negatieve coalitievrijheid. ${ }^{\text {ing }}$ Werknemers verdienen, om nog even terug te keren naar art. 1 van Verdrag no. 98, niet uit hoofde van dit artikel bescherming tegen een werkgever die een dienstbetrekking afhankelijk stelt van de voorwaarde dat zij zich aansluiten bij een vakbond en hun de wacht aanzegt, zodra zij deze vakbond de rug toekeren. Evenmin kan art. 2 van Verdrag no. 87 extensief uitgelegd worden in de zin dat het ook betrekking heeft op de vrijheid van werknemers om zich niet aan te sluiten bij een organisatie.

De veronachtzaming door de ILO van de negatieve coalitievrijheid is niet uniek. Met uitzondering van de Universele Verklaring van de Rechten van de Mens (art. 20), voorziet geen enkel internationaalrechtelijk instrument in de bescherming ervan. ${ }^{100}$ Ons interesseert

wil, mits de werknemer, na in dienstireding, zich aansluit bij de vakbond. Aangezien de gehele problematiek van het verplicht vakbondslidmaatschap in dit hoofdstuk benaderd wordt vanuit het perspectief van de werknemer, is het onderscheid van ondergeschikt belang.

106 Duk, R.A.A. Vhiheid van Veveniging en Werplicht Wakbondslidmaatschap un: SMA 1971, 7-8, pp. 450-451.

107 Vgl. Jacobs A.T.J.M. De rechtstreekse werking van intemationale normen in het sociad rech, Alphen aan den Rijn 1985, p. 17: "Het staat dan ook buiten kijf, dat tal van internationale normen betekenis moeten hebben voor de private werkgever/werknemer-verhouding. Zie ook Jacobs' prosefschrift Her necht op collectief onderhandelen, Alphen aan den Rijn//Brussel 1986, p. 327.

Jacobs merkt trouwens terecht op dat onderkenning van de horizontale werking van een norm nog niet automatisch impliceert dat men van mening is dat die norm zich ook voor rechtstreekse toepassing leent: "Men moet dus onderscheiden tussen "rechtstreeks-horizontale werking" en een indirecte, n.l. door de wetgever te verwezenlijken horizontale werking." Jacobs (a.w. 1985), p. 18. In de vorige paragraaf heb ilk overigens betoogd dat art. 1 van Verdrag no. 98 in beginsel wel rechtstreeks toepasbaar is.

108 Zie hoofdstuk 1, p. 63.

109 Pankert merkt op dat tijdens de discussies die vooraf gingen aan de aanvaarding van het BUPO-Verdrag (art. 21) en de Europese Conwentie voor de Rechten van de Mens (art. 11) voorstellen werden ingediend om het recht om ongeorganiseerd te blijwen te garanderen. Deze voorstellen werden echter verworpen. Bij 
op deze plaats evenwel voornamelijk de vraag of de ILO zich wel dient te bekommeren om de negatieve coalitievrijheid. Een bevredigend antwoord op deze vraag kan uitsluitend gegeven worden indien we voldoende inzicht hebben in de wijze waarop de HO de collectieve belangen van de vakbond afweegt tegen het individuele belang van de werknemer. In $4.3 \mathrm{kom}$ ik dan ook hierop terug.

Een "closed shop"-clausule kan werknemers een verplicht lidmaatschap van een vakbond voorschrijven en daarmee in het midden laten bij welke vakbond zij zich dienen aan te sluiten. Een dergelijke bepaling kan deze verplichting evenwel ook nader specificeren door de te begunstigen vakbond met name te noemen. In zo'n geval komt niet alleen de negatieve coalitievrijheid maar ook het recht van werknemers om zich aan te sluiten bij een vakbond naar eigen keuze, de positieve coalitievrijheid, onder grote druk te staan. Het rijke leven van de "closed shop" kent vele variëteiten. Het meest verstrekkend is de CAO-bepaling die de werknemers uitdrukkelijk verbiedt om lid te zijn van een andere vakwereniging dan de bond die de CAO heeft afgesloten. ${ }^{110}$ Een flagrantere schending van de keuzevrijheid van de werknemer lijkt mij moeilijk denkbaar. Andere "elosed shop"-bepalingen bedingen dat de werkgever uitsluitend werknemers die lid zijn van een bepaalde vakbond, in dienst kan nemen, zonder te reppen over lidmaatschap van andere bonden. ${ }^{\text {"th }}$ Een derde variant treffen wij aan in de clausule die weliswaar een verplicht vakbondslidmaatschap voorschrijft, maar de werknemer de vrijheid laat om uit een aantal, met name genoemde vakbonden te kiezen. ${ }^{132}$

de travaux preparatoires van het ESOCUL-Verdrag (art. 8) is de kwestie van de negatieve coalitievrijheid niet eens te berde gebracht. De ontwerpers van het Europees Social Handvest hebben de in de Bijlage opgenomen formullering dat de relevante bepalingen van het Handvest "shall not be interpreted as prohibiting or authorising any union security clause or practice" letterlijk overgenomen van de ILO. Tenslotte wijst Pankert erop dat de deskundigen het er zelfs niet over eens zijn of art. 20 van de Universele Verklaring van de Rechten van de Mens uitgelegd kan worden als een garantie voor de negatieve coalitievrijheid.

Pankert, A. Freedom of Association in: Blanplain R. (ed.) Comparative Labour Law and Industrial Relations, Deventer 1987, p. 181.

110 Van een dergelijk beding was sprake in Case No. 492 (Mexico). De Federale Arbeidsraad achtte dit beding zelfs een gegronde reden on de registratie van een concurrerende vakbond te weigeren. Tot mijn grote spijt heeft het Comite inzake de Vrijheid van Vakvereniging vamwege de verwarring rond de feitelijke situatie, deze arbitralle uítspraak niet met grote verontwaardiging van de hand gewezen. Vgl. hoofdstuk 5 , p. 238 .

111 In Nederland staat artikel 1, lid 3 van de Wet op de CAO van 1927 aan een dergelijk beding in de weg: 'Het beding, waarbij een werkgever verplicht wordt, arbeiders van een bepaald ras, van eene bepaalde godsdienstige of staatkundige overtuiging of leden van eene bepaalde vereniging niet dan wel uitsluitend in
dienst te nemen, is nietig" (cursivering Hwd

Een dergelijk beding stond ter discussie in het arrest Meinders/Staat (HR 09-04-1954, NJ 1954, p. 1392). te worden en deze clausule vond genade om van een van drie met name genoemde vakverenigingen lid dat het derde clausule vond genade in de ogen van de HR die dienaangaande overwoog: dat bij derde lid van art. 1 wan de Wet op de $\mathrm{CAO}$ naar zijn strekking (...) niet de mogelijkheid uitsluit dat bij een zodlanige overeenkomst, gelijk te dezen, den arbeiders de verplichting wordi opgelegd bij een van met name genoemde vakvereenigingen aangesloten te zijn;" NJ 1954, p. 1394. 
Beide laatstgenoemde vormen van "closed shop"-clausules sluiten, in tegenstelling tot de eerste variant, een dubbel vakbondslidmaatschap niet per se uit. Zij perken de keuzevrijheid van individuelle werknemers echter wel in en vormen zodoende een bedreiging voor de existentie van andere (minderheids)vakbonden. We raken hier aan een aspect van de "closed shop"problematiek dat een afzonderlijke bespreking verdient. Een inbreuk op de positieve coalitievrijheid van de individuele werknemer staat nimmer op zichzelf. Het impliceert altijd een benadeling van het - collectieve - belang van vakbonden om in ieder geval naast de vakbond die een CAO heeft afgesloten, te kunnen opereren en zo nodig diens bevoorrechte positie te kunnen betwisten. In dit verband heeft Duk gewezen op het belang van (minderheids)vakbonden om niet via een beding van verplicht lidmaatschap dat andere bonden in een CAO hebben opgenomen, te worden uitgesloten. ${ }^{113}$.

Bij wijze van voorlopige conclusie kan gesteld worden dat "closed shop"-clausules per definitie onverenigbaar zijn met de negatieve coalitievrijheid. Bovendien perken zij de positieve coalitievrijheid van het individu en het daarmee versmolten bestaansrecht van minderheidsvakbonden in. In hoeverre deze rechten nu voldoende gewicht hebben om, in het licht van de vrijheid van vakvereniging, een negatief oordeel te kunnen uitspreken over "closed shop"clausules, komt aan de orde in de volgende paragraaf.

\subsection{Het verplichte vakbondslidmaatschap als waarborg en als keursijf: een afweging van belangen}

Voor een goed begrip van de discussies die binnen de ILCgevoerd zijn over de toelaatbaarheid van "closed shop"-constructies, is het noodzakelijk om stil te staan bij de motieven die ten grondslag kunnen liggen aan het opnemen van "closed shop"-clausules. Pankert onderscheidt, in chronologische volgorde, vier doelstellingen die met behulp van bepalingen inzake verplicht vakbondslidmaatschap nagestreefd zijn:

a. "closed shop"-clausules stellen vakbonden in staat om het verwerven van banen te controleren;

b. zij versterken de positie van vakbonden in een vijandige omgeving (met name ten opzichte van een werkgever die een anti-vakbondshouding ten toon spreidt);

c. zij dwingen buitenstaanders om de financiële lasten van vakbondsactiviteiten te delen (zij vormen met andere woorden een garantie tegen "free-riders"); en

d. zij maken vakbonden tot onmisbare partners voor de doelmatige werking van het systeem van arbeidsverhoudingen. ${ }^{1 / 4}$

113 Duk, a.w. p. 456. De opmerking lijkt mij ietwat gechargeerd, omdat de meeste bedingen de existentie van andere vakbonden niet, althans niet absoluiut, uitsluitten.

114 Pankert, a.w. p. 182. 
Deze belangen nu, dienen afgewogen te worden tegen het recht wan de individuele werknemer om ongeorganiseerd te zijn en te blijven, diens vrijheid om een vakbond naar eigen keuze op te richten of zich daarbij aan te sluiten, alsmede het simpele bestaansrecht van minderheidsvakbonden. ${ }^{\text {ils }}$

\subsubsection{De negatieve coalitievrijheid}

Binnen het kader van de ILC heeft de negatieve coalitievrijheid aanleiding gegeven tot verwoede debatten. Meestal stond de algemene, principiële vraag ter discussie of de vrijheid van vakvereniging ook het recht om zich niet te verenigen omvatte. De connectie met "closed shop"-constructies werd niet in alle gevallen gelegd. Reeds bij de eerste poging in $1926 \mathrm{om}$ een ILO-Verdrag inzake de Vrijheid van Vakvereniging op te stellen, drongen de werkgevers aan op de expliciete vermelding van het recht van werknemers om zich niet te verenigen. ${ }^{116}$ Een amendement van deze strekking stuitte op de weerstand van de werknemers die op hun beurt hun steun aan het ontwerp-verdrag onthielden, mede gezien het feit dat zij er niet in slaagden om de negatieve coalitievrijheid voorgoed uit te bannen. ${ }^{17}$ Het bewijst hoe gevoelig deze kwestie lag. Enigszins generaliserend, zou men kunnen stellen dat de werkgevers vooral de nadruk legden op het recht van de individuele werknemer (hetgeen waarschijnlijk beter strookte met hun eigen belangen ....), terwijl de werknemers met name oog hadden voor de collectieve dimensie van de vrijheid van vakorganisatie. De voorzitter van de werknemersgedelegeerden, Jouhaux, vertolkte dit standpunt door te stellen dat "wanneer de vrijheid van vakorganisatie aan de orde is, wij het niet hebben over de individuele vrijheid" ${ }^{118}$ Bij de beraadslagingen die vooraf gingen aan de aanvaarding van de sleutelconventies nos. 87 en 98 hervatten de werkgevers hun inspanningen om de negatieve coalitievrijheid te waarborgen. Wederom wierpen de werkgevers zich op als de beschermheren van de individuele werknemer. ${ }^{119}$ De werknemers bleven zich verzetten tegen elke expliciete verwijzing naar de negatieve coalitievrijheid, kenschetsten haar als een vrijbrief om vakbondslidmaatschap te ontmoedigen en wonnen bij alle stemmingen het pleit. ${ }^{120}$

115 Wat dit Imatste betreft, wordt er vanuit gegaan dat "closed shop"-clausules het opereren van minderheidswakbonden wellicht niet onmogelijk maken, maar well ernstig kunnen bemoeilijken.

116 Compte rendu de la Conference Internationale du Travail, Xe session 1927 (= Conf. X), p. 645 .

117 Conf $X$, pp. 373-379.

118 Geciteerd door Ornstein G.F. Vrijheid van Vakomanisatie. Amsterdam 1940, p. 44.

119 Zie met name de werkgeverswertegenwoordigers van Ierland, de Verenigde Staten en de Scandinavische landen; Conf. XXXIT, 1949, resp. pp. 306, 308 en 310.

120 Het voorstel om aan art. 2, Verdrag no. 87 "het recht om zich bili een vakbond aan te sluiten" de zinsnede "of zich niet aan te sluiten" toe te woegen, werd met 50 tegen 41 stemmen verworpen. Conf. $\mathrm{XXX}, 1947$,
p. 354 .

Drie amendementen die de strekking hadden om, in het kader van art. 1, Verdrag no. 98 , naast het vakbondslid ook de ongeorganiseerde werknemer te beschermen tegen ontslag, haalden het evenmin. Conf. XXXII, 1949, 
Deze uitkomst acht ik bevredigend. Indien men, zoals de werkgevers, de positie van de individuele werknemer tot uitgangspunt neemt, dan kan men met Ornstein beweren dat de positieve en de negatieve coalitievrijheid "twee uitingen van eenzelfde vrijheid zijn, de vrijheid van vakorganisatie, d.i. het recht om vrij te beslissen of men zich al dan niet zal organiseeren.". De vrijheid van vakvereniging is er evenwel niet alleen ten behoeve van de werknemer, maar ook ten behoeve van de collectiviteit, zoals Duk terecht opmerkt. ${ }^{12}$ Gezien het feit dat werknemers- en werkgeversonganisaties binnen de ILO de eerste viool spelen, ligt het accent bij het concept van vakverenigingsvrijheid dat de ILO huldigt, duidelijk op de collectieve component. Het beslissingsmoment van de individuele werknemer om al dan niet lid te worden van een organisatie krijgt een dramatische lading, omdat het collectief met argusogen toekijkt of de werknemer wel de juiste keuze maakt. H. Polak stelt het scherp: "De 'vrijheid' om geen lid zijner vakvereeniging te zijn, is een voortdurend gevaar voor het welzijn van alle vakgenooten en kan daarom niet geduld worden". ${ }^{123}$ De op het eerste gezicht fraaie maar nogal bloedeloze symmetrie tussen de positieve en negatieve coalitievrijheid van het individu wordt verstoord, doordat het collectief zijn gehele gewicht in de schaal van de positieve coalitievrijheid werpt. ${ }^{124}$ Juist omdat de ILO zich vooral dient te bekommeren om de belangen van het collectief, lijkt het mij te rechtvaardigen dat de ILO de negatieve coalitievrijheid niet in haar vaandel voert en het verplichte vakbondslidmaatschap niet bij voorbaat veroordeeld heeft. De conclusie van Ornstein dat hiermee de vrijheid van vakorganisatie als individueel vrijheidsrecht is opgeofferd, vind ik te somber ${ }^{12}$ In de eerste plaats staat een zorgvuldige afweging van belangen ervoor garant dat principiële bezwaren tegen vakbondslidmaatschap gehonoreerd worden. In $6 \mathrm{kom}$ ik hier nog op terug. In de tweede plaats laat dit standpunt van de ILO de vrijheid van de werknemer om zich aan te sluiten bij een vakbond naar eigen keuze nog onverlet. Dit brengt mij op de tweede belangenafweging binnen het kader van de vraag naar de toelaatbaarheid van "closed shop"-bepalingen.

\subsubsection{De positieve coalitievrijheid en het bestaansrecht van minderheidsvakbonden}

Instemming met het ILO-standpunt inzake de negatieve coalitievrijheid impliceert nog niet instemming met de opvattingen van de ILO aangaande de toelaatbaarheid van "closed shops" in het algemeen. Zoals gezegd, perkt de $\mathrm{CAO}$-clausule die lidmaatschap van een bepaalde

p. 462.

121 Ornstein, a.w. p. 44.

122 Duk, a.w. p. 454 .

123 Polak H. De Vakvereeniging, Amsterdam 1922, pp. 95-98.

124 In deze zin versta ik ook Kahn-Freund's kritick op het "shallow legalism" orn de vrijheid om zich niet te organiseren naar analogie af te lleiden wit de vrijheid om zich to organiseren. Kahn-Freund's Labour and the Law, bewerkt door Davies P. en Freedland $\mathrm{M}_{;}$, London 1983, pp. 237 en 240.

125 Ornstein, a.w. p. 45. 
vakbond voorschrijft, wel in hoge mate het vrije beslissingsrecht van de werknemer in. Om gestalle te geven aan zijn steun voor een favoriete vakbond, kan de werknemer ertoe besluiten om een dubbel vakbondslidmaatschap aan te gaan, maar dit kan stuiten op bezwaren van financiële aard. Bovendien kan een dubbel lidmaatschap voor de werknemer loyaliteitsconflicten met zich brengen, indien de bonden waarvan hij lid is in een arbeidsconflict tegengestelde standpunten innemen.

De beperking van de keuzevrijheid van de individuele werknemer heeft een grotere draagwijdte, aangezien zij repercussies kan hebben voor de positie van minderheidsvakbonden. In praktijk blijken deze bonden vaak grote moeite te hebben om voet aan de grond te krijgen in een onderneming of bedrijfssector waar een vakbond zich verschanst heeft dankzij een "closed shop"-voorziening. ${ }^{2 *}$ Op welke wijze heeft de ILO nu deze aspecten betrokken in haăr discussie over de "closed shop"? Het is opmerkelijk dat in het kader van de ILC nauwelijks aandacht werd geschonken aan de belangen van minderheidswakbonden. ${ }^{\lfloor z t}$ Waar het verplichte vakbondslidmaatschap van een bepaalde vakbond gegispt werd, stond wederom het belang van de individuele werknemer centraal. ${ }^{12 a}$ Geen van de amendementen die de strekking hadden om dergelijke "closed shop"-clausules te verbieden, haalde de vereiste meerderheid en de Commissie inzake Arbeidsverhoudingen nam in haar eindrapport een formule op die een volstrekte neutraliteit ten aanzien van de "closed shop" impliceerde, ${ }^{18}$

Met name de veronachtzaming van de positie van minderheidsvakbonden werpt de vraag op of het ILO-standpunt inzake de "closed shop" wel geheel overeenstemt met de eigen normen op het gebied van vakverenigingsvrijheid. ${ }^{130}$ Een nader onderzoek naar de in het geding

126 In hoofdstuk 5 (pp. 231-239) heb ik vrij uitvoerig beschreven hoe de "closed shop" de existentie van minderheidsvakbonden bemoeilijkt.

127 Alleen de Zwitserse regeringsgedelegeerde gaf er blijk van oog te hebben voor dit aspect, waar hij met instemming uit een publicatie van de Zwitserse vakbeweging citeerde: "Il ne faut pas perdre de vue que l'institution d'un monopole a pour contrepartie l'asservissement d'une minorité".

Conf. $\mathrm{XXX}_{\text {, p. } 306 .}$

128 Amendement van de Turkse regeringsvertegenwoordiger, Conf. $\times X X$ p. 557; interventie van de Italiaanse regeringsvertegenwoordiger, Conf. XXXII, p.462. Het duidelijkste sprak de Nederlandse regeringsvertegenwoordiger zich uit. Hij diende een amendement in bij art. 1 van Verdrag no. 98 dat de strekking had om individuele werknemers te beschermen tegen verplicht vakbondslidmaatschap van een bepaalde vereniging, watrvan de doelstellingen niet in overeenstemming waren met de religieuze, politieke of sociale overtuiging van de desbetreffende werknemer. Conf. XXXII, p. 463.

"Niets in de onderhavige Conventie (i.e. Verdrag no. 98) dient te worden opgevat als een toestemming of een verbod wan clausules inzzake verplicht vakbondslidmaatschap; dergelijke kwesties vallen onder de nationale regeling en rechtspraktijk." Conf. XXXII (1949), p. 464.

130 Het individuele belang (om de positieve coalitievrijheid te sauveren) en het collectieve belang (van minderheidswakbonden om te kunnen opereren) zijn onverbrekelijk met elkaar verbonden, althans in het gezamenlijk weerstreven van pogingen van de meerderheidsvakbond om door middel van "closed shop"constructies een monopolie te verkrijgen. In deze paragraaf bekijk ik de problematiek vanuit de optiek van de minderheidsvakbond. Waar ik pleit woor een grotere aandacht voor de positie van de minderheidsvakbond, heb ik evenwel ook de bescherming van de positieve coalitievrijheid van het individu op het oog. 
zijnde belangen kan hierover uitsluitsel geven. De afweging van belangen van meerderheïdsen minderheidsvakbonden vallt grotendeels te herleiden tot de aloude discussie over de wenselijkheid en legitimiteit van vakbondsmonopolies versus -pluralisme ${ }^{13}$ Een belangrijke overweging voor de vakbeweging om "closed shops" na te streven is wan oudsher de bundeling van krachten ten opzichte van de werkgever (en de autoriteiten) geweest. Toegegeven moet worden dat een sterke verbrokkeling de macht wan vakbonden kan aantasten en hen kwetsbaar maakt voor overheersing door werkgevers of autoriteiten. Voor zover het argument er evenwel toe strekt om te beweren dat een vakbondsmonopolie de onafhankelijkheid van vakbonden pleegt te garanderen, mist het overtuigingskracht. De situatie in Mexico toont aan dat werkgevers en autoriteiten een effectieve controle kunnen uitoefenen op werknemers die zich verenigd hebben in eén enkele vakbond. ${ }^{132}$

Een tweede argument dat wel wordt aangevoerd tegen vakbondspluralisme, is dat het opereren van verschillende vakbonden in eén onderneming of bedrijfssector een bonte verscheidenheid aan arbeidsvoorwaarden met zich mee zou brengen. Het creëren van een vakbondsmonopolie door middel van "closed shop"-clausules is echter niet een panacee om tegemoet te komen aan de behoefte om de arbeidsvoorwaarden te normaliseren. ${ }^{133}$ Deze doelstelling kan ook verwezenlijkt worden door de CAO die afgesloten is met de meest representatieve vakbond, wettelijk algemeen verbindend te verklaren voor alle werknemers van de desbetreffende onderneming of branche. ${ }^{134}$ Met de gerechtvaardigde belangen van minderheidsvakbonden kan vervolgens rekening worden gehouden door na het verstrijken

131. De ILO heeft deze kwestie immer behandeld in het kader van het recht wan werknemers om zich aan te sluiten bij een organisatie "van hun eigen keuze" (art. 2, Verdrag no. 87). Zij heeft telkens aangegeven dat men uit Verdrag no. 87 niet een voorkeur voor vakbondsmonopolies of -pluralisme mag afleiden, vgl. ILO principles, standards and procedures conceming freedom of associotion, Geneva 1985, p. 13.

132 In dit verband wijst Schregle erop dat zowel een sterk verbrokkelde vakbeweging als een vakbond die een monopoliepositie geniet, gevoelig zijn woor overheersing en controle van de kant van werkgevers of autoriteiten. Schregle J. Labour Law and Industrial Relations in the Third World in: Blanplain R. (ed.) Comparative Labour Law and Industrial Relations, Deventer 1987, p. 66.

133 In deze zin ook Ornstein, a.w. pp. 85 en 92 .

134 Europese landen, waaronder Dütsland, Frankrijk en Nederland, kennen verscheideme varianten van de algemeen verbindend verklaring van CAO's die door de meerderheidsvakbond zijn afgesloten. Dikwijls bieden deze CAO's een bodem-garantic wat betreft de arbeidsvoorwaarden, waarwan in positieve zin kan worden afgeweken. De rigiditeit van het Amerikaanse systeem van exclusileve vertegenwoordiging door de meerderheidswakbond is veel groter. De CAO geldt als "lex dura". De werkgever mag tijdens het van kracht zijn van de CAO niet eens onderhandelen met indiwiduele werknemers of minderheidsvakbonden, noch over gunstiger, noch over minder gunstige arbeidswoorwaarden.

Zie hierover de interessante bijdrage wan Summers, Clyde W. Exchusive Representation by the Majority Union: A Unique Principle of American Labor Law in: Hedendaags Arbeidsrecht, opstellen aangeboden can Prof Mr M.G. Levenbach, Alphen aan den Rijn 1966, pp. 304-318. 
van de termijn van de $\mathrm{CAO}$ vakbondsverkiezingen uit te schrijwen om de krachtsverhoudingen opnieuw te peilen. ${ }^{\text {as }}$

Bij de bestrijding van het verschijnsel van "freeriders" vormt het verplichte vakbondslidmaatschap evenmin het enig denkbare wapen. Alle werknemers die profiteren van de inspanning van een (meerderheids)vakbond om een goede $\mathrm{CAO}$ af te sluiten, kunnen een financiële bijdrage leveren om de kosten te dekken, zonder dat zij verplicht zijn om lid te worden van die vakbond. ${ }^{13}$ Deze bijdrage zal, naar ik meen, evenredig moeten zijn aan de geleverde prestatie en geen belemmering mogen vormen voor het lidmaatschap van een andere vakbond. ${ }^{13}$

Met bovenstaande bespiegelingen heb ik geprobeerd om aan te tonen dat de op zichzelf respectabele doelstellingen die ten grondslag kunnen liggen aan het nastreven van verplicht lidmaatschap van een bepaalde vakbond, langs andere wegen gerealiseerd kunnen worden. De clausule die verplicht lidmaatschap van een bepaalde vakbond voorschrijft is een te grof middel dat onvoldoende recht doet aan de positieve coalitievrijheid van de werknemer en de belangen van minderheidsvakbonden. Deze opvatting valt ook met argumenten van meer formele aard te onderbouwen. In de befaamde Young, James and Webster v. U.K.-case achtte het Europese Hof voor de Rechten van de Mens een "closed shop"-clausule in strijd met art. 11 EVRM, niet in de eerste plaats omdat de negatieve coalitievrijheid van de verzoekers was geschonden, maar op grond van de overweging dat de clausule het recht beperkte om zich aan te sluiten bij een andere vakbond of er zelf én op te richten. ${ }^{138}$

Gedurende de jaren tachtig trachtte de Conservatieve regering in Groot Brittannië, alwaar de "closed shop" een hardnekkig bestaan leidde, de "closed shop"-praktijk stelselmatig te ondermijnen. De Employment Act van 1988 haalde de angel uit het beding van verplicht vakbondslidmaatschap door te bepalen dat elk ontslag van een werknemer wegens het niet-lid zijn van een vakbond automatisch onredelijk was, ook al was een "closed shop"-clausule van kracht. Ook de zogenaamde "pre- entry shop" werd niet gespaard: de Employment Act van 1990 verleent eenieder die door een werkgever geweigerd wordt omdat hij geen lid is van een vakbond, het recht om tegen deze weigering in beroep te gaan bij een arbeidsgerecht. ${ }^{130}$

135 Ook de ILO voorzet in deze mogelijkheid, zic Digest of Decisions $\$ 237$. Summers erkent dat werkiezingen in het Amerikaanse systeem een garantie vormen tegen een statische machtspositie van eên meerderheidswakbond, maar wijst op de neiging om verkiezingen te traineren. Summers, aw. pp. 307 en 310.

136 Kahn-Frieund, a.w. p. 244.

137 Dit laatste wordt met zoveel woorden door de ILO erkend: "However, the sum fixed by law should not be (...) so high as to place ar excessive financial burden on workers who pay contributions to another union of their choice" "Digest; $\$ 250$.

138 Zie Kahn-Freund, a. $w_{n}$ p. 239.

139 Hepple B./Fredman S. Great Britain in: Blanpain R. (Ed. in Chief) Intemational Encyclopaedia for Labour law and Industrial Relations, Deventer/Boston 1991, p. 213. 
In Nederland richt art. 1, lid 3 van de Wet op de CAO (1927) zich tegen het verplichte vakbondslidmaatschap "voorzoover dit gebruikt zou worden om aan een bepaalde richting in de vakbeweging een monopolistische positie te verschaffen of om een bepaalde richting uit te sluiten". ${ }^{1 * 0}$ De Franse wetgever heeft in 1956 de "closed shop" uitgebannen, onder andere met het oog op de bescherming van minderheidsgroepen tegen de machtige CGT. ${ }^{\text {,4t }} \mathrm{Bij}$ wijze van voorlopige conclusie zou ik willen stellen dat de ILO zich dient te spiegelen aan deze ontwikkelingen en een kritischer standpunt moet innemen tegen de "closed shop"-clausule die verplicht lidmaatschap van een bepaalde vakbond voorschrijft.

4.3.3 De "closed shop"-clausule die uitdrukkelijk het lidmaatschap van andere vakbonden verbiedt

Over de "closed shop"-variant die werknemers uitdrukkelijk verbiedt om lid te worden van een andere vakbond, kunnen we kort zijn. Het bezwaar tegen een clausule die de mogelijkheden tot vakbondspluralisme beperkt, geldt a fortiori tegen de clausule die diversiteit beoogt onmogelijk te maken. De jurisprudentie van de ILO biedt naar mijn mening voldoende aanknopingspunten voor de veronderstelling dat de ILO zo'n "closed shop"-clausule niet tolereert. In de eerste plaats lijkt een dergelijk beding onverenigbaar met de algemene opvatting van de ILO dat pluralisme onder alle omstandigheden mogelijk moet zijn. ${ }^{\text {14z }}$ Bovendien zou een werkgever die aanstalten maakt om een lid van een "dissidente" vakbond, uit hoofde van genoemde clausule, te ontslaan, in strijd handelen met art. 1 van Verdrag no. 98. ${ }^{\text {143 }}$ De zware verdragsrechtelijke bescherming van dit artikel dat in algemene bewoordingen gesteld is en niet betrekking heeft op een bepaalde vakbond, kan niet opgeheven worden door een beding in een privaatrechtelijke overeenkomst.

140 Ornstein, a.w. p. 85 .

141 Javillier J.C. Droit du Travail, Paris 1981, pp. 196-197.

142 General Survey, $\$ 136$.

Digest of Decisions, \$ 225 .

143 Vgl. ook hoofdstuk 5, p. 267.

In Case No, 1130, 230e Rap. 8472 overwoog het Comite inzake de Vrijheid van Vakvereniging dat "no person should be prejudiced in his employment by reason of his membership of a trade union, even if that trade union is not recognised by the employer as representing the majority of workers concerned".

Een geheel andere vraag is matuurlijk of de ontslagen werknemer zich ook ten overstaan van de nationale rechter zou kunnen beroepen op art. 1 van Verdrag no. 98. Zoals ik in de worige paragraaf betoogd heb, hangt dit samen met de vraag of de staat in kwestie een monistisch stelsel beeft en zo ja, of de rechter van mening is dat de bepaling zich leent voor directe toepassing. 
4.4 Een nader anderzoek naar de motieven die ten grondslag kunnen liggen aan wettelijke en feitelijke vakbondsmonopolies

In de beide voorgaande paragrafen heb ik geprobeerd om, aan de hand van een afweging van de relevante belangen, aan te tonen dat "closed shop"-clausules op gespannen voet kunnen staan met het recht van vakverenigingsvrijheid. Het principiële onderscheid dat de ILO maakt tussen wettelijke en feitelijke vakbondsmonopolies, wat betreft hun verenigbaarheid met de vrijheid van vakvereniging, kan ik niet onderschrijven. Men zou kunnen stellen dat het voor de individuele werknemer en de minderheidsvakbond weinig verschil maakt of de keuzevrijheid resp. het bestaansrecht bedreigd wordt door de staat of door een (andere) vakbond. Noch bij wettelijke vakbondsmonopolies, noch in het geval van feitelijke vakbondsmonopolies acht ik de belangen die met deze monopolies gediend kunnen worden, van doorslaggevende betekenis om een dermate grote inbreuk op vakbondsrechten te rechtvaardigen.

In deze paragraaf beoog $i k$ het genoemde onderscheid vanuit een andere invalshoek te benaderen. Zoals in de inleiding al is gesteld, baseert de ILO het verschil in benadering van wettelijke en feitelijke vakbondsmonopolies onder meer op de veronderstelling dat de staat en de vakbeweging verschillende intenties hebben om vakbondsmonopolies na te streven. De algemene validiteit van dit uitgangspunt staat hieronder ter discussie..$^{144}$

Het verbod aan het adres van de staat om de organisatiestructuur van de vakbeweging dwingend te regelen, heeft een principieel karakter: de staat heeft zich niet te mengen in een aangelegenheid die beschouwd kan worden als én wan de hoekstenen van de vrijheid van vakvereniging. De dieper liggende reden om met name wettelijk vastgestelde vakbondsmonopolies te wantrouwen, wordt door het Comite van Onafhankelijke Deskundigen haast terloops aangestipt $\left({ }^{145}\right)$ : politieke motieven kunnen ten grondslag liggen aan de voorkeur van de staat voor vakbondsmonopolies, aangezien zij de manipulatie van en controle over vakbonden en vakbondsleden vergemakkelijken. ${ }^{145}$.

Deze, mijns inziens belangrijke, overweging is als bij toverslag verdwenen bij de beoordeling van vakbondsmonopolies die uit de praktijk opborrelen. Bij feitelijke vakbondsmonopolies veronderstelt de ILO dat zij op vrijwillige basis tot stand zijn gekomen en uit deze vrijwilligheid reconstrueert de ILO als het ware de onderliggende drijfveer die de vakbeweging tot deze beslissing heeft aangezet. ${ }^{\text {t47 }}$ Vooropgesteld dat een monopolie inderdaad de vrucht

144 Mijn taxatie van de motieven wan (meerderheids) vakbonden om door middel van closed shops een vakbondsmonopolie nate streven is vooral de (wrange), vrucht van de bestudering van de vakbondssituatie in Mexico. Voor een meer gedetailleerde fundering van mijn visie, verwijs ik naar het Mexico-hoofdstuk.

145 General Survey, \& 135.

146 Pankert; aw: pp. 179-180.

147 "There is a fundamental difference between a situation in which a trade union monopoly is instituted by law and the factual situation in which the workers or their trade unions join together woluntarily in a single organisation(...)," General Survey, \& 136. De onderstreping ontbreekt in het origineel, maar is toegevoegd in de Digest $\$ 224$, waar bovengenoemde passage geciteerd is. 
is van een vrije keuze van alle betrokken vakorganisaties en werknemers, lijkt mij het onderscheid terecht: er bestaan geen bezwaren tegen dergelijke vakbondsmonopolies. In de voorgaande pagina's heb ik evenwel getracht om aan te tonen dat vakbondsmonopolies die het gevolg zijn van "closed shop"-clausules in veel gevallen juist niet de instemming hebben van alle betrokkenen. Door ten onrechte het element van vrijwilligheid te accentueren, stelt de ILO volgens mij de doelstellingen die met feitelijke vakbondsmonopolies worden nagestreefd, te rooskleurig voor. Vakbonden kunnen, door het opnemen van een "closed shop"clausule in een $\mathrm{CAO}$, op effectieve wijze concurrentie weren en lastige werknemers manen tot grotere volgzaamheid. Bovendien lijkt de ILO er onvoldoende oog voor te hebben dat vakbondsmonopolies die het gevolg zijn van "closed shop"-bepalingen, dikwijls werkgevers en autoriteiten in de kaart spelen. In het Mexico-hoofdstuk heb ik getracht om aan te geven dat de regering vakbondsmonopolies niet imperatief hoeft voor te schrijven, maar kan volstaan met het opnemen van een wettelijke bepaling die "closed shop"-constructies toelaat. Door vervolgens de monopoliepositie van vakorganisaties die nauw verweven zijn met de regeringspartij te stimuleren, kan een regering op meer versluierde wijze een oogmerk - politieke controle over de vakbeweging - nastreven, een oogmerk dat de ILO in geval van wettelijk opgelegde vakbondsmonopolies ontoelaatbaar acht. ${ }^{\text {i4 }}$

Aangezien aan wettelijke en feitelijke vakbondsmonopolies dezelfde intenties ten grondslag kunnen liggen, lijkt ook vanuit deze invalshoek een principieel onderscheid tussen beide fenomenen te simplistisch en onhoudbaar.

\subsection{Korte samenvatting en proeve tot herziening van het ILO-standpunt inzake "closed shop"- clausules}

Onvrede met het naar mijn smaak weinig genuanceerde ILO-standpunt inzake de "closed shop"-problematiek heeft mij geïnspireerd tot het schrijven van bovenstaande verhandeling. Het is niet zozeer de opoffering van de individuele vrijheild om ongeorganiseerd te blijven aan de belangen van het collectief, die mij zorgen baart. Hoewel ik hecht aan de keuzevrijheid van het individu, heb ik er begrip voor dat de ILO, die vooral de collectieve component van de vrijheid van vakvereniging in ogenschouw moet nemen, zich niet geroepen voelt om een principiële lans te breken voor de negatieve coalitievrijheid. Mijn bezwaar geldt met name het feit dat de ILO er zich, naar mijn idee, onvoldoende rekenschap van heeft gegeven dat

Vervolgens noemt het Comite van Deskundigen als een wan de belangrijkste motieven om de krachten in Cén organisatie te bundelen, de versterking van de positie van de vakbeweging aan de onderhandelingstafel.

Engerband is een observatie wan Nestor de Buen (Mexico in: Blanplain R. (Ed. in Chief) International control mechanisms of the filles and executive committees by the authorities have to some extent permitted the precarious preserwation of the old union structures, but with an increasingly more evident divorce of the workers themselves. In this sense the exclusion clauses have operated as a safeguard for, not always certain but basically recognized, majorities". (cursivering Hwd) 
niet alleen de keuzevrijheid van de individuele werknemer maar ook de rechten van minderheidsvakbonden in de verdrukking kunnen komen door de pogingen van vakbonden om met behulp van "closed shops" een monopoliepositie te verwerven of te behouden.

In $4.3 \mathrm{heb}$ ik getracht om aannemelijk te maken dat er alternatieven beschikbaar zijn om de doelstellingen die met behulp van clausules inzake verplicht vakbondslidmaatschap worden nagestreefd, te realiseren. Tevens heb ik mij een kleine rechtsvergelijkende excursie veroorloofd om mijn argument dat met name "closed shop"-clausules die verplicht lidmaatschap van een bepaalde vakbond voorschrijven, op onaanvaatdbare wijze inbreuk maken op vakbondsrechten, kracht bij te zetten. Tenslotte heb ik het noodzakelijk geacht om enkele vraagtekens te zetten bij de, mijns inziens, wat naïeve opvatting van de ILO dat feitelijke vakbondsmonopolies haast per definitie voortvloeien uit het nobele streven om de positie van een onafhankelijke vakbeweging te versterken. Zoals de praktijk in een land als Mexico leert, kunnen "closed shop"-clausules ten doel hebben om lastige werknemers in het gareel te houden en concurrentie van onafhankelijke bonden te weren:

Op welke wijze dient de ILO haar opvattingen over "closed shops" dan te herzien? Op grond van het bovenstaande moge duidelijk zijn dat ik een principiële verwerping van alle vormen van verplicht vakbondslidmaatschap niet noodzakelijk acht. Een "closed shop"-clausule die bedingt dat alle werknemers lid moeten zijn van een vakbond, maar hen volledige keuzevrijheid laat, lijkt mij voor de ILO aanvaardbaar. Een zorgvuldige belangenafweging brengt overigens wel met zich mee dat principiële bezwaren tegen elke vorm van vakbondslidmaatschap gehonoreerd moeten worden. Van de principiele werknemer aan wie dispensatie van het lidmaatschap van een vakbond wordt verleend, kan vervolgens gevergd worden dat hij een bepaald bedrag in een fonds stort, teneinde kostenomslag te bereiken en hem niet in een financieel voordeliger positie te brengen dan zijn collega's. ${ }^{149}$ De jurisprudentie van de ILO biedt ruimte voor een dergelijke dispensatie. ${ }^{150}$ Bovendien moet de ILO in het geweer komen tegen royement van vakbondsleden dat, door middel van "closed shop"-bepalingen, automatisch tot ontslag leidt. ${ }^{151}$

149 Zo ook Duk, aiw. p. 459.

$150 \$ 249$ Digest luidt: "Where union security arrangements exist requiring membership of a given organisation as a condition of employment, there might be a discrimination if unreasonable conditions were to be imposed upon persons seeking such membership". (cursivering HwdW)

Onder deze "onredelijke voonwaarden" kan mijns inziens ook miskenning van principièle - politieke of religieuze - bezwaren worden werstaan.

151 Onduidelijk is of de huidige jurisprudentie van het Comite inzake Vakverenigingswrijheid al in deze mogelijkheid voorziet. Pankert (a.w. p. 184) citeert de zojuist besproken uitspraak van het Comite (Digest, \$249) en meent dat er, volgens het Comite, ook sprake van discriminatie kan zijn if members were to be arbitrarily expelled from the organisation concerned". Ter aangehaalde plaatse ben ik deze toevoeging evenwel niet tegen gekomen.

Het is overigens vermeldenswaardig dat in Groot Brittannië de Employment Act van 1980 werknemers die op onredelijke gronden uit een vakbond verstoten zijn, un bescherming neemt; indien in de onderneming 
Tegen de "closed shop"-clausule die verplicht lidmaatschap van een bepaalde vakbond voorschrijft, moet de ILO principieel stelling nemen. Een dergelijk beding vormt een te grote inbreuk op de beslissingsvrijheid van de individuele werknemer en bedreigt de existentie van minderheidsvakbonden. Een uitzondering kan gemaakt worden voor een beding in een CAO dat uitsluitend een financiële bijdrage van alle werknemers aan éen bepaalde vakbond verplicht stelt. Deze "closed shop"-variant staat in de Verenigde Staten bekend onder de naam "agency shop" en in Zwitserland kent men het systeem van de solidariteits-contributie.. Verschillende auteurs onderkennen de noodzaak van kostenomslag. ${ }^{132}$ Dit wordt met bovengenoemd beding bereikt, zonder dat er een wezenlijke inbreuk wordt gemaakt op - individuele en collectieve - vakverenigingsrechten.

Rest mij nog enkele afsluitende opmerkingen te maken. De herziening van het ILOstandpunt inzake "closed shop"-clausules in de door mij voorgestelde zin vereist geen wijziging van Verdrag no. 87. Integendeel: deze herziening is meer in overeenstemming met letter en geest van art. 2 van het onderhavige verdrag dat werknemers het recht toekent om zich aan te sluiten bij organisaties naar eigen keuze. Evenmin betekent het dat de ILO voortaan alle vakbondsmonopolies dient te verwerpen. Tegen feitelijke vakbondsmonopolies die werkelijk de steun van alle vakbondsleden genieten, bestaat geen enkel bezwaar. Tenslotte bergt de herziening het belangrijke voordeel in zich dat het nogal geforceerde onderscheid tussen wettelijke en feitelijke vakbondsmonopolies tot het verleden zal behoren, hetgeen de ILO beter in staat zal stellen om op onbevangen wijze vakbondssituaties aan de normen inzake de vrijheid van vakvereniging te toetsen.

5 - Hoe de verschillen in doelstelling en methodes van "fact finding" de taxatie van een vakbondssituatie door de ILO en NGO's beïnvloeden

\section{I Inleiding}

De ILO is de afgelopen twintig jaar geconfronteerd met een groot aantal klachten over ernstige schendingen van vakbondsrechten in Chili en Colombia. De maatschappelijke en politieke context, waarbinnen deze schendingen plaatswonden, was in beide landen niet dezelfde. Het regime van Pinochet stond bekend als een paria van de internationale gemeenschap. De Chileense vakbeweging was het mikpunt van overheidsrepressie, hetgeen tot uiting kwam in ontbinding van vakbonden, ontslag en diskwalificatie van kritische vakbondsleiders en restricties van vakbondsactiviteiten. Bovendien was de directe betrokkenheid van de autoriteiten, althans in de eerste jaren na de staatsgreep, bij de meest ernstige schendingen van

een "closed shop"-clausule van $k r a c h t$ is. $Z \mathrm{Z} j$ hebben het recht om beroep aan te tekenen tegen het royement bij een arbeidsgerecht. Vgli. Hepple/Fredman, a.w. p. 215.

152 Kahn-Freund, a.w. p. 244 .

153 Duk, a.w. p. 459; Kahn-Freund, a.w. p. 244; Summers, a.w. pp. 313 en 314. 
vakbondsrechten - moord, martelingen en "verdwijningen" - niet aan twijfel onderhevig. Deze rechtstreekse verantwoordelijkheid werd gesignaleerd door de toezichtsorganen van de ILO $\left.{ }^{\text {(st }}\right)$ en andere internationale organisaties. ${ }^{\text {ss }}$

Naarmate de jaren verstreken, nam de repressie in intensiteit enigszins af en ging de regering in toenemende mate ertoe over om betrokkenheid van militairen en geheime politie bij martelingen en moord te ontkennen. Toch is met name het Comité inzake de Vrijheid van Vakvereniging argwanend gebleven en heeft soms de bewering van de regering dat veiligheidsagenten niet de hand hadden in ernstige schendingen van vakbondsrechten, in twijfel getrokken. ${ }^{15 \%}$

De uitgangspositie van Colombia is een geheel andere. Decennialang is de Colombiaanse samenleving geteisterd door structureel politiek geweld, maar dit heeft merkwaardig genoeg de democratische grondslagen van de staat en de redelijk goede betrekkingen tussen overheid en vakbeweging niet aangetast. Vooral na de nationale staking van 1977 is de spanning tussen staat en vakbeweging toegenomen, hetgeen geresulteerd heeft in arrestaties en detenties zonder vorm van proces, ontbinding van vakbonden etc. Door deze gebeurtenissen is de rechtsstaat onder druk komen te staan. Bovendien zijn er aanwijzingen dat er een verband bestaat tussen de overheidsrepressie ten aanzien van vakbondsleden en de opleving van gewelddadỉgheden op het platteland, waarvan vakbondsleden regelmatig het slachtoffer worden. ${ }^{157}$

Toch is er, althans naar het oordeel van de ILO, een cruciaal verschil met de mensenrechten- en vakbondssituatie in Chili tijdens het regime van Pinochet. De meest ernstige schendingen van mensenrechten, zoals moord op of "verdwijning" van vakbondsleden, worden namelijk gepleegd door leden van doodseskaders, guerrillagroeperingen of misdaadsyndicaten. In tegenstelling tot Chili, zijn de Colombiaanse autoriteiten, wederom naar het oordeel van de ILO, niet of nauwelijks bij de terreur tegen vakbondsleden betrokken. Hooguit kan men hen verwijten dat zij de eigen staatsburgers onvoldoende in bescherming nemen. Zo komt uit het rapport van de Direct contact-missie van 1988 naar Colombia het beeld naar voren

154 Zie wooral de conclusies van de Onderzoeks-en Bemiddelingscommissie, hoofdstuk 3, pp. 102-105.

155 Een gepeperde uitspraak wan de Inter-Amerikatanse Commissie inzake de Rechten van de Mens (IACHR) met betrekking tot folteringen, waaraan ook veel wakbondsleden blootgesteld werden, moge ter illustratie dienen:

The solid evidence collected by the LACHR, set forth in this section, makes il possible to state that the practice of torture has not been the result of individual excesses commited by members of the security agencies or a phenomenan tolerated in view of the indifference or weakness of other Chilcan institutions; on the contrary, tonture has been and is a deliberate policy of the Gowemment of Chile and has been pursued throughout the period that began on September 11, 1973." (cursivering HwdW)

Organization of American States, Report on the Situation of Human Rights in Chile, OAS/Ser.L/V/11.66, September 27 1985, p. 102.

$156 \mathrm{Vgl}$ hoofdstuk 3 , p. 138.

157 Vgl. hoofdstuk 4, p. 196 noot 219. 
van een staat die weliswaar bereid, maar niet bij machte is om de ernstige schendingen wan vakbondsrechten door "derden" te bestrijden. ${ }^{\text {ss }}$

In het hoofdstuk over Colombia heb ik angegeven dat deze taxatie waarschijnlijk te behoedzaam is. Deze scepsis ontleen ik aan de bevindingen van Non-Gouvernementele Organisaties (NGO's) die duiden op een grotere mate van betrokkenheid van léger en veiligheidsagenten bij schendingen van vakbondsrechten. ${ }^{159}$

Een dergelijke discrepantie in opvattingen met betrekking tot eenzelfde feitelijke situatie acht ik ongewenst in het licht van een gezamenlijke inspanning om de mensenrechten- en vakbondssituatie in een land te verbeteren. ${ }^{\text {iso }}$ In dit hoofdstuk wil ik dan ook niet alleen proberen om een verklaring te geven voor de uiteenlopende visies van de ILO en NGO's, maar wil ik ook enkele voorstellen doen om de samenwerking tussen beiden te verbeteren.

Vooropgesteld dat de uitkomst van elk onderzoek naar een mensenrechtensituatie in hoge mate beïnvloed wordt door de gehanteerde onderzoeksmethoden ("methods of fact finding") en dat het resultaat van dat onderzoek de basis vormt voor elk streven om schendingen van de rechten van de mens aan de kaak te stellen $\left({ }^{16 i}\right)$, wil ik in 5.2 nagaan welke, door de ILO ondernomen, onderzoeken ter plaatse ("on the spot-visits") het meest geschikt zijn om een goed inzicht te verwerven in een gecompliceerde vakbondssituatie, zoals de Colombiaanse. Vervolgens wil ik in 5.3 wat langer stilstaan bij de oorzaken van de verschillen tussen de opvattingen van Inter-Gouvernementele Organisaties (IGO's) en NGO's in het algemeen en in het geval van Colombia in het bijzonder. In 5.4 wordt aandacht besteed aan de mogelijkheden die NGO's ter beschikking staan om fact finding-missies van de ILO, hetzij voor het vertrek, hetzij tijdens het bezoek, van informatie te voorzien. In 5.5 tenslotte beoog ik tot enkele afrondende conclusies te komen.

158 hoofdstuk $4, \mathrm{p} .193$.

159 Zie hoofdstuk 4, pp. 215-216. Bovendien laat ook de VN-Werkgroep inzake Gedwongen en Onvrijwillige Verdwijningen zich kritischer wit over het aandeel wan millitairen en veiligheidspolitic in schendingen vãn vakbondsrechten en andere rechten van de mens, hoofdstuk 4, p. 194.

160

Deze discrepantie is overigens niet uniek voor Colombia. In de studie "Four Failures" oefenen de WatchCommittees flinke kritiek uit op vier rapporten wan VN-landen- Rapporteurs die schendingen wan mensenrechten slechts oppervlakkig zouden behandelen en overmatig veel aandacht zouden besteden aan de zienswijze van regeringen. De Watch-Committes schrijven deze opstelling toe aan een werkeerde taakopvatting: de VN-Rapporteurs, zouden zich geroepen woelen om met de autoriteitten te onderhandelen, terwijl zij eigenlijk uitsluitend de opdracht hebben om een grondige studie te verrichten.

Americas Watch/Asia Watch/Helsinki Watch "Four Failures". A Report on the U.N. Special Rapporteurs on Human Rights in Chile, Guatemala, Iran and Poland, Washington/New York 1986, met name p. 35.

161 Vergelijk de inleiding wan Rameharan in: Ramcharan B.G. (ed.) International Law and fact finding in the Field of Human Rights, the Hague/Boston/London 1982, p. 1. 
5.2 Fact finding en effectiviteit. De Direct contact-procedure en de procedure wan de Onderzoeksen Bemiddelingscommissie in vergelijkend perspectief

De ILO heeft werscheidene malen gebruik gemaakt van de zogenaamde Direct contactprocedure om de vakbondssituatie in Chili en in Colombia aan een nader onderzaek te onderwerpen. ${ }^{\text {16: }}$

In 1974 werd, met goedkeuring van de Chileense regering, een procedure voor de Onderzoeks- en Bemiddelingscommissie in gang gezet. In deze paragraaf wil ik de achtergronden en de voor- en nadelen van beide procedures, met het oog op het verkrijgen van een zo compleet mogelijk inzicht in een vakbondssituatie, nader belichten.

\subsubsection{De Direct contact-procedure}

De Direct contact-procedure dateert uit 1967. Aanvankelijk was deze procedure bedoeld om impasses in de rapportage-procedure te doorbreken. Noch de schriftelijke communicatie tussen het Deskundigen-Comitê en de regering, noch de massale en dikwijls verhitte bespreking van de rapporten door het Conferentie-Comité was geschikt om belangrijke problemen bij de naleving van ILO-Verdragen op te lossen. Het Deskundigen-Comité was van mening dat rechtstreekse onderhandelingen in een informele sfeer tussen een vertegenwoordiger van de ILO en de regering tot een beter begrip van elkaars standpunten zou leiden en aan de basis zou staan voor de oplossing van slepende kwesties. Het bezoek van de ILO-vertegenwoordiger aan het desbetreffende land diende te geschieden op uitnodiging of in ieder geval met de toestemming van de betrokken regering. ${ }^{13}$

Binnen het kader van de speciale toezichtsprocedure op het gebied van de vrijheid van vakvereniging voorzag de Direct contact-procedure duidelijk in een lacune. Het Comité inzake de Vrijheid van Vakvereniging verrichtte zijn, overigens alom gewaardeerde werkzaamheden uitsluitend op basis van schriftelijke stukken. Het onderzoek ter plaatse dat een bijzonder kerimerk was van de Onderzoeks- en Bemiddelingscommissie, werd node gemist, nu het inzetten van deze Commissie al snel in onbruik was geraakt. Gezocht werd naar een minder "zware" procedure die regeringen niet onmiddellijk zou afschrikken. In navolging van het Deskundigen-Comité ging het Comité inzake de Vrijheid van Vakvereniging vanaf het midden van de jaren zeventig in toenemende mate gebruik maken van Directe contacten. De procedure kreeg al spoedig het karakter van een bliksemactie. Met name in geval van zeer ernstige schendingen van vakbondsrechten kregen de leden van de Direct contact-missie de opdracht om de regering een eerste reactie te ontlokken en deelgenoot te maken van de bezorgdheid

162 Direct Contact-missies bezochten Chili in 1978, 1980 en 1986, terwijl Colombia in 1986 en in 1988 met een bezoek vereerd werd.

163 International Labour Office, Freedom of Associotion and Collective bargaining: Genteral Survey, Geneva 1983, p. $9, \$ 31$. 
van de ILO. Tijdens de eerstvolgende bijeenkomst van het Comite inzake de Vrijheild van Vakvereniging dienden de delegatieleden verslag uit te brengen van hun ervaringen. ${ }^{164}$ De Direct contact-procedure heeft zich in korte tijd ontwikkeld tot een soepel en veel gebruikt instrument. In een artikel van 1981 heeft Valticos een voorlopige balans opgemaakt. Tot dat jaar hadden er reeds 26 Direct contact-missies plaatsgevonden. Het succes van de formule schrijft hij toe aan de snelheid en het informele en discrete karakter van de procedure. De dialoog tussen regering en missie-leden speelt zich af in een klimaat van vertrouwen en de regering heeft niet de indruk dat zij onderworpen is aan een inquisitoriaal onderzoek. ${ }^{165}$ Niettemin merkt Valticos, mijns inziens terecht, op dat de Direct contact-procedure geen panacee is. De complexiteit van sommige vakbondssituaties vergt een diepgaander en grondiger onderzoek. In dit verband verwijst Valticos naar een verzoek van de werknemers-leden van de Raad van Beheer in juni 1980 om een delegatie "van hoog niveau"t naar Chili te sturen. ${ }^{166}$

\subsubsection{De Onderzoeks- en Bemiddelingscommissie: een pleidooi voor eerherstel}

Men kan zich niet geheel aan de indruk onttrekken dat de Direct contact-procedure, de waarschuwingen van Valticos ten spijt, gaandeweg de plaats heeft ingenomen van de procedure van de Onderzoeks- en Bemiddelingscommissie. Delegatieleden van een Direct contact-missie beperken zich al lang niet meer tot het voeren van een dialoog met regeringsvertegenwoordigers, maar winnen op uitgebreide schaal inlichtingen in bij vakbondsleiders, werkgevers en leden van de rechterlijke macht: ${ }^{16}$ Op zichzelf valt het streven om zich van verschillende zijden te laten informeren natuurlijk te prijzen - ik kom hier aanstonds nog op terug - maar onvoldoende wordt onderkend dat de procedure gebruikt wordt voor een doel, waarvoor zij aanvankelijk niet bestemd was. Door deze gang van zaken wordt de schijn van een degelijk onderzoek gewekt, terwijl de kwantitatief magere bezetting van Direct contact-missies en de korte tijd die de missieleden ter beschikking staat, verhinderen dat de onderste steen boven komt. ${ }^{168}$ In geval van een gecompliceerde vakbondssituatie, zoals in Colombia, waar over de exacte toedracht van de schendingen van vakbondsrechten en wel met name over de mate

164 Vgl. International Labour Office, Freedom of association. Digesr of Decusionts and principles of the Fredom of Association Comwittee of the Coventing Body of the ILO; Genewa 1985, p. 17, \$65.

165 Valticos N. "Une Nowiville Fome d'Action Intemationale: les a Contact Directs so d'OI.T. en Matière d'Application de Conventions et de Liberté Syndicale" in: Annuaire Français de Droilt International, 1981. p. 486 .

166 Valticos (1981), a.w. p. 489. Aan dit verzoek werd slechts gedleeltelijk tegemoet gekomen. De sameinstelling gaf de missie het modige gewicht - Valticos makte zelf deel uit van de delegatie -, maar de missieleden dienden hun activiteitten te ontplooien in het kader van een Direct contact-procedure.

167 Valticos (1981), a:w. pp. 468488 en hoofidstuk 4, pp. 192-193.

168 In de meeste gevallen bestaat de missie uit éen lid - een gekwalificeerde ILO-functionaris - of uit twee lleden een onafhankelijke deskundige, vergezeld van een ILO-functionaris. Het bezoek neemi doorgatans niet meer dan een week, hooguit tien dagen in beslag. 
van verantwoordelijkheid van de publieke autoriteiten verschillen van mening bestaan, kan de Direct contact-procedure de werkzaamheden van de Onderzoeks- en Bemiddelingscommissie niet vervangen.

We kunnen ons afvragen wat de ILO ervan weerhoudt om een geregeld(er) gebruik te maken van de Onderzoeks-en Bemiddelingscommissie. Zoals bekend, is het Comité inzake de Vrijheid van Vakvereniging de Commissie gaan overvleugelen, nadat verscheidene staten hun toestemming voor het functioneren van de Commissie hadden geweigerd. Strikt genomen is deze toestemming niet vereist voor wat betreft staten die de sleutelconventies inzake de vrijheid van vakvereniging geratificeerd hebben. In dergelijke gevallen kan de Raad van Beheer namelijk op grond van art. 26 ILO-Statuut de Onderzoeks- en Bemiddelingscommissie aanstellen gehuld in de mantel van een Onderzoekscommissie (Commission of Inquiry). ${ }^{170}$ Maar dit argument is misschien wat te formalistisch, gezien het feit dat elke fact finding-missie voor een doeltreffend optreden aangewezen is op de medewerking van de regering. ${ }^{3 n_{*}}$ Waar het volgens mij op aankomt is dat zowel de ILO als staten een psychologische barrière moeten overwinnen. Het sporadische gebruik van de Onderzoeksen Bemiddelingscommissie heeft ertoe bijgedragen dat deze Commissie haast mythische proporties heeft gekregen. De huiver van de ILO om zich van deze procedure te bedienen lijkt ingegeven door de vrees dat de staat zijn toestemming zal weigeren. Deze vicieuze cirkel kan slechts doorbroken worden, indien de ILO de inhoud van de gezamenlijke ECOSOC-ILOResolutie van 1950 die de juridische basis van de Commissie vormt, ter harte neemt. ${ }^{172}$ In deze Resolutie wordt benadrukt dat de Commissie primair belast is met een zo objectief mogelijk onderzoek naar de feiten en dat de Commissie, eerder dan tot een veroordeling van de staat in kwestie te komen, moet streven naar een constructieve oplossing die bevredigend is voor de partijen in het onderliggende geschil. ${ }^{13}$ Een accent op deze functies van de Commissie kan staten stimuleren om hun medewerking te verlenen en kan bijdragen tot het eerherstel van een ten onrechte in onbruik geraakt toezichtsmechanisme.

169 International Labour Office, LO Principles, Standards and Procedures concerning Freedom of Associalion, Geneva 1985; pp. 8-9.

170 Valticas N. "Un Double Type d'Enquête de IOnganisation Internationale du Travail au Chile" in: Annuaire Françatis de Droit International 1975, p. 485, noot 17 .

171 van Boven Th. "Fact finding in the Field of Humton Rights" in: 3 Israel Yearbook on Human Rights (1973), pp. 112 en 115 .

172. ECOSOC-Resolutie $277(\mathrm{X})$ van 17-02-1950.

173 In een artikel dat speciaal gewijd is aan het karakter en de toekomstperspectieven van de Onderzoeks- en Bemiddelingscommissie, formuleert Valticos dit laatste aspect als volgt: "le souci d'aboutir à une solution constructive acceptable plus qu'à la condamnation de l'une ou l'autre thèse $(\ldots)^{\text {t: }}$.

Valticos N. "La Commission d'Investigation et de Conciliation en Matiere de Liberté Syndicale et le Mecanisme de Protection Intemationale des Droits Syndicaux" in: Annuaire Français de droit internationall 1967, p. 468. 


\subsection{Enkele reflecties over de auard, werkzaamheden en doelstellingen van IGO's en NGO's in relatie tot methodes van "Fact finding"}

Aangezien de visies van de ILO en van sommige NGO's met betrekking tot de vakbondssituatie in Colombia onderling nogal verschillen; is het interessant om na te gaan of dergelijke uiteenlopende visies meer in het algemeen te herleiden zijn tot verschillen in methodes van fact finding tussen IGO's en NGO's. Internationale organisaties plegen een oordeel over de mensenrechtensituatie in een land meestal te baseren op informatie uit schriftelijke bron. Een meer directe manier om inzicht in een specifieke mensenrechtensituatie te verkrijgen, is het verrichten van veldonderzoek ("on the spot-visits"). Zowel IGO's als NGO's maken gebruik van fact finding-missies. De wezenlijke verschillen in doelstelling, karakter en structuur tussen beide soorten organisaties staan evenwel garant voor verschillen in werkwijze.

\subsubsection{IGO's en "Fact finding"}

Gouvernementele organisaties ontlenen hun bestaansrecht aan de hen constituerende staten. Bij de meeste gouvernementele organisaties maakt de zorg voor de rechten van de mens slechts een beperkt deel uit van het gehele aandachtsveld. Fact finding-missies zullen, net als alle andere activiteiten van de IGO, plaatsvinden tegen de achtergrond van de interstatelijke samenwerking, binnen het raamwerk van de IGO ${ }^{174}$ Deze omstandigheid heeft zowel voor-als nadelen. Aan de ene kant geeft het inter-gouvernementele karakter aan de missie het nodige gewicht. De staat die door de missie bezocht wordt; zal haar faciliteiten verlenen en deuren voor haar openen die voor missies met een minder officieel karakter gesloten blijven. Aan de andere kant zal een IGO-missie wellicht concessies moeten doen om zich te verzekeren van de loyale medewerking van een staat, door bijvoorbeeld uitvoerig stil te staan bij de gouvernementele visie op de mensenrechtensituatie. ${ }^{175}$

Naar aanleiding van dit laatste rijst de vraag in hoeverre IGO's gehouden zijn om het "audi et alteram partem"-beginsel in acht te nemen door de visie van de staat af te wegen tegen informatie uit andere, niet gouvernementele bronnen. Tot op zekere hoogte is de specifieke procedure van invloed op de mate waarin niet-gouvernementele betrokkenen slachtoffers, getuigen, NGO's - tijdens de loop van de procedure hun standpunten of ervaringen kenbaar kunnen maken. Men kan hierbij een onderscheid maken tussen procedures die in

174 Thoolen H./Verstappen B. Human Rights Missions. A Study of the Fact finding Practice of Non-govemmental Organizations; Dordrecht/Boston/Lancaster 1986, p. 25.

175 Thoolen en Verstappen (a.w. p. 25) stellen zich de prikkelende, open vraag: "Bestides, if IGO minssions should have less problems in getting access to the territory of a member state, the question can be raised what price had to be paid for that access during preliminary negotiations with the government concerned". 
het leven geroepen zijn, opdat een algemeen beeld van de mensenrechtensituatie in een bepaald land gevormd wordt en procedures waaraan een klacht ten grondslag ligt. ${ }^{126}$

\subsubsection{Procedures met betrekking tot de beoordeling van globale mensenrechtensituaties}

De reguliere rapportageprocedure binnen het kader van de ILO voorziet, zoals al eerder is aangegeven, in de mogelijkheid dat werkgevers- en werknemersorganisaties kritisch commentaar leveren op de regeringsrapporten. Deze structurele betrokkenheid van NGO's bij een rapportageprocedure is eerder uitzondering dan regel. De rapportageprocedures die gebaseerd zijn op VN-verdragen voor de rechten van de mens $\left({ }^{(7)}\right)$ monden meestal uit in een dialoog tussen een regering en het orgaan dat belast is met de beoordeling van de rapporten, hetgeen een eenzijdig beeld oplevert. ${ }^{\text {its }}$

Naast deze reguliere procedures zijn binnen het kader van de Verenigde Naties tal van speciale procedures tot ontwikkeling gekomen die veeleer zijn ingesteld met het oog op het verkrijgen van inzicht in de mensenrechtensituatie in een bepaald land of in een specifieke mensenrechtenproblematiek. $\mathrm{Zij}$ vormen het aandachtsveld van de (gouvernementele) VNCommissie voor de Rechten van de Mens die geassisteerd wordt door de, uit onafhankelijke deskundigen bestaande, Sub-Commissie inzake de Preventie van Discriminatie en de Bescherming van Minderheden. Voorzover deze procedures een openbaar karakter hebben, berusten zij op een resolutie van de ECOSOC, waarin de VN-Commissie werd opgedragen "to make a thorough study of situations which reveal a consistent pattern of violations of human rights". " Zo ontlenen de eerder genoemde Speciale Landen-rapporteurs hun bevoegdheden uiteindelijk aan deze resolutie: De laatste tien jaar is het accent overigens verschoven naar de "thematische benadering", aangezien de "landen-procedures" dikwijls aanleiding gaven

176 Zowel K.T. Samson (Ramcharan (ed), a.w. pp. 56-57) als Justice A. Dieye (Ramcharan (ed.), a.w. pp. 96-102) maken dit onderscheid.

177 Enkele verdragen die in een rapportageprocedure woorzien zijn het Internationaall Verdrag inzake de Uitbanning van alle Vormen van Rassendiscriminatie (1965), het BUPO-Verdrag (1966) en het ESOCULVerdrag (1966).

178 De eenzijdigheid wordt enigsins opgeheven, doordat NGO's leden van VN-organen plegen te benaderen om hen van muateriaal te voorzien. Vgl. Bossuyt M.J. The Development of the Special Procedures of the United Nations Commission on Human Rights, Human Rights Law Jourral, vol.6 (1985), p. 207.

Van Boven wijst bovendien op een interessant initiatief van de Economische en Sociale Raad die NGO's met consultatieve status heeft aangespoord tot het indienen van "written statements which might contribute to full and universal recognition of realization of the rights contained in the International Covenant on Economic, Social and Cultural Rights"'.

van Boven Th. "Political" and "Legal" Control Mechamisms: Their Competition and Coexistence in: Eide A./Hagtvet B. (eds.) Hunan Rights in perspective: a global assessment/Nobel Symposium 74, Oxford 1992, p. 42 .

179 ECOSOC-Resolutie 1235 (XLII) van 06-06-1967. 
tot politiek gekrakeel. ${ }^{\text {soc }}$ De personen en organen die hun werkzaamheden in het kader van deze procedures verrichten, plegen zich doorgaans breed te orienteren en informatie in te winnen uit alle beschikbare bronnen. Voorzover een regering dit toestaat, bezoeken zij het land. NGO's en slachtoffers worden doorgaans ruimschoots in de gelegenheid gesteld om hun visie op de situatie te etaleren. ${ }^{182}$

NGO's kunnen daarentegen geen invloed uitoefenen op het verloop en de uitkomst van de zogenaamde confidentiële procedure die gebaseerd is op ECOSOC-Resolutie 1503 (XLVIII). ${ }^{\text {122 }}$ Deze procedure voorziet in een vertrouwelijk onderzoek van de Sub-Commissie en de Commissie naar kennisgevingen die "duiden op een samenhangend patroon van grove en betrouwbaar gestaafde schendingen van de rechten van de mens en de fundamentele vrijheden". ${ }^{183}$ De inbreng van NGO's (en slachtoffers) is beperkt tot het indienen van "communications" (kennisgevingen). Wat er verder met deze "communications" gebeurt en in hoeverre zij het oordeel van de Commissies beïnvloeden: daar kunnen NGO's alleen maar naar raden. ${ }^{\text {194 }}$

\subsubsection{Klachtenprocedures}

Klachtenprocedures, het is al eerder opgemerkt, hebben min of meer een quasi-judicieel karakter. ${ }^{18 s}$ Het orgaan dat bevoegd is om kennis te nemen van de klacht, zal in een

180 Vgl. van Boven (1992), a.w. p. 44. De thematische benadering heeft gestalte gekregen in de oprichting van, onder andere, de Werkgroep inzake Verdwijningen (1980), de aanstelling van een Speciale Rapporteur inzake Standrechtelijke Executies (1982) en de aanstelling van een Speciale Rapporteur inzake Folteringen (1985).

181 De Draft Model Rules of pracedure suggested by the Secreiary-General of the UN for.Ad Hoc Bodies of the United Nations entrusted with studies of particular situations alleged to reveal a consistent pattern of violations of human rights (UN doc.E/CN.4/1021/Rev.1) refereren aan deze bestendige praktijk in Rule 19: "The ad hoc body shall be entitled to receive oral and written testimony. Such testimony (...) 2, may be received from any sources at the invitation, or upon the decision, of the ad hoc body."

De Draft Módel Rules zijn overigens niet operationeel.

182 De 1503-Resolutie dateert van 27-05-1970. Zie voor een uitvoerige werhandeling over de totstandkoming van de Resolutic en het karakter van de procedure: Zujijdwijk Ton J.M. Pettitoning the United Nations, New York 1982, met name Chapter I (pp. 1-116).

$183 \$ 6$ (b) van de Resolutitie biedt ook nog de mogelijkheid dat een ad hoc-comitê wordt ingesteld, maar tot dusver heeft de VN-Commissie deze weg nog niet beproefd, vgl. van Boven Duty of States to Cooperate in: Nordic Journal on Human Rights, 1987, Nr 3, p. 9.

184 Toch moet het belang van deze "commumications" zeker niet onderschat worden. Cassese merkt op dat, hoewel de 1503-procedure confidentieel is, uit verschillende bronnen blijkt dat de "communications" van enkele NGO's het meeste effect hebben gesorteerd bij het activeren van de procedure. Cassese A. How Could NGO's Use U.N. Bodies More Effectively? in: Universal Human Rights, Vol. 1, No. 4 Oct./Dec. 1979, p. 75.

185 Behalve de bekende klachtemprocedures in ILO-verband, kenten onder andere het BUPO-Verdrag met het bijbehorende Facultatieve Protocol en het Internationaal Verdrag inzake de Uibanning van alle Vormen van Rassendiscriminatie een klachtenprocedure. 
procedure op tegenspraak nauwkeurig moeten onderzoeken of de klacht gegrond is en welke maatregelen zo nodig getroffen moeten worden. Zowel bij de klager als bij de aangeklaagde staat zullen uitvoerig inlichtingen worden ingewonnen en beide partijen zullen ook in de gelegenheid worden gesteld op elkaars opvattingen te reageren. Respect voor het "audi et alteram partem"-beginsel is met andere woorden een wezenlijk element van de klachtenprocedure. ${ }^{\text {to }}$ Bovendien zal, zo er een fact- findingmissie wordt ingesteld, deze missie doorgaans terdege rekening houden met de zienswijze van de klager of van de personen of instanties wier belangen de klager beweert te behartigen. Zo wordt de centrale positie die werkgeversen werknemersorganisaties innemen in de ILO, weerspiegeld in het feit dat Direct contactmissies veel aandacht plegen te besteden aan de mening van lokale of nationale werkgeversen werknemersorganisaties. ${ }^{\text {in }}$

Toch wordt van delegatieleden van Direct contact-missies vooral verwacht dat zij met de autoriteiten van gedachten wisselen over bepaalde knelpunten, teneinde tot een bevredigende oplossing te komen. ${ }^{1}$ Hier manifesteert zich weer bij uitstek het diplomatieke karakter van de procedure.

\subsubsection{Korte evaluatie}

In het licht van de vraag welke procedures NGO's en slachtoffers de beste mogelijkheden bieden om gehoor te vinden bij gouvernementele organisaties, lijkt, bij nader inzien, het onderscheid tussen "globale" mensenrechten-procedures en klachtenprocedures niet zo relevant. Men kan veilig stellen dat openbare procedures die uitmonden in een onderzoek ter plaatse en waarbij een duidelijk onderscheid wordt gemaakt tussen de "fact finding"'- en de conciliatoire fase; NGO's en slachtoffers de meeste ruimte geven. Of dergelijke procedures nu hun oorsprong hebben in klachten - zoals de ILO-Onderzoeks- en Bemiddelingscommissie - dan wel worden ingesteld naar aanleiding van een discussie in de VN-Commissie voor de Rechten van de Mens, is van ondergeschikt belang. Omgekeerd lijken staten zich het meest op hun gemak te voelen bij en blijken zij ook meer bereid om medewerking te verlenen aan rapportage-procedures en procedures met een vertrouwelijk of diplomatiek karakter ${ }^{2}$

Twee kanttekeningen zijn nog van belang. In de eerste plaats is de bereidheid om gewicht toe te kennen aan informatie uit non-gouvernementele bron mede afhankelijk van de persoonlijke voorkeur en taakopvatting van de desbetreffende functionaris(sen)..$^{10}$ In de tweede

186 Van Boven (1992), a.w. p. 42.

187 Vgl. K.T. Samson, Ramcharan B.G. (ed.), a.w. p. 57.

188 Valticos (1981), a.w. pp. 480 en 485.

189 Van Boven (1992) signaleent de statelijke voorkeur voor confidentiële procedures (a.w. p.48) en woor rapportage-procedures (a.w. pp. 51-53).

190 Zo wijzen de Watch-Committees bij hum beoordeling van het rapport van de Speciale Rapporteur voor Chili in 1985 op het feit dat de geringe aandacht voor informatie uit niet-gouvernementele bron in schrijnend 
plaats blijken IGO's bij de meeste procedures het beginsel van "audi et alteram partem" weliswaar tot leidraad te nemen, maar het accent ligt toch veelal op de informatie die van regeringszijde wordt aangedragen.

\subsubsection{NGO's en "Fact finding"}

De doelstelling en functie van NGO's worden vanzelfsprekend eveneens weerspiegeld in de wijze waarop NGO's informatie verzamelen. Aan de oprichting van NGO's ligt de bezorgdheid over schendingen van mensenrechten ten grondslag. Zij stellen zich doorgaans uitsluitend ten doel om schendingen van mensenrechten in de openbaarheid te brengen en trachten een bijdrage te leveren aan de verbetering van de mensenrechtensituatie. De bijzondere betrokkenheid bij de slachtoffers van mensenrechtenschendingen manifesteert zich in de grote aandacht die NGO's in hun rapporten aan hun ervaringen plegen te besteden. De gezichtspunten van autoriteiten nemen daarentegen in de rapporten van NGO's meestal een bescheiden plaats in (zo zij er überhaupt al in verwerkt worden). De redenen liggen voor de hand. Staten en NGO's koesteren een wederzijdse argwaan voor elkaar. ${ }^{191}$ Informatie uit gouvernementele hoek is voor de NGO haast per definitie suspect. Aan de andere kant zijn de meeste staten niet verlegen om kritiek op hun mensenrechtenbeleid. Aangezien NGO-missies dikwijls een meer informeel karakter dragen en in ieder geval het institutionele gewicht van een IGO-missie ontberen, zal de staat, al of niet met een beroep op de vooringenomenheid van de missie, meestal niet de moeite nemen om de missieleden uitvoerig in te lichten. ${ }^{192}$

Kan nu van NGO's verwacht worden dat zij tijdens een missie actie ondernemen om informatie van de autoriteiten te verkrijgen, dan wel dat zij het eindrapport, alvorens het te publiceren, aan de staat voorleggen ter becommentariëring? De meningen van de diverse auteurs hierover lopen nogal uiteen. De International Law Association (ILA) heeft een studie

contrast staat met voorgaande rapporten: "The bulk of the report"s discussion of the human rights situation in Chile is taken up by the Rapporteur's contacts with the Chilean government ( 39 paragraphs; contacts with non-governmentall human rights sources and materials provided by them, are discussed in only ten paragraphs)

191 Vgl. P.H. Kooijmans The Non-Govemmental Organizations and the Monitoring Activities of the United nations in the Field of Human Rights in: The Role of Non-Govemmental Onganizations in the Promotion and Protection of Human Rights Stichting NJCM-Boekerij 16, Leiden 1991, p. 15: "NGO's are the natural opponents of governments since human rights cover that extremely fragile relationship between on the one hand the indridual and on the other hand the State in whose jurisdiction that individual finds himself."

192 Natuurlijk is dit nogal generaliserend gesteld. De egards van de staat jegens de NGO (of het gebrek daaraan) hangen nauw samen met het aanzien dat de desbetreffende NGO geniet. Bovendien hebben sommige staten er well degelijk belang bij om ook NGO's opheldering te verschaffen over de mensenrechtensituatie in hun land, met name indien zij van mening zijn dat de beeldworming in de internationalle gemeenschap negatiever is dan de feitelijke situatie in het land rechtvaardigt. Om de accentverschillen tussen het functioneren van IGO resp. NGO-missies wat sterker aan te zetten, heb ik mel opzet gechargeerd. 
van Franck en Fairley $\left({ }^{15}\right)$ tot uitgangspunt genomen bij het opstellen van een aantal procedureregels die NGO's ter harte zouden moeten nemen bij het organiseren van fact finding-missies. ${ }^{104}$ Deze Belgrado-regels sporen NGO's aan om actief de medewerking van de betrokken staat te zoeken. Zo dient de staat geconsulteerd te worden bij de samenstelling van de delegatie, moet de staat zijn visie op bepaalde bevindingen te berde kunnen brengen en zelfs in de gelegenheid worden gesteld om getuigen te ondervragen. ${ }^{105}$

Weissbrodt en Mc Carthy hebben, mijns inziens terecht, kritiek uitgeoefend op dit standpunt. ${ }^{1 \%}$ Het gaat niet aan om NGO-missies aan de strakke voorwaarden te onderwerpen die aan IGO's gesteld worden. NGO's beschikken bijvoorbeeld niet over de middelen om staten tot medewerking te bewegen, zodat zij geheel afhankelijk zijn van de bereidwilligheid van de staat, indien men besluit dat staatscoöperatie een noodzakelijk element is. Daarbij komt nog dat pogingen van NGO's om de medewerking van de staat te verwerven, hen in de ogen van eventuele slachtoffers weer zullen compromitteren.

Het bovenstaande in overweging nemende, geef ik de voorkeur aan de meer ruimhartige opvatting van Thoolen en Verstappen die NGO's zoveel mogelijk vrij laten bij hun beslissing om al of niet kennis te nemen van de visie van de regering en het slechts wenselijk achten dat NGO's hun rapporten voor publicatie overleggen aan de betrokken regering. ${ }^{197}$ NGO's, zo kunnen we het voorgaande samenvatten, zijn met het oog op een vergroting van de geloofwaardigheid van hun bevindingen, tot op zekere hoogte gehouden om het beginsel van hoor en wederhoor te respecteren, maar het accent dat zij leggen op informatie uit gouvernementele resp. non-gouvernementele hoek, vormt tot op zekere hoogte het spiegelbeeld van dat van IGO's.

193 Franck, Thomas M. and Fairley, H. Scot1 Procedural Due Process in Hiwnan Rigths Fact funding by Intemational Agencies, American Journal of International Law, Vol. 74 1980, pp. 308-345.

194 Belgrade Minimal Rules of Procedure for Intemational Human Rights Fact finding Missions, adopted at the Belgrade Session of the ILA in 1980.

195 Deze "vereisten" vindt men resp. terug in rule 5,12 en 14.

196 Weissbrodt D. and Mc Carthy J. Fact finding by Lntemational Nongovemmental Human Rights Onganisations, Virginia Journall of International Law, Vol. 22 (1) 1981, met name pp. 15-17.

De kritiek spitst zich toe op het feit dat de Franck en Fairley studie wooral betrekking had op de ervaringen wan inter-gouvernementele organisaties en dat de ILAA klakkeloos de aambevelingen van deze schrijvers heeft willen toepassen op fact finding-missies van $\mathrm{NGO}^{\mathrm{s}}$.

197 Thoolen en Verstappen, a.w. p. 133.

Weissbrodt en Mc Carthy nemen een tussenpositie in. Op basis van hun observatie dat het binnen NGOgelederen bestendig gebruik is om de regering te raadplegen; achten zij het aanbevelenswaardig dat NGO's in het algemeen deze consultatie verrichten. Het bewijs dat zij aanworen ter staving van dit "bestendig gebruik" is echter niet erg overtuigend, daar zij uitsluitend refereren aan de praktijk van Amnesty International. Weissbrodt, a.w. pp. 56-57. Zie hierover ook Thoolen, a.w. p. 133. 
Hoe kunnen de bespiegelingen over de verschillen in informatievergaring tussen IGO's en NGO's nu vertaald worden naar de verschillende taxaties van de Colombiaanse mensenrechtenen vakbondssituatie? Het lijkt mij aannemelijk dat, naarmate een bepaalde situatie ondoorzichtiger is, de discrepantie tussen de diverse beoordelingen van die situatie groter zal zijn. In het geval van Colombia wordt de pertinente ontkenning van de regering dat zij betrokken zou zijn bij schendingen van mensenrechten en vakbondsrechten niet prima facie gelogenstraft door de feiten. Een schoorvoetend toegeven ("admission against interest") hoeft men van de Colombiaanse regering niet te verwachten, zolang de ware toedracht van mensenrechtenschendingen voor buitenstaanders zo moeilijk vast te stellen is..$^{198}$ Aan de andere kant zijn de (potentiële) slachtoffers van mensenrechtenschendingen erop gebrand om het aandeel van - met name - het leger en de veiligheidspolitie te bewijzen. In een dergelijk geval is het met andere woorden van doorslaggevende betekenis uit welke bron men overwegend zijn informatie put.

Het komt mij voor dat in Colombia een patstelling is ontstaan. De ILO heeft wel degelijk kennis genomen van de meningen van vakbondsleden die wijzen in de richting van een grotere betrokkenheid van leger en veiligheidsagenten. ${ }^{19}$ Maar zolang vooral de omvang en het structurele karakter van deze betrokkenheid niet met harde bewijzen gestaafd is, vertoont de ILO de neiging om de visie van de regering te onderschrijven.

De kritische evaluatie van de rol van het leger en de veiligheidsagenten door de VNWerkgroep zou in het licht van het voorgaande toegeschreven kunnen worden aan het feit dat de Werkgroep op bredere schaal (dan de Direct contact-missie van de ILO) inlichtingen heeft ingewonnen bij slachtoffers en NGO's.

\subsection{De ILO en NGO's: de noodzaak tot intensievere samenwerking}

Om impasses, zoals geschetst aan het einde van de vorige paragraaf, te doorbreken, verdient het wellicht aanbeveling dat fact finding-missies van de ILO op bredere schaal informatie inwinnen en kennis nemen van de opvattingen van NGO's. ${ }^{x_{0}}$ Hierbij kan onderscheid gemaakt worden tussen pogingen van fact finding-missies zelf om met NGO's in contact te komen enerzijds, en initiatieven van NGO's om fact finding-missies van informatie te voorzien anderzijds.

198. Weissbrodt kenschetst deze "admissions against interest" als een belangrijke methode om de betrouwbaardheid van bewijsmateriaal te testen. Weissbrodit en Mc Carthy, a.w. pp. 73-74.

199 Vgl. hoofdstuk $4, \mathrm{p} .192$.

200 Onder NGO's worden in dit verband niet zozeer werknemers- en werkgeversorganisaties verstaan die conform de reguliere procedures door de ILO gehoord worden. Gedoeld wordt op organisaties als Amnesty International ${ }_{*}$ kerken en lokale mensenrechtenorganisaties. 
Wat betreft de eerste optie, zullen de mogelijkheden bepaald worden door de aard en opzet van de fact finding-procedure.

Van Direct contact-missies kan op dit gebied waarschijnlijk niet veel verwacht worden. Zij moeten hun werkzaamheden binnen een korte termijn - een week à tien dagen - verrichten en kampen bovendien met overvolle agenda's. Zij worden in ieder geval geacht om contact op te nemen met vakministers van relevante departementen - Justitie, Arbeid, Binnenlandse Zaken -, met leden van de rechterlijke macht en met vertegenwoordigers van werkgeversorganisaties en vakbonden. Incidenteel worden inlichtingen ingewonnen bij kerkelijke organisaties. ${ }^{201}$ De bescheiden opzet van Direct contact-missies, waarbij getracht wordt om, naar aanleiding van concrete klachten, opheldering te verkrijgen omtrent betwiste feiten en omstandigheden, brengt met zich mee dat met name partijen bij het onderliggend geschil - regering en vakbondsleden - gehoord worden ${ }^{202}$ Voor een bredere oriëntatie op de algehele mensenrechten- en vakbondssituatie, waarbij op grotere schaal particulieren en organisaties in de gelegenheid worden gesteld om hun visie te berde te brengen, is gezien de tijdsdruk doorgaans geen plaats.

De Onderzoeks- en Bemiddelingscommissie heeft een breder mandaat in die zin dat zij een diepgaand onderzoek instelt naar de algehele vakbondssituatie in een land. Voorafgaand aan een missie pleegt de Commissie uit eigen beweging een breed spectrum van instanties waaronder bepaalde non-gouvernementele organisaties - te consulteren en bovendien stelt zij een lijst van getuigen op die zij wenst te horen ${ }^{203}$ Dikwijls worden partijen bij het onderliggend geschil uitgenodigd om getuigen naar voren te brengen, maar de Commissie maakt ook een eigen selectie, waarbij vertegenwoordigers wit alle maatschappelijke geledingen gehoord worden.

Zoals gezegd, kunnen NGO's natuurlijk ook zelf initiatieven ontplooien om fact findingmissies van de ILO van relevante informatie te voorzien. Allereerst kunnen zij leden van fact findingmissies voor hun vertrek benaderen. Tegen een dergelijke handelwijze bestaat, in het licht van de toelaatbaarheid van het bewijsmateriaal, geen bezwaar. IGO-Organen die belast zijn met fact finding, beschikken over een vrijwel onbeperkte vrijheid om vast te stellen welk bewijsmateriaal zij gebruiken om hun conclusies te funderen en zij plegen hierbij flexibele maatstaven te hanteren. ${ }^{305}$ Dit impliceert dat fact finding-organen niet a priori informatie terzijde leggen of er minder belang aan hechten, omdat deze informatie is aangereikt door

201 Potobsky, $\mathrm{G}$, von Visits on the spot: The Experience of the ILO in: Rameharan, $\mathrm{a}_{\mathrm{n}} \mathrm{w}$. p. 173.

202 Valticos (1981), a.w. p. 486.

203 Ramcharan, aiw. $p_{i} 71$.

204 Zo wijjst Valticos (1975, a.w. p. 492) erop dat leden van de Commissie die in 1974 Chili bezocht; een onderhoud hadden met de kardinaal van Santiago, met de pauselijke nuntius, met advocaten die vakbondsledien verdedigd hadden, met vertegenwoordigers van het Comité woor de Vrede etc.

205 Ramcharan stelt dat de flexibele regel van toelaatbaarheid van bewijsmateriaal brede ondersteuning vindt in de internationale rechtspraktijk en geeft een aantal illustratieve voorbeelden. Ramcharan, aw. pp.68-70. 

een instantie - bijvoorbeeld een internationale $\mathrm{NGO}$ - die hier niet uit eigen ondervinding
over beschikt.

Het is evenwel de vraag of het, uit strategisch oogpunt, verstandig is om missieleden voor hun vertrek van informatie te voorzien. Waar fact finding-organen, wat betreft de vergaring van bewijsmateriaal, plegen te putten uit een omvangrijk reservoir, zal de selectie van de informatie die uiteindelijk het standpunt van het orgaan zal beïniloeden, verschoven worden naar een later stadium, namelijk bij het zorgvuldig wegen van het materiaal. ${ }^{20} \mathrm{Er}$ bestaat een gerede kans dat missieleden bij een dergelijke afweging het materiaal dat aangeleverd is door NGO's met enige reserve in beschouwing zullen nemen. ${ }^{200}$ We moeten in dit verband niet vergeten dat aan de instelling van ILO-fact finding-missies een procedure op tegenspraak ten grondslag ligt. Juist de tegenstrijdige informatie van partijen brengt de LO ertoe om door middel van een missie ter plaatse poolshoogte te nemen. De missieleden zullen zich willen vrijwaren tegen elke vorm van voorafgaande beïnvloeding om tot een zo objectief en onbevangen mogelijk oordeel te komen. Uit deze mentale houding vloeir een voorkeur voor informatie "uit de eerste hand" voort die tijdens de missie door ooggetuigen of slachtoffers van mensenrechtenschendingen verstrekt wordt.

Dit opent voor NGO's een alternatieve, meer indirecte weg om ILO-missies van informatie te voorzien. $\mathrm{Zij}$ kunnen immers hun informanten - zegslieden en zusterorganisaties in het land dat bezocht wordt - aansporen om hun ervaringen en wetenschap ten overstaan van de missie te herhalen. Een dergelijke optie vereist wel dat missieleden toegankelijk zijn voor spontane initiatieven van mensen en organisaties om met hen in contact te komen. Von Potobsky beweert dat ILO-fact finding-organen mensen ontvangen die te kennen geven ben te willen ontmoeten: ${ }^{20}$ Betwijfeld moet echter worden of hier sprake is van een bestendige praktijk. In rapporten van fact finding-organen wordt eigenlijk uitsluitend gerefereerd aan interviews met personen en instanties die door de missie zijn geselecteerd.

Het verdient mijns inziens dan ook aanbeveling dat de ILO vertegenwoordigers van maatschappelijke groeperingen, buiten de kring van direct betrokkenen, actief stimuleert om tijdens "on the spot-visits" missieleden te benaderen. Het kader van de Onderzoeks- en Berniddelingscommissie lijkt zich hier het beste voor te lenen. De brede opzet van het onderzoek van de Commissie, de ruchtbaarheid die aan haar werkzaamheden wordt gegeven en de lange periode waarin zij actief is, bieden in dit opzicht immers meer mogelijkheden dan de Direct contact-procedure.

206 Vgl. Weissbrodt, a.w. p. 65: "Instead of restricting admissibility, IGO's and NGO's engaged in human rights fact finding have been disposed to consider all available evidence but to weigh the evidence very carefully."

207 Judge Cohn geeft enkele richtlijnen omtrent bronnen die met name VN-arganen, belasit met het toezicht op de naleving van mensenrechten $n_{x}$ dienen te radplegen om hun slotconclusies te onderbouwen. Hoewel hij internationale organisaties als het Rode Kruis en het Hoge Commissariaat voor de Vluchtelingen noemt, rept hij met geen woord over NGO's. Cahn H. International Fact finding Processes, Review of the ICJ (1977) No. 18, p. 47.

208. Von Potobsky in: Ramcharan (ed.), a.w. p. 170. 


\subsection{Evaluatie en conclusies}

In deze paragraaf is de mensenrechtensituatie in het algemeen en de vakbondssituatie in het bijzonder in Colombia tot uitgangspunt genomen. Het staat onomstotelijk vast dat in Colombia op grote schaal vakbonds- en mensenrechten worden geschonden, maar over de exacte toedracht van en vooral de betrokkenheid van de autoriteiten bij deze schendingen tast men nog in het duister.

De situatie in Colombia past in een patroon dat steeds duidelijker zichtbaar wordt in Latijns Amerika: waar gedurende de jaren zeventig grootschalige en ernstige schendingen van de rechten van de mens werden toegeschreven aan militaire dictaturen, vinden deze nu voornamelijk plaats in (nominale) democratieën zoals Colombia, Guatemala en Peru. ${ }^{20}$

Het vergelijkend perspectief, waarvoor in dit proefschrift gekozen is, stelt ons in de gelegenheid om de taxatie van de verschillende situaties door de ILO aan een nader onderzoek te onderwerpen. In het geval wan Chili ten tijde van de militaire dictatuur van Pinochet deinsde de ILO er niet voor terug om de autoriteiten rechtstreeks verantwoordelijk te houden voor schendingen van mensenrechten, terwijl de ILO in het geval van Colombia de schuldvraag zoveel mogelijk tracht te omzeilen. ${ }^{210}$ In dit opzicht is gewezen op een zekere discrepantie tussen de opvattingen van de ILO en sommige NGO's, aangezien laatstgenoemden de neiging hebben om de directe betrokkenheid van militairen en veiligheidsagenten bij mensenrechtenschendingen in Colombia meer te benadrukken. In 5.3 heb ik betoogd dat IGO's en NGO's verschillende uitgangspunten en doelstellingen hebben. Deze doelstellingen en uitgangspunten hebben repercussies voor de gehanteerde methodes van fact finding in het algemeen en voor de interpretaties van het beginsel van hoor en wederhoor in het bijzonder. Ervan uitgaande dat de gewijzigde politieke en mensenrechtensituatie in Latijns Amerika zowel IGO's als NGO's voor de opgave plaatst om tot een kritische en realistische analyse te komen en dat sterk uiteenlopende visies op een mensenrechtensituatie een gezamenlijke inspanning in deze richting in de weg staan, heb ik gepleit voor een intensieve(re) samenwerking en informatieuitwisseling.

Wat betreft deze samenwerking met NGO's stuiten we bij de ILO op een merkwaardige paradox. De ILO is op grond van haar tripartiete organisatiestructuur werplicht om uitvoerig

209 Vgl. Manfred Nowak in een inleiding bij een interview met de coördinator van de Perualanse Vereniging voor do Rechten van de Mens (APRODEH), Franciseo Soberon: "It is widely believed that the most widespread and gross violations of human rights in South America do not occur any more in military dictatorships like Chile, but in democracies like Colombia and Peru." SIM Newsletter 3- 1988, p. 28.

210 Het is verleidelijk on een verband te postuleren tussen het democratische karakter van een regime en de terughoudendheid om de autoriteiten aansprakelijk te stellen voor schendingen van mensenrechten. In dit verband merkt Soberon in het interview met Nowak op dat: "Some governments pay very little attention to bur situation because they say that Peru is a democracy. Normally, human rights violations are only expected to occur under dicatatorships:" Later concludeert hij dat " $(.$.$) there is an urgent need in inter-governmental$ organizations to discuss human rights problems within democracies as a specific agenda "item." SIM Newsletter, a.w. p. 32 resp. 34 . 
stil te staan bij de visie van NGO's, in de vorm van werkgevers- en werknemersorganisaties. Op basis van het feit dat de ILO uit verschillende hoeken informatie inwint, zou men een even kritische als grondige evaluatie verwachten, waarbij niet geschuwd wordt om politieke achtergronden in de beschouwingen te betrekken. Van Boven heeft daarentegen gewezen op de, in het algemeen bij de ILO te bespeuren neiging om zich zoveel mogelijk te beperken tot een technisch/juridische evaluatie en voorbij te gaan aan de politieke achtergronden. Mijns inziens terecht bekritiseert hij deze houding, waar hij betoogt dat bijvoorbeeld schendingen van vakbondsrechten niet losgekoppeld kunnen worden van de politieke context. ${ }^{21}$

Bij nader inzien is de gesignaleerde tegenstrijdigheid inderdaad slechts schijn. Juist omdat de ILO zich voortdurend in een spanningsveld van conflicterende meningen bevindt; lijkt het mij aannemelijk dat zij netelige politieke kwesties zal vermijden en zich zal beperken tot een veilige juridische analyse:212

Aangezien een dergelijke benadering zeker in het geval van een ondoorzichtige vakbondssituatie ontoereikend is, heb ik een tweetal suggesties gedaan die de strekking hebben om de ILO tot een grotere voortvarendheid te prikkelen.

In de eerste plaats zal de ILO zich moeten (her)bezinnen op het gebruik van het eigen toezichtsinstrumentarium. Direct contact-missies; waarbij het diplomatiek overleg met de regering centraal staat, schieten in het geval van Colombia tekort. Er zal een grondig en diepgaand onderzoek moeten worden ingesteld en daarbij lijkt de inschakeling van de Onderzoeks- en Bemiddelingscommissie onontbeerlijk.

In de tweede plaats zal de ILO nog meer open dienen te staan voor informatie van de kant van NGO's die niet in de ILO vertegenwoordigd zijn en die dikwijls over een goed inzicht in de algehele politieke en mensenrechten-situatie beschikken. In 5.4 heb ik een voorkeur uitgesproken voor de constructie, waarbij lokale NGO's, al of niet daartoe aangespoord door een internationale koepelorganisatie, tijdens een bezoek van een ILO-fact finding-orgaan de missieleden benaderen.

Zoals gezegd, hangen beide voorstellen onderling nauw samen: de brede opzet van het onderzoek dat met name door de Onderzoeks- en Bemiddelingscommissie wordt verricht, stelt NGO's in de gelegenheid om hun informatie en zienswijze over te dragen.

211 Van Boven (1973), a.w. p. 105

212 In uitspraken van het Comite inzake de Vrijheid van Vakvereniging treft men wel de gelaten constatering aan dat beschuldigingen betreffende ernstige schendingen wan vakbondsrechten categorisch door de regering ontkend worden. Het Comite dringt in dergelijke gevallen aan op het instellen van een grondig onderzoek, teneinde de feitelijke toedracht van de gebeurtenissen vast te stellen en eventuele daders op het spoor te komen en te bestraffen. Een karakteristick voorbeeld is Case No.919 (Colombia), 194e Rap. \$355: "The Committee notes that the Government categorically denies the accusations of ill-treatment (...) As regards allegations concerning ill-treatment, the Committee has stressed in general terms the importance of carrying out an inquiry into the facts in order to establish responsiblities (...) and to apply effective sanctions." Men kan zich afvragen of een dergelijke voorzichtige opstelling die een enigszins naief wertrouwen in formeel/juridische procedures verraadt, veel effect zal sorterem. 
Wat betreft de bereidheid van een regering om haar medewerking te verlenen aan een grondig onderzoek, zal er veel van afhangen hoe de ILO haar voorgenomen plannen presenteert. De ILO zal de betrokken regering duidelijk moeten maken dat de instelling van een Onderzoeks- en Bemiddelingscommissie niet bij voorbaat een veroordeling van de regering inhoudt, maar dat het een ten onrechte in onbruik geraakt instrument is dat bij uitstek geschikt is on in verwarrende situaties de feiten bloot te leggen. Verder zal de ILO zo nodig de regering ervan moeten overtuigen dat het inschakelen van NGO's een integraall en onontbeerlijk onderdeel in de fact finding-procedure is en dat de Commissieleden over voldoende onderscheidend vermogen beschikken om eventuele gekleurde of lasterlijke berichtgeving buiten beschouwing te laten. In verband met dit laatste is het van belang dat de ILO de regeringverzekert dat uitsluitend de informatie van een NGO en niet diens conclusies zullen worden overgenomen. ${ }^{213}$

Mocht de regering nochtans weigeren om medewerking te verlenen, dan kan dit een duidelijke aanwijzing zijn dat de regering wel degelijk iets te verbergen heeft en zal de ILO zich moeten beraden over nadere stappen. ${ }^{214}$ In het specifieke geval van Colombia acht ik het everwel prematuur om te speculeren op de weigering van de regering om in te stemmen met een grondig onderzoek naar de vakbondssituatie. Colombia heeft een groot aantal verdragen op het gebied van de rechten van de mens geratificeerd en hecht er grote waarde aan dat het in de wereldopinie bekend staat als een democratische rechtsstaat. Bovendien zijn er aanwijzingen dat de burgerregering zelf zich ook in toenemende mate zorgen maakt over de machtspositie van het leger. ${ }^{215} \mathrm{Het}$ is mogelijk dat de hierboven gesuggereerde voorstellen een aanzet vormen tot een oplossing van de problemen, waarvoor zowel de ILO als Colombia zich geplaatst zien.

\section{Slotbeschouwing}

Het tripartiete beginsel doortrekt als een zuurdesem de organisatiestructuur van de ILO. Ontegenzeggelijk heeft de tripartiete samenstelling een enorme invloed gehad op de

213 Vgll, Kooijmans, a.w. p. 21" "NGO's on the other hand sometimes have criticized UN mandatories (...) for the fact that the UN mandatories have not explicitly drawn the same conclusions from these allegations as they have done themselves:

$214 \mathrm{Vgl.Cohn,} \mathrm{a:w.} \mathrm{p.} \mathrm{44:} \mathrm{"Non-cooperation} \mathrm{as} \mathrm{such} \mathrm{would} \mathrm{already} \mathrm{have} \mathrm{to} \mathrm{be} \mathrm{regarded} \mathrm{as} \mathrm{a} \mathrm{breach} \mathrm{of} \mathrm{the} \mathrm{state's}$ human rights obligations."

Van Boven (1992), a.w. p. 49 merkt op dat er een groeiende "opinio juris" is met betrekking tot de statelijke verplichting om mee to werken in het kader wan mensenrechten-procedures. Overigens zijn de altematieven in geval wan weigering beperkt. Denkbaar is dat de $\mathbb{R a a d}$ van Beheer een procedure op grond van art. 26 ILO-Statuut zou startem. Een Onderzoeks-Commissie zou vervolgens, op basis van het beschikbare materiaal, een rapport kunnen samenstellen. Een bezoek aan het land in kwestie lijkt bij voorbaat uitgesloten.

215 Vgl. Vervaele J. Criminal Law and the Protection of Human Rights in Colombia in: SIM Newsletter 3-1988, pp. $9-10$. 
ontwikkeling van de ILO-visie op de vrijheid van vakvereniging. Het gedetailleerde normenstelsel in deze dat nader verfijnd en uitgewerkt is in de jurisprudentie van de toezichthoudende organen, mag uniek heten. De totstandkoming van dit respect afdwingende "corpus" kan, althans voor een belangrijk deel, worden toegeschreven aan de grote inzet van werknemers- en werkgeversvertegenwoordigers.

Toch kleven er ook enkele bezwaren aan de tripartiete organisatiestructuur. ${ }^{216}$ Vrijheid van vakvereniging is een hoogst gewichtige en delicate aangelegenheid, waarover regeringen, werkgevers- en werknemersorganisaties dikwijls fundamenteel verschillende denkbeelden hebben. De meningsverschillen kunnen aanleiding zijn tot levendige debatten binnen de Internationale Arbeidsconferentie, maar zij kunnen ook verlammend werken. Vooral met betrekking tot controversiële onderwerpen kan de besluitvorming worden belemmerd door de "parti pris" van de verscheidene vertegenwoordigers. Zo is het niet verwonderlijk dat de ILO de grootste moeite heeft gehad om over de toelaatbaarheid van het ontplooien van politieke activiteiten door vakbonden een duidelijk standpunt in te nemen. Voor de machthebbers kunnen politieke activiteiten een bedreiging vormen, aangezien vakbonden hiermee het terrein van de staat betreden en per definitie het oogmerk hebben om pressie uit te oefenen op de staat. Voor de vakbeweging is politieke actie welhaast een onontbeerlijk onderdeel van haar werkzaamheden, omdat de sociaal/economische politiek in toenemende mate haar belangen raakt. Het bloedeloze compromis dat is neergelegd in de ILC-Resolutie van 1952, zou in dit licht bezien wel eens het resultaat kunnen zijn van een verbeten touwtrekken tussen regerings- en werknemersvertegenwoordigers.

Ook de opmerkelijke voorkeur van de toezichthoudende organen van de ILO voor de interventie van de nationale rechter kan wellicht verklaard worden uit de geïnstitutionaliseerde spanning tussen regerings- en werknemersvertegenwoordigers die het produkt is van de tripartiete structuur. Waar, met name in een klachtenprocedure, staat en vakbond als kemphanen tegenover elkaar staan, kan de behoefte om een neutrale arbiter in te schakelen voortvloeien uit de vrees dat bespreking van de kwestie binnen het tripartiet samengestelde orgaan tot een scheiding der geesten leidt. Het gevaar is daarbij niet denkbeeldig dat de toezichtsorganen van de $\mathrm{LO}$ hun eigen verantwoordelijkheid ontlopen. Bovendien wordt miskend dat de rechter dikwijls slechts in beperkte mate kan corrigeren.

In het licht van het bovenstaande strekt het de ILO tot eer dat zij beide (potentiële) knelpunten op bevredigende wijze heeft opgelost. In de eerste plaats hebben de toezichthoudende organen uiteindelijk concrete criteria opgesteld met betrekking tot de toelaatbaarheid van politieke activiteiten. Het is in dit verband vermeldenswaardig dat het Comite van

216 Osieke merkt op dat: "although tripartism is generally regarded as the very essence of the ILO, it is not without its critics." Als kritiekpunten noemt hij onder andere de grote vertraging in de werkzaamheden van de ILO en de opvatting dat werkgevers en werknemers niet behoorlijk vertegenwoordigd zouden zijn. Osieke E. Constitutional Law and Practice in the Intemational Labour Organisation, Dordrecht 1985, p. 53. 
Deskundigen bij het formuleren van die criteria het voortouw heeft genomen. Het zou een aanwijzing kunnen zijn dat een orgaan van onafhankelijke personen, niet gehinderd door de "patizanenstrijd" binnen een tripartiet samengesteld orgaan, eerder in staat is om in politiekgevoelige kwesties een doorbraak te forceren. In de tweede plaats heeft de ILO duidelijk te kennen gegeven dat de voorkeur voor rechterlijke interventie nog niet impliceert dat de rechterlijke uitspraak in de ogen van de ILO een sacrosankt karakter heeft.

Een ander facet van de tripartiete structuur betreft het vereiste van representativiteil, waaraan vakorganisaties moeten voldoen om hun achterban bij de ILO te vertegenwoordigen. In het eerste hoofdstuk van deze studie bleek al dat het niet altijd eenvoudig is om vast te stellen welke organisatie aanspraak kan maken op de kwalificatie "meest representatieve organisatie". Vakorganisaties die deze begeerde status eenmaal hebben verworven, kunnen er belang bij hebben om hun bevoorrechte positie te behouden. Het verzet tegen afwijzing van "closed shop"-clausules zou heel goed toegeschreven kunnen worden aan de onwil van "representatieve organisaties" om hun privileges die zij wellicht aan het bestaan van "closed shop"-clausules te danken hebben, op te geven. Vanuit deze optiek zou men kunnen stellen dat de half-zachte bejegening van "closed shop"-clausules inherent is aan de tripartiete organisatiestructuur. Maar begrip voor de politieke en institutionele achtergronden van een bepaalde opvatting houdt nog niet in dat men met deze opvatting instemt. "Tout comprendre" is in dit geval zeker niet "tout pardonner".

In het vorige hoofdstuk heb ik twee redenen genoemd, waarom de ILO stelling dient te nemen tegen het fenomeen van de "closed shop". Allereerst beknotten feitelijke vakbondsmonopolies die het gevolg zijn van "closed shop"-clausules, evenals wettelijk opgelegde monopolies, het fundamentele recht van werknemers om vakorganisaties "naar eigen keuze" op te richten of zich daarbij aan te sluiten. In de tweede plaats zal de RLO beter in de gelegenheid zijn om verhulde politieke controle die dikwijls uitsluitend stand kan houden dankzij het bestaan van feitelijke vakbondsmonopolies, aan te merken als een schending van vakverenigingsvrijheid.

Een neveneffect van de tripartiete organisatiestructuur tenslotte, is dat de toezichthoudende organen van de ILO, bij de beoordeling van een vakbondssituatie, de neiging vertonen om hun conclusies grotendeels te baseren op de zienswijzen van regering en vakorganisaties. Vooral in gecompliceerde, ondoorzichtige vakbondssituaties, waar de meningen van de informanten diametraal tegenover elkaar staan, kan dit leiden tot een patstelling. On deze impasse te doorbreken, zou het aanbeveling verdienen dat de ILO op bredere schaal informatie zou inwinnen door zich - bijwoorbeeld - te verstaan met andere non-gouvernementele organisaties (dan werkgevers- en werknemersorganisaties). Zoals ik in de laatste paragraaf van het vorige hoofdstuk betoogd heb, dient de ILO zich daarbij te bezinnen op het gebruik van haar toezichtsinstrumentarium. De terughoudendheid om gebruik te maken van "zware" procedures, zoals de Onderzoeks- en Bemiddelingscommissie, is op zichzelf wel begrijpelijk: Het entameren van een dergelijke procedure kan door een staat worden opgevat als een motie van wantrouwen en de staat in kwestie kopschuw maken om medewerking te verlenen aan het welslagen van 
de procedure. Toch moet de ILO deze schroom overwinnen, ondat "pappen en nathouden" ook geen oplossing is en omdat de slachtoffers van ernstige schendingen van mensenrechten en vakbondsrechten recht hebben op de maximale inzet van een organisatie die beweert zich in te zetten voor hun belangen.

Met een persoonlijke noot zou ik mijn studie willen beëindigen. Vrijheid van vakvereniging is geen luxe-artikel. Vooral in een continent als Latijns Amerika, waar sommige bevoorrechten nog immer het brood consumeren dat anderen "in het zweet huns aanschijns verdienen", is organisatie in vakverenigingen bij uitstek een geschikt middel om gezamenlijk te streven naar een menswaardig bestaan en een evenredige verdeling van inkomen.

In de loop der jaren heeft de ILO kwalitatief hoogstaand werk afgeleverd, zowel op het terrein van het formuleren van normen inzake de vrijheid van vakveteniging als bij het ontwikkelen van toezichtsprocedures. In sommige "schemersituaties", waarin informele controle wordt uitgeoefend over vakorganisaties of waarin vakorganisaties en werknemers het slachtoffer worden van informele repressie, schieten zelfs deze voortreffelijke normen en toezichtsprocedures tekort. Met deze studie heb ik een aanzet willen geven tot een discussie die wellicht kan leiden tot een verbetering van het functioneren van de ILO. 


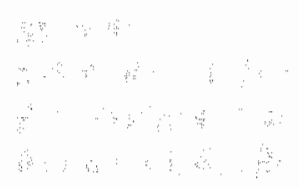




\section{Bijlage}

\section{CONVENTION No. 87}

\section{Article I}

Each Member of the International Labour Organisation for which this Convention is in force undertakes to give effect to the following provisions.

\section{Article 2}

Workers and employers, without distinction whatsoever, shall have the right to establish and, subject only to the rules of the organisation concerned, to join organisations of their own choosing without previous authorisation.

\section{Article 3}

1. Workers' and employers' organisations shall have the right to draw up their constitutions and rules, to elect their representatives in full freedom, to organise their administration and activities and to formulate their programmes.

2. The public authorities shall refrain form any interference which would restrict this right or impede the lawful exercise thereof.

\section{Article 4}

Workers' and employers' organisations shall not be liable to be dissolved or suspended by administrative authority.

\section{Article 5}

Workers' and employers' organisations shall have the right to establish and join federations and confederations and any such organisation, federation or confederation shall have the right to affiliate with international organisations of workers and employers.

\section{Article 6}

The provisions of Articles 2, 3 and 4 hereof apply to federations and confederations of workers" and employers' organisations. 
The acquisition of legal personality by workers" and employers" organisations, federations and confederations shall not be made subject to conditions of such a character as to restrict the application of the provisions of Articles 2, 3 and 4 hereof.

\section{Article 8}

1. In exercising the rights provided for in this Convention workers and employers and their respective organisations, like other persons or organised collectivities, shall respect the law of the land.

2. The law of the land shall not be such as to impair, nor shall it be so applied as to impair, the guarantees provided for in this Convention.

\section{Article 9}

1. The extent to which the guarantees provided for in this Convention shall apply to the armed forces and the police shall be determined by national laws or regulations.

2. In accordance with the principle set forth in paragraph 8 of article 19 of the Constitution of the International Labour Organisation the ratification of this Convention by any Member shall not be deemed to affect any existing law, award, custom or agreement in virtue of which members of the armed forces or the police enjoy any right guaranteed by this Convention.

\section{Article 10}

In this Convention the term "organisation" means any organisation of workers or of employers for furthering and defending the interests of workers or of employers.

\section{Article II}

Each Member of the International Labour Organisation for which this Convention is in force undertakes to take all necessäry and appropriate measures to ensure that workers and employers may exercise freely the right to organise. 


\section{CONVENTION No. 98}

\section{Article I}

1. Workers shall enjoy adequate protection against acts of anti-union discrimination in respect of their employment.

2. Such protection shall apply more particularly in respect of acts calculated to

a. make the employment of a worker subject to the condition that he shall not join a union of shall relinquish trade union membership;

b. cause the dismissal of or otherwise prejudice a worker by reason of union membership or because of participation in union activities outside working hours or, with the consent of the employer, within working hours.

\section{Anticle 2}

1. Workers' and employers' organisations shall enjoy adequate protection against any acts of interference by each other or each other's agents or members in their establishment, functioning or administration.

2. In particular, acts which are designed to promote the establishment of workers' organisations under the domination of employers or employers' organisations, or to support workers' organisations by financial or other means, with the object of placing such organisations under the control of employers or employers' organisations, shall be deemed to constitute acts of interference within the meaning of this Article.

\section{Article 3}

Machinery appropriate to national conditions shall be established, where necessary, for the purpose of ensuring respect for the right to organise as defined in the preceding Articles.

\section{Article 4}

Mearures appropriate to national conditions shall be taken, where necessary, to encourage and promote the full development and utilisation of machinery for voluntary negotiation between employers or employers' organisations and workers" organisations, with a view to the regulation of terms and conditions of employment by means of collective agreements. 


\section{Article 5}

1. The extent to which the guarantees provided for in this Convention shall apply to the armed forces and the police shall be determined by national laws or regulations.

2. In accordance with the principle set forth in paragraph 8 of article 19 of the Constitution of the International Labour Organisation the ratification of this Convention by any Member shall not be deemed to affect any existing law, award, custom or agreement in virtue of which members of the armed forces or the police enjoy any right guaranteed by this Convention.

\section{Article 6}

This Convention does not deal with the position of public servants engaged in the administration of the State, nor shall it be construed as prejudicing their rights or status in any way. 


\section{Lijst van bronnen en van geraadpleegde literatuur}

\section{ILO-Documentatie}

Het ware ondoenlijk de vindplaatsen van alle "cases" van het Comite inzake de Vrijheid van Vakvereniging weer te geven. Telkens is in deze studie verwezen naar het Rapport, waarin de "cases" zijn opgenomen. Tot 1975 werden deze Rapporten gepubliceerd in een Supplement bij het "Official Bulletin", een uitgave van het Internationale Arbeidsbureau. Vanaf 1975 zijn de Rapporten opgenomen in de Series B van het Official Bulletin.

Een samenvatting van de dialogen tussen het Deskundigen-Comité en regeringen treft men aan in de jaarlijkse:

ILO, Report of the Committee of Experts on the Application of Conventions and Recommendations, Report III (Part 4A)

De Rapporten die regeringen op basis van art. 22 ILO-Statuut periodiek moeten indienen ("Memoria's") zijn niet gepubliceerd.

\section{VN-Documentatie}

In hoofdstuk 3 wordt regelmatig gerefereerd aan de bevindingen van het Ad Hoc-Comité en van de Speciale VN-Rapporteur voor Chili. De rapporten worden integraal besproken door de Algemene Vergadering van de Verenigde Naties. De aanduidingen UN-Doc. A/33/331, A/35/ 522 etc. geven aan dat het een document van de AV betreft.

In hoofdstuk 4 wordt gewag gemaakt van de VN-Werkgroep inzake Gedwongen en Onvrijwillige Verdwijningen. De afkorting E/CN.4/1989/18/Add.1 verwijst naar een document van de VN-Commissie voor de Rechten van de Mens. 


\section{OAS-Documentatie}

De volledige titel van het Chili-Rapport (1985) van de Inter-Amerikaanse Commissie voo de Rechten van de Mens luidt als volgt:

Organization of American States, Report on the Situation of Human Rights in Chile OAS/Ser.L/V/II.66 Doc. 17, September 271985

\section{Lijst van aangehaalde literatuur}

Alba V., Politics and the Labor Movement in Latin America, Stanford 1968

Alexander R.J., Organized Labor in Latin America, New York 1965

Alston Ph., The United Nations and the elliptical notion of the universality of human rights in: United Nations, Is universality in jeopardy?, New York 1987

America's Watch/Asia Watch/Helsinki Watch "Four Failures". A Report on the U.N. Special Rapporteurs on Human Rights in Chile, Guatemala, Iran and Poland, Washington/New York 1986

Amnesty International, Colombia: Una Crisis de Derechos Humanos, London 1988

Amnesty International, Colombia; Human Rights Developments - "Death Squads" on the Defensive? London, September 1989

Andean Commission of Jurists, The Right to Justice, Bogota 1988

Anderson Ch. W., Politics and Economic Change in Latin America, New York 1967 Westport 1987

Anderson B./Cockcroft J.D., Control and Coöptation in Mexican Politics in: Horowitz I.L. (ed.), Latin American Radicalism, New York 1969

Angell A., Politics and the Labour Movement in Chile, London 1972

Angell A., Trade Unions in Latin America in: Collier S./Blakemore H. and Skidmore Th. E. (eds.), The Cambridge Encyclopaedia of Latin.America and the Carribean, Cambridge 1985 
Arriagada G., Ideology and Politics in the South American Military (Angentina, Brazil, Chille and Unuguay), Wilson Center Paper No. 55

Arriagada G., Pinochet. The Politics of Power, Boston 1988

Ayala J./Ruiz Duran C., Development and Crisis in Mexico: A Structuralist Approach in: Hartlyn J./Morley S.A. (eds.), Latin American Political Economy: Financial Crisis and Political Change, Boulder 1986

Baehr P.R., Universaliteit en de rechten van de mens in: Intemationale Spectator, februari 1986, $\mathrm{XL}-2$

Barbagelata H., Introduction aux Institutions du Droit du Travail en Amérique Latine, Leuven 1980

Barrera M./Henriquez H./Selamé T., Sindicatos y Estado en el Chile actual, Genève 1985

Barrera M./Valenzuela J.S., The Development of Labor Movement Opposition in: Valenzuela J.S./Valenzuela A., Military Rule in Chile, Baltimore and London 1986

Barría Jorge S., El Movimiento obrero en Chile, Sintesis histórico-social, Santiago 1971

Bejarano J.A., El Despegue Cafetero (1900-1928) in: Ocampo J.A. (ed.), Historia económica de Colombia, Bogotá 1987

Ben Israël R., International Labour Standards: The Case of Freedom to Strike, Deventer 1988

Benadava S., Las relaciones entre Derecho Internacional y Derecho Interno ante los tribunales chilenos in: 59 Revista de Derecho, Jurisprudencia y Ciencias Sociales 1-2 (Enero-Abril 1962)

Bergquist Ch., Coffee and Conflict in Colombia, Durham N.C. 1978

Bergquist Ch., Labor in Latin America, Stanford 1986

Bertrams R.I.V.F., Een rechtsvergelijkende beschouwing over de politieke staking in: NJB 1982

Betten L., The Right to Strike in Communty Law, 's-Gravenhage 1985

Blanchard P., The Origins of the Peruvian Labor Movement; 1883-1919, Pittsburgh 1982 
Bossuyt M.J., La distinction juridiqque entre les droits civils et politiques et les droits économiques, sociaut et culturels in: Human Rights Joumal, Vol. VIII (1975)

Bossuyt M.J., The Development of the Special Procedures of the United Nations Commission on Human Rights in: Human Rights Law Journal, Vol. 6 (1985)

Boven van Th., Fact-Finding in the Field of Human Rights in: 3 Israel Yearbook on Human Rights (1973)

Boven van Th., Duty of States to Cooperate in: Nordic Joumal on Human Rights, 1987 No. 3

Boven van "Th., "Political" and "Legal" Control Mechanisms: Their Competition and Coexistence in: Eide A./Hagtvet B. (eds.), Human Rights in perspective: a global assessment; Nobel Symposium 74 , Oxford 1992

Brandenburg F., The Making of Modem Mexico, New York 1964

Buen de N., Mexico in: Blanplain R. (Ed. in Chief), International Encylopaedia for Labour Law and Industrial Relations, Deventer/Boston 1991

Buve R., Mexico onder Carlos Salinas de Gortari: een revalutie van bovenaf in: Internationale Spectator, mei 1992

Cammack $\mathrm{P}$., The political economy of contemporary regimes in Latin America: from bureaucratic authoritarianism to restructuring in: O'Brien Ph./Carnmack P. (eds.), Generals in retreat. The crisis of military rule in Latin America, Manchester 1985

Campero G., El Sindicalismo Chileno en el Regimen Militar (1973-1984) in: García R. (ed.), "Chile: 1973-1984", Stockholm 1985

Campero G.. Los trabajadores y el sindicalismo en la próxima década in: Martner G. (coord.), Chile hacia el 2000; Desafios y opciones, Caracas 1988

CanÇado Trindade A.A., Exhaustion of Local Remedies under the UN Covenant on Civil and Political Rights and its Optional Protocol in: 28 Intemational and Comparative Law Quarterly, October 1979 
Cardoso F.H., On the Characterization of Authoritarian Regimes in Latin America in: Collier D. (ed.), The New Authoritarianism in Latin America, Princeton 1979

Cardoso F.H./Faletto E., Dependency and Development in Latin America, Berkely 1979

Carr B., Onganized Labour and the Mexican Revolution 1915-1928, Oxford 1972

Carrière J./Haworth N./Roddick J. (eds.), The State, Industrial Relations and the Labour Movement in Latin America, Hampshire 1989

Cassese A., How Could NGO's Use U.N. Bodies More Effectively? in: Universal Human Rights, Vol. 1 No. 4, October/December 1979

Cassese A., Modem Constitutions and Intemational Law, Rec. Cours Academie du Droit International 1985 (III)

Catalán Aravena O., Ontmanteling en Herstel van de Vakbeweging in: Catalán Aravena O./ Gunder Frank A. (red.), Chili onder Pinochet, Amsterdam 1984

Cella G./Treu T., National Trade Union Movements in: Blanplain R. (ed.), Comparative Labour Law and Industrial Relations, Deventer 1987

CEPAL (Comision Económica para América Latina; Naciones Unidas), El Desarrollo Social de América Latina en la Postguerra, Buenos Aires 1963

CEPAL/FAO, El café en América Latina. Problemas de la productividad y perspectivas. I Colombia y El Salvador; Méjico 1958

Clark M.R., La organización obrera en México, México 1979

Cohn H., Intemational Fact-Finding Processes, Review of the ICJ No. 18 (1977)

Contreras Suarez E./Silva Ruíz G., Los recientes movimientos mexicanos pro independencia sindical y el reformismo obrero in: Revista Mexicana de Sociología, Año XXXXIV (1972)

Coomans A.P.M., De internationale bescherming van het recht op onderwijs, Leiden 1992

Córdova E. (ed.), Las Relaciones Colectivas en América Latina, Ginebra 1981

Cranston M., Human Rights Today, New York 1962 
Cranston M., What are human rights?, London 1973

Crouch C., Trade Unions: the Logic of Collective Action, Glasgow 1982

Davies P./Freedland M. Kahn-Freund's, Labour and the Law, London 1983

Davis Ch. L., Working Class Mobilization and Political Control in Venezuela and Mexico, Kentucky 1989

Deutsche UNESCO-Kommission, Menschenrechte und "Rechte der Völker". Ein Gespräch, München 1983

Dijk van P., Toetsing van Overheidshandelen door de Nationale en Internationale Rechter en het Vereiste van een Procesbelang, "s-Gravenhage 1976

Dijk van P./Hoof van G.J.H., De Europese Conventie in Theorie en Praktijk, Nijmegen 1982

Donnelly J., Cultural relativism and universal human rights in: Human Rights Quarterly, Vol. 6, 1984

Duk R.A.A., Vrijheid van Vereniging en Verplicht Vakbondslidmaatschap in: Stichting Maandblad Arbeid, 1971

Epstein E.C. (ed.), Labor Autonomy and the State in Latin America, Boston 1989

Erades L., De verhouding tussen volkerrecht en nationaal recht in Nederland in: NJB 18-03-1950, no. 11.

Everett M.D., The Role of the Mexican Trade Unions, 1950-1963, Ph.D diss. Economics, Washington University, St. Louis 1967

Falabella G., Labour in Chile under the Junta, 1973-1981, London 1981

Fluharty V.L., Dance of the Millions, Pittsburgh 1957 
Foxley A, Economic and Political Transition in South America in. Galjart B./Silva P. (eds.), Democratization and the State in the Southern Cone, Amsterdam 1989

Franck Th.M./Fairley H.Scott, Procedural Due Process in Human Rights Fact-Finding by Intemational Agencies in: American Joumal of International Law, Vol. 74, 1980

Freyre Rubio J., Las Organizaciones Sindicales, Obreras y Burocraticas Contemporäneas en Mérico, México 1985

Frías P., Dimensiones Cuantitativas de la Afiliaciốn Sindical, CED Santiago 1984

George S., A Fate worse than Debt, New York 1988

Golub S.S., The Political Economy of Latin American Debt Crisis in: Latin American Research Review, Vol. 26 No.1, 1991

Gonzalez Casanova P., Democracy in Mexico, Oxford 1970

Graefrath B., Universal Declaration of Human Rights - 1988 in: SIM Special No. 9 The Universal Declaration of Human Rights: its significance in 1988, Utrecht 1988

Grayson G.W., The Mexican Labor Machine: Power, Politics and Patronage, Washington DC. 1989

Guzmán G./Fals Borda E./Umaña Luna E., La Violencia en Calombia, Bogotá 1962

Haba E. P., Tratado Básico de Derechos Humanos, Tomos $I$ y II, San José 1986

Handelman H., The Politics of Labor Protest in Mexico in: Journal of Interamerican Studies and World Affairs, Vol. 18 No. 3, August 1976

Hansen R.D., The Politics of Mexican Development, Baltimore/London 1971

Hartlyn J., The impact of patterns of industrialization and of popular sector incorporation on political regime type: a case study of Colombia in: Studies in Comparative International Develop ment, 1984 Vol. XIX 
Hartlyn J./Morley S.A., Bureaucratic-Authoritarian Regimes in Comparative Perspective in:

Hartlyn J./Morley S.A. (eds.), Latin American Political Economy: Financial Crisis and Political Change, Westview Press 1986

Haworth N./ Roddick J., Tres cambios de Rumbo en la Polltica Laboral del Gobierno Militar en Chile in: Gallitelli B. y Thompson A.A. (eds.), Sindicalismo y Regímenes Militares en Argentina y Chile, Amsterdam 1982

Hellman J.A., Mexico in Crisis, London 1978

Henkin L., International Law: Politics, Values and Functions, Rec. Cours Academie du Droit International 1989 (IV)

Hepple B./Fredman S., Great Britain in: Blanplain R. (Ed. in Chief), Intemational Encyclopatedia for Labour Law and Industrial Relations, Deventer/Boston 1991

Heringa A.W., Sociale Grondrechten, 's-Gravenhage 1989

Higgins R., United Kingdom in: Jacobs F.G./Roberts S. (eds.), The Effect of Treaties in Domestic Law, UKNCCL, Vol. 7, London 1987

Hirschman A.O., The Political Economy of Import-Substituting-Industrialization in Latin America in: Nisbet Ch.T., Latin America: Problems in Economic Development, New York 1969

Hirschman A.O., The tum to authoritarianism in Latin America and the search for its economic determinants in: Collier D. (ed.), The New Authoritarianism in Latin America, Princeton 1979

Hirschman A.O., The Political Economy of Latin American Development: Seven Exercises in Retrospection in: Latin American Research Review, Vol. XXII No. 1 (1987)

Hoefer-van Dongen P., The Right to Strike within the Framework of the ILO, 24 Netherlands International Law Review 1977

Humphrey J., Capitalist Control and Workers' Struggle in the Brazilian Auto Industry, Princeton 1982

Hurtado Beca C., Chile 1973-1981: Desarticulación y Reestructuración.Autoritaria del Movimiento Sindical in: Gallitelli B. y Thompson A.A. (eds.), Sindicalismo y Regimines Militares en Angentina y Chile, Amsterdam 1982 
Ianni O., Populismo y Relaciones de Clase in: Germani G./di Tella T.S./Ianni O., Populismo y contradicciones de clase en Latinoamérica, Méjico 1973

Iglesias S., Sindicalismo y Socialismo en México, México 1970

International Labour Office, The trade union situation in Chile: Report of the Fact-Finding and Conciliation Commission on Freedom of Association, Geneva 1975

International Labour Office, Freedom of Association and Collective Bangaining. General Sumey by the Committee of Experts, Geneva 1983

International Labour Office, Freedom of Association. Digest of Decisions and Principles of the Freedom of Association Committee, Geneva 1985

International Labour Office, ILO Principles, Standards and Procedures concerning Freedom of Association, Geneva 1985

International Labour Office, Human Rights - A Common Responsibility, Geneva 1988

International Labour Office, Labour Law Documents, Geneva 1992/1

International Law Association, Belgrade Minimal Rules of Procedure for International Human Rights Fact-Finding Missions, Belgrade Session 1980

Jacobs A., De rechtstreekse werking van internationale normen in het sociaal recht. Preadvies woor de Vereniging van Arbeidsrecht, Alphen aan de Rijn 1985

Jacobs A., Het recht op collectief onderhandelen, Alphen aan den Rijn/Brussel 1986

Jacobs F.G./Roberts S. (eds.), The Effect of Treaties in Domestic Law, United Kingdom National Committee of Comparative Law (UKNCCL), Vol. 7, London 1987

Javillier J.C., Droit du Travail, Paris 1981

Jelin E./Torre J.C., Los nuevas trabajadores en América Latina: una refiexión sobre la tesis de la aristocracia obrera in: Desarrollo Económico, Buenos Aires, vol. 22 No. 85 (1982)

Jenks C.W., The International Protection of Trade Union Freedom, London 1957 
Jhabvala F., On Human Rights and the Social-Economic Context in: Netherlands Intemational Law Review, 1984

Kapteyn PJ./VerLoren van Themaat P., Inleiding tot het Recht wan de Europese Gemeenschappen, Deventer 1987

Kaufman R.R., Mexico and Latin American Authoritarianism in: Reyna J.L./Weimert R.S. (eds.), Authoritarianism in Mexico, Philadelphia 1977

Kaufman R.R., Industrial Change and Authoritarian Rule in: Collier D. (ed.), The New Authoritarianism in Latin America, Princeton 1979

Kaufman R.R./Stallings B., Debt and Democracy in Latin America, Boulder Colorado 1989

Kelsen H., Reine Rechtslere, Wenen 1960

King T., Mexico: Industrialization and Trade Policies since 1940, New York 1970

Kline H.F., The National Front: Historical Perspectives and Oveniew in: Berry R.A./Hellman R.G./Solaún M, Politics of Compromise, Coalition Government in Colombia, New Brunswick, New Jersey 1980

Kooijmans P.H., The Non-Governmental Onganiations and the Monitoring Activities of the United Nations in the Field of Human Rights in: The Role of Non-Governmental Onganizations in the Promotion and Protection of Human Rights, Leiden 1991

Koopmans T., Compendium van het Staatsrecht, Deventer 1987

Kuczynski P.P., Latin American Debt, Baltimore 1988

Kühnhardt L., Die Universalität der Menschenrechte, München 1987

Landsberger H., The Labor Elite: Is it revolutionary? in: Lipset S.M./Solari A., Elites in Latin America, London 1967

Lardy P., La force obligatoire du droit international en droit interne, Paris 1966 
Lauth H.J., Gewerkschaften in Mexico: zwischen Partizipation und Kontrolle in: Briesemeister D./Zimmerman K. (Hrsg.), Mexico Heute, Politik, Witschaft, Kultur, Frankfurt am Main 1992

Leal Buitrago F., Estado y Política en Colombia, Bogotá 1984

Leary V., Intemational Labour Conventions and National Law, the Hague/Boston/London 1982

LeGrand C., Labor Acquisition and Social Conflict in the Colombian Frontier, 1850-1936 in: Joumal of Latin American Studies, 16 (1984)

Levy D./Székely G., Mexico: Paradoxes of Stability and Change, Boulder (Col.) 1987

Lijnzaad L., Paradoxale universaliteit, of de beperkingen van het verdragenrecht in: Boven van Th./Flinterman C., Universaliteit van mensenrechten: fundamenteel en controversieel, Leiden 1992

Limburg Principles on the Implementation of the International Covenant on Economic, Social and Cultural Rights in: Human Rights Quarterly, 9 (1987)

Londoño Botero R., La Estructura Sindical Colombiana en la Década del 70 in: Gomez Buendía H./Londoño Botero R./Perry Rubio G. (eds.), Sindicalismo y Polííica Económica, Bogotá 1986

Loonstra C.J., Nooit meer staken? in: Intermediair, 20 oktober 1989

Loveman B., Military Dictatorship and Political Opposition in Chile, 1973-1986 in: Journal of Interamerican Studies, 1896/1987, No. 4, p. 2

Malloy J.M., The Politics. of Transition in Latin America in: Malloy S.M./Seligson M.A. (eds.), Authoritarians and Democrats: Regime Transition in Latin America, Pittsburgh 1987

Moncayo V.M./Rojas F., Luchas Obreras y Política Laboral en Colombia, Bogotâ 1978

Mc Greevy W.P., An Economic History of Colombia, 1845-1930, Cambridge 1971

Mc Naïr A.D., Law of Treaties, London 1961

Medina Quiroja C., The Battle of Human Rights, Dordrecht 1990 
Meertens D., Jonkers en Boeren, de strijd om het land in Colombia, Amsterdam 1979

Middlebrook K.J, Political Change and Political Reform in an Authoritarian Regime: The Case of Mexico, Washington DC. 1981

Middlebrook K.J., The Sounds of Silence: Organised Labour's Response to Economic Crisis in Mexico in: Journal of Latin American Studies, Vol. 21 (May 1989)

Monteon M., Chile in the Nitrate Era, Madison Wisconsin 1982

Needler M.C., Mexican Politics: the Containment of Conflict, New York 1968

Niekerk A.E., Populisme en politieke ontwikkeling in Latijns Amerika, Rotterdam 1972

Nowak M., Interview met Francisco Soberon in: SIM Newsletter 3/1988

O'Brien Ph./Roddick J., Chile: The Pinochet Decade, London 1983

O'Donnell G., Modernization and Bureaucratic-Authonitarianism: Studies in South American Politics, Berkeley 1973

O'Donnell G., Reflections on the Patterns of Change in the Bureaucratic-Authoritarian State in: Latin American Research Review (XIII, No. 1) 1978

Oquist P., Violence, Conflict and Politics in Colombia, New York 1980 Organization of American States, Inter American Yearbook on Human Rights 1985, Dordrecht
1987

Ornstein G.F., Vrijheid van Vakorganisatie, Amsterdam 1940

Osieke $\mathrm{E}_{\text {, }}$ Constitutional Law and Practice in the International Labour Organisation, Dordrecht
1985 
Padgett V.L., The Mexican Political System, Boston 1966

Palacios M., Coffee in Colombia, Cambridge 1980

Panhuys van H.F., Reflecties over volkenrechtelijke reflexen in: NJB, 1963, no. 5

Pankert A., Freedom of Association in: Blanplain R. (ed.), Comparative Labour Law and Industrial Relations, Deventer 1987

Parsons J., Antioqueño Colonization in Western Colombia, Berkeley 1949

Pax Christ Netherlands/Dutch Commission Justitia et Pax, Impunity in Colombia, den Haag 1989

Payne J., Labor and Politics in Peru: The System of Political Bargaining, New Heaven Connecticut 1965

Pearce J., Colombia; Inside the Labyrinth, London 1990

Pécaut D., l'Ordre et la Violence, Paris 1987

Pécaut D., Colombia in: Carrière J./Haworth N. and Roddick J. (eds.), The State, Industrial Relations and the Labour Movement in Latin America, Hampshire 1989

Petras J.and Zeitlin M., Miners and Agrarian Radicalism in: Petras J./Zeitlin M. (eds.), Latin America: Reform or Revolution?, New York 1968

Philip G., The Mititay in South American Politics, London 1985

Philip G., Mexican Politics under Stress: Austerity and After in: Philip G. (ed.), Politics in Mexico, London 1985

Pinto Santa Cruz A., Chile, un caso de desarrollo frustrado, Santiago 1962

Plata Castilla A., International Labour Standards and Colombian Legislation, 99 Int. Labour Review (1969)

Poblete Troncoso M. $/$ Burnett B.G., The Rise of the Latin American Labor Movement, New York 1960

Polak H., De Vakvereeniging, Amsterdam 1922 
Potobsky von G., Protection of Trade Union Rights: Twenty Years' Work by the Committee on Freedom of Association in: International Labour Review, January 1972

Potobsky von $\mathrm{G}_{,}$Las Organizaciones Sindicales in: Córdova E. (ed.), Las Relaciones Colectivas en América Latina, Ginebra 1981

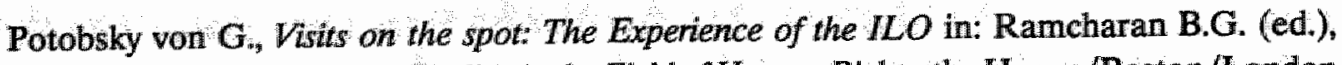
International Law and Fact-Finding in the Field of Human Rights, the Hague/Boston/London 1982

Ramcharan B.G. (ed.), International Law and Fact-Finding in the Field of Human Rights, the Hague/Boston/London 1982

Reyna J.L., Redefining the Authoritarian Regime in: Reyna J.L./Weimert R.S. (eds.), Authoritarianism in Mexico, Philladelphia 1977

Riding A., Mexico: Inside the Volcano, London 1987

Roddick J, Chile in: Carrière J./ Haworth N. and Roddick J. (eds.), The State, Industrial Relations and the Labour Movement in Latin America, Hampshire 1989

Rojas Ruíz H., El frente nacional: solución política a un problema de desarrollo? in: Rodrigo Parra S. (ed.), La dependencia externa y el desarrollo político en Colombia, Bogotá 1970

Romero Vidal M., De la factoría a la microempresa: el desmonte del sindicalismo in: Giraldo J. et al (eds.), Movimientos sociales ante la crisis en Sudamérica, Bogotá 1986

Rood M.G., Akties en loonpolitiek, Stichting Maandblad Arbeid 1980

Rochère de la J.D., France in: Jacobs F.G./Roberts S. (eds.), The Effect of Treaties in Domestic Law, UKNCCL, Vol. 7, London 1987

Roscam Abbing R., Macht arbeiders taant in post-revolutionair Mexico in: NRC.Handelsblad, 17 april 1993

Rother L, Kan Salinas Mexico redden? in: Intermediair, 9 december 1988

Roxborough I., Unions and Politics in Mexico: The Case of the Mexican Automobile Industry, Cambridge 1984 
Rouquié A, Military and the State in Latin America, New York 1985

Ruiz R.E., The Great Rebellion, Mexico 1905-1924, New York 1980

Ruiz Tagle J., Sindicalismo y Estado en el Regimen Militar Chileno, Santiago 1986

Schregle J., Labour Law and Industrial Relations in the Third World in: Blanplain R. (ed.), Comparative Labour Law and Industrial Relations, Deventer 1987

Seiter H., Streikrecht und Ausspernungsrecht, Tübingen 1975

Sepúlveda C., La Situación de los Tratados en el Orden Legal Mexicano in: Comunicaciones Mexicanos al VT Congreso Internacional de Derecho Comparado, (1962)

Serra J., Three mistaken theses regarding the connection between industrialization and outhoritanian regimes in: Collier D. (ed.), The New Authoritarianism in Latin America, Princeton 1979

Silva P., Pinochet op weg naar het einde? in: Intermediair, 8 december 1989

Simamba B.H., The Jurisdiction of the ILO to hear complaints regarding trade union freedom in: XXI CILSA, 1988

Spalding H.A., Organized Labor in Latin America, New York 1977

Stavenhagen R., Seven fallacies about Latin America in: Petras J./Zeitlin M. (eds.), Latin America: Reform or Revolution, New York 1968

Stevens E.P., Protest and Response in Mexico, Massachusetts 1974

Stickell A.L., Migration and Mining Labor in Northern Chile in the Nitrate Era, 1880-1930, Indiana University 1979

Summers C.W., Exclusive Representation by the Majority Union: A Unique Principle of American Labor Law in: Hedendaags Arbeidsrecht, opstellen aangeboden aan Prof.Mr. M.G. Levenbach, Alphen aan den Rijn 1966 
Tammes AJI.P., "Een ieder verbindende" verdragsbepalingen in: NJB 27-01-1962, no. 4 en 03-021962 , no. 5

Teitelboim B., Indicadores Económicos y sociales. Series Anuales 1960-1982; Santiago: Programa de Economía del Trabajo, 1983

Tella di T.S., Stalemate or Coexistence in Argentina in: Petras J./Zeitlin M. (eds.), Latin America: Reform or Revolution?, New York 1968

Thoolen H./Verstappen B, Human Rights Missions. A Study on the Fact-Finding Practice of Non-Governmental Organizations, Dordrecht/Boston/Lancaster 1986

Thürer D., The Right not to Organize in: Die Koalitionsfreiheit des Arbeitnehmers, Rechtsvergleichung und Volkerrecht, Band 2, Max Planck-Institut, Heidelberg 1980

Tìrado Mejia A., The Struggle against Violence and Impunity: A Democratic Commitment, Bogotá 1988

Trejo R., Historia del Movimiento Obrero en Méjico in: Gonzalez Casanova P. (ed.), Historia del Movimiento Obrero en América Latina, Vol. 1, Méjico 1984

Touraine A., La Parole et le Sang, Paris 1988

Trubeck D.M., Economic, Social and Cultural Rights in the Third World in: Meron Th.M. (ed.), Human Rights in International Law: Legal and Policy Issues, Oxford 1985

United Nations, Vienna Declaration and Programme of Action, adopted by the World Conference on Human Rights on 25 June 1993, A/ CONF. 157/23, 12 July 1993

Urrutia Montoya M., Historia del Sindicalismo en Colombia, Medellín 1976

Valticos $\mathrm{N}_{\text {,y }}$ Universalité des Droits de l'Homme et Diversité des Conditions Nationales in: Liber Amiconum Discipulonumque pour René Cassin, vol. 1, Paris 1969

Valticos N., La Commission d'Investigation et de Conciliation en Matière de Liberté Syndicale et le Méchanisme de Protection Internationale des Droits Syndicaux in: Annuaire Français de Droit International, 1967 
Valticos $\mathbf{N}_{.,}$Un Double Type d'Enquête de l'Onganisation Intemationale du Travall au Chile in: Annuaire Français de Droit International, 1975

Valticos N., International Labour Law, Deventer 1979

Valticos N., Une Nouvelle Forme d'Action Intemationale: les « Contacts Directs " de l'O.I.T. en Matière d'Application de Conventions et de Liberte Syndicale in: Annuaire Français de Droit International, 1981

Valticos N., The international protection of economic and social rights in: Rechten van de Merts in Munidiaal en Europees Perspectief, Ars Aequi Libri, Nijmegen 1986

Valticos P., Les méthodes de la protection internationale de la liberté syndicale in: Rec. Cours 144, 1975-I

Vervaele J., Criminal Law and the Protection of Human Rights in Colombia in: SIM Newsletter, $3 / 1988$

Vierdag E.W., The legal nature of the rights granted by the Intemational Covenant on Economic, Social and Cultural Rights in: Netherlands Yearbook of International Law, 1978

Weissbrodt D./McCarthy J., Fact-Finding by International Nongovernmental Human Rights Organisations in: Virginia Journal of Intemational Law, Vol. 22 (1), 1981

Wiarda G.J., Rechterlijke voortvarendheid en rechterlijke terughouding bij de toepassing van de Europese Conventie tot bescherming van de rechten van de mens, "s-Gravenhage 1986

Wijnbergen van S., Mexico: een uitdaging in." NRC-Handelsblad, 16 maart 1989

Wilt van der H.G., De gepolitiseerde vakbond: een dilemma voor de Internationale Arbeidsorganisatie in: NJCM-Bulletin, Jrg. 11-2 (maart 1986)

Wilt van der H.G., Chili's vakbeweging contra Pinochet in: Intermediair, 7 maart 1986

Wilt van der H.G., De Internationale Arbeidsorganisatie en de universaliteit van het beginsel van vakverenigingsvrijheid: Reikwijdte en strekking wan het universele karakter met speciale aandacht voor het stakingsrecht in: Boven van Th./Flinterman C., Universaliteit van Mensenrechten: fundamenteel en controversieel, Leiden 1992 
Zapata F, Las relaciones entre el Movimiento Obrero y el Gobiemo de Salvador Allende, Mejico 1974

Zapata F., El Conflicto Sindical en América Latina, Méjico 1986

Zapata F., Labor and Politics: The Mexican Paradox in: Epstein E.C. (ed.), Labor Autonomy and the State in Latin America, Boston 1989

Zuijdwijk T.J.M., Petitioning the United Nations, New York 1982

\section{Aangehaalde jurisprudentie}

Europese Hof voor de Rechten van de Mens

- Case of Young, James and Webster v. U.K., Judgment of 13 August 1981, Publications of the Court, Series A, vol. 44

- Marckx Case, Judgment of 13 June 1979, Publications of the Court, Series A, vol.31

- Airey Case, Judgment of 9 October 1979, Publications of the Court, Series A, vol.32

\section{Nederlandse Jurisprudentie}

Pres. Rb. 's-Gravenhage 19 decmber 1980, NJCM-Bull. 1981, p. 412

Pres. Rb. 's-Gravenhage 21 januari 1982, NJ 1984, 487

HR 9 april 1954, NJ 1954,

HR 6 maart 1959, NJ 1962, 2

HR 7 november 1984, NJ 1985, 247

HR 23 november 1984, NJ 1985, 604

HR 30 mei 1986, NJ 1986, 688 


\section{Summary}

This study contains the story of an encounter between the International Labour Organization (ILO) and three Latin American countries. The question is addressed how the ILO has assessed the trade union situation in Chile, Colombia and Mexico.

One of the main assumptions is that relationships between the state and the labour movement in Latin American countries have been close. This situation has dammaged the free functioning of labour unions and has put labour rights in jeopardy.

The choice of the three countries has been made on the basis of certain differences in governmental policies towards the labour movement. In literature on Latin American labour politics a distinction is often made between repression and control. Repression ensues from overt conflicts between the authorities and an autonomous and militant labour movement. Grave violations of labour rights and other fundamental human rights are often embedded in and even justified by the National Security-Doctrine. The labour policy of the Pinochetregime in Chile provides a classic example. In the case of control, on the other hand, seemingly harmonious relations between labour and the authorities prevail. Close cooperation reflects mutual interests but at the same time conceals the fact that the labour movement lacks independence and is a continuation of economic policy. Organizational linkages between one or more labour confederations and the government party and huge social gaps between labour leaders and the rank-and-file are typical of control patterns. In Latin America the labour situation in Mexico best matches the above description. The situation in Colombia presents an interesting example-in-between: after having acquiesced in a state-imposed organizational structure, the labour movement gradually radicalized and consequently faced increasing repression.

For the purpose of this study these sketchy typologies are taken as a frame of reference. Whether these patterns of repression and control can be discerned in ILO-case law, is the pivotal question of my investigations. The core hypothesis underlying this research is that it is likely that the ILO has no problems in detecting repression as a (grave) violation of tradeunion rights, whereas control measures could easily escape the attention of the ILO.

Chapter 1 starts with a general introduction on the ILO-standards and supervisory mechanisms in the field of trade union freedom. Next, the intricate question of universality of human rights is extensively discussed. The main conclusion of this section is that, in the opinion of 
the ILO, trade union rights indeed have universal validity in that manner that respect for trade union rights should be judged in each country along the same yard-stick. This is a very important starting-point for the rest of our study as it means that excuses for infractions of trade union rights on political or social/economic grounds will not be accepted.

In order to get a clear picture of the general assessment by the ILO of repression and control, in the next sections those instruments are selected which may be considered as more or less exemplary for repression or control situations. From the analysis of ILO-case law, it is tentatively concluded that formal control measures - such as obligatory arbitration procedures or legally imposed organizational structures - are unequivocally qualified as infractions of ILO-standards in the field of trade-union freedom.

The question why Latin American labour unions have come to be involved in politics is the subject of Chapter 2. Crucial to the understanding of this phenomenon, at least in the opinion of the author, is the rise of national-populist governments in the thirties, in reaction to international developments. In search of political legitimacy these governments courted labour. On the other hand, labour unions were in dire need of state protection, as their bargaining position vis a vis employers was generally weak in view of a tight labour market. Furthermore, there was a certain logic in raising wages gradually: the "easy" phase of Import-Substitution-Industrialization required the broadening of the internal market.

Inconsistencies in the economic policies and new international developments after World War II - especially the rise of Multi National Corporations - caused the decline of the nationalpopulist governments. In the major industrial countries of Latin America the military took power and paved the way for the so called Bureaucratic-Authoritarian State. Labour militancy was totally incompatible with the new economic policy and the authoritarian regimes tried to crush the social and political power of labour by repressive measures.

After the restoration of democracy in the eighties, labour's involvement in national politics has continued, as is shown by the Labour Pacts between the trade union movement and the authorities. However, there are signs that the labour movement is gradually gaining more independence.

Chapter 3 deals with the ILO-reaction on the labour politics of the Pinochet-regime in Chile from 1973 until 1990. The initial harshness of labour repression is explained by the militant and autonomous character which labour in Chile has developed overtime. This militancy can be attributed to the primal importance of the mining sector within the Chilean economy. The experiences of nitrate and copperworkers have strengthened their class-counsciousness, have led to a preference for left-wing political parties and have made them insensitive to co-opting attempts by corporatist and populist governments.

The Coup of 11 september 1973 has induced the ILO to the establishment of a Fact Finding and Conciliation Commission on the Trade Union situation in Chile. The Commission has vehemently disapproved of repressive measures towards labour, such as dissolution of trade unions, dismissal of trade union leaders, detention without trial, torture, "disappearences" 
and executions. After 1976 repression slightly relaxed. However, restrictions of labour rights were formalized by the so called Labour Plan (1979) which was drafted by the authorities in order to minimize the interference of organized labour with the free functioning of the market. The Committee on Freedom of Association has been critical on the Labour Plan and its application. In particular it has criticized the severe restrictions on the right to strike. One remarkable feature of the ILO-case law in connection with Chile is the rejection of the governments' contention that repressive measures were justified as a reaction to political "tresspassing" by the labour movement. The Committee exposed the transparant alibi by emphasizing that politics, within certain limits, belong to the scope of trade union activities.

The appraisal by the ILO of the trade union situation in Colombia is examined in closer detail in chapter 4. Whereas the face of the Chilean labour movement is determined in great deal by the experiences of nitrate- and copperworkers, the origins of the labour movement in Colombia can be traced to the fate of workers in the coffee-zone. Small peasants became massively involved in the struggle for the land and this fostered a specific attitude. Generally individualistic and conservative-minded, the coffeeworkers were not susceptible to the appeals of the political left and the labour movement who naturally advocated collective action. Trade unions made some headway in foreign-owned export enclaves, but generally remained weak. During the thirties the labour movement flourished under the shelter of the Liberal Party and concentrated on "political bargaining". The decline of the Liberal Party after World War II left the labour movement weak and divided. New labour legislation procured the atomisation of the labour movement, as it prescribed that collective bargaining could only be conducted at the level of the enterprise. The ILO has criticized this legislation, as it takes the view that it should be left to the parties to decide at which level collective bargaining should take place. Furthermore, the ILO has rejected legal provisions which allow (for) extensive state interference in labour matters, such as mandatory arbitration in case of labour disputes.

During the seventies, in the face of economic recession, trade unions gradually radicalized and started to join forces in order to confront both employers and authorities. The government reacted with moderate repression, especially after the general strike of 1977 . This repression was the prelude to a general deterioration of the human rights situation and an erosion of the rule of law. Increasingly workers and labour leaders were harassed by narcotic traffickers, death squads and guerrilla's. The involvement of the authorities in these human rights violations is a matter of controversy. Non-Governmental-Organizations in the field of human rights as well as the UN-Working Group on Disapperances have pointed to the close relations between the death squads and the military or security police. The ILO on the other hand, although admitting that isolated cases of official involvement do exist, maintains that neither the army, nor the security police as such can be held responsible for massive violations of human rights.

The pattern of relations between labour and the state in Mexico - the subject of Chapter 5 - has been highly influenced by the Mexican Revolution (1910-1917). From the start, labour 
formed part of the revolutionary family. The cordial relations between the labour movement and the revolutionary government were officially corroborated by the organizational intertwinement of the largest confederation CTM and the governmental party PRI in 1936.

Especially during the fifties and sixties, economic growth was propelled by the effective control of the labour movement. Partly this control was realized by a system of Conciliation and Arbitration (Boards) which provided for meticulous arrangements of work disputes in order to avoid strikes. But the authorities also relied on indireet control: infamous labour leaders (the "charros") were lavishly rewarded for restraining the wage claims of the rank-andfile. During the eighties labour unions in the strategic sectors succeeded in wresting themselves from the tight grip of the government. However, lack of independence from the state remains a remarkable feature of the Mexican labour movement.

If we assume that state control over labour signifies an infraction of trade union liberty, it is quite striking that these Mexican control patterns have hardly surfaced in ILO-case law. One obvious explanation might be that workers who are effectively controled are reluctant to submit complaints to the ILO, in fear of repression. Furthermore, to a large extent Mexican labour legislation as such is not in contravention of ILO-standards in the field of trade union freedom; it only offers possibilities of infringements. Although these explanations undoubtedly have some validity, in the opinion of the author there is a third reason. One quite effective instrument of control is the closed shop-provision: in order to get a job, workers are required to be a member of a particular union. Rebellion or the mere threat of leaving the union in order to join another may occasion expulsion from the union and (hence) dismissal. The ILO, however, does not consider such closed shop provisions a violation of the workers' right to join organizations of their own choosing, a right which is guaranteed in article 2 of ILO-Convention No. 87.

Finally, in Chapter 6 a more thematic approach is followed in analysing the results of the investigations. It is submitted that the initial hypothesis, advanced in the introduction of this study, is too simplistic and needs further qualification. Especially the findings in the Colombiacase give rise to adjust our suppositions. On the one hand, the ILO seems perfectly capable of qualifying formal controlmeasures as a violation of labour rights. On the other hand the ILO is faced with serious difficulties in case of "informal" repression where the involvement of state-sponsored agencies is hard to assess.

In four separate sections reasons are advanced which might account for the ILO"predicaments". The first concerns the ILO-view on political strikes. Investigations reveal that the ILO employs different standards in different cases as to the admissibility of political strikes. The daring suggestion is made that the ILOO tends to be more lenient towards political strikes if they are aimed at a repressive government. This position however, would mean a radical departure from the ILO-view on universality and would shield states such as Mexico where more covert forms of labour-domination are excerted, from criticism. On further consideration this supposition seems unwarranted: overtime the ILO has changed its view in that it has 
extended the possiblities of political strikes. There are no indications that the ILO distinguishes between states on the basis of democratic quality.

In the next section the question is addressed whether the supervisory organs of the ILO show reluctance in criticizing judicial decisions. The proposition stems from the fact that the ILO attaches great value to judicial involvement in case of conflicts between labour and the authorities. However, judicial review may be pointless if judges are bound to apply national law which is not in conformity with international labour standards. The investigations do not confirm this fear. The ILO systematically rejects contentions by governments - especially the Mexican government - that international organizations are not allowed to criticize judicial decisions. The supervisory organs have taken cognizance of judicial decisions and have frankly made critical remarks if the application of national law amounted to a violation of ILO-standards.

The third section deals with the issue of trade union monism versus trade union pluralism. The Mexico-case has demonstrated that the government's indirect control over labour is effectively perpetuated due to the fact that the "official" labour movement enjoys a virtual monopoly. This monopoly is not imposed by law (with the exception of the public sector), but is the result of widely practised union security clauses.

The ILO-standpoint on trade union monism is ambivalent. Whereas trade union monopolies instituted or maintained by legislation are considered to be in conflict with trade union freedom, factual situations which might be the result of closed shop-provisions are condoned. In this study the view is taken that this dogmatic distinction may be untenable in view of the fact that closed shop-provisions in practise impede the free choice of workers to join the organization of their own choosing.

Whereas the previous sections have searched for possible explanations for the difficulties which the ILO faces as regards the assessment of unofficial control, in the last section the emphasis shifts to unofficial repression. Alluding to the Colombia-case, the discussion starts from the premise that large discrepancies in the taxation of a particular trade union situation are undesirable in view of the common effort to improve the situation of human rights. The disparate opinions of the ILO and some NGO's as regards the situation in Colombia are attributed to differences in character and aims which are reflected in different methods of fact-finding. The question is raised whether the ILO-assessment of the trade union situation in Colombia is not overcautious in relying too much on governmental information. Hesitations are expressed about the suitability of informal "Direct Contacts"-procedures to shed a light on complex and obscure trade union situations, such as that in Colombia. The procedure of the Fact Finding and Conciliation Commission on Freedom of Association provides for quite thorough investigations and "on the spot" visits. As this procedure offers extensive possibilities to gather information from $\mathrm{NGO}$-sources and hence might contribute in obtaining a more balanced view, a more frequent use of the Fact Finding and Conciliation Commission is recommended. 


\section{Resumen}

En el presente estudio se narra la historia de un encuentro entre la Organización Internacional del Trabajo (OIT) y tres países Latinoamericanos. La cuestión central es la actitud de la OrT ante la situación de los sindicatos en Chile, Colombia y Mexico.

Una de las tesis principales que aquf se recogen es que en América Latina el Estado ha mantenido una estrecha relación con el movimiento laboral, lo que ha perjudicado el libre funcionamiento de los sindicatos y ha amenazado el ejercicio de los derechos de los trabajadores.

La elección de los países mencionados se basa en determinadas diferencias en la respectiva polfíca gubernamental en relación con el movimiento obrero. Los escritores que tratan la política laboral en América Latina suelen distinguir entre los conceptos de represión y control. La represión es consecuencia de conflictos manifiestos entre las autoridades y los movimientos sindicales independientes y militantes. Bajo la doctrina de la "seguridad nacional" con frecuencia se cubren, e incluso se justifican, graves violaciones de los derechos laborales y otros derechos humanos El régimen de Pinochet en Chile es un ejemplo clásico. En la situación de control, sin embargo, impera una aparente relación de armonía entre trabajadores y autoridades. La estrecha colaboración existente es reflejo de los mutuos intereses, pero encubre al mismo tiempo la falta de independencia del movimiento sindical y su condición de prolongación de la política económica gubernamental. Algunas manifestaciones características de la situación de control son los vínculos organizativos entre una o más confederaciones laborales y el gobierno y las enormes diferencias sociales entre los líderes sindicales y los miembros de base. Claro ejemplo de esta situación es el caso de México. Colombia, por su parte, presenta una interesante coyuntura intermedia. Tras haber aceptado una estructura impuesta por el Estado, el movimiento sindical se ha ido radicalizando paulatinamente para acabar acercándose a una situación de represión.

A los efectos del presente estudio se ha tomado como marco de referencia la tipologia que brevemente se acaba de exponer. El tema central de mi investigación consiste en ver hasta qué punto estas manifestaciones de represión y control se reflejan en la jurisprudencia de la OIT. El estudio parte de la hipótesis de que para la OIT no es difícil constatar situaciones de represión, considerándolas como (graves) violaciones de los derechos sindicales, al tiempo las medidas de control podrían escapar fácilmente a la atención de la OIT. 
El capitulo 1 comienza con una introducción general en la que se tratan los estandards y los mecanismos de control de la OTT en materia de libertad sindical. A continuación se discute extensamente el problema de la universalidad de los derechos humanos. La principal conclusión es que, a juicio de la OIT, los derechos sindicales poseen ciertamente validez universal, en el sentido de que el respeto de dichos derechos deberia ser juzgado en todos los paises de acuerdo con los mismos parámetros. Es éste un punto de partida importante para el resto del estudio, puesto que habrán de considerarse inaceptables las excusas presentadas contra las violaciones de los derechos sindicales y que se basen en argumentos socioeconómicos.

Para adquirir una imagen fiel de la valoración general de la OIT respecto de las situaciones de represión y control, se seleccionan aquellos instrumentos que, en mayor o menor grado, pueden considerarse representativos de dichas situaciones. El análisis de la jurisprudencia de la OIT conduce a una primera conclusión provisional, según la cual las medidas formales de control - tales como la prescripción de procedimientos de arbitraje o la imposición legal de estructuras organizativas - deben ser calificadas sin ningún género de dudas como violaciones de los estandards de la OIT en materia de libertad sindical.

En el capítulo 2 se analiza el proceso que ha conducido a la intervención activa del movimiento sindical latinoamericano en la política. El autor estima que la clave de dicho proceso se encuentra en el surgimiento en los años treinta de gobiernos nacional-populistas, como reacción a determinados acontecimientos internacionales. Estos gobiernos procuraron aproximarse al movimiento sindical en busca de legitimación política. Por su parte, dada su posición negociadora generalmente débil respecto de la patronal a causa del restringido mercado de trabajo, los sindicatos precisaban del apoyo estatal. Además, el paulatino incremento salarial no carecía de sentido: la "sencilla" fase de importación-sustitución-industrialización requería el ensanche del mercado interior.

El declive de los gobiernos nacional-populistas se produjo como consecuencia de diversas incongruencias en las políticas económicas aś como de ciertos desarrollos internacionales en especial el surgimiento de las compañías multinacionales - tras la Segunda Guerra Mundial. En los parses altamente industrializados de América Latina los militares se hicieron con el poder, preparando el camino para lo que habría de llegar a ser el llamado Estado burocráticoautoritario. La militancia sindical era completamente incompatible con la nueva política económica, por lo que los regímenes autoritarios trataron de reprimir el poder político y social de los sindicatos.

La restauración democrática de los ochenta no ha puesto fin a la intervención política de los sindicatos, tal y como demuestran los convenios laborales celebrados entre sindicatos y el poder político. No obstante, se perciben algunos indicios de cambio hacia una mayor independencia sindical.

El capitulo 3 analiza la reacción de la OrT frente a la política laboral del régimen del general Pinochet entre 1973 y 1990 . La dureza de la represión sindical en los comienzos del régimen se explica por el carácter militante e independiente tradicional del movimiento sindical chileno. 
La causa principal de esta militancia debe buscarse en la importancia capital del sector minero para la economía chilena. Las experiencias sufridas por los mineros del nitrato y del cobre ha fortalecido su conciencia de clase, favoreciendo las preferencias por partidos izquierdistas e insensibilizándoles ante los intentos de capatación de gobiernos de corte corporativista y populista.

El golpe de estado que tuvo lugar el 11 de septiembre de 1973 movio a la OTT a la constitución de una Comisión de Investigación y Conciliación para la Libertad de Asociación Sindical que habría de estudiar la situación sindical chilena. Esta Comisión ha reiterado su enérgica condena de las medidas tendentes a la represión del movimiento sindical, como disolución de sindicatos, despido de líderes sindicales, detenciones sin previo proceso, torturas, "desapariciones" y ejecuciones. A partir de 1976 la represión fue mitigándose. Sin embargo, el llamado Plan Laboral de 1979, diseñado por las autoridades con el fin de minimalizar la interferencia del trabajo sindicado en el funcionamiento de un mercado libre, contenfa todavia ciertas restricciones de los derechos laborales. El Comité por la Libertad de Asociación Sindical se ha manifestado en contra del Plan Laboral y de su aplicación, en especial por lo que se refiere a las restricciones al derecho de huelga.

Una característica significativa de la jurisprudencia de la OIT en relación con el caso chileno es el rechazo de la argumentación gubernamental en el sentido de que las medidas represivas venían justificadas como reacción a los "excesos" políticos del movimiento obrero. El Comité desestimó esta evidente coartada señalando que la cuestión política, dentro de ciertos límites, pertenece al ámbito de la actividad sindical.

El capitulo 4 analiza con mayor detalle el tratamiento de la situación sindical en Colombia por la OIT. Mientras que el movimiento chileno está determinado en buena parte por las experiencias de los mineros del nitrato y del cobre, los orígenes del movimiento sindical colombiano hay que buscarlos en las circunstancias de los trabajadores de las zonas cafeteras. Los pequeños campesinos se vieron envueltos en la lucha por la tierra, lo que fomentó una peculiar actitud. Los trabajadores del café, por lo general de carácter individualista y conservador, no se veían especialmente atraldos por posiciones izquierdistas ni por un movimiento sindical de suyo propenso a la acción colectiva. Pese a una cierta penetración en empresas de exportación extranjeras, la presencia sindical permaneció generalmente débil.

Durante los años treinta el movimiento obrero conoció un período de pujanza bajo la protección del Partido Liberal, concentrándose su acción en el plano de "political bargaining". Finalizada la Segunda Guerra Mundial, la caída del Partido Liberal dej6 al movimiento obrero debilitado y dividido. La nueva legislación laboral provocó la atomización de dicho movimiento al prescribir como única forma de negociación colectiva la negociación a nivel de empresa. La OIT ha criticado esta legislación por estimar que deben ser los propios agentes sociales los que decidan el nivel al que debe llevarse a cabo la negociación colectiva. Además, la OIT ha rechazado previsiones legales que permiten una interferencia intensiva del Estado en materias laborales, como pueden ser la conciliación obligatoria en caso de litigio. 
En el transcurso de los años setenta la recesión económica provocó una progresiva radicalización de los sindicatos, que unieron sus fuerzas para una acción común frente a los patronos y el poder politico. La reacción dell gobierno fue una moderada represión, especialmente después de la huelga general de 1977. Esta represión puede considerarse como el preludio de un deterioro general del respeto de los derechos humanos y de la erosión principio de legalidad. Trabajadores y lideres sindicales fueron víctima con creciente frecuencia de narcotraficantes, escuadrones de la muerte y guerrillas. Una cuestión controvertida es el grado de intervención de las autoridades en estas violaciones de los derechos humanos. Tanto organizaciones no gubernamentales activas en el campo de los derechos humanos como el Grupo de Trabajo de las Naciones Unidas sobre Desapariciones Forzadas o Involuntarias se han hecho eco de las estrechas relaciones existentes entre los escuadrones de la muerte y el ejército y las fuerzas de seguridad. Por su parte, la OTT, si bien ha admitido en algunos casos aislados la intervención oficial, estima que ni el ejêrcito ni las fuerzas de seguridad pueden ser consideradas responsables de las violaciones masivas de los derechos humanos.

Las relaciones entre el movimiento obrero y el Estado en México - el tema del capítulo 5 han sido claramente influidas por la revolución (1910-1917). El movimiento obrero formó parte de la familia revolucionaria desde el primer momento. Las cordiales relaciones entre dicho movimiento y el gobierno revolucionario fueron ratificadas oficialmente en 1936 mediante la vinculación organizativa entre la mayor confederación sindical, la CTM, y el partido gubernamental PRI.

El crecimiento económico fue propiciado especialmente durante los años cincuenta y sesenta gracias al control efectivo del movimiento obrero. Este control fue posible, en buena medida, por la implantación de un sistema de Conciliación y Arbitraje que contenía una regulación meticulosa de los conflictos laborales tendente a evitar las huelgas. No obstante, las autoridades también hicieron uso de medios de control indirecto, por ejemplo el soborno de los llamados "charros", infames líderes sindicales, para moderar las reivindicaciones salariales de las bases. En el curso de los años ochenta el movimiento sindical logró escapar al férreo control estatal en diversos sectores estratégicos, aunque la falta de independencia respecto del poder polfitico sigue siendo un rasgo constitutivo del movimiento obrero mexicano. Si se parte de la base que el control estatal dell movimiento obrero constituye una violación de la libertad sindical, llama poderosamente la atención el hecho de que en la jurisprudencia de la OIT apenas se perciban los síntomas del control mexicano que acabo de exponer. Una posible explicación de este fenómeno podría ser el temora las represalias de los trabajadores efectivamente controlados si presentasen sus quejas ante el citado organismo. Además, la legislación laboral mexicana, en buena parte, no es en sí misma contraria a los estandards de la OIT, aunque ofrezca posibilidades de contravención. El autor estima, sin embargo, que aunque estas razones no carecen de validez, hay un tercer motivo más poderoso. La afiliación obligatoria en forme de clausulas de exclusión es, en efecto, un sístema de control efectivo. Los trabajadores que deseen obtener un empleo deben pertenecer a un sindicato determinado. La insurrección o la mera amenaza de abandonar el sindicato para afiliarse 
a otro puede conllevar la expulsión del mismo $y$, en consecuencia, la perdida del empleo. Sin embargo, la OIT no considera la aplicación de clausulas de exclusión una violación del derecho de los trabajadores a afiliarse a las organizaciones que ellos elijan, cuyo derecho garantiza el artícullo 2 de la Convención $n^{9} 87$ de la OIT.

Por último, en el capítulo 6 tiene un carácter más temático, con el fin de analizar los resultados de las investigaciones previas. La hipotesis adelantada en la introducción se demuestra excesivamente simplista y precisa, por ello, ser matizada. En especial los resultados del caso colombiano justifican esta matización. De una parte, la OIT parece estar perfectamente capacitada para calificar las medidas formales de control como una violación de los derechos laborales. De otra, la OIT se ve confrontada con serias dificultades en los casos de represión "informal", en los que es dificil de constatar la intervención de elementos apoyados por el Estado.

En cuatro subcapítulos se exponen las razones que podrían avalar la opinión de la OIT respecto del tema que nos ocupa.

El primer subcapitulo trata la postura de la OrT ante las huelgas políticas. Las investigaciones indican que este organismo emplea diferentes estandards según sea el caso. Se ha dicho, no sin cierta audacia, que la OIT tiende a ser más condescendiente con las huelgas politicas si estas van dirigidas contra un régimen autoritario. Sin embargo, esta opinión significaría el abandono de la opción de la OTT por la universalidad de los derechos laborales y absolvería a estados como México, en los que se dan formas encubiertas de dominación laboral. Si se analiza con detalle, esta tesis se demuestra insostenible. La OTT ha modificado su postura, inclinándose paulatinamente por una mayor aceptación de la huelga política. No existen indicios que apunten a un trato desigual de los estados, segün su mayor o menor inspiración democrática, por parte de la OIT.

En el siguiente subcapítulo se estudia la posible reticencia de los órganos de control de la OrT por lo que respecta a la crítica de las decisiones judiciales nacionales. Esta suposición se basa en el hecho de que la OIT valora en gran medida la intervención judicial en los conflictos entre el movimiento obrero y las autoridades. Debe admitirse, sin embargo, que esta intervención carece de sentido cuando las autoridades judiciales estuviesen obligadas a aplicar una legislación que no se adecúa a los estandards internacionales. Nuestras investigaciones no confirman este temor. La OIT ha rechazado sistemáticamente las quejas de los estados - en especial del Estado mexicano - que estiman que las organizaciones internacionales carecen de autoridad para criticar las decisiones judiciales. Sus organos de control han tomado conocimiento de las decisiones judiciales y han criticado honestamente aquellas aplicaciones de la ley nacional que consideraban en desacuerdo con los estandards de la OIT.

La disyuntiva: monismo o pluralismo sindical, se estudia en el tercer subcapítulo. El caso mexicano demuestra que el control directo de los trabajadores por parte del gobierno se perpetúa efectivamente en virtud del monopolio fáctico de que disfruta el sindicato "oficial". Dicho monopolio, aunque no está impuesto legalmente (salvo en el caso del sector público), es el resultado de una extendida práctica de cláusulas de exclusión. 
La OIT mantiene una postura ambigua ante la cuestion del monismo sindical. Mientras que la implantación o el mantenimiento legal de monopolios sindicales se considera una violación de la libertad sindical, se admiten situaciones de monopolio fáctico como consecuencia de las disposiciones en materia de afiliación obligatoria. El presente estudio estima que esta distinción dogmática no valora suficientemente el hecho de que la afiliación obligatoria puede vulnerar en la práctica la liberiad de elección sindical de los trabajadores.

Si en el subcapítulo precedente trataban de explicarse las dificultades de la OIT en lo que se refiere a la constatación de control oficioso, el último subcapítulo analiza los supuestos de represión oficiosa. El caso colombiano se estudia partiendo del hecho que no es aconsejable mantener grandes diferencias de apreciación en lo que se refiere a una determinada situación sindical cuando es manifiesto el deseo de mejorar la situación de los derechos humanos. La diversidad de opiniones de la OIT y de Organizaciones No Gubernamentales (ONG) por lo que se refiere a la cuestión colombiana se derivan de los distintos caracteres y fines, y se manifiestan en los diversos métodos de analizar los hechos. Cabe preguntarse si la actitud de la OIT no es demasiado cautelosa al basarse excesivamente en información de origen gubernamental. El presente estudio duda de la eficacia de los procedimientos informales de "Contactos Directos" para eselarecer intrincadas y oscuras situaciones sindicales como la colombiana. Las actuaciones de la Comisión de Investigación y Conciliación para la Libertad de Asociación Sindical ofrecen investigaciones lo suficientemente completas y visitas locales. Vistas la posibilidades de esta Comisión para recabar información de las $O N G$, lo que puede facilitar una visión más ecuánime, se propugna una mayor intervención de la mencionada Comisión. 


\section{Curriculum Vitae}

Harmen van der Wilt is geboren op 9 oktober 1955 te Casablanca. In 1974 behaalde hij het Einddiploma Gymnasium B aan het Murmellius Gymnasium te Alkmaar. Na twee jaar Fysische Geografie te hebben gestudeerd, begon hij een studie Rechten aan de Vrije Universiteit te Amsterdam. Deze studie werd in 1982 afgerond, met als specialisatie strafrecht.

Nadien had hij enkele betrekkingen op het terrein van de rechten van de mens - Onafhankelijk Klachtenburo Poltitieoptreden Amsterdam, Commissie Mensenrechten Raad van Kerken, VluchtelingenWerk Nederland. Tevens verdiepte hij zich in de historische en politieke achtergronden van Latijns Amerika, verzorgde hij enkele publicaties over dit onderwerp en maakte hij een reis naar Argentinië en Bolivia.

In $1987 \mathrm{kreeg}$ hij een aanstelling als Assistent-in-Opleiding aan de Rijksuniversiteit Limburg. Sinds 1991 is hij aan deze instelling verbonden als universitair docent bij de vakgroep strafrecht. 